\title{
NO LIMIAR DAS RAÇAS: SILVIO ROMERO \\ (1870-1914)
}

(versão corrigida)

Tese de doutorado apresentada ao Programa de Pós-Graduação em História Social da Faculdade de Filosofia, Letras e Ciências Humanas da Universidade de São Paulo, sob a orientação do Professor Dr. Marcos Antonio da Silva 


\section{NO LIMAR DAS RAÇAS: SÍLVIO ROMERO (1870-1914)}

Tese de Doutorado apresentada ao Programa de Pós-Graduação em História da Universidade de São Paulo para obtenção do título de doutor em História Social, sob orientação do Dr. Marcos Antonio da Silva. 
Autorizo a reprodução e divulgação total ou parcial deste trabalho, por qualquer meio convencional ou eletrônico, para fins de estudo e pesquisa, desde que citada a fonte.

Catalogação na Publicação

Serviço de Biblioteca e Documentação

Faculdade de Filosofia, Letras e Ciências Humanas da Universidade de São Paulo

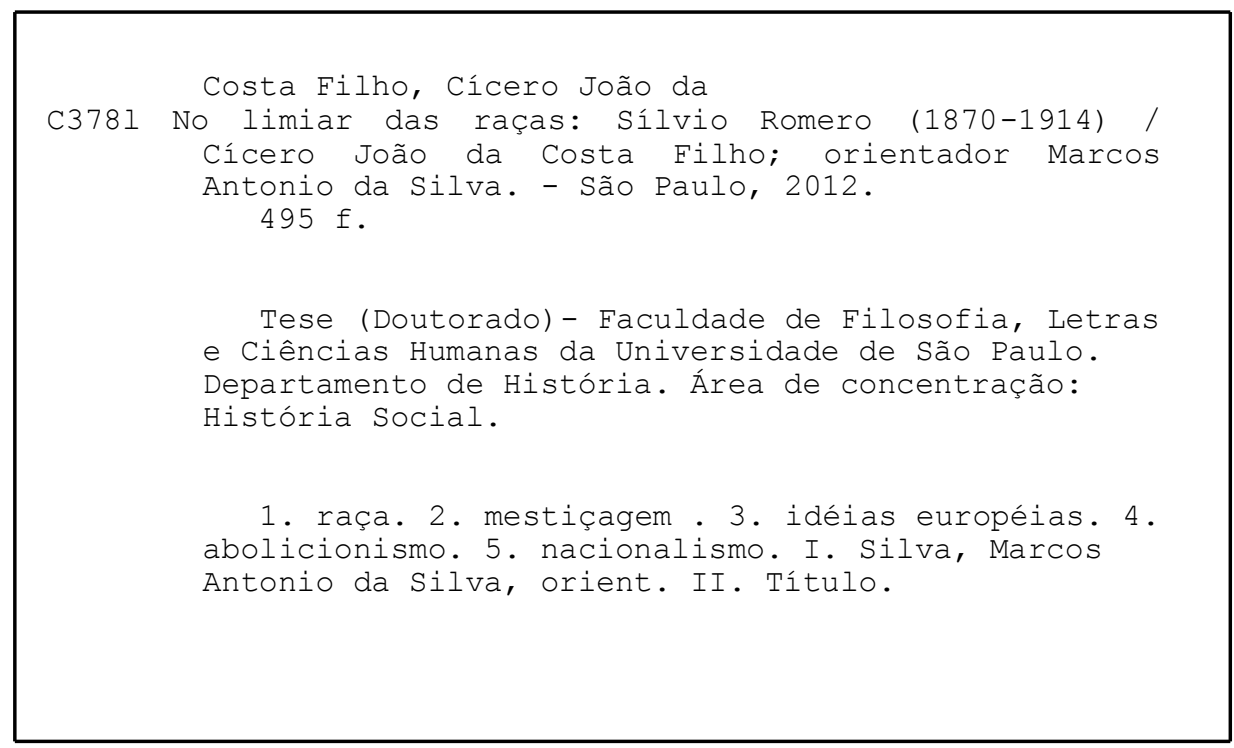




\section{NO LIMIAR DAS RAÇAS: SÍLVIO ROMERO (1870-1914)}

Tese de Doutorado apresentada ao Programa de PósGraduação em História da Universidade de São Paulo para obtenção do título de mestre em História Social, sob orientação do Dr. Marcos Antonio da Silva

Aprovado em:

\section{Banca Examinadora}




\section{IN MEMORIAM}

A Maria Filomena da Costa,

A minha vó Filó 


\section{Sociedade Falida}

Nossas vidas nas ruas já não valem nada Ninguém sabe se está vivo na próxima parada É tanta lama, tanto vício, tanto oportunismo... Ninguém sabe se está vivo no próximo domingo!

Essa vida aqui na terra já não faz sentido Em Brasília ninguém cumpre o compromisso! São tantos gatos, tantos ratos corroendo os partidos... Novamente em Brasília ninguém tem compromisso Ninguém

Sociedade falida Os bons costumes falidos Os trabalhadores falidos

Aposentados falidos... Nossa segurança... a nossa...

Educação falida!

Salas de aula falida...

A juventude falida...

Nossa previdência falida Significa que nossa saúde está toda ofendida

Ôô

As ruas

Andam cheias

De hipócritas

(Edson Gomes) 


\section{SUMÁRIO}

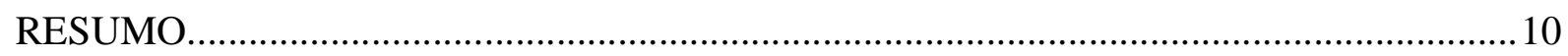

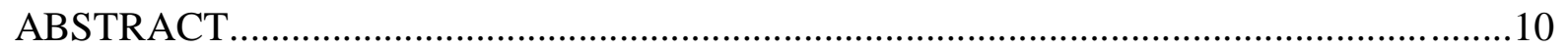

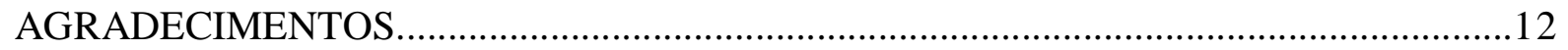

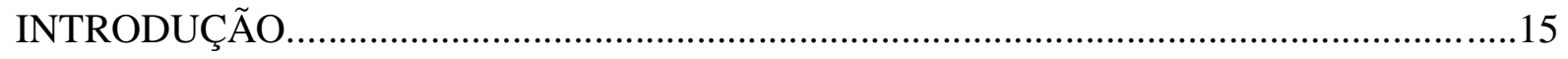

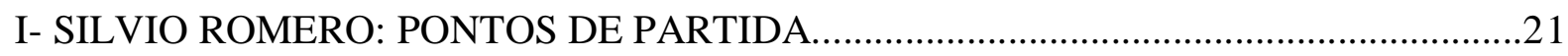

II - LITERATURA É SOCIEDADE

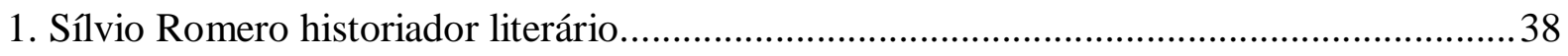

2. A Crítica: entre a crítica literária e a crítica sociológica..................................................52

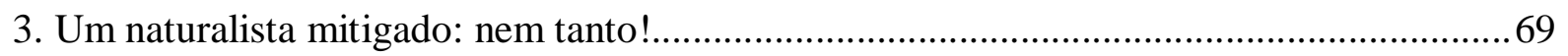

4. Sílvio Romero fora do cânone: intérpretes de sua história literária...................................84

III - RAÇAS: LIMIAR, QUASE ALÉM

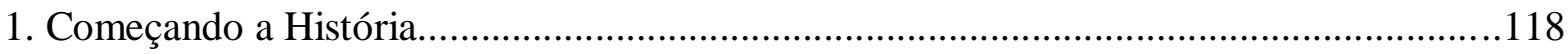

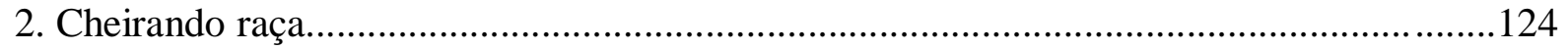

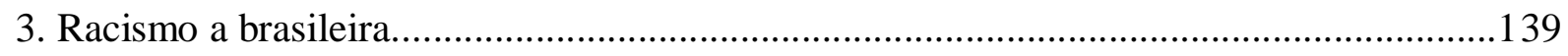

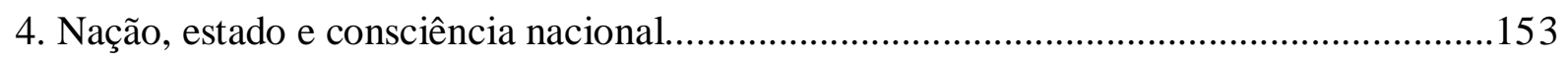

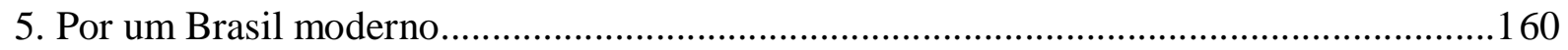

IV - INTERPRETANDO O BRASIL DE SEU TEMPO

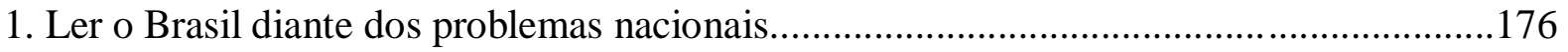

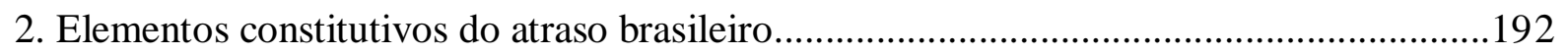

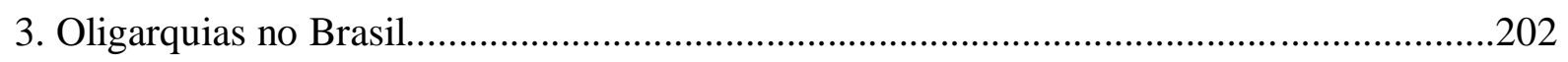

4. O remédio brasileiro: por uma educação enérgica e popular...........................................210

5. O revoar das idéias novas: contextualização e política......................................................223

6. Evolucionismo, determinismo racial e climático: identidade nacional.............................242 


\section{V - A IMAGEM DO ÍNDIO BRASILEIRO}

1- Monogenismo e poligenismo: os apologistas das diferenças..........................................267

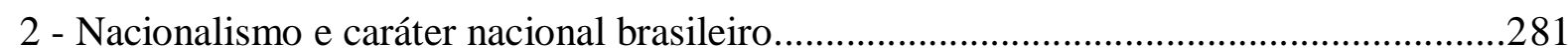

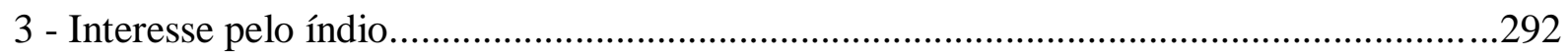

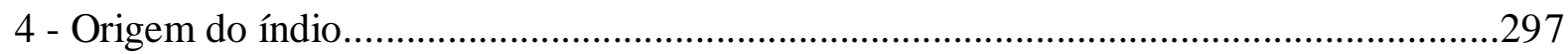

5 - O índio é das Américas: contra o turanismo de Teófilo Braga..........................................312

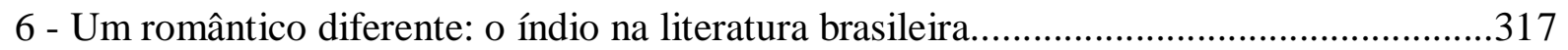

\section{VI - IMAGEM DO NEGRO (OU AFRICANO NO BRASIL)}

1 - Escravidão: bases das representações do Império Brasileiro............................................329

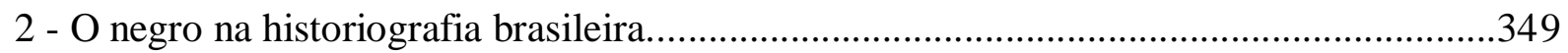

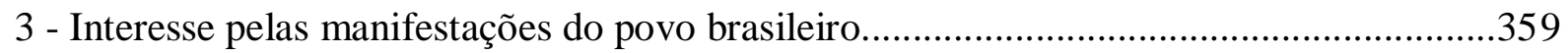

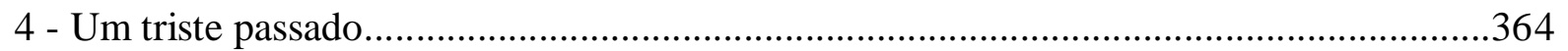

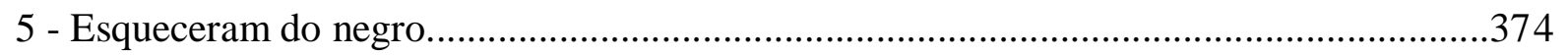

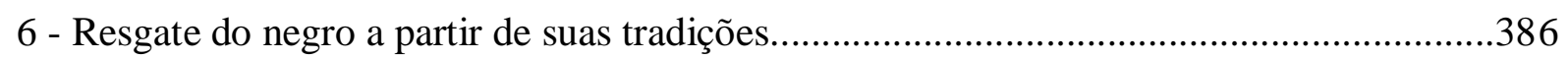

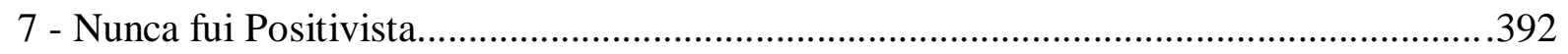

VII - O BRASIL É PORTUGUÊS?

1 - Brasil: objeto da cobiça do estado patrimonial português................................................402

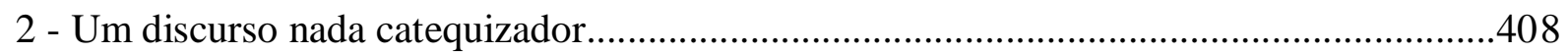

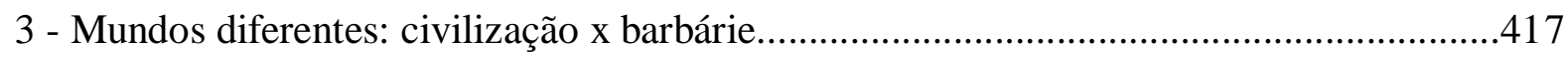

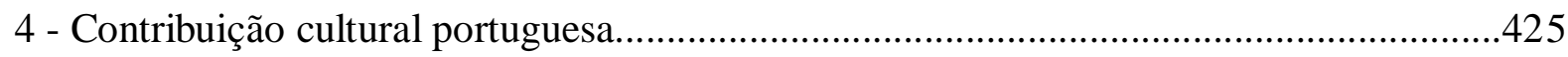

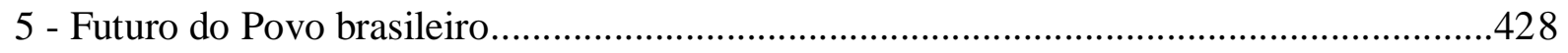

6 - Colonização portuguesa: um bem ou mal?..................................................................431

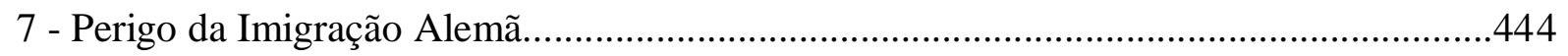

8 - Lusismo versus brasileirismo: paixão pelo Brasil.........................................................456 
VIII - CONCLUSÕES

Ainda faz sentido ler Sílvio Romero "depois" das raças?.........................................................465

FONTES E BIBLIOGRAFIA.................................................................................472

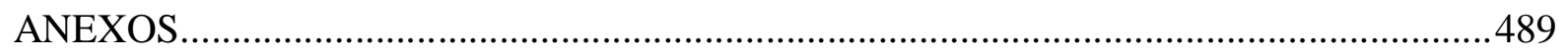




\title{
RESUMO
}

Silvio Romero foi um importante escritor brasileiro da Geração 1870 que pensou o Brasil a partir dos preceitos científicos da Europa e do Liberalismo dos EUA. Influenciado pelos parâmetros do meio e da raça, fatores somados à idéia de evolução e à lei dos três estados (Positivismo), o polígrafo constatou o atraso do país devido à inferioridade das raças formadoras da sociedade brasileira. Nos mais variados segmentos, o atraso brasileiro era visível. Para superar esse atraso, Sílvio pensava que a mestiçagem racial (também biológica) era a singularidade do novo Brasil almejado pela elite econômica e intelectual da época. Pensando um novo Brasil, o ensaísta analisou a contribuição de índios, negros e portugueses para a formação do país, salientando a extrema importância do mestiço, a singularidade brasileira. Bacharel pela Faculdade de Direito do Recife, Romero pensou o Brasil tendo em vista os princípios da Biologia e foi muito influenciado pela idéia de evolução, pela Escola de Le Play e acima de tudo, pelos pensadores que usavam o argumento da raça. A nação brasileira seria pensada tendo por modelo um organismo vivo e a questão racial e cultural seria uma das variantes para compreender o novo Brasil republicano e liberal que estava surgindo.

\section{PALAVRAS CHAVE}

Silvio Romero - Escola do Recife - Raças - Mestiçagem - Brasil (séculos XIX e XX)

E-mail para contato: cicerojoaofilho@gmail.com

\begin{abstract}
Sílvio Romero was an important brazilian writer of the 1870 Generation. His theoretical references was an important brazilian writer of the 1870 Generation. His theoretical references were European scientific principles and U. S. Liberalism. This polygrafh's thought was influenced by the environment and race parameters, factors add to the concept of evolution and the law of the three stages (Positivism), and he explained the backwardness of the country due to the inferiority of races comprise Brazilian society. He said that Brazilian delay was visible at various sectors. To overcome the reason for the delay, Romero proposed that racial miscegenation (which was also organic and cultural) was the uniqueness of the new Brazil pursued by economic and intellectual elite of the time. Thinking about a new Brazil, this pursued by economic and intellectual elite of the time. Thinking about a new Brazil, this essayist analyzed Indian, African and Portuguese contribution to the formation of Brazil, stressing the utmost importance of the mestizo, the Brazilian singularity. Bachelor of Laws by
\end{abstract}


Recife Faculty, Romero thought in view of the principles of Biology and was much influenced by the concept of evolution, the Le Play School and foremost, by the thinkers who used the argument of race in explaining human societies. The Brazilian nation would be designed modeled as a living organism and race and culture for the bachelor would unquestionably the main variants to understand new liberal and republican Brazil that was emerging.

\section{KEYWORDS}

Silvio Romero - Recife School - Races - Miscegenation - Brazil (XIX and XX) 


\section{AGRADECIMENTOS}

Em primeiro lugar, é com enorme reconhecimento e justiça que devo citar pessoas que, mesmo de longe, contribuíram para o desenvolvimento desta pesquisa. Quatro anos de muita luta e empenho, enfrentando dificuldades que tiravam o sono. Mas jamais passou pela minha cabeça desistir!

Quero começar a falar da minha família, especificamente, dos meus pais e minha duas irmãs.

De Cícero João da Costa, meu pai, muito falei sobre sua pessoa, acreditando em fortes e sérias semelhanças, sem as quais eu não seria o que sou hoje. Agradeço a meu pai pelas conversas sérias que tinha comigo, muitas, só bem mais tarde, pude entender. A maneira de me educar, sua forma de pensar e agir com certeza marcaram minha pessoa. O que para muitos pode ser considerado um modelo severo, era o jeito dele e a maneira mais correta dele me instruir, foi o que ele recebeu da vida, foi o que ele presenciou. Sou a pessoa que sou justamente por conta de ter tido um pai como eu tive. Quero ressaltar que ele jamais impediu meus planos e nunca deixou de acompanhar meus estudos. É de admirar que Cícero João da Costa, nunca tenha se queixado do alto custo de me amparar em São Paulo e da formação dos meus irmãos. Certa vez, ouvi de um velho colega, uma expressão que muito me marcou e que serviu de consolo, face às despesas que eu tinha em São Paulo: "pai não paga filho e filho não paga pai”. Ao meu pai, quero desafabar e dizer que passei dias e noites esperando a conclusão da pesquisa, porque este é o maior presente que posso lhe dar, espero que você se sinta orgulhoso de me ter como filho. Como filho é o que posso oferecer a você e gostaria que você soubesse que foi duro demais chegar até aqui, mas demais mesmo, e reconhecesse meu esforço. Nos momentos difíceis, sem bolsa e sem nenhum tostão, não tinha a quem recorrer senão a meu pai. Foi muito difícil, para mim, levar a pesquisa adiante sem bolsa, isso me desgastava diariamente, e confesso que me roubava o sono e infelizmente os aperreios diários comprometeram demais a qualidade da pesquisa. Somado à ajuda material, meu pai me fez homem e valente, me fez ver que a vida não é do meu jeito e tive que escutar quando necessário que existia o certo e o errado. Sou a pessoa que sou porque meu pai me educou justamente da maneira dele, não receio falar, e sinceramente, interiormente, somos parecidíssimos.

O custo de vida de uma cidade como São Paulo, e o fato de não ter conseguido bolsa, muitas vezes me levaram ao desespero, um verdadeiro Deus nos acuda. Confesso que este foi o maior problema enfrentado durante o desenvolvimento da pesquisa. Quanto à alimentação o restaurante universitário inúmeras vezes solucionava nosso problema de subsistência, mas e o resto das coisas!?....

A Raimunda Nunes da Costa, minha mãe, pela duríssima e preocupante posição de mãe, agradeço e peço desculpas por ter passado todo o período de pesquisa fora de casa. 
Quero agradecer a minhas duas irmãs, Cícera Maria Nunes da Costa e Cecília Maria Nunes da Costa, que me ajudaram no contato com meus pais e me incentivaram e torceram por mim. A Cícera Maria, pessoa serena, responsável e séria, agradeço pelas nossas conversas, falando sobre como eu estava em São Paulo e sobre as dificuldades que encontrava no caminho. A Cecília Maria, algumas vezes injusta, espero que possa reconhecer e entender tudo que vivi em São Paulo, pois nem sempre nossas conversas eram amistosas. Mas algo bem maior nos aproxima: somos irmãos!

No mundo acadêmico, gostaria de lembrar nomes de alguns funcionários do CAPH pelos quais tenho muito carinho, como: Eliseu, Élson, Cida. Foram muito boas as conversas com Eliseu e com Élson, momentos de alegrias diante de minhas dificuldades. Agradeço também ao serviço prestado pelos funcionários da Biblioteca Florestan Fernandes, para não cometer injustiça me refiro a todos aqueles de quem cheguei a precisar e por quem fui prontamente atendido, sempre atenciosos e preparados. Raras foram as vezes que busquei um livro nesta biblioteca e não o encontrei.

Um agradecimento especial dedico ao professor Marcos Silva, em primeiro lugar, por ter apostado na pesquisa, se dispondo de maneira atenta e presente na orientação da tese. Enfrentando problemas de saúde e familiares, sempre foi pontual e incisivo em suas colocações. Caro Marcos, você contribuiu demais no desenvolvimento e finalização dessa pesquisa. Seu jeito, suas aulas, e acima de tudo, sua maneira crítica de ver as coisas contribuíram demais para que eu só reforçasse minhas idéias.

Quero lembrar da professora Sara Albieri, sempre simpática, por nossas conversas, sempre apressadas.

A Elenita Martins, a Kika, amiga e companheira de todas as horas, devo agradecer pela força que me deu e pelos bons momentos desde que cheguei a São Paulo. Kika esteve a meu lado nos momentos mais difíceis da minha vida e a ela não posso retribuir a não ser reconhecendo sua presença por tudo que vivemos. Entre idas e vindas, Kika acompanhou meus nervosismos durante toda a pesquisa. Devo reconhecer pessoas de sua família importantes, como a Fabiana, sua filha, e o Felipe, seu filho, pessoas com que eu dividi durante o tempo que estive em São Paulo os mesmos espaços. Quero lembrar outros familiares seus, os irmãos Otávio e Mário, seus sobrinhos Rodrigo e Rafael. Não poderia deixar de lembrar das converas com o Thiago, namorado da Fabiana, nossas conversas sobre o mundo, com suas desigualdades e a espécie humana, responsável por sua própria decadência.

Aos colegas, alunos de variados cursos da universidade, destaco conversas que muito me alegravam e me impulsionavam para os difíceis momentos que precisava superar. Devo citar o Leandro, aluno e amigão das horas cruciais. Conversávamos sobre as dificuldades que enfrentávamos numa cidade como São Paulo, junto à dura batalha sobre como seria nosso futuro, conseguirmos um emprego. Conversamos, colocamos para fora nossos medos e nossas revoltas, e assim acabava mais um dia como alunos em busca de alcançarmos nossos objetivos. Quantas vezes saímos para 
almoçarmos e jantarmos no bandejão, carentes e sozinhos, mas sempre em busca de um ideal. Trocamos idéias, brincamos, tomamos café e acima de tudo, buscávamos energias para continuarmos lutando. Leandro, nossas conversas foram muito frutíferas e merecemos tudo que falamos, pois somos pessoas dedicadas. A você Leandro, valeram demais meu irmão nossas conversas, as partidas de futebol a que assistíamos, e a ajuda mútua que nos demos. Desejo sucesso em seu caminho e que você nunca desista de ser a pessoa que é e coloque em prática seu conhecimento. Falar um simples oi é uma coisa, outra coisa é falar de nossos problemas.

Outros colegas que devo lembrar são o Renato Negrão, o Jurandir, o Renato e o Rodrigo (cabeleireiros), o Pereira (dono do bar onde por vezes comíamos), pessoas que sempre me fizeram bem, mesmo ilhados por tantas preocupações. A Iraci (do carrinho do cachorro quente), seu esposo Claúdio, e suas filhas, a Bruna e a Gisele, meu abraço quando eu chegava cansado e desafogava, sentado com vocês e brincando. Ao meu querido Luís, funcionário do departamento de Letras, amigo e vizinho, que bom que foram nossas conversas. A todos vocês, minhas sinceras lembranças. Sucesso para todos nós. Conversas nada eruditas, sem os clichês e chavões do mundo acadêmico que só esvaziam e simplificam demais os problemas maiores da mera sobrevivência.

Nessa ótica, os meus colegas funcionários do bandejão, com quem tantas vezes falei e que abracei, não poderiam ficar de fora dos meus agradecimentos. O clima sempre alegre desafogava as tensas leituras, sempre com prazo marcado, pois pela frente havia muitas outras leituras, sempre intermináveis.

Como sou uma pessoa por demais extrovertida e nada formal, momentos de alegria e brincadeira me proporcionavam mais ânimo. O ambiente acadêmico para mim sempre significou conhecimento dos clássicos, espaço de sérias discussões somado a boas aulas. Por isso sempre estive nas estantes na biblioteca, em busca deste ou daquele livro, ensaio ou recortes de jornal. É oportuno parabenizar e reconhecer o excelente acervo da biblioteca Florestan Fernandes, o IEB, o material já digitalizado que hoje integra o acervo da Brasiliana, doado pelo bibliófilo José Mindlin. Todas as minhas fontes se encontravam digitalizadas. 


\title{
INTRODUÇÃO
}

\begin{abstract}
"Há muito tempo, com efeito, nossos grandes precursores, Michelet, Fustel de Coulanges, nos ensinaram a reconhecer: o objeto da história é, por natureza, o homem. Digamos melhor: os homens. Mais que o singular, favorável à abstração, o plural, que é o modo gramatical da relatividade, convém a uma ciência da diversidade. Por trás dos grandes vestígios sensíveis da paisagem, [os artefatos ou as máquinas,] por trás dos escritos aparentemente mais insípidos e as instituições aparentemente mais desligadas daqueles que as criaram, são os homens que a história quer capturar. Quem não conseguir isso será apenas, no máximo, um serviçal da erudição. Já o bom historiador se parece com o ogro da lenda. Onde fareja carne humana, sabe que ali está a sua caça". Marc Bloch. Apologia a história ou o ofício do historiador
\end{abstract}

O objetivo desta pesquisa é analisar a interpretação brasileira de um importante escritor ligado ao campo explicativo de raças num momento de redefinição do Brasil do "passado" ao novo Brasil almejado pelas elites econômicas, política e intelectual. Como bem nos lembra Caio prado Junior, a partir de 1850, o Brasil atravessou uma conjuntura social e política que marcou profundamente a segunda metade do século XIX, tornando-se decisiva na transição Império-República. Enfrentando o problema da escravidão (que caracterizava o país como atrasado, fator associado a uma população negra e mestiça), razão alegada pela elite material e intelectual para explicar a barbárie do país, esta elite elegeu as Teorias do Evolucionismo, do Determinismo racial e geográfico e do Positivismo, para compreender o Brasil e apontar quais os rumos na empreitada do "progresso".

Do Determinismo racial de Buckle e Taine, emergiram os mais diversos olhares, a sociedade brasileira foi pensada e representada tendo por base as raças formadoras do país. Como resultado, surgiu à idéia de um caráter nacional, ideologia tão bem estudada por Dante Moreira leite. Sílvio Romero, por exemplo, como um dentre os vários polígrafos de seu tempo, foi um típico e fecundo escritor de sua época, introduzindo tensões inovadoras no campo da argumentação racial.

Sílvio foi um escritor que redirecionou o argumento das raças para a busca do povo, dos mais pobres e despossuídos, donos de uma cultura iletrada, mas não menos importante.

Essas teorias raciais e até racistas chegam ao Brasil especificamente em 1870, em instituições como museus, institutos históricos e faculdades de direito, e foram utilizadas pelas classes médias citadinas no combate ao Brasil de então em prol de um novo Brasil. Ainda com laços com as tradicionais oligarquias rurais, a Geração 1870 que contou com a participação de escritores como Sílvio Romero, Graça Aranha, Capistrano de Abreu, Euclides da Cunha, etc, elegeu como "chave explicativa" do novo Brasil o parâmetro racial e do meio ambiente. Esses dois parâmetros serviram para ojerizar o antigo Brasil, de economia rural e contando com uma população negra e mestiça e inaugurar um país moderno, "civilizado" e tendo que lidar com aquela população, todavia dotada de cultura e capacidade. 
Juntamente com o escritor sergipano e mulato Tobias Barreto (possivelmente uma das mais importantes referências para Sílvio), Romero fundou em torno da Faculdade de Direito do Recife, a Escola do Recife, rivalizando com os grupos e as panelas literárias cariocas. Defendeu arduamente a cultura de sua província, o Parnaso Sergipano, vendo nela originalidade em detrimento da macaqueação dos francesismos que chegavam da Corte. Nada de imitação de idéias e de costumes, clamava Sílvio, tudo por um Brasil real, sem ilusão, sem a mania de passar por aquilo que não somos. Guerreou políticos e escritores que se preocupavam, segundo ele, apenas com a vaidade, esquecendose do país, o Brasil Social é que merecia todas as atenções.

Sua paixão pelo Brasil ficou bastante evidente no momento em que identificou as várias oligarquias espalhadas de Norte a Sul do Brasil. A personalidade de Sílvio, um nacionalista ferrenho, não aceitava tanta corrupção num país onde milhões de pobres e analfabetos trabalhavam para manter a vaidade de meia dúzia de homens no poder. Inúmeras vezes reclamou dos políticos brasileiros despreocupados com os reais problemas nacionais, buscando identificar tais problemas, repará-los e prover os meios de mudança.

Autor de vasta obra, conhecedor das diversas áreas do saber, Sílvio escreveu desde a área literária ao campo do Direito. Sílvio Romero da Silva Ramos nasceu na pequena cidade de Lagarto, cidade pertencente ao estado de Sergipe, em 21 de Abril de 1851. Atendendo ao questionário de João do Rio em $O$ Momento Literário é que podemos conhecer sua trajetória. Como afirma Sílvio, o que parecia fácil num primeiro momento deixou-lhe neurastênico em função do pouco tempo que tinha. Mesmo antes do tempo combinado, João do Rio enviara o questionário, ressaltando que "Se não servir, rasgue" ${ }^{1}$. Sobre o questionário dizia Sílvio que, "Quando me afundei em mim mesmo, para sondar como se tinha operado o que se poderia chamar a minha origem e formação especial, conheci que essa espécie de exame de consciência não era nada fácil".2.

Filho de comerciante bem estabelecido em sua província de origem, de mãe portuguesa e bisneto de um poderoso político e dono de terras, Sílvio é um típico representante do Brasil em transição. Aos 18 anos se dirige ao Rio para realizar seus preparatórios, cinco anos depois ingressaria na Faculdade de Direito de Recife. No Recife, escreve nos mais importantes jornais e tem conhecimento de Comte, substituído depois pelo Evolucionismo de Spencer, acabando sua trajetória intelectual ligado aos escritores da Escola Social. Foi nesses tempos que produziu seus primeiros artigos, que culminaram na crítica ao Romantismo brasileiro e sua Obra Filosófica.

Polêmico e arrojado, Sílvio travou contendas literárias com os mais prestigiados homens de letras do cenário nacional. Romero participou como anota Nelson Werneck Sodré de todos os

\footnotetext{
${ }^{1}$ ROMERO, Sílvio. Outros Estudos de Literatura Contemporânea. Op.Cit.p.217.

${ }^{2}$ Ibidem. pp. 217-218.
} 
problemas concernentes aos rumos do país. Com uma fala afiada, desautorizou tudo e todos na implantação de um Brasil moderno.

Munido pela crítica naturalista, Sílvio interpretou o Brasil com as idéias mais recentes e “científicas" de sua época, inaugurando um novo olhar na compreensão de Brasil, não mais sob a visão Metafísica levada a cabo pela figura de Monte Alverne e pelas vertentes do Espiritualismo de Cousin. Proclamando ser o primeiro escritor a compreender o país sob o critério das raças, desautorizando escritores como Martius, Varnhagen e Veríssimo, Sílvio compreendeu seu país à luz da evolução social, das leis dos três estágios e da vitória do mais forte. Defensor da superioridade do branco em detrimento de índios e negros, no decorrer do processo histórico, defendia a vitória do europeu tanto no plano biológico como no plano cultural. Ao mesmo tempo, valorizou a mestiçagem e as culturas indígenas e africanas.

Por ter sido o Brasil colonizado pelos portugueses (raça latina, mas em estágio de decadência), encontrava-se o país em atraso nas mais variadas áreas. No campo das artes e das letras, o marasmo de nossos poetas era patente, nossa poesia era fraca e sem vida. Em algumas passagens de sua vasta obra, Sílvio ora mostrava-se um escritor determinista com argumentos racistas, ora pontuava possibilidades remotas da influência da cultura na mudança do quadro conjuntural brasileiro. Entre idas e vindas, a raça na obra de Sílvio é uma constante, embora associada a cultura e capaz de transformações.

Desse modo, é indispensável pontuarmos o desenvolvimento da pesquisa.

No primeiro capítulo, procuramos realizar uma leitura do Sílvio historiador da literatura, por algumas questões que consideramos indispensáveis. Primeiramente para mostrar a visão de um escritor munido da crítica naturalista, influenciado pelo evolucionismo, transformismo e pela influência dos fatores ambientais em sua leitura de Brasil. Romero pensou o Brasil literariamente tendo por base algumas teorias européias, e elaborou sua história literária apoiado nestas teorias. Possuidor de uma larga visão literária, - toda e qualquer manifestação da inteligência humana -, é de vital importância analisar a visão literária do polígrafo para que o leitor compreenda como o bacharel representou literariamente o Brasil e esboçou seus pensamentos em outras áreas, como a Sociologia, a Filosofia e a Política. Outra questão importante é a figura polêmica que foi Sílvio.

No segundo capítulo, iremos contextualizar o sentido da adoção da terminologia raça na Europa, situando sua entrada no Brasil e sua recepção/instrumentalização pelos escritores da geração de Sílvio. Conceito surgido no campo das ciências naturais, a terminologia raça acabou se tornando um verdadeiro fetiche na interpretação dos escritores da América Latina e do Brasil perante a situação de seus países. Pertencentes a uma nova camada social e formados culturalmente sob o influxo das teorias científicas, os intelectuais brasileiros compreenderam o Brasil vendo na raça a chave explicativa do país. Era consenso para os ensaístas da época de Sílvio o atraso do Brasil, no que cabiam meios para 
todo este quadro nos mais variados segmentos da sociedade brasileira. Sílvio, convicto de que era pela raça que se explicava o atraso do Brasil, e assim como vários escritores de sua época, identificava o país como atrasado e propôs meios de superação deste atraso, (social, cultural, político e econômico), para só assim ver seu país se tornar uma nação como as européias, branca e civilizada.

Em Interpretando o Brasil, analisamos a compreensão de Sílvio com relação aos elementos constituintes do atraso brasileiro. Influenciado pelo Determinismo racial, chega a Gobineau, Oto Ammon e Lapouge, dentre tantos escritores, Romero apontava os inúmeros problemas brasileiros, a seu ver, causas do atraso do país. Por ser a sociedade brasileira formada pela decadente raça latina, os problemas brasileiros possuíam ligação direta com a mesma, da qual os íberos eram descendentes. Imbuído do pensamento evolutivo, somado ao pensamento orgânico que admirava da Escola Social Francesa, fundada por Le Play, Sílvio elaborou uma análise minuciosa do Brasil, dividido em suas zonas sociais, do Oiapoque ao Chuí. Preocupado com o caráter nacional brasileiro e acreditando na importância de cada regional na formação deste caráter, Sílvio procurou entender o modo de vida, o trabalho, a família, o poder do chefe político, o grau de cultura, etc, da maior parte da sociedade brasileira, inculta, pobre e despossuída, no quadro deste atraso.

$\mathrm{O}$ atraso brasileiro nas mais variadas ordens devia-se à herança portuguesa, formadora de um caráter apático, sem vida, e acima de tudo, de um povo que não se preocupava com os problemas nacionais. Sílvio culpava a elite intelectual e política pelo desconhecimento da "verdadeira" ciência, elemento sine qua non para reverter todo esse estado de coisa.

Com tantos problemas, a ser ver alguns insolúveis, Romero propôs mudanças, apoiado acima de tudo na teoria evolutiva e na influência da raça, parâmetros formadores do campo das Ciências Sociais no Brasil na segunda metade do século XIX. O ensaísta buscou os "remédios" para alterar todo o quadro social brasileiro, fosse no campo econômico, político, literário, etc.

No capítulo sobre o índio, Sílvio releva a influência do nativo, esquecido pelos escritores nacionais e estrangeiros na compreensão do Brasil. Demarcando a rica contribuição deste, mesmo vivendo no estágio de barbárie, Romero procurou mostrar a importância indígena na formação da cultura brasileira. Umas das revoltas do polígrafo era a visão romântica da sociedade Brasileira por parte dos escritores nacionais que partiam da visão "tupiniquim" e "cabocla" para compreenderem o país. Na corrente romântica, formada por escritores como Alencar, Gonçalves Dias, Varnhagem, dentre outros, de estrema ligação com Pedro II, agremiados no IHGB, Sílvio desautorizou tofa a imagem erigida por estes homens de letras. Convicto da origem humana em vários pontos do mundo, Sílvio procurou provar a origem do índio "brasileiro" nas Américas, objetivando com isso erguer uma cultura brasileira autônoma, embora reconhecendo a participação maior do português na formação da sociedade brasileira. Desse modo, elabora o polígrafo toda uma análise do Brasil ao longo de sua 
história com a finalidade de mostrar os elementos formadores do caráter nacional brasileiro. Discutindo com autoridades intelectuais da época como Batista Caetano, Couto de Magalhães, Ladislau Neto, Teófilo Braga, Barbosa Rodrigues, Varnhagem, etc, Romero busca provar a independência do "selvagem" americano. O que mais o incomoda é a visão romântica da sociedade brasileira erigida pela elite política e letrada.

No capítulo a Imagem do Negro (africano), arrolando diversas populações africanas, o escritor sergipano salienta as injustiças cometidas pelo branco com as populações negras. Embora convicto da inferioridade biológica e cultural do africano com relação ao branco europeu, Sílvio tratou de analisar a história da escravidão do mesmo, não concordando com essa triste história. Salientamos a importância da escravidão no Império brasileiro, pensamos ser imprescindível traçar o ponto de vista da historiografia com relação ao africano que habitou o Brasil, seja no campo econômico, político ou intelectual.

No capítulo sobre o português, segundo Romero, raça que mais contribuiu para a formação brasileira, elaboramos uma leitura do tema desde a chegada de Cabral, inaugurando a visão idílica a partir da carta de Caminha ("certidão de nascimento") do Brasil para que fique clara a visão européia e científica do colonizador em relação à barbárie dos povos nativos. Escritores católicos como jesuítas e inacianos, alguns donos de vastíssimas terras, empreenderam uma visão literária completamente eurocêntrica, onde a rica cultura indígena era concebida como inferior. Embora não existisse na época uma Teoria sobre as raças, já se notava a aferição moral dos homens tendo por base a tônica dessa questão.

Por serem os primeiros habitantes no Brasil, Sílvio buscou traçar a contribuição do indígena, assim como do negro e do português, pensando encontrar o que era a base do caráter nacional brasileiro. Influenciado pelos estudos do Romantismo alemão que valorizavam a importância do "povo" (surgida numa Alemanha carente de identidade nacional), dos irmãos Grimm, acreditava na alma nacional, o que considerava ser o elemento mais importante na formação dessa identidade. Buscando encontrar esta alma, formada pela junção das três raças, Sílvio produziu sua obra etnográfica formada pelos Cantos Populares, Contos Populares e pelos Estudos sobre a Poesia Popular. Empreende o escritor uma difícil análise em busca das tradições de cada umas das raças, dessa rica tradição folclórica Sílvio concluiria pela singularidade do mestiço, elemento que dava identidade ao país por ser nosso traço diferenciador.

O mestiço mostrava-se ser a singularidade do país, tanto no plano biológico como cultural. Partindo deste Sílvio iniciava a primeira síntese cultural brasileira, resultado das Teorias e idéias científicas chegadas ao Brasil a partir de 1870, influenciando diretamente escritores como Gilberto Freire, Sergio Buarque e Oliveira Viana. Tema já tratado por Martius e Varnhagem, é da figura 
mestiça que Sílvio pensa o Brasil moderno, uma vez que este Brasil já possui sua identidade. E é a partir desse enfoque que chega ao limiar das raças, abrindo a análise social para campos de Cultura. 


\title{
I - SÍLVIO ROMERO: PONTOS DE PARTIDA
}

\begin{abstract}
(...) Meu amigo. - O seu questionamento pôs me em sérios embaraços .Logo que o recebi, supus ser cousa facílima o dar-lhe o dar-lhe imediata resposta.

Quando me afundei em mim mesmo, para como se me tinha operado o que se poderia chamar a minha origem e formação especial, conheci que essa espécie de exame de consciência não era nada fácil ${ }^{3}$ (...)
\end{abstract}

\begin{abstract}
"Este livro é um livro de amor feito por um homem que sente há perto de vinte anos sobre o coração o peso do ódio que lhe se tem votado em sua pátria

Não é fantasia; nem o autor precisa inventar sofrimentos, que lhe tenham sido infligidos, para passar por mártir. Bem longe disto.As calúnias, injúrias e descomposturas, que lhe começaram a atirar desde que pela vez primeira, em princípios de 1870, na Crença do Recife ,publicou um artigo de crítica, não deixaram mais de o visitar no correr dos muitos meses e muitos anos, que desde então se têm seguido".
\end{abstract}

A imagem de Sílvio Romero é bastante comprometida em função das inúmeras polêmicas que teve ao longo de sua carreira com as mais prestigiadas figuras do cenário literário, jornalístico e político brasileiro. Ao longo de seus quarenta anos de atividade literária, Sílvio esteve constantemente na arena literária, defendendo ou rebatendo idéias frente a seus opositores, muitas vezes se comportando de maneira agressiva, ferindo e humilhando frontalmente a honra pessoal do adversário. O próprio Romero descreve as origens de seu tom agressivo decorrente dos maus tratos que recebera de irmãos quando criança. Para além de uma análise de crítica psicológica que busca investigar as relações entre a produção artística e a personalidade do autor, toda a produção de Sílvio é fortemente marcada por esse lado temperamental que ele mesmo tratou de legitimar ao longo de sua carreira literária. Utilizava de uma passagem de Tobias Barreto, amigo, conterrâneo, fundador da Escola do Recife, e muitas vezes se apoiou no autor dos Estudos Alemães. Tobias Barreto foi um dos raros nomes que ficaram infensos as duras críticas de Sílvio Romero

"Se o fim dos que escrevem, como pensava o velho Vilemain, é agradar, ninguém mais há falhado a esse fim do que o autor. Ele tem consciência de haver desagradado em toda a linha.

\footnotetext{
${ }^{3}$ Silvio Romero transcreve sua entrevista concedida a João do Rio em seu estudo citado a seguir. ROMERO, Sílvio. O Momento Literário. In: Outros Estudos de Literatura Contemporânea. Lisboa: Tipografia: Lisboa, 1906. Porém, na edição comemorativa publicada em 2002 pela editora imago e com participação da Universidade Federal de Sergipe, o capítulo $O$ Momento Literário não se encontra. Desse modo iremos recorrer às duas obras para o desenvolvimento deste capítulo. A entrevista de Sílvio concedida a João do Rio é o documento mais importante que serve de base para uma série de trabalhos sobre a vida e a obra do autor. Consultamos alguns trabalhos, como os seguintes. ABRANCHES, Dunshee de. Notícia biográfica do autor. In: ROMERO, Sílvio. Evolução da Literartura Brasileira (Vista Sintética). Campanha, 1906. pp. 9-18. MENDONÇA, Carlos Sussekind de. Silvio Romero: sua formação intelectual 1851-1880. São Paulo-Rio de JaneiroRecife-Porto Alegre: Companhia Editora Nacional, 1938. RABELO, Silvio. Itinerário de Silvio Romero. Rio de Jan eiro: José Olimpio, 1944. SOUZA, João Mendonça de. Silvio Romero, o Crítico e o Polemista. Rio de Janeiro: Companhia Editora Americana, 1976. BARRETO, Luiz Antonio. Silvio Romero, uma Informação Bibliográfica. In: Compêndio de História da Literatura Brasileira. Rio de Janeiro: Imago Ed., Universidade Federal de Sergipe, 2001. pp. 407- 415. LIMA, José Augusto da Rocha. Silvio Romero: Pensador, Escritor e Mestre. In: Revista de Aracaju, no 4. Aracaju, 1951. VENANCIO FILHO, Alberto. Introdução; Cronologia. In: Doutrina contra Doutrina. ROMERO, Silvio. São Paulo: Companhia das Letras, 2001. pp.7-31.
} 
Entretanto, não quer fazer supor que se tem na conta de um inocente, atacado sem motivo; não. A razão da bulha, da gritaria, dos insultos, sabe o autor que foi ele quem a forneceu.

$O$ arrojo nervoso de seu temperamento manifestou-se sempre em sua critica e a tornou desde o principio capaz de rudimentar e chocar os espíritos mais desabusados. Todos os seus artigos, todos os seus livros deram ensejo a queixas e a ressentimentos. Não é mister chegar até aos inimigos para o provar; o testemunho dos próprios amigos e suficientissimo aqui.

Tobias Barreto, que não peca por moderado, no Contra a Hipocrisia, disse que o critico e o polemista faziam no autor um tal aliança que infalivelmente haviam de depenar quem lhe caísse nas unhas. Citou então a celebre fabula do individuo que tinha duas apaixonadas, uma que não gostava dos cabelos pretos e a outra que não gostava dos brancos, e pozera-se a arrancal-os cada uma de seu lado ao amante, reduzindo a completa calvície” " ${ }^{4}$ (...) (grifos nosso)

A face polêmica de Romero ganha cada vez mais sentido e força a partir de um artigo que até hoje encontra respaldo numa historiografia literária bastante conhecida, mas muito atualizada, norteando estudos e mais estudos sobre sua vasta produção ensaística. É o artigo de Araripe Junior, Silvio Romero, Polemista ${ }^{5}$, crítico literário contemporâneo de Romero e uma das vítimas de seus ataques, publicado na Revista do Comércio em 1898. Conhecedor das leituras do positivismo e do evolucionismo, integrante da Academia Francesa surgida em 1872 no Ceará, Araripe analisa o caráter polêmico do bacharel desprovido da flexibilidade indispensável às convenções para habitar nos grandes centros, "Um elemento, contudo, lhe faltava, - e isto é bastante para explicar a grita que se levantou então, - um elemento indispensável a todos aqueles que, propondo-se uma propaganda difícil, são forçados a realizá-la rapidamente e entre gente habituada aos requintes da vida incomparável das grandes capitais. Esse elemento é a sagacidade ou a polidez artificial dos centros civilizados, e a que Schopenhauer se referia, dizendo que, sem ela, os homens se entre devorariam. Sílvio Romero não a possuía. Apresentando-se na arena nu, como um atleta antigo, e com os seus hábitos de franqueza nortista, o crítico sergipano foi recebido a maneira de um bárbaro. Pouco importava que esse bárbaro trouxesse um cérebro iluminado pelos focos científicos do neocriticismo alemão. A dinâmica de suas idéias, a rudeza dos seus argumentos, a negação peremptória de um regime literário extinto na Europa, não podiam deixar de produzir, em seu espírito, indignações indefiníveis; estas não buscaram contornar a suscetibilidade dos que ainda sustentavam os programas de 1830 como expressão última do progresso" 6

Mas foi justamente o temperamento polêmico de Romero um dos motivadores de sua vasta produção e contribuição ao pensamento brasileiro. O lado polêmico salientado por Araripe Junior chama atenção para um escritor de caráter agressivo, temperamento violento que não se furtava a

\footnotetext{
${ }^{4}$ ROMERO, Silvio. História da Literatura Brasileira. 6a. Rio de Janeiro: José Olímpio, 1960.p.33

${ }^{5}$ ARARIPE JUNIOR, Tristão de Alencar. Silvio Romero, Polemista. Revista Brasileira, XV, 1898, PP. 185-203, 371-9; XVI, 1898, PP.112-21, 188-204; XVII, 1899, PP. 43-70; Os Anais, Rio de Janeiro, II, 15, 19 de janeiro de 1905, pp. 34-37. Reeditado em Araripe Junior, Obra Crítica, Ed. Afrânio Coutinho. Rio de Janeiro, Casa de Rui Barbosa, 1958-70, 5 vols., vol.III, 1963, pp. 271-332.

${ }^{6}$ Ibidem. p. 273
} 
entrar nas discussões literárias e políticas sempre se contrapondo a seus adversários para mostrar seus ideais e responder, quando se sentia no direito, com posição definida. Diversas vezes falou que era agredido, perseguido e caluniado, motivo para suas duras respostas. Desse modo, faz-se necessário relatar alguns episódios polêmicos da carreira literária de Romero, clareando a imagem do polígrafo agressivo e que dizia agir em nome da verdade, para só então partirmos para sua contribuição.

Iniciando pela análise do artigo de Araripe Junior, que era segundo Romero, “réplica á resposta que lhe eu havia dado relativa às suas objeções sobre nossa História literária", ${ }^{\text {, }}$ respondia o sergipano em Ainda a História da Literatura Brasileira e o Dr. Araripe Júnior. O cerne da discussão dizia respeito a quatro pontos em dúvida: influência dos índios, apreciação dos cronistas, divergência dos núcleos primitivos e energia do clima. Contrário a Araripe, Romero dava mais influência à raça do que ao meio e apontava a falta de estudos dos negros por parte dos escritores brasileiro do período, afirmando:

\footnotetext{
“Devemos também iniciar os estudos africanos. O negro, espalhado pela África e América, é uma raça que oferece interessantes problemas.

Muitos sábios europeus, seguindo o exemplo do ilustre Bleek, atiram-se a estas pesquisas. Façamos o mesmo. O negro e seu parente mestiço tocam o nosso povo bem de perto. Não sejamos presunçosos, nem tenhamos medo de dizer a verdade ",
}

Interessado pelas origens da formação brasileira, era imprescindível para Romero averiguar a participação do negro, tema esquecido pela geração romântica e somente abordado de maneira descritiva por Martius, carecendo dos nexos causais. Polemizou com os escritores do Romantismo pelo fato de exagerarem a contribuição do índio, desconsiderando o negro, posotura alicerçada sobre a suposta nobreza tupiniquim, "Já não é mais tempo de o representar na figura dum caboclinho, mais ou menos boçal, que se dava por agente de 1822 e supunha ter aqui suplantado o reinol..."." Zeverissimações Ineptas da Crítica, última obra de Sílvio, é um ajuste de contas com o também crítico literário paraense José Veríssimo, por ele considerado de pouca capacidade filosófica além de beneficiado pelos medalhões literários para seguir carreira literária no Rio de Janeiro, “Com os medalhões fundou revistas, ajudou a formar academias, fez círculos de palestras, nos quais havia, oh! maravilha rara! um curioso Five ó cloc-tea...". 10

\footnotetext{
7 ROMERO, Silvio. Estudos de Literatura Contemporânea. Rio de Janeiro: Imago; Sergipe: Universidade Federal de Sergipe, 2002.p. 119.

${ }^{8}$ ROMERO, Sílvio. Estudos de Literatura contemporânea. Op.Cit.p.123

${ }^{9}$ ROMERO, Sílvio. História. Op.cit.p. 36

${ }^{10}$ ROMERO, Sílvio. Autores brasileiros: (edição comemorativa). Rio de Janeiro: Imago; Aracaju, Sergipe: Universidade Federal de Sergipe, 2002. p.504
} 
Com o hábito de apelidar seus adversários, denominou Veríssimo de tucano empalhado, Saint Beuve boi, criticastro paraense, manhoso pescador, pescador de tartarugas, sedoso marajoara, patureba de Belém, atrazadíssimo criticalho, que "não comprehende a ethnographia, a historia e a philosophia, nada sabe de mythologia, de critica religiosa, de economia política, de direito, de moral, de sciencia social, o que importa dizer, que é um incapaz e um incompetente para julgar a vida intrínseca d'um povo qualquer, porque desconhece as mais rudimentares sciencias que se occupam das creações fundamentaes da humanidade. Não conseguiu passar dos primeiros annos da Polytechnica; fez uns pequeníssimos estudos de parcos preparatórios; abeberou-se em revistas de sovadas idéias geraes, de noções rápidas a respeito de todas as cousas, sem a mais leve especialisação; percorreu como amador alguns livros de Taine, de Brunetière, de Renan, principalmente d'este ultimo; encheu a cabeça de pedagogices suspeitas, de leituras de romancistas e poetas de segunda e terceira ordem, e achou-se preparado para julgar quaesquer livros nacionais, que lhe vão caindo nas mãos". 11

Zeverissimações é um árduo revide ao Zezé, considerado por Romero um desconhecedor da crítica, que só papagaiava sem ao menos saber ler francês. Não poupou de retratar a alegada ignorância do crítico paraense quando este analisava uma publicação de Lichtenberg

\footnotetext{
Dificilmente poder-se-ia encontrar um mais autêntico documento da ignorância $e$ incapacidade do famigerado tucano.

Nem de propósito, nem por encomenda, poderia ele fornecer um mais genuíno testimonium paupertatis de seu lastimável estado mental. Erros e ignorâncias acerca de triviais assuntos brasileiros abundam ali. Acerca de Schopenhauer, Nietzsche, metafísica, sistemas filosóficos, questões de arte, coisas políticas, não passa o tal artiguete de charivari de mil diabos.

Cada tese tem na rabadilha a sua antítese um tecido pelo direito e pelo avesso um rosário de contradições por atacado nuns retalhos de poucas linhas. Que lástima.

Ora para que havia de servir o livro de Lichtenberg: José Veríssimo metido a falar de filosofia e filósofos, palavras que ele nem sabe soletrar!.... ${ }^{12}$.
}

Sílvio queria atestar de todas as formas que dominava várias línguas para comprovar sua capacidade de assimilar as idéias novas. Neste estudo, o intuito de Sílvio foi demonstrar que as leituras científicas se tornaram conhecidas entre nós primeiramente no Recife e que sabendo com facilidade o alemão, era ele o responsável pela introdução do critério etnográfico que norteou seus estudos. Não se conformava por não ser reconhecido como o introdutor da nova maneira de conceber os estudos sociais baseado no caráter etnográfico que dizia ter introduzido. Sempre defendeu o pioneirismo de seu grupo do Recife, inovador na maneira de conceber as ciências sociais no Brasil se apoiando na influência da cultura alemã que salientava a importância das raças ${ }^{13}$.

\footnotetext{
${ }^{11}$ Ibidem. p. 507

12 Ibidem. p.532

13 Que é Literatura? e outros escritos publicado em 1907 é a causa para que tempos depois, em 1914, Sílvio publicasse as suas Zeverissimações Ineptas da Crítica. O cerne da discussão entre Romero e Veríssimo se dá por que o paraense
} 
As acusações de Sílvio com relação a Veríssimo eram graves, descrevendo os vários empregos do paraense, como ser diretor da Revista do Comércio devido a suas relações amigáveis com personagens como Escragnole Taunay, Joaquim Nabuco, Rui Barbosa, Machado de Assis, Lúcio de Mendonça, Ferreira de Araújo, Araripe Júnior, Capistrano de Abreu, João Ribeiro, Arthur de Azevedo, Medeiros de Albuquerque, Graça Aranha, Magalhães de Azeredo, João de Souza Bandeira, Rodrigo Otávio e Oliveira Lima.

\footnotetext{
"Por meio da luta e só da luta não obteria nada, absolutamente nada. A prova temo-la no seu desastradíssimo concurso de historia...

Nem as duas poderosas muletas do envenenado Capistrano de Abreu e do nobilíssimo Gabaglia o puderam salvar do pavoroso desastre que o deveria ter feito emudecer por vinte anos, se ele tomasse mais a serio a devastação das derrotas irreparáveis.

Medalhões que the fabricaram renome, jornais que lhe dão dinheiro e fornecem a arena para exibições diárias e semanais, homens poderosos que the garantem empregos ou comissões não lhe bastariam". 14
}

Outra polêmica que marcou profundamente a face pública de Sílvio foi com Machado de Assis. O livro dedicado ao ilustre romancista brasileiro é um protesto contra a consagração ali julgada não merecida da figura do escritor, que não superaria Tobias Barreto. Para Lafayette Rodrigues, o livro bem poderia se chamar de Tobias Barreto. Não aceitava Sílvio a consagração literária de Machado enaltecido por aqueles que legitimavam a imagem do escritor mais ilustre do Brasil para benefício próprio, considerava o autor de Brás Cubas um mau escritor e um poeta de terceira ou quarta ordem. À luz da crítica de escritores como Hennequim, Taine, Scherer e Fauguet, analisava Sílvio o espírito de Machado "um representante do espírito brasileiro, mas num momento mórbido, indeciso, anuviado, e por um modo incompleto, indireto, e como que a medo". ${ }^{15}$ Continuava descrevendo o espírito machadiano que "não possui ainda ideais conscientes a realizar, nem um corpo de tradições $e$ feitos históricos que constituam uma espécie de modelo, de paradigma para ações futuras". ${ }^{16} \mathrm{O}$ estilo

considera Francisco Adolfo de Varnhagen "o instituidor da nossa História literária". Não admitia Romero o argumento de Veríssimo de considerar o autor do Florilégio e da História Geral a hipótese de "Continuo a sustentar, e todos os documentos me dão razão, que Varnhagen foi o instituidor da nossa História literária, principalmente da História literária como a concebeu e realizou o Sr. Sílvio Romero na sua História da Literatura Brasileira, cuja inspiração e economia derivam muitíssimo mais das locubrações de Varnhagen que das generalizações, ainda desapoiadas de uma informação completa e exata, de Fernando Denis ou Norberto Silva. O que eu quis e quero dizer, é que Varnhagen foi o primeiro que, depois de Barbosa Machado, um simples e desconchavado bibliófilo, fez pesquisas e achados dos nossos documentos literários, suprindo ou completando as lacunas do bibliófilo português, e ao invés dos seus antecessores, que quase só da poesia se ocuparam, abrangendo nas suas pesquisas e estudos todos os produtos da nossa incipiente vida espiritual. Sei perfeitamente (relevem-me o vitupério) o que antes dele fizeram Norberto Silva e Ferdinand Denis, Bouterwek e Sismondi, etc. Mas tudo o que estes fizeram antes de Varnhagen, o único deles talvez que tinha capacidades de erudito e não foi um simples repetidor, é inferior, pálido, e descolorido em comparação da obra de Varnhagen sobre as nossas origens literárias. VERÍSSIMO, José. Que é Literatura? E outros estudos. São Paulo: Landy, 2001.

${ }^{14}$ ROMERO, Sílvio. Autores brasileiros. Op.Cit.p.506

15 Ibidem. p. 205

${ }^{16}$ Ibidem. p. 205 
machadiano era senão a "fotografia exata do seu espírito, de sua índole psicológica indecisa. Correto e aneiroso, não é vivace, nem rutilo, nem grandioso, nem eloqüente. E' plácido e igual, uniforme e compassado. Sente-se que o autor não dispõe profusamente, espontaneamente do vocabulário e da frase. Vê-se que elle apalpa e tropeça, que sofre de uma perturbação qualquer nos órgãos da palavra. Sente-se o esforço, a luta. Ele gagueja no estilo, na palavra escrita, como fazem outros na palavra falada», disse-me uma vez não sei que desabusado n'um momento d'expansão, sem reparar talvez que dava-me destarte uma verdadeira e admirável notação critica. Realmente, Machado de Assis repisa, repete, torce, retorce tanto suas idéias e as palavras que as vestem, que deixa-nos a impressão d'um perpétuo tartamudear. Esse veso, esse sestro, para muito espírito subserviente tomado por uma coisa conscienciosamente praticada, elevado a uma manifestação de graça e humor, é apenas, repito, o resultado de uma lacuna do romancista nos órgãos da palavra. ${ }^{17}$

No estudo sobre Machado, Sílvio considera o romancista como um homem "frívolo e inofensivo como é, é tanto mais para ser combatido, quanto pela dubiedade de seu caráter político e literário em nada pode ajudar a geração que se levanta e a quem insinua-se por amigo" ${ }^{18}$. Desprestigiou o dito mestre incomparável do romance nacional primeiramente em razão do ceticismo de Machado com relação às idéias novas defendidos pela Escola do Recife, a nova geração, cujo nome maior seria o próprio Romero; em segundo lugar, em função do intelectual que era Machado, "sem convicções políticas, literárias ou filosóficas, não é, nunca foi um lutador. Esse auxiliar de todos os ministérios, esse rábula de todas as idéias, é, quando muito, o conselheiro da comodidade letrada" ${ }^{19}$. Acusado por Sílvio de não ter identidade literária, daí surgia o cerne das críticas movidas deste ao romancista. O modelo de escritor combatente e polêmico que era Sílvio era o oposto em todos os níveis do escritor supostamente plácido que seria Machado. O escritor carioca, assim como Veríssimo e tantos outros, sofreram críticas devido à acusada ausência de nacionalidade presente em suas respectivas obras. Em relação a Machado, "Não tem, por certo, tido influência quase nenhuma no espírito nacional, não pelas razões apontadas pelo Sr. José Veríssimo; porem pura e simplesmente pela índole mesma de seu gênio literário: a falta de calor, de comunicabilidade, de entusiasmo, de vida, essa centelha de proselitismo própria das almas combatentes". ${ }^{20}$

Machado era, para Romero, a representação de uma visão de mundo arcaica, que precisava ser combatida,"simboliza hoje o nosso Romantismo velho, caquético, opilado, sem idéias, sem vistas, lantejoulado de pequeninas frases, ensebadas fitas para efeito. Ele não tem um romance, não tem um volume de poesias que fizesse época, que assinalasse uma tendência. É um tipo morto antes de tempo

\footnotetext{
${ }^{17}$ Ibidem. p. 180

${ }^{18}$ ROMERO, Sílvio. Estudos de Literatura contemporânea. Op. Cit.p.144

${ }^{19}$ Ibidem.p.144-145

${ }^{20}$ ROMERO, Sílvio. Autores brasileiros. Op.Cit.p.334
} 
na orientação nacional". ${ }^{21} \mathrm{Na}$ verdade, incomodava a Romero o estilo pessimista, humorístico e conteur de Machado, que, em seu entendimento, não condizia com o cenário nacional brasileiro, diferentemente dos grandes prosadores que escreviam de maneira espontânea devido ao rigor da observação. Jamais aceitaria Sílvio devaneios literários, por isso considerava Machado um escritor de "Natureza eclética e tímida, sem o auxílio de uma preparação conveniente, entrou a ser um parasita, espécie de comensal zoológico, vivendo à custa de uma combinação do classicismo e do Romantismo" 22. Machado de Assis propõe não somente a defesa de Tobias Barreto, visto por Romero como escritor injustiçado, maltratado, mas superior ao autor de Quincas Borbas, como também é um protesto para o reconhecimento do grupo intelectual formado sob responsabilidade sua e de Tobias Barreto, de escritores jamais reconhecidos porque não se encontravam no Rio, porque nunca saíram de estados como Maranhão e o Sergipe.

Pôs em xeque a capacidade criadora de Machado de Assis por sua poesia tranquila, entendida por Sílvio como sem força e calor porque o escritor, para ele, teria que ser combatente, uma vez que tinha uma missão a cumprir. O autor de Dom Casmurro era o escritor oposto a Sílvio. Enquanto para Machado era preciso certo sentimento íntimo, um ideal de crítico diferente do que esperava Sílvio que analisava obras querendo ver patriotismo nestas a partir da visão dele próprio, o escritor sergipano foi bem o intelectual que Nicolau Sevcenko denominou de mosqueteiro intelectual que lutava na linha de frente do jornalismo literário participando das lutas abolicionistas e republicanas durante os idos de $1870{ }^{23}$. Para Machado não bastava pura e simplesmente assimilar o "bando de idéias novas" oriundo da Europa para falar do Brasil, fosse por meio da prosa ou da poesia, era preciso, a priori, um sentimento íntimo para buscar a nacionalidade literária, "Um homem pode ter as mais elevadas idéias, as comoções mais fortes, e realça-las todas por uma imaginação viva; dará com isso uma excelente página de prosa, se souber escrevê-la: um trecho de grande ou maviosa poesia ser for poeta. O que é indispensável é que possua a forma em que se exprimir. Que o Sr.Romero tenha tenha algumas idéias de poeta não lho negará a crítica: mas logo que a expressão não traduz as idéisa, tanto importa não as ter absolutamente. Estou que muitas decepções literárias originam-se nesse contraste da concepção e da forma; o espírito, que formulou a idéia, a seu modo, supõe havê-la transmitido nitidamente ao papel, e daí um equívoco. No livro do Sr. Romero achamos essa luta entre o

\footnotetext{
${ }^{21}$ ROMERO, Sílvio. Estudos de Literatura contemporânea. Op.Cit. p.144

${ }^{22}$ Ibidem. p. 144

${ }^{23}$ SEVCENKO, Nicolau. Literatura como missão: tensões sociais e criação cultural na Primeira República. $4^{\mathrm{a}}$ ed. São Paulo: Brasiliense, 1995.
} 
pensamento que busca romper do cérebro, e a forma que não lhe acode ou só lhe acode reversa e obscura: o que dá a impressão de um estrangeiro que apenas balbucia a língua nacional" 24

Romero criticou o "papa" da Literatura nacional justamente devido a sua descrença com relação às idéias científicas "Não tendo, por circunstâncias da juventude, uma educação científica indispensável a quem quer ocupar-se hoje com certas questões, e aparecendo no mundo literário há cerca de vinte e cincos anos, o Sr. Machado de Assis é um desses tipos de transição, criaturas infelizes, pouco ajudadas pela natureza, entes problemáticos, que não representam, que não podem representar um papel mais ou menos saliente no desenvolvimento intelectual de um povo. Quando ele apareceu, já na Europa o Romantismo estava plenamente em dissolução, e no Brasil o olhar exercitado podia bem distinguir os germens de decadência que lhe rompiam no seio. O Romantismo já tinha produzido entre nós suas melhores obras na poesia, no romance e no drama. Magalhães, Porto Alegre, Pena, G. Dias, Álvares de Azevedo, Macedo, Teixeira e Souza, Junqueira Freire para só falar nestes oito, haviam levado a efeito suas melhores produções e criado em torno de si uma multidão de epígonos. Alencar já tinha produzido seu Guarani, rasgando novos horizontes ao romance nacional. O Sr. Machado tinha, portanto, de ocupar um lugar secundário na cauda do Romantismo, na frase de Zola, a não ser ele uma inteligência superior. É o que não é, e por isso ficou justamente no lugar que lhe competia", 25

Diferentemente, Machado de Assis argumentava: "Não se pode exigir da extrema juventude a exata ponderação das coisas; não há impor a reflexão ao entusiasmo" ${ }^{26}$. Romero viria a discordar de Machado primeiramente porque não era este um intelectual como pensara o bacharel, o autor de Esaú e Jacó era o típico escritor que primara pelo estilo e não por uma Literatura onde se pudesse expor da maneira mais livre possível uma denúncia. Machado era possuidor de um estilo e de uma capacidade irônica crítica apurados, ao passo que Sílvio era o agitador e vulgarizador de idéias. O autor de Dom Casmurro ironizaria o entusiasmo da nova geração por meio do célebre personagem Simão Bacamarte, que chega à Vila de Itaguaí conhecendo as idéias do positivismo e do evolucionismo. Incutido o médico das idéias de teorias de Pinel e Esquirol acerca da loucura a cada dia punha mais pessoas no sanatório restando o trágico fim de que a anormalidade residia no próprio médico. ${ }^{27}$

\footnotetext{
24 ASSIS, Machado de. Obra completa. V.III. Rio de Janeiro: Editora Nova Aguilar, 2008.p.828. "Reconhecido o instinto de nacionalidade que se manifesta nas obras destes últimos tempos, conviria examinar se possuímos todas as condições e motivos históricos de uma nacionalidade literária; esta investigação (ponto de divergência entre literatos), além de superior às minhas forças, daria em resultado levar-me longe dos limites deste escrito. Meu principal objeto é atestar o fato atual; ora, o fato é o instinto de que falei, o geral desejo de criar uma Literatura mais independente" ${ }^{24}$. Op.Cit.p.802

${ }^{25}$ ROMERO, Silvio. Estudos de Literatura Contemporânea. Op.Cit.pp.143-144

${ }^{26}$ ASSIS, Machado de. Op.Cit.p. 810

${ }^{27}$ MURICY, Kátia. A razão cética: Machado de Assis e as questões de seu tempo. São Paulo: Companhia das letras, 1988.
} 
Mas os desafetos de Romero não findaram em Machado de Assis. Veio a criticar Romero toda a geração dos escritores românticos, como Alencar, os Macedos e os Magalhães, a filosofia espiritualista de Victor Cousin, esteio simbólico do primeiro Império Brasileiro, tão bem assimilada e divulgada pelo católico Monte Alverne, porque a imagem divulgada pelo Romantismo brasileiro, além de não incluir o negro na História literária nacional, era fantasiosa. Sua crítica ao status quo imperial, como a de grande parte de sua geração, recaía sobre os escritores do Romantismo brasileiro, criadores e divulgadores de uma imagem considerada fantasiosa da realidade nacional. Vale lembrar que Silvio Romero começara sua carreira literária escrevendo na Crença do Recife, combatendo os escritores do Romantismo. A crítica aos escritores do Romantismo brasileiro se processava na medida em que considerava como mania tupiniquim destes escritores, quando no Brasil chegavam às idéias do determinismo e do evolucionismo, caracterizando o início da agitação do bando das idéias novas. O ataque ao Romantismo datava dos tempos em que era aluno na Faculdade de Direito quando publica seu primeiro ensaio, A Poesia contemporânea e sua intuição naturalista, em 1869.

É bem verdade que divagara Sílvio pelo campo da poesia com seus Cantos do Fim do Século (1878) e Último Arpejo (1883), sendo considerado por Antonio Candido um mau poeta, e adotou os preceitos da crítica naturalista como preponderante em sua vasta produção. Mas o que nos interessa é sua contribuição como intérprete do Brasil. Foi Sílvio o promotor de uma nova forma de percepção, de e interpretação da cultura brasileira: seu nome é a própria personificação da Escola do Recife. Em seu quadro da filosofia brasileira, criticou todos os seguidores do positivismo no Brasil que seriam os inauguradores do comtismo no Brasil, poupando somente Tobias Barreto. Combateu o médico Luis Pereira Barreto, autor das Três Filosofias; o Visconde do Rio Grande que publicara em 1875; o Fim da Criação ou a Natureza Interpretada pelo senso Comum, e a tese intitulada As Funções do Cérebro do médico Dr. Domingos Guedes Cabral. Combatendo diversos escritores, mesmo que depois viesse a reconhecer o merecimento dos mesmos, podemos arrematar o espírito combatente com relação à situação filosófica no Brasil. Sílvio carregava a fama de belicoso e destemperado, escritor que não poupava ninguém. Era bem o que traça Antonio Dimas quando afirma que o bacharel, "nunca se intimidou na sua coragem sertaneja e nem economizou seu verbo abundante, algumas vezes prolixo, algumas vezes repetitivo e prolixo, na defesa de seus pontos de vista." ${ }^{28}$ Nada restava para Sílvio quando analisava livros, artigos, poemas. Era característica de sua personalidade a reprovação, a polêmica, a crítica. Máximas como essa eram corriqueiras nas análises de Sílvio: "Pode afirmar, em virtude da indagação histórica, que a Filosofia, nos três primeiros séculos de nossa existência, nos foi totalmente estranha" 29

\footnotetext{
${ }^{28}$ DIMAS, Antonio. O turbulento e fecundo Sílvio Romero. In: Um enigma chamado Brasil: 29 intérpretes e um país. p.78

${ }^{29}$ ROMERO, Sílvio. Obra Filosófica. Rio de Janeiro: José Olímpio; São Paulo: Edusp, 1969. p.7
} 
Discordando dos seguidores de Comte no Brasil, Romero trazia consigo as concepções naturalistas embutidas em sua maneira de interpretar a sociedade brasileira. O movimento de renovação cultural que começou pela Faculdade de Direito do Recife reprovou tudo e todos, exceto o nome de seu conterrâneo Tobias Barreto, assim como Sílvio, responsável pelo surgimento do grupo intelectual e modelo de escritor polêmico que só reforçou seu temperamento. Apesar de ter afirmado que Tobias não fora seu mestre, mesmo reconhecendo que lhe devesse algumas idéias, pontuando pontos de encontro e desencontro, o também sergipano jamais sofrera conflitos com Sílvio. $\mathrm{O}$ fato de nunca ter ido ao Rio de janeiro e de ser mulato são argumentos elencados por Sílvio em defesa da injustiça cometida contra Barreto.

Essa é só mais uma das polêmicas de um escritor de vasta produção, que não deve ser lido deixando que esse viés se torne mais relevante do que o conhecimento de sua produção e contribuição para o entendimento do Brasil. É redundância ou simplismo por parte da historiografia se ater preferencialmente ao lado polêmico do autor na tentativa de compreender sua obra porque embora saibamos que boa parte de tal produção tenha sido motivada por questões pessoais até em defesa da honra, o sentido da produção ultrapassa esse limite. Fazemos tal ressalva porque sabemos que as obras de Romero não se propõem a esmiuçar o caráter dele próprio, visam a nomes específicos, buscam o reconhecimento de seu grupo do Recife e escritores que ainda não eram beneficiados com o que ele considerava relações amistosas na república das letras. Toda essa vasta produção é sim comprometida com o tipo de escritor que foi provido de forte temperamento, mas nos cabe apenas registrar este aspecto e seguirmos suas convicções para avançarmos em nossas análises a partir de sua visão e contribuição de interpretar o Brasil. É inadmissível descartar o traço polêmico como inseparável de suas leituras e interpretações adotando o Naturalismo para interpretar a sociedade brasileira, ponto de inflexão para pensar um novo Brasil com o impacto das idéias novas, diferentes da geração anterior que bem se confortou no Romantismo, a retórica e a metafísica. O grito de alarma contra toda uma ordem considerada atrasada justifica a reprovação constante aos vários escritores e à conjuntura do país, almeja Sílvio um Brasil totalmente livre, independente, e acima de tudo, com uma nacionalidade ou identidade própria, diferente dos tempos em que predominava o atraso em todas as esferas.

Outro episódio que só reforçou a figura polêmica de Sílvio e muito comprometeu-lhe a carreira literária foi sua defesa de tese em 1875, quando receberia o grau de doutor em ciências jurídicas e sociais. Durante a arguição, chegou a desacatar frontalmente a banca examinadora da Faculdade de Direito do Recife. Chegado o momento da sabatina, o professor Dr. Antônio Coelho Rodrigues sustentava suas idéias tendo ainda por base a metafísica clássica, principal elemento da crítica de Romero. Afirmava Sílvio que 
“- Nisto não há metafísica, senhor doutor, há lógica.

- A lógica não exclui a metafísica.

- A metafísica não existe mais, senhor doutor. Senão sabia, saiba!

- Não sabia.....

- Pois vá estudar e aprender para saber que a metafísica está morta.

- Foi o senhor quem a matou?

- Foi o progresso e a civilização!

- Não estou para aturar essa corja de ignorantes, que não sabem nada" 30.

Quando perguntado quem matou a Metafísica, respondeu Romero que havia sido o progresso e a civilização. Esbravejando de raiva, levanta o bacharel, toma dos livros e denomina a banca examinadora de corja de ignorantes, mandando os três professores estudarem para ficarem a par das idéias novas. Esse episódio constitui, juntamente com a birra que tinha em relação a Machado de Assis, os mais marcantes dentre suas polêmicas. Falava Romero que não estava "para aturar esta corja de ignorantes, que não sabem nada" ${ }^{31}$. Algum tempo depois, viria a escrever um opúsculo denominado Se a Economia Política é uma Ciência, tese de um professor da Faculdade de Direito do Recife de 1873 , onde descrevia a situação do atraso cultural da Faculdade de Direito do Recife, “ $A$ Faculdade de Direito do Recife tem o privilégio do estacionamento. Há cinqüenta anos agita-se o mundo científico por fora, e ainda ali não se ouviram os ruídos de tantas pugnas. Há cinqüenta anos a sua congregação togada vai recebendo como religiosa herança, o mesmo punhado de princípios vertidos nas mesmas fórmulas programáticas. Quem intentasse escrever a História daquele instituto da ciência achar-se-ia, de pronto, diante do fato anômalo de um corpo docente, que repete as mesmas noções, repisa as mesmas idéias, declama as mesmas decrepitudes e, ao todo, ordena as mesmas dissertações no vasto período de meio século" 32

Eram comuns no prefácio das obras de Sílvio algumas justificativas argumentando que tinha sido traído ou injustiçado e salientando buscar a verdade sem ter interesse próprio "Sou o primeiro a reconhecer que, neste país de terrível egoísmo, cada um deve tratar de si, proteger o seu lugar entre os turbulentos e ambiciosos que nos assaltam de todos os lados. Já não é pequena a tarefa” ${ }^{33}$. E, mais adiante "Zangue-se quem quiser; eu não recuo; não está nos meus hábitos recuar. Ter-me-ia calado, ha muito, no assunto, se me não tivessem contestado e imposto a obrigação de justificar o meu próprio critério e os motivos de minhas afirmativas, que não são feitas levianamente" ${ }^{34}$. No prólogo a

\footnotetext{
${ }^{30}$ VENTURA, Roberto. Estilo tropical: História cultural e polêmicas ignorantes no Brasil. São Paulo: Companhia das letras, 1991. p.127.

${ }^{31}$ Todos os trabalhos que tratam de investigar a figura polêmica de Sílvio Romero aludem ao incidente de sua defesa de tese tomando como fonte a obra História da Faculdade de Direito de Clóvis Bevilaqua.

${ }^{32}$ ROMERO, Sílvio. Obra filosófica. Op.Cit.p.687

${ }^{33}$ ROMERO, Sílvio. Autores brasileiros. Op.Cit.p. 187

${ }^{34}$ Ibidem. p.187-188
} 
História da Literatura Brasileira e em outros trabalhos como em Doutrina contra Doutrina, Romero se dizia um escritor injustiçado ou caluniado, muitas vezes perseguido.

Diante de tantas polêmicas, somente o conterrâneo Tobias Barreto de Menezes não fora vítima de seu temperamento, embora o autor dos Estudos Alemães nunca tenha sido professor de Romero, como pensavam seus adversários, e se ligasse a pensadores alemães, desacreditando no poder da ciência como forma de querer explicar as questões concernentes ao arbítrio humano. Tobias Barreto se liga ao nome de Romero somente enquanto partícipe da invenção do grupo saído da Faculdade de Direito do Recife, a Escola do Recife ou Escola Teuto-Sergipana ${ }^{35}$, ironia de Carlos de Laet pelo fato da simpatia dos jovens Sílvio e Tobias pela cultura germânica. Para vários adversários de Sílvio, a Escola do Recife era uma escola sem discípulos.

Valia-se Silvio do nome de Tobias Barreto para se proteger diante dos ilustres nomes da Literatura nacional como Machado, Veríssimo, Valentim Magalhães, Laet, Murat, e tantos outros. Defendia ardentemente a prioridade do seu grupo literário para contrabalançar o peso dos escritores que residiam na corte. A apologia de Tobias é senão uma maneira de se dar legitimidade diante de seus desafetos que não foram poucos, e nada melhor do que chegar na então capital federal escandalizando a corte com A Filosofia no Brasil, provando seu preparo e conhecimento com relação às novas teorias. O sentimento de injustiça e de calúnia tomou ainda mais conta da missão de Sílvio "Durante dezenas e dezenas de anos tenho sofrido os insultuosos assaltos, reeditados pelas zeverissimações da crítica e já não é possivel deixar de os rebater de uma vez". ${ }^{36}$ Ao lermos seus escritos, chegamos a perceber um escritor ressentido, que não fora agraciado por medalhões, como acusou José Veríssimo e Machado de Assis, motivo de colocar em dúvida a capacidade intelectual deste e acusando aquele de favorecimento por ter mais de um emprego.

Alegava que era sempre em nome do progresso brasileiro e nunca por interesse próprio que entrava em cena. Vários estudos de Romero possuem endereço certo e alguns deles foram respostas diretas a políticos, literatos ou jornalistas não só brasileiros, por exemplo, a polêmica que teve com o escritor português Teófilo Braga.

Para além da análise polêmica, Sílvio conhecia bem o Brasil, fora um exímio erudito, e o que mais nos interessa: inovou a maneira de interpretar seu país, baseando-se nos critérios científicos e naturalistas da época. Interpretou o Brasil com idéias estrangeiras sim, mas aproximou-se de e trouxe um Brasil real, embora, ao seu tempo, muitos não lhe dessem ouvido. Se somente atinarmos para o lado polêmico do escritor, pode resultar a noção de um Silvio Romero até mesmo desequilibrado,

\footnotetext{
35 PAIM, Antônio. História das idéias filosóficas no Brasil. São Paulo: Editora Convívio em convênio com o Instituto Nacional do Livro, Fundação Nacional Pró-Memória, 1984.

${ }^{36}$ ROMERO, Silvio. p. 527
} 
desconectado de seu meio social ou do momento histórico, fruto de uma análise que gira sobre si mesma e que finda nesta; se sairmos de seu lado polêmico, podemos perder justamente o que motivou boa parte de sua produção. A melhor maneira de abordar o polígrafo é ver até que ponto seu lado polêmico não fora justamente o ponto de partida para pesquisar os problemas brasileiros condizente ao escritor encarregado de uma missão. Somente assim se torna vantajoso investir na imagem polêmica do crítico, o que em nenhum momento exclui a imagem do escritor agressivo e contraditório que foi Romero. É o próprio Araripe Junior que ressalta, "Fazer o que ele fez, isto é, desprezar os cânones acadêmicos, as fórmulas consagradas e aceitas pela turba literária de seu tempo era um fato tão natural como seria em outra época dada as mesmas condições do seu temperamento defender aqueles cânones, impondo-os aos rebeldes mediocres com a ferocidade do selvagem". ${ }^{37}$.

Antonio Candido resume de maneira clara o personagem polêmico que fora Sílvio, "Todos tinham e não tinha razão. Ele foi incoerente em muita coisa, a começar pelo grande contraste que parece ter havido entre o seu ameno modo de ser como homem e a sua truculência como escritor. $O$ testemunho dos contemporâneos mostra uma pessoa bonacheirona, de excelente humor, desinteressado, generoso, comunicativo; mas que de pena em punho preferia atacar, desfazer em tudo que o contrariasse, manifestando um ciúme que roçava pela inveja, uma vaidade que tocava na soberba, uma suscetibilidade vizinha da paranóia. No campo das idéias e convicções, não é difícil mostrar que primeiro foi positivista e depois atacou desabridamente o positivismo; que na política de Sergipe desancou um lado e depois se ligou a ele; que considerou Luís Delfino um poetastro e, em seguida, um dos maiores poetas brasileiros; que proclamou Capistrano de Abreu o maior sabedor de História do Brasil e, mais tarde, um medíocre catador de minúcias; que era evolucionista agnóstico e afinal aderiu a Escola da Ciência Social, de raízes católicas, e assim por diante. Não é difícil, ainda mostrar como fazia e refazia as suas divisões de períodos, os seus catálogos de bons e maus escritores, com a mania classificatória e enumerativa que era um dos seus modos de ver a Literatura 38

Já Sílvio Rabelo escreve que "todo o seu gosto consistia em impor pela palavra autoritária e agressiva as suas opiniões, sem nenhum respeito pelas opiniões do autor que criticava. E algumas vezes, a sua atitude era agravada pela intenção de fazer ridículo ou pelo insulto que dirigia ao próprio autor e ao próprio homem" 39.

Mais frutífero que tentar compreender os motivos das polêmicas de Romero com seus adversários é admitir que foi justamente essa postura que o tornou uma figura relevante no cenário

\footnotetext{
${ }^{37}$ JUNIOR ARARIPE, T.A. Sílvio Romero Polemista. Ibidem. p.276.

${ }^{38}$ CANDIDO, Antonio. Sílvio Romero: teoria, crítica e História literária. Rio de Janeiro: livros técnicos e científicos; São Paulo: Edusp, 1978.p. IX-X.

${ }^{39}$ RABELO, Sílvio. Op.Cit.107
} 
brasileiro. Cabe-nos descer à conjuntura social do momento para desvelar os elementos constituitivos das polêmicas encabeçadas pelo crítico, como a questão de num momento de ruptura com a sociedade imperial considerada obsoleta e atrasada pela nova geração de escritores.

Sabemos do conturbado momento histórico vivenciado por Romero, que muito contribuiu para seu nacionalismo, motivando suas pesquisas e provocando polêmicas e mais polêmicas na busca dos males brasileiros. Seu traço polêmico é inseparável do nacionalismo e associado a sua vasta produção em prol do progresso do país. Assim se explica o ataque de Silvio Romero a seus inúmeros adversários, à classe dirigente do país, à elite intelectual, que segundo ele, não tocava nas raízes dos problemas brasileiros, fosse por desconhecimento da crítica ou por decorrência de alguma manobra política. Salientar o lado polêmico de Romero é mais do que se deter numa mera questão de personalidade: é saber que grande parte de sua produção ensaística fora motivada por questões que envolviam a honra ${ }^{40}$, traço singular do ensaísmo brasileiro na transição império/república. Acerca das polêmicas que deram a tônica da geração de Romero, aponta Roberto Ventura, "São antes lutas pelo poder, no nível local, municipal, estadual ou nacional, marcadas por divergências pessoais e pelo caráter secundário das oposições de classe. Não apresenta relevância, neste momento, a formação de uma consciência ideológica a partir da qual possam se explicar as tensões entre os estratos superiores e inferiores de uma mesma parentela ou oligarquia. Ao invés disso, as tensões são encobertas por mecanismos ideológicos, como o paternalismo e o favor, permitindo que os estratos se solidarizem no interior do grupo, por meio da coesão vertical. Reforçada pela existência do inimigo externo, a coesão interna e vertical é fundamental à sobrevivência do grupo e a extensão do seu poder sobre as facções adversárias." "41

Não se pode perder de vista o momento histórico e ver que boa da produção literária da época tinha como motivação a agressão direta entre os contendores. Mas é a partir dessas contendas literárias que podemos descobrir e analisar os argumentos existentes e manipulados pelos polígrafos. Caso exemplar é o de Sílvio Romero, que recorre a uma gama de teorias para se defender dos adversários. É justamente nessas querelas que podemos conhecer e adentrar as idéias adotadas por Sílvio para analisar o Brasil. Boa parte de sua produção literária possui o traço polêmico, que se justificava como revide a esse ou àquele personagem. Sempre alegou que sofrera perseguição e calúnia. Assim, retrucava de maneira violenta à perseguição sofrida, mostrando seu nacionalismo em nome da justiça e da verdade. Dizia-se apaixonado pelas coisas do Brasil, pregando uma espécie de justiça literária ou verdade histórica que somente ele poderia ter.

\footnotetext{
${ }^{40}$ Roberto Ventura nos informa a importância das polêmicas na produção literária dos escritores brasileiros das três últimas décadas do século XIX. Muitas vezes era a honra pessoal que motivava os escritores a produzirem seus textos ficando em segundo plano as reais preocupações literárias. VENTURA, Roberto. Op.Cit.

${ }^{41}$ Ibidem. p. 147
} 
Diante da face polêmica de Sílvio, não se sustenta a imagem de um escritor que se bateu na arena sem motivo ou totalmente sem idéias, imagem de autor embriagado e fascinado com o revoar das idéias novas. Sempre que sentia agredido ou se achando no direito de resposta, lá estava Silvio a falar de uma forma que se pretendia clara e objetiva. Romero foi por excelência um escritor combatente que sentiu, pelas circunstâncias do momento, a necessidade de contribuir para o desenvolvimento de seu país. Viveu um momento conturbado da História brasileira, quando a questão da abolição dos cativos estava na ordem do dia, influenciando a formação de um personagem polêmico. "No momento em que traço estas linhas troa por toda a parte o ruído das festas da abolição. A lei foi sancionada pela regente há poucos dias, está-se no período dos festejos promovidos pela imprensa da capital" ${ }^{42}$. Afirmara sempre ter falado em nome da verdade e nunca de interesse próprio, o interesse da nação seria sua maior causa e motivo maior de sua luta. $\mathrm{O}$ sentido de sua vasta produção atesta bem a tarefa do escritor de seu tempo ao pensar que, "Todo homem que empunha uma pena no Brasil, deve ter uma vista assentada sobre tais assuntos, se ele não quer faltar aos seus deveres, se não quer embair o povo. Sem a pretensão de doutrinar e disciplinar a opinião vou expender meu modo de pensar. Rapidamente, sem dúvida. O Brasil é um país ainda em via de formação; nunca é demais esclarecer o seu futuro", 43

Sabia Sílvio da estreiteza de campo no Brasil, da falta de oportunidades para o escritor, da centralização literária deitada no Rio de Janeiro, desconsiderando talentosos escritores localizados bem distantes da Capital Federal, como Tobias Barreto, chegando a questionar a capacidade ou o talento de capacidades simplesmente medianas "Era então o que sempre fui e sempre serei: um revoltado contra a sandice letrada, a tendência adularia de certos presumidos, a falsa sabedoria de figurões de palha”. ${ }^{44}$ Não se limitou Romero aos estudos de criação artística ou da criação literária porque, como nos moldes de seus grandes ídolos Sainte-Beauve, Scherer e Taine, a missão social do intelectual era mais que escrever poemas ornados de uma sensibilidade fina.

O nacionalismo de Romero impossibilitou uma visão estética em sua maneira de ver o Brasil. Não se preocupou com nenhum gênero senão a crítica sociológica para julgar e atribuir valores a quem realmente merecia. Nunca levantou uma discussão sem esperar respostas, nunca adotou idéias para mandá-lo ao campo da mera abstração. Talvez o motivo de ser um personagem lembrado pela historiografia seja não apenas sua visão de um Brasil mestiço, mas seu tom polêmico. O tom polêmico de Sílvio faz boa parte de a historiografia literária julgá-lo um autor pragmático, possibilitando a concepção de um escritor que só assimilou idéias estrangeiras para bem aplicar a seu país, mas

\footnotetext{
${ }^{42}$ ROMERO, Sílvio. História. Op.Cit.p.37

${ }^{43}$ Ibidem. p. 36

${ }^{44}$ ROMERO, Sílvio. Autores brasileiros. Op.Cit.p.525
} 
desconhecendo este. Tinha Romero a intuição artística para analisar uma obra literária e o fato de ter sido mau poeta não invalida tal hipótese. Suas contradições ao longo da carreira literária não justificam supor um escritor limitado, em decorrência da ausência de estilo poético, como pensavam Veríssimo e Machado.

Conhecia Sílvio tanto a linguagem científica das teorias emanadas das academias e universidades européias como a linguagem simples das pessoas pobres das paragens sergipanas abastecidas de seus folguedos e das missas aos domingos da população simples de sua inesquecível Lagarto. No fim da vida, em recepção aos calouros da Faculdade de Direito do Recife, surgiu um Sílvio falando de maneira simples, sem os arroubos e o fanatismo das idéias de outrora.

A experiência do homem simples suplantava o espaço dos tempos de erudição, quando sempre recorreu aos preceitos científicos para justificar suas análises. Discordou Sílvio de um sem número de homens porque não era e jamais poderia ser um diletante. Sua concepção de intelectual era combater e contribuir para promover o progresso de seu país. Perpétuo defensor das idéias novas, Romero não deixara de ser um romântico por acreditar de forma desmesurada nos atributos científicos, não privando sequer nomes consagrados da Literatura brasileira nem tão pouco nomes consagrados da Literatura mundial; e estadistas brasileiros como Sinimbu, Cotegipe, Joaquim Nabuco e José Bonifácio.

É simplismo por parte da crítica e da História se ater ao traço polêmico em busca de compreender sua obra. Sabemos que as obras de Romero não se propõem a esmiuçar o caráter dele próprio, mas sua escrita jamais ficou reduzida ao tom intempestivo do agitador de idéias. Fazemos tal ressalva porque percebemos que muitas vezes os estudos sobre ele se preocupam muito mais em salientar o traço polêmico do escritor do que estudar sua verdadeira contribuição no amplo campo da cultura brasileira. Da infinidade de trabalhos sobre o ensaísta, poucos são os que merecem atenção minuciosa, como os estudos de Araripe Júnior, Sílvio Rabelo, Carlos Sussekind Mendonça e Antonio Candido, além dos trabalhos mais recentes de Ricardo Seqeira Bechelli e Ricardo Luiz de Souza. Quando não é o tom polêmico que prevalece no estudo de Sílvio, nos deparamos com uma ótica memorialística que não nos possibilita a imagem mais certeira sobre o bacharel sergipano.

Este traço polêmico, inseparável do nacionalismo de Sílvio, muitas vezes impede um olhar mais justo para a verdadeira contribuição do escritor porque a restringe ao homem polêmico, de personalidade agressiva, e que acima de tudo, era destituído do estilo poético necessário aos grandes críticos. O que nos interessa aqui é sua contribuição como intérprete do Brasil, como historiador.

Romero frequentemente é visto como fruto direto de seu temperamento, o que parece relegar para um segundo plano os fundamentos históricos de seu próprio momento de atuação. É como se toda a produção do crítico literário repousasse sobre esse temperamento, o que em não nos faz avançar na 
análise de seu pensamento e de sua importante contribuição ao Brasil. Em nada contribui atinar para o temperamento intempestivo de Sílvio Romero porque sabemos que o escritor fora sim um crítico literário limitado, mas também um exímio pesquisador e que em muito contribuiu para pensadores posteriores como Gilberto Freire, Oliveira Viana, Sérgio Buarque, e tantos outros.

Torna-se mais importante conhecer a obra romeriana, mesmo sabendo de suas inúmeras contradições. Mais profícuo que buscar em Romero um pensador mais ou menos nacionalista é conhecer a obra romeriana mesmo para aqueles que reduzem sua contribuição à teoria da mestiçagem e do branqueamento.

Este caráter polêmico é inseparável da recepção e adoção de inúmeras idéias, mais díspares que pudessem ser, assumidas pelo crítico para dar respostas aos inúmeros problemas brasileiros. Romero não aderiu à crítica sem razão, não estava preocupado com a criação literária da arte pela arte, o que buscou na crítica foi um ponto de apoio, um recurso metodológico para guiar seu vasto cabedal de leituras partindo dos fatores condicionantes, porque pensava que conhecendo tais fatores poderia propor os caminhos e corrigir os problemas do país. Esta crítica só tinha sentido na medida em pudesse ser aplicada ao país e suscitasse uma nova forma de interpretar o Brasil.

As polêmicas de Romero são parte de seu temperamento, mas nutrida por um conturbado momento da História brasileira que clamava por uma identidade. As inquietações de Sílvio não eram somente suas, eram também de grande parte da geração de escritores de seu tempo. Só se torna significativo ressaltar o tom temperamental de Romero quando percebemos que seu exacerbado nacionalismo é proveniente de sua personalidade, na medida em que, esta norteara incessantemente Romero em busca do caráter nacional brasileiro, daí o sentido de sua missão literária, e assim, de sua farta produção intelectual.

Em nada contribui tomar Sílvio Romero tendo por base prioritária seu caráter temperamental porque tal preocupação é uma tarefa da crítica psicanalítica que quando muito encontra os porquês e sentido da criação literária, mas não dá conta da realidade mais ampla. Boa parte da historiografia mais insiste em endossar o tom polêmico do crítico do que investigar a contribuição deste, situando-o no clima agitado e polêmico da época. Dessa forma, resulta um personagem de caráter temperamental, de verve biliosa e outros adágios possíveis, como se vários escritores da época não houvessem enfrentado polêmicas. Para além de uma análise concebida a partir de então, e assim reduzida a tal raciocínio, torna-se mais importante conhecer a obra romeriana. 


\title{
II - LITERATURA É SOCIEDADE.
}

\begin{abstract}
Este livro deveria formar um só volume de umas 700 páginas neste formato e tipo. Tal o plano primitivo. Começando a sair aos pedaços na Revista Brasileira, aproveitando-se a composição para a impressão em separado, e havendo cessado de aparecer a Revista, foi mister utilizar-se o que estava feito. É o que constitui o primeiro volume, que hoje sai a público. $\mathrm{O}$ autor viu-se destarte, forçado a partir da segunda época da nossa Literatura, deixando para o volume seguinte a continuação. É uma grande macula com que será perdoada por todos aqueles que sabem das dificuldades com que se luta em empresas dessas do Brasil.

Nada se dirá aqui sobre o intuito geral da obra. O leitor inteirar-se-á por si. Apenas lembra-se que este ensaio não teve por alvo principal descobrir fatos novos, no campo, aliás, pouco fértil da Literatura nacional, senão dar um sentido geral e teórico aos factos já conhecidos.

(Sílvio Romero. Introdução a Literatura Brasileira)
\end{abstract}

\section{1- Sílvio Romero historiador literário}

Debruçar-se sobre a farta produção intelectual de Sílvio a partir de um campo específico, como o fazem de uma maneira ou de outra muitos dos intérpretes do autor da História da Literatura Brasileira, buscando encontrar aquilo que o polígrafo nunca almejou, é tarefa embaraçosa. Para o historiador preocupado em analisar a História literária escrita por Sílvio, é preciso, antes de tudo, entender o que Sílvio entendia por Literatura, facilitando o caminho da investigação histórica, o que não significa a solução do problema. Uma vez que Sílvio concebia Literatura como toda a manifestação da inteligência humana, cabe selecionar quais seus escritos que tratam da História literária brasileira. Os problemas só avultam: ainda que o próprio Sílvio dividisse seus trabalhos, toda sua produção era tida pelo mesmo como literária.

Encontrar, dividir, selecionar se torna tarefa imprenscindível para encontrarmos o Sílvio historiador literário. O problema da investigação histórica torna-se de fundamental importância quando se trata de um polígrafo que, em sua Literatura, colocava todos os problemas brasileiros em pauta. Embora tenha sido Sílvio um crítico literário, sabemos que este nunca ficou restrito a sua área: trazia por meio de sua História literária tudo que tivesse ligação com os problemas nacionais.

Mesmo se tratando de um historiador literário que fundamentou seu trabalho nesse campo e, em menor grau, seus estudos folclóricos, a partir do evolucionismo e do darwinismo, Sílvio foge a toda e qualquer especialidade do saber que hoje encontramos rigidamente demarcados. E por uma razão muito óbvia, a concepção de Literatura do escritor sergipano diferia dos outros críticos de seu tempo, como José Veríssimo e Machado de Assis, que concebiam Literatura como arte literária. Esta foi a principal razão das polêmicas de Sílvio com esses adversários, fazendo com que o escritor sergipano expandisse a Literatura para além do fenômeno estritamente literário: pensava Sílvio que a Literatura tinha sempre relação direta com o que acontecia na sociedade. Concebendo Literatura como reflexo 
das transformações sociais, sendo estas, por sua vez, influenciadas pelo meio, pela raça, pelos antecendentes históricos e acima de tudo, pela figura diferencial do mestiço. Rigidamente preso ao determinismo, por vezes admitindo que os fatores pudessem alterar as causas, trabalhava Sílvio com tudo que existisse à vista na elaboração de sua História literária.

Seu desejo maior era a elaboração de uma História da Literatura brasileira, uma vez que esta Literatura trataria de temas concernentes às mais variadas questões do país, sobretudo, a formação do povo brasileiro. Sempre se queixou da falta de documentos não apenas para este ou aquele assunto, como também para a elaboração da História literária. Sabia Sílvio que o Brasil era retratado por escritores portugueses, franceses e não raras vezes por ingleses, homens que viram o país a partir de fora, eis o que considerava a principal causa da pobreza dos trabalhos literários sobre o Brasil. A boa ou a má Literatura, para Sílvio, só tinha sentido na medida em que o escritor retratasse a situação do país; eis que surge seu nacionalismo literário avassalador, poucos são os literatos que merecem sua aprovação, visto que jamais contribuíram para a evolução da Literatura brasileira, "as pátrias letras, entre outras muitas lacunas, mostram bem claramente a grande falha causada pela ausência de trabalhos históricos. Se não existe uma História universal escrita por um brasileiro, se a nossa própria História política, social e econômica tem sido apenas esboçada e foi mister que estrangeiros nos ensinassem a escrever; no terreno da Literatura propriamente dita a pobreza nacional ostenta-se ainda maior". 45

Os parâmetros a que devemos submeter Sílvio são aqueles que o próprio autor pensava serem imprescindíveis para a compreensão da História literária do Brasil. Nesse sentido, sua contribuição no plano da História literária, uma vez sabendo da visão elástica com relação a esta, traz consigo o cerne e o sentido de sua farta produção e de sua carreira tempestuosa. O que buscava o crítico sergipano era analisar o vasto campo cultural do Brasil para só assim identificar a situação do país, os males e dessa forma, propor os meios de superação.

História da Literatura Brasileira é um vasto quadro dos mais variados aspectos do país. No primeiro volume, investia nos fatores que condicionavam a Literatura brasileira. Estes fatores eram o meio, a raça, os antecedentes históricos e, sobretudo, a aparição do mestiço, elementos responsáveis pela formação da psicologia nacional que por sua vez, explicava a pobreza da Literatura brasileira e uma apatia geral no quadro maior da cultura. As diversas interpretações da significativa contribuição de Sílvio, por parte de setores da crítica, por vezes são injustas, uma vez que simplificam a visão de um escritor que nunca se eximiu de retratar como pensava a Literatura de seu país.

\footnotetext{
${ }^{45}$ ROMERO, Sílvio. História da Literatura Brasileira. V. I. Op. Cit. p.51
} 
Antes de tudo, torna-se mais fácil julgar o polêmico escritor da História da Literatura Brasileira do que incorrer no sentido teórico que atribuía à Literatura brasileira. Para tal, é relevante apontar questões relevantes e indispensáveis sobre Sílvio. O momento histórico, tanto com relação à crença num dos elementos da tríade tainiana como a função social do escritor, singularidades de maior relevância de sua época, sua posição diante das teorias estrangeiras que conheceu, tendo que selecionar qual a que melhor servia para interpretar o Brasil, nos leva a considerar tais questões para compreendermos a Literatura empreendida por Sílvio. Toda e qualquer análise que busque compreender a Literatura do autor de Ensaios de Sociologia e Literatura não pode desprezar tais questões.

Embora viesse, em seus quase quarenta anos de atividade literária, a cometer injustiças e contradições (por exemplo, ter endeusado mestres racistas, ter reprovado e depois reconhecido homens como Capistrano de Abreu, Machado de Assis, José Veríssimo, Euclides da Cunha, etc, ter dirigido ásperas críticas as diversas oligarquias que cobriam o país de norte a sul, se envolvendo no famoso caso de Sergipe), cabe não perdermos de vista a História literária escrita por Sílvio. Sua Literatura, no sentido amplo que concebia o bacharel, deixa clara a maneira como via o Brasil, o que deveria ser mudado e quais os caminhos para o país superar o atraso refletido nos mais variados campos. É por isto que o político, professor do Colégio Pedro II e depois lente da renomada Faculdade de Direito do Recife causa tanta polêmica, ao mesmo tempo que admiração.

Àqueles que se debruçam sobre a contribuição de Sílvio, especificamente, no que tange a sua maneira de interpretar o Brasil, cabe relevar tais elementos, prevendo o risco de sacrificar a vasta contribuição do escritor em função de seu lado polêmico. Não propomos analisar Sílvio tendo por base alguns episódios de sua vida, mas suas ásperas críticas só ganharam força e se tornaram cada vez mais evidentes por meio de sua concepção literária. Concebendo Literatura como produto do meio e da raça, Sílvio não apenas tentava conhecer o Brasil, denunciando o que considerava ser de primeira ordem, como tratava de avaliar os polígrafos anteriores, a partir de suas produções literárias, o que gerava um duplo movimento: primeiramente, julgava uma obra literária a partir da representação social que esta embutia; em segundo lugar, não concebia a produção literária sem ligação alguma com as transformações ocorridas na sociedade, reflexo dessas transformações sociais. O anseio de Sílvio era julgar, realizar uma espécie de assepsia do atraso brasileiro a partir do conhecimento.

Por meio de sua crítica sociológica, almejava Sílvio dar a mão à palmatória, ao escritor que o sergipano pensava ter o mérito ou a credibilidade, ou seja, quando Sílvio pontuava este ou aquele escritor, independentemente de seu campo de atuação, trazia para primeiro plano a História do Brasil. Acreditava na capacidade transformadora da Literatura, e porque não dizer, do conhecimento. Sabedor da realidade do país, trazia consigo a missão social do escritor que, tal qual o político, tem o poder de 
operar as mudanças sociais necessárias para superar o atraso de seu país. Eis o sentido das severas críticas à centralização literária, o que, para Sílvio, punha em evidência a corrupção no campo das letras.

$\mathrm{Na}$ Corte, pairava o favorecimento entre os pares, dentre estes, o exemplo de Machado de Assis, que não era mais capacitado que Tobias Barreto, assim como o favorecimento a José Veríssimo, que segundo Sílvio teve a notoriedade que não merecia devido a sua posição em grande jornal da Capital Federal. Ainda no campo literário, quando Sílvio criticava o indianismo tupiniquim, no início de sua trajetória intelectual, criticava a priori a Corte como centro não apenas político, como também no campo da cultura num sentido amplo. Para Sílvio, a História literária enquanto tal seria julgada pelo parâmetro de diferenciação nacional, deveria mostrar a singularidade brasileira frente a Portugal e aos países europeus, só assim poderíamos falar numa Literatura plenamente brasileira. Quanto mais um autor lutou, por meio de sua História literária, pela diferenciação desta Literatura, mais contribuiu para sua formação e, como conseqüência, se mostrou brasileiro. Por isso, um dos parâmetros de Sílvio na seleção de escritores brasileiros é a paixão pelo Brasil. A História literária elaborada por Sílvio é a História da formação do Brasil e de seu povo. Daí é que o bacharel remonta aos cronistas e viajantes, pois foram estes os primeiros escritores que elaboraram uma representação de Brasil, visando ao conhecimento do país.

Nesse sentido, são estes mesmos cronistas, principalmente, o jesuíta Anchieta, que Sílvio combate, haja visto traçar um quadro melancólico do território brasileiro. Mesmo que Sílvio critique esses primeiros cronistas, se apóia em alguns deles, como Nóbrega, Aspicuelta, Navarro, Gandavo, no combate à imagem melancólica de Anchieta. Faz isto para chamar atenção para as riquezas do país, tentando a todo instante despertar a atenção para o que diferencia o Brasil de Portugal. Sabendo que algo de diferente deve ser encontrado para erigir a História literária brasileira, Sílvio nos chama atenção para os colonos que habitam a nova terra, juntamente com seus futuros filhos nascidos no Brasil, tudo isso para que estes vejam com melhores olhos as belezas da terra. Mas o sentido teórico da Literatura brasileira não é este, ainda que os novos brasileiros tenham um melhor caráter com relação aos portugueses. O ponto nevrálgico para Sílvio é o surgimento do mestiço, influenciando a cultura e a vida espiritual do país. A seleção de elementos que Sílvio levava em consideração para a constituição de sua História literária passa irremediavelmente pelo viés etnográfico, sua visão da situação cultural do país estava ligada à formação da sociedade brasileira. Típico de seu pensamento e do personagem polêmico que foi, considerava que nunca algum escritor escreveu uma História do Brasil, existiam apenas elementos para essa História.

Reprovando o que havia sido escrito sobre o Brasil, não sabia Sílvio por onde começar pois o que existia de trabalhos escritos acerca do país eram trabalhos de cunho corográficos, biográficos, 
crônicas, Histórias parciais, que não ofereciam um quadro completo. Diversos são os elementos considerados por Sílvio em sua análise literária, mas o pano de fundo é a formação brasileira, daí "que os maiores ou menos gabos que nos merecem a terra e seus habitantes, já o dissemos, as maiores ou menores censuras que lhes façamos, questão afinal do temperamento de quem escreve ou da feição do tempo em que vive, não são um critério rigoroso e completo de caracterização de nossa índole, como povo, em qualquer das esferas em que nos tenhamos excercitado". " 46 (grifos nosso)

Somente trazendo o que diferencia o Brasil em relação aos outros países, no caso, o caráter nacional, é que Sílvio erige sua História literária. Sua forma de escrever esta História literária só faz sentido porque busca freneticamente mostrar o mestiço como elemento diferenciador da História brasileira. Era o mestiço a base da formação cultural do país, o que equivalia a afirmar que era este a base de nossa História literária. Muitas foram as Histórias literárias do país, juntamente com artigos esparsos, mas é Gregório de Matos que merece os apalusos de Sílvio porque “é a mais perfeita encarnação da do espírito brasileiro, com sua facécia fácil e pronta, seu desprendimento de fórmulas, seu desapego aos grandes, seu riso irônico, sua supercialidade maleável, seu gênio não capaz de produzir novas doutrinas, mas apto para desconfiar das pretensões do pedantismo europeu”. 47 (grifo nosso)

Ressentia-se Silvio da ausência por parte dos escritores que escreveram sobre o Brasil de trabalhos históricos, como também da ausência de trabalhos políticos e sociais. Sua visão elástica do fenômeno literário levava-o a afirmar que se não houve algum escritor que escreveu uma História universal, no terreno da História literária propriamente dita, a pobreza de nossas letras era evidente. Nenhum dos escritores merece o reconhecimento de Sílvio, porque não trataram do Brasil, quando muito, chegaram a falar do país com os olhos voltados para Portugal, uma vez que pensavama a Literatura brasileira como mero apêndice da Literatura portuguesa. Portanto, escritores como Ferdinand Wolf, Bouterweck, Sismondi, Denis e Garret foram simples organizadores da História literária de Portugal, da qual, a História da Literatura brasileira seria extensão. Com tamanha pobreza de obras que retaratavam o Brasil como queria Sílvio, concluía que "Denis foi o primeiro a fazer um quadro mais ou menos inteiro de nossa Literatura, quadro sólido e incorreto, é certo, mas que se impõe, por estar no singular. E já lá vão bastantes anos que o livro foi publicado, e até bem pouco era o compêndio oficial de nossos cursos!", 48

Nem os escritores portugueses nem os escritores brasileiros traçaram um quadro completo da História literária brasileira. Os portugueses escreveram sobre o Brasil a partir do olhar lusitano, ao

\footnotetext{
${ }^{46}$ ROMERO, Sílvio. Quadro Sintético da Evolução dos Gêneros na Literatura Brasileira. Op. Cit. p. 13

${ }^{47}$ ROMERO, Sílvio. História da Literatura Brasileira. V. II. Op Cit. p.365

${ }^{48}$ Ibidem. p.51
} 
passo que os escritores nacionais, segundo Sílvio, simplesmente traçaram quadros isolados. Ao olhar de Sílvio, era indispensável, na representação da Literatura brasileira, identificar o que havia de mais importante, aquilo que diferenciava o país da ex-metrópole, o mestiço brasileiro. O mestiço era o que diferenciava o Brasil e servia de símbolo para a Literatura nacional. O escritor que tivesse lutado para elevar o que diferenciava o país com relação à antiga metrópole merecia os aplausos de Sílvio, mas “quem tiver sido um mero imitador português, não teve ação, foi um tipo negativo", 49

As Histórias do Brasil do momento resumiam-se a relatos de viagens, chegadas de donatários e capitães mores, governadores, vice-reis, bispos e jesuítas. Faltava a História brasileira "o eterno sofredor, o eterno agitador, o eterno herói - o povo" ${ }^{50}$. Arremata Sílvio que "o verdadeiro historiador do Brasil deveria ser bastante naturalista para no pórtico de seu livro distender a descrição vasta, exata, verdadeira da terra nacional, determinando-lhe as zonas, os climas, os aspectos, todos os cem modos diversos, pelos quais os meios colaboram com os homens; deveria ser bastante etnologista para compreender e amar as diversas raças, que levantaram n'este país as suas tendas e agitaram á luz do sol brasileiro seus músculos de combatentes, travando a luta da vida, a luta da civilização; para entendê-las em seus cantos, em suas aspirações; deveria ser bastante filantropo e democrata para rir e chorar com o povo, segui-lo na sua formação gradativa e suas transformações progressivas, assistir a geração do nosso terceiro estado e da nossa burguesia, acompanhá-los na vida municipal, nas agitações da vida política, nos anelos de liberdade; deveria ser bastante economista para surpreender o povo no seu trabalho, tomar nas mãos os fios determinadores da formação de nossa riqueza publica e particular, mostrando a irradiação d'esse pólipo enormissimo - a escravidão -, polipo de nova espécie, fecundo, produtor, sugado pelo parasitismo imenso e infamante, o grande crime da raça colonizadora, o grande crime que tem feito, que ainda hoje faz, a nossa historia ser uma obra de privilegio e iniqüidade; deveria ser bastante filósofo - para ter uma nítida idéia da cultura e dos destinos humanos, compreender a formação das pátrias recentes, o advento d'essas nações coloniais, mestiçadas, herdeiras de antigas glorias e antigos ideais, prestes a transformar-se, urgidas por necessidades novas, deveria ser bastante erudito para conhecer a fundo todos os fatos, todas as peripécias do passado nacional, deveria, finalmente, ser bastante poeta para construir de tudo isto uma obra artística, viva, palpitante de seiva e de entusiasmo". ${ }^{51}$

Vale lembrar que todos os escritores anteriores a Sílvio não merecem crédito por parte do crítico por ser a Literatura vigente no Brasil especulativa, fundada no mero traço biográfico, nas anotações antológicas, cuja maior preocupação visava simplesmente ao enaltecimento do escritor. Os antecessores

\footnotetext{
${ }^{49}$ Ibidem. p.54

${ }^{50}$ ROMERO, Sílvio. Novos estudos de Literatura contemporânea. Op. Cit. p. 7

${ }^{51}$ Ibidem. p. 7
} 
de Sílvio, com exceção de Denis, - considerado o fundador da História literária brasileira -, escreviam seus apêndices, antologias, parnasos, poesias, etc, presos à visão de um Brasil como mero apêndice ou extensão da Literatura realizada pelos escritores portugueses.

Reprovando nomes como Rocha Pita, Taques, Jaboatão, Madre de Deus, Southey, Abreu e Lima, Macedo Soares, Francisco Lisboa, Candido Mendes, Joaquim Caetano da Silva, dentre outros, reconhecia Sílvio que, "Varnhagem ocupa uma posição especial, foi um erudito, e como tal, publicou muitas monografias meritórias, e quis também ser um historiador, e, como tal, escreveu a História Geral do Brasil, livro notável pelas pesquisas que revela, pela erudição que desvenda; livro medíocre pela falta de crítica, pela ausência de intuições teóricas, pela aspereza e mortificação do estilo". 52

Escrevendo sobre o Brasil a partir de fora, sem as bases nacionais que mais tarde iriam sedimentar o traço singular nacional, primeiramente esboçado no Resumo da História Literária do Brasil, do escritor francês, “Com Denis, principia (no que se refere aos dois últimos temas) a longa aventura dos fatores mesológico e racial na crítica brasileira, que Sílvio Romero levou ao máximo de sistematização. Era, com efeito, o tempo das especulações sobre o espírito nacional e a influência das latitudes; da peculariedade e atuação dos climas". 53

Na verdade, Sílvio busca em sua História da Literatura Brasileira encontrar o caráter nacional brasileiro, daí incorrer numa ampla análise histórica, não deixando de adentrar aspectos sociais, econômicos e políticos brasileiros. Erige esta História literária partindo de Scherer, onde pensa este que duas são as maneiras de representação da Literatura: a primeira é pender para as considerações gerais, buscando por meio dos efeitos as respectivas causas; e a segunda é basear-se na análise específica dos poetas e escritores. Sem documentação necessária para traçar a "História íntima, pinturesca, viva e anedótica dos escritores do Brasil" ${ }^{54}$, Sílvio optava por uma análise literária onde os fatores que condicionavam o processo de criação textual eram da mais alta relevância. Não existindo o fenômeno literário em si mesmo, mas sim aspectos que condicionavam a Literatura de um país, afirmava que "um conhecimento, que se não generaliza, fica improfícuo e estéril, e, assim, a História pinturesca deve levar à História filosófica e naturalista". ${ }^{5}$

Não fazia sentido para Sílvio se a representação literária brasileira desse ou daquele autor não se generalizasse. Com este método, queria Sílvio buscar um ponto de partida para consolidar o elemento

\footnotetext{
${ }^{52}$ ROMERO, Sílvio. Estudos de Literatura Contemporâena. Op. Cit. p. 174

${ }^{53}$ CANDIDO, Antonio. Formação da Literatura brasileira: momentos decisivos. 6a . Ed. Belo Horizonte: Itatiaia, 1981.p.323 Guilhermino Cesar tem posição análoga a de Antonio Candido: “o ambientalismo, mAas tarde levado a conhecidos exageros por Sílvio Romero, com o Resumé principia a fazer carreira. E bem se pode avaliar o que representou de estímulo para os nossos escritores semelhante colocação teórica". CÉSAR, Guilhermino. Historiadores e críticos do Romantismo: a contribuição européia, crítica e História literária. Rio de Janeiro: Livros Técnicos e Científicos; São Paulo: Editora da Universidade de São Paulo, 1978. p. 28

${ }^{54}$ Ibidem. p. 55

${ }^{55}$ Ibidem. p. 55
} 
diferenciador da nossa História. Como em outros estudos, no campo da História literária, não podia ser diferente: munia-se do método crítico para dar status de verdade a sua análise da História literária. Assim, tornava-se inevitável conhecer a História do Brasil, a ação do colonizador, a ação do meio, das idéias estrangeiras, juntamente com a influência de índios, negros e mestiços. Quais escritores figurariam na História literária de Sílvio?

Somente aqueles que viveram, lutaram e morreram pelo Brasil. Sem sombra de dúvida, História da Literatura Brasileira é uma apaixonante empreitada pela busca do caráter brasileiro, donde se fazer indispensável a leitura dos inúmeros problemas nacionais do país, uma vez que estes tinham íntima ligação com a psicologia nacional. Claro que muitas são as questões levantadas na obra, mas em sua obra mestra, buscava Sílvio analisar os elementos que determinavam o brasileiro. Nesse caso, esta obra é a aclamação do mestiço. Mestiço este que fez com que Sílvio, a todo o momento, enfatizasse sua importância racial, sem a qual, o quadro "literário" brasileiro ficava sempre incompleto. Foi dessa maneira que o bacharel discordou de um sem número de escritores, porque estes simplesmente escreviam galerias, preterindo, pois, aspectos singulares ao seu olhar. Afirmava que:

\footnotetext{
"Não tratar-se-á de saber qual foi o primeiro brasileiro que escreveu uma poesia ou um livro, e outras tantas questões impertinentes e ociosas.

Nada se terá que ver com alguns frades despreocupados ou ociosos que mataram o tempo a escrever versos latinos, ou a publicar sensaborias em Roma. São Homens que nunca viveram na consciência da pátria, não foram forças vivas ao seu serviço. Foram indiferentes na vida e sê-lo-ão sempre na morte e no esquecimento. Não merecem uma justificativa e ressurreição histórica." 56
}

A Literatura propugnada por Sílvio era uma Literatura que tratava dos aspectos sociais, econômicos e políticos brasileiros. O apego de Sílvio ao Naturalismo da época, a utilização da Crítica como instrumento de validação para seus argumentos, são a demonstração cabal de sua busca pelo que caracteriza o brasileiro em relação ao europeu. Antes de partirmos de pontos que consideramos imprescindíveis para a compreensão de sua História literária, cabe mais uma vez chamar atenção para a visão crítica de Sílvio, o que explica a maneira como este concebia a História literária do Brasil.

Mesmo que a Crítica adotada por Sílvio já embuta uma crítica histórica, sem esta, não nós é possível meios de alcance para a compreensão de seu pensamento. Em primeiro lugar, Sílvio sempre reclamava da falta de documentos para traçar o quadro completo da Literatura brasileira. O problema das origens, para Sílvio, era uma questão de primeira ordem. Em seus escritos, sobretudo, seus estudos folclóricos, onde busca avaliar a contribuição de cada uma das raças, Sílvio exaustivamente alude ao problema das origens.

\footnotetext{
${ }^{56}$ Ibidem. p. 56
} 
A visão de Sílvio historiador literário é constituída pelo modelo de pensamento da crítica de sua época. São questões que integram sua concepção literária como parâmetro de avaliação do imenso leque cultural de seu país. Sílvio farejava a verdade documental, por isso é que reconhecia a erudição de Varnhagen, esta é apenas uma das questões que facilitam nosso entendimento sobre sua visão de historiador literário. Não nos cabe julgar erros ou acertos de Sílvio, apenas buscar perguntas que nos levam à compreensão de sua concepção nesta ou naquela área, no caso, no campo da História literária, no tempo em que viveu. Antes de tudo, cabe-nos atinar ou elaborar perguntas pertinentes ao tempo presenciado por Sílvio, pois como bem lembra Marc Bloch, "desde que nos não resignemos a registrar pura e simplesmente o que dizem as nossas testemunhas, desde que entendemos forçá-las a falar, mesmo contra sua vontade, impõe-se mais do que nunca um questionário. E é esta, efetivamente, a primeira necessidade de qualquer investigação histórica bem conduzida" 57

Homem preocupado com os mais variados ramos do conhecimento, donde a Crítica presidiria os mais variados campos do saber, qual o Sílvio que queremos elucidar e quais são as perguntas que devemos formular? Quais dos seus livros, textos ou artigos deveremos ter em mãos para apresentarmos sua contribuição diante da área escolhida por nós como análise, no caso, o Sílvio historiador da Literatura brasileira? Como não misturar aquilo que para o crítico estava sob a mira da nova intuição surgida sob o escopo naturalista daquilo que para muitos pertencia à Literatura?

Tais questões não podem passar despercebidas. Poderíamos tentar aprofundar toda uma discussão promovida pela revolução historiográfica dos Analles, que pôs em xeque a verdade do documento, uma História elaborada a partir dos grandes fatos e dos grandes acontecimentos visando a sagrar vultos considerados importantes. Mas tal forma de análise seria incorrer em questões que Sílvio nunca se propôs. Sílvio foi um homem de seu tempo, quando o Naturalismo era a palavra de ordem. Tal assertiva nos basta para encararmos o pano de fundo de suas análises em que toda a geração de polígrafos acreditava que assim como a biologia e a mecânica, a História possuía suas leis. Sílvio buscou historiar a Literatura brasileira pensando sempre no princípio geral que fundamentava todos os ramos do conhecimento, que era o princípio da evolução. Não adianta buscar em Sílvio aquilo que ele não se propôs, muito menos elaborar perguntas fora de seu tempo e longe de suas preocupações. Salientamos mais uma vez: Literatura para Sílvio era toda e qualquer manifestação da inteligência humana.

Analisar a contribuição de Sílvio como historiador literário é adentrar as mais variadas áreas que integravam tal concepção. Não se pode falar de Sílvio sem falar de sua maneira de ver o que fundamentava toda e qualquer manifestação "literária" da sociedade brasileira da época, e sua História

\footnotetext{
${ }^{57}$ Ibidem. p. 60
} 
literária foi esse intento. É Sempre recorrendo ao método crítico que o escritor interpretava os quadros isolados seguidos de seus respectivos autores. Dificultoso é querer entender como Sílvio analisava as mais variadas formas de manifestações culturais sem este método crítico, o que leva muitos de seus intérpretes a reduzir Sílvio ao escritor polêmico que fora e se aterem a seu lado racista, desconsiderando sua enorme contribuição na síntese literária brasileira. Quando não é esta a imagem que se tem, logo aparece a afirmação de que o escritor sergipano foi um bom historiador, muito mais sociólogo do que crítico literário, mas um mau poeta. Assim, exige-se de Sílvio, conforme os padrões de análise de sua época e que ainda nos deixa marcas, que corrente se liga o ensaísta, seja no campo filosófico ou literário. Esta questão só dificulta a análise de Sílvio enquanto historiador literário, mas lembremos que o próprio Sílvio agitou como nenhum escritor de sua época as idéias científicas e lutou tenazmente para ser reconhecido como o inaugurador do Naturalismo no Brasil. O fato de ter sido um escritor que escolheu a crítica como a área mais conveniente a sua personalidade, como chega a afirmar no questionário a João do Rio, não nos autoriza a reduzir a amplitude de sua contribuição literária. Uma vez que em Sílvio a diferenciação entre História e Literatura é bastante tênue, é de vital importância compreendermos que o escritor busca encontrar o brasileiro. Trazendo em sua História da Literatura Brasileira os mais ilustres escritores, das mais variadas áreas, que de uma forma ou de outra contribuíam para o conhecimento do país, almejava Sílvio encontrar o gênio nacional. Este gênio nacional era o povo, era a vida brasileira, as manifestações das pessoas mais simples, enfim, era o Brasil que estava por vir depois do contato com o português. A questão literária em Sílvio tinha fundamentação histórica e racial, só fazia sentido se adentrasse a formação do povo brasileiro, daí é que "trata-se de saber se na História literária de um povo, devem entrar, como parte integrante desse povo, todos aqueles que dele se ocuparam". 58

A paixão pelo Brasil não deixa de ser um instrumento por demais relevante na compreensão da contribuição literária dos escritores avaliados por Sílvio, pois sabemos que é dela que surgem as reprovações aos vários escritores com suas respectivas obras. Em sua História literária, jamais se separam o homem polêmico do homem erudito, mas sempre amante das coisas simples, o patriota com espírito de província do ilustrado folclorista, apaixonado pelas missas ao domingos e reisados em sua querida Lagarta, e acima de tudo, avulta o desejo de libertação da História de seu país em relação a Portugal. Historiar a Literatura brasileira era, para Sílvio, mostrar o que era o Brasil e para isso, não havia como deixar de lado os grandes acontecimentos da História pátria.

O encontro entre a História e a Literatura em Sílvio, como em tantos outros escritores que contribuíram para o conhecimento do Brasil, é inevitável, enquanto responsável por um discurso

\footnotetext{
${ }^{58}$ ROMERO, Sílvio. Estudos de Literatura Contemporânea. Op. Cit. p. 124
} 
literário que sempre é histórico, e que por isso, fornece elementos que nos levam ao entendimento de sua atividade literária, enquanto portador de uma identidade. Poderíamos usar a expressão textos de fundação ${ }^{59}$, de Manoel Luiz Salgado Guimarães, em que o historiador analisa a indissociabilidade entre a atividade literária e o discurso historiográfico. Sílvio trouxe problemas de ordem geral, que iam a seu ver, da melhor maneira de ver o país à melhor maneira de ensinar, fosse nas escolas ou nas faculdades. Salgado Guimarães analisa a formação dos discursos historiográficos, de modo específico, o do Brasil oitocentista, imprescindível para confecção de um discurso literário, sempre histórico e de estreita ligação com as classes dominantes. Reflexo de toda uma estrutura econômica, por sua vez, ligada às classes dominantes, a escrita literária reflete a sociedade do momento. A abordagem do historiador não deixa de ser relevante para pensarmos a importância literária de Sílvio, quando sabemos que é de sua ampla visão literária que os inúmeros temas brasileiros vêm a tona.

Romero elaborou sua História literária querendo conhecer a formação do povo brasileiro orquestrada pela lei da evolução e pela lei do mais forte. No fundo, buscou chamar atenção para a diferença do Brasil, que era o surgimento do mestiço, uma vez que "a Literatura brasieira, como todas as Literaturas do mundo, deve ser a expressão positiva do estado emocional e intelectual, das idéias e dos sentimentos de um povo. Ora, nosso povo não é o índio, não é o negro, não é o português: é antes a soma de todas estas parcelas atiradas ao cadinho do Novo Mundo" 60

Seguindo as diretrizes do Naturalismo europeu, a História literária de Sílvio tinha a função de esboçar o quadro racial, visto que "uma Literatura tem uma base, tem elementos e tem órgãos. A base da nossa é o sentimento do brasileiro, como nação à parte, como produto étnico determinado; os elementos são as tradições das três raças sem predomínio de uma sobre as outras; os órgãos são os nossos mais notáveis talentos, todos aqueles que sentiram como brasileiros ". ${ }^{1}$

O Autor preteriu toda a História literária brasileira passada porque esta apenas tratava de quadros isolados e deixava de lado o mestiço. Iniciando sua História literária desde o contato português com os povos "bárbaros", sempre considerando a raça do escritor, concluía que "não sendo o fito deste livro a pretensão de ser uma História exaustiva da Literatura brasileira, tendo só por alvo formular uma teoria geral de nossa intuição literária, bem se compreenderá que nele não se agitem uns quantos problemas impertinentes, tais como: qual o primeiro, ou os primeiros brasileiros que escreveram uma obra qualquer, e outros semelhantes. Obrigado a tratar somente dos espíritos autonômicos $e$ instigadores do pensamento nacional, nada tenho a falar sobre alguns enfastiados que, se diz. escreveram aqui no primeiro século alguns versos latinos, ou coisas, da laia semelhante, que se

\footnotetext{
${ }^{59}$ GUIMARÃES, Manoel Luis Salgado. Uma História da História nacional: textos de fundação. Op. Cit.

${ }^{60}$ ROMERO, Sílvio. História... Op. Cit. p. 371

${ }^{61}$ Ibidem. p. 373
} 
perderam. São quase todos tipos mortos, estéreis, inúteis. Sufocados pelo culteranismo jesuítico, desprendidos da consciência nacional, para cuja determinação nada contribuíram, passaram a vida a versejar sensaborias e não tem o direito de figurar na História" ${ }^{2}$ (grifos nosso)

Não sendo a Literatura brasileira a simples descrição da natureza do país, a descrição dos selvagens com seus costumes, dos cantos indígenas, a persistência do elemento português, de todos os colonos emperrados, de todos os governadores e de todos os reis da metrópole, concluía Sílvio que a Literatura "tem uma base, tem elementos e tem órgãos. A base da nossa é o sentimento do brasileiro, como nação a parte, como produto étnico determinado; os elementos são as tradições das três raças; os órgãos são os nossos mais notáveis talentos, todos aqueles que sentiram como brasileiros". ${ }^{63}$ (grifo nosso)

Os vários escritos sobre o Brasil eram reprovados por Sílvio por não passarem de simples monografias, quadros, sinopses, "faltavam-lhe, porém, trabalhos sistemáticos que lhe fixassem os trâmites." ${ }^{64} \mathrm{O}$ brasileirismo e a atenção do escritor para a novidade do país, que era o mestiço, se mostram de primeiro plano na confecção da História literária. Assim é que o crítico avalia os prosadores e poetas na formação da História literária nacional. É bem verdade que a História literária de Sílvio é indissociável dos acontecimentos históricos materializados nos diversos campos da cultura, mas é somente a partir do mestiço que ela faz sentido. A partir de então, a teoria geral para a Literatura brasileira, a Filosofia da História, só validam a insistência de Sílvio em atribuir importância ao mestiço brasileiro. Dali em diante, a confecção da História literária brasileira se transforma numa História da formação do povo brasileiro, o que leva o ensaísta a avaliar qual o escritor que pontuou a contribuição de cada uma das raças, sobretudo, a do mestiço. Discorda de Buckle, de Martius e de Varnhagen justamente porque tais escritores não trataram, a seu ver, da formação racial brasileira. Sobre Martius, falava que "o famoso botanista, no escrito citado, dá apenas um conselho e faz uma enumeração meramente exterior dos elementos que entraram em nossa população. Não os estuda; não os aprecia em sua ação mútua; não os mostra fusionando-se e reagindo uns sobre outros; não tenta a determinação nem ao menos vaga, do que devemos a cada um dos três fatores principais de nossa nacionalidade em particular e a todos eles conjuntamente. Deixa, o que é fundamental na questão, em completo esquecimento o ponto saliente do problema: o mestiço, sobre quem peculiarmente deveria insistir, esudando, repetimos, o especial quinhão de cada fator e definindo o caráter do resultado”. ${ }^{65}$

Não era outra a razão da discordância de Sílvio com relação ao Visconde de Porto Seguro

\footnotetext{
${ }^{62}$ Ibidem. p.359

${ }^{63}$ ROMERO, Sílvio. Introdução a História da Literatura. Op. Cit. p. 120

${ }^{64}$ TÁTI, Miécio. Sílvio Romero e a História da Literatura Brasileira. In. Autores Brasileiros. Op. Cit. p. 629

${ }^{65}$ ROMERO, Sílvio. Quadro Sintético. Op. Cit. pp. 16-17
} 


\begin{abstract}
"De certo tempo a esta parte, é de notar a insistência com que se tem andado, com evidente preocupação, a proclamar Varnhagen o criador da História da Literatura brasileira!...Criador... Como e por quê? Se a própria História geral, Varnhagen não a criou, como poderá ter criado a História da Literaturaw Varnhagen não fez mais do que, sem plano, sem sistema, sem doutrina, sem Filosofia, sem análise, sem síntese, escrever meia dúzia de biografias destacadas de poetas e escritores e a introdução da seleta a que pôs o nome de Florilégio da Poesia Brasileira: pouco mais fez do que repetir Barbosa Machado, Januário Barbosa, Noberto Silva, Pereira da Silva e outros mais. Varnhagen não tinha capacidade teórica e filosófica, e pouco além ia de pesquisas puramente eruditas. Se fazer biografias e apurar datas e fatos anedóticos fosse criar História literária, não haveria livro mais fraco em o gênero do que a História da Literatura Inglesa - de Taine, porque ali o grande mestre nem faz biografia, nem apura questiúculas bibliográficas.

Não é verdade que Varnhagen tivesse, como alguns tem afirmado, precedido Fernando Denis e Noberto Silva no tratar historicamente as coisas literárias brasileiras. Neste particular são-lhe não só anteriores os escritos de Barbosa Machado, Bouterweck, Sismondi, como os primeiros e decisivos de Fernando Denis, Noberto Silva, não falando já nos de Januário Barbosa, Almeida Garret, Nunes Ribeiro, Pereira da Silva, Gonçalves de Magalhães e outros.

Não é também verdade que tivesse, como igualmente se tem dito, sido o autor da História Geral do Brasil quem primeiro tivesse contado o gentio entre os fatores de nossa Literatura. Esteticamente, tinham-no feito antes dele algumas dúzias de poetas; criticamente, todos os autores acima citados. Cumpre advertir, finalmente, que o termo fator é mal empregado em relação a esses críticos e historiadores: estes consideram sempre o índio mais como um assunto a ser tratado pela Poesia e pelo romance do que com um fator da Literatura". ${ }^{66}$
\end{abstract}

Mesmo que saibamos da concepção literária de Sílvio, o que explica suas investidas nas mais variadas áreas do saber, sua História literária repousa sobre a formação racial do brasileiro, donde sua rica contribuição. Portanto, a História deveria buscar as riquezas folclóricas existente nas mais recônditas paragens brasileiras. Não bastava ao historiador literário falar do gênio criador em busca da musa ou da deusa da Arte, não bastava como faziam os antecessores de Sílvio arrolar simples Florilégios e Bosquejos. ${ }^{67} \mathrm{O}$ gênio nacional era, para Romero, o que havia de mais íntimo numa sociedade, era a base formadora de um país que se queria nação, ou melhor: o gênio brasileiro era formado pela singularidade brasileira constituído pelo meio que nos diferenciava e pela singularidade da raça mestiça. Como uma concepção bastante clara do que competia ao escritor quando da confecção de sua História literária, a Literatura deveria representar o nacional, deveria representar

\footnotetext{
${ }^{66}$ ROMERO, Sílvio. História. Op. Cit. p. 313

${ }^{67}$ Para uma boa compreensão do desenvolvimento da História e da Crítica literária brasileira consultar sobre o tema as publicações de Regina Zilberman. Por exemplo. ZILBERMAN, Regina; MOREIRA, Maria Eunice. Porto Alegre: Mercado Aberto, 1998; Críticos e historiadores da Literatura: pesquisando a identidade nacional. Via Atlântica, na. 4, Out, 2000; A fundação da Literatura brasileira. In: Revista brasileira de Literatura comparada. São Paulo: Abralic, (2): 59-68, maio 1994. CAIRO, Luiz Roberto Velloso. Do Florilégio a Antologia da Poesia Brasileira da Invenção: uma reflexão sobre o Paradigma da História da Literatura Brasileira. Revista de Estudos de Literatura. Belo Horizonte, V.3, pp. 43-53, out.95 Disponível em http://www.letras.ufmg.br/poslit
} 
elementos intrínsecos para a gestação de um povo num Brasil ainda não constituído de maneira homogênea, mas que Sílvio sempre sonhou representar em sua análise literária.

Literatura, para Romero, deveria servir de agente transformador, completamente diferente da concepção literária do escritor preso à forma e ao estilo. Sílvio não é o tipo de intelectual de gabinete, como foram Martius, Varnhagen e os escritores viajantes a serviço de suas nações. Literatura, para ele, era o domínio amplo das mais variadas áreas do saber, mas precisava também ser um conhecimento que se estendesse ao povo, porque este povo tinha fundamental importância na formação brasileira em função de suas tradições culturais. Era necessário representar o que havia de mais íntimo num povo, aquilo que lhes dava sentido, era esta a base formadora de um país que se queria nação: o gênio brasileiro era formado pela singularidade brasileira, o meio e as raças aqui presentes.

Sílvio era um herderiano, acreditava na nacionalidade literária porque era pela Literatura que se firmava uma nação. Sua visão larga, que viabilizava encontrar o "povo" brasileiro, deixava bastante clara a importância dos esquecidos da História literária. Dentre as tantas influências sofridas por Sílvio, Herder foi o escritor que mais profundas marcas deixou. Como Lembra Carpeaux:

\begin{abstract}
“Johann Gottfried Herder não deixou, entre os seus muitos escritos, uma só obra definitiva; mas é o maior dos precursores. Convergem em Herder todas as correntes espirituais da segunda metade do século XVIII - a Crítica, o individualismo estético, o senso histórico, o gosto das expressões populares; aprofundam-se, entram em novas combinações, e irradiam pelos tempos futuros. Dotado de extraordinária capacidade de análise intuitiva, Herder deu os primeiros exemplos de Crítica criadora: cria imagens permanentes de poetas, cria o seu Shakespeare, por exemplo; e depois de Herder será impossível contentar-se alguém com meras indicações biobibliográficas. O registro dos livros é substituído pela História das obras e das idéias. Mas Herder não cria apenas indivíduos; também cria, por assim dizer, indivíduos coletivos. Com o mesmo poder de intuição apanha os traços característicos das Literaturas nacionais, da inglesa, da espanhola, da grega, da hebraica, cria o conceito "Literatura nacional" como a expressão mais completa da evolução espiritual de uma nação.

Todo o nacionalismo do século XIX se inspirará em Herder, que é até avô, embora involuntário, do pan-eslavismo e do racismo alemão. Contudo, é um homem do século XVIII: $o$ seu ideal supremo é a Humanidade, e todas aquelas literatursa nacionais lhe aparecem como vozes mal isoladas, consonando na grande sinfonia Literatura Universal: conceito que também se deve a Herder". ${ }^{8}$
\end{abstract}

Romero buscou tenazmente a índole da Literatura brasileira confiando na importância do povo, donde surgia seu interesse em avaliar a contribuição racial desse povo. Tal era a concepção romântica que engendrou toda a historiografia até meados do século XIX. Era Sílvio um tainiano, que pensava que a Literatura possuía suas causas, sofria influências, bem ao modo de Sherer e Lanson; não foi menos positivista por valorizar a importância das origens do acontecimento em suas narrações acerca da evolução dos gêneros literários. Confiou em Schlegel devido ao paralelismo histórico das civilizações, no que advogava que primeiro era preciso conhecer a Literatura ocidental para analisar a Literatura brasileira. Todos esses aspectos derivavam de sua ampla visão literária. Foi Sílvio

\footnotetext{
${ }^{68}$ CARPEAUX, Otto Maria. História da Literatura Ocidental. V. 1. Rio de Janeiro: Edições O Cruzeiro, 1959. p. 20
} 
influenciado por esta ou por aquela corrente, o intelectual que foi Goethe, que vivenciou e foi ele próprio banhado por um humanismo, pela noção de uma Literatura mundial.

Auerbach fala do escritor humanista de feição goethiana, escritor que elabora sua Literatura a partir da visão de conjunto. Sílvio foi sujeito de seu tempo, quando o Romantismo lançava a visão para a construção da História literária, propiciando encontrar o povo para a formação das nações. Dali diante, como pontua Carpeaux, veríamos o alargamento dos horizontes, e Romero fora profundamente influenciado por toda esta herança: "a herança do humanismo goethiano foi breve, mas aí realizou-se ou deu início a muita coisa hoje em curso, e mesmo em expansão e ramificação crescentes. No fim de sua vida, Goethe tinha a sua disposição um material literário mundial muito mais rico em comparação ao que se conhecia a época de seu nascimento - e muito menor do que nosso patrimônio atual. Esse patrimônio, nós o devemos ao impulso do humanismo histórico daquela época; e não se trata aqui apenas da descoberta de novos materiais ou do desenvolvimento de métodos de pesquisa, mas, além disso, de sua difusão e utilização com vistas a uma História imanente da humanidade, a uma noção unitária do homem em meio a toda sua multiplicidade. Foi esse, desde Vico e Herder, o verdadeiro objetivo da filologia, e foi esse objetivo que lhe conferiu seu lugar de liderança: ela atraiu para si a História das Artes, a História religiosa, jurídica e política, associando-se a metas comuns. Não é preciso evocar os resultados obtidos, tanto no campo da pesquisa como no da síntese”. 69

\section{2- A Crítica: entre a Crítica literária e a Crítica sociológica}

Romero afirmava que escolhera a Crítica porque era o gênero que melhor se ajustara ao seu temperamento, "Existem em mim, encerram os germes de minhas tendências de analista e crítico. Aliadas as que tiveram origem no engenho Moreira, explicam em grande parte, toda a minha vida $e$ toda a minha obra”. ${ }^{70}$ Valeu-se da Crítica naturalista, alicerçada sob os paradigmas das Ciências Naturais em voga na Europa, para delinear sua forma de ler o Brasil, submetendo a cultura de seu país a um processo de renovação mental, estendendo seu olhar aos mais variados campos de observação, "É preciso que nos entendamos: eu também suponho ser naturalista, quero também a verdade dos fatos, e é justamente por isto que julgo estreita a fórmula de Zola" 71

Crítica, para Romero, era um instrumento por assim dizer metodológico de analisar todo um estágio de cultura, preocupando-se com os fatores condicionantes, para ele, responsáveis por toda e qualquer forma de produção artística emanada do espírito humano. Influenciado por mestres como

\footnotetext{
${ }^{69}$ AUERBACH, Erich. Ensaios de Literatura ocidental: filologia e Crítica. São Paulo: Duas Cidades; Ed. 34, 2007. p. 359

${ }^{70}$ ROMERO, Sílvio. Outros estudos de Literatura contemporânea. Op.Cit.p.222-223

71 ROMERO, Sílvio. O Naturalismo em Literatura. In: Literatura, História e Crítica. Rio de Janeiro: Imago; Sergipe: Universidade Federal de Sergipe. p.354.
} 
Taine, Scherer, Saint-Beuve, a Crítica de Sílvio ultrapassava a Crítica descritiva, a seu ver, refém da Estética, da Metafísica e da Retórica, “A Crítica moderna não é antiga Crítica literária; é uma disciplina científica que se aplica a todas as manifestações da humanidade. Seu domínio não é a Literatura em sentido restrito, a beletrística em linguagem alemã: a Poesia, o romance e o drama. Seu domínio é a totalidade das criações da inteligência humana. Seu método é o histórico comparativa e por isso ela chama-se a Crítica histórica. A sua mais vigorosa aplicação na Alemanha foi as línguas, as mitologias e as religiões". 72

Elabora sua Crítica reunindo a contribuição das diversas áreas do conhecimento, em função da influência dos procedimentos utilizados nas Ciências Naturais. Sua Crítica "literária" é sociológica porque despreza os verdadeiros fatores internos da obra criativa. Não pretendemos esmiuçar de maneira categórica os elementos pertinentes à Crítica científica, mas é indispensável abordar o modelo de Crítica para que se compreenda sua maneira de interpretar o Brasil amparado das grandes generalizações do momento formado pelos determinismos das leis evolucionistas.

Cabe-nos elucidar, de maneira breve, qual modelo de "Crítica literária" adotou Sílvio para empreender sua leitura de Brasil. Antes de tudo, vale salientar que fora a Crítica o maior instrumento do bacharel para legitimar sua visão e seus argumentos sobre o Brasil. Discorrendo sobre a dificuldade da concepção da Crítica no artigo Da Crítica e sua Exata Definição, onde traça um histórico a respeito da concepção de Crítica que sustentava, podemos compreender o modelo adotado por Sílvio. Concebida ora à luz da Poética ou da Retórica, da Estética, da História literária, dificultada ainda mais pela polissemia da palavra, Sílvio delimitava a importância da Crítica. Concluía que, "Ora, claro é que uma coisa, que se tem aplicado a todas as criações da humanidade,- artísticas, religiosas, jurídicas, morais, políticas, econômicas, científicas, - nem podem ser uma ciência à parte, uma nova ciência livre, independente, autônoma; nem pode deixar asfixiar no mero estudo das Belas Letras e belas Artes" 73

No artigo em questão, ele arrolou os grandes nomes da critica, desde clássicos como Aristóteles, que concebia a Crítica ligada à Retórica, o que foi a "causa principal do mais sério desvio que tem experimentado a Estética e a Crítica no correr dos séculos", ${ }^{74}$ aos nomes da Crítica moderna, como Henequim, Brunetière, Lessing, Saint-Beuave, Taine, dentre outros. Aqui, já podemos ter a noção daquilo que nortearia a visão do crítico literário e que moldaria, portanto, o perfil de Crítica modelador de suas análises. Após traçar um longo histórico sobre a concepção Crítica nos parágrafos finais do artigo, sintetiza que

\footnotetext{
${ }^{72}$ Ibidem. p. 345

${ }^{73}$ ROMERO, Sílvio. Da Crítica e sua exata definição. p. 391

${ }^{74}$ Ibidem. p.376
} 


\begin{abstract}
"Vê-se, pois, claro, que a Crítica, na qualidade de disciplina mental, é alguma coisa que se pode aplicar não diretamente aos fenômenos ou fatos quaisquer da natureza ou da sociedade porque essa é a função própria da ciência, senão às vistas, teorias, doutrinas, interpretações que de tais fatos deram os que deles se ocuparam

Existe, entretanto, uma ciência que preside ao desdobrar das ciências, servindo para todas elas de elemento formador indispensável: a lógica, a ciência das formas do mundo subjetivo, as formas do pensamento, as formas da razão e do raciocínio. A Crítica é uma parte dessa ciência quando ela se encarrega praticamente de verificar se as leis que regem as criações espirituais foram convenientemente utilizadas pelos que delas escreveram". ${ }^{75}$
\end{abstract}

A Crítica de Romero era considerada por ele mesmo científica porque formada a partir das leis. Sabemos hoje que fora Sílvio um crítico literário limitado porque priorizou os fatores externos da produção, preterindo analisar o conjunto de obras produzidas e a relação com o surgimento de outras. Desconsiderou as formas e as normas do bom gosto, onde o estilo é predominante. Não é por acaso que Romero classifica o que seja ciência e não ciência porque busca a certeza que as leis podem oferecer e que os fatos históricos podem comprovar. Divide as diversas áreas do conhecimento a partir do que considera ciências propriamente ditas, quase ciências e falsas ciências para só então estudar os fatos históricos, como ditavam as teorias do Positivismo e da evolução. Para Sílvio, os fatos históricos comprovariam esta ou aquela hipótese porque pensava que "não é mais possível a História sem a Crítica, como não é admissível esta sem as Ciências Naturais" "76. Influenciado principalmente por Taine, confiava nos nexos causais, generalizando toda e qualquer criação artística determinada pelo momento histórico, pela raça e pelo meio. Sílvio elaborara um modelo de Crítica "científica" e uma Literatura determinista. Em História da Literatura Brasileira falava, "Eis o grande fato firmado pelo século XIX nos seus últimos anos: estabelecer os outrora ditos estudos morais sobre bases experimentais. $O$ processo tem sido complicado e longo; foi mister passar em revista o método de todas as ciências e expulsar do seu conselho mais de uma pretendida sem validade em seus títulos. $O$ desenvolvimento gradativo de todos os fatos observáveis, alçado a altura de principio dirigente, mostrou a necessidade de melhor estabelecer a genealogia cientifica: a nova classificação, quaisquer que sejam ainda as dissonâncias entre os filósofos, tem por base tal principio" 77

Nesse sentido, a Crítica literária de Romero é de cunho naturalista, prioriza os fatos sociais, os elementos étnicos e o momento histórico. Toda e qualquer espécie de criação funda raízes na sociedade e é representação direta da mesma. Com sua História da Literatura Brasileira, almejava traçar um quadro naturalista da Literatura nacional, mostrando suas fases e os escritores que contribuíram para representar o país. Seu modelo de Crítica é profundamente utilitarista e inseparável

\footnotetext{
${ }^{75}$ Ibidem. p.396

${ }^{76}$ ROMERO, Sílvio. História da Literatura brasileira. Op.Cit.p.70

${ }^{77}$ Ibidem. p.70-71
} 
da raça, do meio, dos antecedentes históricos, da influencia estrangeira, da dieta alimentar etc. Era indispensável o conhecimento da História do país para traçar de maneira pontual os fatores condicionantes dessa Crítica "cientifica”. Só mesmo diante dela, considerada por Sílvio imparcial, seria possível encontrar os nexos causais para julgar a situação cultural do país " $O$ crítico deve ter bastante ciência e bastante coragem para distribuir os papéis e dar a palma a quem merecer diante dos fatos e da verdade provada" 78 .

Antonio Candido arremata bem o método crítico de Romero: "Com todos esses elementos em mão, pode repetir no Brasil a lição corrente na Europa- que o fenômeno literário não era uma criação saída ex-sponte da cabeça do escritor, fruto da razão e da vontade aplicadas ao sentimento, mas um produto, formado pelo concurso da vontade humana e dos fatores externos que lhe indicavam o caminho e lhe condicionavam as decisões. Pode, numa palavra, introduzir entre a noção de determinismo literário, o escritor sendo fruto da cultura, e esta um produto da raça, do meio, das tradições e das influências estrangeiras, submetida, como todos os fenômenos do mundo, a lei geral e básica da evolução transformista. ${ }^{79}$ (grifo nosso)

Primeiramente, quando se fala que Sílvio fora o introdutor da Crítica moderna, como nos lembra Candido, não significa afirmar que antes dele não tenha existido Crítica no Brasil. Uma vez que para Sílvio a História literária estava inserida no campo maior da Crítica, é preciso pontuar três aspectos desta. O primeiro é formado pela História literária e disciplina afim, constituindo a investigação metódica das criações literárias em relação com o tempo e a personalidade do autor; a teoria da Literatura que se preocupa especificamente com o problema literário, seguida da Crítica propriamente dita, que é o esforço de interpretação direto da obra. O segundo é a teoria da Literatura formada pelos livros propriamente teóricos que são os manuais e compêndios de Retórica, Poética e Crítica, somado à Estética literária escrita pelos poetas. Figuras como Fernandes Pinheiro, Costa Honorato e Freire de Carvalho integram a primeira corrente, ao passo que Gonçalves de Magalhães, Junqueira Freire e Álvares de Azevedo compõem a segunda. O terceiro aspecto é Crítica propriamente dita, denominada por Candido por Crítica militante, elaborada nos jornais e revistas, e dentre as mais importantes entre nós, aparecem Niterói, Minerva Brasileira, Revista Brasileira, Guanabara e Revista Popular. Aqui, figuram nomes como os de Emilio Adet, Nunes Ribeiro, Joaquim Noberto, Pinheiro, Torres Homem, Machado de Assis e Francisco Otaviano.

O primeiro gênero a florescer são as antologias, por onde se processavam as análises e os estudos da Literatura portuguesa e brasileira. O mais importante desse gênero é Januário da Cunha Barbosa,

\footnotetext{
${ }^{78}$ ROMERO, Sílvio. O Naturalismo em Literatura. Op.Cit.p.348

79 CANDIDO, Antonio. Introdução ao Método Crítico de Sílvio Romero. Op. Cit. p. 156. Ainda do autor. Silvio Romero; teoria, Crítica e História literária. Rio de Janeiro: Livros técnicos e científicos; São Paulo: Edusp, 1978.
} 
autor de o Parnaso Brasileiro, de 1831. Com o mesmo nome e surgida em 1843, Pereira da Silva justifica a elaboração de seu Parnaso em função da dificuldade da obra de Januário da Cunha Barbosa. Em 1841, Joaquim Noberto traçava suas Modulações Poéticas. Nesse mesmo molde, surge, em 1825, o Parnaso Lusitano, de Almeida Garret. Mas obra capital para o despertar nacional viria com o Discurso sobre a Literatura do Brasil, de Gonçalves de Magalhães. Obra de extrema importância, sem as divagações anteriores é a de Varnhagen, "dando ao Brasil, com efeito, o primeiro exemplo do que seja uma edição erudita, baseada no estudo da vida do autor, na pesquisa dos textos, suas variantes e circunstancias que os possam esclarecer. Retificador de erros e descobridor de subsídios, Varnhagen revela neste trabalho a sua vocação para a História”. ${ }^{80}$

Para o Visconde de Porto Seguro, Literatura, "é um aspecto da sociedade dum dado tempo, cuja fisionomia podemos apreender através das produções do espírito". ${ }^{81} \mathrm{~A}$ Crítica de Varnhagem fundase estritamente na erudição. Sotero dos Reis, estudioso dos árcades brasileiros, dos poetas românticos e assíduo colaborador das revistas da época, é um típico crítico de sua época: suas biografias, repletas de dados, datas e informações, evidenciam sua paixão documental. Outro gênero da época era a formação das antologias e galerias dos homens ilustres, mas aqui se trata de uma nova forma de Crítica. Juntamente com Sotero dos Reis, aparece a figura de Pereira da Silva, que, ao contrário de Varnhagen, não estabeleceu um quadro orgânico da Literatura brasileira limitando-se ao comentário e informações sobre escritores brasileiros e portugueses. Professor de Retórica, a concepção literária de Pereira da Silva está intrinsecamente ligada a esta, sendo nada mais que "a expressão de conceitos, sentimentos e paixões do espírito humano feita por modo agradável" ${ }^{82}$. Com este olhar, vê a Literatura portuguesa e brasileira conforme as regras e normas do bom gosto desconhecendo que uma obra literária influi sobre a outra, no que arrolava uma série de românticos, como Chateaubriand, Lamartine, Vitor Hugo, Manzoni, Foscolo, Schiller, Goethe, Byron, Moore e Martinez de La Rosa. Apontou esparsamente a influência do meio e da raça, mas duas questões são de alto relevo para o crítico: assim como seus predecessores, buscou inventariar os nomes célebres da Literatura portuguesa e por isso foi "o primeiro brasileiro que escreveu um livro sistemático sobre a evolução literária de Portugal e do Brasil" 83

No campo da teoria literária, a Crítica era praticada por meio dos manuais de Retórica e Poética. As Lições elementares de Poética nacional seguidas de um breve ensaio sobre a Crítica literária, somadas à Eloqüência Nacional, são o modelo de obra que serve de referência aos tratadistas brasileiros. Em 1866, aparecem As Sinopses de Eloqüência e Poética nacional acompanhadas de

\footnotetext{
${ }^{80}$ CANDIDO, Antonio. Introdução ao Método Crítico. Op. Cit. p. 18

81 Ibidem. p. 18

82 Ibidem. p. 22

${ }^{83}$ Ibidem. p. 23
} 
algumas noções de Crítica Literária, do cônego Manoel da Costa Honorato, e em 1871, as Positivas de Retórica e Poética, de Fernandes Pinheiro. Estes eram os trabalhos através dos quais os jovens críticos entravam em contato com o ideal crítico para feitura de seus quadros sinópticos e esquemáticos. Sotero dos Reis, Honorato e Fernandes Pinheiro, filiam-se à tradição clássica inspirada em Aristóteles, aprisionada pelo bom gosto, pelo belo e sublime, pontos centrais sobre os quais, tempos depois, incidiriam as Críticas de Sílvio com relação à concepção de Literatura. Neste âmbito, cabia a Crítica, formada pelo gosto e pelo bom senso, buscar na obra literária o belo. O gosto seria o ponto central na análise das obras literárias, avaliadas a partir dos meios retóricos e poéticos. O objetivo das análises é somente reparar aquilo que não é belo, esse é o princípio ponto da Crítica erudita, tributária do pensamento aristotélico. Fernandes Pinheiro concebe a análise literária da mesma maneira que Freire de Carvalho: cabe ao crítico, utilizar-se da Crítica na busca pelo belo, sendo indispensável à imparcialidade, a erudição sólida, a inteligência profunda e, acima de tudo, grande honestidade.

Contrastando com este modelo de Crítica formalística, ligada que era, a Retórica e a Poética, encontra-se a Crítica elaborada pelos poetas, figurando nomes como os de Álvares de Azevedo, e Junqueira Freire. Neste modelo de Crítica, o que prevalece é a análise pessoal do escritor, resultando na posição deste perante seu tempo e eivado de missão diante da sociedade, o que havia de certa forma empreendido a Crítica de Joaquim Noberto e Pereira da Silva, e ganharia força máxima com Sílvio.

Todos estes escritores estavam aprisionados à Retórica, amparados pela comparação e ampliação. No primeiro instante, não se pode caracterizar estes estudos tendo por base o método comparativo seguido por Sílvio, estimado e já consolidado pela Literatura Comparada: esse modelo de análise, de uma forma ou de outra, é sim teoria da Literatura, porque busca uma teoria que explique o surgimento dos gêneros literários e do fenômeno poético.

Por último, aparece a Crítica elaborada nos jornais e revistas, que fez avançar o interesse literário em função do estimulo interpretativo. Nas revistas é que saiam as notícias da civilização européia, era onde havia espaço para os folhetins, e para divulgação do desenvolvimento das ciências e das Artes. Poetas românticos surgiram no cenário nacional a partir de revistas conhecidas nacionalmente, como é o caso da Niterói, reduto dos primeiros criadores da identidade brasileira e como não poderia de ser, aqueles que primeiro realizaram a Crítica no país recém libertado. O que de mais importante há de ressaltar neste momento é a preocupação de tais escritores, seja por meio da prosa ou da Poesia, com a autonomia literária, tendo que para isso, encontrar elementos de brasilidade. Conhecido é o lema da Niterói, publicada somente dois volumes, “Tudo para o Brasil e pelo Brasil”. A Minerva Brasiliense é a primeira revista literária publicada no Brasil, contendo a participação de Santiago Nunes Ribeiro, Emilio Adet e Joaquim Noberto. A Guanabara, dirigida inicialmente por Joaquim Manuel de Macedo, 
Gonçalves Dias e Araujo Porto Alegre, onde tempos depois se somaria a participação de Joaquim Noberto, Capanema e outros, e depois orientada pelo cônego Pinheiro, após a ruptura provocada por Cândido Costa, em 1857, é outra importante revista. Dessa ruptura, surge a Revista Brasileira, consagrando pouco espaço para a elaboração e as análises literárias escritas principalmente por Norberto. Não menos importante é A Revista Popular, financiada pelo editor Garnier, com aspiração mais ambiciosa. A participação de Noberto e Pinheiro dotou a revista de um caráter bastante informativo com a produção de suas notas biográficas e esboços históricos. Nesta revista, figura o nome de Macedo Soares, que para Sílvio foi um homem de transição. Nele, aparece o importante papel da Crítica e sua azeda desavença está ligada ao jornalismo literário, comercial e político, feito da noite para o dia.

Adotando quatro modelos de Crítica, (contemplativa, administrativa, noticiosa, satírica), um ponto é tangente nas visões de Macedo Soares e Sílvio, o desejo por uma renovação ética literária. A importância das revistas se dá não apenas pela oportunidade literária para escritores e poetas, chegados à corte de todos os cantos do Brasil, mas sim porque estas despertavam o interesse e o gosto pela Literatura, facultando assim uma consciência de análise da obra. O jornalismo foi de fundamental importância para a divulgação literária e, simultaneamente, para despertar o gosto literário porque deixava espaço para os folhetins onde se mostravam as finezas européias e facultavam a evasão dionisíaca de mulheres tiranizadas por uma educação patriarcal. Futuros romances, os folhetins anunciavam no canto debaixo dos jornais a evasão e o desejo tanto de escritores frustrados como de mulheres sonhadora.

Diz Ubiratan Machado que "Mulheres e estudantes formavam a grande maioria do público dos escritores românticos. Mulheres jovens e sonhadoras, ainda tiranizadas pela mão de ferro do pater famílias, mas já vivendo as primeiras aventuras da libertação - como a grande aventura espiritual de ler. Ou a aventura muito mais instigante e assustadora de não se dobrar a vontade paterna na imposição de um marido, resolução em boa parte influenciada pela rebeldia acintosa de algumas heroínas de romance. Heroínas francesas, ardendo de paixão, rompendo todos os laços sociais por amor, e heroínas brasileiras, tipos fisgados entre as exceções da vida nacional, mas que, ao se transformarem em modelos literários, iriam ampliar os impulsos recalcados de muita Iaiá em seu direito de escolha" ${ }^{84}$. O folhetim foi o espaço privilegiado da geração romântica, servindo para a formação de um publico leitor e conseqüentemente para despertar o gosto literário. Informa José Ramos Tinhorão que, "Os romances-folhetim, ou de folhetim, como passariam a ser chamados no Brasil a partir da década de 1840, vinham representar no Brasil - repetindo o que acontecera na

\footnotetext{
${ }^{84}$ MACHADO, Ubiratan. A vida literária no Brasil durante o romantismo. Rio de Janeiro: EdUERJ, 2001. pp. 38-39
} 
França - uma abertura dos jornais no sentido da conquista de novas camadas do público, principalmente feminino, pois o tom da imprensa diária tinha sido, até então, o do comentário e doutrinação política, o que evidentemente só interessava a homens das áreas do governo, do capital, do comércio e da elite intelectual dos profissionais liberais". ${ }^{85}$ Conclui Antonio Candido que o "folhetim e a crônica contribuíram para a formação daquela atmosfera de civilidade, no bom sentido, sem a qual a Literatura não prospera e o gosto não se refina”. ${ }^{86}$

Desse modo o que os salões fizeram nos séculos XVII e XVIII o jornalismo cumpriu no século XIX, socializando a Literatura, criando um canal de debate e comunicação entre os escritores, o que não significa dizer que o jornalismo literário brasileiro tenha sido de boa qualidade, haja vista a periodicidade das revistas e a ausência de regularidades das seções literárias. O que predominava nessas seções era o mero caráter informativo.

Romero sofrera influências de escritores como Renan, Taine, Lessing, Émile Zola, grandes conhecedores da História universal e conhecedores da Crítica moderna, mas o bacharel não estava preocupado com a mera apreciação Estética da Arte pela Arte. Não basta para Sílvio conhecer a gênese literária, acreditava que havia algo de impessoal marcado pelo momento da época refletindo na criação. Tendo analisado os diversos modelos de Crítica aplicada aos diversos ramos do conhecimento que continuavam presos à velha Retórica, escrevia "Mas aqui dá-se um caso interessante: as criações científicas, a ciência, para dizer a cosia numa só palavra, não se contenta com esmerilhar o mundo exterior, o mundo físico, a natureza, como se costuma falar. Não. A ciência investe pelos domínios de suas companheiras de origem e quer a todo o transe, explicá-la também, determinar-lhes o sentido, o alcance, o valor. Temos, pois, de um modo geral, ciências da natureza e ciências da sociedade. A primeira divide-se em tantas ciências quantos são os aspectos consideráveis do mundo exterior e desdobra-se em matemática, mecânica, física, astronomia, geogenia, química, biologia”. ${ }^{87}$

Impregnado de tanto cientificismo, o modelo de Crítica de Sílvio transcendeu os de seus mestres e foi determinista. Em todas as análises, amparava-se nas leis, e na lei máxima que é a evolução transformista para interpretar a cultura brasileira, considerada por ele atrasada devido à pobreza material e ao analfabetismo dos 18 milhões de habitantes. Fez Sílvio crítica sociológica e não literária, escreveu poemas fracos no início de sua carreira, era um exímio conhecedor da História universal e enfrentou o drama da objetividade. Conhecia bem os críticos das áreas da religião, da Arte e, sobretudo, da "Crítica científica", modelo maior do que considerava ser a Crítica moderna. Passara o olhar pelas teorias do conhecimento - fosse o sensualismo-empirismo de Hume ou o criticismo

\footnotetext{
${ }^{85}$ TINHORÃO, José Ramos. Os romances em folhetins no Brasil: 1830 à atualidade. São Paulo: Duas Cidades, 1994. p. 13

${ }^{86}$ CANDIDO, Antonio. Introdução. Op. Cit. p. 31

${ }^{87}$ ROMERO, Sílvio. Da Crítica e sua exata definição. Op.Cit.p.392
} 
Kantiano -, buscando o método mais seguro para analisar o estágio de um Brasil miserável e coberto pelo cadinho de raças e sub-raças. Portador de um conhecimento enciclopédico, não serviria para Romero uma Crítica que não revelasse os fatores ou causas do atraso brasileiro e uma vez identificados esses problemas, queria subtrair seu país do atraso cultural e da situação de miséria.

Lembra Antonio Candido que "o intuito de Sílvio Romero foi submeter à cultura de seu país a um processo integral de Crítica, afim de desbastá-la das excrescências incômodas e mostrar-lhe o caminho certo, - ambição que pode parecer pueril a quem não estiver familiarizado com a sua altiva auto confiança, mas que vem explícita já nos seus primeiros livros" "88. Ansioso por encontrar as respostas aos males brasileiros para assim promover o progresso do país, Romero concebera a Crítica de um ponto de vista estritamente "científico", dando a esta um caráter altamente pragmático.

Resume bem Silvio Rabelo o ideal de Crítica para Romero: “O que falta ao seu maior livro, á História da Literatura Brasileira, resulta da sua incapacidade de intuição artística. Considerando a Crítica em sua mais larga acepção, como disciplina aplicável a toda a atividade do espírito - uma espécie de controle a se exercer como lógica, Silvio Romero não conseguiu caracterizar devidamente a Crítica literária em sua significação, artística, como gênero de criação, de aventura de personalidade. Não distinguia na Crítica literária o seu aspecto de sistematização lógica, fora da liberdade pessoal e arbitrária, do seu aspecto propriamente de Arte, sob a dependência dos poderes de criação" 89

Considerado por boa parte de sua geração como escritor desprovido de estilo, sem a sensibilidade artística indispensável aos grandes escritores, Sílvio defendia a Crítica imparcial em busca da verdade. Segundo Rabelo, foi Sílvio um homem de espírito geométrico, bem condizente com o espírito da época em que a sociedade e as nascentes áreas do conhecimento eram concebidas a partir do poder das Ciências Naturais. Buscando sempre encontrar as leis que presidiam o desenvolvimento da cultura, fosse tomando como objeto a Arte, a Literatura, a Sociologia, sua disposição mental estava impregnada pelo mesmo procedimento aplicado às Ciências Naturais. Buscava encontrar respostas precisas praticando Crítica sociológica e histórica com a inovação do método histórico comparativo, menos Crítica literária. Sobre a definição da Crítica, afirmava que nem seus próprios mestres Lessing, Winckleman, Saint-Beuve, Taine, Scherer, Hennequin, Gottschall, De Sanctis e George Brandes haviam delimitado o terreno nem definido a natureza da mesma. Buscava Romero não mais que um recurso metodológico para sustentar suas idéias e para isso, evocava os maiores nomes da Crítica à medida que os determinados campos do saber iam se formando.

\footnotetext{
${ }^{88}$ CANDIDO, Antonio. Introdução. Op. Cit. p. 145

${ }^{89}$ RABELO, Ś́lvio. Itinerário de Sílvio Romero. Op.Cit.p.99
} 
Romero ultrapassou seus próprios mestres, como Taine e Scherer, porque não lhe bastava simplesmente descrever a participação dos fatores condicionantes, tinha em mente que a criação literária possui algo de impessoal "Tenho pensado, escreve Scherer, algumas vezes que haveria um novo gênero de Crítica a tentar. A teoria dos meios fracassou sem sombra de dúvida, porque só nos dava o que existe de mais geral, de mais vago, de mais abstrato na Literatura, quero dizer, o que há de mais estranho à Literatura. A Crítica foi bem inspirada e logrou mais fazer compreender e apreciar a obra literária, quando lhe procurou o segredo na pessoa do autor, nas circunstâncias de sua vida, nas particularidades de sua educação, na análise, em suma, de seu caráter e na narrativa de seus destinos. Aí, porém, falta ainda uma coisa: o encadeamento dos fatos literários, o sentimento da evolução para a qual concorrem todos os esforços dos artistas e da Arte. E é justamente isto, se não me engano, o que faltaria procurar; porque as Artes também estão sujeitas à lei do progresso, não como as ciências ou a indústria, mas por um modo que é peculiar. Na indústria qualquer descoberta vem juntar-se as precedentes as precedentes, aumentar-lhes o poder, e fornecer, por seu turno, a pedra básica, o ponto de partida dum novo progresso. É uma massa que sem cessar vai aumentando de volume e rodando sobre o declive com ligeireza crescente. Há nos mais belos trabalhos desta ordem alguma coisa de impessoal: a obra entra no uso geral e perde a marca do inventor, se é que algum dia a teve. É exatamente o contrário nas Artes. A obra de Arte é, acima de tudo, pessoal. É por aí que ela vale. É por este predicado que ela existe. É por este lado que ela dura ${ }^{90}$. (grifo nosso)

Sua maneira de compreender a Crítica recai sobre si a imagem de um escritor desprovido de intuição ou sensibilidade artística e sem posição filosófica definida, e, sobretudo, um pensador determinista. Sílvio Rabelo comenta o caráter crítico de Sílvio "O que dependesse, porém, de uma apreensão pela sensibilidade ou pela intuição escaparia sempre a sua capacidade Crítica. Por isso, Sílvio Romero cometeu em Literatura os mais graves erros de julgamento" ${ }^{91}$. Ainda reitera o autor citado que Silvio Romero nunca pode se manter no nível em que as idéias se desligam da viciosa contingência humana. Mas si os seus erros mais graves foram cometidos por uma incapacidade de intuição artística, os mais freqüentes foram cometidos por sua paixão, uma paixão que vinha do seu temperamento indisciplinado e da feição da sua inteligência rigidamente unilateral ${ }^{92}$.

O contato com as inúmeras idéias que teve no Recife (principalmente, com a visão mesológica encabeçada por Curtius, Buckle e Gervinus; a Etnologia, com Herder, Tierry e Renan; a Fisiologia com Taine e Zola; a Psicologia com Saint-Beuve, Hermann Hettner e Karl Frenzel; o método histórico de Macaulay e Villemain; o julgamento científico de Scherer e Julian Schmidt influenciou-lhe a visão

\footnotetext{
${ }^{90}$ ROMERO, Sílvio. Da Crítica e sua exata definição. Op.Cit.p.386.

${ }^{91}$ RABELO, Sílvio. Op.Cit.p.95

92 Ibidem. p.95-96
} 
científica. ${ }^{93} \mathrm{O}$ farto conhecimento que tinha da História universal, das correntes epistemológicas e um sem número de autores que chega a citar em sua vasta produção fez boa parte da Crítica pensar Romero como um escritor que recorria a vultos importantes da época somente como recurso de autoridade para se defender em suas inumeráveis polêmicas. Todo esse estado de coisas fez de Romero um pensador que viveu em agonia, a agonia de, em meio a tantas ideias, escolher a que melhor explicasse o país .

Diante de seu vasto conhecimento científico, jazia a "agonia de um nacionalista frustrado" expressão de Thomas Skidmore - na medida em que seu país era composto basicamente por uma população analfabeta e de composição mestiça. $\mathrm{O}$ momento agitado da transição do regime imperial para o republicano só fez de Romero o intelectual missionário, engajado nas lutas de modernização do país. A Crítica foi para Romero o fundamento de seus estudos e apodo de suas idéias. A crença no meio e na raça são parte da influência crítica que recebeu de Lessing, Herder, Taine. Buscou entender as diversas teorias do conhecimento - empirismo, idealismo, racionalismo, criticismo - a partir de uma gama de escritores europeus para só assim escolher a corrente mais adequada a seu método crítico e validar suas argumentações. Citava os mais célebres escritores da Crítica européia, fosse da Crítica religiosa, da Crítica científica ou mesmo artística, acreditando está fazendo Crítica literária, mas não saía do campo da Crítica histórica ou sociológica. Impregnou-se de tantas leituras somente para ter um ponto de partida. Recorreu a Kant para comprovar que o conhecimento era o mais relevante instrumento, elaborar sua Crítica naturalista trabalhando apenas com os fatores externos.

Romero não avançou a Crítica literária, embora inovasse no método e sua contribuição histórica, sociológica, e folclórica seja ímpar. Concebia o processo de cultura como produto das relações sociais, donde todo o processo de transformação ser ditado pela lei evolutiva. Acreditava nas causas às quais as leis evolutivas serviam de escopo. Sua busca incessante e minuciosa é consequiência da fé inabalável dos homens de sua geração, somada a seu temperamento irrequieto. Seu temperamento uniu-se com as contingências do momento agitado atravessado pelo Brasil priorizando a Crítica sociológica e naturalista em detrimento da Crítica literária que transcende a mera identificação dos fatores condicionantes que elucida, mas não dá conta da criação artística. Foi então que buscou conhecer as diversas teorias do conhecimento, aderindo primeiramente ao Positivismo e preterindo tempos depois a escola de Comte em favor do Evolucionismo de Spencer. À medida que ia conhecendo o Evolucionismo de Spencer, ia se tornando árduo defensor da doutrina de Spencer, a partir da qual, inúmeras vezes, esboçou em seus trabalhos, "As doutrinas do Evolucionismo spenceriano tinham-me posto na pista do desdobramento dos vários ramos da atividade humana;

\footnotetext{
${ }^{93}$ Ibidem. pp. $97-98$
} 
tinham-me despertado a atenção para as formações díspares dos povos mestiçados, nomeadamente os da América do Sul, e, por esse caminho, havia sido conduzido as conclusões a que cheguei em todos os meus escritos acerca de minha pátria". ${ }^{94}$

Interpretou o Brasil com idéias importadas da Europa, o que, para boa parte da historiografia, servia como justificativa colonizadora não apenas para o Novo Mundo, como para a África. Sua Crítica é parte integrante de um conhecimento ocidental que concebe o resto do mundo a partir das leis eurocêntricas, justificando a superioridade do europeu em detrimento dos povos mestiços. Seguindo Sílvio Rabelo, a Crítica de doutrina foi o modelo de Crítica adotado por Sílvio ao longo de sua atividade. Sem adentrarmos as nuances das Críticas literária, filosófica, histórica ou religiosa, como bem conhecia e escrevia Romero, como elucida o próprio bacharel, recorreu a inúmeras teorias em busca de um método de aplicação e de análise para interpretar o Brasil para assim identificar seus inúmeros problemas. Esteve sempre em sintonia com as últimas teorias estrangeiras, inaugurando uma corrente de idéias novas no Brasil. Ficou conhecida na historiografia literária brasileira sua Escola do Recife, movimento filosófico formado por jovens bacharéis da Faculdade de Direito, e ele sempre defendeu o pioneirismo do grupo com relação à assimilação e divulgação das idéias naturalistas no país. Adotou a Crítica como recurso diante de seu esforço de objetividade influenciado pelos paradigmas da ciência da época na mira de um conhecimento seguro que identificasse as causas do atraso de seu país, e assim, mostrasse os caminhos para subtrair este atraso.

Mas os problemas que enfrentava o Brasil eram inúmeros e o polígrafo se preocupou com sua infinita gama que ia desde a formação de seu povo, atinando para o caráter nacional, aos problemas da economia brasileira, chamando atenção para o câmbio do país. Conhecedor dos variados modelos de Crítica, recorria a esta para dar sustentação e respaldo teórico a suas hipóteses, por isso associava o atraso brasileiro como reflexo ou decorrência do desconhecimento dessa realidade pelos escritores brasileiros. Confundindo Crítica histórica e sociológica com Crítica literária, adotou a Crítica que julgava, diferente da concepção de Taine e Scherer, para avaliar o valor da obra e sua contribuição às letras brasileiras. Em Martins Pena, afirmpi que: "No espírito da Crítica sociológica é que temos procurado estudar a Literatura Brasileira e particularmente agora o tipo simpático e altamente representativo de Martins Pena. E não é de hoje o nosso entusiasmo por tão sugestivo escritor, que vemos ainda em nossos dias tão maltratado. Há cerca de vinte anos já nós o colocávamos entre os prógonos do pensamento brasileiro. Nunca tratamos então nem agora de discutir, se ele escreveu farsas ou verdadeiras comédias, se possuiu ou não o espirit à la Molière, se dispunha ou não de um estilo elegante, ou outros problemas de igual jaez.". 95

\footnotetext{
${ }^{94}$ Ibidem. p.189

${ }^{95}$ ROMERO, Sílvio. Autores brasileiros. Op.Cit.p.345
} 
Do crítico literário que se preocupa com as categorias da Arte ou da Literatura para analisar a obra criativa, Romero encaminhou-se, sob o influxo naturalista, para o campo da Crítica sociológica priorizando os fatores externos da criação literária. Antonio Candido, em seu conhecido estudo sobre o método crítico de Sílvio Romero, chega a comentar: Desde os primeiros escritos, é evidente que não lhe basta uma Crítica de caráter puramente literária. Quer segundo o modelo cientificista dos seus mestres europeus, descer a análise dos fatores condicionantes - meio, raça, evolução social, tradições; - quer atingir setores da vida coletiva - política, ensino. Passa pela Filosofia, pela Etnologia, pela Sociologia 96

Foi Silvio um homem preocupado com os porquês da criação, mas a criação de Romero era muito mais que qualquer obra artística: como diversas vezes afirmava, seu maior sonho era ver os problemas do Brasil solucionados e o país formado enquanto nação moderna. Para isso, sustentou sua visão científica e averiguou a raiz de inúmeros problemas. Do crítico literário que buscava analisar a obra a partir da produção de outras obras existente, leitura dos textos, etc, Romero é exemplo maior das doutrinas deterministas que não consideravam a intuição subjetiva inerente do artista. Carregava consigo o modelo de escritor representativo que incorpora e reflete as transformações do momento. Por isso é que seu modelo de Crítica acarreta um determinismo literário. Assimilara inúmeras idéias somente se estas dessem às suas perguntas respostas plausíveis e pudessem ser aplicadas ao Brasil que urgia rapidamente mudar. Não se limitou Silvio aos encantos da Arte, sua sensibilidade era falar a verdade, toda a sorte de corrupção e miséria que via em seu país.

A par da Crítica naturalista, almejava Romero um recurso científico para interpretar o Brasil, adentrando as estruturas sociais e assim conhecer a essência dos problemas do país. Afirmava que " $A$ aplicação ao Brasil é a preocupação constante; as considerações etnográficas, a teoria do mestiçamento, já físico, já moral, servem de esteios gerais; o Evolucionismo filosófico é a base fundamental", 97

Romero viveu o conturbado momento histórico da segunda metade do século XIX, presenciando uma nova forma de conceber a sociedade de então: a sociedade passava a ser estudada à imagem e semelhança de um organismo vivo, que evoluíam inevitavelmente do menos complexo ao mais complexo, processo sempre ditado pela lei do mais forte. A nova sociedade sentida por Romero e sua geração sofreu a transposição do método aplicado nas Ciências Naturais para o campo das Ciências Sociais, donde sua busca fremente de se perguntar pelos males brasileiros, sendo indispensável o conhecimento dos diversos ramos do conhecimento na formulação de suas generalizações.

\footnotetext{
${ }^{96}$ CANDIDO, Antonio. Introdução ao método crítico... Op.Cit.p.146

${ }^{97}$ ROMERO, Sílvio. História da Literatura brasileira. Op.Cit.p.48.
} 
Analisando o Brasil à luz das idéias naturalistas, tendo por base o pensamento de Buckle, segundo Sílvio o autor que mais se preocupara com o Brasil, ressalta a importância da Crítica. Era de fundamental importância a Crítica para fundamentação dos vários campos do conhecimento e assim solidificar cientificamente sua leitura de Brasil, "Mas o certo em tudo isto é que as três características se supõem e se completam; não é mais possível a História sem a Crítica, como não é admissível esta sem as Ciências Naturais. Eis o grande fato firmado pelo século XIX nos seus últimos anos: estabelecer os outrora ditos estudos morais sobre bases experimentais. $O$ processo tem sido complicado e longo; foi mister passar em revista o método de todas as ciências e expulsar do seu conselho mais de uma pretendida sem validade em seus títulos 98

Somente classificando as determinadas áreas do conhecimento em ciências e quase ciências, aderindo à Crítica como recurso metodológico envolto por sua teoria da mestiçagem e pela lei do mais forte, somada à influencia do meio e da raça, é possível compreender o modelo de Crítica adotado pelo bacharel para empreender sua leitura de Brasil. Se por um lado Romero é concebido como um autor contraditório, interpretado algumas vezes como um desconhecedor das reais teorias e do pensamento dos autores mais significativos da época, reside aqui o sentido de sua Crítica. Ainda remetendo ao importante trabalho de Sílvio Rabelo sobre o escritor sergipano, afirma que "O que dependesse porem, de uma apreensão pela sensibilidade ou pela intuição escaparia sempre a sua capacidade Crítica. Por isso, Sílvio Romero cometeu em Literatura os mais graves erros de julgamento" 99.

A Crítica era, para Sílvio, valorativa, daí pensar o crítico que só deveriam figurar em sua História da Literatura Brasileira aqueles escritores que contribuíram de uma forma ou de outra para representar o Brasil real. Mas de que forma e como Sílvio realizava sua seleção?

Leitor de tantas correntes de idéias e baseando-se no criticismo de fundamentação kantiana para sustentar suas análises, Romero metia sua Crítica de acordo com os preceitos do Positivismo e Evolucionismo. Foi a partir dessa forma de conceber a sociedade semelhante a um organismo vivo, onde as instituições seriam equivalentes aos órgãos precisando funcionar de forma harmônica, que fez de Romero ao mesmo tempo em que um grande erudito, um escritor considerado desprovido de intuição artística e sem postura filosófica definida. Diante do bando de idéias novas oriundas da Europa e dos EUA, Romero tornou-se um perpétuo defensor do Evolucionismo de Spencer. O temor pela instalação da nova religião da humanidade logo o fez escrever um duro ataque ao pensamento de Comte. Doutrina contra Doutrina é uma ácida Crítica ao Positivismo, que buscava ser a nova religião, "Doutrina contra doutrina- é o nosso brado e, se é verdade que o Positivismo conta hoje no Brasil (caso único em a História de um sistema filosófico ser defendido por batalhões armados) se o

\footnotetext{
${ }^{98}$ Ibidem. p.70-71

${ }^{99}$ RABELLO, Silvio. Op.Cit.p.95
} 
Positivismo conta hoje no Brasil homens de guerra dispostos a o defenderem pelas armas, nós, os fracos e desarpecebidos, cometemos talvez uma imprudência expondo o nosso peito ao chanfalho do inimigo"! 100.

A Crítica maior de Romero ao Positivismo se dava porque a Filosofia de Comte metia os demais ramos do conhecimento, como a Ciência, a Filosofia, a Moral, a Arte, a Política, a Indústria, a Religião, num círculo de ferro obstando o desenvolvimento desses ramos para o desenvolvimento da ciência debaixo de um olhar verdadeiramente científico. Nesse sentido, o Positivismo, segundo Romero, precisava ser combatido,

\begin{abstract}
"O Positivismo é uma coisa perigosa e deve ser combatido com seriedade. Desde que uma doutrina, qualquer que ela seja, tornou-se o pão espiritual de algumas centenas de homens, essa doutrina constitui um fator social e um estímulo de ação; essa doutrina distribui alento e entusiasmo, aviventa as forças da alma, afirma-se como um incentivo em nome do futuro. E coisas assim tão graves só podem ser tratadas com severidade e compostura. Podemos tomar com elas a nossa parte de divertimento e gracejo; porque tudo neste mundo tem o seu cômico; mas este expediente deve ser passageiro e relegado para o segundo plano.

O Positivismo no mundo, e nomeadamente no Brasil, deve ser combatido larga, tenaz e sistematicamente, ponto por ponto, idéia por idéia, doutrina por doutrina" 101
\end{abstract}

Para Sílvio, o sistema não trazia inovação alguma pois a base de seu conhecimento já era aplicada desde os tempos de Lessing, Saint-Martin, José de Maistre e Saint-Simon. Nesse opúsculo, Romero traça a falta de originalidade por parte do Positivismo, as razões de sua Crítica e, sobretudo, se apóia no Naturalismo para preterir a nova religião da humanidade ansiosa com os ares de universalidade, como acontecera com o Catolicismo quando de seu surgimento em Antioquia, “ $A$ razão de ordem, por assim dizer, o primum mobile do Positivismo está no seu modo peculiar de encarar a marcha da civilização, nomeadamente da civilização ocidental. Desde sua especiosa maneira de apreciar o desenvolvimento da cultura moderna origina-se o determinado e invencível desacordo em que ele se acha para com a Filosofia crítico-naturalista, para com o Evolucionismo em suma” 102

O Evolucionismo transformista acabara sendo a idéia central para Silvio Romero e grande parte da elite intelectual brasileira na segunda metade do século. Fosse recorrendo ao meio ou à raça, a inteligensia brasileira da geração de Romero fora entranhada pelas leis de Spencer. Diante de tantos ismos, aderiu Romero ao Evolucionismo transformista porque acreditava, assim como grande gama

\footnotetext{
${ }^{100}$ ROMERO, Sílvio. Obra Filosófica. Op.Cit.p.316

${ }^{101}$ Ibidem. p.314

102 Ibidem. p.319
} 
dos divulgadores da Literatura científica ${ }^{103}$ de seu tempo, que o Brasil era atrasado quando comparado com boa parte dos países europeus e com os EUA e que o modelo de Spencer dava uma excelente justificativa para subtrair seu país de tal situação. Romero sempre lutou por um Brasil moderno, amparado nas novidades científicas do momento, desde que conheceu o revoar das idéias novas, quando ainda era aluno da Faculdade de Direito do Recife.

Apesar de seu conhecimento enciclopédico, de nada serviria para Romero se este conhecimento não desse as respostas que esperava para subtrair seu país do estado de extremo pauperismo, dirigido pelas inúmeras oligarquias num país de 12 a 18 milhões de pobres e analfabetos. Não adiantava ser possuidor de um conhecimento enciclopédico, fincado sob os mais ilustres nomes da ciência da época, sabendo do analfabetismo da população de seu país. Ser um grande admirador das festas e tradições populares que sempre lembrava só reforçava a agonia e frustração de Sílvio num momento de transição de uma sociedade considerada atrasada para os novos tempos anunciados pelo imaginário republicano. As idéias novas assimiladas desde 1868 no Recife e seu conhecimento da língua alemã em meio à paixão por coisas tão simples fazem de Romero um personagem ambíguo. Toda essa situação faz de Romero um pensador que viveu em agonia, a agonia de, em meio a tantas ideias, escolher a que melhor aplicaria e explicasse o país. A idéia do momento por parte dos intelectuais era condenar uma sociedade que não tinha mais razão de ser.

Em tempos em que o Rio de Janeiro era a única oportunidade para os que almejavam viver das letras, fosse concorrendo a um emprego público no prestigioso Colégio Pedro II ou na redação de algum jornal, participando primeiramente das reuniões literárias nas adjacências da Rua do Ouvidor, Sílvio Romero era um extremo conhecedor não só da realidade brasileira como da cultura universal e é pressa demais afirmar que o crítico recorria a nomes importantes somente como recurso de autoridade. O momento histórico explica seu apego à ciência da época como também seu lado polêmico, contraditório, mas conhecedor tanto da cultura científica como da linguagem dos simples cantadores de sua província nos dias de folguedos.

Sua Crítica tem sim o peso do que recebeu sua geração presa ao Positivismo e ao Evolucionismo, acreditando que o conhecimento das leis explicava a origem de toda e qualquer forma de criação literária e também os problemas brasileiros. Romero fora um exemplo da crença inabalável no poder da ciência como Taine, Lessing, e outros. Ao contrario de seus mestres buscou não apenas identificar que ou quais os fatores condicionavam a criação artística, mas pensava que tais fatores pudessem servir de instrumento para explicar a situação brasileira. Não era um esteta ou não concebia a Arte pela

${ }^{103}$ LEITE, Dante Moreira. O caráter nacional. O caráter nacional brasileiro: História de uma ideologia. $4^{\mathrm{a}}$ ed. São Paulo: Pioneira, 1983.p. 193. 
Arte. Não foi Sílvio Romero um poeta ou o modelo de escritor preocupado diletante em um contexto social e político coberto por polêmicas marcando significamente a produção ensaística do momento.

Segundo Antônio Candido, "Vimos que a História da Literatura Nacional passado o livro $1^{a}$ e abstraídas as premissas gerais, se desenvolve como uma série de julgamentos funcionais, isto é, julgamentos da contribuição trazida pelo escritor para o panorama intelectual do seu tempo e o progresso da cultura pátria. Não apenas verificação das ligações e das influências entre escritor e momento, como fariam um Taine ou um crítico sociológico moderno -, mas verdadeiros julgamentos de dar a palma a quem merece, que tornam a sua Crítica mais utilitarista do que propriamente funcional. É esse pragmatismo sociológico que o levou a escrever na História da Literatura : A vida de um povo tem sempre em cada época meia dúzia de espíritos capitais, homens representativos, que a simbolizam e dão-lhe o sentido.Todos os mais são trambolhos de que a História deve ser escoimada por amor ao método e á clareza" 104 .

Para Romero, não bastava se prender ao prazer diletante dessa ou daquela escola, às novas teorias oriundas de França, Itália, Alemanha, Estados Unidos. As idéias assimiladas só tinham razão de ser enquanto propiciadoras de possíveis mudanças que esperava para seu país. Se por um lado boa parte da Crítica concebe Romero como um autor contraditório, visto como um desconhecedor das reais teorias e do pensamento dos autores mais significativos da época, reside aqui o sentido de sua Crítica valorativa, sentido que vimos permear sua maior obra História da Literatura Brasileira.

Sílvio Romero, como ressalta Antonio Candido, fora bem um acobertado pela emergência da Ciência Social no Brasil e pela chegada das teorias científicas a partir de 1870, que serviram de estofo contra a Metafísica espiritualista propagada nos seminários e preparatórios e acomodada pelo tom retórico por ele considerado retrógrado. Sempre combateu a imagem indianista divulgada pelos escritores do Romantismo brasileiro e corroboradas pelos escritores em torno do IHGB sob o mecenato imperial. A Crítica, para Romero, jamais poderia ser a pura Crítica dos admiradores da deusa da Arte. Criticou diversas vezes o domínio oligárquico corroborado pela pena dos literatos brasileiros submissos aos Pinheiros Machado, o isolamento de dois brasis raciais e, sobretudo, o estágio de miséria material de seu país em decorrência do desconhecimento dos pressupostos científicos. Toda uma estrutura social e econômica considerada obsoleta era questionada pelo bacharel, que tinha na ciência da época as respostas para tornar o Brasil um país à imagem e semelhança dos grandes centros europeus considerados civilizados.

Sílvio Romero não estava preocupado com a pura criação literária, nem tão pouco com o estilo, responsável pelo diletantismo que não oferece respostas práticas. Foi um escritor bem nos moldes dos

${ }^{104}$ CANDIDO, Antonio. Introdução. Op.Cit.p.155 
autores da Geração de 1870, sem a devida especialização literária, que participou ativamente no processo de transformação para o advento do regime republicano. Não foi um poeta ou um modelo de escritor diletante num momento de busca por um cargo público, que fora um dos motivos da adoção das idéias científicas e sua instrumentalização. Daí é que se explica o apego de Romero e sua geração às teorias científicas, atendendo primeiramente a suas perguntas e legitimando suas argumentações e hipóteses por meio da Crítica. O apego ao cientificismo é parte do que brotava de suas inquietações, a certeza para bem se defender.

É falha por parte de boa parte de a historiografia literária ver em Romero um escritor desprovido de intuição ou sensibilidade artística em razão de sua concepção de Crítica. Lendo seus trabalhos de Crítica, presenciamos um autor que bem conhecia a História da Filosofia, a Filosofia da História, as teorias de conhecimento e os grandes mestres da Crítica literária, científica e religiosa. Afirmar que Romero não tinha sensibilidade artística é, antes de tudo, desconsiderar o momento histórico vivido pelo escritor e o nacionalismo preocupado em identificar, buscar os porquês e somente assim sanar os problemas brasileiros. Que tenha sido Romero um autor preocupado com os destinos do Brasil não nos resta qualquer dúvida, outra coisa é pensar o autor da História da Literatura Brasileira como um pensador sem sensibilidade artística. Isso não nos exime de apontar as incoerências de Sílvio, suas arengas literárias e, sobretudo, sua mania de sempre querer ser o primeiro e o escritor que melhor interpretava as teorias estrangeiras.

Se por um lado encontramos um escritor polêmico, adotando idéias que sabia serem conflitantes com o Brasil do momento, fosse no campo da Arte, do folclore, da Literatura, da Poesia, tornando-se mais um dos pensadores brasileiros a ler o país a partir das cores estrangeiras, não se pode subtrair de Sílvio a centralização do olhar para a denuncia dos problemas nacionais. Buscou conhecer as causas do atraso do Brasil para bem justificar suas argumentações e dar validade a suas ideias, que acreditava explicar as raízes dos males brasileiros. Discordou de um sem número de figuras de seu tempo porque sua concepção de intelectual não era de um diletante, mas de um lutador em constante luta na arena literária para promover o progresso de seu país.

\section{3- Um naturalista mitigado: nem tanto!}

Somado ao caráter polêmico de Sílvio, recaí sobre todo seu pensamento outra pecha, não menos importante, que é o fato de ter sido o crítico literário um escritor determinista, representante do Naturalismo de sua época. Não temos a pretensão de adentrar a temática das escolas literárias no Brasil, enveredando por uma discussão teórica e formal do assunto, mas sim abordar a forte influência do Naturalismo no escritor sergipano. Sílvio é um típico representante do Naturalismo europeu no 
Brasil, escritor que se não buscava erigir sistemas teóricos, almejava explicar o quadro social do país a partir do que ofereciam os avanços científicos da modernidade européia.

Com o desenvolvimento econômico, acarretando cada vez mais a mecanização das forças produtivas, a sociedade passa a ser vista conforme as leis científicas e considerada passível de serem explicadas conforme os mesmos avanços adquiridos no progresso técnico. O maior trunfo do Naturalismo foi não somente mostrar ao mundo os avanços técnicos, mas trazer a ciência, especificamente, o conhecimento, como recurso explicativo para explicar as mais variadas formas de pensar, "o extraordinário avanço no campo experimental, porém, e, algumas generalizações, mas principalmente desligadas da realidade, provocam, de um lado, a ilusão de que se chegara ao fim dos conhecimentos, de outro lado, a ânsia em estender a domínios complexos descobertas hauridas em outros domínios, mais simples" 105

No campo literário, como sintoma desse progresso material, aparecem os livros de Claude Bernard, Lições de Filosofia experimental aplicada à medicina e Introdução ao estudo da medicina experimental; Lombroso publicava seu $O$ Homem Criminoso e em 1888, saía $O$ homem de gênero; Renan, escrevendo livro de mesmo título do de Strauss, a Vida de Jesus, em 1863, perde a cadeira que ocupava no Colégio de França. É nesse cenário que saía em 1848 o Manifesto do Partido Comunista e em 1859, A Origem das Espécies.

Sílvio conhecia todo esse panorama da transição Romantismo-Naturalismo, da mudança da nova ordem que a Europa e o Brasil atravessavam, onde as obras literárias mostravam ora os avanços científicos, ora as chagas sociais em suas taras e neuroses, e dialogou com boa parte dos escritores mencionados. A tomarmos o ponto de vista de Nélson Werneck Sodré de que "o Romantismo foi o meio de expressão própria da ascensão burguesa; o Naturalismo seria o de sua decadência" ${ }^{106}$, no que acarretou toda a Crítica aos moldes românticos, Sílvio é um escritor naturalista sem medidas. Se essas obras mostravam o cenário europeu, Sílvio tratou de mostrar a quadro da realidade brasileira a par da Crítica moderna. Toda a obra de Sílvio é um esforço constante de observar o que há de males na estrutura social, política, econômica, e cultural brasileira, a par das doutrinas européias, para só assim esboçar sua Literatura. Não bastasse o homem convicto nas leis científicas, o tipo de escritor que foi, a visão que tinha de Literatura e o ataque que impôs ao Romantismo são provas cabais do pensador naturalista que se tornou. A Crítica ao Romantismo permite-nos muito mais que filiar Sílvio a esta ou àquela escola, nos faz perceber e entender quais os temas tratados em sua Literatura. Acreditando na marcha da História, na evolução do mais simples ao mais complexo, segundo premissa tomada da leitura darwiniana, na inserção da nossa História na História mundial, tais preocupações demonstram o

\footnotetext{
${ }^{105}$ SODRÉ, Nélson Werneck. O Naturalismo no Brasil. 2a . Ed. Belo Horizonte: Oficina de Livros, 1992.p.43.

${ }^{106}$ Ibidem. p. 46.
} 
Naturalismo de Sílvio. Dizia o escritor em sua obra mestra que desejava traçar um quadro naturalista da Literatura brasileira. Para além da discussão que adentramos, o certo é que Sílvio precisou do apoio cientifico para só assim validar toda sua produção.

Tantas vezes salientado, obedecendo às correntes do Naturalismo, do Evolucionismo e, em menor grau, do Positivismo, o que em nada se presume uma leitura simplista, foi ao alvorecer das idéias novas que a figura de Sílvio esteve intrinsecamente ligada. A crença de que a cultura e, neste caso, de modo específico, a Literatura era condicionada pelo meio e pela raça, o que num primeiro momento evidencia um Sílvio preso ao determinismo de Taine e Buckle, mostra o cerne da discussão para compreendermos sua visão literária. A influência do criticismo filosófico influenciado por Kant modelou a visão de Sílvio, que muitas vezes mostrou-se extremo conhecedor não somente da Crítica literária, seu campo de atuação, mas um crítico do conhecimento ou um crítico sociológico ou da cultura. Ressaltando ilustres figuras francesas ligadas ao campo da Crítica, voltando ao criticismo filosófico alemão, onde presenciamos a revolução operada pelo autor da Crítica da Razão Pura no campo do conhecimento, Sílvio muniu-se da Crítica do conhecimento presente na Filosofia de Kant para validar suas investigações. O germanismo literário dos tempos do ex-professor Primo de Aguiar, somado à forte influência do amigo de refregas literárias e de temperamento semelhante ao seu, Tobias Barreto, formaram a mente de Sílvio.

No Campo específico da Crítica literária, esboçava em sua formulação teórica a visão Crítica de personagens como Taine, Sherer, e Beuve, no que justificava sua amplitude de conceber Literatura como espelho da sociedade. Para Sílvio, a Literatura, uma vez condicionada pelo meio e pela raça, era reflexo das transformações ocorridas na sociedade, nunca existiria em si mesma, mas somente enquanto produto de um amplo processo cultural. Não é sem razão que, para ele, a Literatura, apesar de ser uma das criações artísticas, compara-se a um organismo que evolui tendendo sempre a diferenciação, sofrendo a interação do meio e da raça, onde a vitória está sempre ao lado das idéias mais fortes. Pretendia traçar um quadro naturalista da Literatura, o que faria com a História literária do país, esboçando as concepções dos críticos já aludidos, seus métodos, as correntes mais em voga, etc. O combate de Sílvio à Metafísica e à Retórica, bases da Crítica reinante até o advento da nova intuição, não era gratuito: o escritor sergipano era a prova maior de um novo Brasil, de um país que carecia de sua História, onde fizesse valer a voz dos esquecidos, daqueles que nunca figuraram em nossa História literária. Apoiando-se no ideal maior do Naturalismo, que seria a investigação dos problemas sociais, trazia Sílvio à "boa nova", concebendo a Literatura não como Arte literária, mas tão somente como parte de um processo bastante complexo do que ocorria na sociedade.

O Naturalismo de Sílvio é ponto de ruptura com a História brasileira de então, no que desconsiderou um sem números de escritores, fossem poetas ou prosadores, resistindo somente 
aqueles que esboçaram em seus escritos o sentimento pelo país, reprovando um sem número de escritores que concebiam Literatura a partir da base Metafísica e Retórica, traçando seus bosquejos e suas galerias em prol do desenvolvimento das Belas Letras do país. O Naturalismo que tanto impressionou a visão de Sílvio e a que a todo custo buscou traçar em sua História da Literatura Brasileira rompe com as antologias e os bosquejos dos inúmeros autores de outrora, uma vez que "os escritores portugueses, atrás citados, acham-se no mesmíssimo caso, e os brasileiros, conquanto mais conhecedores do assunto, só quiseram escrever quadros isolados e só trataram de alguns tipos destacados. É inútil analisá-los agora; seus méritos e defeitos serão estudados no correr deste trabalho". 107

O modo de Sílvio interpretar o Brasil divergia daquele dos antigos escritores da História literária brasileira. Indo além da mera descrição dos vultos nacionais, dos varões brasileiros, não se limitou ao caráter de verdade das fontes, tal qual um Varnhagen, embora reconhecesse o Visconde de Porto Seguro justamente pelo cuidado deste com as fontes, que caracterizou toda a produção dos autores de parnasos e bosquejos na formulação da História literária brasileira, na busca por aquilo que era singular ao Brasil, o que era indispensável na construção da História nacional brasileira. A busca pela verdade, conseqüência das necessidades de um estado recém-independente em que o campo historiográfico se mostrava inseparável do campo literário, marcava a narrativa historiográfica: uma História elitista que tinha como fundamento a simples linearidade, donde bastava a exposição da galeria dos ilustres varões nacionais. O principal objetivo dessa História literária era fornecer elementos para erigir uma memória nacional. Sílvio mostrava a pobreza da nossa Literatura porque apesar de ser o Brasil visto por escritores europeus, raros foram aqueles que em suas obras mostraram o sentimento pelo país. A História literária elaborada por Sílvio, prenhe de seu método naturalista, destrona toda a erudição dos cronistas anteriores, uma vez que baseada na Crítica moderna tão celebrada pelo escritor. Não é sem razão que sobre a obra de Denis, tido pela historiografia como o escritor que fundou a História literária brasileira, afirma Sílvio: “O livro de Ferdinand Wolf, Le Brésil Littéraire (1863), tem sido, e continua a ser com razão, o oráculo de todos na matéria; porque é o único em seu gênero. O escritor austríaco foi o primeiro a fazer um quadro pálido e incorreto, é certo, mas que se impõe, por está no singular. E já lá vão bastantes anos que o livro foi publicado, e até bem pouco era o compêndio oficial de nossos cursos!", 108

Queria Sílvio por meio de suas obras literárias chamar atenção para os problemas nacionais, o que considerava serem problemas que condicionavam a criação da obra, que a melancolia romântica e a mania tupiniquim mascarada sob a imagem indígena só acobertavam. A querela que desde jovem

\footnotetext{
${ }^{107}$ ROMERO, Sílvio. História... Op. Cit.p. 53

${ }^{108}$ Ibidem. p. 51
} 
dirigiu contra os românticos era a maior manifestação de seu Naturalismo, em que tudo que fugisse à objetividade, avaliada por meio das leis científicas, era fantasioso e só atravancava o progresso do país na formação de uma nação moderna. Até mesmo desejava Sílvio uma Poesia científica, donde seus frágeis poemas e a acusação de ter sido um mau crítico literário, homem de espírito geométrico sem a sensibilidade imprescindível para a elaboração artística.

$\mathrm{Na}$ busca de um ponto de partida para iniciar sua História literária, balizada sempre pelo que permitia o Naturalismo europeu, arrola um sem número de autores com suas respectivas obras, busca Sílvio inserir qual o autor merece desfilar na História literária do país, levando em consideração sua contribuição, literária tendo em vista quem trabalhou pela diferenciação nacional. Silvio dava à Literatura um teor pragmático e lançava a idéia do escritor representativo imbuído de sua missão social, político e, acima de tudo, transformador. Mas quais seriam os critérios para inserir o escritor, brasileiro ou estrangeiro na História literária brasileira? Qual a visão de Sílvio sobre a maioria dos cronistas com relação ao Brasil? Como Sílvio pensava essa História literária?

A priori, o esteio de sua visão literária prendia-se aos quadros científicos da época. Nesse caso, "A Literatura brasileira não se furta as condições gerais de toda a Literatura antiga ou moderna, ser a resultante de três fatores fundamentais: o meio, a raça, as correntes estrangeiras. Da ação combinada destes três agentes, atuando nas idéias e nos sentimentos de um dado povo, é que se originam as criações espirituais a que se costuma dar o nome de Literatura. É que se deixou de ver em tais criações a obra do acaso, do capricho ou das imposições de um poder estranho qualquer. Eram estas últimas presumidas manifestações da Metafísica do absoluto em tal ordem de assuntos. A Crítica moderna desterrou de seu seio esta classe de fantasmas" 109

Sem ser ainda um campo delimitado, para Sílvio, a Literatura, como um ramo ligado à Sociologia que, como tantos outros ramos do saber, possuíam um ponto de partida de análise porque se tratava de um organismo presidido pelas mesmas leis que presidiam as Ciências Naturais. Dessa forma, após definir o que cabia à Literatura, mostra-se Sílvio um escritor ao mesmo tempo sabedor da flexibilidade da criação artística, um escritor rigorosamente naturalista, creditando à Literatura um meio de interação entre os povos, em que o meio e o momento histórico tinham profunda influência na criação de toda e qualquer maneira de representação social. O salto de Sílvio ou a grande diferença do escritor é seu grito de guerra a favor do que considerava ser de fundamental importância na construção da nação brasileira: levar em consideração o povo, não desprezando a contribuição dos negros (como o fizeram os românticos) em nossa História.

${ }^{109}$ Ibidem. p. 266 
Tal visão era parte da adoção do método histórico comparativo que permitia a sintonização das idéias de fora sem perder de vista o Brasil. Isso porque, como dito, a Literatura tal qual um organismo vivo, sofria o processo de evolução. As análises de Sílvio partiam desse raciocínio, a Literatura é parte de todo um processo histórico que antes de servir como meio elucidativo para mostrar o que acontece fora do país, requer antes de tudo o conhecimento da sociedade que o produz, no caso, a sociedade brasileira. Escrever exige a priori o conhecimento real por parte do escritor, por isto mesmo que transcende as normas do bom gosto com relação à criação artística; e o bom escritor é aquele regido pela objetividade, "é preciso que nos entendamos: eu também suponho ser naturalista, quero também a verdade dos fatos, e é justamente por isso que julgo estreita a fórmula de Zola" ${ }^{110}$. A objeção de Sílvio a Zola não se dava apenas com relação a sua concepção de Crítica e dos fins da Literatura, se estendia à própria concepção literária. Se o Naturalismo de Zola merecia as reprovações de Sílvio, uma vez que não acreditava na neutralidade do escritor quando da elaboração do romance, nem por isto deixava de aludir à nova maneira de encarar a criação artística, pois "ao lado de um realismo puramente fotográfico e inerte, é possível um realismo fundado na intuição cientifica hodierna". 111

Os limites entre Literatura, História e Crítica, em Sílvio, eram por demais tênues e bastante rígidos, aqui entravam a influência do ambientalismo de Gervinus, Buckle e Curtius; da Etnologia, de Herder, Thierry e Renan; da Fisiologia de Taine e Zola; da Psicologia com Hermann Hetner e KarlFrenzel; tudo isso somado à influência das correntes históricas tratadas por Macaulay e Vilemain, responsável por sua maneira de tratar a Literatura, sempre justificada pela nova intuição moderna. Por mais que Sílvio fosse e voltasse em suas análises, citasse vários personagens conhecidos mundialmente, não deixava de tomar por base o critério étnico herdado, sobretudo de Taine, processado pelo Evolucionismo de Spencer:

"Toda Literatura desdobrada no curso dos séculos oferece, destarte, o espetáculo de um gérmen, dum organismo que se desenvolve, já sob o estimulo de forças internas, inerentes a si mesmo, já sob a pressão de correntes estranhas que partem dum ou mais pontos do horizonte intelectual do mundo num tempo dado

Infelizmente estas correntes estranhas tem sido quase as únicas notadas na Literatura brasileira por alguns pseudocríticos que dela se tem ocupado". ${ }^{112}$ (grifo do autor)

A visão literária de Sílvio revestia-se profundamente dos preceitos naturalistas que tanto o empolgou e lhe serviu para analisar a cultura de seu país. Silvio reprova a Crítica de Zola não por conta de acreditar o romancista francês na possibilidade de uma descrição exata da realidade, donde originaria para isso as classificações. Segundo Sílvio, o autor de Nana entrava em contradição quando

\footnotetext{
${ }^{110}$ ROMERO, Sílvio. O naturalismo em literatura. Op. Cit. p. 354

${ }^{111}$ Ibidem. p. 355

${ }^{112}$ ROMERO, Sílvio. História... Op. Cit. p. 267
} 
pensava ser possível a neutralidade do romancista frente a sua própria criação. Desse modo, " $a$ doutrina zolaiana, tomada em seu todo, a concepção artística deste Naturalismo, tomada em seu conjunto, é algum tanto árida, não quando prega a observação, arida, vida animal em ação; existem também todo o imenso trabalho da cultura, todas as forças vivas com que o fator humano pode tirar da grosseria dos instintos mecânicos, a Arte, a ciência, a Poesia, o direito, a justiça e a moral. A natureza, a natureza!...Muito bem: é ela a grande fonte; mas uma fonte acre e despótica em seu mecanismo determinada e fatal. O homem tomou-a em suas mãos e a tem modificado por meio da ciência, da indústria, e cada uma destas criações é um organismo que evolui por seleção artificial, as vezes contra a natureza, bela dama, bela expressão Metafísica como outra qualquer...." 113

Sílvio ia de um extremo a outro, sabia que toda e qualquer produção artística tinha a marca do criador e dessa forma, buscando a realidade dos fatos, abria uma brecha dentro do próprio Naturalismo, ou seja: reprovando a Crítica de Zola, não por desacreditar na fotografia do real, o escritor brasileiro levava em consideração a velha tríade taineana formada por meio, raça e momento histórico. Zola era elogiado por Sílvio por ter sido o escritor francês responsável pela nova maneira de tratar a Literatura e a Arte, "Zola não é, porém, um sectário vulgar; trouxe para o seio da doutrina vistas próprias, que afirmam com força a sua individualidade. Entre elas destacam-se a idéia que o romancista faz da Crítica, o seu conceito da Literatura, a sua doutrina sobre a Arte". 114

Não acreditando na possível neutralidade do escritor, nem na existência da obra artística que não contivesse elementos do real, Sílvio punha em questão a influência da clássica tríade taineana e voltava ao ponto de partida: analisa a criação artística tendo por base a Crítica moderna. Entre idas e vindas, reprovando Hugo e admitindo Taine e Delacroix, Sílvio se mostra um naturalista. Lembremos que para ele Naturalismo era simplesmente "o contrário da intuição fantasista, do Romantismo aéreo, mórbido, inconsistente, histérico. Entre os naturalistas, entretanto, pode num predominar a impressão subjetivista e idealista, como em Sully-Prudhomme, ou a objetiva, como em François Copée." 115

Como num movimento de vai e volta, reconhecendo a flexibilidade da criação literária, pontuava Sílvio que "a Literatura não só é produto da natureza, não tem por fim descrever as paisagens da terra, ou tirar fotografias do mundo exterior. A Literatura é um produto humano, histórico, social, evolutivo das nossas faculdades Estéticas, e, com Buckle contra Zola, creio que na História ao lado dos fatores naturais há os fatores mentais neutralizadores da natureza" ${ }^{116}$. Fala como esta evidencia claramente que apesar da forte influência dos autores racistas e figuras significativas como Taine e Buckle, Sílvio abre uma fenda em seu próprio determinismo. O fato é que em meio às doutrinas,

\footnotetext{
${ }^{113}$ ROMERO, Sílvio. O Naturalismo em Literatura. Op. Cit. pp. 353-354

${ }^{114}$ Ibidem. p. 343

${ }^{115}$ Ibidem. p. 341

${ }^{116}$ Ibidem. p. 354
} 
buscava qual a melhor teoria para interpretar o Brasil, o que justifica simultaneamente ora uma fala determinista, ora considerar a importância dos "fatores mentais neutralizadores" na maneira de conceber a atividade literária.

\footnotetext{
"Assim, pois cumpre, não perder de vista de serem os fatores primordiais e permanentes de nossa vida espiritual, respectivo de nossa Literatura, a natureza e a raça, que lhe constituem o organismo e a alma, e ser o fator móbil, variável, externo, a influência, a imitação estrangeira. Aberra quem desconhece os primeiros; erraria quem escondesse o último. Há mister estudá-los mais de perto". ${ }^{117}$
}

Mesmo com este aparato explicativo, com suas sínteses e generalizações, bem a modo do que oferecia a ciência de seu tempo, Sílvio mostrava não apenas acompanhar as idéias elaboradas no exterior, como se mostrava um escritor relativista, uma vez que, considerava a influência social como condição de alterar as próprias bases do que considerava serem fatores condicionantes. Lembremos que Sílvio citava o higienista francês Michel Lévy, adotou a teoria climática de Buckle, mesmo fazendo ressalvas ao escritor britânico, dada a incoerência com relação a sua descrição do país, como por exemplo, a inexistência de vulcões, ciclones, desertos, geleiras, grandes primatas, etc, descritas por um cientista que sequer conheceu o Brasil. Não era incoerente analisar o Brasil da época a par das grandes sínteses e generalizações, era o que se conhecia na época, era o que oferecia a ciência dos tempos de Sílvio.

As grandes correntes históricas, as Filosofias existentes eram desdobramentos das Ciências Naturais e toda sua concepção tinha por base o principio da evolução. Na atividade Crítica, os reflexos fizeram-se sentir. Cabe destacar que Sílvio elabora uma interpretação diferente das de vários polígrafos, contemporâneos seus, mas com poucas exceções. Boa parte dos escritores acreditava na evolução histórica, na importância das raças e na passagem de um estágio a outro, conforme a mensagem de Comte. Literatura para Sílvio não apenas retrataria toda e qualquer forma de conhecimento, como embutia os elementos do enorme organismo que era a sociedade. Mantendo relação direta com este organismo, a Literatura não deixava de ser termômetro ao mesmo tempo em que meio de transformação para um estágio mais avançado. Tal maneira de interpretar advém da influência que tinha o escritor sergipano de ter uma visão elástica sobre a Literatura, marcada pelo fundamento crítico onde esta, de uma forma ou de outra, manifestava o estágio de um povo, uma vez que era produto de toda uma série de elementos que ao mesmo tempo em que condicionava era condicionada.

Sílvio permite uma interpretação literária ancorada em dois pólos: o primeiro é efeito de seu “determinismo", onde não há espaço para a subjetividade do artista, uma vez que sendo a Literatura

${ }^{117}$ ROMERO, Sílvio. História... Op. Cit. 267-268 
condicionada pelos fatores naturais e sociais, cabe a esta somente retratar de maneira fiel a realidade, donde a influência da época em que se encontra a sociedade. acompanhada da raça por esta formada; a outra interpretação provém justamente da inversão deste próprio determinismo, quando Sílvio ressalta a influência social imerso no quadro maior do "Naturalismo" que seguira. Da primeira interpretação, meramente pragmática, resulta sua concepção do escritor representativo, disposto a apontar em sua Literatura as singularidades brasileiras, diferente da imagem oferecida pelos escritores portugueses ou mesmo daqueles nascidos no Brasil, que concebiam a Literatura brasileira como prolongamento da Literatura portuguesa. Nessa ótica, o Naturalismo, para Sílvio, facultava o engajamento do escritor, afastando a Literatura a partir das regras do bom gosto, preterindo o olhar estético, visto que a Literatura guardava profundas implicações com a sociedade. Introduzindo o olhar etnográfico e evolutivo na concepção literária e artística, Sílvio não apenas reprovava a análise puramente Estética como trazia e pontuava de maneira detida a contribuição de cada raça na História literária brasileira. Para Sílvio, o escritor trazia algo de sua época, encarnava o gênio nacional e acima de tudo era influenciado pelo meio e pela raça, quadro somado à novidade do mestiço confrontando-se com as outras raças.

Diz Antonio Candido que "Sílvio repudia os padrões estéticos absoluto em nome do princípio relativista, que, afirmado pela dialética hegeliana, ilustrado pelo historicismo, teve uma demonstração tão brilhante nos estudos dos seus mestres naturalistas" ${ }^{118}$. E conclui que "O meio, a raça, a evolução histórica, os costumes admiráveis para compreender a obra do pensamento, despojada, de um lado, do seu caráter caprichoso e exclusivamente voluntário. Sílvio proclamou a boa nova, mas proclamando-a, não se sujeitou a certas durezas esquemáticas que comprometiam a plasticidade de muitas das obras dos seus mestres" ${ }^{119}$

A outra interpretação permite ao leitor adentrar aos fatores condicionantes da Literatura a que tantas vezes aludira Sílvio. Aqui, reside a linha tênue relativista de Sílvio. O "principio relativista" e as "certas durezas esquemáticas" aludidas por Candido referem-se a um autor que, bebendo dos preceitos do Naturalismo, do Positivismo e do Evolucionismo, reconheceu a fluidez racial, o que parece ambíguo, uma vez que a raça brasileira ainda não estava constituída e só a História futura, ao longo de três séculos, poderia dar respostas a esta nação. Segundo Sílvio "A Literatura é um produto humano, histórico, social, evolutivo das nossas faculdades Estéticas, e, como Buckle contra Zola, creio que na História ao lado dos fatores naturais há os fatores mentais neutralizadores da natureza" 120

\footnotetext{
${ }^{118}$ CANDIDO, Antonio. Introdução. Op. Cit. p. 68

119 Ibidem. p. 69

${ }^{120}$ ROMERO, Sílvio. O Naturalismo em Literatura. p.354.
} 
Diante da conjectura pela qual se formaram os vários campos do saber, Sílvio se voltava para a Poesia. Sabendo que a intuição geral, no caso, a evolução, fundamentava cada uma das áreas, perguntava se era possível a existência da Poesia. Apontando a influência da História no campo das Ciências Naturais, buscando hierarquizar as Ciências em mundo orgânico ou super-orgânico e salientando o emprego do método histórico e comparativo mais na Ciência dos Homens do que na Biologia, importava a Sílvio adentrar a área da Poesia. Mesmo nessa área, não abandonava a marcha das idéias esteadas pela evolução, "à luz deste principio bem se compreende que nada se aniquila, mesmo no mundo intelectual e moral: antes se modifica, se transforma, se transmite de algum modo na evolução do grande todo". 121

A Arte, como a Poesia, embora não tivessem fins científicos, eram para o crítico regidas pela intuição geral. Frente às transformações sociais e econômicas sentidas no Brasil, repercutidas também no campo das idéias, no qual emergiam as Teorias explicativas que serviam para avaliar a situação de atraso ou não dos países que estavam por se modernizar e onde presenciávamos o impacto do método comparativo regendo os mais variados campos do saber, dentre estes a prosa e a Poesia, queria Sílvio saber se viria a Poesia a se salvar da Ciência que tantas vezes ousara matar. O que inquietava Sílvio era se a revolução causada pela influência do Evolucionismo traria a morte da Poesia. Para isso, como não podia ser diferente, voltava seu olhar para o Brasil, apoiando-se em figuras como Wolf, Lessing, etc.

Para analisar a Poesia, Sílvio remetia à mudança de conceber diversas áreas de conhecimento, em função da influência tantas vezes aludida, dos pressupostos científicos nestas áreas. Aqui, aparecia a mesma visão de Sílvio quando analisava os mais variados campos do conhecimento: a intuição geral regia e dava sentido ao campo do conhecimento. Era a partir da forte influência provocada pelo Evolucionismo e pela seleção natural que Sílvio analisava a Poesia. Devido ao impacto das grandes transformações, onde a Ciência fora o mais importante elemento, áreas como a Filosofia, a Arte e a Religião, estavam com seus dias contados. Sílvio abordava se face às transformações do momento a Poesia viveria, "desde os primeiros anos de nosso tempo, desde M. de Stael e Chatteaubriand se discute sobre o desaparecimento próximo da nobre dama, que fez as delícias de Dante e de Shakespeare". ${ }^{122}$

Para alguns escritores, a Poesia morreria por conta da Modernidade; para outros, imbuída esta de uma alma moderna, tornar-se-ia esta cada vez mais forte e brilhante. A Poesia apenas encontravase doente. Para os primeiros, a Poesia acabaria no futuro próximo, para os segundos caracterizava esta

\footnotetext{
${ }^{121}$ ROMERO, Sílvio. Luís Murat. In: Autores Brasileiros. Op. Cit. p. 74

122 Ibidem. p. 76
} 
com uma sobrevivente na alma moderna das faculdades primitivas, "um survival que tende a limitarse cada vez mais, ainda que não venha jamais a desaparecer de todo". ${ }^{123}$

A voz de Sílvio era a palavra de Scherer, que, ao contrário de alguns escritores, por exemplo, Lefèvre, viam a Poesia dotada de forma e conteúdo. A Poesia era assim considerada uma maneira diferente de sentir, era imaginativa e não reflexiva, sendo o poeta provido de uma faculdade que apenas sentia a vida, ao passo que a faculdade reflexiva era o elemento imprescindível para o campo da Ciência. A Poesia estava voltada para o abstrato, daí ser da naturalidade do poeta extrair os objetos como eles são, enquanto ao cientista cabe produzir a partir do mundo exterior as idéias. A linguagem do poeta brota daquilo que ele vê e sente, por isso, é aquilo que exprime. Ainda que não seja o poeta um cientista, ele tem uma grande importância para sua cultura. A concepção de Sílvio de Poesia devia-se a Herder, mais importante pensador do Romantismo alemão, que apontava a importância da alma popular revelando o que havia de mais profundo na alma de um povo.

Embora defendesse a independência da Poesia com relação à Ciência, sustentando a sobrevivência da primeira, reconhecia Sílvio que a Ciência podia deprimir a pobre senhora. O que era brotado naturalmente da imaginação do poeta poderia ser atacado pela Ciência, uma vez que, " $a$ Poesia é produto da vida simples, espontânea, da comunhão com a natureza, da impressão imediata das coisas e estas condições, próprias da humanidade em sua infância, desaparecem necessariamente todos os dias diante do progresso científico e industrial das sociedades. " 124

Sílvio não concordava com o ponto de vista de Scherer de que a Ciência traria a morte da Poesia. O fato de ser a Poesia uma das criações mais antigas do gênero humano não significava que esta fosse morrer. A indústria e a Religião eram mais antigas do que a Poesia e continuavam vivas, e o que fazia sobreviver a Poesia era justamente sua espontaneidade. A causa da preocupação de Sílvio se dava pelos avanços científicos, que trazia pontos positivos e negativos paa a Poesia, "pode no seu trajeto através das idades ter a Poesia visto apagar-se mais de um gênero, como os grãos inúteis que se atrofiaram. Podem ter morrido a tragédia clássica e o poema épico, mas assim como a pintura não faleceu por ter definhado o gênero religioso, também a Poesia não há de sucumbir por ter murchado o gênero em que Ésquilo e Sófocles fizeram prodígios". ${ }^{125}$

Uma vez que a segunda metade do século XIX foi um momento de acontecimentos que acabaram por acelerar a queda da monarquia, somado à influência dos livros de Darwin, Huxley, Haeckel, Comte, Litttré, Buckle, Lombroso etc, a Poesia não ficaria infensa a toda essa conjuntura. Somente alguns ignorantes, conforme alegava Sílvio, perdiam tempo mastigando a prosa de Ramalho

\footnotetext{
${ }^{123}$ Ibidem. p. 76

${ }^{124}$ Ibidem. p. 78

${ }^{125}$ Ibidem. p. 79
} 
e Eça e a Poesia de Junqueiro e Quental. Com inúmeras escolas surgidas nos últimos vinte anos de vida do império brasileiro, "fenômeno altamente instrutivo e de grande significação", Romero concluía, "que a vitória havia de caber afinal ao simples lirismo, forma da Poesia que mais se coadunava com sua própria natureza intrínseca e forma mais em harmonia com o gênio de nosso povo". 126

Acreditava Sílvio num novo lirismo oriundo da alma moderna, no que ressaltava o livro de Luis Murat. Sendo o novo lirismo a substância da Poesia brasileira, Murat era, ao lado de Olavo Bilac e Guimarães Passos, a mais nítida expressão do gênero artístico. O elogio de Sílvio a Murat não se deve à especificidade deste no campo da lírica nacional e sim à natureza sã e à índole rebelde do poeta, responsável “por desmanchar o cenáculo, o impagável sínodo da nova geração..." 127

Muitas vezes acusado de não ter a sensibilidade artística, indispensável aos grandes poetas, devido a sua crença inabalável nos padrões científicos, Silvio preocupou-se com a situação da Poesia porque esta revelaria, frente à complexa agitação no campo das idéias, a situação de um tempo: de uma maneira ou de outra, o poeta falaria algo estritamente singular de seu tempo. Ainda que o escritor sergipano estivesse preso a uma estrutura regida pelas leis científicas, pela qual, pensando sempre no embate das leis esteada sobre uma lei geral, a Poesia tinha uma preocupação diferente da prosa. Embora o autor do Parnaso Sergipano incorra numa divisão dos períodos ou das gerações de poetas e prosadores, onde pontua o filosofismo poético de sua geração científica, para o mesmo, o que cabe à Poesia é o belo.

Analisando o lirismo nacional, Sílvio buscava a definição deste, revelando primeiramente aquilo que ele não quer ser! O nó da discussão residia na interpretação doutrinária gerada por uma ramificação do Romantismo brasileiro com relação à Poesia e Arte, donde "Originou-se este erro, ainda hoje defendido e consagrado pela critica atrasadíssima do Brasil, de um duplo malentendu: de um lado, falsa intuição da natureza da Arte, cuja origem é a emoção e cujo fim é produzir o prazer estético, e a que absurdamente se quis atribuir a função de criar e propagar idéias; de outro lado, a intenção de resistir á guerra absurda da Ciência, imiscuindo nos fins e desígnios desta, isto é, tentando espalhar também doutrinas e Teorias. Tão grandes absurdos meteram raízes tão sólidas no fundo granítico de nossa ignorância, que vinte anos de lutas não têm sido suficientes para arrancálas de todo. Ainda hoje assistimos á comedia de um critica transviada, que, pegando de um livro de versos, de um poema, de um quadro, de uma estatua, de uma sinfonia, assume atitudes doutorais e

\footnotetext{
${ }^{126}$ Ibidem. p. 81

${ }^{127}$ Ibidem. p. 82
} 
pergunta, a ingênua!... qual a doutrina, qual a Teoria, qual o sistema, que nos veio ensinar - este poeta, este pintor, este escultor, este componista?" 128

A falsa intuição da natureza concebida pela Crítica transviada brasileira se dava porque o que cabia à Arte era facultar o prazer estético, sem a preocupação de propagação de idéias. Uma vez que não competia à Arte divulgar idéias e Teorias, para se defender de uma visão científica, acabava por se preocupar com aquelas, tornando-se uma Arte que se misturava com os desígnios da Ciência. Eis a razão de vinte anos de grandes absurdos e de ignorância operada por uma Crítica transviada que quando tomava um poema, um quadro, uma sinfonia, logo perguntava que sistema ou qual Teoria pretendia dissipar. Esta era a razão para que alguns chegassem a falar numa prosa Poética ou numa Poesia prosaica. Para Sílvio, "Deixemo-nos de confusões: uma coisa é a Arte, outra coisa é a Ciência, outra cousa é a moral, outra coisa é a Religião." 129

Sílvio era bastante claro no que diz respeito a sua concepção de Poesia: “O artista, o poeta nada tem que ver com as teses da mecânica, ou da Biologia, ou da Ciência Social. Da Ciência, em quaisquer de seus domínios ele poderá, ter apenas as conclusões e intuições gerais, toda. aquela parte que se evapora, por assim dizer, dos estudos particulares, e vai constituir o que se pode chamar a atmosfera intelectual de um período histórico. O poeta, como, ha de, por força, respirar no ambiente de sua época, ha de entrar na corrente espiritual do período humano que atravessa, e daí o interesse que todos os grandes artistas revelaram sempre pelos sérios problemas que lhes foram coevos. Mas esse interesse é indireto: mostra apenas a emoção, o afeto que na alma dos poetas ficou, determinado pelo espetáculo da luta das idéias, espetáculo representado por outros, sábios e filósofos, - idéias oriundas de outras cabeças, que não as cabeças dos sonhadores, artistas e poetas. E a prova experimental e histórica d'isto, está em que, n'um período qualquer da evolução humana, a missão de descobrir e formular idéias e doutrinas, coube sempre a um grupo bem diferente do outro, que teve por tarefa notar a vibração dos sentimentos provocados justamente por aqueles sistemas $e$ Teorias". 130

Há de se ressaltar a alusão de Sílvio à intuição geral, àquela parte que se evapora e que, portanto, estava ligada à singularidade do momento histórico. A independência da Arte com relação à Ciência ficava evidente e fora de dúvida quando, ao longo da História, percebeu-se que aos poetas coube "notar a vibração dos sentimentos provocados justamente por aqueles sistemas e Teorias". 131 Apostava Sílvio que a Arte nada tinha que ver com a Ciência. Baseando-se na autoridade de Scherer, segundo o sergipano, “um dos homens mais cultos de nosso tempo”, seguia o pensamento daquele,

\footnotetext{
${ }^{128}$ Ibidem. p. 83

${ }^{129}$ Ibidem. p. 83

${ }^{130}$ Ibidem. pp. 83-84

${ }^{131}$ Ibidem. p. 84
} 
que discordava da visão utilitarista da Arte de Dumas, para mostrar sua visão de Poesia. Poesia é Arte e, como tal, se preocupa apenas com a busca do belo. Para Dumas, não existe a clássica idéia de Arte pela Arte, ponto central da discordância com Scherer; segundo este, a célebre expressão poderia ser dita de outra forma: a Arte pelo belo. Pensava Scherer que se existia uma Arte útil era a Arte industrial, mas a Arte era a busca pelo belo, e o que era o belo?

Não pretendendo adentrar questões de ordem Metafísica, concluía Scherer que o belo é aquilo que causa admiração e que acaba por impressionar. Mas, alguns atribuem à Arte a tarefa de instruir, o que, para esse crítico, não compete a ela, e sim à Ciência. A visão utilitarista de Dumas não desprezava a busca pelo belo, mas atribuía à Arte a função de instruir, invertendo uma situação: se o belo era o fim, agora passava a ser meio. Acontece que a preocupação com instruir levaria à morte da Arte porque matava o que há de mais natural, a espontaneidade da criação, que causava admiração e enlevava, diferentemente do que ensinavam os livros de Ciência, de Biologia ou de Mecânica. Enquanto cabia à Ciência, constituída pelos livros de doutrina, instruir e disciplinar, conforme a visão utilitarista de Dumas, correspondia à Arte a função de buscar o belo. A Arte não tinha que ver com moral, não podia ser vista como um bem ou um mal, simplesmente era bela e "o meio mais acertado para um poeta representar o seu papel neste mundo é ser sempre o que ele é e só se preocupar com o belo, do qual é o divino interprete". 132

Havia uma natureza intrínseca à Arte e à Ciência. Se a Crítica brasileira só dava crédito quando via estamparem nomes europeus cobertos por suas Teorias, Sílvio trazia seu Scherer para desautorizar os que designava como pacotilheiros de sensaborias com suas ladainhas.

O segundo motivo da Crítica de Sílvio se dava porque o novo lirismo não era mais coberto de lamúrias, de sentimentos mórbidos e tudo de pessimista. A concepção de Poesia para os poetas brasileiros até então era vista como triste porque estes concebiam a lírica com morbidez, o que combatia Sílvio, porque, "que haverá de mais lírico em Poesia do que algumas páginas de Píndaro e Horácio, e que também de menos triste e melancólico?" 133

O novo lirismo brasileiro era confundido pelos poetas brasileiros por ser um lirismo doentio ou mórbido o que era uma inverdade, pois afirmava Sílvio que nem o lirismo clássico e nem o lirismo romântico caracterizavam tal visão. Ainda que Romero concebesse a espontaneidade da criação artística compreendendo esta como sendo a mais livre expressão da imaginação, descia a particularidades, com sua mente racionalista, ao que diferenciava o elemento singular do que caracteriza uma Poesia de melancolia emem relação a uma Poesia péssima, “o melancólico lamenta-

\footnotetext{
${ }^{132}$ Ibidem. p. 86

133 Ibidem. p. 87
} 
se e seus lamentos tem alguma coisa da prece; o pessimista ataca, revolta-se, e os seus brados tem alguma coisa da maldição. Num o pranto e noutro a cólera, sem rebuço ou velada na ironia" 134

Diante de toda essa discussão, o que Sílvio defendia era uma nova Poesia era o novo lirismo brasileiro, impactado pelas visões de homens como Darwin e Spencer, que influenciavam o sentir e a emoção, "a revolução nas idéias, em marcha ascendente nos últimos tempos, acabou por alterar a emocionalidade, que tomou outros e diversos tons". 135

Não por que fosse um escritor preocupado com o estilo ou com a forma, mas sim porque, para além dos padrões estéticos, pensava que assim como os diversos campos do saber se processavam por uma intuição geral, a Poesia também não só se fazia tendo por base tal aspecto, como era sintoma de elementos condicionantes. No que pesem as idéias e Teorias, os diversos ismos de correntes que anunciavam o que havia de mais "científico" e inovador do momento, perguntava Sílvio se com todas as transformações da Ciência, que pôs fim à Metafísica, adviria a morte da Poesia.

Mesmo diante das transformações científicas, Sílvio, convicto de que a razão justificava o estágio cultural da sociedade, uma vez que concebia o escritor imbuído de missão e representação social, considerava que a Poesia era o que havia de mais natural, e assim existia desde muito tempo, mas nem por isso ficava imune à forte influência das transformações científicas. Sílvio analisava a Poesia num momento de grandes transformações, quando se presenciava "uma completa revolução que se manifesta pelo desordenado dos afetos". A morbidez da Poesia tinha ficado no passado, era coisa de melancólico, contrário ao que caracterizava a nova Poesia, no caso, o pessimismo, mas trazendo junto a isto a força do protesto. Além de mencionar a diferença entre a melancolia e o pessimismo, o novo lirismo tinha uma nova forma, resultado da Filosofia e da crença da época. Essa singularidade do novo lirismo era reflexo de um momento marcado por uma nova maneira de conceber os mais variados campos do conhecimento, o que fazia Sílvio concluir que "o novo lirismo que não é doutrinário, que não é moralizante, que não é choramingas, que muitas vezes é pessimista, que tem a intensidade do pensamento hodierno, representa também uma revolução na forma. E esta revolução estendeu-se também a prosa. A maneira contemporânea de escrever no romance, na História, na Crítica e no verso é bem diversa do feitio romântico e muito mais ainda do modo clássico". 136

Tendo vivido um momento de rupturas, arrolando a passagem dessa para aquela escola Poética, com os seus mais proeminentes poetas, mesmo admitindo a transição dos tempos, defendia Sílvio a sobrevivência da Poesia. Há se perguntar por que o escritor defendia veementemente essa

\footnotetext{
${ }^{134}$ Ibidem. p. 87

${ }^{135}$ Ibidem. p. 88

${ }^{136}$ Ibidem. p. 88
} 
sobrevivência. Para Romero, o poeta sentia sua época, e era a partir dessa capacidade que muito dizia sobre a época. Desse modo, o olhar de Sílvio com relação à Arte e à Poesia possui um fundo precipuamente científico, acredita o polígrafo que pelo campo poético muito se pode saber sobre o caráter de um povo num determinado momento histórico. Aparecia aqui um dos elementos clássicos da tríade taineana, a singularidade do momento histórico. Mas isso não confere a Sílvio um olhar determinista se lembrarmos que o autor, em diversos pontos de suas argumentações, atribuía à raça a causa do atraso brasileiro. Vale sempre lembrar a importância do método comparativo utilizado por Sílvio, que permitiu aos estudiosos compreender os mais variados campos do saber apoiados no rigor das leis, uma destas, a mais significativa, a lei evolutiva. Argumentava Sílvio que foram as Ciências humanas que influenciaram as Ciências Naturais, Ciências com um grau de complexidade maior do que as Ciências inferiores, pressupondo a fundamentação da Poesia tendo por base as leis evolutivas. No cenário nacional, paralelamente ao tumulto de tantas idéias, ocorria uma série de episódios políticos relevantes para o futuro do país como a Guerra do Paraguai, o Manifesto do Partido Republicano e a lei do Ventre Livre em 1871.

O novo lirismo brasileiro, a nova efusão lírica de Luis Murat, autor de Ondas, era diferente da Poesia chorosa, sem força, dos românticos nacionais, daí o combate de Sílvio a "uma Literatura de canto de canto escuro, cheirando a mofo, seqüestrada da vida real e positiva da nação, e em luta aberta com a sua historia" ${ }^{137}$. Homem de sínteses generalizantes, apontava o disparate daqueles que viam a Poesia a partir de uma posição doutrinária.

\section{4 - Sílvio Romero fora do cânone: intérpretes de sua História literária}

Sílvio foi um importante sistematizador da História Literária Brasileira. Tantas vezes lembrado, para Sílvio, a Literatura extrapolava o campo específico do fenômeno literário, abrangia toda e qualquer manifestação da inteligência humana. Mesmo no campo literário, apenas uma das maneiras de representação, não compreendia Sílvio uma Literatura em si mesma, do ponto de vista estético. É por isto que não aceitava a Arte pela Arte, a Crítica pela Crítica. Sua visão literária confunde-se com os problemas brasileiros que buscou subtrair, atinando para os fatores condicionantes.

Inúmeros são os trabalhos que analisam de maneira específica e generalizante a produção intelectual de Sílvio. Ele tem despertado muito interesse em pesquisadores das mais variadas áreas, porque sua produção abrange os mais diversos campos do conhecimento, hoje muito bem delimitados.

${ }^{137}$ Ibidem. p. 82 
Por isso é que várias são as áreas ou as frentes onde a importância de Sílvio é evidente, como a Sociologia, a Educação, a Antropologia, ou especificamente, a História literária.

Como lembra Antonio Candido, Sílvio é uma figura que ao mesmo tempo em que nos causa paixão desperta ódio, porque por mais numerosas que tenham sido suas incoerências, buscou ler o Brasil com Teorias de seu tempo, esforçando-se demasiadamente para escolher qual dessas Teorias era a mais adequada para interpretar o país. Soma-se a isto o homem bonachão que era, como aponta Araripe Júnior, pessoa que se dizia justa e que admirava as tradições culturais das pessoas mais simples. Diante dessas questões, o que há de mais importante é sua maneira de interpretar o Brasil, valorizando a dimensão etnográfica, dizendo ter sido o primeiro escritor a introduzir este método de análise, mas que Varnhagen e Martius já haviam relevado.

Seu modo "carbonário" de falar, traço apontado por todos aqueles que analisam Sílvio, motiva escritores de seu tempo, e esse é um dos principais elementos a despertar a análise de sua História literária. Assim, Sílvio desperta interesse desde seus contemporâneos, como Veríssimo, Laet, Capistrano, Araripe Júnior, Machado, e tantos outros, até os dias de hoje. Em tempos de ruptura, a palavra de Sílvio respondia às questões do atraso brasileiro. Sílvio continua a despertar o interesse da Crítica. Do difícil momento histórico vivido pelo país, como pontuava, surgia o crítico, o turbulento escritor nordestino. Mas, surgia também o historiador da Literatura que contestava o esquecimento dos poetas sergipanos em detrimento das celebridades nacionais residentes na Corte. A denúncia de Sílvio diante dos mais variados problemas brasileiros não se separavam de sua História literária. Do momento febril por que atravessara o Brasil, tenazmente lembrado por Sílvio, quando da chegada das Teorias estrangeiras, é que emergia a confecção de sua História literária.

Neste sentido, é o tom polêmico do ensaísta um dos fatores motivadores da Crítica. Insistimos em salientar a adoção da Crítica naturalista para deixar clara a visão de Sílvio. Nesse caso, vale lembrar a importância dos elementos, pelos quais, Sílvio acreditava influenciar a evolução da sociedade brasileira. Esta visão é parte integrante de seu temperamento, traço a que todos os trabalhos aludem e que o próprio escritor lembrava ter aflorado desde criança, quando sofrera maus tratos dos seus próprios irmãos. Impossível separar a empolgação das idéias de Sílvio em sua análise da Literatura brasileira desse caráter polêmico, dos arroubos de um escritor que sempre se achou injustiçado por parte das panelinhas da corte, dos políticos corruptos, e, sobretudo, de adversários que segundo o polígrafo não tinham crédito, uma vez que eram desconhecedores da Crítica moderna.

Como era sintomática do seu tempo, a polêmica fazia parte dos trabalhos literários, ou melhor, muitos livros eram acertos de contas entre o escritor e seus oponentes. Eis um dos motivos de Sílvio ser estudado por homens de seu tempo por conta tanto de sua vasta produção como em função de seu novo olhar sobre o Brasil. Olhar que não foi somente seu mas também da maioria dos escritores de seu 
tempo que recorreram aos critérios da raça e do meio para interpretarem o Brasil. Sílvio buscou esmiuçar o critério etnográfico e sua História da Literatura é a análise da influência racial na História cultural do país.

Sobre os tempos iniciais de Sílvio, embora os primeiros textos do escritor estejam todos perdidos, é de extrema importância o artigo de seu contemporâneo Araripe Junior, onde podemos conhecer um pouco a vida, a carreira e a vasta produção do escritor sergipano. Esse artigo serve de base para inúmeros trabalhos futuros que tratam de analisar a vasta produção de Sílvio, como os de Carlos Sussekind Mendonça e Sílvio Rabelo, dentre outros. Araripe analisa de maneira pormenorizada toda a produção de Sílvio, salientando sempre o caráter polêmico do escitor. Sobre o primeiro volume da História da Literatura Brasileira, onde o escritor sergipano analisa os condicionantes da cultura e busca a Psicologia do brasileiro, afirma Araripe Junior que, "O eixo do primeiro livro, incontestavelmente o mais interessante da obra, é o fato da fusão das raças, preta e vermelha no Brasil, sob o influxo da cultura trazida nas caravelas de Pedro Álvares Cabral. Esta tese, que Von Martius já em 1847 discutia com a amplidão de vistas que lhe era peculiar, Sílvio Romero desenvolvea brilhantemente, auxiliado pelo aparelho da Crítica vigente e pela interpretação biológicopsicológica da História à la Darwin. O que há de mais importante, porém, nesse livro, que vai até a página 140, é o relevo que o crítico conseguiu dar ao produto de origem popular, bem como a Psicologia nacional. Incontestavelmente, nessas páginas, feitas as reduções dos exageros que os excessos de doutrina nelas puseram, encontra-se, esteriotipado, o nosso perfil no convívio das nações, embora tosco, flutuante em muitos pontos, mas já indicando o ponto de onde brotará, quaisquer que sejam, de ora em diante, os elementos de imigração, o brasileiro do futuro". ${ }^{338}$

O trabalho de Araripe Junior, escritor que divergiu de Sílvio com relação ao elemento de maior participação na História da Literatura brasileira (se o meio ou a raça), evidencia o caráter polêmico de Romero, mas é a primeira grande análise sobre a vasta produção do ensaísta. Contemporâneo de Sílvio, como José Veríssimo, Souza Bandeira, Machado de Assis, Valentim Magalhães, dentre outros, Araripe acentua o traço polêmico presente até em sua História da Literatura Brasileira, "o talento de polemista de Sílvio, mais do que em qualquer outra de suas obras, avulta neste estudo". 139

Não nos interessa reforçar cada vez mais o tão divulgado caráter polêmico de Sílvio, mas todos os intérpretes de sua História literária aludem ao traço intempestivo do escritor sergipano. $\mathrm{O}$ escritor cearense e também crítico literário vai além da caracterização de Romero como figura polêmica, "Sílvio Romero é um pensador, e um pensador audaz; iludir-se-á, porém, aquele que pretender encontrar nesse pensador um Michelet, um Renan, ou mesmo um Taine. Ninguém, no Brasil, se tem

\footnotetext{
${ }^{138}$ JUNIOR, Araripe. Op. Cit.p. 299

${ }^{139}$ Ibidem. p
} 
mostrado tão apto para investigar as origens e estabelecer a filiação do pensamento brasileiro, sob o ponto de vista de todas as suas manifestações, vis-à-vis dos produtos da cultura européia; ninguém, no Brasil, dispõe de envergadura tão apropriada para empreender trabalhos semelhantes aos que fizeram Teuffel e Barnhardy relativamente às Literaturas romana e grega; devo, porém, confessar que as construções de caráter estético não são as que mais se amoldam a natureza das suas faculdades. Para isto, seria indispensável que ele fosse mais acessível à sensação concreta das coisas, isto é, - que tivesse, em maior escala, o sentimento de cuja ausência se ressentem, não sei se bem ou mal, muitos analistas profundos, a causa eficiente do interesse e do colorido que se notam em certas obras de Críticas, como, por exemplo, na História da Literatura Inglesa, de Taine. ${ }^{140}$

Desafeto de Sílvio, Araripe Jr. analisa de maneira sintética e pormenorizada a vasta produção do escritor sergipano no desenvolvimento da cultura brasileira. Tal artigo influenciou a série de trabalhos futuros dedicadas a Romero como um dos nomes mais marcantes na interpretação da sociedade brasileira. Os trabalhos posteriores não deixam de recorrer ao artigo de Araripe Junior chamando atenção para o caráter temperamental de Sílvio, “cascavel”141, responsável pelas inúmeras polêmicas com os mais importantes escritores da época.

As linhas que separam o personagem Sílvio Romero da criação de seu grupo literário e filosófico, a Escola do Recife, são muito tênues, muito se falou que ela nada mais era que uma escola sem discípulos, tratando-se, pois de uma invenção de Sílvio para fazer frente às confrarias literárias da Corte. A renovação literária e filosófica que Sílvio tanto defendeu frente ao pioneirismo do Recife se confunde com o próprio crítico porque não há como separar o autor de O Naturalismo em Literatura das correntes deterministas, positivistas e evolucionistas, chegadas ao Brasil a partir de 1868.

Outro nome importante no cenário literário da época e apenas um dos tantos adversários de Sílvio foi o também crítico literário José Veríssimo. Às vezes exagerado em suas análises como ressalva Antonio Candido, a maior desavença de Veríssimo não residia somente em função da concepção literária do crítico paraense, no que divergia da de Sílvio, para quem a Literatura era reflexo das transformações sociais, mas sim, coloca em questão a primazia das idéias científicas que Veríssimo denominava de alvoroço das idéias novas. A primazia defendida por Sílvio com relação às idéias do cientificismo europeu, divulgadas pela Escola do Recife, segundo Veríssimo, não tinha existência real, o que se tornava o principal motivo para as divergências entre os dois jovens escritores.

Situando a influência das idéias estrangeiras da época no pensamento intelectual do momento, ressaltando que estas idéias chegavam ao Brasil aproximadamente vinte anos depois, Veríssimo pontua os centros de irradiação do alvoroço das idéias novas. O crítico destaca que "Destes fatos não é

\footnotetext{
${ }^{140}$ Ibidem. pp. 273-274

${ }^{141}$ Ibidem.
} 
lícito se não concluir que a ação de Tobias Barreto, conquanto considerável, não foi tal qual se tem presumido, e que efetivamente só entrou a exercer-se pelo ano de 1882. Então já no Ceará e em São Paulo pelo menos, e no Rio de Janeiro, desde o princípio do século passado o nosso mais considerável centro intelectual, manifestamente se desenhava o movimento a que tenho chamado de modernismo. Principalmente reflexa, a ação de Tobias Barreto nesse movimento operou-se mediante os seus discípulos imediatos, dos quais um ao menos, o Sr. Sílvio Romero (S.Paulo de quem Tobias é o Cristo), teve considerável influência na juventude literária dos últimos vinte anos do século passado. No empenho, aliás simpático na sua inspiração, de o exaltarem, inventaram uma "escola do Recife", do qual o fizeram instituidor. Não viram, como atiladamente noto o mesmo Sr.Graça Aranha, que "a força singular desse homem estava na genialidade Poética por onde lhe veio a intuição científica e filosófica" e que "essa genialidade, essa imaginação faltaria aos seus discípulos porque ela era uma expressão puramente individual e que não se repete. Extraíram dos livros e das frases do mestre apenas as fórmulas audazes, confundiram a sátira com a seriedade do pensamento, tomariam os vagos delineamentos por conclusões definitivas e espalhariam numa língua bárbara a dogmática doutrina para as quais não teriam nem a Ciência, nem a advinhação profética". A "escola do Recife" não tem de fato, existência real. $\underline{O}$ que assim abusivamente chamaram é apenas um grupo constituído pelos discípulos diretos de Tobias Barreto, professor decerto e, sobretudo, ultrabenévolo, eloqüente orador literário e poeta fecundo, mais do que Tobias pensador e escritor. Cumpre, aliás, repetir que esse grupo, salvo imigrações individuais posteriores, restringiu-se ao Norte, donde era máxima parte de seus alunos, e mais exatamente Pernambuco". 142 (grifo nosso).

O livro de Veríssimo não tratava de um simples acerto de contas com Sílvio, antes servia para evidenciar a concepção literária do crítico sergipano e, por conseguinte, como o escritor interpretava seu país salientando a concepção literária daquele. Para além do revide de José Veríssimo ao ataque de Sílvio e João Ribeiro no Compêndio de História da Literatura Brasileira, onde o crítico paraense se defende afirmando ser avesso a polêmica, razão "de cair na falta que censuro como um dos nossos mais feios costumes asseguro que nunca fiz senão forçado e com profundo aborrecimento" ${ }^{143}$, as intrigas entre Sílvio e Veríssimo nos oferecem muito mais do que meros ataques: mostram como os dois polígrafos concebiam Literatura e qual o seu papel.

Dizendo-se atacado por Sílvio e João Ribeiro, afirmando que até então era amigo e até admirador pessoal daquele devido a sua participação no desenvolvimento das letras pátrias, em Sobre alguns conceitos de Sílvio Romero, escreve Veríssimo, “O Sr. Senhor Sílvio Romero é o mais completo tipo

\footnotetext{
${ }^{142}$ VERÍSSIMO, José. História da Literatura Brasileira. pp. 343-344

${ }^{143}$ VERISSIMO, José. Sobre Alguns conceitos de Sílvio Romero. In: Que é Literatura? e outros escritos. São Paulo: Lany, 2001.p.237
} 
representativo, que eu conheço. Nele se reúnem num acordo harmonioso, todas as nossas qualidades e defeitos. Os senões, como os méritos da sua obra, que nas nossas letras é uma das mais volumosas, são a manifestação sincera e ingênua da sua personalidade”. 144

Se Veríssimo citava a si mesmo, era porque este fora o recurso tantas vezes utilizado por Sílvio. Logo a seguir pontua, "Criticar e compreender, e não se precisa de uma grande penetração Crítica para entender o Sr. Sílvio Romero. É mesmo um dos seus principais méritos, aliás independente da sua vontade e só filho do seu temperamento: ele não é uma natureza complicada e difícil, antes clara, espontânea e aberta. Mas também incoerente, impulsiva, sem medida nem comedimento. Isso explica as suas incoerências, a sua inconstância de caráter e de espírito. E, digo-o em toda a sinceridade, por muito o desculpa, não podendo quem o conhece, querer-lhe mal. É pronunciado nele o sentimento, ou como melhor se lhe chame, de que é perseguido; por isso em toda a discordância das suas opiniões, em toda a discrepância do que julga ser a sua doutrina, em toda a sua Crítica da sua obra vê um propósito firme de o atacar, de o diminuir, de o contestar. Se não se emenda, é um candidato ao delírio de perseguição. Porque o que Sr. Araripe Junior, o mais benigno dos críticos, chamou a Varnhagen, no seu Gregório de Matos, de criador da História da nossa Literatura, porque eu, repetindo-o inadvertidamente, chamei ao nosso grande historiador de "instituidor da nossa História literária”, sem que nem do contexto das frases, nem do espírito dos nossos escritos, se pudesse concluir nenhuma intenção oculta de ferir alguém, o Sr. Sílvio Romero, entretanto, escreveu que era “de notar a insistência com que este dois críticos, com evidente preocupação (?) andam a proclamar Varnhagen o criador da História da Literatura brasileira (o grifo é dele). E para rebater a nossa imaginária preocupação cai sobre o pobre Varnhagen de punhos cerrados (V.Prefácio citado). Como o Sr.Graça Aranha, a quem o Sr. Sílvio Romero não perdoa o colossal sucesso de Chanaan sem o seu beneplácito, nem o ser um dissidente da "escola do Recife", um espírito independente da sua influência, disse que o critério etnográfico no estudo da nossa cultura já se achava em Martius (e apesar das degenerações do Sr.Sílvio, disse a verdade) o Sr.Sílvio arremete contra ele. E não porque ele tenha errado, mas porque lhe atribui o inocente reparo ao "despeito que the causou o não havermos endossado - diz ele - sua versão da famosa lei da repetição abreviada da História”; chama-lhe de apaixonado crítico, de fantasista e outros nomes feios. Asseguro ao Sr. Sílvio que ele nunca escreveu maior injustiça, e pelo conhecimento íntimo que tenho do Sr. Graça Aranha garantolhe que este não deu sequer pelo seu tal não endosso" ${ }^{145}$ (grifos nosso)

A discussão girava em torno de Veríssimo considerar Varnhagen o instituidor da nossa História literária. Com isso, o crítico paraense queria dizer que alguns pontos tocados por Sílvio, como por

\footnotetext{
${ }^{144}$ Ibidem. p. 243

${ }^{145}$ Ibidem. p. 244
} 
exemplo, a importância do mestiço ou da mestiçagem, não eram novidades, o que feria frontalmente a fera. Não apenas tinha Vanhargen tocado no que Sílvio sustentava ter sido ele mesmo o primeiro escritor brasileiro a trazer para suas análises literárias o traço etnográfico sob o influxo de seu tão alardeado espírito crítico, como também tinha sido, "o primeiro que as viu no seu todo e não somente como mais ou menos fizeram os seus antecessores, na sua Poesia, e ocupou-se embora de passagem, (e nem fazia uma obra volumosa e exaustiva) de todos os autores nacionais que pode conhecer, $e$ ainda de portugueses abrasileirados pela sua residência no Brasil e preocupações brasileiras (Gabriel Soares, Antonil, Cardim) fossem poetas ou historiadores, cronistas, moralistas, viajantes, economistas, como faria o Sr. Sílvio Romero muito anos depois". ${ }^{146}$

As afirmativas de Veríssimo contrariavam frontalmente o que Sílvio anunciava ser novidade em sua maneira de interpretar o Brasil, que era a influência das raças, e mais expecificamente, do mestiço, explicando o atraso do país desde os primórdios da colonização portuguesa. Não bastasse às injustiças cometidas por Sílvio a sua pessoa, até então discípulo e admirador do mestre sergipano, somadas às incoerências deste no que diz respeito à contribuição de Martius e Varnhagem, autores que segundo Veríssimo salientaram a importância das raças, reforçava o crítico paraense que, "Varnhagen foi também o precursor do Sr. Sílvio Romero naquilo mesmo que este julga uma das suas originalidades na concepção da História da nossa Literatura, no incorporar nela todo o gênero de obras $e$ escritores, sem distinção de fins e estilos artísticos. Implicitamente foi o que fez Varnhagen, já na introdução do seu Florilégio, já na História Geral, onde nas páginas consagradas à Literatura, trata de historiadores, cronistas, oradores, economistas, etc., e até, justamente como o Sr. Sílvio Romero, mas trinta anos antes deste, de artistas, músicos, pintores, etc”. ${ }^{147}$

Sílvio jamais aceitaria o posicionamento de Veríssimo de ver em Varnhagen o instituidor das letras brasileiras, autor da primeira grande obra literária, escritor que depois de Martius atinou para a importância das raças para empreender a História literária brasileira. Podemos dizer que por Literatura estes escritores pretendiam encontrar os heróis, os ilustres varões literários, esquecendo-se dos negros e vendo as populações indígenas de maneira estilizada. Sílvio reprova a História literária brasileira produzida por Martius, Varnhagem, Capistrano, Machado de Assis e Veríssimo porque esta se baseava numa análise Estética e nada realista, contrária ao resultado oferecido pela fundamentação científica da Crítica moderna.

Se para Veríssimo o Ensaio histórico sobre as letras no Brasil é a "primeira pedra solidamente assentada do edifício da nossa História literária, o núcleo em torno do qual ela se devia aglomerar e constituir a célula de que ela se devia desenvolver, e de que de fato se desenvolveu, do que são ainda

\footnotetext{
${ }^{146}$ Ibidem. p. 254

${ }^{147}$ Ibidem. p. 255
} 
prova os grossos volumes do Sr. Sílvio Romero", ${ }^{148}$ este reconhecia o mérito literário do Visconde de Porto Seguro por que o autor do Florilégio da Poesia Brasileira "compreendeu ser impossível fazer a historia sem os documentos originais, e, por isso, muito andou, muito pesquisou, muito leu e de tudo conseguiu extrair essa Historia Geral do Brasil, que, apesar de seus defeitos de redação e da estreiteza de sua Filosofia, é um livro de grande mérito”. 149

Sílvio elogiava Varnhagen não por conta de sua visão literária, mas sim pela farta produção histórica e a busca pela verdade documental. Ainda que em sua História Geral do Brasil muitos fossem os erros de redação, foi Varnhagen "o que primeiro compreendeu ser impossivel fazer a História sem os documentos originais". 150

A leitura de Veríssimo punha em xeque a primazia de Sílvio com relação a sua Teoria literária pelo fato de o escritor paraense considerar Varnhagem antecipador da nova maneira de interpretar o Brasil, no caso, levando em conta a importância das raças na formação da Literatura pátria. Veríssimo defendia veementemente a interpretação de Varnhagen e até dizia que a História da Literatura Brasileira, sobretudo o capítulo, Fatores da Literatura Brasileira, sofria enorme influência do pensamento daquele historiador. Para além das intrigas entre Veríssimo e Sílvio, o crítico paraense deixava claro que o que Romero dizia ser prioridade sua já tinha sido preocupação dos antigos críticos, investir no elemento raça só voltava à velha preocupação tocada pelos escritores indianistas da escola romântica. Discordar da primazia de Sílvio no que diz respeito a sua contribuição de historiador e crítico literário era antes de tudo reprovar sua suposta "nova" maneira de interpretar o Brasil a partir dos elementos que o escritor sergipano tinha de mais nobre.

Como se não bastasse a defesa de ser Varnhagem o instituidor das letras nacionais, escritor que montou do ponto de vista literário um quadro sólido para a compreensão da sociedade brasileira, sobrava para Sílvio duras reprovações com relação a seu maior estudo, a História da Literatura Brasileira, "Este era uma colcha de retalhos em que se confundiam todas as Filosofias e todas as Estéticas, e em que as contradições se contavam pelas páginas. Animava-o, entretanto, o entusiasmo juvenil do autor, a sua veia às vezes vigorosa, a desabusada confiança da mocidade. Mas ele entrou logo a repetir-se, a repisar-se, a cantar a mesma enfadonha cantiga: Tobias, escola do Recife, prioridade de Pernambuco, mestiçagem, beletrística, cientificismo, critério etnográfico, nacionalística, meio físico, classificações e categorias em barda, o que naturalmente acabou por fatigar até aqueles mesmos dos seus devotos (eu fui um deles) que não tinham de todo perdido a capacidade de raciocinar

\footnotetext{
148 VERISSIMO, José. O que é Literatura?.. Op. Cit. p.257

${ }^{149}$ ROMERO, Sílvio. Quadro Sintético da Evolução dos Gêneros na Literatura Brasileira. Porto: Livraria Chardron. p.58

${ }^{150}$ ROMERO, Sílvio. Evolução da Literatura brasileira. Op. Cit. p. 83
} 
ou que do estudo dos mesmos assuntos em que ele doutrinava verificaram as falhas do mestre e da doutrina". ${ }^{151}$

Apesar desses conflitos, Veríssimo sempre reconheceu o talento de seu oponente: "Não é difícil, e já tem sido feito, apontar-lhe as contradições, as incoerências, as repetições, as inexatidões de fato ou de juízo, os abusos de generalização, a carência de serenidade e imparcialidade Crítica. Nada disto, quando fosse bem verificado, lhe tira, ou sequer diminui, o mérito próprio, que é, penso eu, aquele. Nem tudo o que lhe pôs o autor é novo ou original, apesar do seu manifesto e nem sempre legítimo desdém pelos seus antecessores na História da Literatura brasileira, desdém próprio dos temperamentos de luta e de negação, como o seu. Não obstante, a História da Literatura Brasileira do Sr. Sílvio Romero é com certeza um dos livros mais originais, ou pelo menos mais pessoais, mais sugestivos, mais copiosos de opiniões e idéias, mais interessantes, de mais veias e temperamento que jamais se escreveram no Brasil. Se inovou muito menos do que cuida o autor no, que respeita a concepção, o método da nossa História literária, foi o primeiro que para ela trouxe as noções da Crítica e da Filosofia modernas, que nela agitou, com maior conhecimento das doutrinas, e mais capacidade de aplicação e generalização, as idéias que fora daqui haviam desde muito revolucionado as criações semelhantes. E a pretexto de Literatura, a sua História discutia todos os problemas e questões que direta ou indiretamente interessavam a nossa vida nacional: políticas, econômicas, científicas, industriais, Estéticas, administrativas, étnicas, costumes, crenças, língua, ideais, aspirações e opiniões. Apenas se achará alguma de que o livro não trate ou sobre a qual não dê o autor o seu parecer, e como ele é um nervoso, um apaixonado, um temperamento de combate, um propagandista de idéias, e traz da Academia, e lhe ficará por toda a vida, o gosto da discussão, calorosa, entremeiada da chalaça, que a camaradagem escolar desculpa, e que ele tem da melhor espécie luso-brasileira, a exposição delas é sempre viva, jamais monótona, nunca banal. Se em dois fartos volumes ela acaba por fatigar um pouco, é por causa das repetições, que na primeira edição eram demasiadas, e que não sei se foram tão suprimidas quanto convinha nesta Segunda. Este defeito, porém, como outros que se podem apontar no livro, derivava da maneira por que o Sr. Sílvio Romero realizou a sua obra. Apesar da unidade de título e de composição que aparenta, ela é por muito fragmentária, feita em grande parte de artigos diversos em, cada um dos quais o autor repetia as suas idéias favoritas de pregador de doutrinas que lhe eram caras. O seu livro é de polêmica, como de polemista é essencialmente o temperamento literário do autor. "Porque esta-perdoem-me citar esta apreciação por mim escrita em 1895 a propósito do livro do Sr. Sílvio Romero, Doutrina contra Doutrina - é a característica dominante do Sr. Sílvio Romero: ser um polemista. Fazendo História ou Crítica literária, política ou

${ }^{151}$ VERISSIMO, José. O Que é Literatura? Op. Cit. p. 270 
Filosofia, escrevendo ou conversando, apesar da bonomia afetuosa, natural e amável do seu trato, que estão longe de suspeitar os que só por seus livros o conhecem, o Sr. Sílvio Romero é um polemista”. 152 Outra obra aparentemente relevante, a que não tivemos acesso, é Sílvio Romero de perfil, de Argeu Guimarães, que Sílvio considerava um de seus discípulos. Artur Guimarães, filho de Argeu, analisa a obra de seu pai assinalando que "Aquelas páginas saíram-lhe de um fôlego, verdadeiro depoimento d'alma, transbordante de sinceridade e afeto, a que juntou elementos biográficos deixados em vida pelo próprio mestre e amigo. Vinte anos de colóquio intelectual, de amor ao Brasil, de convivência diuturna, davam-lhe autoridade para render a primeira grande homenagem a Sílvio, $e$ isso mesmo reconheceram os filhos, sobretudo, Edgard, Sílvio Filho e Nélson, os herdeiros mais diretos da privilegiada inteligência. A evocação apresenta-nos, sobretudo o homem, nas particularidades de sua vida, nas notações do seu caráter, nas diretrizes da sua mentalidade. Perfil moral, intelectual, afetivo. Ali está todo Sílvio Romero, e quanto sobre eles escreveram depois, recorreram à fonte preciosa e fidedigna, embora algumas vezes, como o fez o desaforado Osório Duque Estrada, se esquecessem de citá-la, na ligeireza infelizmente tão comum em nosso meio. Não podia deixar se servir a muito plumitivo apressado, aproveitador de notas alheias, sem indicação de procedência. Sem pretensão, porque trato de meu pai, poderia repetir a frase jocosa de Sílvio, quando dizia de obras de valor: É um livro para ladrão”. Neste caso, dada a fidelidade da fonte, a exatidão da fonte, a exatidão das informações, e o alto critério que ditou aquelas páginas, seja-me lícita a reivindicação. Na singeleza da sua forma e na espontaneidade do conteúdo, Sílvio Romero de Perfil era livro para ficar, e "livro para gatuno". ${ }^{153}$

Embora se trate de uma obra de cunho memorialista, seu estudo chama a atenção para a importância de Sílvio no pensamento social brasileiro de seu tempo, "O perfil, rótulo apropriado que os léxicos consignam como "pequeno escrito em que faz a traços rápidos o retrato de uma pessoa", dá bem uma idéia da figura de Sílvio, com seu temperamento, suas indiosincrasias, seus ímpetos de bom humor, suas cóleras e paixões, que não excluíam a simplicidade, a meiguice, a ternura pela família, a intemerata defesa dos amigos. Ao mesmo tempo a cultura, a erudição, o denodado labor intelectual, o ardor na defesa e propaganda das idéias, a coragem nas lutas, e o brasileirismo inabalável, que só via defeitos em nossa gente para indicar-lhes os caminhos da redenção. Tudo foi dito e documentado com a evocação de frases, o registros de cartas íntimas, a anotação dos livros, $e$ conceitos, sátiras, ápodos irreverentes, e episódios de vária índole, desde 1896 até a data da morte”. 154

\footnotetext{
152 VERÍSSIMO, José. História da Literatura Brasileira. Op. Cit.

${ }^{153}$ GUIMARÃES, Argeu. Rio de Janeiro: organização Simões. pp.110-111

${ }^{154}$ Ibidem. pp. $112-113$
} 
Importantes trabalhos são Silvio Romero - Sua formação intelectual (1851-1880), de Carlos Sussekind de Mendonça, cuja primeira edição é de 1938; e Itinerário de Silvio Romero, de Silvio Rabelo, publicado em 1944 pelo editor José Olímpio.

Carlos Mendonça analisa a vasta produção de Sílvio, pontuando os momentos cruciais de sua vida literária, chegando a esmiuçar sua vasta produção intelectual à medida que os livros e artigos do sergipano eram publicados. $\mathrm{O}$ autor pontua os primeiros momentos da vida de Romero, desde os tempos do engenho, até ao período em que o bacharel chega ao Rio trazendo em mãos A Filosofia no Brasil, aparecendo no cenário nacional como uma das figuras polêmicas e onde viria a prestar concurso para o célebre colégio Pedro II. Cabe-nos demarcar a visão de Mendonça no que tange a Literatura produzida pelo escritor sergipano. Enfrentando três fases ao longo da vida, é interessante notar que é na primeira que Sílvio esboça sua visão literária, uma vez que os primeiros artigos quando ainda estudava na Faculdade de Direito do Recife, se voltam contra os escritores românticos vestidos da indiomania e do caboclismo tupiniquim. Para ele, o fato de ser o índio erigido como símbolo nacional camuflava a realidade brasileira, o que não cabia na visão de um autor, que tanto combateu as ilusões nacionais, tentando sempre falar a realidade do país. É nesse primeiro momento de sua trajetória intelectual que Romero toma conhecimento das leituras de Darwin, afirmando que após conhecer o Evolucionismo e a Teoria do mais apto, abole de seu universo de pensamento o Positivismo. Sua História da Literatura Brasileira evidencia o que ele pensava e escrevia nessa primeira fase de sua longa carreira literária. Pensando e realizando uma Literatura de cunho estritamente naturalista, Sílvio analisava o passado brasileiro à luz do Evolucionismo, regido por estágios onde a vitória final caberia ao mais forte. Embora a História da Literatura Brasileira seja publicada em 1888, é sobre a série de artigos publicados contra o Romantismo brasileiro que Mendonça volta seu olhar.

\footnotetext{
"O que representou para a cultura brasileira essa primeira fase da atuação Crítica de Sílvio ainda não se disse.

A conspiração do silêncio não foi uma invenção dos nossos dias.

Como, entretanto, além de se desconhecer o mérito excepcional do seu esforço, ainda se pensou diversas vezes em atribuí-lo a outrem, foi preciso que ele próprio se incumbisse de reivindicar o seu quinhão.

Não estou disposto a deixar de ser bifado o meu lugar na História intelectual brasileira, disse ele, de uma feita, na sua esplendida simplicidade

E se poz a gisar, a traços largos, a sua posição, o seu papel, em relação a Arte de criticar no Brasil. "155
}

Sílvio Rabelo, apesar de não trazer tantas informações como a obra de Mendonça, chama atenção para o lado polêmico e partidário de Sílvio, que explicaria uma produção intelectual repleta de

${ }^{155}$ MENDONÇA, Carlos Sussekind. Op.Cit.p.91 
contradições. Rabelo situa a posição e importância do intelectual de Romero, combatendo nas lutas de partido ao mesmo tempo em que se envolvia nas discussões públicas. ${ }^{156}$ No que tange à visão literária de Sílvio, argumenta:

\begin{abstract}
"A História da Literatura de Sílvio resume bem todo o pensamento de Sílvio Romero em relação aos problemas do Brasil - problemas de raça, de História, de política, de economia. E não, apenas de Literatura. Como critério, é a História da Literatura uma aplicação a larga experiência de doutrina a todas as produções da inteligência do povo brasileiro, quanto a sua origem étnica, num determinado meio físico e sob a influência européia. Uma aplicação do darwinismo à Literatura, já tentada em livros anteriores, na Literatura brasileira e a Crítica Moderna e nos Estudos sobre a Poesia popular no Brasil. Na História da Literatura é, entretanto, que melhor se sente o darwinista a estender até o domínio da produção intelectual, os princípios biológicos da seleção e da sobrevivência dos mais capazes. Mas o Determinismo literário é encontrado, apenas, nas páginas de introdução. Nas demais, em quase todo o livro, Sílvio Romero estuda a evolução histórica, fase por fase, tendência por tendência, da Literatura, sem que se note a presença do darwinista da primeira parte, o que dá a impressão de um livro escrito por autores diferentes". ${ }^{157}$
\end{abstract}

Atuando dessa forma, concluía Rabelo que: "A propósito desse livro- por tantas razões o livro mais sério de Sílvio Rabelo - disse José Veríssimo que era um desdobramento do Florilégio e da História Geral, de Varnhagen, sobretudo, porque deste autor se apropriara ele do conceito de Literatura no seu sentido mais amplo, como abrangendo "todo o gênero de obras e escritores, sem distinções de fins e estilos artísticos”. Mas apesar de ter Sílvio Romero aproveitado a contribuição não só de Varnhagen, como de todos os autores que o precederam - de Norberto Silva, de Fernandes Pinheiro, de Domingos de Magalhães, de Denis e de Woff - ainda assim a História da Literatura é o primeiro livro sistemático sobre o assunto. Pela primeira vez, a História literária do Brasil foi estudada numa tão ampla extensão. O principal defeito da História da Literatura decorre do seu Naturalismo aplicado ao fenômeno literário - exatamente o que Sílvio julgava a sua qualidade máxima; ou como escreve Nelson Werneck Sodré, a propósito da sua obra - baseadas em “preconceitos do tempo, muito mais do que preconceitos do autor”. Mas não é este o único defeito do livro, considerado monumental, de Sílvio Romero. Ainda um outro, e este de composição, que lhe dá o aspecto de obra desigual e fragmentária, é o aproveitamento por justaposição, de seus ensaios anteriores, escritos na época em que dominava a sua intuição pessimista acerca dos homens e dos acontecimentos do Brasil. Era assim que ele se referia ao seu tempo de demolição dos valores mais representativos da Literatura nacional. Apesar de sua intenção de conservar-se eqüidistante da Crítica apaixonada e do elogio desmedido - num justo termo que seria de esperar no escritor que envelhecia - a História da Literatura traz a marca da sua exaltação e do seu personalismo: o crítico e

\footnotetext{
${ }^{156}$ Nesse sentido a obra de João Mendonça de Souza, Silvio Romero - o crítico e o polemista é merecedora de bastante atenção.

${ }^{157}$ RABELLO, Silvio. Op. Cit.p 100
} 
o polemista jamais se separaram nele. Tobias Barreto tinha dito, num dos seus momentos de fraqueza, que em Sílvio Romero, a Crítica e a polêmica faziam uma aliança indestrutível. E não deixa de ter boa dose de pitoresco aproximar, em todo o curso da História da Literatura, os julgamentos que trazem a velha prevenção dos seus tempos heróicos da "escola do Recife" - julgamentos acerca de autores $e$ de obras, acerca de questões de prioridade e de influências - com a sentença que escreveu logo no pórtico do seu livro: "mais calma e mais confiança, meus senhores; é bom adiar as paixões e dar entrada à imparcialidade" 158

Vale mencionar a conferência Sílvio Romero - Pensador e Sociólogo, pronunciada pelo crítico literário Alcides Bezerra - segundo Skdimore, autor de menor quilate - em 17 de outubro de 1929, na Sociedade Brasileira de Filosofia, onde estuda Sílvio à luz de seu tempo, coberto pelas idéias científicas de uma época: "Como Taine, Sílvio Romero é evolucionista, e explica os fenômenos literários pelas influências complexas do meio, da raça, do momento histórico, a que servem juntas a interferência dos fatores exóticos. Discípulo e mestre explicam a Literatura, a antropogeografia, e os produtos aéreos e subtis da imaginação e da inteligência, como a lã dos carneiros e a plumagem dos papagaios, sem vêm prender por estreitos laços causativos aos quadros climato-botânicos, a geomorfologia, a paisagem natural. As plantas hidrófilas e xerófilas, o clima nival, freático ou árido, as precipitações aquosas mais ou menos abundantes, tudo isto é fator e determina as idéias e os sentimentos dos artistas que são obrigados por um estranho mimetismo a tomar a cor e o aspecto da sua terra e da sua gente. O máximo de concessão que faz esse Determinismo rígido é permitir que os poetas se deixem arrastar pelas correntes exóticas e possam afinar a sua lira pela de Anacreonte..." 159

Com relação ao Naturalismo de Sílvio aplicado a Literatura, esteado pelo Evolucionismo e pelo Determinismo, a propósito da grande obra de Sílvio, surgida em 1888, afirma

\footnotetext{
"Sílvio Romero, em 1888, pagou o seu tributo a esse Determinismo inelutável, como muitos outros aqui e além estão pagando ainda seduzidos pelo quadro deveras empolgante em que tudo se explica e se acolcheta, e leis magestosas nivelam na sua indiferença os climas, as floras, as raças, os produtos da natureza e as flores do espírito irmanado o homem culto com os rebanhos que ele manda ao matadouro.

Mas, a verdade está numa Filosofia que, sem negar o Determinismo cósmico e biológico, admitindo mesmo a humildade de nossas origens, faça as forças espirituais as maiores concessões e jamais nivele o Kulturmensch com o Naturmensch, o homem culto com o homem natural. Há coordenadas mais importantes do que as espaciais, as cordenadas do tempo, as coordenadas da cultura.

Pensai no mito de Prometeu roubando o fogo dos deuses. Cada sábio, em seu laboratório, é um novo Prometeu. Todos os dias se reproduz a façanha, e o filho na natureza, o primata feliz, cria um novo mundo: o mundo cultural". ${ }^{160}$
}

\footnotetext{
158 Ibidem. p. 81-82

${ }^{159}$ BEZERRA, Alcides. Sílvio Romero, o pensador e o sociólogo: conferência pronunciada no dia 17 de outubro de 1929 , na Sociedade Brasileira de Filosofia. Rio de Janeiro: Oficinas Gráficas do Arquivo Nacional, 1935. p.6

${ }^{160}$ Ibidem. p. 6
} 
Antonio Candido, em sua Introdução ao método crítico de Silvio Romero, analisa a História literária de Sílvio marcada pelo Naturalismo da época. Buscando trazer para a História literária os mais variados aspectos da cultura brasileira, Candido aponta os elementos que marcaram sua visão literária. Assim, Romero é o fundador da Crítica moderna, o que não significa dizer que a Crítica tenha surgido com este. A visão de Sílvio é resultado das transformações por que passara o Brasil a partir de 1850, quando toda uma conjuntura moderna se anuncia em contraposição ao passado do atraso colonial. Conforme Candido, o Naturalismo literário de uma geração de escritores brasileiros é ideologia burguesa - resultado da inserção nacional da economia brasileira, frente ao conjunto de transformações econômicas já aludidas -, como mostram os escritores que influenciaram o pensamento de Sílvio. O movimento crítico empreendido por Sílvio Romero "foi à primeira manifestação orgânica e flagrante do processo de aburguesamento refletindo-se nas esferas mentais" ${ }^{161}$.

Antonio Candido abre um capítulo sobre o método de que se valeu Romero para conferir sua produção literária, de forma específica, a História da Literatura Brasileira.

\begin{abstract}
"A História da Literatura é o ponto máximo da sua obra. Nos vintes anos que a precederam, organizou as suas idéias e as foi aplicando a setores diversos da cultura nacional. Nos vinte e seis que a sucederam, apurou e desenvolveu normalmente aquelas idéias, de tal modo a podermos dizer que, do ponto de vista não só do método quanto da sua aplicação, quem conhecer este livro conhece Sílvio Romero de maneira mais ou menos completa.

Se lermos com a atenção a História da Literatura, após havermos estudado toda a obra anterior, verificaremos que ela é o enfeixamento das linhas ideológicas que vimos acompanhando desde os primeiros artigos. Verificaremos, ainda, que não há uma só afirmação de caráter teórico que não tenha sido feita antes. Encontraremos, a cada

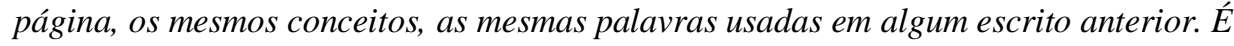
um hábito de Sílvio, que conservou até a morte: a repetição, a reafirmação. Alguns princípios fundamentais, ele nunca mais os abandonou, e os foi apurando à medida que os anos corriam e podia meditá-los a luz das realidades brasileiras. Foi este o fio condutor de sua obra - e a atitude que considerava normal no processo da nossa cultura". ${ }^{162}$
\end{abstract}

Ainda nesse trabalho, o autor traça a marcha das idéias balizadoras da formação literária de Romero. O sociólogo e critico literário analisa a Crítica moderna fundada no Brasil por Sílvio, esclarecendo a abordagem cultural do bacharel, mostrando a visão naturalista daquele. Em artigo específico, Candido aborda detidamente as nuances entre Teoria, Crítica e História literária, buscando compreender a Literatura de Sílvio esboçada em sua História da Literatura Brasileira. Sobre esse livro, afirma: "É a sua obra principal, onde pôs o essencial do que desejava dizer sobre a cultura $e$ mesmo a sociedade do seu país. Ela representa, do ponto de vista teórico, um amadurecimento,

\footnotetext{
${ }^{161}$ CANDIDO, Antonio. Introdução. Op.cit. p.181.

${ }^{162}$ Ibidem. pp. 103-104
} 
porque Sílvio aparece aqui como um naturalista mitigado, atenuando ao máximo o papel do meio físico na configuração da sociedade, compreendendo o cunho mediato do fator biológico e trazendo para a primeira plana os fatores sociais e psíquicos" 163

E adentrando a concepção literária de Sílvio, principalmente, no primeiro volume da História da Literatura Brasileira, onde estão expostas as bases do pensamento do ensaísta, conclui Candido: “ $O$ livro I é uma espécie de vasta introdução ao estudo da sociedade e da cultura brasileiras, das quais a Literatura emerge como produto que, por sua vez, se torna como fator. As partes seguintes abordam de maneira desigual a produção intelectual até mais ou menos 1880, com a falha grave de omitirem os ficcionistas do século XIX. Mais grave ainda é o fato de culminarem numa desconcertante apoteose de Tobias Barreto, que ocupa 120 páginas, ou seja, mais espaço do que o século XVIII com a Escola Mineira e tudo, se vê guindado praticamente à posição de maior escritor brasileiro, superior a Castro Alves como poeta, a Machado de Assis como prosador e a toda a gente como pensador. Este traço de irresponsabilidade Crítica desequilibra a economia do livro, mas não desfaz o seu interesse como obra apaixonada e penetrante em todas as partes. É preciso lê-la com o desconto desta e outras irregularidades, como as demasias, altos e baixos, digressões soltas, juízos sentimentais, pirraças, para sentirmos o quanto possui no fim das contas de monumental ". 164

João Alexandre Barbosa, também preocupado com a formação do cânone brasileiro, analisa o desenvolvimento da História literária nacional. Para José Veríssmo e outros escritores brasileiros, Literatura era Arte literária; para Sílvio, era o resultado das transformações sociais. Traçando um panorama da História literária brasileira, Barbosa situa Sílvio: "De qualquer modo, trazendo para a leitura histórica-literária o peso de uma formação cultural ampla, em que os métodos positivistas e evolucionistas, fossem inspirados em Taine ou em Spencer, eram postos a serviço da urgência de interpretação do próprio desenvolvimento da sociedade e da cultura no Brasil, a História de Sílvio Romero impunha um certo discurso histórico-literário que foi decisivo na formação e fixação do cânone literário, ao menos aquele que correspondia desde as primeiras manifestações literárias nos séculos XVI e XVII até a época de formação intelectual do próprio autor, isto é, o momento crucial de transformações empreendidas a partir de 1870, embora cometendo o grave erro de omitir os ficcionistas do século XIXI. Assim, se aqueles séculos preenchem o primeiro volume da História, ao segundo correspondem as várias fases do que chama Romantismo a partir de 1830"165

Não menos importante é Medo a Utopia: o pensamento social de Tobias Barreto e Sílvio Romero, de Evaristo de Moraes Filho, que nos oferece uma visão panorâmica sobre os pontos mais

${ }^{163}$ CANDIDO, Antonio. Sílvio Romero: Teoria, Crítica e História literária. Rio de Janeiro: livros técnicos e científicos; São Paulo: Edusp, 1978. p. XV

${ }_{164}$ Ibidem. p. XVII

${ }^{165}$ BARBOSA, João Alexandre. A Biblioteca Imaginária. São Paulo: Ateliê Editorial, 1996. pp.32-33. 
importantes abordados por Romero. Uma vez que não foi Sílvio o tipo de intelectual preso à torre de marfim, escritor de gabinete, o polígrafo preocupado com a Arte pela Arte, como bem chamava atenção, narra Evaristo de Moraes: "Embora livresco, intelectualista, empapado de cultura e erudição, foi a política a nota característica de sua vida, aquela que lhe marcou os escritos e sempre o encheu de paixão. Além da política partidária, que lhe substituiu a Poesia na sua obsessão, em nenhum dos seus livros deixou o escritor sergipano de opinar sobre o estado social do País. Não se trancou em nenhuma torre de marfim. Não ficava só nas idéias e no plano teórico, como seria de esperar da sua forma mental; a sua biblioteca abria-se para a vida e para os homens concretos, de carne e osso; envolvia-se com as pessoas nominalmente, nunca neutro, apaixonado sempre, com amor ou ódio. Envolvia-se com os partidos, com os fatos diversos do dia-a-dia. Foi sempre uma consciência ardente e desperta, bem atenta a todos os problemas do seu país, para o qual desejava o melhor. Para nós, mais historiador da Literatura do que propriamente crítico literário, ainda assim, não aceitava a Crítica pela Crítica, preferindo o que chamava de Crítica sociológica, na qual o individuo era estudado e compreendido pelo que representava das correntes sociais do seu tempo e da mensagem que deixava para o futuro. O escritor era um homem situado na sua época e no seu meio, quase como um corpo poroso, atravessado pelas idéias e pelos sentimentos que o cercavam " ${ }^{166}$ (grifos nosso)

Evaristo de Moraes sintetiza bem a concepção de Sílvio, sua ânsia de reformar o Brasil, sua paixão pelo conhecimento, e acima de tudo, a fé que tinha nesse conhecimento como o maior instrumento para projetar um novo Brasil. Com tantas leituras, fruto de sua paixão pelo conhecimento sempre colado a sua ânsia de reformar o Brasil, conclui o autor citado que "Em tudo o que escreveu, por mais abstrato e teórico que parecesse o tema, logo estaria Sílvio a perder-se do assunto central, para ocupar-se com as necessidades da sociedade brasileira e os modos de satisfazê-las. Aí então colocava toda a sua cultura, todo o ser ardor, a serviço desse desiderato. Em 1878, com a Filosofia no Brasil, numerosas são as passagens de análise e de Crítica política do Império, apesar do título e da matéria do livro". 167

No campo da História das Idéias, cabe mencionar uma série de importantes trabalhos como os de Antonio Paim, João Cruz Costa, Nelson Werneck Sodré e Wilson Martins, dentre tantos outros. Todos estes trabalhos situam o alvorecer das idéias da época como reflexo do conjunto de transformações por que passara o Brasil na segunda metade do século, de maneira específica, a partir de 1850, que põe fim ao tráfico de escravos, reforçando no mercado a mão de obra livre, e que nos idos de 1870, começa a ampliar uma extensa Literatura de divulgação científica assentada sobre os elementos do meio e da raça. Experimentando um novo momento da História, os polígrafos brasileiros, conscientemente ou

\footnotetext{
${ }^{166}$ MORAES FILHO, Evaristo de. Op.Cit. pp. 214-215

${ }^{167}$ Ibidem. p. 215.
} 
não, lançavam mão de um discurso de cunho estritamente científico, sempre acobertado pelas questões que levavam a civilização e progresso. Carecia esse novo Brasil de uma imagem positiva, não mais degenerado por conta da presença do homem que não era branco, responsável pela economia do país ao longo de todo o processo de dependência não apenas econômica como cultural. Nesse sentido, Sílvio é apenas um dentre os vários polígrafos influenciados pelas novas correntes que chegavam ao país. O bando de idéias novas alardeadas e defendidas por Silvio são reflexos dessa nova conjuntura social, econômica e política.

Todos esses autores contribuem para a compreensão de Romero, uma vez que situam o polígrafo em seu tempo, nos auxiliam no entendimento da recepção e seleção dessa e não daquela Teoria, mesmo que não explorem de maneira minuciosa a farta produção e a relevância de Sílvio como um dos mais significativos intérpretes da formação dessa sociedade brasileira em transição.

Antônio Paim, em seu estudo acerca da contribuição das idéias da chamada Escola de Recife, trata de analisar qual a corrente assimilada por Sílvio e toda a influência sofrida pelo jovem estudante desde os tempos da Faculdade de Direito. Em sua obra Contribuição das Idéias Filosóficas no Brasil, investiga as respectivas escolas, enquadrando Sílvio como figura de proa no movimento das idéias novas surgidas em torno da Faculdade de Direito do Recife. Noutro estudo, denominado A Escola do Recife, é que o autor aborda de maneira mais detalhada a importância de Sílvio no desenvolvimento filosófico da época por ter promovido a renovação mental no plano literário e filosófico, propondo uma nova maneira de interpretar o Brasil, não mais a partir do plano metafísico, onde a Retórica se mostrava em primeiro plano. Analisando especificamente A Filosofia no Brasil e, portanto, a importância de Sílvio de posse dessa nova maneira de pensar o Brasil tendo em vista seu arroubo científico fundado sob o espírito crítico, onde desacredita o sergipano de todo o quadro brasileiro então atual e de antes, Paim situa o surgimento do espírito crítico inaugurado pelo escritor, enquadrando-o na corrente de pensamento crítico de fundamentação kantiana. $\mathrm{O}$ autor descreve a trajetória inicial de Sílvio, a participação do mesmo na Imprensa, o momento da agitada movimentação de idéias e, acima de tudo, mostra as filiações teóricas de Sílvio. Após esmiuçar o amplo processo de desenvolvimento filosófico de Romero a partir do livro A Filosofia no Brasil, primeira obra do crítico literário, é somente no fim do trabalho em questão que o estudioso salienta a importância da História literária de Sílvio. Na parte bibliográfica, alude o autor:

"História da Literatura Brasileira (1888). Interessam de perto ao estudo da evolução das concepções filosóficas do autor, a Introdução e todo o livro I - Fatores da Literatura brasileira (p. I a XXVIII; 1 a 140, da $1^{a}$ edição); esses trabalhos constam do tomo $1^{\circ}$ das edições recentes da Livraria José Olímpio; a parte de introdução do cap. X do livro III ( $2^{a}$ época ou período do desenvolvimento autonômico - Economistas, jurisconsultos, publicistas, oradores, linguistas, moralistas, biógrafos, teólogos e literatos), no $1^{o}$ volume da $1^{a}$ edição p. 605 a 625 (consta do tomo $2^{\circ}$ das edições da José Olímpio; na $3^{a}$, da p. 294 a 310); a parte de 
introdução do cap. Do livro IV (Terceira época ou período de transformação romântica Outros poetas), no $2^{\circ}$ volume da $1^{a}$ edição, da pág. 1.171 a 1.176. trata-se do resumo das considerações tecidas a propósito de artigos de Araripe Júnior, incluídas em seu texto integral no livro Estudos de Literatura Contemporânea - "A História da Literatura Brasileira e o Dr. Júnior", p. 191 a 241; figura no tomo $4^{\circ}$ das edições da José Olímpio (Cap. II. Quinta fase do Romantismo, p. 87 a 100 da $3^{a}$ edição). Na $1^{a}$ edição da História da Literatura Brasileira acham-se transcritos os capítulos de A Filosofia no Brasil nos quais se examina a obra filosófica de Monte Alverne, Domingos de Magalhães e Tobias Barreto, como parte do estudo do conjunto de sua obra. As edições da José Olímpio conservam integralmente a parte relativa aos dois primeiros". 168

Preocupado com a historicização das idéias filosóficas no Brasil, à primeira vista, o trabalho de Paim pouco contribui para a análise da História literária produzida por Sílvio. Isso não significa desinteresse do autor em questão pela História literária de Sílvio, pelo contrário, é pelo caminho filosófico que se entende e deve ser analisada a História da Literatura Brasileira. Mais uma vez, lembremos que o esteio principal da Literatura romeriana era o Naturalismo, donde o princípio evolutivo e a vitória final do mais forte. Era pelo meio literário que Sílvio buscava alterar todo o quadro social brasileiro, mas sempre lembrando o filósofo inglês Spencer. A História literária do Brasil deveria conter os mais variados pontos para subtrair o atraso do país. Daí é que não há como separar em Sílvio o que seja propriamente Literatura de Filosofia e outros campos do conhecimento.

Mesmo em seu trabalho filosófico, Romero mostra claramente sua visão literária, científica, crítica, política, etc. Paim traça sua análise sobre A Filosofia no Brasil, e da longa análise, cabe-nos ressaltar a seguinte fala, "A obra que examinamos escrita por um moço entre os 25 e os 27 anos de idade representa um fato alvissareiro no Brasil da década de 70, um sintoma eloqüente da força e da amplitude do surto de idéias novas. O aparecimento de A Filosofia no Brasil (fins de 1878) coincide com a fixação de Sílvio Romero na capital do Império, que será marcada por uma colaboração constante na Imprensa da Corte. A agressividade de sua Crítica - que desde logo estendeu à atividade parlamentar em artigos no jornal de Lopes Trovão, $\boldsymbol{O}$ Repórter, por sinal que assinados com $o$ pseudônimo de Feuerbach, elucidativo das tendências filosóficas do autor-mais o tom rumoroso de que se revestiu o seu concurso para a cadeira de Filosofia do Colégio Pedro I, em 1880, - posto que conquistou apesar de seu desacordo flagrante com a Filosofia oficial - tudo isto serviu para projetar enormemente o pensador sergipano no sul do país. Dessas circunstâncias saberá aproveitar-se o notável crítico para estender, no campo filosófico, o raio de ação do movimento a que chamará Escola do Recife e granjear-lhe adeptos entre os moços estudantes do Rio de Janeiro". "169 (grifos nosso)

${ }^{168}$ PAIM, Antonio. A Escola do Recife. p. 116
${ }^{169}$ Ibidem. p.116 
Buscar separar em Sílvio o que seja Literatura do que seja Filosofia ou outra área do conhecimento é desconsiderar o polígrafo sergipano no que ele trazia de mais importante: empreender, aparatado pelas mais diversas correntes de pensamento, equacionadas de inúmeros escritores, sua interpretação brasileira. Se a Escola do Recife, como fala o próprio Paim, não tem sustentação real, argumentação de José Veríssimo, quando trocava farpas com Sílvio, isto é o que menos nos interessa. Também não é mais importante buscar identificar onde as idéias científicas ecoaram primeiramente, se em Recife, São Paulo, Rio de Janeiro, etc.

Interessa mesmo é o ponto de apoio teórico de Sílvio, mesmo sabendo de suas incoerências e injustiças para com escritores como Machado de Assis e Teófilo Braga, mas que tentou, com o leque oferecido pelos argumentos de objetividade científica de sua época, sempre acreditando na evolução da sociedade brasileira e na vitória do mais forte, tanto no plano biológico como no plano da cultura, interpretar seu país. A contribuição literária de Sílvio é somente parte de sua visão filosófica, ancorada no espírito crítico que levava o escritor aos mais variados campos de saber, aparatado pela verdade científica. Sílvio era enfático quando em sua História da Literatura Brasileira escrevia que almejava traçar um quadro naturalista da Literatura brasileira. Quer em trabalhos poéticos, que segundo Antonio Candido foram de péssima qualidade, quer em suas análises de Crítica literária, que Sílvio Rabelo afirma serem uma crítica de autores e não de obras literárias, fica claramente evidente a concepção de Romero com relação a Literatura brasileira.

Em sua História da Literatura Brasileira, o escritor vai além da simples exposição de obras e autores. O processo literário esboçado por Sílvio almeja sempre perscrutar os elementos condicionantes da Literatura brasileira, e como tal, esses elementos são sociais e por ele considerados os reais agentes de transformação.

Outro clássico trabalho no plano da História das idéias é de autoria de João Cruz Costa. Em Contribuição à História das Idéias no Brasil, Cruz Costa trata de reconhecer a importância de Sílvio, "A ligação que se tem feito do seu nome com o de Tobias Barreto determinou freqüentemente que, em proveito deste, se esquecesse ou diminuísse o maior alcance e sentido da importante obra daquele. Não há, porém, acreditamos, quem, na nossa terra, possa deixar de admirar esse homem que, na História das idéias nacionais, marca a primeira fase ou, sobretudo os que dizem respeito à História da cultura, passam a ocupar a atenção dos nossos letrados. É Sílvio Romero o precursor do esforço de interpretação do Brasil, que se vem processando desde os primeiros trabalhos do grande escritor, a partir de 1871. Quando estudamos a nossa História da segunda metade do século XIX, a figura de Sílvio Romero aí aparece dominando os mais variados assuntos, abrindo caminhos, ensaiando novas 
idéias, mas sempre atentos aos problemas brasileiros que lhe mereceram o mais desvelado carinho". ${ }^{170}$ (grifos nosso)

Num outro estudo, Cruz Costa afirma que "Sílvio Romero é o precursor do movimento de interpretação que caracteriza uma das preocupações essenciais de nossa época. E é com ele, também, que se poderia marcar um primeiro momento de transformação e de reforma de nossa inteligência". Apesar da cultura européia e do homem ilustrado que foi, para Costa, "Não se isolando da terra, não se submetendo a cultura européia, às idéias alemãs, inglesas ou francesas; procurando compreender a tradição portuguesa e as transformações que esta sofreu no contato com o meio novo da terra, mergulhando nas raízes do próprio Brasil, Sílvio Romero não fez dessa cultura européia o isolador que tem sido para tantos letrados brasileiros... Considerou-a, ao contrário, como ele mesmo dirá, como um tônico para seu espírito. Respondendo ao ensaísta argentino Garcia de Meron que, ao escrever sobre Tobias Barreto, dissera esperar do mesmo alguma coisa de mais original, de mais nativo, - esclarece-nos, ao mesmo tempo, sobre a sua concepção da Filosofia. O digno diplomataescreve Sílvio Romero no prefácio do livro Polêmicas, de Tobias Barreto -, o digno diplomata parece permanecer envolvido no erro de supor que ainda hoje só se deve considerar Filosofia a qualquer dessas monstruosas construções fantasistas, abstratas e arbitrárias que tinham o nome de sistemas e a pretensão de dar a chave do enigma de todas as coisas, e só devem ter na conta de filósofos os autores de tais fábricas ciclópicas e seus discípulos confessos "171

Significativa é a análise que nos oferece Nelson Werneck Sodré porque explora a participação do meio no desenvolvimento das letras do país. Esse autor percebe a Literatura brasileira não presa ao formalismo estético, mas sim surgida sob a influência dos fatores sociais, imersa num quadro onde as bases são justamente as transformações sociais esboçadas pelo momento histórico e pelo meio social, onde jamais podem ser desprezadas as limitações de um meio tacanho que não oferece maiores possibilidades ao labor intelectual e assim, ao desenvolvimento da Literatura. Sendo a Literatura diretamente influenciada pelas condições provincianas, onde somente uma classe reduzidíssima possui acesso à Educação (as elites provincianas), não deixa a Literatura de ser um recurso e, ao mesmo tempo, tarefa para poucos, cujo sentido maior é a legitimação da ordem capitalista.

Por se tratar de autor marxista, Sodré não perde de vista a limitação do meio social, utilizando conceitos próprios da historiografia daquela tradição, algumas vezes caros para que possamos compreender a História literária do momento, recaindo sobre si uma concepção determinista. Com relação à geração de escritores que adotaram as idéias naturalistas da época de Sílvio, Sodré salienta

\footnotetext{
${ }^{170}$ COSTA, João Cruz Contribuição à História das Idéias no Brasil. 2a . Ed. Rio de Janeiro: Civilização Brasileira, 1967. pp. 297-298.

${ }^{171}$ COSTA, Cruz. Panorama da História da Filosofia no Brasil. São Paulo: Cultrix, 1959. p.59
} 
todo o quadro brasileiro que se transformava em função de uma nova elite que surgia: "É verdade que então, e só então, começam a aparecer, na vida intelectual, elementos da classe média e manifestações típicas dessa classe, na relatividade com que se apresentava no quadro brasileiro e nos condicionamentos que, nesse esboço de sua função, reduziam de muito a sua influência. O trabalho intelectual, de tradição aristocrática numa sociedade como a nossa, continuava a pertencer, como um privilégio, de vez que diferenciava e distinguia, guardava um traço de classe inconfundível, aos elementos ligados a classe territorial. Nele se infiltravam, entretanto, em busca de destaque, a procura de um lugar ao sol, elementos outros, provenientes de camadas decadentes da classe dominante ou da classe média que esboçava a sua função. A herança externa dos postulados e das posições que, em todos os terrenos, assinalam a expansão burguesa no mundo, é aqui acolhida por uma classe dominante a que se associam os elementos mercantis e outros de classe média. Surgiam, com as primeiras diferenças de interesses, as divergências de orientação e de formulação, particularmente no campo político de que participavam, por ser reduzida a camada com acesso ao ensino, os intelectuais". ${ }^{172}$

As idéias chegadas ao Brasil são reflexos das transformações econômicas porque passara o país, não sem razão, à propensão de toda uma geração de intelectuais voltada ao campo das Ciências positivas. Frente à nova ordem, os intelectuais brasileiros e estrangeiros buscavam na Ciência respostas para suas inquietações, somadas ao fato de ser o conhecimento literário um distintivo de classe, uma vez que, a própria condição de acesso às instituições de ensino já caracteriza o elitismo da Educação brasileira, onde não raras eram as vezes que ficava evidente o pragmatismo da Literatura vigente.

Em se tratando da visão marxista ou não do autor, o que nos interessa é salientar o pano de fundo da farta produção intelectual do Brasil no momento. A leitura que nos permite Nelson Werneck Sodré, para além de uma estrita análise reducionista, possibilita sempre um olhar de pé, sustentado pela série de transformações ocorridas no momento. Se por um lado, a visão de Sodré permite uma análise determinista na qual as idéias são sempre produtos das transformações econômicas, por outro, nos livra da análise estilística e meramente formal que não percebe relação alguma com o próprio cenário que as gerou porque frisa o autor que "não apenas mudava o ambiente do ponto de vista das idéias novas que encontravam acolhida o debate. Mas também do ponto de vista objetivo de reformas as mais variadas...". 173

Se o surto das Ciências positivas nos meados do século XIX já deixa claras as necessidades das nascentes classes médias, o Naturalismo não só era parte desse vasto arsenal teórico conhecido no

\footnotetext{
${ }^{172}$ SODRÉ, Nélson Werneck. História da Literatura Brasileira. $4^{\text {a }}$ Ed. Rio de Janeiro: Civilização Brasileira, 1964. p. 342

${ }^{173}$ Ibidem. p. 344
} 
Brasil em função das transformações já mencionadas, como base maior de análise para se pensar o futuro do país, um Brasil dominado não mais pela Coroa lusitana e destituído da presença do índio e do negro, que tanto amedrontava as elites letradas e denegria a imagem do Brasil no exterior ${ }^{174}$. Não só os cursos da Escola Central sofriam alterações e a Escola Politécnica se organizava, como se conformavam cada vez mais os cursos de Ciências Naturais, Físicas e Matemáticas, e surgiam a Escola de Minas de Ouro Preto, o Museu Nacional e a Biblioteca Nacional. O movimento de idéias é visto por Nelson Werneck por vezes como inconsciente, ou seja, mesmo que as idéias adotadas pela elite brasileira encontrem pela frente um cenário totalmente diferente do cenário europeu, locais de surgimento dessas idéias, principalmente a França, “claro está que tais reformas, como o movimento de idéias, iriam fornecer a classe média em ascensão os seus instrumentos, os seus caminhos para exteriorizar reivindicações ostensivas ou veladas, conscientes ou inconscientes". 175

Coberto por um leque de transformações que acabavam por adentrar nos padrões mais íntimos da sociedade brasileira, os valores e o comportamento das famílias tradicionais frente à clausura colonial, “as formulações politicas e as formulações artísticas sofrem mudanças correspondentes” ${ }^{176}$. É nessa conjuntura que aparece o impetuoso Sílvio, liderando o movimento literário e filosófico em torno da Faculdade de Direito do Recife. Nesse novo cenário brasileiro é que Sílvio merece a atenção de Sodré porque, a princípio, "expressava, inclusive na sua incontida e profunda curiosidade, os anseios e os estímulos de tudo o que, no Brasil, começava a denunciar as transformações do fim do século, acabadas no início seguinte. Daí também a sua necessidade de participação política, a maneira com que intervém em todos os terrenos e em todos os temas, desde os mais simples e especializados aos mais complexos e amplos", 177

Sendo Romero um escritor audaz e apaixonado pelo Brasil, mesmo que viesse a adotar idéias de maneira incoerente justamente por conta de seu nacionalismo, preso aos Determinismos da época, Sodré salienta sua importância: "Nessa participação ativa e dentro das possibilidades do tempo e do meio, os serviços que presta são dos mais importantes. Oscilando entre as conclusões que lhe forneciam os mestres externos, a que se submete quase sempre apaixonadamente, e os ensinamentos que lhe provêm da observação do quadro em que vive, comete erros graves, mas assinala, com a sua profunda intuição, traços de uma realidade indesmentida. Serve-se daquilo que lhe ensinam os livros de fora e acredita no etnografismo, no tropicalismo, no que lhe dizem os seus Buckle, os seus Taines, os seus Le Play, quando não os seus Comte e os seus Spencer, admite os critérios da hereditariedade

\footnotetext{
${ }^{174}$ ALENCASTRO, Luiz Felipe de. Vida Privada e ordem privada no Império. In: ALENCASTRO, Luiz Felipe de (Org). Império: a corte e a Modernidade nacional: Cia das Letras, 1998.

${ }^{175}$ SODRÉ, Nélson Werneck. História. Op. Cit. p.345

${ }^{176}$ Ibidem. p.346

${ }^{177}$ Ibidem. p.364
} 
como prepoderantes, inclina-se para o mito da arianização, aceita um mundo de falsidades cujos fundamentos não examina. Mas examina o problema da abolição como um critério próprio e objetivo, que o faz incompreendido; mostra os perigos do imperialismo, com uma clareza surpreendente para o tempo; indica os obstáculos ao desenvolvimento na presença de uma estrutura arcaica de produção. Mas do que isso: volta-se para as fontes mais puras da criação literária, fundamenta um pensamento nacionalista inequívoco, combate a imitação servil dos modelos literários externos". ${ }^{178}$

Werneck Sodré menciona ainda dois momentos em que aparece a importância de Sílvio. "Conserva uma fidelidade exemplar às fontes populares, acolhe-as em seus textos, estuda todas elas e discrimina os valores que representam. Sente que a Arte literária deve ter raízes no povo e deve traduzir o sentimento nacional, o ambiente nacional, os traços nacionais. Os seus trabalhos folclóricos são pioneiros, em muitos sentidos, e obedecem ao critério de ligação com a formulação literária. São acolhidos com interesse pelo que revelam, e levados para a interpretação e não apenas objeto de um colecionamento indiscriminado. E Sílvio Romero entende, pela primeira vez entre nós, a Literatura como uma das manifestações da sociedade. Não a aprecia como fato isolado, arbitrário, produto apenas da imaginação. Sabe que ela traduz a realidade, corresponde a uma das mais profundas manifestações coletivas. Busca, por isso, apreciar, com os critérios ao seu alcance, tudo o que influi na manifestação literária, a sua elaboração, o seu desenvolvimento, a influência do meio. E manifesta, em muitos pontos, a convicção sobre o condicionamento social da Arte literária. Apaixonase pela idéia, que está presente em todas as suas páginas, da criação de uma Literatura nacional, autônoma, voltada para a realidade do país, e compreende, apesar de seus erros de visão, as dificuldades que se apresentam para a concretização daquilo que tanto deseja. Muitas vezes, e quase sempre com propriedade, indica aquelas dificuldades e situa precisamente as deficiências que impedem, em seu tempo, formular e dar à criação literária artística o toque próprio, que a torna inconfundivel, que lhe confere a marca da nossa terra e da nossa gente”.

Em A Ideologia do Colonialismo - seus reflexos no pensamento Brasileiro, Sodré analisa especificamente o pensamento de Sílvio com relação a sua História da Literatura Brasileira, principalmente o primeiro volume de sua obra monumental, adentrando, como não podia deixar de ser, a visão literária do crítico. Sodré reconhece a adoção errônea das leituras deterministas por parte de Romero, sua paixão pelo Brasil, e acima de tudo, a luta enfrentada para subtrair o atraso do país, o que só faz salientar a justa contribuição do escritor sergipano. Com relação à contribuição literária de Sílvio, afirma Sodré que "Escrevendo uma História da Literatura Brasileira, que até hoje permanece como obra de interesse indiscutível, teve oportunidade, em suas páginas, desde as primeiras, desde as

${ }^{178}$ Ibidem. 364-365. 
de introdução, de dar a sua palavra a propósito dos assuntos que mais interessavam ao Brasil naquele momento. Por tratar de Literatura, não se viu desobrigado de apreciar os referidos assuntos, fugindo ao debate deles. Muito ao contrário, deu-lhes um lugar, chamou a atenção do público para eles, e discutiu-os conforme verificaremos.". ${ }^{179}$ (grifos nosso)

O Determinismo literário de Sílvio, apontado por Sodré, aprisionado pelas teias deterministas da época, não invalida o pensador audaz e combatente que Romero fora, merecendo ser visto à luz de seu tempo. Adotando o que era considerado na época a última palavra em Ciência, Sílvio utilizou o que estava a seu alcance, interpretou a situação brasileira conforme os parâmetros científicos conferidos pelas instituições de saber e que acabaram por convencer boa parte dos intérpretes de seu tempo. Interpretações errôneas, mas não foram interpretações somente dele. $\mathrm{O}$ que mais interessa na análise de Sodré, embora sua leitura permita uma visão reducionista ou determinista, é que mesmo diante de tantas incoerências, polêmicas, e de ser Sílvio uma figura bastante conturbada, não deixa o autor de mencionar a importância dos temas tratados pelo bacharel. Ao mesmo tempo em que Sodré nos faz compreender o pensamento de Sílvio, ele nos faz entender sua importante contribuição para a remoção de toda a História do passado brasileiro no aspecto cultural, social, político e econômico. Tais questões fazem de Romero um pensador que não se limitou ao formalismo da criação literária, mas sim o escritor embutido de missão e pronto para contribuir nas mudanças do país. Sílvio pensara para além do discurso formal e estilístico que não faculta a análise a partir da realidade das coisas, segundo as transformações que de uma forma ou de outra influenciam o escritor no momento de sua criação literária, e não é sem razão que a Literatura de Sílvio é pragmática, que somente faz sentido se posta em prática, daí seus temas literários serem de denúncia, questões pertinentes à corrupção política do país, à falta de capacidade dos mais importantes homens de letras nacionais, à falta de amor ao país etc. Temas sem os quais não há possibilidade alguma de mudança.

Em Sílvio, a Literatura algumas vezes se mostra num estilo panfletário, em que a Crítica contra tudo e contra todos assume o primeiro plano, sem as preocupações devidas que caracterizam e identificam este ou aquele estilo ou gênero literário. Trata-se, pois, do meio mais sério de protesto, uma vez que essa Literatura carrega os foros de verdade, a última verdade científica que o autor tanto buscou ao longo de sua trajetória intelectual. Em Sílvio, seu protesto é manifesto, sua maneira de falar e de escrever são claras e objetivas, suas agressões são explícitas, mas sua vontade de subtrair o atraso do Brasil é nítida. A Metafísica e a Retórica eram as bases do pensamento brasileiro de outrora, não havia mais razão de ser assim, porque eram a representação da mentalidade arcaica e só justificavam o Brasil do passado: um país onde predominava a elite fundiária em consonância com parte da elite

${ }^{179}$ SODRÉ, Nelson Werneck. A ideologia do colonialismo - seus reflexos no pensamento Brasileiro. Op.Cit.p.71. 
portuguesa. Por isto mesmo é que a História literária de Sílvio é a procura pelo brasileiro, por suas características, para dotar a identidade nacional. Daí é que a Literatura brasileira de Sílvio finca-se sobre elementos reais, como o meio e a raça.

Mesmo que tenha sido o português o que mais contribuiu na formação da sociedade brasileira, o crítico incessantemente busca encontrar o que singulariza o Brasil. Para além da apreciação estilística e formal da Literatura produzida por Sílvio, não se pode perder de vista os temas tratados que, em sua ótica, eram os mais relevantes para a mudança do Brasil arcaico, regido pelos clãs oligárquicos, alimentados pela economia açucareira nordestina juntamente com os políticos portugueses. Daí, “Está claro que Sílvio Romero assumia uma posição a que não se poderia negar aplauso. Não fugia ao debate dos problemas que interessavam a sua gente: trazia esse debate para o texto de suas obras, ainda as menos especializadas nesse sentido. Por tratar de Literatura, não se entendia escusado de abordar temas estranhos ao que era específico de sua tarefa circunstancial. Muito ao contrário, pregava a participação, falava em deveres a que se não podia falar, e mencionava a falha de embair $o$ povo. Tinha, pois, uma posição definida. Pregava que todos a tivessem. Acentuava a obrigação do escritor nesse sentido. Estava sob a influência trazida pelo ato da regente, que concedera liberdade ao trabalho, e já indicava outros problemas e outras soluções. "' 180 (grifos nosso)

Já Wilson Martins pensa que "a arrogância ingênua de Sílvio Romero, provincianamente deslumbrado como o conhecimento de alguns livros estrangeiros, conseguiu lançar o descrédito e o ridículo sobre a idéia da "renovação literária entre nós"; contudo, não é menos certo que ele refletia, mais do que provocava, o sentimento geral de que a inteligência brasileira estava então passando por um processo modernizador, sob o signo geral do criticismo contemporâneo. "181

João Mendonça de Souza, em depoimento apaixonante, deixa clara sua admiração por Sílvio:

"A sua História da Literatura Brasileira é por isso, profundamente cultural. É certo que as Histórias de Literatura não são eternas. Fazendo-las eternas nas exatas e prestativas informações que nos possam dar. Na verdade, sempre se modificam de acordo com as épocas e as novas divisões correntes. Dentro de um mesmo século, por exemplo, podem-se apresentar modificadas, ampliadas ou complementadas no surgimento de novos grupos literários, de novas idéias, de novas posições do homem em face do universo.

Na História de Sílvio, procuramos e encontramos a ilustração válida no conhecimento que hoje temos dos escritores que criticou e difundiu. Não estabelecemos registro de nomes em seus trabalhos. Fizemos reconhecimento da Filosofia e Ciência focalizadora de problemas. E, naturalmente acompanhamo-lo na identificação fecunda da Literatura. Nesta, vimos e compreendemos os estudos objetivados.

Evidentemente, o aluno, o leitor, o intérprete poderão aqui verificar quando procuramos ser claro. Sabemos como verdade incontestável, a História literária de um povo não se pode condensar num só livro. É infinita no tempo e no espaço. A expressão História da Literatura do Brasil está superada. Podemos por exemplo, localizar Capítulos de Literatura, Problemas de Literatura, Estilistas de Literatura, Literatura e Sociedade, A Literatura como Imagem ou coisa parecida", 182

\footnotetext{
${ }^{180}$ Ibidem. p.73

${ }^{181}$ MARTINS, Wilson. História da Inteligência brasileira. 2a . Ed.Vol. IV. (1877-1896). São Paulo: Cultrix, 1996. p.67.

182 pp. $27-28$
} 
Abdala Junior escreve que: "Sílvio Romero vê em sua História da Literatura Brasileira uma evolução de sua personalidade. Autor e obra constituíram dois organismos que seguiram percursos paralelos, evoluindo numa sucessão de fases e em interação com o público. Sua concepção de sistema seguia essa organicidade, de acordo com modelos biológicos da luta pela vida. O sistema literário seria resultante de uma interação com outros sistemas e estaria ligado as condições da circulação literária de cada momento histórico. Este seria determinante, colocando a literatura como um produto cultural, subordinando-a assim aos fatos históricos, a determinação de caráter político-social. Essa idéia de sistema ligado a interação com o público será retomada em novas bases e maior complexidade, sem subordinação aos fenômenos políticos e sociais, por Antonio Candido, em sua Formação da Literatura Brasileira: momentos decisivos. ", 183

Antonio Dimas conclui que:

\begin{abstract}
“..... a História da Literatura carrega a virtude de seus defeitos: a da abrangência generosa que pretende compendiar, de forma inédita, todo um rol de informações de procedência variada, mas com o fito único de apresentar um quadro orgânico e sistemático da literatura brasileira a um país que se esforçava para se deslocar de seu estatuto colonial.

Diante de tarefa tão original, tentada pela primeira vez, Sílvio Romero, como que tomado por um sopro providencial e genésico, expandiu o alcance da História da Literatura Brasileira a ponto de nela incluir muito mais daquilo que uma precária tradição já admitida como obras de nossos poetas e nossos ficcionistas. Ainda apegado a uma compreensão bem alargada de literatura, Sílvio Romero abria um espaço facilmente ultrapassado pelos textos que a poesia, a ficção, o teatro e a crítica haviam criado, até então. Mais que uma história da literatura, o crítico de Sergipe acabou por construir uma história da cultura brasileira, sob uma ótica racial e carregada de demasias". 184
\end{abstract}

Há uma série de trabalhos monográficos juntamente com publicações bastante conhecidas, só referendando uma história intelectual, que embora não analise especificamente a visão literária do escritor sergipano, esclarecem o período histórico vivenciado pelo autor, suas influências, clareando, pois a compreensão da visão literária de Sílvio. Nessa ótica lembremos trabalhos como os de Thomas Skidmore, Preto no branco; Renato Ortiz, Cultura Brasileira e Identidade Nacional; Roberto Ventura, O estilo tropical: história cultural e polêmicas literárias no Brasil, 1870-1920; Lilia Moritz Schwarz, O espetáculo das raças: cientistas, instituições e questão racial no Brasil-1870-1930 e Ângela Alonso, Idéias em movimento: a geração 1870 na crise do Brasil - Império.

O pequeno, mas importante ensaio de Renato Ortiz, Cultura Brasileira e Identidade Nacional, é relevante porque aborda a questão da imitação do pensamento europeu pela elite intelectual brasileira, desconstruindo a noção ainda ressaltada das idéias fora de lugar ${ }^{185}$ de Roberto Schwartz. Segundo

183 ABDALA JUNIOR, Benjamim. Sílvio Romero: História da Literatura Brasileira. In: Introdução ao Brasil. Um banquete nos trópicos. São Paulo: Editora SENAC, 2001. pp. 196-199.

184 ANTONIO, Dimas. O turbulento e fecundo Sílvio Romero. (Org). BOTELHO, André e SCHWARCZ, Lilia Moritz: Um enigma chamado Brasil: 29 intérpretes e um país. São Paulo: Cia das Letras, 2009.p.79.

${ }^{185}$ SCHWARZ, Roberto. Idéias fora do lugar. In: Cultura e Política. São Paulo: Paz e Terra, 2001. 
Ortiz, as idéias adotadas pelos escritores da geração de Romero estavam sim em seus devidos lugares, uma vez que respondiam a dois critérios indispensáveis: o problema da política imigratória e a formação de uma identidade brasileira futura. Mas que isso, estuda Ortiz a importante contribuição dos ensaístas do final do século XIX na construção do novo Brasil, obviamente, fundamentadas e pensadas tendo por base as idéias científicas do pensamento europeu. A respeito de Sílvio, lembra Ortiz uma fala bem conhecida do bacharel: Todo homem que empunha uma pena no Brasil deve ter uma vista assentada para tais assuntos, se ele não quer faltar a seus deveres, se não quer embair o povo”. Pertinente é a interrogação do sociólogo: “Que assuntos são esses, que preocupam a elite intelectual brasileira? A abolição, o aproveitamento do escravo como proletário, a colonização estrangeira, a consolidação da República. Só é possível conceber um Estado nacional pensando-se os problemas nacionais. No entanto, se a abolição significa o reconhecimento da falência de um determinado tipo de economia, ela não coincide ainda com a implantação real do trabalho livre, ou sequer apaga a tradição escravocrata da sociedade brasileira. Por outro lado, a nação vive o problema da imigração estrangeira, forma através da qual se procura resolver a questão da formação de uma economia capitalista. A questão da raça é a linguagem através da qual se apreende a realidade social, ela reflete inclusive o impasse da construção de um Estado nacional que ainda não se consolidou. Nesse sentido, as teorias "importadas" tem uma função legitimadora e cognoscível da realidade. Por um lado elas justificam as condições reais de uma República que se implanta como nova forma de organização político-econômica, por outro possibilitam o conhecimento nacional projetando para o futuro a construção de um Estado brasileiro. É interessante observar que a política imigratória, além de seu significado econômico, possui uma dimensão ideológica que é o branqueamento da população brasileira. O fato de este branqueamento se dar em um futuro, próximo ou remoto, está em perfeita adequação com a concepção de um Estado brasileiro enquanto meta. Retomando Roberto Schwartz, eu diria que as idéias "estão no seu devido lugar”, uma vez que sua importação resolve, no nível intelectual, o dilema proposto. "186

A História literária de Romero contempla todas as questões elencadas por Ortiz. Sílvio buscava encontrar a chave para um novo Brasil, para isso era necessário descobrir o que diferenciava seu país da importante contribuição portuguesa, somado a contribuição dos negros e dos indígenas. Tais elementos nos fazem entender a visão literária de Sílvio. Para além da clássica indagação se estava às idéias fora ou não de lugar, o que nos interessa é que Sílvio, assim como tantos outros ensaístas de seu tempo, pensou e projetou o Brasil a partir do arsenal teórico europeu. Mas, não basta pura e simplesmente reconhecer que Sílvio adotara tais idéias para projetar o Brasil do futuro, é preciso

${ }^{186}$ ORTIZ, Renato. Op. Cit.pp. 30-31 
adentrar a questões levantadas por Ortiz, como por exemplo, a temática da colonização, a visão de república, oriunda de sua crença na evolução social, e acima de tudo, no estabelecimento de uma nação branca. Aqui cabe um pouco de cautela: reconhecendo a superioridade do homem branco europeu, Sílvio colocava a cultura européia como superior, sem deixar de olhar para a situação interna do Brasil. Um dos exemplos é a questão do Socialismo que pensava não ser viável para a realidade brasileira onde as classes não estavam devidamente formadas. Outra questão é a importância dada por Sílvio à literatura popular. Como na Alemanha, a base de formação do novo Brasil pensado por Sílvio levou-o a pensar na participação do que até então não havia sido lembrado na história nacional: dos povos sempre esquecidos.

Se pensava Sílvio que a ampla contribuição das tradições populares no decorrer do tempo seriam superadas pelas idéias mais fortes, em nenhum momento podemos deixar de lembrar o quanto ele tentou representar o povo na História do Brasil. Embora saibamos como bem lembra Raymond William, da possível visão de inúmeros "amantes esclarecidos" que olham a partir do recanto estreito das academias, interessados no resgate da cultura folclórica francesa, que concebem toda a tradição popular como bela e morta, em nenhum momento se pode desmerecer o resgate de todo um conhecimento que para Sílvio serviria como inspiração para sua História da Literatura Brasileira. Ao tempo de Sílvio, fusão racial era também fusão cultural ou das idéias, o que entendemos hoje por assimilação cultural.

Não restam dúvidas que era Sílvio um crente convicto da superioridade da cultura européia. Mas, por mais que a luta no plano das idéias, atendendo à lei do mais forte, fosse sempre favorável ao europeu, cabe destacar a ampla contribuição de índios e negros. Esse era o nó górdio enfrentado por Sílvio, sabedor da participação de milhões de negros e mestiços ante seu novo Brasil. Era esse o impasse ideológico enfrentado por Sílvio, que diferente dos cronistas de outrora, dos escritores românticos, e de nomes como Martius e Varnhagen, desejava em sua História Literária inventariar o que coube a cada uma das raças, "a essa luz, a literatura brasileira lhe parecia um produto cada vez mais diferenciado da portuguesa, devido a atuação dos fatores peculiares ao país, conforme a seleção natural. Tais fatores desaguavam na raça, que pôs em primeiro plano, segundo as tendências dominantes do século. Mas a sua originalidade vem do fato de haver compreendido e avaliado devidamente a importância da mestiçagem, - traço fundamental que teve, como vimos, o mérito de focalizar com nitidez e usar como instrumento de interpretação, a despeito de aceitar como princípio científico indiscutível a teoria da desigualdade das raças. De qualquer modo, abriu sobre a cultura 
brasileira uma perspectiva heterodoxa, que só em nossos dias começou a ser devidamente explorada". 187

Com relação à História literária de Sílvio, escreve Skdimore, "Em sua História da Literatura Brasileira (1888), Sílvio Romero estimava que o processo de "branqueamento" levaria de três a quatro séculos. Agora, pensava que tomaria “uns seis ou oito, se não mais" - para a absorção de índios e negros. Ademais, chegara à conclusão de que os mestiços jamais desapareciam" "188 Conclui ressaltando: "o desparecimento total do índio, do negro e do mestiço poderia ocorrer, dizia Sílvio Romero, apenas se toda a miscigenação futura incluir um parceiro extremamente claro (senão branco). Não havia estatísticas na análise de Sílvio Romero. Ele argumentava baseado nas suas próprias impressões e leituras. Sempre indomado, era do seu estilo duvidar de toda conclusão uma vez que se tornasse opinião estabelecida". 189

Dante Moreira Leite ainda que considere Sílvio como um dos ideólogos do caráter nacional brasileiro, alonga seu olhar sobre a posição literária deste,

\footnotetext{
"Em primeiro lugar, Sílvio Romero nunca se conformou com o maior prestígio literário do Rio de Janeiro; com ou sem propósito, a todo momento reivindicava os direitos e o valor do grupo nordestino de sua época. Quanto ao segundo aspecto, a Alemanha, depois de vencer a França na guerra de 1870, despontava como o novo centro industrial e intelectual da Europa continental. O prestígio da Inglaterra, como a maior potência do século XIXI, era indiscutível, e isso justificava as palavras de Sílvio Romero.

A respeito, cabe ainda outra observação: Sílvio Romero deseja comparar o Brasil às nações de maior prestígio - onde, deve-se notar, além da França, Inglaterra, Alemanha, Itália, inclui também os Estados Unidos, o que indica o prestígio corrente deste país. Aparentemente, não lhe ocorre pensar que, entre dezenas e dezenas de países, apenas nesse seria possível distinguir originalidade; como se verá nos capítulos seguintes, o mesmo argumento será válido para os outros ideólogos. Também para eles, o Brasil deve ser comparado aos países mais ricos, e deve haver uma razão brasileira que explique as diferenças". ${ }^{190}$
}

Uma das melhores leituras de Sílvio é a realizada por Maria Aparecida Rezende Mota. Analisando a generalidade do pensamento romeriano, para a autora: "Sua compreensão da literatura como testemunho social levou-o a procurar a entender a sociedade brasileira de forma abrangente, analisando tudo o que poderia influir na manifestação literária. Daí o valor conferido ás fontes populares. Nelas, Sílvio encontraria o processo de mestiçamento brasileiro como base da formação nacional. Quando se ocupou, portanto, dos “cantos e contos populares”, abriu aos estudos literários uma nova direção: a da interpretação sociológica do material folclórico. Luis da Câmara Cascudo observa, sobre o pioneirismo de Romero nos estudos folclóricos, o quanto é notável que "devotos de

\footnotetext{
${ }^{187}$ CANDIDO, Antonio. Sílvio Romero: teoria, crítica e história literária. Op. Cit. p. XIX

${ }^{188}$ SKDIMORE, Thomas. Preto no branco. Op. Cit. p.86

${ }^{189}$ Ibidem. p.86.

${ }^{190}$ LEITE, Dante Moreira. Op. Cit.p.
} 
livros e da ciência social do tempo”, Romero tivesse preferido estudar a ciência social do folclore, "que era apenas uma curiosidade e uma pilhéria para a inteligência da época". 191

Maria Aparecida elabora uma análise das teorias adotadas por Sílvio. Dentre as influências sofridas pelo escritor, salienta a autora que Romero salientava a importância do clima, da topografia, da geologia, da dieta, determinando seu pensamento e sua visão de Brasil. ${ }^{192}$. De acordo com ela, o escritor sergipano mitigou o naturalismo, idéia sustentada antes por Antonio Candido: Sílvio teria ofuscado o determinismo racial e climático pontilhando suas análises sociais para legitimar a divisão hierárquica de classes. Ainda com a autora, o impasse racial resultante das diversas idéias da época suscitou na solução pelo embranquecimento, somente equacionados pela formação de "tipos característicos orientais e europeus, especialmente, italianos, espanhóis e portugueses" 193

Obras que, de modo específico, tangenciam a relevância de Sílvio como pensador brasileiro atinando para suas análises acerca da formação do povo brasileiro são as de Cláudia Neiva de Matos, A poesia popular na república das letras: Silvio Romero folclorista; Wilmihara Benevides da Silva Alves dos Santos, Povo e Raça na formação da nação: um debate entre Manoel Bonfim e Silvio Romero; Hilton Costa, Horizontes Raciais: a idéia de raça no pensamento social brasileiro 18801920; Ricardo M. Pinto, Silvio Romero: contribuições a formação do pensamento racial no Brasil (1870-1914); e Alberto Luiz Schneider, Silvio Romero: hermeneuta do Brasil.

Para Wilmihara Benevides, enquanto Bonfim foi um intelectual cívico, Romero era um "amante da retórica, da linguagem de efeito moral, sem exatidão de análise”. ${ }^{194}$ Recorria a uma infinita gama de autores para se manter em seu campo intelectual, recurso que o caracterizava como um intelectual da sociedade. Sobre a contribuição literária afirma Benevides: "No campo da crítica literária, Silvio Romero produz A História da Literatura Brasileira (1888), introduzindo o determinismo histórico e racial na análise das obras literárias. Esta obra permitiu reivindicar um novo olhar sobre a população, apresentando-a como um produto da sociedade em que vive”. 195

Hilton Costa, afirma que basta o primeiro volume da História da Literatura Brasileira, "porque sob a égide de história da literatura, o letrado pretendia desenvolver uma análise de toda uma produção cultural e intelectual brasileira. Realizar isso no seu momento histórico era enfocar a questão da raça, já que, para o pensamento vigente, a raça definiria tais capacidades. Devido a isso

\footnotetext{
${ }^{191}$ MOTA, Maria Aparecida Rezende. Sílvio Romero: dilemas e combates no Brasil da virada do século XX. Rio de Janeiro: Editora FGV, 2000. pp. 41-42

${ }^{192}$ Ibidem. p. 64

${ }^{193}$ Ibidem.,p. 73.

${ }^{194}$ SANTOS, Wilmihara Benevides da Silva Alves dos. Povo e raça na formação da nação: o debate entre Manoel Bomfim e Silvio Romero. Dissertação de Mestrado em Ciências Sociais defendida na Universidade Estadual Paulista. Marília, 2006.p. 123

${ }^{195}$ Ibidem. p.28
} 
localizamos nesta obra, uma importante fonte para o desenvolvimento desta pesquisa, por ser ela reveladora dos pressupostos, postulados e mesmo algumas ambições (em termos de projeto para o Brasil) desse homem de letras" ${ }^{196}$. Conforme o autor, para além da mera imitação da simples adoção das teorias estrangeiras, foi a partir da realidade nacional que ensaístas como Silvio Romero aplicaram o modelo racial que julgavam mais adequado, objetivando construir uma sociedade nos moldes da Europa e dos EUA. Ainda que houvesse uma defasagem entre a adoção das teorias raciais e sua aplicação no Brasil, Romero centrou-se no mestiço como a singularidade brasileira, do ponto de vista não apenas racial, mas também cultural. Nesse sentido, o caráter mestiço fundamentaria não apenas a originalidade da contribuição ideológica de Sílvio, como explicaria a cultura brasileira de um modo geral.

Convicto na superioridade da raça branca, isso em nada faz desmerecer sua investida e sua grande esperança de averiguar a contribuição pelos meios literários a devida contribuição de cada raça na formação do povo brasileiro. Sua opção pela colonização européia no Brasil jamais desmerece sua teoria de Brasil. Pelo contrário, é a partir de sua teoria intrinsecamente européia que Sílvio volta seu olhar ao país que tanto dizia amar buscando as nossas raízes, formadora do nosso caráter ou psicologia

Ricardo M. Pinto, em Silvio Romero: contribuições à formação do pensamento racial no Brasil (1870-1914) abordando a questão da raça como categoria formadora e indiscutível da identidade brasileira, aborda o determinismo racial de Romero e sua adequação corroborada pela elite letrada em benefício da formação do estado nacional brasileiro. O autor salienta a crença do bacharel na superioridade da raça branca, engendrando as transformações sócio-econômicas na transição do trabalho escravo para o trabalho livre. Sílvio centra-se no mestiço para a formação do povo brasileiro, ao mesmo tempo em que o relega, evidenciando assim sua xenofilia.

Cláudia Neiva de Matos elabora uma análise contundente quando aponta os falsos acordes orquestrados por Silvio Romero. Conforme a autora, a crença na inferioridade do negro é construída pela opacidade ideológica do bacharel, fazendo com que os reais elementos de investigação sejam esquecidos. Para Matos, mesmo que de forma inconsciente, Romero maneja suas categorias que facultam dois propósitos: "reforça seus pressupostos teóricos e traz o negro para a história, ao mesmo tempo em que o relega a uma posição inferior" ${ }^{197}$. A autora percebe as teorias raciais adotadas por Romero como apanágio colonizador do Novo Mundo, sendo indispensável à idéia de raças inferiores em relação aos países europeus abrigados pela civilização. No que diz respeito à

${ }^{196}$ COSTA, Hilton. Horizontes raciais: a idéia de raça no pensamento social brasileiro, 1880-1920. Dissertação de Mestrado defendida no Programa de Pós Graduação do Instituto de Filosofia e Ciências Humanas da Universidade Federal do Rio Grande do Sul, 2004. p.16

${ }^{197}$ Matos, Cláudia Neiva de. A poesia popular na república das letras: Silvio Romero Folclorista. Rio de Janeiro: Funarte/ Ed. da UFRJ, 1994.p. 
concepção de "cultura popular", tendo por base os estudos folclóricos, a autora explicita a visão etnográfica de Romero, percebendo a poesia do povo franqueada por uma arte erudita, vista a partir do homem ilustrado ${ }^{198}$. A tradição folclórica é, pois, reinventada por Romero, tendo por base os critérios etnográficos sustentados pelo olhar científico ${ }^{199}$.

João Hernesto Weber pontua que "É fácil perceber o peso que a questão nacional adquire na História de Sílvio Romero: se o objetivo é escrever uma história que detecte, na literatura, a expressão do processo de formação e afirmação, digamos assim, do brasileiro, o critério da nacionalidade literária passa tanto a ordenar o corpus literário, imprimindo-lhe uma determinada lógica - o arrolamento das obras em função do processo de diferenciação nacional -, como, também, a servir de fator de seleção e de valoração de obras e autores. Conforme afirma o próprio Sílvio Romero na passagem anteriormente citada ("Tudo quanto há contribuído para a diferenciação nacional, dever ser estudado, e a medida do mérito dos escritores é este critério novo"), à história literária devem interessar aquelas obras que refletem a especificidade nacional e, reflexamente, tenham contribuído para o processo de diferenciação nacional. Não é por menos, assim, que a sua proposta de periodização a literatura brasileira tenha como orientação básica justamente o critério da afirmação nacional: nos "Fatores da Literatura Brasileira”, aponta para a existência de quatro grandes fases literárias - o período de formação, o período de desenvolvimento autonômico, o período de transformação romântica e o período de reação crítica. As "fases" literárias apontadas por Sílvio Romero, a par de indicarem uma concepção orgânico-evolutiva da literatura, que "se forma", "se desenvolve", o que era certamente do método, indicam também, para além do método, o que lhe estava implícito: trata-se da formação da literatura brasileira, “nacional”, e de seu desenvolvimento autonômico... Um outro exemplo, mas fortuito porque tópico, mas não menos importante: Sílvio Romero confere a Gregório de Matos Guerra o título de "fundador da literatura brasileira" justamente pela expressão das peculiaridades do país que nele encontra. A nacionalidade é critério de seleção, ordenação e valorização do literário, enfim". ${ }^{200}$

Alberto Luiz Schneider, em Sílvio Romero: hermeneuta do Brasil analisando de modo geral o pensamento romeriano busca encontrar a teoria do Brasil do crítico literário. Segundo Schneider, Romero partia da mestiçagem de uma forma abstrata para a construção da singularidade brasileira, desse modo, “A História da Literatura Brasileira é, como a própria trajetória de seu autor, um livro generalizante, onde se encontram considerações sobre vários domínios do saber, no qual se percebe

\footnotetext{
${ }^{198}$ Ibidem.

${ }^{199}$ Ver a respeito WILLIAMS, Raymond. O Campo e a Cidade na História e na Literatura. São Paulo: Cia das Letras, 1989. Ver também CERTEAU, Michel de. A Cultura no Plural. Campinas: São Paulo: Papirus, 1995. Ainda. ORTIZ, Renato. Cultura popular: românticos e folcloristas. Op. Cit.

${ }^{200}$ WEBER, João Hernesto. A nação e o paraíso: a construção da nacionalidade na historiografia literária brasileira. Florianópolis: Ed. da UFSC, 1977. pp. 70-71
} 
um esforço para encontrar explicações cientificamente respaldadas e articuladas. Não devemos nos surpreender com o fato de o autor ter escrito sobre Etnologia, Crítica Literária, História, Ciências, Filosofia, Direito, Política e ainda coligido cantos e contos populares - um século antes, Goethe fazia o que hoje chamamos de literatura e também praticava experimentos químicos. Em outras palavras, apenas no século XIX é que começaram a surgir as disciplinas, e sua institucionalização foi lenta. Assim, além da literatura, o interesse de Sílvio voltava-se ainda mais aos assuntos relativos à sociedade e ao Estado, o que ampliou a dispersão temática de seus domínios". 201

Essa é a visão de José Guilherme Merquior sobre Romero: "apesar de familiarizado com vários determinismos (a causa geográfica de Buckle, a racial de Taine, a do trinômio lugar-trabalho-família de Le Play,) Sílvio Romero ergueu a sua monumental História da Literatura Brasileira (1888) de maneira bem pouco sistemática. Seu conceito de literatura é, aliás, sociológico mais que estético; pois compreende todas as manifestações da inteligência de um povo. Mas a despeito dessa latitude do conceito de literatura e da erudição exibida pelo autor, a História principia por uma longa parte introdutória (originariamente estampada na Revista Brasileira, em 1882), em que apregoa e discute as doutrinas históricas, etnológicas e geográficas do tempo, no horizonte de uma darwinização da crítica - limitando-se a justapor-lhe o painel das quatro fases da nossa literatura (1500-1750; 17501830; 1830-1870; de 1870 aos dias de então). Entre os fatores apontados na primeira parte (a história natural de nossas letras) e a seqüência concreta dos autores e obras, ou mesmo das fases estilísticas, a ligação é a mais frouxa possível. Os juízos de Sílvio Romero são as vezes claudicantes, as vezes insustentáveis (p.ex., o endeusamento de Tobias - dado por superior a Castro Alves...- a subestimação parcialíssima de Machado de Assis); contudo, o estilo ágil e combativo facilita a leitura, e o patriotismo sem ufanismo faz desse colosso historiográfico, ao qual de deve a fixação definitiva (em termos globais) do nosso corpus literário, um depoimento fundamental sobre o itinerário da cultura brasileira. De registro igualmente obrigatório são os livros em que Sílvio coligiu, de forma pioneira, os contos e cantos folclóricos do Brasil”. ${ }^{202}$

Ricardo Bechelli, em Metamorfoses na interpretação do Brasil - Tensão no paradigma racista resume de maneira bastante clara a História literária de Sílvio:

\begin{abstract}
"a forma como Romero vê a história e a literatura brasileira é a de uma evolução, dos portugueses chagando no Brasil até ao final do século XIX quando aquela literatura, como um retrato da sociedade nacional, já começaria a ganhar um novo significado e uma maior coesão. Mas ainda, isto refletiria ainda a própria evolução histórica do povo brasileiro, que, no entender de Romero, com a miscigenação, já estaria apto a mostrar os seus valores, as suas idéias e criações. Era através da miscigenação - seja ela biológica ou cultural - que se processava a evolução histórica do Brasil, que ganhava cada vez mais força à medida que o país se formava, que ganhava a sua identidade através da mestiçagem entre as três raças".
\end{abstract}

\footnotetext{
${ }^{201}$ SCHENEIDER, Alberto Luiz. Sílvio Romero, hermeneuta do Brasil. São Paulo: Annablume, 2005. pp. 24-25

${ }^{202}$ MERQUIOR, José Guilherme. De Anchieta a Euclides: breve história da literatura brasileira I. $3^{\text {a }}$. Ed. Rio de Janeiro: Topbooks, 1996. pp. 154-155
} 
Mais do que apenas retratar a evolução histórica, Romero aqui decidiu fazer um quadro evolutivo onde a literatura se mostra como uma força de expressão, com o objetivo claro de ilustrar o quanto o povo brasileiro já tinha ganho em relação a sua identidade, em razão da miscigenação. A literatura servia de parâmetro para Sílvio ilustrar o quanto o povo brasileiro já estava formado ou em estágio de formação.

Neste sentido, o ensaísta via a literatura como sendo algo essencial na história do país, pois representava todo o pensamento, toda a forma de manifestação cultural escrita, sejam estudos literários, folclóricos ou científicos. ${ }^{203}$

Ricardo Luiz de Souza, em trabalho de tese, após analisar a forte influência da raça e do meio na análise literária de Sílvio, conclui que: "seu objetivo final, nada modesto, é criar uma filosofia da história brasileira, o que seria feito a partir do estudo de uma série de fatores que ele mesmo encarrega-se de arrolar: a ação do meio físico, as qualidades etnológicas das raças constituintes, as condições biológicas e econômicas que determinaram a formação nacional, o processo de miscigenação, os incentivos de psicologia social. Fatores justapostos e empilhados a condenarem o objetivo inicial, no final das contas, à inevitável desintegração". ${ }^{204}$

${ }^{203}$ BECHELLI, Ricardo Sequeira. Op. Cit. pp. 97-98

${ }^{204}$ SOUZA, Ricardo Luiz. Identidade nacional e modernização na historiografia brasileira: o dialogo entre Romero, Euclides e Freire. Tese de doutorado apresentada ao Programa de Pós-Graduação em História da Faculdade de Filosofia e Ciências Humanas da Universidade Federal de Minas Gerais, 2006.p.68 


\section{RAÇAS: LIMIAR, QUASE ALÉM.}

\section{I- COMEÇANDO A HISTÓRIA}

O pensamento de Silvio Romero moldou-se a partir da transposição do método que havia sido aplicado às ciências naturais e que era agora transferido para as análises sociais, avaliando o estágio evolutivo dos grupos humanos, tendo por base, principalmente, a lei dos três estágios de Comte e o evolucionismo de Spencer ${ }^{205}$. A sociedade era concebida à imagem e semelhança de um organismo vivo, onde cada órgão se transformava sempre do mais simples ao mais complexo. ${ }^{206}$

Essa nova maneira de ver a sociedade brasileira tinha estreita implicação com o conjunto de transformações econômicas ocorridas na Europa, abrangendo a maioria dos países dependentes do mercado europeu. No Brasil, há um cenário propício para a assimilação da nova visão da sociedade em decorrência das discussões acerca da escravidão e das possíveis mudanças com o advento da república. 1850 é uma data marcante devido à lei que teoricamente põe fim ao tráfico de escravos, mesmo que o comércio de negros entre as províncias ainda persistisse. Depois da lei Eusébio de Queirós, posteriormente, surgiriam mais três leis num cenário em que a economia do café era à base do Império Brasileiro, fomentando discussões sobre o trabalhador ideal, suscitando e respaldando "cientificamente" qual a melhor raça indissociável de alguns questionamentos acerca de um Brasil melhor, um Brasil evoluído, sem a presença do escravo e a caminho do progresso e da civilização.

Sílvio Romero, assim como tantos polígrafos de seu tempo, insere-se nessa conjuntura de pensar um Brasil sem escravidão, projetando a formação de uma nação, preocupando-se, portanto com a infinidade de problemas nacionais, que segundo ele, explicavam o atraso do país.

Caio Prado Júnior indica o ano de 1850 como "o ponto de partida de toda a evolução posterior brasileira" ${ }^{207}$. Essa conjuntura acolheria as novas idéias científicas e filosóficas, com as quais se deparou a geração de Silvio Romero, misturadas às teorias raciais que o escritor usaria para analisar o Brasil.

$\mathrm{Na}$ segunda metade do século XIX, especificamente, em meados de 1860/70, como desdobramento da entrada das idéias do determinismo racial e climático, floresceu o debate em torno das principais questões nacionais, que eram a escravidão e a república, e de outros problemas pertinentes ao progresso do país. O Brasil foi interpretado pelas correntes do positivismo, do

\footnotetext{
${ }^{205}$ CANDIDO, Antonio. A Sociologia no Brasil. Tempo Social, Revista de Sociologia da USP, V.18, n.1, 2006. Ainda. IANNI, Octávio. A sociologia e o mundo moderno. São Paulo: EDUC, 1988.

${ }^{206}$ LEITE, Dante Moreira. O caráter nacional brasileiro. São Paulo: Pioneira, 1976. p. 192

${ }^{207}$ PRADO JR, Caio. Evolução Política do Brasil. Colônia e Império. 4ª . Ed. São Paulo: Brasiliense, 2007. p.50.
} 
evolucionismo e do determinismo. Todo esse debate toma sentido para solucionar o problema da mãode-obra escrava, originando a discussão imigracionista de pensar um novo Brasil, um dos temas tratados de maneira pormenorizada por Sílvio.

Extremo conhecedor de tantos livros de ciência e de filosofia que lhe caíam às mãos, sintonizado com muitas correntes de pensamento européias, primeiramente aderiu ao Positivismo de Comte, preterindo o autor do Cours de Philosophie Positive pelas idéias de Spencer, que pregava a questão de struggle for life e que Sílvio conhecera quando estudante de Direito no Recife. Do Positivismo, reconheceu a validade das leis dos três estágios, embora tenha desferido duras críticas ao sistema de Comte por impedir a liberdade ou o desenvolvimento da ciência, devido a seu "círculo de ferro". Creditara à raça branca a maior contribuição na formação do povo brasileiro por ser esta a mais forte, estendendo a idéia de seleção natural não somente ao plano biológico, como no plano moral e das idéias. Para Sílvio, foi o branco a raça que mais contribuiu para a formação da singularidade brasileira refletida pela figura do mestiço, que era o genuinamente brasileiro ou o brasileiro por excelência.

Um dos mestres de Sílvio foi Spencer, fazendo do crítico literário um defensor das leis evolutivas em que todo o processo de transformação social: "Os que sabemos ser a lei máxima de todos os fenômenos da história, como a de todos os fenômenos do mundo físico, a lei da evolução, cuja fórmula mais completa é aquela que é devida ao gênio de Herbert Spencer." 208 Defendia, mesmo que de forma ambígua, a originalidade da cultura brasileira, em detrimento da herança racial portuguesa, daí, seu brasileirismo onde mesmo reconhecendo esta forte herança lusa, buscou por meio de seus recortes naturalistas identificar aquele escritor que mais refletia a alma nacional.

Para analisar o Brasil, Sílvio guiou-se pela Escola Social de Le Play e seus divulgadores Desmoulins, Rousiers, Preville, Bureau - afirmando que "os processos da Escola de Le Play fizeramme penetrar mais fundo na trama interna das formações sociais e completar as observações exteriores de ensino spcenriano. É uma confirmação, em última instância, de conclusões obtidas por outros meios e estradas" ${ }^{209}$. Outra forte influência sofrida por Sílvio foi à Antroposociologia assentada por nomes como os de Gobineau, Lapouge, Quatrefagez, Ammom, Topinard, que o fizeram estudar o Brasil à luz do caráter étnico e o levaram a esmiuçar suas análises muito além do critério das raças.

Estas três influências são cruciais para a leitura que Sílvio faz do Brasil. Traçando um quadro social brasileiro nada promissor, ora em função do caráter étnico da psicologia nacional apática e desinteressada pelos problemas nacionais do país, ora devido a um meio propício ao surgimento de verdadeiros clãs políticos responsáveis pela miséria de milhões de pessoas, tudo isto somado ao

${ }^{208}$ ROMERO, Sílvio. Introdução a Doutrina Contra Doutrina. Op. Cit., p. 65.

${ }^{209}$ ROMERO, Silvio. História... Op. Cit. p. 189. 
desconhecimento das elites brasileiras em relação às novas idéias da crítica moderna, Romero buscou identificar como sempre afirmava os males do país, justamente para apontar os reais elementos constituintes do verdadeiro Brasil. Para Sílvio, tanto a elite econômica como a ilustrada, formada por médicos, literatos e jornalistas, não enxergavam as raízes dos verdadeiros males nacionais, esboçando sempre um Brasil irreal, de Haia. Criticava ainda a mania de passar por aquilo que não somos!

Para além das análises raciais, realizava Sílvio obras sociológicas e ensaios políticos, buscando apontar os verdadeiros males do país. Ao passo que encontramos figuras como as de Araripe Júnior e Capistrano de Abreu credenciando o meio geográfico como determinante na formação da cultura brasileira, Silvio se ligou à categoria racial ${ }^{210}$ e climática para explicar o atraso brasileiro. O bacharel sergipano ampliava suas análises a um quadro bastante complexo, esmiuçando as zonas sociais brasileiras, buscando compreender o caráter do brasileiro, influenciado que foi pela Escola de Le Play.

Desse modo, mesmo se apoiando em autores deterministas como Buckle, discordou de algumas de suas idéias, mas não de sua teoria, em razão de o autor inglês ter dedicado somente oito páginas sobre o Brasil sem nunca ter visitado o país. Mesmo adotando a teoria do meio ambiente exposta em History of civilization England, afirmou que a visão do escritor era cosmológica demais ${ }^{211}$, carecendo, pois, de um nexo causal. A respeito do escritor inglês, afirmava que "Buckle é verdadeiro na pintura que faz do nosso atraso, não na determinação de seus fatores" ${ }^{212}$. A influência de Buckle, de Taine e da corrente de Antroposociologia levou o polígrafo sergipano a estudar as diversas zonas sociais do Brasil para traçar um quadro geral e que ele afirmava real do país. Frente a tantas leituras, reconhecia que o meio brasileiro (clima, temperatura, geologia, geografia) era o agente diferenciador ${ }^{213}$, sendo o mestiço a singularidade brasileira. Afirmou que "a ação do clima tem contribuído para nossa integração nacional; na literatura, ela tem ajudado a efusão sentimental de nosso lirismo mais doce, suave e ardente do que o lirismo herdado dos portugueses" 214 . O meio ambiente era de inteira importância, segundo Romero, para explicar porque "não temos filosofia, nem ciência, nem a grande poesia impessoal dos grandes gênios europeus. Temos o palavreado da carolice, a mística ridícula do beatério enfermo e fanático, de um lado, e de outro, os devaneios fúteis da impiedade impertinente e fácil; na poesia, o lirismo subjetivista, mórbido, inconsistente, vaporoso, nulo", 215

\footnotetext{
${ }^{210}$ ROMERO, Sílvio. Etnografia Brasileira: Estudos Críticos sobre Couto de Magalhães, Barbosa Rodrigues, Teófilo Braga e Ladislau Neto. Rio de Janeiro: Livraria Clássica de Alves \& C. 1888.1

${ }^{211}$ ROMERO, Sílvio. História da Literatura Brasileira. Op.cit., p,63.

${ }^{212}$ Ibidem. p.87.

${ }^{213}$ Ibidem. p. 268

${ }^{214}$ Ibidem. p. 96.

${ }^{215}$ Ibidem. p.93-94.
} 
Analisando o Brasil miserável ao longo dos quatro séculos de escravidão, Romero concluiu que "a ação do meio físico em sociologia e na literatura pode-se determinar pelo clima, pelo aspecto geológico e topográfico do país, pela alimentação do povo" (mais que o meio ambiente, portanto) ${ }^{216}$. Poligenista e crente na diferença inata das raças como fator de fundamental relevância, Romero estendeu o critério etnográfico, que dizia ter introduzido entre nós, às explicações sociais na busca de compreender o verdadeiro Brasil, o que tanto motivou sua vasta produção literária. Ele se dedicou a todas as manifestações do espírito. Daí, o amplo sentido de sua concepção literária, tributária da influência germânica tomada de Tobias Barreto, que não se reduzia às Belas Letras.

Desse modo, todo o atraso material e cultural do país era considerado resultado de uma sociedade de caráter apático, carecendo de uma educação enérgica. Conseqüências desse estado de coisas eram os cerca dos 16 a 18 milhões de pessoas vivendo em situação de extrema miséria devido à colonização portuguesa, ou seja, colonização processada por uma raça em estado degenerativo, que não facultou um espírito de iniciativa na luta pela vida como os ianques, alemães, franceses, ingleses e noruegueses. Sílvio explicava a situação de extrema pobreza e de atraso cultural do país em suas mais variadas instâncias como decorrência da colonização ibérica, apenas preocupada com a política alimentária, bem como o mal do emprego público, etc ${ }^{217}$. Não era sem razão que sofria o Brasil desse último mal, da mania de grandeza, mostrando no exterior justamente aquilo que não era, pois a raça portuguesa, há muito desligada de seu tronco, cada vez mais se degenerava, sendo responsável por uma Educação apática, desinteressada pelos reais problemas políticos do país. O fator étnico era responsável, diretamente, para explicar o quadro de miséria, uma vez que sua concepção de raça carregava consigo uma índole, por sua vez, portadora de determinada capacidade moral e criadora.

Pensador dos mais significativos do país por ter alongado as influências européias aos inúmeros problemas nacionais, Sílvio é uma figura proeminente da geração científica de sua época por ter inovado a maneira de interpretar o Brasil, após as análises românticas legitimadoras de uma sociedade hierárquica em razão da economia escrava. Embora seu manancial teórico fosse o de todos os homens de sua geração, Sílvio não foi um escritor preocupado em legitimar o status quo, escrevendo da maneira mais simples para que a elite brasileira soubesse aquilo que Romero considerava serem as verdadeiras raízes dos males do país.

Por mais que se baseie nos preceitos do Determinismo e do Evolucionismo, Sílvio vai além da mera análise determinista, seja da raça ou do meio climático. Mesmo reconhecendo a contribuição dos portugueses, busca encontrar a singularidade brasileira. Seus estudos folclóricos deixam clara a importância que atribuía aos grupos mais simples dos sertões e vilas brasileiras, como pescadores e

\footnotetext{
${ }^{216}$ Ibidem. p.95

${ }^{217}$ ROMERO, Sílvio. O Brasil Social... Op.Cit.
} 
vaqueiros. Se não acreditava nas idéias socialistas como forma de alterar a conjuntura brasileira, porque o Brasil ainda não estava rigidamente hierarquizado em termos de classes sociais, não se pode simplificar a vasta contribuição ao Determinismo de Taine. Sílvio moveu severas críticas à elite do país, ao ensino de cunho retórico, à presença das oligarquias presente em todo o país, à dependência da economia brasileira, etc. Afirma Nelson Werneck Sodré que "Sílvio Romero, interessou-se por todos os grandes problemas de seu tempo. Participou-se do debate que se desencadeou-se em torno de cada um. Teve uma posição". 218

Mesmo conhecedor das idéias de Buckle, Taine, e tantos outros autores, Silvio não simplificou suas análises da sociedade brasileira aos parâmetros raciais e mesológicos. Não é sem razão que concebia literatura em seu sentido mais amplo, no que buscou seus fatores condicionantes constituídos pelo meio geográfico, pela raça, pela influência estrangeira e por todo o passado do Brasil. Tais fatores contribuíram diretamente para a explicitação da formação da sociedade brasileira. Assim, retratou em sua vasta produção ensaística o estágio evolutivo da cultura brasileira frente aos países europeus, utilizando-se do método comparativo para avaliar o perfil cultural do Brasil com relação aos países europeus. Para o crítico sergipano, "a literatura brasileira não se furta às condições de toda a literatura antiga ou moderna, sendo a resultante de três fatores fundamentais: o meio, a raça, as correntes cientificas" ${ }^{219}$.

Antonio Candido afirma que para Romero, "a literatura só pode ser compreendida se a estudarmos em função dos fatores condicionantes, e nunca em si mesmo" ${ }^{220}$. Sílvio interpretou o Brasil de maneira rigorosamente científica, influenciado que foi pelo impacto das ciências naturais sobre a nascente sociologia, balizando suas análises a partir da lei do mais forte e dos estágios evolutivos, promovendo uma renovação literária e filosófica iniciada no Recife, da qual se considerava o introdutor no país. No plano filosófico, combateu o espiritualismo de cunho retórico de Victor Cousin, personificado no Brasil pelo franciscano Monte Alverne, e outras figuras como Eduardo França, Gonçalves de Magalhães, Pedro Américo, Guedes Cabral e Pereira Barreto, porque pensava que "o espírito crítico é uma necessidade permanente e fundamental do pensamento, é uma condição da luta pela vida na esfera das idéias" ${ }^{221}$.

Sílvio inaugurou uma nova linha de interpretação no pensamento brasileiro, que tinha por base a crítica naturalista, ancorada em seus mais renomados representantes, como Taine, Scherer, Saint Beuve, etc. Para compreender a formação da história do Brasil e de seu povo, valorizou a mestiçagem

218 SODRÉ, Nelson Werneck. A ideologia do colonialismo: seus reflexos no pensamento brasileiro. Rio de Janeiro: Civilização Brasileira, 1965. p.71.

${ }^{219}$ ROMERO, Sílvio. História da Literatura Brasileira. Op.cit. p. 266.

${ }^{220}$ CANDIDO, Antonio. Introdução ao Método Crítico de Sílvio Romero. Op.Cit. 156.

${ }^{221}$ ROMERO, Sílvio. Obra Filosófica. Op. Cit., 60 
e o modelo de crítica supostamente imparcial para só assim descrever o cenário do país. Sobre a crítica, afirmava que não era esta "um sistema, uma teoria, uma doutrina feita e completa, uma ciência, mas um processo, um método, um controle, que se devem aplicar às criações do espírito em todos os ramos de sua atividade" 222 .

A importância dos elementos raciais concebidos a partir da escola darwinista-social seria central para a compreensão de sua análise brasileira. Esta escola baseava-se na Anatomia comparada, na Frenologia e na Fisiologia. O estágio cultural brasileiro devia-se, pois, a três fatores: naturais (raça, meio, solo, equilíbrio bio-psíquico), sociais e psicológicos.

Seria nodal para sua compreensão de Brasil a questão da mestiçagem, porque pensava que essa era a grande singularidade do país. Teoria já aludida de forma sutil por Varnhagen e de forma clara pelo alemão Martius, Romero discordou da proposta das forças diagonais deste porque o ganhador da monografia do IHGB apenas "aconselha aos historiadores brasileiros de contemplar os feitos das duas raças inferiores, ao lado das ações dos portugueses, e de notar as modificações nestes operadas pelo influxo dos que neles com eles coabitam" ${ }^{223}$. Concluía Sílvio que era "Por isso, sua teoria é puramente descritiva" ${ }^{224}$ carecendo do nexo causal, uma vez que, deixa intocável a questão do mestiçamento, do meio físico, de nada adiantando aos espíritos indagadores ${ }^{225}$.

A situação mestiça do país, ao contrário do pensar de ensaístas como Euclides da Cunha e Nina Rodrigues, (que começaram a escrever depois dele), ao invés de ser um mal, era responsável pela singularidade brasileira, viabilizadora da identidade nacional, chave para a compreensão da história brasileira. Mesmo sendo parcialmente um teórico racista, defensor da raça superior, afirmando que a maior contribuição na sociedade brasileira foi do português, analisou de maneira minuciosa a influência das raças ditas inferiores, como indígenas e negras. ${ }^{226}$ Procurou explicar o Brasil indo muito além do critério racial, o que parece contradição em relação às bases raciais dos teóricos que o influenciaram, adentrando Sílvio os mais diversos e variados problemas nacionais objetivando subtrair a miséria mental e cultural do país para só então escrever sobre o verdadeiro Brasil. ${ }^{227}$ Nesse sentido, via a questão da mestiçagem muito além da influência biológica: para Sílvio, a formação da sociedade brasileira jamais desprezaria a contribuição dos grupos despossuídos, residentes nos sertões ou nas vilas mais recônditas do país. O comportamento das elites brasileiras e a cegueira destas, diante dos

\footnotetext{
${ }^{222}$ ROMERO, Sílvio. História da Literatura Brasileira. Rio de Janeiro: José Olímpio, 1960, p.338.

${ }^{223}$ ROMERO, Silvio. Op.cit. p, 1531.

${ }^{224}$ Ibidem. p. 61.

${ }^{225}$ Romero dedica no primeiro volume de sua História da Literatura Brasileira um capítulo sobre as Teorias da História do Brasil e retoma de forma detida essa discussão no quinto volume desta mesma obra. Cabe apenas mencionar que a questão do contato das três raças já estava esboçada pelo naturalista bávaro Martius, autor premiado pelo IHGB com a dissertação Como se deve escrever a história do Brasil.

${ }^{226}$ Ibidem. p, 120.

${ }^{227}$ SCHNEIDER, Alberto Luiz. Silvio Romero: hermeneuta do Brasil. São Paulo: Annablume, 2005. pp. 71-96.
} 
reais problemas nacionais, eram motivados não só pela questão de um caráter comunário, como também pelo desconhecimento das teorias oferecidas pela crítica naturalista, emanadas da Europa e dos Estados Unidos.

Foi Sílvio, como menciona Antônio Candido e Alcides Bezerra, um autor que acreditou nas Teorias e doutrinas da Ciência da época, mas seu tempo abrigava outras linhas de análise, certamente. Proclamou diversas vezes a primazia das idéias científicas sob a égide de um grupo de amigos surgido em torno da Faculdade de Direito do Recife, cuja figura mais conhecida é seu conterrâneo Tobias Barreto. Era Sílvio um dos mais significativos interessados em apontar os problemas nacionais brasileiros, um homem polêmico que nunca aceitou retratar um Brasil que considerava irreal na compreensão da formação da sociedade nacional.

\section{CHEIRANDO RAÇA!}

Vale de início ressaltar que o conceito de raça não possui sustentação científica, embora "raça é um grupo de indivíduos que podem ser reconhecidos como biologicamente diferentes de outros. Para que sejam "reconhecidos" em termos científicos, as diferenças entre a população que gostaríamos de designar como raça e as populações vizinhas precisam ser estaticamente significativas de acordo com algum critério definido. O limiar de significação estatística e arbitrário. A probabilidade de uma distância determinada atingi-lo aumenta com o número de indivíduos e genes testados” 228.

Antes de tentar um breve histórico do racismo à brasileira, cabe relevar alguns dados. Conceito negociado, a discussão em torno da idéia de raça é antes de tudo um debate que esconde relações de poderes respaldadas pelos argumentos "científicos" datados das três últimas décadas do Império brasileiro, devido à assimilação do pensamento racista europeu somado ao Liberalismo "democrático", mal disfarçado sob a veste nacionalista e bem encaixado com as necessidades do Brasil que passava por uma série de transformações. A tradição democrática no país data dos tempos das revoluções liberais, dos movimentos de libertação colonial do século XIX, que apelavam para os argumentos franceses de liberdade, igualdade e fraternidade, em nome de melhores condições de vida. $\mathrm{O}$ nacionalismo apaziguou as divergências de classes e de cor em nome de um ideal maior, regidos e orquestrados por senhores, fazendeiros de terra, comerciantes portugueses, etc, sem prescindir do trabalho escravo.

${ }^{228}$ CAVALLI-SFORZA, Luigi Luca. Genes, povos e línguas. São Paulo: Cia das Letras, 2003. pp. 44-45. Sobre a inconsistência do conceito de raça ver. GUIMARÂES, Antônio Sérgio Alfredo. Classes, raças e democracia. São Paulo: Editora 34, 2002. pp. 48-61. 
Sabemos que raça humana é um conceito inconsistente porque não se sabe da existência de uma raça pura, da qual as demais seriam herdeiras, e com os avanços trazidos pela moderna Biologia, a partir de áreas como a Genética das Populações assim como os estudos da Antropologia, provou-se que são as relações entre os seres em suas respectivas culturas que acabam determinando a permanência ou não de caracteres morfológicos responsáveis pela variação da espécie.

No Brasil naquele momento, presenciava-se toda uma preocupação em torno da questão racial. Ganhava corpo o campo disciplinar da Antropologia Física, especialmente na renomada Faculdade de Medicina da Bahia, onde figuraria o médico maranhense Raimundo de Nina Rodrigues. Em 1876, surge em conexão com o Museu Nacional o laboratório de Fisiologia experimental. Ladislau Neto, primeiro diretor do museu, havia organizado já em 1882 a exposição Antropologia Brasileira. Em 1885, surgia o Museu Paraense, fundado pelo suíço Emílio Goeldi. Em 1876, era reorganizado no Rio de Janeiro o que seria a maior referência do país em relação à Antropologia, o Museu Nacional, sob a direção de João Batista de Lacerda.

Mas, referência singular seriam os estudos de Antropologia Física envolvendo o nome do maranhense Raimundo da Nina Rodrigues. Seus trabalhos acerca da mestiçagem e sobre a religião dos africanos mostram bem o quadro do momento, evidenciando o medo da elite intelectual brasileira com relação à degeneração devida o cruzamento do branco com a raça inferior. Convicto na degeneração do mestiço, Rodrigues atribuía diversas síndromes, como a mielite, a epilepsia, a vesânia, a “impulsividade criminal”, práticas como as do alcolismo, do jogo, ao caráter mestiço, este um desequilibrado mental psicologicamente inferior ao branco, de modo que "A degenerescência das populações mestiças se constitui, sem dúvida, num fenômeno muito complexo que não podemos reduzir a manifestações mórbidas fatais ou irremissíveis. Proteiforme, ela pode bem tomar formas que vão desde brilhantes manifestações de inteligência, como entre os degenerados superiores, passando por uma média de capacidade social de tipo inferior, mal tocada por tendências degenerativas, que tomarão corpo mais e mais nas gerações futuras, até as manifestações estridentes da degenerescência enfermidade, nas quais os estigmas se impõem pelo franco desequilíbrio mental ou sob a forma impressionante de monstruosidades físicas repugnantes". 229

${ }^{229}$ RODRIGUES, Nina. Mestiçagem, degenerescência e crime. Archives d'Anthropologie Criminelle de 1899. O exemplar usado para esta tradução, cópia do existente na Faculdade de Medicina da Bahia, trazia uma dedicatória em francês, manuscrita, para Alfredo Britto, na qual só é legível a palavra amitié, assinada por Nina Rodrigues, com a data de 10 de janeiro de 1900. Abaixo, a informação sobre a editora: Lyon: A.. Storck \& Cie, Imprimeurs Éditeurs. Tradução de Mariza Correa. Nina Rodrigues sofreu forte influência dos modelos deterministas e evolucionistas de seu tempo, seguindo diretamente os preceitos da Escola Criminalista Italiana fundada por Lombroso. A admiração pelos escritores desta escola estar presente nos agradecimentos de sua maior obra. Em Raças Humanas e a responsabilidade penal no Brasil, Rodrigues dedica o livro a Lombroso, Garofalo, Ferri, Lacassagne e Corre. Fundador da Antropologia Criminal, o médico e professor de medicina legal da Faculdade de Medicina da Bahia associava de maneira determinista o crime a inferioridade da raça que quando em contato com a raça superior se degenerava. Citando os mais importantes escritores, estes em grande parte 
Nina Rodrigues fora fortemente influenciado pela escola italiana de Criminologia, onde figuravam os nomes de Lombroso e Broca ${ }^{230}$, que associavam comportamentos e certos valores morais a raça, "entre seus muitos textos (contei 65 artigos na sua bibliografia, ainda não completamente estabelecida, e seis livros), quatro são artigos que ele e seus herdeiros intelectuais deixaram em francês - certamente não por acaso, todos dizem respeito à influência da raça na degeneração do povo brasileiro, o mesmo assunto que predomina nos seus dois livros póstumos - ou três, se contarmos que o Animismo foi editado apenas em francês durante sua vida”. ${ }^{231}$ Conforme suas análises, a raça falaria mais que qualquer outro elemento, chegando a determinar o criminoso antes do crime em função da lei atávica, como por exemplo, a delinqüência, a indolência, a bruteza, a perversão, a epilepsia, responsável pelo lado imoral a que tinha chegado o ser humano na escala evolutiva.

Já dizia Joaquim Nabuco, político, ensaísta e importante líder abolicionista: "Se, multiplicandose a raça negra sem nenhum dos seus cruzamentos, se multiplicasse a raça branca por outro lado mais rapidamente, como nos Estados Unidos, o problema das raças seria outro, muito diverso-talvez mais serio, e quem sabe se solúvel somente pela expulsão da mais fraca e inferior por incompatíveis uma com a outra ; mas não se deu isso no Brazil. As duas raças misturáram-se e confundiram-se; as combinações as mais variadas dos elementos de cada uma tiveram logar, e a esses juntáram-se os de uma terceira, a dos aborígenes. Das três principaes correntes de sangue que se confundiram nas nossas veias, o Portuguez, o Africano e o Indígena, a escravidão viciou sobre tudo os dois primeiros. Temos ahi um primeiro effeito sobre a população: o cruzamento dos caracteres da raça negra com os da branca, taes como se apresentam na escravidão ; a mistura da degradação servil de uma com a imperiosidade brutal da outra", 232.

Embora o conceito de raça tenha marcado uma era de avanços técnicos e se tornado o parâmetro de análise para avaliar o grau de avanço ou de atraso de determinadas sociedades, tal terminologia trata-se apenas de uma categoria abstrata, mas que atua sobre categorias reais. É por se tratar de uma categoria abstrata, atuante nas relações humanas que se faz necessário investigar o racismo moderno

defendiam que a mestiçagem levava a degeneração. Nina Rodrigues estudou a população de Serrinha, município da Bahia, que possuía de 10 a 12 mil habitantes, localidade já analisada por Agassiz. Sobre a importância da mestiçagem nos dicursos sobre a identidade nacional consultar. BARROS FILHO, José. Indo a Nina Rodrigues: as "premissas" de As raças humanas e a responsabilidade penal no Brasil. Caderno Pós Ciências Sociais - São Luis, v.2, n.4, Julho/ dezembro. 2005. COSTA, Sérgio. A mestiçagem e seus contrários - etnicidade e nacionalidade no Brasil contemporâneo. Tempo Social. Revista de Sociologia, USP, São Paulo, 13 (1): 143-158, maio de 2001. DANTAS, Carolina Vianna. O Brasil café com leite: história, folclore, mestiçagem e identidade nacional em periódicos. Rio de Janeiro, 1903-1914. Tese defendida em 2007, no Programa de Pós-Graduação em História da UFF.

${ }^{230}$ DARMOM, Pierre. Médicos e assassinos na bélle epoque: a medicalização do crime. Rio de Janeiro, Paz e Terra, 1991.

${ }^{231}$ CORREA, Mariza. Raimundo Nina Rodrigues e "garantia da ordem social. REVISTA USP, São Paulo, n.68, p. 130139, dezembro/fevereiro 2005-2006. p. 37

${ }^{232}$ NABUCO, Joaquim. O abolicionismo. London Abraham Kingdon, 1883. pp. 137-138 
${ }^{233}$ no Brasil, iniciado com a geração de Sílvio. Raça, em nosso país, assumiu um papel da mais alta importância porque falar dessa questão aqui requer que compreendamos o que acontecia e dava sentido a esta tal categoria classificatória e explicativa. Se existia uma teoria que advogava a superioridade de uma raça em detrimento de outras, isto era somente parte de toda uma ordem de coisa. O substrato que dava sentido à raça no Brasil era de ordem totalmente política e econômica. Antônio Sérgio Guimarães é bastante claro quando afirma que, “O racismo brasileiro, entretanto, não deve ser lido apenas como reação à igualdade legal entre cidadãos formais, que se instalava com o fim da escravidão; foi também o modo como as elites intelectuais, principalmente aquelas localizadas em Salvador e Recife, reagiam às desigualdades regionais crescentes que se avolumavam entre o Norte e o Sul do país, em decorrência da decadência do açúcar e da prosperidade trazida pelo café. Quem não se lembra do temor de Nina Rodrigues ao ver se desenvolver no Sul uma nação branca, enquanto a mestiçagem campeava no Norte?", 234

Conclui o sociólogo que, "O racismo duro da Escola de Medicina da Bahia e da Escola de Direito do Recife, entrincheirado nos estudos de medicina legal, da criminalidade e das deficiências físicas e mentais, evoluiu, principalmente no Rio de Janeiro e em São Paulo, em direção a doutrinas menos pessimistas que desaguaram em diferentes versões do "embranquecimento", subsidiando desde as políticas de imigração, que pretendiam a substituição pura e simples da mão-de-obra negra por imigrantes europeus, até as teorias de miscigenação que pregavam a lenta mais contínua fixação pela população brasileira de caracteres mentais, somáticos, psicológicos e culturais da raça branca, tais como podem ser encontrados em escritos de Batista Lacerda (1911) e Roquette Pinto (1933). Foi também no Sul, centro da vida econômica e política, que as campanhas de sanitarização $e$ higienização públicas ganharam vigência, forçando a amenização das teorias eugenistas em versões que privilegiavam as ações de saúde pública e de educação, em detrimento de políticas médicas de controle da reprodução humana e dos casamentos". 235

A visão de Antônio Sergio é de total relevância para sabermos que ainda que vários fossem os autores elencados na interpretação brasileira, originando daí diversas interpretações, de uma forma ou de outra a tônica racial integrava o novo olhar sobre o Brasil do futuro processado pelos homens de letras e de ciência. Mas o que é há de mais relevante frente às vertentes ideológicas e correntes de idéias é que o racismo assimilado pelos bacharéis formados nas faculdades de Recife e de São Paulo tendeu a ter como objetivo maior legitimar as desigualdades sociais - quer fossem de ordem regional ou nacional. Tratava-se de uma pequena elite europeizada e detentora de um capital suficiente para

${ }^{233}$ GUIMARÃES, Antonio Sergio Alfredo. Preconceito de cor e anacronismo no Brasil. Revista de Antropologia, São Paulo, USP, 2004, v.47, na. 1.

${ }^{234}$ Ibidem. p. 11

${ }^{235}$ Ibidem. pp. 11-12 
temer as massas, sendo indispensável o surgimento da categoria racial que avistava dois Brasis: o do passado e o do futuro. Essa elite de bacharéis e médicos foi formada sob a novidade naturalista de anular as "diferenças" no plano social, político e econômico, remetendo a "diferença" que existia no plano racial, uma diferença que só justificava simultaneamente as desigualdades sociais e o atraso do país. Essa era a pedra angular que servia de termômetro para avaliar a situação do Brasil. Sobre esta elite Ventura afirma que "os letrados se mostravam divididos entre a valorização dos aspectos originais do povo brasileiro e a meta de se construir uma sociedade branca de molde europeu. Adotavam teorias sobre a inferioridade das raças não brancas e as culturas não-européias, ao mesmo tempo que buscavam as raízes das identidades brasileiras em manifestações compósitas e mestiças. Observado por viajantes estrangeiros, analisado com ceticismo por cientistas europeus e norteamericanos, temido por boa parte das elites locais, o cruzamento de raças era tomado como pista para explicar a possivel inviabilidade do Brasil como nação”. ${ }^{236}$

É bem verdade que múltiplas foram as leituras realizadas por médicos e bacharéis, o que impede afirmarmos que só existira o fator racial como categoria de análise para o Brasil que se queria, mas é fora de dúvida a quase sacralização em torno do conceito de raça nos meios acadêmicos da época. Ainda que outras correntes adentrassem estes espaços, "No entanto, no caso das escolas de direito, se existiam concepções partilhadas, a amarra institucional não chegou a encobrir diferenças teóricas fundamentais: o argumento racial construído por Recife, contrastou com a interpretação liberal da academia paulista. De fato, partiam de Recife as leituras germânicas sobre as determinações das raças e a defesa - que consagrou a figura de Silvio Romero - de uma mestiçagem moral e física, enquanto recurso de unidade nacional. Já a escola paulista analisava com cautela a introdução dos modelos darwinistas sociais, com " a critica de quem reconhece a verdade de alguns conceito e repele os exageros desses júris consultos..." 237

Buscando eliminar diferenças, o conceito de raça ao mesmo tempo em que servia para excluir índios, negros e mestiços, considerados raças inferiores, serviria também para criar a idéia de homogeneidade a partir da nação brasileira. Foi a tão sonhada corrida em busca do caráter nacional brasileiro que instigou escritores como Sílvio, Euclides da Cunha, Nina Rodrigues e tantos outros homens da época, cada qual com sua singularidade - de forma nuançada em cada um, todavia. No plano genético não tinha consistência alguma a idéia de uma raça única, ainda que se saiba numa dada população da existência de traços em comum. Nessa perspectiva, o que sustenta o sentido de raça são os genes. De forma sumária, a identificação pelos genes mostrou-se inviável, dado não ser possível

\footnotetext{
${ }^{236}$ VENTURA, Roberto. Um Brasil mestiço: raça e cultura na passagem da monarquia a república. São Paulo: SENAC, 2000. pp. 331-332.

${ }^{237}$ SCWARCZ, Lilia Moritz. Espetáculo da miscigenação. Estudos Avançados, São Paulo, vol.8, janeiro/abril, nº. 20, 1994. pp. 141-142
} 
partirem as diversas raças de uma raça única, tanto devido às migrações desde a chamada "PréHistória" como em função das prováveis mutações surgidas numa dada população.

Mesmo que raça não ultrapasse a condição de uma idéia vaga, existiram tentativas classificatórias que perduraram até o final do século XIX e mesmo depois, como se observa no racismo do século XIX - Nazismo, Apartheids e mesmo depois, como se observa nos racismos do século XX. Darwin havia chamado atenção da questão de que a continuidade geográfica impedia qualquer possibilidade de classificação das raças. É somente na modernidade, como desdobramento do conjunto de transformações ocorridas em decorrência da Revolução Industrial, sob a égide maior do liberalismo que veremos o advento das Teorias raciais, das diferenças entre o gênero humano.

Em 1864, o francês François Bernier utilizava o conceito de raça para diferenciar as classes sociais, (no caso, a nobreza, fosse esta de possível origem franca ou germânica), com relação à plebe. Surgida num momento de expansão industrial, onde se presenciava a ideologia maior do liberalismo, tanto no plano político como econômico, enfrentando os antigos resquícios feudais, no contexto da Revolução Francesa, a questão racial veio à tona para dividir grupos e assim atribuir o estatuto de superioridade e inferioridade no gênero humano.

$\mathrm{O}$ século XV trouxe não apenas o empreendimento das grandes navegações, concomitante a formação dos Estados nacionais modernos europeus, indissociáveis da exploração das respectivas colônias, expandindo a dimensão do globo quando ainda pairava dúvidas sobre a circularidade da terra, como punha em dúvida a capacidade dos povos "selvagens" que habitavam abaixo da linha dos trópicos. Não bastasse a exploração do Novo Mundo num momento em que as grandes nações européias buscavam fundar colônias, objetivando obtenção de matérias prima, ao mesmo tempo em que aspiravam que estas colônias consumissem seus produtos manufaturados as diferenças humanas são postas em cheque sempre a partir da visão eurocêntrica. Nesse mesmo contexto, entre 1550 e 1551, presenciaríamos o conhecido debate entre dois padres. De um lado, o Frei Juan Ginés Sepúlveda argumentava que a distância que separava um espanhol de um índio era a mesma que separava um homem de um macaco, numa clara apologia a superioridade do conquistador. Já o dominicano Las Casas substituía o índio pelo negro, mas não derrubava a diferença apontada por Sepúlveda ${ }^{238}$. O conquistador europeu via os povos americanos a partir de seu mundo, impossibilitando qualquer visão das diferenças quando o objetivo central era a busca por novas riquezas donde a idéia de escravidão por natureza era mera conseqüência da sua visão mercantil.

A “descoberta” da América só reforçou a idéia não apenas da existência de povos diferentes, de seres humanos bestiais, equivalência direta de inferioridade quando comparados ao homem europeu,

${ }^{238}$ TODOROV, Tzvetan. A conquista da América: a questão do outro. São Paulo: Martins Fontes, 1996. IANNI, Otávio. Dialética das relações raiciais 18 (50), 2004. 
como sedimentou a associação de que o fator racial explicava a vida que os povos do Novo Mundo levavam sem as menores regras ou padrões. Ainda não se tinha uma teoria para o racismo, embora o fator raça continuasse servindo como critério de avaliação para os diferentes povos em suas respectivas culturas. A sede pela classificação como nos lembra Levi Strauss, seguido pela busca das categorias segundo Hodgen, teve significativos avanços científicos e a celebração de nomes importantes sem os quais jamais teriam sido possíveis tempos depois a cristalização das teorias raciais. Tentativas foram realizadas por naturalistas como Buffon e Lineu buscando localizar e situar a espécie humana na grande cadeia do ser, mas só ficou claro a impossibilidades de uma classificação do gênero humano em torno do conceito de raça. Afirma Cavalli-Sforza que, "propor uma classificação mais aperfeiçoada só pode redundar em fracasso. Basta observar as variações entre grupos étnicos para nos convencer disso". 239

É no momento de expansão dos mercados europeus que o homem "civilizado" em seu avançado estágio cultural buscou legitimar sua superioridade em detrimento de seres bestiais que habitavam um paraíso terreal. Na verdade tratava-se de uma visão que se arrastava desde a Idade Média e que remontava aos tempos bíblicos, mas que ainda não era formulada como teoria científica. Por isto, "pode-se assim dizer que bestiários e mapas-mundi respondiam à exigência taxionômica de produzir uma série progressiva de "seres" intermédios entre o humano-cristão e a alteridade absoluta". 240

Neste cenário nos lembra Munanga, "Eles recolocam em debate a questão de saber que eram esses outros, recém descobertos. Assim laçam mão do conceito de raça já existente nas ciências naturais para nomear esses outros que se integram à antiga humanidade como raças diferentes, abrindo o caminho ao nascimento de uma nova disciplina chamada História Natural da Humanidade, transformada mais tarde em Biologia e Antropologia Física", ${ }^{241}$

Até o século XVII as diferenças humanas eram respaldadas pela autoridade da teologia e das escrituras. A Península Ibérica se mostrou um cenário por excelência durante os séculos XVI e XVII, quando da expansão ultramarina no momento em que o conquistador europeu constrói a visão de inferioridade por parte dos seres não brancos, povos bestiais que viviam em estágio de inocência, numa civilização que ainda dormia, no bojo maior na avaliação das “diferenças”. O Século das Luzes, momento áureo da filosofia racionalista que vinha se processando desde Bacon, Kepler e Descartes, careceu de uma teoria das diferenças. Junto à necessidade e a realização de uma nova maneira de conceber o processo histórico, não mais concebido a partir de toda a tradição cristão de uma história

${ }^{239}$ CAVALLI-SFORZA, Luigi Luca. Genes, povos e línguas. São Paulo: Companhia das Letras, 2003.p. 49

${ }^{240}$ MAZZOLENI, Gilberto. O Planeta Cultural: Para uma Antropologia Histórica. São Paulo: EDUSP, 1992. p.25

${ }^{241}$ MUNANGA, Kabengelê. Uma abordagem conceitual das noções de raça, racismo e etnia. Uma abordagem conceitual das noções de raça, racismo, identidade e etnia. Palestra proferida no $3^{\circ}$ Seminário Nacional Relações Raciais e EducaçãoPENESB-RJ, 05/11/03. p.2. Do mesmo autor. Algumas considerações sobre "raça", ação afirmativa e identidade negra no Brasil: fundamentos antropológicos. Revista USP, São Paulo, nº 68, p. 46-57, dezembro/fevereiro 2005-2006. 
cíclica e teleológica ${ }^{242}$, com um fim já anunciado, se processando de maneira cumulativa e linear, o descobrimento do Novo Mundo impactou o homem europeu curioso sobre a vida dos selvagens habitados abaixo da linha dos trópicos, daí que "as classificações produzidas com base nessa realidade tinham como critérios essenciais o fenótipo, a suposta ausência de linguagem (ou de inteligência), o comportamento selvagem e a ausência de religião". ${ }^{243}$

Uma vez que a quantidade de raças era muito grande fazia-se necessário a mania classificatória! Nesse âmbito era questão de tempo ver as implicações de ordem classificatórias, antes restritas ao campo da ciência natural, servirem de argumentação na legitimação das mais díspares questões políticas, como por exemplo, conferir legitimidade a determinados grupos políticos em seus respectivos estados, fenômeno característico do nacionalismo a-nacional europeu a partir de 1870. Das grandes sínteses classificatórias tentadas pelos grandes naturalistas aos estudos de Antropologia Física de Broca medindo crânios, fronte, e extremidade das mãos, seria só uma questão de tempo. A instrumentalização do conceito de raça se dava logicamente porque era seguida de sua operacionalização, mas para isso cabia a ciência alimentar sua própria conceituação ou até mesmo investir na certeza de que raça explicava a "capacidade" do ser humano.

No século XIX presenciaremos sob a formação de campos já definidos como a Antropologia Física e a Biologia, a existência de uma teoria racial, dada à existência de fatores que comprovavam a completa vinculação com a raça, como por exemplo, a capacidade de determinadas sociedades de se comportarem com as normas civilizadas européias, ou a vinculação do crime, da violência, da perversão, ligadas a raça. Aqui aparecia a influência de Broca, Ferri e Lombroso respaldando os estudos desenvolvidos nas faculdades de medicina e nos institutos legais, tornando célebre a figura de Raimundo de Nina Rodrigues. Fatores como o tamanho do nariz, dos lábios, o formato do nariz, o ângulo facial, punha fora de dúvida o racismo como teoria científica. Pairava a idéia de que seres de crânios alongados (dolicocéfalos), especificamente, nórdicos e saxões, seriam seres superiores quando comparados aos de crânios pequenos e arredondados (braquicéfalos), típicos da raça amarela e negra, considerados inferiores na escala evolutiva, como pensava Sílvio Romero.

No século XX, sob as bases da Genética Humana chegou-se à conclusão de que o conceito de raça nem explicava possíveis diferenças e nem fundava a idéia de caráter, o que acreditavam todos os ensaístas brasileiros da segunda metade do século XIX. Pelo contrário, as diferenças entre seres da mesma "raça" podem ser ainda maiores do que o que se pensa entre seres do mesmo grupo de pessoas.

\footnotetext{
242 Sobre a concepção cíclica e teleológica da história Ver. Campinas: LE GOFF, Jacques. História e Memória. Universidade de Campinas, 1990. Ainda. BODEI, Remo. A história tem um sentido? Tradução de Reginaldo Di Piero. SP/Bauru: Edusc, 2001.

${ }^{243}$ SEYFERTH, Giralda. O beneplácito da Desigualdade: breve digressão sobre o racismo. In: Racismo no Brasil. São Paulo: Petrópolis; Abong, 2002.
} 
Apesar dos avanços científicos, o prejuízo maior não foi por conta da classificação, de onde o conceito de raça tem estreita relação, mas sim a associação que até hoje se faz entre raça e cultura. Nesse sentido, Munanga reflete nossa idéia quando afirma que, "O maior problema não está nem na classificação como tal, nem na inoperacionalidade científica do conceito de raça. Se os naturalistas dos séculos XVIII-XIX tivessem limitado seus trabalhos somente à classificação dos grupos humanos em função das características físicas, eles não teriam certamente causado nenhum problema à humanidade. Suas classificações teriam sido mantidas ou rejeitadas como sempre aconteceu na história do conhecimento científico. Infelizmente, desde o início, eles se deram o direito de hierarquizar, isto é, de estabelecer uma escala de valores entre as chamadas raças. O fizeram erigindo uma relação intrínseca entre o biológico (cor da pele, traços morfológicos) e as qualidades psicológicas, morais, intelectuais e culturais. Assim, os indivíduos da raça "branca”, foram decretados coletivamente superiores aos da raça "negra" e "amarela", em função de suas características físicas hereditárias, tais como a cor clara da pele, o formato do crânio (dolicocefalia), a forma dos lábios, do nariz, do queixo, etc. que segundo pensavam, os tornam mais bonitos, mais inteligentes, mais honestos, mais inventivos, etc. e conseqüentemente mais aptos para dirigir e dominar as outras raças, principalmente a negra mais escura de todas e conseqüentemente considerada como a mais estúpida, mais emocional, menos honesta, menos inteligente e, portanto a mais sujeita à escravidão e a todas as formas de dominação". 244

Para Roberto DaMatta, "esse uso diferenciador das diferenças quando elas são conscientemente elaboradas objetivando um rendimento político é que acaba produzindo uma "teoria da diferença" que, no caso do mundo ocidental, ficou muitas vezes revestida de uma capa de respeitabilidade científica. É essa história que desejamos abordar aqui, já que ela está ligada intrinsecamente ao desenvolvimento da sociedade européia a partir dos séculos XV e XVI. Mas se tais desenvolvimentos tem um claro aspecto ideológico, justificando a superioridade do explorador e colonizador europeu, eles também revelam - como prova a existência das Ciências Sociais e da Antropologia - tendências contraditórias, pois que carregam consigo motivações que objetivavam manter desigualdades, tanto quanto impulsos libertadores, nascidos dos ideais igualitários que, paradoxal e dialeticamente, surgem nesta mesma Europa aristocrática e hierarquizada. É esse impulso igualitário que acabará permitindo o nascimento das modernas doutrinas de igualdade e fraternidade entre os povos, criando a vertente de nossa disciplina como um domínio especial onde podemos realizar uma importante reflexão sobre nós mesmos através do estudo dos outros. " 245

\footnotetext{
${ }^{244}$ MUNANGA, Kabengelê. Uma abordagem conceitual... Op. Cit. p. 5

${ }^{245}$ DAMATTA, Roberto. Relativizando: uma introdução à antropologia social. Rio de Janeiro: Rocco, 1987.p.88
} 
Hoje sabemos que as teorias raciais foram instrumentalizadas e nasceram no bojo de um projeto totalitário que inicialmente tinha como meta dar conta das "diferenças". Ao longo do processo, o que era diferente tornou-se por meio dos foros "científicos" inferior, o que já caracterizava o racismo de fato. Ao longo do amplo e tortuoso caminho ideológico do racismo, e por sua vez, do preconceito racial, criou-se o mito que não existe racismo no Brasil, mascarando a realidade enquanto tal e apagando da memória o etnocídio das comunidades negras e as atrocidades cometidas desde a chegada do colonizador as populações indígenas. Racismo este que continuou vivo após a abolição e que não ofereceu as mínimas condições ao ex-escravo de se tornar cidadão. As teorias raciais tanto no Brasil como na Europa guardam uma íntima relação com o poder.

A visão das "diferenças" sempre partiu do homem branco de cultura européia, criador do racismo, pronto para servir de instrumento na exploração desse ou daquele povo, em busca de riquezas naturais ou minerais, dizimando vítimas consideradas inferiores tanto no plano biológico como no plano da cultura. Se os avanços do capitalismo mostraram ao mundo ser possível ligar partes jamais pensadas, trouxe seus paradoxos, e a principal delas: a desigualdade entre as camadas sociais. Mas este expansionismo desenfreado, puxado pela produção em grande escala esteada sob a vertente maior do liberalismo, trouxe seus protestos como o Socialismo, o Anarquismo e o Comunismo. Num momento em que expandir era a palavra de ordem transcendendo toda e qualquer possível ação filantrópica, a sede de acumular riquezas por parte das metrópoles com relação a suas colônias se mostrou cada vez maior. Não é de assustar que o conceito chave da biologia, no caso, o de luta pela vida, tenha animado as ciências sociais e marcado o início da sociologia no Brasil, legitimando infelizmente as mais hediondas práticas políticas e científicas. Se como escreve José Paulo Paes, “o pensamento dos séculos XVII e XVIII teve na mecânica, como se sabe,o seu modelo epistemológico por excelência. Já o século XIX, sem abrir mão inteiramente da causalidade mecanicista, voltou-se de preferência para outro modelo de explicação do mundo: o biológico”, ${ }^{246}$ as bases teóricas que fundamentaram o Evolucionismo Darwiniano - a Anatomia, a Embriologia, a Zoologia, a Botânica - agora fundamentavam outras disciplinas, de modo específico, a nascente sociologia que nasceu em torno da ordem e do progresso, e por que não afirmar como pensa Antonio Candido, sob a égide do evolucionismo.

A Modernidade implicou uma nova maneira de conceber as transformações dos mais variados ramos do conhecimento, da lingüística ao campo historiográfico, tudo decorrente dessas transformações que dava a esperança de que o conhecimento científico pudesse explicar os diversos campos do saber, uma vez que, “expressões de ordem e progresso sintetizam uma perspectiva de

${ }^{246}$ PAES, José Paulo. Canaã: o horizonte racial. Estudos Avançados, São Paulo, vol.5, nº 13, 1991. p. 161. 
interpretação da sociedade urbano-industrial, de classes, em sua formação e transformação. A idéia de progresso identifica-se com a da sociedade urbano-industrial, burguesa, capitalista. Sociedade essa vista como uma forma superior, aperfeiçoada, da história social. Aí, o estado deve ser forte, dirigente, para que as diversidades e desigualdades entre grupos, classes, regiões, nacionalidades, etc, não afetem a harmonia e o funcionamento do todo. O progresso econômico, industrial, capitalista, depende da ordem, harmonia, entre uns e outros. A ordem social é uma exigência dos interesses representados ou simbolizados no governo, regime, estado. Segundo essa orientação, nada melhor do que o estado forte para por a sociedade em ordem, conforme a religião da paz social." 247

Se antes de todos estes efeitos causados pelas grandes transformações sob todos os ângulos e nos mais variados aspectos refletiam o que foi conhecido como o século da biologia, daqui para frente não era descabível falar em progresso para explicar as transformações sociais. Agora, a tônica era tentar explicar todo o processo social tendo por base um princípio, que no caso, era tributário do campo das ciências naturais. Bem lembra Francisco Iglesias "que o reflexo da obra de Darwin não se resumiria à sua ciência, pois marcou ainda outras. Assiste-se, nas últimas décadas do século, ao processo de biologização da ciência social, aceitando-se as similitudes da sociedade com outros organismos. $O$ organicismo teve voga e exprimiu-se em vários autores, marcando uma das orientações da época. Acontece, no entanto, que a extrapolação da idéia de luta e evolução para esse plano social não foi feita por Darwin, mas por outros, que não se contiveram nos limites da prudência”. ${ }^{248}$

Afrânio Coutinho tem posicionamento semelhante quando afirma, "que a idéia de evolução espalhou-se largamente como a maior e a mais sedutora das crenças românticas. É o novo ideal científico, a noção revolucionária do século, cuja presença é constante na sua vida intelectual e nas crenças dos homens. A sociedade for encarada, sob o influxo da biologia, como um organismo composto de células em funcionamento harmônico e obedecendo as leis biológicas de crescimento e morte. Ao interesse pela história do passado, pela tradição, característico do romantismo, acrescentaram-se a atitude biológica e o método evolucionista, a idéia de mudança e desenvolvimento contínuo, de evolução e progresso. "249

É no campo das ciências naturais que vamos encontrar a definição do termo raça, o que por si só não elucida o sentido da instrumentalização do conceito num determinado momento da história, legitimando os mais trágicos e as mais autoritárias práticas políticas. Não sendo nossa preocupação traçar ou esboçar uma história das teorias raciais, até mesmo por falta de estudos, nos cabe chamar atenção para o momento em que sob a bandeira do expansionismo europeu, e mais tarde, do

\footnotetext{
${ }^{247}$ IANNI, Octávio. A Sociologia e o mundo moderno. Op.Cit.p.16.

${ }^{248}$ IGLESIAS, Francisco. História e Ideologia. 2a ${ }^{\text {a }}$ Ed. São Paulo: Perspectiva, 1981. pp.97-98

${ }^{249}$ COUTINHO, Afrânio. Introdução à literatura no Brasil. 16a ${ }^{\text {a }}$ Ed. Rio de Janeiro: Bertrand Brasil, 1995.p. 183
} 
imperialismo, o conceito de raça seguido de sua instrumentalização se mostrou fora de dúvidas. É na época dos nacionalismos onde se presencia de modo desenfreado a expansão dos mercados que o elemento étnico, apenas um dos elementos arregimentado pelo Estado para prover sua nacionalidade, que as argumentações em torno da raça ganham sua maior força. De maneira contraditória é na era dos nacionalismos que o racismo surge de maneira explícita. Mesmo que o racismo se oponha ao nacionalismo, seja este qual for como sustenta Hobsbawm, e sabemos que outros elementos foram manipulados para dá unidade aos povos como a língua, uma tradição comum, um mesmo território compartilhado, foi no cenário europeu de expansão colonial que o traço étnico se descortinou.

Desse modo a preocupação com a raça é parte integrante das transformações ocorridas na Europa após 1830 que fez despertar o sentimento nacional em países que lutavam pela sua unificação. A questão nacional despertou em quase todos os países europeus um sentimento nacional em que a raça se tornou requisito indispensável. Com vários países lutando para tornarem-se estados nacionais na Europa, Hobsbawm pontua que, “o nacionalismo étnico recebeu reforços enormes; em termos práticos através da crescente e maciça migração geográfica; na teoria, pela transformação da "raça” em conceito central das ciências sociais do século XIX”. ${ }^{250}$

Embora não seja o nacionalismo o responsável pelo racismo "científico" foi com a expansão dos territórios que se presenciou a instrumentalização do conceito de raça, na medida em que o elemento língua não podia ser herdado, e por isto, não poderia servir de símbolo nacional. Assim, foi o conceito de raça que se construiu a "identidade nacional", uma vez que, pairava a idéia de pureza racial. Poderíamos arrolar diversos escritores para provar a manipulação do conceito de raça nos liames da História, que ficou cada vez mais evidente no momento de expansão dos mercados europeus quando do período expansionista. Segundo Antônio Olímpio de Sant'ana, “O século XIX foi o da consolidação das doutrinas racistas. Em 1815, as nações colonialistas - Inglaterra, França e Alemanha reuniram-se em Viena para repartir o mundo conhecido da época. Neste encontro nada se falou sobre o tráfico de escravos. O representante do Papa, presente ao encontro, calou-se para não prejudicar os países majoritariamente católicos e praticantes da escravidão negra”. ${ }^{251}$

A manipulação do conceito de raça gravitando em torno da busca por novos territórios era evidente, uma vez que, “interessava às grandes potências imperialistas européias o endosso da ciência a uma doutrina racista, pois dessa forma teriam uma justificativa para a anexação de outros territórios, a submissão e a exploração das suas populações, apontadas como inferiores. Neste sentido, algumas nações, como a Inglaterra, a França e a Alemanha, reestruturaram seu universo

\footnotetext{
${ }^{250}$ HOBSBAWM, Eric. p.131

${ }^{251}$ SANT'ANA, Antônio Olímpio. História e conceitos básicos sobre o racismo e seus derivados. Superando o racismo na escola. 2a . Ed. Revisada. Brasília: Ministério da Educação: Secretaria de Educação Continuada, Alfabetização e Diversidade, 2005. p. 47
} 
simbólico, acionando signos, idéias e valores que sugeriam a união, a força e a capacidade de vencer do povo e do regime". 252

Mas o século XIX sacramentou o racismo pelos foros científicos em decorrência dos avanços técnicos e científicos que argumentavam a diferença entre as raças. Vale lembrar que 1859 é ano de publicação da cartilha do evolucionismo, no caso, A Origem das Espécies. Hannah Arendt em Origens do Totalitarismo nos mostra não apenas a instrumentalização em torno do conceito de raça, sendo antes de qualquer teoria científica uma das maiores ideologias políticas, onde este caráter científico é secundário, como também nos lembra como se formou todo o pensamento racial antes do racismo. $\mathrm{O}$ que há de mais relevante segundo o estudo apontado é que a idéia de raça é apenas uma ideologia a serviço das práticas imperialistas e como tal, só existiu na medida em que justificou as necessidades expansionistas que confundiam interesses de uma minoria com as necessidades dos estados nacionais, que na verdade era somente interesse de uma pequena nobreza. E partiu dos nobres as argumentações repousadas sobre a noção de raça na busca por novos mercados, que de maneira ambígua não unificou nenhum dos povos, apenas permitiu práticas imperialistas levando o autoritarismo e morte aos vários lugares do mundo. A tão buscada consciência nacional não facultou a união entre os povos, trouxe simplesmente a revolta contra a espoliação e escravidão por parte dos povos subjugados.

Toda a prática imperialista bem confundida com as necessidades dos estados nacionais, manipulada por uma minoria em detrimento de todos os estratos sociais das supostas nações emergentes, mesmo pensadas como comunidade imaginada, serviu de arma política, revelando-se uma ideologia, uma vez afeita à vontade e a gana do poder. Como toda ideologia que se preze argumenta Arendt que, "a extraordinária força de persuasão decorrente das principais ideologias do nosso tempo não é acidental" ${ }^{253}$. Instrumentalizada por homens gananciosos de poder, a ideologia racista juntamente com a lei que dizia que a história regia-se pela luta de classes e pela lei que confere ao mais apto a sobrevivência do mais apto, mostrou sua força em todo o mundo ocidental. Foi no momento de definição dos estados nacionais que a ideologia racista emergiu com toda a força. $\mathrm{O}$ racismo ou o racista, de maneira ambígua, embora fosse instrumento para a constituição das nações foi um fenômeno a-nacional, tratando-se, pois dos "piores patriotas que os representantes de todas as ideologias internacionais; foram os únicos que negaram o princípio sobre o qual se constroem as organizações nacionais de povo - o princípio de todos os povos, garantido pela idéia de humanidade". 254

${ }^{252}$ CARNEIRO, Maria Luiza Tucci. O racismo na História do Brasil: mito e realidade. São Paulo: Ática, 1994.p. 20

${ }^{253}$ ARENDT, Hannah. Origens do Totalitarismo. São Paulo: Companhia das Letras, 2004. p. 189

${ }^{254}$ Ibidem. p. 191 
O interesse pela diversidade dos povos acompanhado pela visão bucólica de países europeus como França, Inglaterra, Alemanha, com relação ao desconhecido Novo Mundo, trouxe em seu bojo o princípio da própria destruição das diferenças culturais. Ao mesmo tempo em que a França alargava a possibilidade da existência de povos nos lugares jamais imaginados acompanhado pelo interesse de novas culturas, trazia consigo o princípio diferenciador, mas também excludente, que era a diferença a partir da raça. Foi à França que ofereceu ao mundo o típico modelo de revolução democrática com suas bandeiras tricolores como pontua Hobsbawm, primando pela soberania popular, alertando o mundo para os princípios de igualdade entre os povos e lutando pela instalação de formas de representação política que deixasse falar a voz do povo que surgiu o racismo. Se por um lado o ideário democrático emergiu na França com todo vigor, por outro não passava de aparência o contexto social e político francês, pois o contexto que colocou nobres contra a burguesia mostrou que aqueles se utilizaram apenas de um distintivo com relação à grande parte da população, no caso, o distintivo racial.

Não é estranho nem por puro acidente que o maior divulgador e concebido como o pai da doutrina racial seja apenas mais um dos nobres franceses porque foi na França que se verificou uma conjuntura política propícia a aclamação de nobres, herdeiros de uma raça superior, que se opunham a ascensão de uma incipiente burguesia que punha em risco a política daqueles. Instituidor do racismo, Gobineau deu ao racismo estatus científico. Como conde, o autor do Ensaio sobre a desigualdade das raças humanas, "já começou a vida desprezando duas coisas: a revolução e a burguesia” 255 . Ao contrário do que se pensa não foi na Alemanha que a ideologia surgiu, mas sim num país que a nobreza cada dia perdia prestigio político para a burguesia em ascensão.

Teoria de nobres como nos mostra Arendt, - Boulainvilliers, Charles François Dominique, Montloisier, Sieyès, - é curioso, paradigmático, e ao mesmo tempo revelador da instrumentalização que o conceito de raça veio a assumir. Ameaçada pela burguesia em ascensão, responsável pela empreitada imperialista, o conceito de raça justificava a supremacia de povos superiores em detrimento dos povos atrasados. Da conjuntura interna francesa a nobreza buscou sua descendência não com o povo francês, mas com os francos, de origem germânica diferente da plebe, "em que se consideravam de sangue puro, insinuando suas habilidades especiais e aptidões naturais para dirigir, administrar e dominar os Gauleses, que segundo pensavam, podiam até ser escravizados. Percebe-se como o conceito de raças "puras" foi transportado da Botânica e da Zoologia para legitimar as relações de dominação e de sujeição entre classes sociais (Nobreza e Plebe), sem que houvessem diferenças morfo-biológicas notáveis entre os indivíduos pertencentes a ambas as classes. ", 256

\footnotetext{
${ }^{255}$ HERMAN, Arthur. A idéia de decadência na história ocidental. Rio de Janeiro: Record, 1999.p.55

${ }^{256}$ MUNANGA, Kabengele. Uma abordagem conceitual das noções de raça, racismo, identidade e etnia. Op. Cit.
} 
Contrário ao "racismo" francês, o racismo alemão a serviço da nobreza equacionou-se com as necessidades da monarquia absoluta que com exceção das reformas prussianas não se receou a uma coligação entre as classes médias e com a monarquia. Desse modo, diferente da situação ocorrida na França, na Alemanha à ideologia da raça surge fora da nobreza provocando um nacionalismo estritamente baseado na língua e na raça. Conforme autores como Arendt, Hobsbawm, Gelner, dentre outros, os nacionalismos não são responsáveis pelas teorias raciais, pelo contrário, manipulam a idéia de raça visando tão somente o expansionismo, uma vez que outros podem ser os elementos fundantes desse ou daquele nacionalismo, no caso, uma herança comum, um idioma, um evento histórico, etc. Fundamento básico na constituição das nações, a ideologia racial foi operacionalizada conforme se processou a formação nacional, no que se estabeleceu o racismo propriamente dito. A Alemanha buscava por meio da definição orgânica e naturalista dos povos tendo como ponto de partida seu Historicismo sua formação como nação, o que não se tratava de nenhuma teoria racista, mas seria um traço diferenciador que serviu para escamotear as necessidades nacionais, no caso, a busca ou a necessidade de expandir seus mercados.

O Romantismo político ${ }^{257}$ que tornou possível, “inventar qualquer outra opinião irresponsável, desde que se queira” ${ }^{258}$ seria outra fonte do racismo alemão. Da mente de escritores românticos como Mueller, Schlegel, Novalis, etc, pode o povo ser confundido e facilmente transformado como necessidades do Estado, da família ou mesmo da nobreza. Os mais importantes nomes da ideologia racial tornaram-se importantes por nos permitir por às claras a manipulação política em torno da questão racial. Célebres escritores europeus, fossem poetas ou filósofos só nos faz lembrar que, “não existe ideologia a que não se submetam de bom grado, quando está em jogo a única realidade que nem mesmo um romântico poderia dar-se a luxo de ignorar: a realidade das posições pessoais. Para este tipo de conduta, o romantismo serviu de excelente pretexto em sua ilimitada idolatria da "personalidade” do indivíduo, cuja própria arbitrariedade era prova de gênio. Qualquer coisa que servisse à assim chamada produtividade do indivíduo, ou seja, ao jogo totalmente arbitrário de suas "idéias", podia tornar-se o centro de todo um modo de encarar a vida e o mundo". 259

Os intelectuais alemães de classe média, embora nunca tenham travado luta no campo político com a nobreza nem com outros setores da classe a que pertenciam enfrentaram uma batalha em benefício de sua classe social. Mesmo que a ideologia surgida na Alemanha seja diferente da ideologia francesa, estes intelectuais mesmo quando aplaudiam a nobreza sentiam-se ameaçados perante sua classe social de origem. Surgiu na Alemanha de então os fundamentos do racismo como a

\footnotetext{
${ }^{257}$ Para uma análise tipológica do romantismo Ver LOWY, Michel e SAYRE, Robert. Romantismo e Política. Rio de Janeiro: Paz e terra, 1993.

${ }^{258}$ ARENDT, Hannah. Op. Cit.p.197

${ }^{259}$ Ibidem. p. 198
} 
personalidade inata e a idéia de desenvolvimento orgânico, e logo escritores liberais vangloriavam-se de seu estatuto de nobreza em contraposição aos inferiores títulos de barão e quejandos. Ressalta Arendt que as raízes para o pensamento racista não devem ser procuradas na relação entre os Junker e os padrões da nobreza, mas sim no Conde de Gobineuau, "um nobre altamente talentoso e frustrado". 260

\section{3 - RACISMO À BRASILEIRA}

Se o contexto brasileiro era diferente do europeu, existia toda uma situação favorável para a utilização do conceito de raça porque era o Brasil um país formado por milhares de negros e mestiços, composto de raças e subraças que tanto incomodavam a elite política e intelectual do país. Como nos lembra Lilia Schwarcz, era o Brasil um verdadeiro paraíso racial, um espetáculo das raças que serviu muito bem de laboratório racial dada sua população de milhões de negros e mestiços, e outros milhares remanescentes de índios. Como se não bastasse à inadequação da cópia, a clássica discussão das idéias fora do lugar, que dava ao Brasil uma identidade pela falta ${ }^{261}$, as múltiplas leituras em torno do Evolucionismo ${ }^{262}$, fosse no Museu Nacional ou nas Faculdades de Medicina e Institutos Históricos e Geográficos, do Determinismo e do darwinismo social, os pesquisadores nacionais e brasileiros fizeram do país um verdadeiro laboratório racial. Não é por acaso que nesse momento, "raça é um dado científico e comparativo para os museus; transforma-se em fala oficial nos institutos históricos de finais do século; é um conceito que define a particularidade da nação para os homens de lei; um índice tenebroso na visão dos médicos. O que se percebe é como em determinados contextos reelaboram-se símbolos disponíveis dando-lhes um uso original. Se a diferença já existia, é nesse momento que é adjetivada”. ${ }^{263}$

Já Martius, em sua História, apontava a influência das raças por meio de suas forças diagonais, continuada por Varnhagem, combatida "cientificamente" por Sílvio Romero, a partir de sua sistematização racial espreitada por estudos etnográficos e folclóricos. Num país constituído em grande parte de mulatos, herdeiros diretos de negros africanos, o racismo era nublado pela idéia da inexistência de um apartheid racial como nos Estados Unidos, dando a impressão de que por aqui não existia desigualdade entre as raças. Nessa ótica, como outra era a situação brasileira, o negro de

\footnotetext{
${ }^{260}$ Ibidem. p.201

${ }^{261}$ SCWHARTZ, Lilia. Complexo de Zé Carioca: notas sobre uma identidade mestiça e malandra. Disponível: http://www.anpocs.org.br/portal/publicacoes/rbcs_00_29/rbcs29_03.

${ }^{262}$ GUALTIERI, Regina Cândida Ellero. O Evolucionismo na Produção Científica do Museu Nacional do Rio de Janeiro (1876-1915). In: DOMINGUES, Heloisa Maria Bertol (Org). A Recepção do Darwinismo no Brasil. Rio de Janeiro: Editora Fiocruz, 2003.

${ }^{263}$ SCHWARCZ, Lilia Moritz. O espetáculo das raças: cientistas, instituições e questão racial no Brasil, 1870-1930. São Paulo: Companhia das Letras, 1993.p.342
} 
origem nos Estados Unidos que muito dificilmente conseguiria ascender socialmente, por conta de sua origem racial, no Brasil, devido à ausência de um apartheid formal, surgia a sensação de uma democracia nesse campo. Democracia esta que em tese, segundo concepção dos escritores racistas da época, dava condições para a emancipação do negro, que primeiramente embranquecia para depois tornar-se um negro de alma branca. Desse modo, dada a não separação jurídica entre espaços estritos a negros e brancos no Brasil, possibilitando aos primeiros adentrarem o mundo dos brancos, inexistia no Brasil o preconceito de origem, mas sim preconceito de cor, instrumento sine qua non para sedimentar e cristalizar a idéia de democracia racial, ideologia que seria tenazmente combatida pelo grupo de escritores surgido em torno da Universidade de São Paulo especialmente em torno de Roger Bastide e Florestan Fernandes.

Antes das Teorias assimiladas pelos ensaístas brasileiros, pregadores da inferioridade cultural de negros e mestiços, o que predominava era uma visão romântica que mais chamava atenção para os aspectos naturais do Brasil do que algum estudo sobre os seres considerados inferiores, "não faltaram senhores benévolos e dedicados que tratavam seus escravos com humanidade, nem escravos que revelavam sua devoção, às vezes, de forma patética, mas a instituição escravista propiciava os excessos, os crimes, a espoliação de um grupo pelo outro. A idealização da escravidão, a idéia romântica da suavidade da escravidão no Brasil, o retrato da do escravo fiel e do senhor benevolente e amigo do escravo que acabaram por prevalecer na Literatura e na História foram alguns dos mitos forjados pela sociedade escravista na defesa do sistema que não julgava possível prescindir." 264

Não existia uma leitura realista baseada na especificidade do estudo do homem que veio momentos depois surgir sob o manto da Antropologia Física. Fazia-se necessário naturalizar as diferenças, "afinal, qual seria o futuro de um país evidentemente cruzado em sua conformação?”. 265 O discurso que colocava fora de dúvidas a inferioridade do Brasil simultaneamente trazia a idéia de suavidade por parte das relações raciais. Como existir racismo se o darwinismo social apregoava a superioridade do homem branco?

De maneira ambígua, foi devido à crença na superioridade da raça branca presente no desenrolar do processo da formação da cultura brasileira que resultou a idéia de que não existia racismo no Brasil. Ao longo deste processo, cronistas, viajantes e ensaístas contribuíram a sua maneira em busca do nacional, mesmo que a visão sobre o Brasil não incidisse de maneira clara sobre a raça, como viria a acontecer com a geração de Sílvio, num “momento em que são absorvidos os Determinismos científicos e todas as ideologias que o acompanham, adotam-se também ali as Teorias sobre o clima, o solo, a mestiçagem, idéias duradouras de grande trânsito no horizonte cultural e que teriam vida

${ }^{264}$ COSTA, Emília Viotti da. Da senzala à colônia. 4 ${ }^{a}$. Ed. São Paulo: Fundação da Editora da UNESP, 1998. p.335.

265 SCHAWARCZ, Lilia Moritz. Racismo no Brasil. São Paulo: Publifolha, 2001.p. 26 
longa no pensamento intelectual brasileiro, só vindo a ser questionadas radicalmente pelos modernistas na década de 1922". ${ }^{266}$

Esta vertente modernista de que fala Emília Viotti "suprimia" e transferia o olhar da raça para a cultura, trazendo em primeiro plano o regionalismo nordestino e a figura de Gilberto Freyre, discípulo e aluno de Franz Boas, se confrontando com o Modernismo paulista da paulicéia desvairada de Mário e Oswald de Andrade. O mito da democracia racial confundido com a própria figura de Freire era visto pela Crítica acadêmica como sendo a representação das decadentes oligarquias do nordeste, dentre estas, as de Pernambuco. De volta ao Brasil, após sua estadia nos Estados Unidos Freyre recordava ter visto "um bando de marinheiros nacionais - mulatos e cafuzos" ${ }^{267}$, no que arrematava o autor de Casa Grande e Senzala, “deram-me a impressão de caricaturas de homens”. ${ }^{268}$

Freire fala pelas decadentes oligarquias regionais nordestinas. "Casa Grande e Senzala foi a defesa de Freyre da miscigenação brasileira" ${ }^{269}$. Ele se propunha não apenas a responder às antigas doutrinas raciais e climáticas, que davam como certo o fracasso da colonização de países europeus nos trópicos, mas mostrar que o europeu - e de modo específico, o português - podia se aclimatar civilizadamente com a participação de negros, mulatos e índios, sem ter maiores choques culturais. Conforme Odália, "A afirmação tão peremptória de Gilberto Freyre sobre a existência de uma sociedade constituída no Brasil, isto quer dizer nos trópicos, é uma resposta direta aos cientistas europeus, como Lapouge, Buckle e tantos outros, que, no século XIX, não admitiam a possibilidade de terem sucesso as tentativas de constituição de sociedades estáveis nos trópicos; e indireta, a todos os cientistas brasileiros, antropólogos, sociólogos e, especialmente, historiadores, que ou concordavam com as opiniões expressas pelos cientistas europeus, ou tentando superá-las buscavam formas de ação política, através da atuação do Estado, visando constituir uma sociedade brasileira, de características européias, mas sempre como uma projeção futura, e não uma realidade atual”. 270

O nome de Freyre confunde-se com a idéia de democracia racial brasileira. Os conflitos raciais se diluíam frente à flexibilidade dos portugueses e à sexualidade da raça negra. Pensando que a questão não era de raça e sim de classe social, embora reconhecesse o sociólogo as disparidades e do preconceito racial no Brasil, "Freire quis demonstrar que houve uma solução brasileira para um acordo entre diferentes tipos de vivência, diferentes padrões culturais. No Brasil, teria havido um bem sucedido ajustamento para um profundo desajustamento. Freyre é um autor criativo, sensível ao

\footnotetext{
${ }^{266}$ Leituras brasileiras: itinerários no pensamento social e na Literatura. SANTOS, Maria Veloso Motta e MADEIRA, Maria Angélica. São Paulo: Paz e Terra, 1999.p.76.

${ }^{267}$ FRY, Peter. Política, nacionalidade e o significado de "raça" no Brasil. In: Brasil: fardo do passado, promessa do futuro. Dez ensaios sobre política e sociedade brasileira. Org. Leslie Bethell. Rio de Janeiro: Civilização Brasileira, 2012. p. 161.

${ }^{268}$ Ibidem. p. 161

${ }^{269}$ Ibidem. p. 161

${ }^{270}$ ODALIA, Nilo. Gilberto Freyre: uma interpretação etno-cultural do Brasil, 2001 (digitado). p. 26
} 
cheiro, à cor, ao ruído, ao amor e ao ódio, ao riso e ao choro. O passado colonial brasileiro é percebido com o seu cheiro e prazer de viver. Ele penetrou no seu tecido social e expressou o inconsciente da vida coletiva, a sua cotidianidade afetiva. Ele produziu uma radiografia do passado interno brasileiro, afirma Merquior". ${ }^{271}$

Se durante tanto tempo pairou o mito da democracia racial no Brasil, convencendo boa parte de escritores brasileiros, cabe-nos entender os porquês da crença compartilhada de que não existia racismo no Brasil. Isto nos leva a adentrar o mundo das Teorias raciais, sobretudo, a Teoria que advogava a superioridade do homem branco para compreender o Brasil da época, como fazem muitos trabalhos.

Sabemos que todo o arsenal teórico oferecido pelas Teorias raciais não foi aceito de maneira passiva, isso nos leva a inserir a questão racial no universo maior das relações sociais ao longo do desenvolvimento econômico, na Economia de base rural de um país dependente, o que caracteriza o Estado brasileiro patrimonialista, frente os países de capital independente. É nessa estrutura patrimonial que devemos entender as implicações da raça. Uma vez que era o senhor branco o mais prestigioso elemento dessa estrutura, o que restava aos milhares de escravos negros e brancos livres pobres eram pequenos cargos e desempenho de tarefas manuais indispensáveis à auto produção do sistema escravista. É nessa ótica que se realiza a leitura do grupo de intelectuais revisionistas que combatem a idéia de democracia racial brasileira que tem como expoente máximo Florestan Fernandes influenciado pelo pensamento de Roger Bastide, de quem foi assistente na FFLC/USP.

Numa análise minuciosa, Florestan Fernandes vê a sociedade brasileira como estamental, onde o predomínio do senhor, detentor do poder e responsável pela formação do Estado brasileiro, se exerce sobre mestiços e brancos livres a partir das necessidades da metrópole. Esmiuçando como se processaram as várias formas de dominação na sociedade estamental brasileira, partindo da concepção weberiana diante de uma colonização de exploração, quer o autor mostrar o caráter estamental da sociedade brasileira, o que implica uma sociedade que se processou sob a dependência. Como colônia, cabia ao Brasil ser fonte para acumulação primitiva de capital, o que caracterizou as Economias coloniais com relação a suas metrópoles. É dos dinamismos nas relações surgidas entre a colônia e metrópole, caracterizando o Estado nacional brasileiro, por sua vez, provocando relações hierárquicas que podemos entender a relação racial, pois "o ponto de apoio estrutural e dinâmico desse tirânico estilo de acomodação inter-étnica e inter-racial nascia da confluência e da conjugação de formas de repressão, de controle armado e de despotismo generalizado (forjadas e mantidas pela superposição de estamentos e castas), graças às quais uma rala minoria não só monopolizava socialmente todo o

\footnotetext{
${ }^{271}$ REIS, José Carlos. As identidades do Brasil: de Varnhagen a FHC. Rio de Janeiro: FGV, 2009. p.52
} 
poder, como o aplicava ao seu bel prazer. Essa monopolização permitia que, com relativa facilidade, as instituições-chave pusessem nas mãos dessa minoria, em qualquer momento e em qualquer nível das relações comunitárias e societárias, os meios necessários para defender a ordem, impedindo qualquer evolução explosiva da "anarquia reinante", do "rancor do escravismo" e dos possíveis atropelos da gente miúda branca e mestiça”. ${ }^{272}$

É a partir da sociedade estamental brasileira que Fernandes pensa a questão racial brasileira. Para Fernandes, o que dava a tônica era sempre o poder do senhor ou de uma minúscula elite branca. Exceções existiam, mas não eram a regra, raros foram casos de mulatos ou negros que chegaram a conhecer o mundo dos brancos, como Machado de Assis e André Rebouças. Isso porque, "excetuados os casos de exceção, a regra era ditada pelo esforço de preservar a estabilidade da ordem senhorial e escravocrata, bem como de fortalecer o seu padrão de equilíbrio racial e estamental. O que estava em jogo era a defesa num e crua do senhor e dos interesses senhoriais. E se alguma vez as autoridades coloniais ou a Coroa interferiram com o intuito de resguardar o escravo ou "os limites" da escravidão, o significado dessa interferência é patente: tratava-se de impedir que a transgressão da violência institucional média, pelos próprios senhores e por seus prepostos, se convertesse no fulcro de tensões raciais incontroláveis e de uma instabilidade que transcendesse o poder conjunto de autodefesa armada dos senhores, das autoridades coloniais e da Coroa", 273

Na mesma linha pensa Thomas Skidmore quando escreve que "essa hierarquia paternalista, na qual a hierarquia social estava altamente relacionada com a cor, desenvolveu-se como um aspecto inerente à Economia escravista colonial. Mas na época da abolição ela não dependia mais da escravidão para continuar existindo. Em que momento exato essa dependência desapareceu é uma questão que só pode ser respondida mediante uma análise profunda da História social brasileira. $O$ importante aqui é que a maioria dos plantadores brasileiros, especialmente os das prósperas regiões cafeeiras, entenderam que a abolição não significaria necessariamente uma ameaça à sua dominação social e econômica. Sua expectativa foi confirmada. Os escravos recém-libertados ingressaram numa estrutura social multirracial e paternalista que há muito ensinara aos homens de cor livres os hábitos da submissão no relacionamento com empregadores e superiores sociais em geral. É dentro deste contexto, denominado pré-industrial por Bastide, que as relações raciais se têm processado na maior parte do Brasil, na maioria do período posterior a abolição". ${ }^{274}$

A nostalgia de Sílvio, seu pessimismo, sua agonia, sua frustração - designações de Skdimore deviam-se à aceitação de índios, negros e mestiços, num Brasil arcaico diante do olhar de um extremo

\footnotetext{
${ }^{272}$ FERNANDES, Florestan. Circuito Fechado: quatro ensaios sobre o "poder institucional”. 2a . Ed. São Paulo: Hucitec, 1977. p. 38

${ }^{273}$ Ibidem. p.41.

${ }^{274}$ SKIDMORE, Thomas E. O Brasil visto de fora. 2a . Rio de Janeiro: Paz e Terra, 1994. pp. 106-107
} 
conhecedor das correntes científicas da época. Skidmore demonstra a forte influência das três escolas do pensamento científico da época marcando o pensamento da elite intelectual em toda a América Latina e no Brasil. Assim, insere Sílvio como um dos representantes do darwinismo social. Frente à incoerência das idéias existentes entre o Brasil e a realidade dos países europeus e dos EUA, onde havia uma barreira de cor institucionalizada que caracterizava o negro e o branco, a solução adequada para este impasse no Brasil foi a ideologia da mestiçagem, solução singular para entendermos a mistura biológica e cultural, ponto chave para compreendermos o pensamento de Sílvio. Skidmore concebe Romero como reformador liberal e nacionalista frustrado. Estudando as vertentes científicas da época, mostrando não somente quais as escolas científicas mais importantes, como chamando atenção para a disparidade entre o cenário brasileiro e a situação européia dos países já formados como nação, o autor em questão pontua a presença do Determinismo racial e geográfico assimilada por boa parte da intelligentsia brasileira e, no caso específico de Sílvio, apropriando-se das idéias de Buckle para explicar a Psicologia ou o caráter nacional brasileiro.

Sílvio difere de outros escritores que falaram sobre o Brasil não apenas ao reconhecer a mestiçagem do país como novidade, mas também por ter sido o primeiro que a partir de então buscou esmiuçar de maneira detida o que coube a cada uma das raças, isso porque, de seu ponto de vista, a mestiçagem não ficava somente no plano racial, acabava por influenciar o aspecto cultural da sociedade brasileira. Sua maior investida era identificar e traçar o que coube a cada uma das raças. Fora Sílvio o primeiro escritor a ver a mestiçagem como fator positivo, ao contrário dos posteriores Euclides, Nina Rodrigues e Oliveira Viana. Acreditando na superioridade da raça branca, investiu na formação do povo brasileiro que ia desde o homem da cidade aos sertanejos e pescadores habitantes dos vilarejos. Embora sua tese não seja original e algumas vezes se mostre contraditória, a diferença de Sílvio com relação aos escritores anteriores - e mesmo alguns posteriores - é a aposta na mestiçagem justificada por sua visão científica.

Como se não bastasse uma estrutura social brasileira modelada a partir do poder econômico, a possibilidade de ascensão social do negro era quase nula. Deriva daí o sentido pejorativo que o termo mestiço veio a adquirir, este soava não somente como uma raça diferente da branca, mas o mais grave: era isto como inferior e acusado de chegar a colocar em risco todo o projeto de modernização do país. Não sem razão, inúmeros escritores brasileiros por trás de suas penas carregavam para sempre o estigma da cor, obstando toda e qualquer forma de ascensão pelas Letras. O próprio Sílvio Romero, quando polemizou com Machado de Assis e José Veríssimo, trazia à tona a questão da cor. Sem nenhuma comprovação científica, foi a partir da ótica racial que a situação do país foi avaliada.

A questão principal e que norteou as análises desses ensaístas foi como um país que pretendia progredir na escala do progresso ou da civilização, guardava em seu interior uma boa parte de 
população mestiça. O que fazer para fugir a essa grave situação, que refletia o atraso ou a barbárie em todos os níveis do país?

Skdimore aponta a importância do "racismo científico" operacionalizado pelos "construtores de mitos", divulgado pela Literatura de cunho naturalista, em que Sílvio é um dos escritores mais importantes. Assim, é Sílvio, dentre tantos outros autores naturalistas, influenciado pelas idéias evolucionistas e deterministas, responsável pela construção de um Brasil branco, que pensa o Brasil superado pela vitória do europeu devido à superioridade da raça branca. Apostando nesse futuro branco como superação de toda a História brasileira, Sílvio é visto por Skdimore como um autor racista, fortemente influenciado pelas idéias do Determinismo e da desigualdade natural entre as raças, sendo o mais importante nome do racismo científico brasileiro.

Roberto Ventura, por sua vez, aponta o momento áureo da vigência das Teorias raciais "enviesando" as discussões em torno da implantação do Liberalismo no Brasil. As Teorias raciais foram dominantes no Brasil de 1870 a 1930, como forma de legitimar uma hierarquia social consoante a nova ordem liberal. ${ }^{275} \mathrm{O}$ autor deixa clara a forte presença do Naturalismo na Literatura de Sílvio

\begin{abstract}
"As noções de raça e natureza, de trópicos e miscigenação estão no centro de todo o debate do século XIX sobre a nação brasileira e sua Literatura. Um povo branco ou mestiço? Cultua ou barbárie? Pode haver civilização nos trópicos? Estes foram alguns dos dilemas vividos pelos críticos que se perguntavam qual o tipo de Literatura, quais as formas de estilo criadas, em meio à natureza tropical, por um povo mestiço.

A adoção do Naturalismo tornou possível o enfoque da Literatura e da cultura de um ponto de vista histórico-social. Até que ponto a abordagem da Literatura se tornou dependente da interpretação da sociedade e da História? A relação entre Crítica e História desponta como questão fundamental. Sílvio Romero procurou aproximá-las, ao atribuir à Crítica a missão de contribuir para a construção da nacionalidade, no que dava continuidade à tradição romântica, apesar de se opor a sua Estética”. ${ }^{276}$
\end{abstract}

Esmiuçando as vertentes científicas, Lilia Schwarz se debruça sobre a chegada e a circulação das idéias que advogavam a superioridade inata das raças, uma das mais importantes crenças de Sílvio, sustentando e resguardando toda uma estrutura liberal, a partir de 1870, momento áureo do racismo científico. A antropóloga não apenas identifica os estabelecimentos responsáveis pela recepção das Teorias raciais - no caso, os museus, Institutos Históricos, Faculdades de Direito e de Medicina -, como aponta o novo olhar sobre a interpretação brasileira a partir das idéias científicas. Dentre as inúmeras leituras chegadas ao Brasil e os assimiladores destas, com relação a Sílvio, escreve:

"Se existe alguém que procura de forma quase doentia orientar sua vida tal qual um "homem de Ciência”, esse alguém é Sílvio Romero. Intelectual de muitos radicalismos, de erros e

\footnotetext{
275 VENTURA, Roberto. História e Crítica em Sílvio Romero. Op.cit.

276 VENTURA, Roberto. História e Crítica em Sílvio Romero. In: MALLARD, Letícia. História da Literatura: ensaios. Campinas, SP: Editora da Unicamp, 1994.p.41.
} 
acertos em suas avaliações, Romero foi, sobretudo um ao tentar aplicar todo um ideário científico à complexa realidade nacional.

Sílvio Romero era antes de mais nada um grande agitador. Autodidata e pouco preocupado com o que chamava "pura especulação", utilizou com entusiasmo a última palavra em Ciência e Filosofia para lidar de forma direta com os problemas nacionais. Na verdade, as diferentes matrizes teóricas só o interessavam na medida em que ajudavam a pensar em um compromisso com as questões locais, em novas aspirações de uma nacionalidade.

Dentro do contexto intelectual da época, a produção de Romero se destacou pelo radicalismo das posições e o apego ao Naturalismo evolucionista, em oposição ao Positivismo francês. Empregando uma terminologia até então desconhecida - retirada de autores como Haeckel, Darwin, Spencer -, esse intelectual de Recife acreditava ver na mestiçagem - tão temida - a saída para uma possível homogeneidade nacional.

A novidade estava, porém, não apenas na argumentação, como também na postura teórica (compartilhada por boa parte dos mestres de Recife), que encontravam no "critério etnográfico" a chave para desvendar os problemas nacionais. Nele, o princípio biológico da raça aparecia como o denominador comum para todo o conhecimento. Tudo passava pelo fator raça, e era a ele que se deveria retornar se o que se buscava explicar era justamente o futuro da nação.

Assim, se as posições de Romero abrandaram-se com o tempo, o mesmo não pode ser dito desses periodos finais do século XIX. Frases como "o povo é o que é, o que ele vale o que dele a raça”. 277

Numa estrutura fechada como a sociedade brasileira que viu o momento áureo do escravismo desde os fins do século XVIII até a primeira metade do século XIX, quase nenhuma possibilidade de fundo estrutural do ponto de vista social era deixada aos negros, mestiços e brancos livres, porque oferecer o mínimo recurso a essas camadas era o mesmo que por em risco o poder do senhor ou do próprio modelo de reprodução do sistema escravista. Não é em razão que pontua Florestan Fernandes que "ora, a revolução social vinculada à desagregação da produção escravista e da ordem social correspondente não fazia para toda a sociedade brasileira. Seus limites históricos eram fechados, embora seus dinamismos históricos fossem abertos e duráveis. Naqueles limites, não cabiam nem o escravo e o liberto, nem o "negro" ou o "branco pobre" como categorias sociais. Tratava-se de uma revolução das elites, pelas elites e para as elites; no plano racial, de uma revolução do BRANCO para o BRANCO, ainda que se tenha de entender essa noção em sentido etnológico e sociológico. Colocando-se a idéia de democracia racial dentro desse vasto pano de fundo, ela expressa algo muito claro: um meio de evasão dos estratos dominantes de uma classe social diante de obrigações $e$ responsabilidades intransferíveis e inarredáveis". ${ }^{278}$ (grifos nosso)

Emilia Viotti analisa os três fundamentos do mito da democracia racial, o que nos leva a entender como se processou a questão das raças no Brasil. Tendo como objetivo maior desconstruir a idéia de democracia racial, surgida pela importante contribuição intelectual de Gilberto Freyre, somente posta em xeque com a geração de Florestan Fernandes e Otavio Ianni, a autora chama atenção para duas questões importantes. A primeira é que a ideologia de discriminação ou de preconceito

${ }^{277}$ SCHWARCZ, Lilia Moritz. O espetáculo das raças: cientistas, instituições e questão racial no Brasil - 1870-1900. Op. Cit. pp.153-154

${ }^{278}$ FERNANDES, Florestan. Um mito revelador. In: Significado do protesto negro. São Paulo: Cortez, 1989. 
racial não sofreu nenhuma Crítica na geração de Freyre, o que muito inquieta a autora, e que foi contestada somente pela geração de Florestan Fernandes e Octavio Ianni. Era o grupo de intelectuais surgidos em torno da Universidade de São Paulo, frutos da nova sociedade urbana industrial que via aparecerem novas classes médias. Lamenta Viotti da Costa não ter sido a idéia de democracia racial combatida na época de Gilberto Freyre.

Conforme a autora, não basta tentar explicar o mito somente buscando entender a acomodação das Teorias raciais provenientes do EUA ou da Europa no Brasil, uma vez que as idéias não foram assimiladas de maneira passiva, mas sim voltar o olhar para a situação do país do momento, o que torna possível a compreensão dessa vertente de idéia e não daquela. No fundo, as Teorias de fora eram secundárias, mas são por demais importantes para compreendermos como se processou o racismo à brasileira sem perdermos de vista a situação do país no momento. Defende Viotti da Costa que sempre houve no Brasil certa discriminação, mas não fora sem razão que esta se tornou explícita nas três últimas décadas do Império, quando ruía a Economia de base rural e o país começava a sofrer um pequeno surto industrial, com o surgimento de estradas, bancos e ferrovias. $\mathrm{O}$ racismo materializado por meio das Teorias raciais no Brasil consumou-se por uma elite apta a buscar seus espaços num momento de transição, quando um novo Brasil se anunciava. Não fazia mais sentido tudo que levasse a lembrar o Brasil do passado.

O que cabe destacar é a nova conjuntura de Brasil, uma conjuntura que cada vez mais se tornava competitiva, fazendo-se necessária, para setores dominantes, a aparição manifesta do racismo. O Brasil desse argumento da democracia racial era o Brasil tradicional de Freyre, era o mundo da casa grande e da senzala, coberto de sonhos oníricos, de evocações bebidas de Proust a procura do tempo perdido, ao passo que o Brasil discutido por Florestan Fernandes e Ianni era o Brasil urbano, industrial e acima de tudo, competitivo, representante das emergentes classes médias. É num novo Brasil industrial e urbano que toma sentido a manifestação explícita do racismo. Segundo Viotti, "e seria possível argumentar, segundo a análise de Van der Berghe em Race and Racism, que os padrões raciais no Brasil passaram de um modelo paternalista para um modelo competitivo - da acomodação racial para o conflito racial, de um sistema de relações raciais no qual o preconceito, embora presente, não era "necessário", para um sistema no qual o preconceito é "necessário". 279

Viotti elabora uma leitura de Florestan Fernandes em que, no Estado nacional brasileiro, não existia uma condição sui generis para a clara manifestação do racismo, embora as Teorias advogassem a inferioridade das populações negras e mestiças. Conforme a historiadora, a elite senhorial afastou justamente dois argumentos que justificavam cientificamente a inferioridade de negros e mulatos, no

${ }^{279}$ COSTA, Emília Viotti da. Da monarquia à república: momentos decisivos. 6 ${ }^{\text {a }}$ Ed. São Paulo: Fundação Editora da UNESP, 1999. p. 374 
caso, a inferioridade inata das raças e a degeneração pelo contato sanguíneo na elaboração do mito da democracia racial brasileira.

Uma vez que, no mundo paternalista do Brasil de outrora, negros e mulatos supostamente tinham as mesmas condições sociais de oportunidades, pairava a idéia de que não existia no Brasil discriminação racial, eximindo de qualquer responsabilidade o racismo por parte das elites. Outra manifestação apagada deste racismo verificava-se na conformidade solidária das pessoas, diluindo o que de real acontecia no nível das relações entre brancos e negros. $\mathrm{Na}$ ausência do racismo à brasileira, negros e mestiços podiam adentrar espaços antes somente ocupados pela minoria branca, como clubes e salões. Era neste momento que o racismo se manifestava no Brasil.

O mito não se reduz a essa análise simplista, pois não foram somente os brancos que foram favorecidos com o mesmo, mas é o meio que nos leva a adentrar as relações raciais que estavam intrinsecamente ligadas às relações sociais e econômicas bem analisadas por Fernandes. Cabe uma pergunta: por que a elite brasileira, certamente europeizada, para fugir ao "atraso" do Brasil, buscou refúgio nas idéias raciais?

Mais do que apontar nomes como os de Machado de Assis, Nabuco de Araujo, Rui Barbosa, Euclides da Cunha, Nina Rodrigues, Sílvio Romero, etc, assim como políticos e letrados conceberam o mestiço e o negro como inferior, é mais relevante perceber porque "raça" fora a terminologia por onde nossos homens de Letras interpretaram o país. Não menos importante é saber que o conceito de raça foi o espelho para a constatação do progresso ou da barbárie do país que, para boa parte desses homens de mente europeizada, punha cada vez mais o Brasil a caminho da degeneração. Não se pode esquecer, após discussão acercas das Teorias racistas, que o que antes servia para legitimar diferenças entre seres, com o passar do tempo, mostrou ser o racismo real, concreto e de fato.

$\mathrm{Na}$ estrutura patriarcal brasileira, não houve as mínimas condições para que o escravo, visto como coisa ou peça, fosse repudiado pelo senhor sob a ótica dessa ou daquela Teoria racial, embora não fossem desconhecidas as mais variadas argumentações que advogavam a inferioridade de negros e mulatos. Por aqui, a barreira de cor sempre existiu e pouco depois, com a emergência das idéias do Determinismo, do Positivismo, e do Evolucionismo, sob a égide do racismo científico, veríamos as argumentações claramente racistas sobre a superioridade do homem branco.

Pertencente ao grupo de estudiosos fortemente influenciados pelos estudos de Roger Bastide, Octavio Ianni elabora uma leitura semelhante à de Florestan Fernandes. É a partir da estrutura econômica que Ianni buscava entender a questão racial no Brasil. Assim, "além de ser um fenômeno étnico ou racial, demográfico ou cultural, a "questão racial” é uma expressão das tendências de acomodação, reajustamento ou expressão dos mercados de força de trabalho, em escala regional ou nacional. Essa é a natureza fundamental, que dá sentido às suas expressões sociais, culturais, 
demográficas, políticas, as quais, quando são vistas isoladamente, pouco elucidam o problema. Tanto nos países de emigração como naqueles em que os imigrados ou seus descendentes se encontram em absorção, a questão tem em sua base, esse componente estrutural determinante: a força de trabalho. O significado econômico econômico-social e político da força de trabalho esclarece manifestações culturais, raciais etc., que obscurecem ou tornam abstratas certas análises de sociólogos e antropólogos. Em outras palavras, certas transformações em cursos nos setores primários, secundário e terciário da Economia dos países em industrialização estão na base do "problema racial”, na medida em que a desagregação da ordem econômico-social escravocrata libertou forças produtivas capazes de iniciar a expansão industrial que diferencia a estrutura global. ",280

Dois são os eixos que colocam em questão a problemática racial no Brasil: se apelarmos para raça, a raiz do problema gira em torno da classe social; e se tomamos como parâmetro o distintivo de classe, o problema redunda na questão racial. Conclusão: a concepção de raça no Brasil é tema ambíguo. Por ser o Brasil um país hipoteticamente democrático, tem-se a impressão de que os negros jamais sofreram algum tipo de racismo e que tiveram as mesmas possibilidades na vida que os brancos. Dada a inexistência de um racismo às claras, o racismo real só se perpetuou justamente por conta da idéia de democracia racial. A tônica do racismo a brasileira espelhava-se na sociedade americana que sofria um preconceito de origem, ao passo que no Brasil o que existia era um preconceito de cor. Se nos Estados Unidos, o ser humano, uma vez descendente de negro, tinha barrada toda e qualquer possibilidade de mobilidade social ao longo da vida, no Brasil, a possibilidade de ascensão, uma vez que por aqui existia preconceito de marca e não de origem, viria por meio do embranquecimento, tornando-se, na expressão de Florestan Fernandes, "negro de alma branca".

Restou dessse processo, às raças inferiorrizadas, conforme Fernandes, serem relegadas para o canto da História em função ou da inferioridade dita comprovada cientificamente ou por meio de uma "pobreza compartilhada", mas o preconceito no Brasil era camuflado pela sensação de democracia racial surgida principalmente com o pensamento de Gilberto Freyre. Conforme Octavio Ianni, “os estudos sobre mestiçagem estavam diretamente vinculados ao complexo de inferioridade difuso na cultura nacional, constituindo no longo período de escravização de índios e negros e de total ou ampla dependência externa. No processo civilizatório, o problema da inferioridade do mestiço se colocara como um tema importante, em particular devido às doutrinas criadas na segunda metade do século XIX, época de intensa ação imperialista européia nos vários continentes. Em certo sentido, as obras de Gobineau, Lapouge e outros exprimem esse aspecto do processo de europeização do mundo". 281

\footnotetext{
${ }^{280}$ IANNI, Octavio. Raças e classes sociais no Brasil. São Paulo: Brasiliense, 2004.p. 317

${ }^{281}$ Ibidem. p.295
} 
Em meio ao desenrolar da noção de raça, nossos homens de Letras e de Ciência se depararam muito frequentemente nos museus, institutos históricos ou geográficos, com o temor da degeneração do país em função das raças inferiores, sempre apostando no Brasil do futuro. Esse Brasil do futuro deveria ser, antes de tudo branco, e - por que não dizer? - de uma Economia urbana e industrial que dispensava a participação dos negros. Para Sílvio, o mestiço abriria esse novo Brasil; já para outros ensaístas, negros e mestiços eram a manifestação do atraso do país e, portanto, obstáculo para o progresso. Num país fortemente marcado pela mestiçagem, sendo o último a abolir o cativeiro, as idéias do Evolucionismo e do Darwinismo Social caíram como uma luva para os promovedores do novo Brasil em detrimento do Brasil do passado, apoiado na monarquia romântica de Pedro II e sob a Economia de base rural, objetivando instaurar a Modernidade do país à imagem e semelhança dos países "civilizados".

Antonio Candido analisando o início da Sociologia no Brasil identifica as fases porque passou esta no momento em que ecoavam as idéias cientificistas do momento. Com relação a Sílvio Romero, esclarece que "esta atitude metodológica se explica pela ideologia que norteava o trabalho destes homens, ainda aí seguidores de Sílvio: o nacionalismo, o empenho de desvendar necessidades e características nacionais com o fim precípuo de servir ao progresso do país, em relação ao qual se verificava acentuado pessimismo no primeiro quartel deste século $X X$, após as esperanças iniciais da República. No fundo, importava menos o cuidado da investigação ou o rigor da inferência do que a interpretação coerente do país no seu conjunto, para se apontarem remédios de ordem políticoadministrativo. A isso de chamou Sociologia entre nós, desde então quase até os nossos dias, não faltando quem ainda a conceba sob este aspecto, que correspondeu, realmente, a um decisivo momento na tomada de consciência ideológica da nossa sociedade”. ${ }^{282}$ Fernandes e Ianni, em estudos financiados pela UNESCO ${ }^{283}$ tentaram apontar a real situação de um país que sempre enfrentou a

\footnotetext{
${ }^{282}$ Ibidem. pp. 278-279.

${ }^{283}$ O objetivo das pesquisas sociais financiadas pela UNESCO era combater a idéia de democracia racial no Brasil. Surgida em meio aos horrores do Nazismo, da Segunda Guerra Mundial, da Guerra Fria, da segregação racial existente na África e da descolonização da mesma, a agenda de estudos pensada por Artur Ramos no final da década dos anos 40 do século XIX, serviu como base para os estudos da UNESCO. O que começou sendo um estudo sobre as relações raciais, especificamente na Bahia e no Rio, foi muito além do combate a idéia de democracia racial, onde apareceria São Paulo como importante núcleo de estudos. Portanto, o que seria uma simples investigação sobre as relações raciais no Brasil, começando na Bahia, se ampliou por conta de um pensamento estruturalista que perscrutava os porquês da totalidade das relações antes de tudo sociais no Brasil. Em são São Paulo as relações raciais eram analisadas, a partir da nova perspectiva de desestruturação das relações "harmônicas" formadas pelo senhor e pelo escravo, agora vista sob a ótica de classes em cidades que sofriam um forte processo de urbanização como Rio e São Paulo. É sob este olhar que surge o grupo de pesquisadores ligados a Universidade de São Paulo, influenciados pela visão de Roger Bastide, como por exemplo, o sociólogo Florestan Fernandes. Mesmo tendo escrito uma das mais importantes obras juntamente com Bastide, a visão de Fernandes destoava da do escritor francês, denominada por aquele de "verdade redentora", aparente no perdão mútuo, no esquecimento, a superação pelo negro das "injustiças" (ele evitava converter a descrição em julgamento); os dois capítulos que escreveu para Negros e brancos em São Paulo demonstram que o apego estrito a objetividade científica ia a par com o nuançamento dos elementos dos elementos chocantes, com uma dialética proudhoniana, que exibia o mal sem ignorar o bem, ou o mal sem desenhar o bom. FERNANDES, Florestan. Apud. SOARES, Eliane Veras; BRAGA, Maria Lucia de Santa; COSTA,
} 
questão racial. Assim, trataram os estudiosos de apontar o preconceito racial existente no Brasil, o que, para Munanga, não é suficiente, "uma vez que não é possivel ignorar o flagrante contraste entre o clima de relações inter-raciais que predomina nos Estados Unidos e o que caracteriza o Brasil." ${ }^{284} \mathrm{O}$ cerne da discussão gira em torno de preconceitos raciais apenas diferentes. Enquanto nos EUA o preconceito é marcado pela origem tornando impossível a ascensão do negro, no Brasil, esse preconceito se caracteriza pela marca, onde a cor, parte do fenótipo, aparece como critério ou elemento distintivo. No fundo, conforme Munanga, o tipo de preconceito a que se assiste no Brasil é uma reformulação do preconceito de origem que existe na sociedade americana. Era muito difícil a possibilidade de ascensão social para o negro que morava nos Estados Unidos ou para o negro que morava no Brasil, situação modificada apenas na segunda metade do século XX, a partir de diferentes movimentos sociais de negros nesses e noutros países. Como lembra Oracy Nogueira, concepções de brancura e de negritude não passam de categorias ideais, abstratas, inferidas para as análises raciais e não significam que, no plano concreto, esses parâmetros sejam bem sucedidos, o que leva a quiprocós quando se trata de analisar as relações raciais no Brasil, fazendo com que "indivíduos ligeiramente negróides ou completamente brancos e que, como brancos, sempre viveram, no Brasil, indo aos Estados Unidos, podem ter a surpresa de serem considerados e tratados como negros". 285

Para Oracy Nogueira, "Onde o preconceito é de marca, como no Brasil, o limiar entre o tipo que se atribui ao grupo discriminador e o que se atribui ao grupo discriminado é indefinido, variando subjetivamente, tanto em função dos característicos de quem observa como dos de quem está sendo julgado, bem como, ainda, em função da atitude (relações de amizade, deferência etc.) de quem observa em relação a quem está sendo identificado, estando, porém, a amplitude de variação dos julgamentos, em qualquer caso, limitada pela impressão de ridículo ou de absurdo que implicará uma

Diogo Valência de A. O dilema racial brasileiro: de Roger Bastide a Florestan Fernandes proposição política. Sociedade e Cultura, v. 5, n.1, Janeiro/Junho, 2002. Enquanto Bastide enveredava por uma análise estruturalista não percebendo tensões entre as raças, Fernandes via cada vez mais a exclusão de negros e índios por parte da ordem capitalista. O Projeto UNESCO contou com a participação de intelectuais brasileiros e estrangeiros, como: Anísio Teixeira, Thales de Azevedo, Oracy Nogueira, Mario Wagner Vieira da Cunha, Octávio da Costa Eduardo, Otto Klineberg, Paulo Estevão de Berredo Carneiro, Ruth landes, Frazier, Metraux. MAIO, Marcos Chor. O Projeto UNESCO e a Agenda das Ciências Sociais no Brasil dos anos 40 e 50. Revista Brasileira de Ciências Sociais. Vol. 14, No 41, Outubro, 1999. IANNI, Octavio. Raças e classes sociais no Brasil. Op. cit. p. 304

${ }^{284}$ MUNANGA, Kabengele. Preconceito racial de marca e preconceito racial de origem (sugestão de um quadro de referência para a interpretação do material sobre relações raciais no Brasil). Apresentado originalmente ao XXXI Congresso Internacional de Americanistas, realizado em São Paulo, de 23 a 30 de agosto de 1954, no Symposium EtnoSociológico sobre Comunidades Humanas no Brasil, organizado por Florestan Fernandes. Reprodução da versão apresentada em Porto Rico, em 1957. p. 77.

${ }^{285}$ NOGUEIRA, Oracy. Preconceito racial de marca e preconceito racial de origem: sugestão de um quadro de referência para a interpretação do material sobre relações raciais no Brasil. Tempo Social, Revista de Sociologia da USP, v. 19, $\mathrm{n}^{\mathrm{a}}$. 1, p. 295. Para a discussão sobre a difícil tarafe de definição do negro no Brasil consultar. MUNANGA, Kabengele. A difícil tarefa de definir quem é negro no Brasil. Entrevista do autor. Estudos Avançados 18 (50), 2004. FERREIRA, Ricardo Franklin \& CAMARGO, Amilton Carlos. As relações cotidianas e a construção da identidade negra. Psicologia: Ciência e Profissão, 2011, 31 (2), 374-389. 
insofismável discrepância entre a aparência de um indivíduo e a identificação que ele próprio faz de si ou que outros lhe atribuem". 286

Num país formado pelo concurso de índios, negros e brancos, somado a dificuldade de diferenciar o homem branco do não branco, se torna cada vez mais difícil aceitar a idéia de democracia racial. A elite fez de tudo para transmitir a sensação de que não existia racismo no país, mas pecou justamente pela concepção de raça, que nunca teve confirmação científica. Se raça serviu para justificar diferenças que outrora eram respaldadas pelo cânone "científico", após os frenéticos tempos do racismo dito científico, não foi fácil encontrar o que seja um elemento negro ou branco no Brasil. De tal modo que "a concepção de branco e não-branco, varia no Brasil, em função do grau de mestiçagem, de indivíduo para indivíduo, de classe para classe, de região para região". ${ }^{287}$ Apoiado na esperança de que um dia negros e mestiços poderiam compartilhar os mesmos espaços, de terem as mesmas oportunidades, o preconceito no Brasil era mascarado de maneira assimilacionista, ou seja: acreditava-se que da contribuição de índios, negros e estrangeiros surgisse o brasileiro caracterizado por sua "cultura nacional", formado pela língua, pela Religião ou pelos costumes, barrando a importância do negro na formação da sociedade e da cultura brasileira. Assimilar aqui significa acabar, deglutir, matar toda a contribuição do negro nos mais variados aspectos da cultura brasileira.

Sem barreira de cor, sem um aparato jurídico que legitime o que é negro e o que é branco no Brasil, e acima de tudo, com a dificuldade desde as origens de identificar o que seja branco e o que seja negro, a questão racial no Brasil é problemática, o que torna os argumentos racistas explícitos pouco sustentáveis. Como se não bastasse essa situação, baila nas mentes de homens de mentes civilizadas que não se dizem racistas a crença de que negros e mestiços serão assimilados tanto biologicamente como culturalmente, que para o olhar da elite tanto incomodam com suas manifestações culturais vistas como nada civilizadas ${ }^{288}$. É que, como argumenta Schwarcz, "pode-se dizer que o racismo brasileiro constitui uma espécie de discurso costumeiro, praticado como tal, porém pouco oficializado. Com efeito, uma das especificidades do preconceito vigente no país é seu caráter não-oficial. Enquanto em outras nações se adotaram estratégias jurídicas que garantiram que a discriminação fosse amparada pelo corpo da lei, no Brasil, desde a proclamação da República, afirmou-se a universidade dos Direitos". ${ }^{289}$

\footnotetext{
${ }^{286}$ Ibidem. p. 293

${ }^{287}$ MUNANGA. Preconceito racial de marca e preconceito racial de origem. Op. Cit. p.80.

${ }^{288}$ VELLOSO, Mônica Pimenta. As Tradições populares na belle époque. Rio de Janeiro: FUNARTE, 1988.

${ }^{289}$ SCHAWARCZ, Lilia Moritz. Racismo no Brasil. Op. Cit.p.52.
} 


\section{4 - Nação, estado e consciência nacional.}

O termo Nação, como prerrogativa política, é uma invenção moderna, que emerge após longo processo histórico, entre unificações e rupturas, buscando a formação do estado nacional. Guibernau vê traços singulares que caracterizam a nação moderna em comunidades étnicas e grupos anteriores ao que alguns teóricos vêem como fenômeno político moderno. Defendendo traços de lealdade e identidades de certos grupos, argumenta a autora que "se voltarmos nossa atenção para as mudanças na organização da sociedade através dos tempos, podemos ver como, depois da queda de Roma e da subseqüente desintegração do Império carolíngio, a Europa ocidental dividiu-se em feudos relativamente pequenos e áreas de influência que, por meio da conquista, dos casamentos e da anexação, criaram grandes unidades que desenvolveram um senso de comunidade, sobretudo mediante a guerra contra outros grupos". ${ }^{290}$

Benedict Anderson, em seu clássico estudo, busca as possíveis raízes culturais dos elementos integrantes que podem explicar a idéia de nação. Mesmo reconhecendo e dando importância à perda de prestígio da "comunidade imaginada", ligada a uma "comunidade sagrada", nação é algo que contempla elementos novos e que, por isso, não é de fácil análise, uma vez que "é perfeitamente possivel conceber o surgimento das novas comunidades nacionais imaginadas, sem que algum deles, talvez nenhum deles, estivesse presente. Num sentido positivo, o que tornou imagináveis as novas comunidades foi uma interação semifortuita, mas explosiva, entre um sistema de produção e de relações produtivas (capitalismo), uma tecnologia de comunicações (a Imprensa) e a fatalidade da diversidade lingüistica do homem”. ${ }^{291}$

Hobsbawm, em seu estudo acerca das nações, considera que uma vez que a concepção de nação é fruto da Modernidade, "o melhor modo de entender sua natureza é seguir aqueles que, sistematicamente, começaram a operar com esse conceito em seu discurso político e social durante a Era das Revoluções, especialmente a partir de 1830, com o nome de principio da nacionalidade ${ }^{292}$.

Novidade histórica, como entendem Hobsbawm e outros autores, o que a princípio se tomou como nação nada tem a ver com os elementos que integram o conceito revolucionário de nação num momento onde os estados dessa natueza estavam a se formar e o mapa da Europa era redesenhado. Não bastasse a dificuldade para conceituarmos o que seja uma nação, lembra Hobsbawm que categorias analíticas como língua e etnia, são ambíguas, mutáveis e opacas, o que torna problemática a

${ }^{290}$ GUIBERNAU BERDUM, M. Montserrat. Nacionalismos: o estado nacional e o nacionalismo no século XX. Rio de Janeiro: Jorge Zahar, 1977.p.59

${ }^{291}$ ANDERSON, Benedict. Nação e consciência nacional. São Paulo: Ática, 1989.p.52

${ }^{292}$ HOBSBAWM, Eric. Nações e nacionalismo desde 1780: programa, mito e realidade. Rio de Janeiro: Paz e terra, 1990. p. 31 
definição daquilo que seja uma nação. Seguindo o autor, o que mais tarde veio ser indispensável às nações e ao nacionalismo, servindo como princípio da nacionalidade, especificamente a partir de 1830, era um quadro inovador que via a ascensão das burguesias liberais, representadas por seus intelectuais, que agora se debatiam com o problema de que nem todos os estados coincidiam com nações. Objetivando a delimitação dos estados nacionais, que requer a existência de um "povo", é que fazem sentido elementos a serviço do nacionalismo como território, língua, etnia, o que aqui nos interessa. Portanto, ao momento histórico do Estado como suposta expressão política de um povo, conforme pensam Gellner e Hobsbawm, que vamos nos ater.

O Estado requer um corpus político indispensável à viabilização dos elementos integrantes da nação, que leva ao despertar do sentimento ou da consciência nacional. É com a vinda da Corte para o Brasil em 1808 que as ferramentas para a formação do Estado nacional começam a ser articuladas entre nós. Isso porque, como colônia de Portugal, não foi possível o Brasil engendrar um sentimento de nação, dada a relação política, econômica e social que ligava o país a sua metrópole. Tornando-se independente de Portugal, toda uma estrutura política, econômica e social precisou se elaborar. O movimento de independência não deixou de ser um acontecimento "revolucionário", uma vez que toda uma estrutura política, econômica, social agora tinha que se ordenar, embora mantendo relações de dependência em relação a outros países (particularmente, a Inglaterra) e vigorasse em seu interior o forte poder de uma elite fundiária. A emergência do Estado nacional brasileiro apenas se readaptou a essa nova ordem. Ele foi pensado a partir de sua herança colonial, donde as rupturas e continuidades frente aos vários Brasis pensados pelas elites provinciais dominantes.

Uma vez independente, o Brasil carecia de todo um aparato político que respaldasse juridicamente sua condição de nação, tendo que esboçar projetos políticos. Esses esboços surgem das províncias mais significativas economicamente, como a Bahia. A princípio, mesmo que os projetos políticos da formação do Estado nacional fossem provenientes das províncias de forte Economia, em defesa dessa ou daquela ordem, desse ou daquele modelo de Brasil, cabia readaptar toda uma estrutura de práticas políticas, com os costumes e Educação da camada senhorial para a nova ordem legal. O Liberalismo fora de vital importância na articulação das rupturas e continuidades na formação do Estado nacional, isso se deveu, conforme Florestan Fernandes, a interpretações oriundas da assimilação das idéias liberais, tanto pela camada senhorial quanto por grupos menos privilegiados, o que acabou diluindo uma possível divisão do país numa estrutura apenas autoritária e permitindo uma leitura que se opunha aos interesses exclusivos da camada senhorial.

Sabemos das interpretações provenientes das leituras liberais materializadas nos movimentos de contestação colonial, que iam desde o protesto contra a dependência do Brasil em relação a Portugal até ao sonho socialista almejado pelas camadas subalternas, pessoas "perigosas", condenadas por 
conta da cor, como negros e mulatos, e mais milhares de trabalhadores livres. Ainda que se saiba do forte prestígio político da camada senhorial, agenciando as mais variadas práticas políticas, o autoritarismo dos donos do poder não foi maior, como pontua Florestan Fernandes, por conta do Liberalismo, o que parece ser ambíguo porque à medida que servia para manter a camada senhorial no poder, ao mesmo tempo, desinflava esse mesmo autoritarismo, uma vez que, contrariava muito da estrutura do mundo senhorial, mas não o poder e a força do dono de terra.

Essa bipolarização liberal tornou possíveis continuidades do mundo senhorial na ordem legal, sendo possível readaptar elementos da vasta herança colonial, de modo específico, questões de ordem política, cultural e social. O aparato político do Estado nacional brasileiro modelou-se sob as instâncias do ancien règime, do projeto monárquico que tinha como base a figura do rei como instância máxima. Primeiramente, vale lembrar que predominava na colônia o poder das camadas senhoriais que, mesmo sendo os legítimos donos do poder, eram parte e peça da política patrimonial implantada pela Coroa. Embora o status de colônia ainda perdurasse por mais quatorze anos, é com a vinda de do regente D. João (a partir de 1816, rei D. João VI) que se articulam as premissas para a formação do Estado brasileiro. Uma vez que não existe Estado sem nação, ou seja, a existência de um "povo" provido de sua identidade, é a partir do rompimento com a metrópole portuguesa, com o movimento da independência, que veremos o Brasil se pensar como nação.

Antes de refletirmos sobre como se desenrolou o complexo processo da emergência do Estado nacional brasileiro, é preciso remontar ao estatuto colonial, não apenas no nível de situação política, mas a partir da vasta herança colonial, abordando aspectos sociais e culturais, para que possamos compreender que grosso modo o emergente estado apenas fora uma readaptação dos elementos herdados do Brasil colonial. Dominado por uma camada senhorial imersa numa sociedade estamental, somente possível por causa da relação patrimonialista daquela camada com a política lusitana, o Brasil independente que se forma é a transplantação dos donos do poder, reinante ao longo do Império brasileiro, agora estabelecido na ordem legal do Estado independente.

É paradoxal ter experimentado o Brasil diversos motins liberais para legalizar uma monarquia constitucional que tanto lutou para por fim à dominação frente à mãe pátria, conclamando sempre o "povo", quando sabemos que o Estado nacional brasileiro apenas suprimiu a exploração da colônia pela metrópole ficando agora submetida à elite fundiária de seu próprio país. Uma vez independente, e contando com raças diferentes, donde o medo constante das elites fundiárias no que se refere a uma revolução por parte da população escrava, cabia apaziguar as diferenças por meio da idéia nação. Se tomarmos as falas dos responsáveis pela formação da nação brasileira, veremos não apenas um discurso fechado, típico de suas formações na Europa, como também a dificuldade na criação da idéia de nação porque "devido à ausência de uma universidade ou mesmo da Imprensa na colônia, esses 
autores publicavam seus trabalhos na metrópole e para um público metropolitano, sob o olhar vigilante da Igreja e do Estado. Assim seus escritos não podem ser considerados como representativos do desenvolvimento de uma consciência de sua própria classe e muito menos da massa dos habitantes iletrados da colônia, especialmente aqueles de origem africana, indígena ou mestiça”. ${ }^{293}$

Mesmo que imaginadas como semióforo ${ }^{294}$, as representações se processaram por práticas enviesadas de um Liberalismo conservador, onde "nação" muito mais excluía do que incorporava ou integrava as camadas despossuídas do país. Nas falas que sustentavam os projetos nacionais, nação acabava por excluir qualquer homem não branco, obstando-lhe qualquer possibilidade de cidadania. Mas muitos eram os brasis, grandes e difíceis de abordar, tanto no plano geográfico, de sua riqueza material, e acima de tudo, com uma população mestiça. Muitos eram os homens que pensavam o Brasil, vários foram os projetos políticos para o país que não mais se encontrava sob o jugo português. A partir de então, os projetos políticos, orquestrados por homens herdeiros da tradição iluminista, começam a serem pensados num país constituído por milhares de índios, negros, mulatos etc. Para além da mera constatação de ser o Brasil um país formado por uma pluralidade de populações indígenas, urgia amalgamar diversas etnias na população integrante do nascente estado brasileiro. Conforme a assimetria apontada (o projeto político do nascente estado brasileiro marcado pelos caracteres do Antigo Regime), um dos mais importantes problemas era conformar hierarquicamente uma sociedade em nada homogênea.

Segundo visão de Hipólito da Costa, redator do Correio Brasiliense, a equação era a primazia no corpus político da monarquia dos Braganças num país juridicamente livre de Portugal. Schwartz conclui que "O Brasil, enquanto idéia, foi frequentemente mais um projeto do que uma realidade, às vezes geográfica, às vezes nacional ou até social. A definição do "verdadeiro Brasil”, em oposição ao Brasil do momento, se tornou um método de estratégia argumentativa e discursiva, assim como uma projeção para o futuro" ${ }^{295}$. Portanto, o Brasil é mais uma idéia, no sentido de projeção, do que algo em si.

As peças do mosaico luso brasileiro se mostravam cada vez mais complexas quando se buscava dar homogeneidade a uma sociedade estratificada. István Jancsó aponta as peças indissociáveis de sua moldura, o que acabava por resultar na assimetria entre rei e nação. Enfrentando os movimentos liberais, tanto em Portugal (Revolução Liberal do Porto, impedindo qualquer forma de recolonização) como as agitações no Brasil (que iam de encontro à política absolutista da metrópole), os responsáveis

\footnotetext{
${ }^{293}$ SCHWARTZ, Stuart B. "Gente da terra brasiliense da nasção. Pensando o Brasil: a construção de um povo. p. 106. In: MOTA, Carlos Guilherme (Org). Viagem Incompleta. A experiência brasileira. Formação: Histórias. São Paulo: Editora SENAC São Paulo, 1999.

${ }^{294}$ CHAUÍ, Marilena. Brasil: mito fundador e sociedade autoritária. São Paulo: Ed. Fundação Perseu Abramo, 2000.

${ }^{295}$ SCHWARTZ, Stuart. Viagem Incompleta. Op. Cit. p. 105
} 
pela liquidação do Ancien Régime em Portugal tiveram que reorganizar um Estado brasileiro completamente diferente do cenário português. Nesse sentido, a dificuldade se mostra patente pois, lembra Jancsó, "o fato de a matriz das formações sociais luso-americanas radicar-se na lógica do Ancien Régime português faz com que as especificidades americanas devam ser tomadas como problema crucial a ser enfrentado. Por um lado, porque aquelas sociedades reciclaram os paradigmas peninsulares por força da sua condição colonial e escravista, e por outro, porque a longa História da interface entre a metrópole européia e suas colônias americanas não foi linear „296

Tendências e rupturas se configuram na instauração dos projetos políticos quando da formação do estado brasileiro. Habitado por diversas nações indígenas, escravos, mulatos, somado à variedade das diversas formas de escravidão, que ia do trabalho na lavoura ao trabalho mecânico, cabia ao estado brasileiro unir toda esta multiplicidade na nação brasileira.

É aqui que aparece o projeto conservador do estado brasileiro, uma vez que, mesmo com a independência, mantém algumas práticas da monarquia lusitana, que Nilo Odália resume tão bem: " $a$ independência, analisada sob esse aspecto, nada mais é do que a realização de um pacto e de um consenso em que se achavam envolvidos tão somente os senhores de terra e de escravos e que visava preservar o que lhes interessava basicamente, a saber, um modo de produção escravista e a propriedade da terra. Assim, os regionalismos se acomodam, momentaneamente, e os grupos sociais, limitados e poucos numerosos, que manifestavam idéias revolucionárias puderam ser facilmente dominados" 297

O Estado brasileiro que nascia era produto das elites locais, educadas sob a tendência liberal, mais ou menos inspiradas pela independência americana de 1776, tudo isso somado aos argumentos de igualdade, que teoricamente trariam o povo para o centro de discussão. Do Liberalismo se filtrou o rompimento com a metrópole; dos ares revolucionários que chegavam da França e influenciaaram as demais revoluções por todo o Atlântico, restava à idéia de soberania popular.

Sendo o proprietário de terra e o comerciante de escravo basess de análise de uma sociedade composta por homens escravos e livres, cidadãos e não cidadãos, a complexa organização social não possa ser simplificada a mera identificação da presença da escravidão no Brasil. Com uma variedade de formas de trabalho, fosse escravo ou livre, o certo é que a sociedade colonial moldou, com suas rupturas e continuidades, o Estado nacional brasileiro. Diante de um complexo quadro social, a História da emergência do Estado nacional brasileiro guarda profundos antagonismos sociais,

\footnotetext{
296 JANCSÓ, István. Independência, independências. Independência: História e historiografia. São Paulo: Hucitec: FAPESP, 2005.p.22.

${ }^{297}$ ODÁLIA, Nilo. As formas do mesmo: ensaios sobre o pensamento historiográfico de Varnhagen e Oliveira Vianna. São Paulo: Fundação Editora da UNESP, 1997.p.27.
} 
econômicos, políticos e culturais. Onde buscar um ponto de apoio ou uma identidade num país onde poucas eram as províncias de destaque comercial, como Rio de Janeiro, Bahia, Pernambuco, Pará?

Não é surpreendente que as cartas para a formação do Estado brasileiro tenham sido lançadas pelas províncias mais significativas do ponto de vista econômico. Uma vez que sociedade e nação são categorias analíticas diferentes, a cada passo que damos para enxergar o Brasil independente, mais percebemos a complexa estrutura na qual teve de se amoldar o Estado brasileiro. A cada passo em que verificamos "linhas de corte" com relação à política do Ancien Régime mais se torna traumática a formação deste estado.

Se, como aponta Schwartz, "O Brasil - colônia foi uma sociedade escravista não meramente devido ao óbvio fato de sua força de trabalho ser predominantemente cativas, mas principalmente devido às distinções juridicamente entre escravos e livres, aos princípios hierárquicos baseados na escravidão e na raça, as atitude senhoriais dos proprietários e à deferência dos socialmente inferiores. Através da difusão desses ideais, o escravismo criou os fatos fundamentais da vida brasileira" ${ }^{298}$, todo esse estado de coisas não desapareceu com a independência do país, pelo contrário, as bases do emergente Estado nacional foram articuladas pela camada senhorial, que, no dizer de Schwartz, ditou "os padrões sociais na colônia e foram os que mais se aproximaram dos modelos vigentes na metrópole. Assim, examinando a composição e o comportamento desse grupo, podemos estabelecer a norma com a qual os demais indivíduos na sociedade eram comparados". 299

Após todo o processo revolucionário influenciado pelas idéias liberais, articularam-se as bases constitucionais do Brasil, formadas por pessoas ligada à antiga nobreza, do alto e do baixo clero, homens do magistério, das Forças Armadas e do Judiciário. Para formação das bases constitucionais brasileiras, várias foram as posturas políticas dos deputados que confeccionavam os mais díspares e variados discursos clamando pela soberania nacional. Conforme Márcia Regina Berbel, "o trabalho do Congresso era de "regeneração" da monarquia e dos Direitos tradicionais da nação portuguesa, os quais, estipulados desde a formação do Reino, haviam sido desvirtuados pelo absolutismo, em nome da "idéia sacrílega" do poder divino dos reis. O "soberano Congresso" aparecia, nesse discurso, como legítimo herdeiro das antigas Cortes. A proposta de Constituição era a afirmação dos Direitos tradicionais e não uma transcrição dos publicistas modernos”. 300

Sociedade formada pela intolerância, sob a égide do poder oriundo da exploração do braço escravo, o estado que se formava no Brasil era afeito as benesses para as camadas favorecidas, os

\footnotetext{
${ }^{298}$ SCWARTZ, Stuart B. Segredos internos: engenhos e escravos na sociedade colonial, 1550-1835. São Paulo: Companhia das Letras, 1988. Op. Cit. p. 208.

${ }^{299}$ Ibidem. p. 224.

${ }^{300}$ BERBEL, Márcia Regina. A nação como Artefato: deputados do Brasil nas cortes portuguesas (1821-1822). São Paulo: Hucitec: FAPESP, 1999.p.52.
} 
proprietários de terra. Não causa nenhuma surpresa ser o estado brasileiro formado a partir dos interesses das classes abastadas, ilustradas e fechadas em seu mundo "ilustrado". As simetrias entre o nascente estado brasileiro e a monarquia lusitana não eram poucas nem tênues, eram óbvias. Sem corte com as bases herdadas do passado, o Liberalismo brasileiro, ao mesmo tempo em que suscitou a negação da ordem colonial reforçada pela busca da soberania, fora muito bem conduzido por uma elite que buscava não abrir uma maior participação política a outros grupos sociais, mas tão somente romper com a antiga situação de colônia. Assim é que as bases políticas constitucionais do novo Brasil só podem ser compreendidas tendo em vista o movimento de independência, que trazia consigo todo o poder senhorial legitimado por uma corrente ideológica por demais artificiosa e certeira. De maneira genérica, o Estado nacional brasileiro nascia sob a égide das elites agrárias que manifestaram a aversão ao pacto colonial, mas sabiam dos limites desse Liberalismo, vigiando atentamente o olhar sob a propalada soberania. Fernando Novais e Carlos Guilherme Mota sintetizam bem o Estado nacional brasileiro

\footnotetext{
"Não se tratava propriamente de contestar os fundamentos da organização do regime monárquico. Estava-se, antes, diante do que Vicente Barreto denominou "Liberalismo monárquico da Restauração”. O próprio constituinte Antônio Carlos, durante a Assembléia, combaterá seus oponentes que vinham, segundo dizia, com a "arenga da Assembléia Constituinte que em si concentra os poderes todos". Ora, a monarquia era anterior, $e$ qualquer ampliação "seria usurpação". Nesse sentido, no novo pacto social, o Executivo surgia fortalecido, com o monarca ocupando o centro da organização política.

O revolucionário da época do Reino Unido via-se parcialmente amortecido e canalizado após 1822. A revolução intentada mostrava sua verdadeira face, ao buscar o estado ideal dos proprietários, preservando a dinastia. As justificativas mais sólidas foram encontradas nas idéias do jurista Benjamin Constant, que forneceria aos liberais e ao próprio imperador os elementos para o controle da vontade popular, definindo sua extensão e seus limites. Ao dirigir-se aos constituintes, pela pena de José Bonifácio, o imperador definiria claramente tais limites, oferecendo idéias para uma constituição que pusesse "barreiras inacessíveis ao despotismo quer real, quer aristocrático, quer democrático" e afungentasse a "anarquia". Mas os constituintes ultrapassaram, com seus debates, os limites visualizados pela dinastia, vendo dissolvida a Assembléia e outorgada a Constituição de 1824, em que se preservava o livre-cambismo e consagrava-se a base jurídica para o Estado de proprietários, a partir do voto censitário" 301.
}

Mesmo que se tratasse de um projeto, a idéia de nação era forjada por homens ilustrados, por uma elite rural coberta de etiqueta de nobreza. Foi essa elite europeizada e treinada nas universidades européias que lançou as sementes para a formação do Estado brasileiro, seguida de suas peças constitutivas: a nação e a consciência nacional.

${ }^{301}$ NOVAIS, Fernando Antônio. A independência política do Brasil. 2a . Ed. São Paulo: Hucitec, 1996.p.75. 


\section{5 - Por um Brasil moderno!}

1869: culturalmente falando, verifica-se no Brasil uma ruptura com o passado. A partir de então, as estruturas econômicas, políticas e mentais do país seriam arduamente reprovadas por Sílvio, apoiado em padrões e visões emanados da Europa. Nesse momento, o país seria pensando e projetado conforme idéias europeias, que reforçavam e sustentavam retoricamente, segundo o crítico, o atraso brasileiro. Atraso esse visto por Sílvio como refletido nas mais diversas áreas, o que fez dele um homem que enveredou pelo campo não apenas da Crítica literária, mas pelos mais variados ramos do conhecimento. Desse modo, interessou-se por História, Filosofia da História, Folclore, Sociologia, e História literária do país.

Sílvio Romero se formou na condição de um novo modelo de bacharel, não mais preso às instituições arcaicas; esse novo intelectual tinha a visão europeizada que ia de encontro à mente conservadora da elite anterior. O poderio econômico do bacharelado de outrora estava ligado uma visão política conservadora que não possibilitava uma forma de representação política a grande população, embora tenha o Brasil presenciado focos liberais em prol de melhores formas representativas. A sociedade imperial, adormecida sob o manto do governante, significava o atraso do país, e não é sem razão o combate de Sílvio ao pensamento haurido pela Igreja Católica, uma visão diletante, hermética, heurística, que não interessava ao crítico, uma vez que só legitimava uma sociedade de senhores e pobres.

Sílvio era um homem que visava a alterar todo esse quadro do atraso do país, daí seus ataques em várias frentes, fosse no campo político, literário, filosófico etc. Suas antipatias se davam por conta da estagnação de nosso ensino retrógrado, não baseado nos preceitos da Ciência da época. Na política, era Sílvio um defensor de um Estado forte, descentralizado, que não caísse em mãos oligárquicas e chegou a elencar as províncias e seus respectivos oligarcas. No campo filosófico, nada sobrou para ele da Filosofia ensinada por padres. Na História literária, rogava ter sido o primeiro a elaborar uma História da Literatura Brasileira conforme os padrões do que de mais novo existia na Crítica moderna. Sílvio pretendia ser por excelência um homem moderno.

Sua ânsia de modernizar o Brasil a partir da ampla renovação cultural a que se propôs só tem sentido se entendermos que Brasil atrasado era aquele que o escritor tanto combateu. Antes da imagem de Brasil fornecida por Sílvio quando de sua empreitada modernizante, os elementos para a visão do país estavam por conta do clero, propagador das Letras latinas e disseminador da evangelização. O que existia era a preocupação com temas como a existência de Deus e a base de apreensão do conhecimento - no caso, o Espiritualismo. A tradição cristã herdada pelo ensino católico serviu para 
integrar o Brasil, num momento em que não existia uma visão realista do país, tratava-se de uma leitura para dentro. Nesse cenário, o que predominava era uma tradição literária e eclesiástica na qual a tendência ao diletantismo, somado à hostilidade pelo trabalho manual, dificultava o interesse pelas Ciências Naturais: "formou-se, por esse modo, a tendência intelectualista e literária que se desenvolveu por mais de três séculos, para o bacharelismo, a burocracia e as profissões liberais. Se para ela devem ter concorrido às tradições intelectualistas do judeu, a cuja influência Gilberto Freyre atribuiu o gosto pelo anel do dedo, com rubi ou esmeralda, do bacharel ou do doutor, e a mania dos óculos e do pince-nez, "reminiscência oriental, de saber israelita”, é certo que nenhuma influência nesse sentido, na Metrópole e na Colônia, foi maior do que o sistema de ensino e a cultura que dele resultou”. ${ }^{302}$ Bem sintetiza Fernando de Azevedo, referindo-se a essa cultura, que "a formação intelectual que recebiam, eminentemente literária, orientada não para a técnica e a ação, mas para o cuidado da forma, adestramento na eloqüência e o exercício das funções dialéticas do espírito, não podia fazer desses mestres em Artes e licenciados senão letrados, imitadores e eruditos, cujo maior prazer intelectual consistia no contato com os velhos autores latinos". 303

Sílvio Romero foi o oposto dç intelectual caracterizado por Azevedo, cultor da Arte e mais preocupado com a vulgarização dos clássicos latinos do que com a aplicação do conhecimento na resolução dos inúmeros problemas de seu país. A começar pelo combate à Retórica, que para Sílvio soava a tradicionalismo, uma vez que ia de encontro a sua vasta erudição naturalista, que foi um dos cernes de suas críticas ao ensino de cunho metafísico. Não se tratava de uma mera crítica ao estilo ou forma de ensino, mas a toda uma visão concebida como representação direta da elite fundiária, que, por sua vez, formou-se sob o tradicionalismo coimbrão. Ainda que pareça determinista a associação entre o ensino retórico de cunho ornamental, característico do Brasil colonial, que não desapareceu mesmo depois de instalada a república, ao tradicionalismo cultural, foi nota predominante processada pelo ensino jesuítico, no qual se prestigiava o culto às humanidades clássicas, até o momento de ruptura, representado pela influência promovida pelo bispo e governador Azeredo Coutinho. Frente a um cenário desssa natureza, tornava-se cada vez mais difícil o surgimento espontâneo do espírito crítico, o que veio a ocorrer somente com a geração de Sílvio. Ainda que já nos fins do século XVIII tenha o Brasil visto emergir uma série de pesquisas em decorrência das necessidades da metrópole, ligadas ao interesse em desvendar o potencial do solo e do clima, nesse momento já principiara uma nova situação. Lembra Maria Odila Silva Dias que "o fomento e a difusão dos estudos naturais na colônia, até então tidos como "suspeitos e ignóbeis", constituíam fenômeno inteiramente revolucionário se o confrontarmos com os moldes do ensino jesuítico que predominava até o

\footnotetext{
${ }^{302}$ AZEVEDO, Fernando de. A cultura brasileira: introdução ao estudo da cultura no Brasil. 4a ${ }^{\text {a }}$ Ed. São Paulo: UNB, 1963.

${ }^{303}$ Ibidem. p. 278
} 
momento. Particularmente interessante e digna de nota foi a fundação, em 1798, do Seminário de Olinda, pelo bispo D.José Joaquim de Azeredo Coutinho, com um currículo inteiramente voltado para a modernização do ensino, dando ênfase especial à Botânica e à Mineralogia”. 304

Tal afirmação nos leva não apenas a tomar conhecimento de que as interpretações deste novo Brasil partiam do que oferecia o repertório de idéias de fora, mas antes de tudo nos força a esboçar com qual Brasil Sílvio se deparou em seu tempo para que dessa forma fiquem claras as razões de toda sua ânsia modernizadora.

A modernização proposta por Sílvio recaía sobre três fatores: o Ecletismo espiritualista, a Filosofia católica e o Positivismo. Lutar pela modernização do Brasil era, antes de tudo, eliminar o Ecletismo de Cousin, não mais que "uma Filosofia incoerente e pretensiosa, inimiga da observação $e$ da experiência, uma sortida no campo do absoluto, divinizado o homem por meio da razão impessoal. Entretanto, a Filosofia que tem por dogma a relatividade de todas as coisas, mudando de método e reforçando os seus princípios, continuava surdamente a acumular os achados e da fortalecer a verdade". 305

A citação acima não poderia ser mais fiel a um homem formado sob o espírito crítico, caracterizado por Sílvio Rabello como um homem de espírito geométrico, que buscou mudar o Brasil, tendo que, para isso, enveredar pelas mais variadas áreas de conhecimento, não abrindo margem para a simples especulação, fosse literária ou científica. Para além das fortes críticas de Sílvio ao Ecletismo, a importância dessa corrente fora por demais relevante para o desenvolvimento da cultura brasileira: "Victor Cousin foi vítima de mesquinha disputa literária e acabou passando à posteridade como uma figura de segundo plano graças ao que escreveu Hippolite Taine (1828/1898) em Lês philosophes classiques du XIX siècle em France. A chamada geração de setenta investiu furiosamente contra a Escola criada por seus discípulos no Brasil, sem reconhecer-lhe qualquer mérito, salvo Tobias Barreto (1839/1889) que, mesmo encampando as Críticas proclamava ter-lhe despertado o gosto pelos estudos filosóficos". 306

A Filosofia católica, personificada pela figura central do franciscano Montalverne, mais Eduardo França e Gonçalves de Magalhães, sofreu duros golpes de Sílvio, pois se mostrou "tão pobre, tão insalubre foi o alimento que lhe forneceu a cultura de sua pátria, em seu tempo; tão ingratas as influências a que teve que ceder, que a Crítica sente-se com impulsos de o absolver,". 307

\footnotetext{
${ }^{304}$ DIAS, Maria Odila Leite da. A interiorização da metrópole e outros estudos. São Paulo: Alameda, 2005. p. 53

${ }^{305}$ ROMERO, Silvio. A Filosofia no Brasil. In. Obra Filosófica. p. 16

${ }^{306}$ PAIM, Antonio. Escola eclética. Estudos Complementares a História das idéias filosóficas no Brasil. Vol. IV. $2^{\text {a }}$. Ed. Londrina: CEFIL, 1999.p.5

${ }^{307}$ ROMERO, Silvio. A Filosofia no Brasil. Op. Cit.p.13
} 
A Crítica de Sílvio à qualidade do ensino de cunho religioso que formou a mentalidade das elites brasileiras, divulgada nos seminários e nos ateneus, era antes de tudo a Crítica ao atraso do país, sem estabelecimentos educacionais e culturais de bom nível e que sempre copiava os costumes e as idéias que vinham de fora, especialmente, da França, criando uma imagem de si mesmo irreal, o que muito contrariava os anseios do bacharel.

Foi contra o Positivismo que Sílvio elaborou uma análise mais detalhada, não porque menosprezasse o poder das idéias anteriores, pois estas vigoraram por longo tempo, mas sim porque era a Filosofia de Comte que punha em risco toda sua empreitada modernizadora, por isso merecia ser combatida: “a pretensão positivista de formular nova síntese, novo dogma, nova doutrina, novo culto, novo poder espiritual, novo clero, que devam guiar a humanidade e, como a maravilha suprema, trazer-lhe a paz geral e absoluta, por ser a sintese e o dogma e a doutrina e poder espiritual e o clero definitivos e finais, tal pretensão não tem o menor fundamento histórico e psicológico.” 308

Para alguns intérpretes de Sílvio, ele não pretendia propriamente uma síntese da cultura brasileira, buscava entender o país a partir das leis sociológicas, no tempo, influenciado pelo Evolucionismo, ele promoveu uma detida análise do Positivismo em seu livro Doutrina contra Doutrina, guiando-se pela visão de Spencer. Nessa perspectiva, a Filosofia de Comte, ainda que elaborada por etapas, chocava-se com a concepção evolucionista de Spencer.

A modernização do país passava inevitavelmente pela crença em que, a partir da cultura e do conhecimento dessa concepção, tornava-se possível aquela Modernidade. Já é essa uma visão modernizadora quando comparada com aquela que permitiam a Igreja Católica e o Romantismo brasileiro, onde não existia uma relação entre as causas e os efeitos. Sílvio rompeu com o Culturalismo de Tobias Barreto, promoveu uma aproximação entre cultura e natureza. Ao contrário de Barreto, que não acreditava na Sociologia e na Psicologia como Ciências, Sílvio punha todas as áreas em condição da análise científica - História, Sociologia etc.

A Escola do Recife era um projeto reformador que não deixava de ser ambicioso uma vez que almejava alterar todo o cenário brasileiro em busca da modernização. Outros grupos modernizadores se formavam no Brasil, como a Academia Francesa ${ }^{309}$, formada justamente por bacharéis que saíram do Ceará para estudarem na Faculdade de Direito do Recife e quando retornaram a sua província de origem divulgavam o que de mais novo existia no plano das idéias científicas. Surgida para divulgar os benefícios de uma sociedade regida pelos avanços da Ciência moderna, a Academia Francesa, nome

\footnotetext{
${ }^{308}$ Ibidem. p. 325

${ }^{309}$ COSTA FILHO, Cícero João da. Padaria Espiritual: cultura e política em Fortaleza no final do século XIX (1892-1898). Dissertação de Mestrado apresentada a Faculdade de Filosofia, Letras e Ciências Humanas de São Paulo, 2007. pp. 63-64. BARREIRA, Dolor. História da Literatura Cearense. Fortaleza: Instituto do Ceará, 1948. AZEVEDO, Sânzio de. A Academia Francesa do Ceará (1873-1875). Fortaleza: Casa de José de Alencar da Universidade Federal do Ceará, 1971.
} 
escolhido por gracejo e que "acabou pegando" para se contrapor a outros centros, também redutos das idéias novas, como Recife e, remotamente, São Paulo, era um movimento filosófico, segundo o crítico Tristão de Ataíde. A “moderna geração cearense” era constituída por Rocha Lima, Capistrano de Abreu, Thomas Pompeu de Souza Brasil Filho, Xilderico de Faria, França Leite, Araripe Junior, Antônio José de Melo, Felino Barroso e Amaro Cavalcante.

A designação "Academia Francesa", escolhida por Rocha Lima - o mais novo de todos -, era inspirada pelo simples fato de seu grêmio recorrer às leituras de autores franceses em contraposição ao grupo "moderno" de Recife, que se baseou também em obras de pensadores alemães. O grupo da Academia Francesa se reunia na casa de Rocha Lima, segundo Capistrano de Abreu, a "mais fulgurante estrela" que rebentou no Ceará.

No Amazonas, surgiu a Revista Amazônica e bem antes que as demais regiões brasileiras uma universidade, que contou com a colaboração de José Veríssimo, no momento em que grupos positivistas e evolucionistas se formavam respectivamente no Rio e em São Paulo e quando surgiam os germanistas do Rio Grande do Sul.

A personalidade de Sílvio não permitia reconhecer a existência desses grupos, o que confundia a Escola do Recife com sua própria imagem: "o maior crítico da Escola do Recife tomou a valorização do legado de Tobias Barreto como uma questão pessoal, o que fez com que muitas de suas polêmicas tenham tido, como ponto de partida, a defesa do "amigo" atacado por "adversários desleais". Romero fez a apoteose ou o elogio irrestrito de Tobias Barreto de Menezes, o bacharel pobre e mulato que, apesar dos conflitos com a Faculdade de Direito do Recife, acabou por fazer parte de seu corpo de professores". 310

Foi através do grupo fundado pelo mulato e também sergipano Tobias Barreto que Sílvio obteve repercussão nacional. Se a Escola do Recife não tem existência real, como apregoa José Veríssimo, o escritor paraense reconhece e elogia a importância da História da Literatura de Sílvio, caracterizando seu autor como um escritor arrojado e de caráter aguerrido. No que pese a confusão entre Sílvio e o grupo de leitores da Faculdade de Direito, é inegável a importância desses jovens bacharéis em busca de modernizar o Brasil. Tomando conhecimento das leituras de Kant, Bagehot, Joufrroy, que se propunham por a prova de que maneira se apreendia o conhecimento, o que prevaleceu foi uma interpretação científica. Nesse sentido, conhecendo as leis da História e da Sociologia, mais fácil se tornaria resolver os males brasileiros. Tratava-se, pois, de um movimento fortemente nacionalista, que trazia para fora o que ainda não havia sido tocado e que agora passava a ser encarado de maneira crítica. Essa Crítica que Sílvio tanto buscou elaborar em sua concepção era a própria prova da

\footnotetext{
310 VENTURA, Roberto. Estilo tropical: História cultural e polêmicas literárias no Brasil, 1870-1914. São Paulo:
} Companhia das Letras, 1991. p.140 
Modernidade. "A Escola do Recife estimula e desenvolve o interesse e o amor pela produção intelectual brasileira, herdada dos primeiros românticos, mas despindo-a da feição ingênua de que se revestira. Esse trabalho agora assume a forma de inventário, pretende-se científico e duradouro. Embora não tenha autoridade para dizer-lo, tenha a impressão de que se revestem desse caráter o que nos legaram em matéria de História da Literatura brasileira, de registro de manifestações folclóricas e da cultura popular." 311

Muito antes do ousado plano iniciado por Tobias Barreto, houve manifestações de reforma como a promovida pelo Marquês de Pombal, defendendo a cultura portuguesa, o de Luís Antônio Verney, objetivando alguns segmentos da cultura, e o programa dos ecléticos, cuja ambição era reformar todas as instâncias culturais. Aqui, sobressai a figura de Gonçalves de Magalhães, "O primeiro em data dos nossos homens de Letras, e um dos maiores pela inspiração fundamental, variedade e ainda mérito da sua obra. Pode dizer-se que ele inicia, quanto ela é possível aqui, a carreira literária no Brasil e ainda no Brasil e ainda por isso é um fundador", ${ }^{312}$. Mas, o plano do grupo de jovens bacharéis era ambicioso. Era ousado não apenas porque disseminava saberes e assim tornava possível o surgimento de novos campos, como por exemplo, a Ciência jurídica, mas porque buscava por em prática nos mais variados planos o projeto modernizador discutido pelo grupo.

O projeto reformador tanto no plano cultural quanto político e social, calcado nas leis científicas, formadoras dos novos campos do conhecimento, confundiu-se com a visão de Sílvio no sentido em que o escritor sergipano pôs em prática as ideário científico dessa modernidade. Atesta Paim que "Essa preferência pela vida espiritual no que ela tem de mais nobre e elevado configura bem o eixo do projeto da Escola do Recife. Reformar o país é alterar e redirecionar essa camada mais alta de sua tradição cultural, inclusive a meditação de caráter ético. É certo que, como disse, visaram também às instituições políticas, mas sempre com esse vezo intelectualista, tão bem caracterizado por Evaristo de Moraes Filho, a que pretendo voltar para exame mais detido. Na medida em que o país não os segue é que irão dar-se conta de que a cultura tem efetivamente um "mundo subterrâneo”, constituído pela tradição da vida cotidiana, a que chamaram ora de costumes ora de Psicologia coletiva”. 313

Não sabemos de que outra forma poderiam se dirigir tais bacharéis às estruturas do país sem esse vezo intelectualista que fala Paim. Apesar das várias leituras conhecidas no âmbito da Escola do Recife, esse repertório integrava e era o próprio projeto modernizante. Em todas as frentes se dava o ataque ao Brasil arcaico para a construção do moderno Brasil. Não existe exemplo melhor desse projeto modernizante do que a figura do próprio Sílvio Romero. Buscando um ponto de partida em sua

\footnotetext{
${ }^{311}$ PAIM, Antonio. A Escola do Recife. Londrina: UEL, 1999. p.95

312 Ibidem. p. 93

${ }^{313}$ Ibidem. p.94
} 
empreitada modernizadora, Sílvio partia sempre do que tinha fundamentação científica. A Ciência era seu único instrumento de análise, somente a Crítica filtraria o que podia se aproveitar do que ficou do passado brasileiro. Era assim que Sílvio partia para as leituras de seus Comte e seus Buckle, dos seguidores da Escola de Ciência Social e dos escritores que chegou a considerar como seus mestres para decretar a morte do Brasil do passado.

Sua visão é a de um experimentalista objetivando mudar a sociedade em que vive. Daí se entender que Sílvio nunca ficou apenas no terreno da Crítica literária, nunca viu Literatura como apenas Arte, nunca separou Teoria de prática, nunca se prendeu à pura especulação. Apegou-se à Escola de Le Play porque esta lhe permitia observar de maneira objetiva a trama da sociedade, visando a identificar que sociedade era a nossa e como esta tinha sido formada. Tal era a maneira como Sílvio pensava que tinha conclusões certas sobre o brasileiro, uma delas, a de que este era apático por nascimento devido a sua formação não particularista ou individual, o que não possibilitou o desenvolvimento do povo brasileiro e do país. Eram explicações baseadas no que oferecia a Ciência da época. Tínhamos um caráter que explicava até no plano literário a apatia de nossas Letras e de nossos poetas que morriam precocemente.

Não é gratuito que Sílvio tenha fundamentado toda sua obra sobre essa falta de iniciativa, mostrando o caráter brasileiro não interessado pelas coisas nacionais e que, imerso nas vilas, se prendia ao chefe local em busca apenas do que comer. Esse caráter explicava a situação de atraso do Brasil. Num país onde milhares de pessoas trabalhavam para manter uma pequena elite no poder, seria necessário conhecer os escritores da Crítica moderna para alterar tal estado de coisa. $\mathrm{O}$ atraso do país tinha suas causas e como um cientista, Sílvio identificava quais elementos eram esses. Um deles era a raça, a História do país teria sido outra se outra tivesse sido a raça colonizadora pois esta se encontrava em estágio de degradação. Segundo Sílvio, há um passado em que nada se aproveira, uma herança que só com o mestiço abre a esperança de um Brasil moderno.

Diversas eram as idéias de sua época, mas a que prevalecia era a de evolução, que serviu para articular a visão de atraso e conseqüentemente abriu novas perspectivas para sua superação. O apelo de Sílvio pela instauração da Crítica Moderna era apenas instrumento para subtrair o atraso de seu país e instaurar a Modernidade no mesmo. Antes de elencarmos alguns dos elementos constitutivos desse atraso, temos que ressaltar que a imagem de um Brasil atrasado só tem razão de ser em função do laboratório racial aqui existente, o que abria uma questão mais profunda que era sermos um país de Economia rural apoiada no braço escravo. A Modernidade do país passava pela nova fase de industrialização requerida pelo cenário europeu, que tornava os países periféricos consumidores das mercadorias daqueles e meros imitadores dos ares modernos. 
Entender a busca da tão alardeada Modernidade era irremediavelmente fazer uma revisão da História do país nos mais variados âmbitos, e foi o que tentou Sílvio. O intento de Modernidade de Romero recaía sobre todos os temas relacionados ao Brasil, o que levou o escritor a buscar nos mais variados campos do saber os fatores do atraso nacional.

Sílvio nada viu de positivo no Brasil de outrora, seus estudos de política social e até mesmo de História e Crítica literária somente atestam as razões do atraso nacional. Não são poucas as Críticas severas do bacharel ao Brasil, o que levava o escritor sergipano a buscar nossas heranças e tentar entender seus porquês. Seu intento ganhou fôlego e se confunde com a formação de escritores bacharéis em torno da Faculdade de Direito do Recife, agremiando nomes como os de Clovis Bevilaqua, Arthur Orlando, Fausto Cardoso, tendo como figura central o mulato e professor Tobias Barreto.

Ricardo Bechelli é categórico e pontual quando afirma que, "A obra de Sílvio Romero, mais que tudo simbolizava uma contestação ao Brasil "arcaico" do período monárquico e abria caminho para uma modernização do pensamento brasileiro, mesmo que, com suas crenças nas doutrinas raciais, isto produzisse uma tensão, uma contradição dentro de seu pensamento, que levaria inevitavelmente a uma contestação das mesmas Teorias, o que não acabou acontecendo nas obras de Sílvio Romero, mas sim em autores que vieram depois e se utilizaram de suas idéias, tais como Gilberto Freyre". 314 (grifos nossos)

Um breve olhar sobre esse grupo de intelectuais deixa clara a ousadia de promover uma reviravolta cultural a partir do conhecimento científico. Mesmo que tais posturas fossem díspares e as posições políticas divergissem, o plano dos jovens bacharéis de buscarem a compreensão repousada na cultura denota a ansiedade pelo que havia de mais avançado para época. Num meio nada propício à fermentação das ideias, até um jornal em alemão fora publicado, possivelmente tendo como único leitor o próprio autor - no caso, Tobias Barreto.

Entre as diferentes interpretações desses jovens bacharéis de mentes européias, fundamental era utilizar a física social de Comte, acompanhada da idéia de evolução, pois assim, junto à observação, estava a idéia dos três estados e da lei do mais forte. Mas nem todos os integrantes do grupo concordavam em que as leis mecânicas fossem capazes de explicar alguns problemas, ou seja, uma área do conhecimento que para um poderia ser elevada à categoria de Ciência, para outro apenas podia ter uma orientação científica. Assim como pairava a enorme credibilidade do Monismo de Haeckel e do Evolucionismo, ponto de vista que mais atraiu seguidores, a Modernidade era o próprio projeto

\footnotetext{
${ }^{314}$ BECHELLI, Ricardo Sequeira. Metamorfoses na interpretação do Brasil: tensões no paradigma racial (Sílvio Romero, Nina Rodrigues, Euclides da Cunha e Oliveira Vianna. São Paulo, 2009.p. 61.
} 
desses bacharéis que acreditavam que o conhecimento de causas possibilitava alterar a situação brasileira. A intenção reformadora de toda a sociedade brasileira era um Positivismo no mais alto grau, era a crença em que tudo tinha uma causa e que a partir daí a situação do país poderia ser alterada. Buscar entender a ousadia do grupo do Recife, de onde sai o enfurecido Sílvio Romero, criticando tudo e todos, é tentar compreender o projeto de modernização desse grupo de bacharéis.

Os integrantes do grupo do Recife se mostraram modernos não por serem somente avessos ao Brasil do passado, pois existiram outros homens de sua geração que também criticaram o passado, mas sim porque foi do bojo de uma estrutura estritamente "liberal" que emergiu a possibilidade de várias leituras de Brasil. Não basta afirmar que a Modernidade de homens como Sílvio tem como característica principal a mera alusão a uma gama de nomes da Ciência da época, como Comte, Taine, Scherer e tantos outros, porque as leituras foram passíveis de interpretações diferentes. O que é de destacar é a existência de um grupo de bacharéis que, para entender o Brasil, colocaram em discussão novas ferramentas de análise, onde se destaca o método crítico de Sílvio Romero.

Não podemos simplificar a figura de Sílvio em seu Determinismo, seu caráter de polemista nato e suas contradições. Romero encontrou pela frente um Estado que não estimulava o desenvolvimento da Ciência, em que bem se acomodava a estrutura arcaica dos bacharéis formados em Coimbra. Este ensino "acomodava-se bem com as tradições, continuou a condicionar a nossa formação intelectual, com raras exceções, e permaneceu impermeável ao progresso científico, do qual desconfiava como de inovação perigosa compreendendo que a pesquisa e a descoberta substituem de certo modo a autoridade e a transmissão de verdade seculares. Nada de extraordinário, pois, que fosse um sistema educacional bem aceito pelo patriciado rural, conservador e cioso de autoridade. A formação jurídica, não afetada pelo sopro renovador do Grande Marquês e transmitida às nossas faculdades com o velho formalismo canônico, pouco contribuiu para a emancipação do espírito, embora contribuísse para a paisagem cultural com o tipo urbano e anti-patriarcal do bacharel, tornando-se quase símbolo depois do estudo de Gilberto Freyre". 315

Foi relevante a atenção dada pelos escritores românticos brasileiros chamando atenção para temas nacionais, sobretudo, a busca de uma língua nacional, contexto no qual presenciamos a posição de polígrafos como Capistrano e Alencar, a importância do financiamento das comissões científicas pelas áreas desconhecidas do Brasil, objetivando descobrir potencialidades do meio brasileiro, mas é somente a partir da argumentação sobre um Brasil atrasado que emerge o Brasil moderno pela mente de seus polígrafos. Nessa ótica, Antonio Candido comenta sobre Sílvio: “ora, num Brasil entorpecido pelas humanidades, que sob aspectos constituíam verdadeiro fenômeno de inércia cultural, a

${ }^{315}$ CANDIDO, Antônio. Introdução ao método crítico de Silvio Romero. Op. Cit. p.179 
campanha pela cultura científica e pela revisão filosófica apareceu como força de renovação mental. A Crítica de Sílvio, tão profundamente ligada a ela, corre paralela ao incremento dos estudos de matemática, relacionados em parte com o Positivismo: a intensificação dos estudos de Ciências Naturais; a constituição da etnografia e da Etnologia brasileira; a transformação do Direito sob o influxo do Evolucionismo; a fundação da escola de Minas, etc. Um verdadeiro movimento de despertar, através da revalidação dos padrões da cultura". ${ }^{316}$ (grifos nossos)

Antes de toda essa revalidação dos padrões culturais, era o Brasil um país de Economia agrária onde a sociedade era formada a partir do poder oriundo da quantidade de escravo e da posse da terra: era a civilização agrícola que menciona Gilberto Freyre. Não há como compreender a Modernidade tentada pelo bacharel sergipano e todo um grupo de escritores sem mencionar o mundo que se abria para estes. Ao ver nascerem somente nos idos de 1870 incipientes classes médias, portas-vozes diretas da modernização brasileira no Brasil, nas faculdades de Direito ou de Medicina, muita coisa havia acontecido no país combatido por Sílvio. Onde repousava o atraso brasileiro, ou de outro modo, quais os elementos desse atraso? Sílvio era voz única nesse cenário? Como fugir de um Brasil atrasado e alcançar o seu contrário, o Brasil moderno?

A considerar que os meios de tomada formal de conhecimento são acessíveis somente às elites, o que deu a tônica para a formação da elite brasileira formada nas universidades européias, não é sem razão que data do término do decênio de 60 do século XIX a absorção no Brasil do surto de idéias novas que iam de encontro ao atraso brasileiro. Embora não seja adequado fazer uma associação determinista entre o mundo das idéias e a classe social, uma estreita elite era conhecedora do que existia de mais avançado no campo da Ciência, não podemos excluir que esses portas vozes integravam um privilegiado status social. Sílvio Romero era filho de um comerciante português bem estabelecido, casado com uma filha de senhores de engenho. Vamos entender os diversos pontos de sua Crítica a partir da situação brasileira da época, quais os caminhos apontados por ele, em que se apóia sua ampla e desmedida renovação mental no amplo campo da cultura. Quando Romero se empolgava com o bando ou o revoar de idéias novas, acreditava que determinado conhecimento oriundo de países "civilizados" trouxesse a chave para o surgimento de Brasil moderno.

A Modernidade do Brasil, defendida por Sílvio, era formada não sob a ótica do Direito canônico, mas conforme a tônica naturalista. Essa Modernidade fora defendida por vários escritores, que mesmo com divergências ideológicas face às interpretações das Teorias européias ou diferenças de posição de classe não titubeavam quanto à situação de atraso do país. Buscou Sílvio, assim como muitos de seus contemporâneos, combater os males do atraso brasileiro, na crença de que, estudando a colonização

\footnotetext{
${ }^{316}$ Ibidem. pp. 179-180
} 
portuguesa e sua responsabilidade nos mais variados setores, fosse possível entender e, como conseqüência, projetar e construir um Brasil diferente. Romero foi um escritor moderno, muitas vezes áspero, que a todo custo queria ver o Brasil surgir dos tantos escritores europeu lidos no fervoroso momento.

O Brasil não era a Europa. Nem por isso Silvio deixou de acreditar numa das ideologias mais importantes do momento, a ideologia do caráter nacional, surgida das necessidades para criação dos estados nacionais modernos. Buscando autores que acreditavam nas forças do meio e da raça como fatores explicativos de todo um quadro social, Sílvio precisou não apenas acomodar e dar sentido às idéias estrangeiras no Brasil, como também teve que mostrar porque assumia tais idéias. Para isso, era indispensável conhecer a História brasileira a fim de prover sua análise. Romero se depara com um país atrasado e é dali que surgiria o Brasil moderno, almejado por ele mesmo.

Escritor que sempre deixou claro que nunca escrevia para agradar, mas sim para identificar os problemas de seu país, o Brasil que Sílvio almejava era um novo país. O passado brasileiro não deixou praticamente nada de positivo para Sílvio. O Império, nas mãos do imperador Pedro II, os intelectuais que transitavam entre o IGHB e o contato com os românticos, a Educação propagada nos seminários, de cunho eclético e banhada de Metafísica, a série de corrupções da elite política que não possibilitava nenhum interesse pelos reais problemas nacionais, tão pouco a paixão pelo país, e acima de tudo, o desconhecimento daquilo que poderia alterar todo esse conjunto de coisas, no caso, das Teorias européias em voga na época: eis o conjunto de alvos de suas falas. De posse de idéias que explicavam os mais variados porquês dos problemas brasileiros, nada parecia passar desapercebido para seu olhar. 317

Não sendo antes possível a busca pela Modernidade num país que teve o início de desenvolvimento cultural apenas com a vinda da Corte Portuguesa, é com o aparecimento das faculdades de Direito que se tornou viável o projeto de modernização do país. Independente, voltando o olhar para suas particularidades em busca de uma identidade, com a instauração de uma rede de estabelecimentos de Ensino, institutos históricos e museus é que pode ser possível a modernização do país, o que era indispensável para esse novo Brasil, que não estava disposto a colocar no poder políticos autoritários responsáveis pelos mais variados desmandos.

Sílvio foi um porta-voz da Modernidade porque surgiam no país elementos nunca vistos, integrando toda a série de transformações técnicas e econômicas que acabavam por refletir também no campo das idéias, para que só assim se tornasse possível consolidar o novo Estado brasileiro. Não é sem razão que Mariza Corrêa pontua que “o saber organizado por ela apareceria a seus próprios

\footnotetext{
${ }^{317}$ DIMAS, Antonio. O turbulento e fecundo Sílvio Romero. Op. Cit. ABDALA JUNIOR, Benjamin. História da Literatura
} Brasileira. In: Introdução ao Brasil. Um banquete nos trópicos, 2. São Paulo: Editora SENAC, 2001. 
olhos como o resultado da apreensão, pela Ciência, das leis que regiam as relações entre os homens, leis que seriam socialmente, institucionalmente, institucionalmente reforçadas. Tentando aprofundar o conhecimento da nossa realidade, as novas "classes ilustradas" chegariam, por vias transversais, a uma problemática que era também central no pensamento científico europeu e norte americano do seu tempo: como dar conta, teoricamente, das evidentes desigualdades concretas entre os homens" 318

Mesmo que se levem em conta as diferenças com relação às interpretações das idéias de fora somadas às possíveis vertentes políticas, resta um substrato que pensamos servir de base para compreender a Modernidade de Sílvio e de toda sua geração. Compreender isso requer antes de tudo conhecer o Brasil de sua época, para que daí entendamos quais foram os elementos priorizados pelo bacharel, o que nos leva a compreender parte de sua Crítica e sua produção como intelectual.

O Brasil com que Sílvio se deparou era considerado "atrasado" porque predominava o prestígio do dono de terra de um lado, e de outro, havia uma massa despossuída, analfabeta, pobre e mestiça: era o Brasil agrário, onde o português teve que se sintonizar com um meio áspero e com raças que não possuíam a menor condição de alcançarem o estatuto de um "povo civilizado". Não bastasse a transplantação de toda a cultura portuguesa para o Brasil, formadora desse Brasil agrário, de uma sociedade conservadora, com uma "civilização do açúcar", como mostra Gilberto Freyre, seguido pelo ciclo do ouro, vendo surgir tempos depois o café, o que mais inquietava Sílvio era a visão da elite. Economia rural, dissipação do pensamento católico na formação da cultura brasileira no mais alto grau, despotismo, aparecendo com toda força o autoritarismo do imperador somado ao mandonismo local das elites regionais, formavam a estrutura arcaica do Brasil.

O problema maior não era a de ser o Brasil uma sociedade formada sob o ruralismo em que só a partir da segunda metade do século XIX, especificamente com a geração de Sílvio, presenciamos o surgimento de novas classes médias, embora boa parte desses grupos tivesse estreita ligação com as tradicionais elites fundiárias, mas sim ser o país acompanhado por um pensamento conservador onde predominava a força do doutor. Numa sociedade marcada pelo prestígio do dono de terra, do senhor de escravos e de uma camada de negociantes, frente uma grande maioria de analfabetos, de escravos e homens livres dedicados a pequenos ofícios, o cultivo ou o acesso às Letras era possível somente para uma minoria privilegiada e para aqueles que buscavam ao menos a garantia da sobrevivência, a solução era a formação religiosa. Para agravar esse quadro nada favorável ao interesse pelo conhecimento, as dificuldades só aumentavam diante da diversidade de grupos sociais presentes no Brasil colonial, que ia do degredado ao homiziado, o que dá sentido às palavras de Nelson Werneck Sodré: "na estrutura econômica levantada, e que só fez acentuar os seus traços, aprofundando o

${ }^{318}$ CORRÊA, Mariza. As ilusões da liberdade: a Escola Nina Rodrigues e a Antropologia no Brasil. Bragança Paulista, EDUSF, 1998. p. 33 
desnivelamento entre as classes, não poderia existir espaço para as cogitações do pensamento e ainda menos para as da criação artística. Teria sido um contra-senso, um absurdo". 319

O revoar das idéias novas que Sílvio tanto defendera era parte integrante de um novo país que se configurava. Na expressão de Sílvio de que era todo um mundo que vacila evidenciando os elementos constituintes do atraso brasileiro, a partir de então, estavam lançados os elementos do novo Brasil. Há que se ressaltar que 1850 é o ano em que surge a lei contra o tráfico de escravos, quando se passou a ver a canalização do dinheiro outrora aplicado na compra de escravos para outras áreas de investimento, o que forçava o Brasil a prover sua autônima financeira acompanhada da Modernidade de maneira ampla. Junto ao surgimento de ferrovias financiadas pelo capital inglês, assim como o surgimento de bancos que emitiam crédito, emergia uma nova visão de mundo, conseqüência direta do Liberalismo, por sua vez tributária da Revolução Industrial. O mundo sofria modificações na ordem econômica, panorama responsável pelo alvorecer do Positivismo, do Evolucionismo e do progresso, Filosofias de cunho utilitarista, bem típicas do primeiro momento industrial, "quando os homens, fascinados pelas novas possibilidades de manufaturar, pensavam todas as coisas em termos de meios e fins" ${ }^{320}$. A base do Brasil estava ruindo, como afirma Cruz Costa, "o principal esteio da monarquia, até então constituído pela aristocracia territorial, estava a braços com a crise que produzia com a extinção do tráfico, manancial de braços baratos que lhe havia fornecido até então a costa da África. Começava a se revelar, em toda a sua extensão, a precariedade de uma sociedade baseada na escravidão", 321

Se não bastasse a dificuldade do acesso à cultura, sendo esta um distintivo de classes e não deixando de possuir um cunho ornamental, vale lembrar que ela, até mesmo nas últimas décadas do Império, fora tonificada pelo desprezo em relação ao trabalho manual e como consequiência, pela primazia da investigação supostamente desinteressada. Civilização transplantada aos trópicos brasileiros, a cultura brasileira se fez à medida que se readaptava com a herança rural formada pelo senhor de terra e pelo que havia no momento, no caso, os costumes e valores do português colonizador, partícipe da formação cultural brasileira. Desde cedo, ficou evidente, dado um arcabouço estrutural conservador, a tendência à especulação associada ao menosprezo pela atividade manual. Vários escritores perceberam com nitidez a dedicação ou a tendência intelectualista e literária, mas Sérgio Buarque foi pontual quando afirmou que "o trabalho mental, que não suja as mãos e não fatiga o corpo, pode constituir, com efeito, ocupação em todos os sentidos digna de antigos senhores

\footnotetext{
${ }^{319}$ SODRÉ, Nelson Werneck. História da Literatura Brasileira: seus fundamentos econômicos. 4 ${ }^{\mathrm{a}}$. Ed. Rio de Janeiro: Editora Civilização Brasileira. p. 54.

${ }^{320}$ ARENDT, Hannah. Entre o passado e o futuro. 6ª Ed. São Paulo: Perspectiva, 2007. p.115

${ }^{321}$ COSTA, João Cruz. Contribuição à História das Idéias no Brasil. 2a . Ed. Rio de Janeiro: Civilização Brasileira, 1967. pp.119-120
} 
de escravos e dos seus herdeiros. Não significa forçosamente, neste caso, amor ao pensamento especulativo - a verdade é que, embora presumindo o contrário, dedicamos, de modo geral, pouca estima as especulações intelectuais - mas amor a frase sonora, ao verbo espontâneo e abundante, a erudição ostentosa, a expressão rara. É que para bem compreender ao papel que, mesmo sem o saber, lhe conferimos inteligência há de ser ornamento e prenda, não instrumento de conhecimento e de ação". 322

O Ensino e a cultura de tradição religiosa estavam para o senhor de terras assim como a escravidão estava para a monarquia brasileira. Durante os três primeiros séculos da colonização, o Ensino esteve nas mãos dos jesuítas, que estavam bem aparelhados com uma rede de escolas. Tudo compelia à disseminação de uma saber humanista misturado à força da Poesia de clássicos. Aliás, todo o processo de colonização realizou-se pelo Ensino católico, base da colonização portuguesa no Brasil, somada a um meio nada favorável ao desenvolvimento da Ciência.

Coube aos clérigos não apenas o processo de catequização ou conversão do cativo, como a disseminação das Letras no Brasil colonial. Embora o Ensino jesuítico não facultasse o despertar do livre pensamento, uma vez que se regia por um formalismo sem relação alguma com o meio ou com a terra, afirma Fernando Azevedo que ao menos serviu para integrar o país num momento em que não havia comunicação entre as províncias. No cenário das Letras, na época colonial, de um lado encontrávamos homens cultivadores de uma Educação precipuamente classista, admiradores de Horácio e Virgilio, por outro, reinava a grande massa analfabeta. Não se trata de menosprezar a importante contribuição de toda a tradição católica para a formação da cultura brasileira, pois como salienta Azevedo, nem mesmo as reformas e as tentativas de libertação conseguiram superar o forte predomínio mental da visão católica, e não foi a visão da Igreja a responsável pela falta de interesse pelas Letras no Brasil, uma vez que "nenhum outro Ensino, a não ser que a colonização tivesse sido diferente, o que não pertence à História, teria tido condições de sucesso, e nem havia possibilidades, numa sociedade dividida entre uns poucos grandes proprietários e numerosos escravos relegados a mais completa ignorância, para qualquer atividade intelectual. O Ensino jesuítico, conservado à margem, sem aprofundar a sua atividade e sem preocupações outras senão as do recrutamento de fiéis ou de servidores, tornava-se possível na medida em que não perturbava a estrutura vigente, condicionando-se aos imperativos do meio". 323

Capistrano de Abreu nos informa o quadro da situação mental da época, afirmando que " $a$ Educação reduzia-se a vivacidade e a espontaneidade dos pupilos. Meninos e meninas andavam nus em casa até a idade de cinco anos; nos cinco anos seguintes usavam apenas de camisas. Se porém iam

\footnotetext{
${ }^{322}$ HOLANDA, Sérgio Buarque de. Raízes do Brasil. 26a . Ed. São Paulo: Companhia das Letras. p. 83

${ }^{323}$ SODRÉ, Nélson Werneck. Op.Cit.p.57
} 
a Igreja ou a alguma visita, vestiam com todo o rigor da gente grande, com a diferença apenas das dimensões. Poucos aprendiam a ler. Com a raridade dos livros exercitava-se a leitura em manuscritos, o que explica a perda de tantos documentos preciosos" ${ }^{324}$. E mais, "gozavam de prestígio os padres, os genuínos representantes da mentalidade até o começo do segundo Império, quando os substituíram no cenário bacharéis formados pelas academias de São Paulo e Olinda. As virtudes de sua vocação raros possuíam, mas o caso de tão comum não causava estranheza”. 325

Prevalece até o surgimento das escolas formadoras de profissionais liberais (Engenharia, Medicina e Direito) o culto à especulação. Fora este caráter especulativo e supostamente desinteressado que predominou no Brasil nos três primeiros séculos, em que a importância da Retórica pronta para ser aplicada ao fazer literário, nos discursos, se fez presente, e que fora tenazemente combatida por Sílvio.

O pensamento conservador da elite agrária brasileira da primeira metade do século XIX, formado sob o tradicionalismo coimbrão, era agora suplantado pelo Liberalismo jurídico chegado do exterior, inspirado por filósofos ingleses e franceses, idéias revolucionárias que iam de encontro à mentalidade imperial. Sintetiza Fernando de Azevedo, referindo-se a essa cultura, que "a formação intelectual que recebiam, eminentemente literária, orientada não para a técnica e a ação, mas para o cuidado da forma, adestramento na eloqüência e o exercício das funções dialéticas do espírito, não podia fazer desses mestres em Artes e licenciados_senão letrados, imitadores e eruditos, cujo maior prazer intelectual consistia no contato com os velhos autores latinos", 326

Sílvio Romero foi o oposto de intelectual citado por Azevedo (cultor da Arte onde o que predominava era a análise estilística e a forma aparecia como o elemento mais importante), “foi um típico intelectual do século XIX, foi jurista, crítico literário, ensaísta, poeta, filósofo, historiador, professor, político e, especialmente, polêmico. Por meio de suas discussões, muito defendeu a Faculdade que o formou, tendo sido o responsável pela alcunha que a eternizou: a Escola do Recife” 327

Sílvio é um homem que acredita nas idéias divulgadas pela Ciência da época, é um agitador, mas um agitador que buscou subtrair o marasmo de seu país, por isso é que se trata de um homem moderno, que busca solver o atraso do país a partir das Teorias européias. Ele sentiu na pele o peso da Modernidade, tendo vivido uma nova época em que surgia uma outra maneira de pensar o Brasil, razão de sua fremente busca e que deu sentido para suas análises, da fundamentação de seu olhar, e

\footnotetext{
${ }^{324}$ ABREU, J. Capistrano de. Capítulos de História Colonial. 7ª Ed. São Paulo: Editora Itatiaia Limitada; EDUSP, 1988. p. 250

${ }^{325}$ Ibidem. p. 251

${ }^{326}$ AZEVEDO, Fernando de. A cultura brasileira: introdução ao estudo da cultura no Brasil. $4^{\mathrm{a}}$. Edição: Brasília, Editora Universidade de Brasília, 1963. p.278

${ }^{327}$ HIRATA, Alessandro. Sílvio Romero: o polemista da Escola do Recife. São Paulo, 2011.
} 
que em seus trabalhos não deixava de aludir à intuição geral. Em sua produção, era sempre a partir do que ofereciam os preceitos da Ciência moderna que Romero sustentava sua visão de Brasil, por isto é que "Sílvio Romero considera que, para compreender a Evolução da sociedade brasileira e determinar, pressentir ou averiguar os caminhos de seu desenvolvimento futuro, necessário se faz recusar as explicações simplistas ou meramente descritivas, submeter à Crítica aquelas Teorias que isolam um ou outro fator e a partir exclusivamente destes pretendem apresentar uma visão global, e, finalmente, examinar em profundidade o conjunto de elementos constituintes e integrantes do contexto social." 328

Romero foi um vulgarizador das idéias mais adiantadas de seu tempo no campo científico, visando a identificar os problemas nacionais, o que era parte de sua ambição moderna, pois só assim acreditava solucionar os diversos problemas do seu país. Combateu a Retórica, uma vez que escondia a real situação do país e acobertava todo o pensamento disseminado pelo Império, visto que este ia de encontro a sua visão naturalista, que foi o ponto basilar de sua concepção de mundo.

\footnotetext{
${ }^{328}$ PAIM, Antonio. Sílvio Romero, 1851-1914: bibliografia e estudos críticos. Centro de Documentação do Pensamento Brasileiro, 1999. p.49. A Escola do Recife. Estudos complementares à História das Idéias Filosóficas no Brasil. Vol. V. Londrina:UEL, 1999.
} 


\section{IV- INTERPRETANDO O BRASIL DE SEU TEMPO.}

"Sabemos bem ser a primeira condição para agradar em política ter os vícios do ofício, ter a marca igual a todos, meter-se a gente num grupo, comungar com ele pura e simplesmente na mesma mesa, isto é, engolir muitas vezes a justiça e a verdade quando se trata dos nossos, e vomitá-las depois, como afronta, na face dos adversários" ${ }^{329}$ Sílvio Romero

\section{1- Ler o Brasil diante dos problemas nacionais.}

As bases teóricas do pensamento de Sílvio Romero foram formadas em contraposição ao Espiritualismo e ao Ecletismo filosófico reinante na primeira metade do século XIX. Contrário à Metafísica transcendental, Sílvio levanta o problema da cultura no Brasil.

Francisco Martins de Souza designa as discussões filosóficas surgidas no grupo do Recife como Culturalismo sociológico ${ }^{330}$ iniciado por Tobias Barreto e Sílvio Romero e continuado por Alcides Bezerra. Combatendo toda a Filosofia eclética e Metafísica, o Positivismo foi adotado por Sílvio como o elemento de síntese para a explicitação dos mais variados ramos do conhecimento. A Ciência Social de Frederic Le Play e seus discípulos a Antroposociologia de Amom, Lapouge e Gobineau, combinadas com o Positivismo, e a Evolução foram as bases teóricas do pensamento de Sílvio Romero. Dentre a infinidade de autores das mais diversas áreas, o Evolucionismo do mestre Spencer modelou o espírito de uma figura que buscava identificar os vícios e defeitos do país, falando de uma forma que se pretendia direta e objetiva. Após preterir o Positivismo de Comte, à medida que ia conhecendo as leituras de Spencer, Romero salientava a importância da escola de Le Play: "As doutrinas do Evolucionismo spenceriano tinham-me posto na pista do desdobramento natural dos vários ramos da atividade natural dos vários ramos da atividade humana. Tinham-me despertado a atenção para as formações díspares dos povos mestiçados, nomeadamente os da América do Sul, e, por esse caminho, havia sido conduzido as conclusões a que cheguei em todos os escritos acerca da minha pátria. As doutrinas da escola de Le Play, posteriormente, fizeram penetrar-me mais fundo na trama interna das formações e completar as observações exteriores do Ensino spenceriano”. 331

Aderiu aos ensinamentos da Ciência Social devido ao método de observação, priorizando a organização familiar a fim de analisar as bases da estrutura social brasileira,

\footnotetext{
${ }^{329}$ ROMERO, Sílvio. Outros estudos de Literatura contemporânea. Lisboa: Tipografia da Editora, 1906.p.122

${ }^{330}$ SOUZA, Francisco Martins de. A Questão teórica da cultura na Escola do Recife. In: O Brasil social e outros estudos sociológicos: Senado Federal, Conselho Editorial, 2001. A primeira edição da obra se denomina O Brasil Social, publicada em 1908. Por questões didáticas, utilizaremos esta edição. Para uma abordagem cultural sobre o pensamento de Sílvio Romero, ver do mesmo autor. O culturalismo sociológico de Alcides Bezerra. São Paulo: Editora Convívio, 1981.

${ }^{331}$ ROMERO, Sílvio. O Brasil social e outros estudos sociológicos. Ibidem.p.34. Ainda. A América Latina. Análise do livro de igual título do Dr. M. Bonfim. Porto: Livraria Chardron, 1906. p. 8.
} 
"A doutrina de Le Play, vigorizada por Tourville, Demolins, Rousiers, Poinsard, Pinot Descamps e toda uma plêiade de ousados investigadores, presta o inestimável serviço de ensinar e observar o povo nas diversas zonas do país na labuta especial de seu viver, de seus modos e meio de trabalho, determinar a conseqüente estrutura da família que brota naturalmente daqueles fatores primordiais e o caráter inevitável que dali advém a população. Causa, neste, ultimo ponto, verdadeira estranheza darem alguns ignorantes, entre nós, a doutrina dessa escola social o título de reacionária, como se pudesse ter esse caráter quem ensina e proclama acima de tudo, o revigoramento do espírito de iniciativa, de autonomia pessoal, de coragem empreendedora, em suma, esse particularismo, que tem feito a fortuna dos ingleses e dos anglo-americanos" 332

O conhecimento da Escola de Le Play ou Escola Social, composta por nomes como H. de Tourville, Ed. Demolins, P. Rousiers, A. de Preville e P. Bureau, dentre outros, divulgada pela revista La Science Sociale, serviu de base para Sílvio traçar um quadro social da realidade brasileira: encontrar os males do atraso brasileiro tendo em vista um método de observação que não carecesse de dúvidas. Neste momento, já era Sílvio adepto do Evolucionismo, que conheceu quando era aluno da Faculdade no Recife entre os anos de 1868 a 1873, quando teve uma breve passagem pelo Positivismo. Os estudos de Romero Política e Estado Social são a manifestação direta da influência de Le Play em sua produção literária. Na ânsia por conhecer o Brasil e encantado pelas ideias novas, elaboraria Sílvio uma análise minuciosa da sociedade brasileira.

Desejava encontrar as leis que presidiam o desenvolvimento social na busca pela índole da nação brasileira para, só a partir de então, apontar o rumo do Brasil. Desse modo, realizou uma análise minuciosa da sociedade brasileira, aludindo sempre aos aspectos de formação do país. Estando o Brasil dividido em treze regiões, interessava a Romero identificar quais os elementos significativos na formação da sociedade. Dentro do quadro social oriundo da Escola Social, considerou a relevância de elementos como as diversas zonas sociais do país, o trabalho, a propriedade, os bens móveis, o salário, a Economia ou poupança e o modo de família que seria o traço mais relevante, de acordo com os preceitos de Le Play, "Esta é a base de tudo na sociedade humana: porque, além da função insubstituível e essencial de garantir a continuidade das gerações sucessivas, forma o grupo próprio para a prática do modo de existência, o núcleo legítimo da maneira normal de empregar os recursos criados pelos meios de viver" 333

Para Argeu Guimarães, filho de Artur Guimarães (nas palavras de Sílvio, “dois de seus discípulos”), "ele queria ver aplicada ao Brasil idêntica pesquisa, para explicar os caracteres profundos da nossa formação. Se não desceu as minúcias de um inquérito detalhado e documentado pelo Brasil a fora, lançou, pelo menos, os lineamentos gerais desse trabalho, tomando por base o

\footnotetext{
${ }^{332}$ ROMERO, Sílvio. O Brasil social e outros estudos sociológicos. Op.Cit.230.

${ }^{333}$ Ibidem. p.36.
} 
conhecimento real que possuía das populações do norte a sul, praeiros, matutos, tabaréus, caipiras, sertanejos, e a visão, a intuição sociológica de que era dotado", 334

Seguidor da Escola Social de Le Play, em que funda sua visão sociológica, almeja traçar de maneira minuciosa o quadro da sociedade brasileira em seus aspectos sociais, políticos e econômicos. Elabora um artigo ${ }^{335}$ em que toma como parâmetro o modelo de família, descrevendo minuciosamente vinte e cinco aspectos que influenciaram a formação do caráter nacional brasileiro. Debruçando-se sobre a influência da Escola Social de Le Play, defende a Educação particularista dos países modernos, formadores de um caráter forte e de iniciativa, como os países anglo-saxões, em contraposição à Educação comunária responsável pelo caráter apático ou sem iniciativa. Após sofrer influência do Espiritualismo de Jouffroy, do Positivismo de Comte, do Evolucionismo de Spencer, foi com o modelo francês de Antroposociologia que Sílvio Romero levantou o quadro de pobreza beirando a miséria de seu país: “A posição do Brasil, seu verdadeiro estado social, esclarecido com o critério íntimo dos elementos primários e essenciais da vida, é que me proponho a elucidar”. 336

Nos estudos de Política e Estado social, designação cunhada pelo próprio Sílvio quando tratou de dividir sua produção intelectual, o polígrafo analisou o quadro da sociedade brasileira composta por várias regiões. Em O Brasil Social e outros estudos sociológicos, Provocações e Debates ${ }^{337}$, O Brasil na Primeira Década do Século XX, ${ }^{338}$ Ensaios de Crítica Parlamentar ${ }^{339}$, Introdução a Doutrina contra Doutrina ${ }^{340}$, revela os males brasileiros e busca identificar o remédio para os problemas nacionais. Preocupado com tantos problemas, procura os caminhos para melhorar um país miserável, fruto de uma formação comunária. Traça de maneira criteriosa, clara e contundente o quadro social, político, econômico e cultural da situação nacional, procurando falar de maneira que considerava objetiva e sem a ostensiva erudição de seus estudos de Crítica literária.

A paixão por um dia presenciar o Brasil no rol dos países modernos fez com que buscasse as últimas Teorias, adotando a que melhor se adequava, de seu ponto de vista, à análise do país. Dizendose apaixonado pelo Brasil, não tinha sentido para Sílvio o modelo de intelectual diletante, mas sim o escritor que empunha a arma à procura dos males do país. ${ }^{341}$ Toda uma vida dedicada a pensar o Brasil

\footnotetext{
${ }^{334}$ GUIMARÃES, Argeu. Presença de Sílvio Romero. Rio de Janeiro: Organização Simões, 1956. p.117.

${ }^{335} \mathrm{O}$ artigo intitula-se Edmond Demolins transcrito de sua obra Provocações e Debates na qual iremos recorrermos inúmeras vezes. Romero levava em consideração os seguintes fatores na formação de cada tipo social: lugar, trabalho, propriedade, família, modos de existência, patronagem, comércio, culturas intelectuais, Religião, vizinhança, corporações, comuna, cidades, província, estado, expansão da raça, o estrangeiro em relação a raça, a sua História, o seu papel e posição mundial.

${ }^{336}$ ROMERO, Sílvio. O Brasil social. Op.Cit.p.40

${ }^{337}$ Publicado originalmente em 1909.

${ }^{338}$ Publicado originalmente em 1912.

${ }^{339}$ Publicado originalmente em 1883.

${ }^{340}$ Publicado originalmente em 1894.

${ }^{341}$ ROMERO, Sílvio. História da Literatura Brasileira. Op.Cit.
} 
fez de Sílvio um conhecedor das diversas Teorias estrangeiras visando a entender um país que, para ele, poderia ser mostrado da maneira real e sem ilusões. Denunciou de maneira contundente as mazelas sociais do Brasil para encaminhar seu país para o progresso, o que a seu ver não fazia a elite brasileira. Denunciou os problemas nacionais de um Brasil miserável, arcaico, regido por verdadeiros clãs e que precisava urgentemente ser pensado não mais sob a exploração do homem pelo homem, mas nos quadros de um regime que pudesse prover o desenvolvimento do país. Denunciou todo um quadro social desses problemas munido das ideias da Escola de Le Play, a fim de procurar mostrar um Brasil sem ilusões.

Segundo Nelson Werneck Sodré, "Sílvio Romero, interessou-se por todos os grandes problemas de seu tempo. Participou-se do debate que desencadeou em torno de cada um. Teve uma posição. Defendeu-se com a com os arremessos de seu espírito vivo e inquieto. Escrevendo uma História da Literatura Brasileira, que até hoje permanece como obra de interesse indiscutível, teve oportunidade, em suas páginas desde as primeiras, desde as de introdução, de dar a sua palavra a propósito dos assuntos que mais interessavam ao Brasil naquele momento. Por tratar de Literatura, não se viu desobrigado de apreciar os referidos assuntos, fugindo ao debate deles. Muito ao contrário, deu-lhes um lugar, chamou a atenção do público para eles, e discutiu-os conforme verificamos", 342

Todo o cabedal teórico-científico que assumiu ${ }^{343}$ seria sem sentido não fosse sua ambição de ver seu projeto de nação aplicado ao país que dizia amar, aumentando cada vez mais sua vontade de denuncia social e política num Brasil que sofria profundas transformações desde os idos de 1850. Apoiado no vasto repertório de leituras que conhecia, partiu de uma concepção de sociedade evolucionista e orgânica para explicar as causas do atraso brasileiro e seus males, o estágio do país na escala evolutiva com relação aos países modernos. Assimilara Sílvio ideias somente quando considerasse ser possível aplicá-las ao Brasil para viabilizar o processo de passagem da situação de atraso à Modernidade.

Buscou apontar e explicar os fatores constituintes do atraso brasileiro, chamando atenção para seus infinitos problemas: a corrupção política, reinante em todo o Brasil sob as mais variadas formas, corroborada pelos dirigentes da nação por desconhecerem a Crítica moderna como alternativa de prover o progresso; a condição do Ensino público; a distribuição de terras após a Abolição; a questão da política econômica brasileira; a questão da imigração; a questão da mão de obra após a Abolição; a

\footnotetext{
${ }^{342}$ SODRÉ, Nélson Werneck. A ideologia do colonialismo - Seus reflexos no pensamento brasileiro. $2^{\mathrm{a}}$. Ed. Rio de Janeiro: Civilização Brasileira, 1965.p.71.

${ }^{343}$ MORAES FILHO, Evaristo de. Medo a utopia: o pensamento social de Tobias Barreto e Sílvio Romero. Rio de Janeiro: Nova Fronteira; Brasília: INL, 1985.
} 
questão da língua nacional como fator de integração nacional. Fazendo jus às palavras de Nelson Werneck Sodré, Romero “interessou-se por todos os grandes problemas de seu tempo" 344.

Preocupado com os inúmeros problemas brasileiros, recorria a argumentos como os atavismos de raça e os antecedentes históricos que, a seu ver, justificavam a situação brasileira. $\mathrm{O}$ caráter brasileiro explicava a situação da penúria social e material do país. Responsabilizava a predominância de verdadeiros clãs políticos em todo o Brasil devido à falta de conhecimento que, por sua vez, era indissociável da raça que colonizou o Brasil já em estado de decadência.

Apesar de atinar para toda a estrutura cultural, social e econômica do país, pensava que somente com o cruzamento com o branco, o caráter do povo brasileiro, de índole mestiça, mudaria, seria possível transformar o caráter apático do brasileiro e de todo o quadro social. Como bom positivista embora afirmasse que, do Positivismo, só aceitara a lei dos três estados - e ardoroso evolucionista, Sílvio olhava a sociedade brasileira de forma análoga a um organismo vivo, onde cada órgão era concatenado a outro, carecendo funcionar harmonicamente. Afirma Francisco Martins de Souza que "é a esta doutrina do organicismo spenceriano que mais se atém a busca de Sílvio Romero, ligada não só ao pensamento especulativo, teórico, mas a observação dos fatos e a História do desenvolvimento humano". 345

O sentido teórico de suas análises e a busca irrefreada para tudo explicar descendem dessa visão onde todo e qualquer problema possuía suas causas inteligíveis, donde resultava possível conhecer e apontar as soluções. Analisando a viabilidade ou não da formação de um partido operário no Brasil em Introdução a Doutrina contra Doutrina, é clara a visão de um escritor preso ao fascínio da Ciência, dessa sedução de grande parte de sua geração

Sílvio Romero não via mais a separação entre as Ciências Morais, como a Sociologia e a História, das Ciências Naturais. Neste sentido, suas análises possuem estreita ligação entre raça e cultura. Os problemas nacionais estão sempre ligados à formação étnica do país. A raça, mais que o meio, tangencia as análises que acabam por identificar o atraso do Brasil. Cada raça é portadora de um caráter, uma Psicologia, fazendo do crítico um escritor determinista. Sua crença nas últimas ideias, geralmente oriundas da Europa, o torna um pensador profícuo e preocupado com os problemas nacionais. Ciente das últimas Teorias europeias, buscou sempre o conhecimento científico para sustentar suas análises, mostrando assim uma visão ilustrada, buscando eliminar o Brasil da situação de completa barbárie e pauperismo que inúmeras vezes denunciou.

\footnotetext{
${ }^{344}$ SODRÉ, Nelson Werneck Sodré. Op.Cit.p.71.

${ }^{345}$ SOUZA, Francisco Martins de. A questão teórica da cultura na Escola do Recife. Prefácio. In: O Brasil Social. Op.Cit.p.17.
} 
Se o problema era pertinente à Educação brasileira, salientava a mania liberalizante, o excesso de realismo e acima de tudo, um Ensino que não despertava o amor à pátria. Quando tratava do Ensino brasileiro ou de alguma Teoria filosófica para analisar o Brasil, rebatia o Positivismo de Comte porque se tratava de uma corrente de idéias que impedia a formação e o desenvolvimento das Ciências, defendendo, em contrapartida, o Evolucionismo de Spencer. Pensava que a Filosofia carecia da Lógica para só assim ser possível a formação técnica responsável pela consolidação de um caráter forte num povo de índole apática. Em todo e qualquer debate onde estavam em voga os interesses nacionais, sempre se posicionara com respostas pretensamente objetivas e muitas vezes agressivas. Nessa perspectiva, faltava ao Ensino ou à Educação brasileira a disseminação dos elementos da Educação enérgica: "Se queremos continuar a ser uma gente de comunários, vivendo da política alimentaria, o ideal em matéria de Ensino é exatamente o que temos: se queremos, porém mudar de rumo, no sentido das grandes iniciativas, é seguir o que fazem os ingleses e aconselha Demolins. " 346

Quando discutia a formação nacional brasileira, alegava que o país ainda não era uma nação homogênea devido à presença das três raças que inviabilizava a formação de uma identidade contempladora de um caráter nacional forte. Se a discussão era sobre a melhor forma de representação política, pensava que o caminho a seguir devia ser equivalente à índole nacional incapaz de absorver as idéias parlamentaristas inglesas ou o perfil republicano americano. Afirmava que o melhor regime seria aquele que falasse a voz do povo. Não bastava pura e simplesmente absorver ideias estrangeiras e imitá-las, a exemplo do Parlamentarismo americano e do Liberalismo sustentado por Stuart Mill, num povo de índole apática, resultado que era da formação comunária.

Contrário à macaqueação ou à pura imitação com relação às ideias ou à formação de um partido operário no Brasil, discutiu a inviabilidade das propostas de Marx, Engels, Bebel e Liebknecht. Pensava Sílvio que não existia no Brasil uma sociedade dividida de maneira hierárquica indispensável à luta de classes para que fosse possível a formação da voz proletária. Continuava fiel a um de seus mestres que era Spencer, baseando-se nas leis evolucionistas, justificadora de suas idéias quando tratava de analisar a sociedade a partir dos princípios da Ciência política. Argumentava que faltavam antes de tudo estudos demográficos e estatísticos sobre o Brasil para uma discussão séria a respeito do tema.

Quando abordava a dependência econômica brasileira, percebia esta como reflexo da ausência de um produto original brasileiro e uma das causas da pobreza da indústria nacional brasileira. Como bom evolucionista, posicionou-se sobre a questão da escravidão, discordando da emancipação dos

\footnotetext{
${ }^{346}$ Ibidem. p.75.
} 
escravos sem que estes se tornassem colonos porque enfrentariam uma situação ainda mais difícil de vida do que o regime escravista.

Tomou das idéias científicas, sobretudo, o Transformismo de Haeckel e o Evolucionismo de Darwin, para apontar um novo Brasil, combatendo a visão Metafísica cristã, onde predominava a Retórica propagada nas escolas e nos seminários do Império brasileiro. Apesar de seu apego às Teorias deterministas da Ciência da época, Romero falava como um intelectual de cultura enciclopédica de seu tempo. Devemos ressaltar que neste momento, não existia a especialização literária, predominando o modelo de escritor que fora Sílvio, influenciado pelos grandes críticos franceses e alemães, que o fizeram conhecedor dos mais variados ramos do saber.

Sílvio tratou das inúmeras questões brasileiras, preocupado com o futuro de um país assolado por tantos problemas sociais de âmbito geral. É a partir de sua concepção cientificista e positivista, somada a sua visão literária que percebemos a importância e a singularidade da raça. Quando trata de investigar os autores brasileiros e a situação nacional, recorre aos elementos da Crítica moderna sempre para identificar a índole brasileira como responsável pelos inúmeros problemas e daí propor os remédios. O intuito de Romero não é uma análise especificamente literária, mas sim social. Busca na influência do meio, no cruzamento das raças e nos antecedentes históricos, investigar as causas da situação brasileira miserável e pobre.

Por estar preocupado mais com a situação de atraso de seu país do que com a especificidade da gênese literária, baseia-se no Evolucionismo de Spencer para analisar a situação de miséria e ignorância do povo brasileiro. Independentemente da ordem dos problemas arrolados pelo próprio bacharel, podemos apreender algumas idéias centrais em seus trabalhos. O elemento racial é o principal. Sem ser o Brasil uma nação homogênea, devidamente formada, em função do cadinho de raças que, segundo Sílvio, explicava o cenário de atraso do país, apostando num processo de fusão que tendia ao branqueamento, era indispensável que a classe dirigente do país, formada por políticos, jornalistas e literatos, tomasse conhecimento da real situação do país para que só então fosse possível transformá-lo numa nação moderna.

Faltava ao Brasil, na visão de Romero, a constituição de um povo formado por um sentimento nacional forte, produto do meio, da raça, e dos antecedentes históricos. Somente conhecendo o caráter do brasileiro seria possível identificar os reais problemas do país, viabilizadores de uma mudança de ordem estrutural. Pensar o Brasil como nação era, antes de tudo, identificar as raças formadoras da sociedade brasileira para, só assim, buscar a identidade de um povo mestiço! Sílvio acreditava na Evolução transformista e na lei do mais forte. Desse modo, a origem dos males brasileiros e o motivo principal do país não ter-se constituído ainda como nação tinha, ligação direta com a formação comunária, responsável pelas mazelas sociais e políticas do país, justificando a pobreza “dos doze 
milhões de brasileiros residentes nas matas, sertões, campos gerais, chapadas, chapadões, planaltos, fora das restritas gentes das grandes vilas e cidades, da costa ou mesmo do centro" ${ }^{347}$.

Do cruzamento das raças, resultava o caráter deliqüescente do brasileiro, o que fez o escritor investigar as inúmeras áreas do país, influenciado pela Escola de Ciência Social, em busca das raízes do mal, embora afirmasse que alguns problemas eram insolúveis. Aqui, reside uma dura Crítica oriunda da historiografia tradicional, como também atual: perceber Silvio Romero como um adepto das Teorias estrangeiras de maneira acrítica, construindo a idéia de um escritor que desconhecia seu próprio país, o que tanto combateu na macaqueação ou imitação das idéias estrangeiras porque discordava da imagem do Brasil divulgada pela elite dirigente, corroborada por jornalistas e escritores. Não estava o Brasil preparado para receber as últimas ideias da Crítica moderna, nem era o Brasil aquilo que nossos dirigentes defendiam, resultado que era da embriaguez dionisíaca. As raizes dos males brasileiros eram o desconhecimento do próprio país, como lembrava o polígrafo, "a mania de passar pelo que não somos". ${ }^{348}$ Como um profundo conhecedor da realidade nacional, o crítico literário apontava o estado de ignorância, pauperismo, miséria e opressão do povo brasileiro: "Nosso maior mal, disse ,é não termos a consciência positiva do que realmente somos e, muito ao invés disso, darmo-nos a nossos próprios olhos uma superioridade, uma grandeza, um poderio, um progresso, uma cultura, um adiantamento, uns predicados quase sem par por aí além entre as demais nações". 349

A imitação, o cerne dos diversos males brasileiros, era conseqüência da mania de passar por aquilo que não somos, do ilusionismo por parte da elite brasileira, que mascarava os reais problemas do país. Somava-se a isto o desconhecimento dos preceitos da Crítica moderna, o que só reforçava o quadro de "atraso" do país. O ilusionismo, sentido de toda a Crítica de Sílvio, foi tenazmente combatido, motivo de suas investidas, de sua ânsia para conhecer o país, no que buscou investigar as várias regiões e zonas do país, conforme influência da Escola Social, acreditando, assim, encontrar as raízes do mal, para prover o progresso do país. Em sua análise sociológica, concluía que:

\footnotetext{
"O maior mal do Brasil, e não é coisa que lhe seja exclusivamente peculiar, porque muitos outros povos participam do mesmo achaque: é pretendermos ser, como nação, como todo político-social, o que não somos realmente.

É um estudo de Psicologia popular, de anthroposociologia nacional que não tem sido feito e do qual darei apenas algumas linhas gerais " 350
}

\footnotetext{
${ }^{347}$ ROMERO, Sílvio. O Brasil social. Op.Cit.p. 88

${ }^{348}$ ROMERO, Sílvio. Provocações e debates. Contribuições para o estudo do Brasil social. Porto: Livraria Chardron, 1910.

${ }^{349}$ Ibidem. p. 105.

${ }^{350}$ ROMERO, Sílvio. Provocações e debates. Op.Cit.p.102
} 
Em suas reflexões, Sílvio se prendeu ao caráter racial, fundamentação maior do que seria o brasileiro, a singularidade de cada parte do país, uma vez que acreditava na participação do meio como agente diferenciador. O elemento racial, que para o escritor fundamentava o "brasileiro" ou a Psicologia nacional, palavras suas, aparecia como preponderante, norteando as análises acerca de toda a estrutura social brasileira. Uma série de problemas decorria da questão racial como, por exemplo, a imitação:

"É que quando discursamos de ideias e doutrinas, somos repetidores das Teorias que julgamos mais avançadas, nesse prurido infantil, muito nosso, de nos mostrarmos muito inteligentes e sabedores; e, quando aplicamos, quando descemos à prática daquelas mesmas instituições que copiamos dos outros, revelamo-nos tais quais somos: os atavismos acumulados no povo pela raça e pela História surgem em cada um de nós; o tipo meio selvagem aparece.

É regra que não falha, nem pode falhar.

DestArte, todos os nossos pretendidos chefes e guias políticos são-no de fato, não, como ingenuamente todos supõem, pelas ideias que pregam, ideias de que são autores, mas sim pelo modo como as realizam, pela feição pessoal que lhes dão, quando as desvirtuam na prática " ${ }^{351}$ (grifos nosso)

Em que pesem seus antagonismos e contradições somados ao lado pragmático de suas ideias, cabe-nos apenas perceber Silvio Romero, como nos lembra Antonio Candido e Alcides Bezerra, como um exemplo dos jovens bacharéis saídos recentemente das academias, empolgados e acreditando de maneira desmesurada na verdade da Ciência. A visão de Sílvio Romero é de totalidade, orgânica, para quem as Teorias raciais fundamentam o caráter dos povos. Suas idéias só possuem sentido quando imersas nesse projeto ilustrado e orgânico, num encadeamento rígido que tem por base os mesmos rigores das leis científicas. Somente identificando as causas ou os elementos formadores do atraso brasileiro é que se torna compreensível a visão de Romero.

Trabalhava o ensaísta a partir da terminologia em voga no momento, que englobava a ideia de caráter nacional, traço maior de suas inquietações, num movimento de cima para baixo e vice-versa, que o escritor buscou por meio dos fatores condicionantes. Caráter este que foi a grande ideologia presenciada no momento de formação das Ciências Sociais no Brasil, quando, por meio dos ditames científicos, se buscou simultaneamente identificar a situação do país e forjar os elementos de brasilidade.

Nessa perspectiva, somente com amor à pátria seria possível transformar a realidade miserável ou pobre da população brasileira, algo que os dirigentes da nação não possuíam, sendo para Sílvio um dos fatores da corrupção política deitada nas mãos dos clãs dos Lucenas, dos Pinheiros ou dos Borges de Medeiros. Como se não bastasse o quadro de atraso do país, somado ao nacionalismo de Sílvio, o

${ }^{351}$ ROMERO, Sílvio. O Brasil social. Op.Cit.p.185 
povo brasileiro é herdeiro de uma raça latina já em estágio degenerativo, aclimatada num meio onde as zonas sociais só reforçam cada vez mais a degeneração desses ascendentes ibéricos. De sua pena e de sua paixão pelo Brasil, temperadas pela presença num cenário de forte disputa entre intelectuais, surgem às duras Críticas que moveu a diversos escritores, como por exemplo, Euclides da Cunha, José Veríssimo, Manoel Bomfim, acreditando falar somente a "verdade", pouco se preocupando com a forma ou maneira de dirigir suas argumentações.

Supunha que, por amar o Brasil, falava sempre a verdade, dizendo ser caluniado e perseguido. Talvez a partir daí se explique seu apego às Teorias cientificas, à razão absoluta, aquela que não possibilita a contra argumentação de quem quer que seja para o estabelecimento da verdade. Sempre apelava para o conhecimento real dos fatos como se este fosse um grande laboratório, como se fosse possível comprovar os antecedentes históricos do país. Ressaltava a cadeia dos fatos históricos brasileiros como resultado das leis sociológicas resguardadas sob o Evolucionismo de Spencer, almejando um dia ver contada a História do Brasil e sonhando com a formação da nação brasileira. Evolucionista convicto, falava Romero o que pregavam as leis evolutivas: argumentava que só falava a partir dos fatos, daquilo que aconteceu, dispensando discussões de cunho estético que não apontassem os caminhos para as mudanças pelas quais tanto lutou.

Exímio conhecedor da Literatura e da História universal, falava apontando fatos, ponto de partida para toda e qualquer discussão, porque acreditava na infabilidade das leis. Diante dos inúmeros problemas constituintes do atraso brasileiro, argumentava por meio de uma alma nacional, do gênio da História, da Psicologia dos povos, uma vez que sua concepção de escritor era a de um intelectual que deveria falar a verdade, o grande responsável por mostrar ou denunciar os verdadeiros problemas do país. Acreditava tenazmente na alma brasileira, índole ou Psicologia nacional, razão de sua incessante busca pelos inúmeros problemas do país enquanto uma sociedade analfabeta e miserável dirigida de norte a sul pelas vinte e três oligarquias dominantes. Somente alterando o caráter nacional brasileiro de índole apática por meio de uma Educação particularista, seria possível mudar toda a estrutura de miséria mental, social, política e cultural de nossa sociedade.

Investiu contra o Ensino retórico de cunho espiritualista personificado em Cousin, aderindo primeiramente ao Positivismo, mas sempre insistindo no conhecimento da Escola Social, no conhecimento de Le Play e na Antroposociologia, alternativas para alterar a índole do povo brasileiro.

Tendo por base a preocupação com o caráter nacional brasileiro, acreditando nele sem questionamento, traçaria suas análises e a categoria racial entrava aqui de forma determinista. Criticava os dirigentes da nação (categoria em que incluía jornalistas e escritores) por não conhecerem nem a realidade do próprio país nem o caráter do povo ou a Psicologia nacional. Adotando o método de observação direta proposta pela escola de Le Play e tomando conhecimento dos trabalhos de 
teóricos que tinham como objeto um campo conceitual de Psicologia dos povos, como Fouillé, Greard, Lavisse, Liar, Guyau, perguntava Romero se o Ensino brasileiro facultaria o amor à pátria:

“Temos nós, brasileiros, de longe ou de perto, trabalhado em igual sentido? Ai de nós!-que somos forçados a confessar o nosso criminoso descuido neste ponto vital Povo semi-barbaro, tomado em seu conjunto, povo de analfabetos em sua quase totalidade, nós brasileiros, sofremos da pior das moléstias: a mania liberalizante.

Esta fatal moléstia, denunciadora da leviandade do caráter nacional, que não tem fixidez, firmeza, segurança; que não assenta na rocha indestrutível de um complexo de tradições que sejam o sangue de nosso sangue, a base adamantina de nossa alma; esta fatal moléstia já nos tem feito amargar e há de ser-nos fatalissima nos tempos por vir " 352.

Nessa perspectiva, a apatia do brasileiro era oriunda da nossa formação étnica, responsável pelo atraso social, político e cultural. A mania liberalizante, resultado direto da falta de conhecimento do Brasil, explicava para Romero o motivo de tanta macaqueação, da imitação francesa, uma vez que não possuía o brasileiro uma índole ou Psicologia preparada para lidar com as instituições vigentes nas nações modernas. Faltava no Brasil um Ensino que despertasse o sentimento nacional: "Falta-nos a emulação, a consciência de estarmos a colaborar numa grande obra nacional ou humana, o entusiasmo do sacrifício as nobres causas". 353

Daí que a Crítica moderna facultaria o conhecimento real do país frente a uma estrutura social miserável, responsável por várias contradições como, por exemplo, existir uma minoria de intelectuais diante de uma nação de pobres, composta por milhões de miseráveis e analfabetos. Creditava à Educação a função de fomentar o caráter brasileiro forte e severo em contraposição ao caráter passivo e atávico, resultado da raça colonizadora íbera latina já em estado de degeneração. Sendo o Ensino brasileiro produto da decadente raça, baseava-se nos exemplos de França, Itália, Inglaterra, Alemanha, uma vez que nesses países os escritores contribuíram para o despertar de uma Educação patriótica e uma índole de iniciativa. Ressaltava a importância da Educação brasileira como um dos fatores do atraso brasileiro.

Em O problema brasileiro em $1891^{354}$, analisava a situação nacional, chamando atenção para a volta do Sebastianismo deixando claro que o país em nada mudou: "Na política, na vida social, nas Letras, nas Artes, na Ciência, no jornalismo, por todos os lados e por todas as formas por que se costuma revelar a alma de um povo, a voz brasileira tem ainda o mesmo som, o mesmo gaguejar de quem não tem consciência e nem sabe o que quer., 355

\footnotetext{
${ }^{352}$ ROMERO, Sílvio. Ensaios de Sociologia e Literatura. Rio de Janeiro: H.Garnier, 1900.p.169

${ }^{353}$ ROMERO, Sílvio. O Brasil social. Op. Cit.p.144

${ }^{354}$ ROMERO, Sílvio. O problema brasileiro em 1891. In: Estudos de Literatura contemporânea. (Edição Comemorativa). Rio de Janeiro: Imago.; Aracajú, SE: Universidade Federal de Sergipe, 2002.pp. 359-397.

355 Ibidem. p.359.
} 
Alertava para a volta da monarquia e descrevia a corrupção do governo provisório, herdada do lucenismo, "As mesmas questiúnculas, os mesmos vícios, os mesmos pequenos interesses pessoais, as mesmas chicanas, as mesmas pepineiras, e, para tudo dizer numa só palavra, a mesma desengraçada comedia representada quase pelos mesmos atores", 356

Fervoroso nacionalista, Romero afirmava que o Brasil precisava ser dirigido por homens de um caráter severo, pois sequer o povo brasileiro conhecia a História de seu próprio país. Sempre falava que faltavam documentos para narrar à História literária do Brasil e para isso, respaldava-se na ausência dos ideais científicos, desconhecidos pelos dirigentes da nação. Definidor de rumos políticos do país, perguntava pela melhor forma de representação a seguir. Segundo suas análises, o caráter nacional não estava em condições de acolher o sistema representativo. O regime parlamentarista, como nos moldes do federalismo inglês e americano, encontrava-se acima da índole brasileira, "Assim como $o$ instinto de conservação da raça sugere o tuana, o oligarca, o caudilho, o clã dirigente $e$ compressor, em oposição ao tribuno, o retórico, o fantasista liberalizante, pela mesma forma ele mostra bem claro, nessas ásperas provanças que nos inflige, que o federalismo democrático e livre está muito acima de nosso estado social, o qual não deve ser aferido pelos literatos da Academia, os eruditos do Instituto Histórico, os cientistas da Politécnica ou das Faculdades de Medicina e Direito" 357

Por vezes contraditório em suas análises e quanto à melhor forma de governo para a sociedade brasileira, posicionava-se a favor de um federalismo onde o poder autoritário dos Pedros fosse extinto, dando maior liberdade às províncias, mas foi justamente essa liberdade a razão maior para atuação e formação das oligarquias estaduais, com o advento da ordem republicana. Nesse sentido, o Brasil republicano só confirmou os inúmeros problemas nacionais ligados à formação comunária.

A falta de seriedade ou comprometimento por parte dos dirigentes da nação, segundo Romero, era resultado desta formação comunária em que a população pobre e analfabeta dependia do proprietário de terra para sobreviver. Aqueles que deveriam se contrapor a toda sorte de desmandos políticos eram justamente os próprios políticos, jornalistas e escritores, tornando-se a "classe" mais perseguida por Romero.

O estado de pobreza da maior parte do povo brasileiro devia-se a essa formação incapaz do espírito de iniciativa, que somente a nova Educação seria capaz de reparar. Somavam-se a esses fatores o caráter étnico e histórico de nossa população, causas de toda a sorte dos problemas nacionais. Toda a raiz do mal brasileiro devia-se à raça colonizadora, que em seu país, dedicava-se ao comércio

\footnotetext{
${ }^{356}$ Ibidem. p.359.

${ }^{357}$ ROMERO, Silvio. O Brasil Social. Op.Cit. p. 189.
} 
numa determinada região, ao pastoreio noutras e no resto do território nacional vivia da cultura doce 358 que é uma quase jardinagem ${ }^{359}$.

No Brasil, a raça colonizadora recorreu ao índio, ao negro e aos mestiços que, para Sílvio, eram raças alheias ao trabalho agrícola, "mas todo o mundo não podia ser no campo senhor de engenho, fazendeiro de gado ou de café" ${ }^{360}$. Daí, a razão da pobreza das populações campestres, que viviam sob o peso do chefe de terra ou do coronel, donde deriva uma série de práticas sociais que bem atestam a relevância do patriarcalismo no Brasil. Sem ser o brasileiro uma raça já formada e sendo portadora de índole passiva, várias características emergiam daí, sendo a principal destas a cegueira ou o desinteresse pelas verdadeiras questões políticas. Com uma população analfabeta, na qual as pessoas nada levavam a sério, política no Brasil nada mais era que politiquice. Citando vários oligarcas em seus respectivos clãs estaduais, apontava Romero à falta de seriedade por parte dos dirigentes da nação brasileira, uma vez que política para os políticos brasileiros "continua a ser a Arte de mentir habilmente" 361 . A Psicologia do povo brasileiro necessitava de mudanças para que estivesse em condições sociais e culturais de lidar com a ordem republicana, regime defendido não apenas por Romero, mas por grande parte dos escritores de sua geração, uma vez que com o advento da "nova ordem", acreditavam existir maiores oportunidades políticas em contraponto a um Brasil imperial excludente e fechado às aspirações democráticas.

Se por um lado Sílvio Romero é considerado um escritor determinista porque atribui o atraso do país ao caráter racial, num Brasil composto por mestiços, identifica no mestiço a solução para o progresso do país. Aplicando os preceitos da Escola Social, pensa que toda a situação de pobreza do povo brasileiro se dá por conta de um caráter apático, responsável pela situação dos pobres sertanejos, que somente se preocupam em comer. Como consequêncial, o país estava sob o mando das oligarquias e milhares de brasileiros totalmente despossuídos e desassistidos dependiam diretamente do chefe local. Outro problema era uma pequena elite de intelectuais iludindo-se pela mania de grandeza, pensando um Brasil de Haia, com seus finos discursos políticos e literários, mais preocupada com a abertura de ruas e avenidas do que com a condição de pobreza da população.

Os problemas brasileiros que Sílvio datava em 1891 já de desenrolavam há muito tempo na História nacional, decorrentes da índole apática de um povo formado sob a Educação comunária, somados aos elementos já aludidos anteriormente.

\footnotetext{
${ }^{358}$ Ibidem. p.88

${ }^{359}$ Ibidem. p. 88

${ }^{360}$ Ibidem. p. 88

${ }^{361}$ Ibidem. p.88
} 


\begin{abstract}
"Um falso pudor vela-nos a grosseria dos fatos; a tendência da raça para a facilidade atraente das ideias geradas e simplistas põe-se em ação; o orgulho latente em todas as almas, sem sermos já tão bons como os melhores, leva-nos não só a copiar as instituições dos mais aptos, como até a lançar-lhes em muitos casos a barra adiante

Daí essas constituições e leis que muitas vezes são verdadeiras obras de Teoria, sem aplicabilidade prática" 362
\end{abstract}

Apesar de algumas contradições, Sílvio salientava a ausência de seriedade dos políticos, que não tinham a menor paixão pelas coisas nacionais em decorrência de sua falácia ou verborragia dos mesmos e de jornalistas e literatos, "as três classes que têm mais de perto dirigido a vida mental e pública do povo brasileiro" 363 .

Defendendo a formação particularista responsável pelo crescimento das grandes nações devido a seu espírito de iniciativa, salientava Romero ser a ausência desse fator a causa principal do atraso brasileiro nos mais diversos aspectos. Como consequência da formação comunária, existia no Brasil toda uma massa despossuída e miserável, sustentando os políticos formadores de verdadeiros clãs. Os chefes do país buscavam a política como meio de prevaricação, realizando as mais diversas formas de corrupção, ao passo que nove décimos da população buscavam apenas sobreviver, almejando pequenos cargos públicos. A maioria da população miserável das vilas e cidades dependia exclusivamente dos chefes de partido, fazendeiros, vigários das vilas, juízes de Direito, advogados, médicos.

Nesse sentido, o que cabia ao Estado era somente alimentar grande parte da população em função dos poucos que trabalhavam, visto ser o funcionalismo público a única forma de sobrevivência. Somente La Nouvelle Éducation possibilitaria alterar a índole do brasileiro, espalhado nas diversas zonas sociais do país, enfrentando uma situação miserável. Em O Brasil Social, analisa o quadro social nacional sob a influência da escola de Ciência Social de Le Play por meio de um de seus discípulos, que era Edmond Demolins. Analisava o pensamento e a importância de Demolins, mal lido e por isso mesmo desconhecido no Brasil pelos "crichanás da Crítica brasileira", 364 referindo-se a José Veríssimo e Euclides da Cunha, no que resultava a visão ilusionista do país dirigido por políticos corruptos como o oligarca Pinheiro Machado, do Rio Grande do Sul, e outros do Brasil inteiro.

A adesão de Sílvio Romero ao pensamento da Ciência Social se dá por uma questão muito óbvia: “Como quer que seja, os méritos da escola, a despeito desta e doutras divergências, se me antolham preciosíssimos para quem quer conhecer a fundo um país qualquer e a gente que o habita" ${ }^{365}$. Sílvio abordava a questão da nova Educação aplicada em algumas escolas inglesas estabelecidas no campo,

\footnotetext{
${ }^{362}$ ROMERO, Sílvio. O Brasil social. Op.Cit.p. 184.

${ }^{363}$ Ibidem.

${ }^{364}$ ROMERO, Sílvio. O Brasil social. Op.Cit.p.72.

${ }^{365}$ ROMERO, Sílvio. História da Literatura brasileira. Op.Cit.p.190.
} 
responsáveis por um caráter de iniciativa, em contraposição às sociedades de formação comunária, responsável por um caráter apático. Lembrava, em História da Literatura Brasileira, depois de ultrapassar as teias do Positivismo em seu "círculo de ferro", que "Os processos da escola de Le Play fizeram-me penetrar mais fundo na trama interna das formações sociais e completar as observações exteriores de Ensino spcenceriano. É uma confirmação, em última instância, de conclusões obtidas por outros meios e estradas" 366.

Toda a adesão de Sílvio Romero à Escola de Le Play era uma forma de ver o Brasil e discutir com a geração de sua época.

Boa parte da Crítica vê em Romero um pensador pragmático por recorrer a Teorias estrangeiras somente na medida em que estas pudessem fornecer respostas para transformar o cenário nacional, o país que dizia amar, mas de forma nenhuma se pode associar este pragmatismo a um desconhecimento da nação. Qualquer que fosse o problema concernente ao Brasil, lá estava Romero a discordar, apoiando-se a partir desta ou daquela ideia, querendo dar a última palavra sobre a visão que, para ele, seria a verdadeira. Tinha a mania de querer ser o primeiro, de afirmar que sempre introduzira essa ou aquela Teoria no Brasil e a criação de sua Escola do Recife seria a comprovação direta de sua visão, com a defesa da superioridade do amigo e conterrâneo Tobias Barreto e sua transformação em gênio.

Personagem polêmico e nacionalista, mais significativo é perceber como Sílvio Romero observava o Brasil, o país ao qual dedicou toda uma vida. Ele mesmo, já no prólogo da História da Literatura Brasileira, falava que não escrevia para agradar, lembrando Villemain e argumentando que nunca agira em benefício próprio, já prevendo futuras e possíveis reprovações como de fato aconteceria. Se foi a política partidária a grande sedução ${ }^{367}$ de Romero, como nos lembra seu biógrafo Sílvio Rabelo, derivada justamente de seu nacionalismo, optamos por não antepor o político ao escritor, embora saibamos que o caso do bacharel é de tomar da pena e apontar os males do país à classe dirigente e aos tantos escritores que sofreram suas duras críticas.

Afirmava sempre que o que falava era a verdade, como um justiceiro julgando tudo e todos. Chamou a atenção diversas vezes contra o mal da cópia e de uma História brasileira fantasiosa, como a criada e interpretada pela geração do Romantismo, que traçou um quadro nacional que ele considerava mentiroso, irreal, omitindo a participação do negro na História pátria e depositando no índio o símbolo nacional brasileiro. Como outros integrantes de sua geração, sustentou que para o Brasil alcançar o estágio moderno ou civilizado, à imagem e semelhança dos países europeus, seria necessário antes de tudo descortinar e denunciar os verdadeiros problemas para só então fazer sentido a assimilação das ideias de fora, fossem essas ou aquelas. Mas o próprio Sílvio, mais do que qualquer outro escritor, se

\footnotetext{
${ }^{366}$ Ibidem. p. 189.

${ }^{367}$ RABELO, Sílvio. Op.Cit.
} 
apoderou das Teorias européias, com seu germanismo literário e os preceitos da Ciência Social e da Antroposociologia, para ficarmos apenas nessas duas correntes de idéias. Aqui, reside uma ambigüidade de Romero: compreender o Brasil e fornecer os fundamentos formadores do caráter nacional se apoiando nas idéias de fora como Evolucionismo, Positivismo e, sobretudo, Darwinismo Social. Contrário à macaqueação das idéias européias, falava que não adiantava assimilar pura e simplesmente as interpretações e as instituições liberais e democráticas e implementá-las no Brasil, como várias vezes chegou a denunciar.

A ânsia por ver seu país como uma nação moderna foi a razão para tanta confusão de ideias por parte de um escritor que era um revoltado contra o sistema, como chegou a afirmar, denunciando a camaradagem literária da Corte, onde somente com a ajuda dos medalhões seria possível adentrar as rodas literárias, o jornalismo literário ou os empregos públicos. O momento histórico experimentado por Romero fez dele um homem político na medida em que processava uma ruptura na forma de conceber o intelectual frente a sua nação.

Na recepção a Euclides da Cunha, (ingresso deste na Academia Brasileira de Letras), afirmava que não pretendia uma reforma pelas cimalhas porque "Já andamos fartos de discussões políticas $e$ literárias". ${ }^{368}$ Acreditava o engenheiro Euclides da Cunha na total extinção dos povos do litoral pelo processo de seleção natural, algo que para Romero não apenas era uma inverdade como apagaria " $a$ maior parte da nação e é aquela que fundou as nossas riquezas, e é aquela que tem mantido a nossa independência, porque é aquela que sempre trabalhou e ainda trabalha, sempre se bateu e ainda se bate" 369 .

Sílvio analisava detidamente as seis antinomias derivadas de adesão à Ciência Social. Crente na Evolução histórica, desmente a visão de Euclides da Cunha, apoiando-se no Determinismo biológico europeu com relação aos mestiços residentes no interior do país. Sempre que analisava o Brasil, partia do método da Ciência Social para atingir a índole da nação e então identificar os elementos do atraso e propor suas soluções, "Basta-me consignar que o nosso estremecido povo brasileiro apresenta a sintomatologia geral das noções a cujo grupo pertence esse grande número de povos de índole $e$ formação comunária, especialmente os latinos americanos, que tem de suportar a nova concorrência das nações de formação particularista, colocadas atualmente a frente da civilização industrial do nosso tempo: ingleses, alemães, americanos, canadenses, australianos, flamengos, holandeses,

\footnotetext{
${ }^{368}$ ROMERO, Sílvio. O Brasil social. Op.Cit.p.85

369 Ibidem. p. 86-87. Para compreendermos o confronto de idéias entre Sílvio Romero e Euclides da Cunha ver o importante artigo de NAXARA, Márcia. Brasil e Brasileiros: interpretações cientificistas/ Ensaios de caracterização. Revista História, São Paulo, nº 129-131, pp. 31-51, Agosto-Dezembro/93 a Agosto-Dezembro/94.
} 
franceses do norte, povos que retêm em suas mãos os capitais movimentadores do mundo moderno" 370

Dizendo-se farto de tantos discursos políticos e literários, discordava de Euclides da Cunha, que "reclamava que a Evolução biológica reclama a garantia da Evolução social” ${ }^{371}$. Em sua análise, o autor de Os Sertões pensava que as populações sertanejas iriam desaparecer devido à inferioridade biológica com a vinda de imigrantes. Romero reconhecia a existência de dois Brasis, mas não pensava na futura extinção das populações sertanejas como nos moldes de Euclides, que via a mestiçagem como um fator de degeneração. Reconhecendo as inúmeras zonas sociais do país, seria necessário falar dos caipiras, tabaréus, caiçaras, matutos, povo que, para Euclides da Cunha iria desaparecer.

\section{Elementos constitutivos do atraso brasileiro.}

Toda a conjuntura social, cultural, e política em que se encontrava a sociedade brasileira atormentava Sílvio Romero. Na obra O Brasil Social, publicada em 1908, encontramos de forma minuciosa a descrição da situação brasileira e da maioria da população pobre e despossuída espalhada pelas diversas regiões do país. Estudando e classificando os diversos tipos brasileiros, ele reafirma que é indispensável conhecer a sociedade brasileira para viabilizar o progresso do país, "Sob o aspecto social, direi, de modo geral, pelo que toca às nossas classes puramente populares, no restrito sentido que impropriamente se costuma dar a este qualificativo, que elas, nas zonas rurais, quase por toda a parte, se distinguem pelo analfabetismo, atraso, pobreza vizinha da miséria em grandíssimo número de casos, caráter dispersivo, falta completa de iniciativa, marasmo radical", 372

Com sua visão organicista spenceriana, utilizava-se da metodologia divulgada pela Escola de Le Play e de seus seguidores, como Demolins, Paul de Rousiers, A. de Preville, Henri de Tourville, se inspirando nos "melhores trabalhos sobre a índole das nações" ${ }^{373}$. Uma vez identificado o tipo de sociedade brasileira, buscou em primeiro lugar apontar os reais problemas do país não mencionados pela classe dirigente para só então propor os caminhos de mudança do quadro social do país.

Para adentrar e conhecer a estrutura social brasileira, "seria indispensável estudar o país, zona por zona, porque existem diferenciações várias a notar aqui e ali, exigidoras de diagnósticos divergentes e terapêuticas especiais" ${ }^{374}$. Num país constituído por uma população de 12 a 15 milhões de habitantes, salientava o crítico o quadro geral da situação brasileira, donde resultava um panorama

\footnotetext{
${ }^{370}$ Ibidem. p.87

${ }^{371}$ Ibidem. p.86

372 Ibidem. p. 136

${ }^{373}$ Ibidem. p.33

${ }^{374}$ Ibidem. p.87
} 
de extrema ignorância, pauperismo, miséria e opressão. Dessa população, um milhão era de índios, considerados inúteis, um milhão de escravos tidos como quase inúteis, distribuídos em povoados e situados raramente nas antigas fazendas e engenhos, restando nove milhões que, por sua vez, compunham-se de 500 mil pertencentes a antigas famílias de escravos, fazendeiros, médicos, engenheiros, empregados administrativos, negociantes, restando desse contingente " 6 milhões (atualmente mais) de habitantes, pelo menos, nascem vegetam e morrem, sem ter quase servido a sua pátria. No campo serão agregados de fazendas, caipiras, matutos, caboclos; nas cidades serão capangas, capoeiras, ou simplesmente vadios e ébrios" 375.

Para agravar ainda mais o quadro social brasileiro, a distância entre a reduzida classe dirigente e os setores pobres era de perder de vista. Seis milhões de habitantes estavam distribuídos nas vilas e cidades, constituindo nas primeiras caipiras, matutos, caboclos; e nas outras os vadios e ébrios. Toda essa situação social era senão consequêncial da formação comunaria brasileira, "O estado funcional das gentes brasileiras pode-se resumir numa palavra: o Brasil não tem povo! Dos seus doze milhões de habitantes (hoje serão talvez quinze, o que não altera o raciocínio) um milhão é de índios inúteis ou quase, um milhão é de escravos (hoje os ex-escravos e seus descendentes andam quase inúteis, esparsos nos povoados e raros nas antigas fazendas e engenhos). Ficam nove milhões (serão talvez agora doze) mais ou menos. Destes, 500 mil pertencem a famílias proletárias de escravos; são fazendeiros, advogados, médicos, engenheiros, empregados, administradores, negociantes. Acontece, porém, que o largo espaço compreendido entre a alta classe dirigente e os escravos (agora criados $e$ empregados de toda ordem) por ela utilizados não se acha suficientemente preenchido. Seis milhões (atualmente mais) de habitantes, pelo menos, nascem, vegetam e morrem sem ter quase servido a sua pátria. No campo serão capangas, capoeiras, ou simplesmente vadios e ébrios." 376

Em carta endereçada a José Oiticica ${ }^{377}$, denominada A Escola de Le Play no Brasil, admite Sílvio ser adepto fervoroso dessa linha de análise e que se encarregava de descrever sua província, utilizando-se do método do escritor francês. Como afirma em seus estudos de política social, sua maneira de analisar o país já embutia os preceitos da nova doutrina. Prefaciou Sílvio a obra de seu discípulo Artur Guimarães, Questões Econômicas Nacionais, em 1904. Criticava Romero os verdadeiros intelectuais brasileiros, médicos, engenheiros, magistrados, advogados, oficiais de curso de terra e mar pelo conhecimento apenas de correntes como as do Positivismo, Evolucionismo e Socialismo, mas desconhecerem os belos trabalhos da Escola de Le Play, doutrina existente há vinte

\footnotetext{
375 Ibidem. p.94

376 Ibidem. p.94.

${ }^{377}$ A Escola de Le Play no Brasil (Carta ao Il.mo Sr. Dr. José Oiticica). Em nota de pé de página Sílvio esclarece que Não esquecer o que já foi dito em nota a uma das páginas anteriores. Desta escola não aceito as idéias católicas dum ou doutro de seus membros. Sigo os processos, as idéias econômicas, sociais e políticas. O Brasil Social. Op. Cit.p. 45.
} 
anos. Alertava que no Brasil, quando alguma doutrina tornava-se conhecida, esquecia a Crítica a seus reais divulgadores sempre se colocando na dianteira do movimento ou da inauguração dessa ou daquela corrente de idéias.

Ressentia-se Sílvio mais uma vez de falta de reconhecimento por parte da Crítica brasileira da importância de seu nome como divulgador de idéias ou Teorias em que se dizia ser sempre o inaugurador. É a partir do conhecimento da Escola de Le Play e de seu divulgador maior, Ed. Demolins, que traça o quadro social brasileiro, viabilizando a partir dos problemas identificados uma solução que possa eliminar o país de seu atraso social. Em Introdução a Doutrina contra Doutrina (1894), acerca da viabilidade da formação de um partido operário no Brasil, Silvio mostrava a pobreza do país, "uma nação embrionária, cuja mais importante indústria é ainda uma lavoura rudimentar, extensiva, servida ontem por 2 milhões de escravos e hoje por trabalhadores nacionais e algumas dezenas de milhões de colonos de procedência européia, cem vezes mais felizes do que na mãe pátria” ${ }^{378}$, concluindo que "não conseguimos formar ainda um povo devidamente organizado de cima a baixo" ${ }^{379}$. Sílvio só reforçava o que havia escrito em Provocações e Debates. Classificava a sociedade brasileira em sete classes, onde a mais pobre era composta pela "turbamulta, indistinta, viciosa, que possuímos em larga escala, que vivem ao deus-dará, ou de suas agências, como eles dizem”." ${ }^{380} \mathrm{O}$ resultado geral da sociedade brasileira imersa nesse profundo pauperismo e extrema barbárie não era nada promissor. Somente $O$ Brasil Social deveria atrair todos os esforços na busca pela descrição do verdadeiro Brasil, mostrando a situação e as condições reais do povo, sem ilusionismo e sem o traço verborrágico dos dirigentes da nação predominantes ao longo da História do país.

Este Brasil Social era a nova forma de conceber ou analisar a sociedade brasileira de acordo como os preceitos da Escola de Le Play. Frente a todo o quadro de miséria social e cultural, só existia uma única maneira para alterar a condição do brasileiro: fazia-se necessária a nova Educação, responsável pela formação de um caráter diferente.

Os problemas brasileiros eram inúmeros e admitia Romero que alguns eram insolúveis. Toda a situação de pobreza material e mental brasileira, refletida nas inumeráveis formas de corrupção política, na apatia do povo brasileiro, na falta de interesse do povo pelas verdadeiras questões políticas, na macaqueação das idéias e instituições internacionais, na falta de amor pelas coisas nacionais, na Educação Retórica que não despertava o amor à pátria correspondente ao caráter apático da alma nacional, era decorrente da colonização da raça ibérica já degenerada. Traçando o quadro brasileiro tendo em vista a divisão em sociedade de formação comunaria e particularista, o autor

\footnotetext{
${ }^{378}$ ROMERO, Sílvio. Introdução a doutrina contra doutrina. São Paulo: Companhia das Letras, 2001. pp.84-85

${ }^{379}$ ROMERO, Sílvio. O Brasil Social. Op. Cit.p.90

${ }^{380}$ ROMERO, Sílvio. Introdução a doutrina contra doutrina. Op.Cit.p. 90
} 
entendia que o Brasil ligava-se ao primeiro modelo de sociedade, justificando assim a apatia da índole brasileira responsável pela situação de pobreza e miséria do país. O parâmetro para dividir cada sociedade estava intrinsecamente ligado à raça. Todos os problemas do país ligavam-se à formação comunaria, "Se queremos continuar a ser gente de comunarios, vivendo da política alimentaria, o ideal em matéria de Ensino é exatamente o que temos; se queremos, porém, mudar de rumo, no sentido das grandes iniciativas, é seguir o que fazem os ingleses e aconselha Demolins" 381

Presenciava-se à formação comunária reinando "quase exclusivamente" nas sociedades do Oriente Asiático, ao passo que as sociedades de formação particularista localizavam-se no norte ocidental da Europa e na América do Norte, sendo a raça anglo-saxã o modelo tomado por Romero para aludir a um caráter de iniciativa em contraposição ao viés apático do brasileiro, formado sob uma Educação comunária. Países como a Inglaterra e os Estados Unidos tinham atingido seu desenvolvimento não apenas econômico, mas político e moral, em função do tipo de Educação que adotaram, estimuladora de um espírito de iniciativa que preparava o homem para a luta pela vida.

Percebemos que Sílvio justifica toda a situação do atraso brasileiro em função do caráter apático do brasileiro, herdeiro da Educação comunária que não propiciou a iniciativa pelas lutas da existência. Com isso, não podemos afirmar que Sílvio desprezasse a influência da cultura: para o autor, o meio social tinha vital importância na alteração das bases sociais, tanto no plano cultural quanto no político, no econômico.

Sintonizado com as últimas doutrinas da época, recorria a todo instante às obras de Demolins, como Les Routes de L'Antiquité, e criticava os intelectuais brasileiros pelo desconhecimento das ideias do pensador francês, "Recomendamos aos brasileiros, libertos das literatices baratas dos desocupados, que leiam, dizemos mal, que estudem os livros do autor de que damos agora pálida notícia e peculiarmente em Lês Routes de l'Antiquité - as páginas relativas ao chamado Povo-Rei" 382

Por ser o Brasil um país de formação comunária, propiciadora de um caráter apático ou sem iniciativa, resultava uma sociedade atrasada coberta por diversas ambigüidades, sendo a primeira dessas "a disparidade entre uma pequena elite de possuidores e proprietários e o avultadíssimo número dos que nada tem, nada possuem, principalmente nas populações rurais". ${ }^{383}$ Pensava Romero, com sua visão organicista inspirada por Spencer e nos teóricos integrantes da Escola de Le Play, que as causas dos males brasileiros ligavam-se à falta de harmonia entre os inúmeros elementos considerados pelo mesmo como indispensáveis, fazendo com que buscasse o ponto de partida ou a raiz

\footnotetext{
${ }^{381}$ ROMERO, Sílvio. O Brasil social. Op.Cit.p.75

382 Ibidem. p.79-80

383 Ibidem. p.89
} 
dos males brasileiros, “urge enfrentar a situação nacional como ela é, em si mesma, no seu caráter, na sua índole, na sua estrutura interna, na substância íntima de seu ser, na trama fundamental da sua organização, nos seus elementos formativos, na essência intrínseca que a constitui ",384.

Encontrava-se o Brasil numa situação de miséria social e profundo atraso econômico na época do carvão, do vapor e da eletricidade. Outro problema era a contradição entre uma pequena elite de intelectuais, composta por políticos, jornalistas e literatos, e a maioria da população analfabeta, caracterizando uma sociedade bárbara. As inúmeras mazelas que arrolava derivavam dessa ordem de coisas que só aumentavam quando o Brasil era visto pela elite brasileira como um país desenvolvido, criando um ilusionismo responsável pelo maior mal brasileiro que era a mania de passar por aquilo que não somos.

Sílvio, à medida em que traça a conjuntura social brasileira, criticava justamente a macaqueação e a pura imitação, principalmente francesa, mas foi justamente aos escritores franceses que sempre recorreu para validar suas idéias. Em sua perspectiva, de nada adiantava mostrar no exterior a imagem de um Brasil que na realidade não correspondia ao Brasil real. O Brasil não era um país desenvolvido, capaz de absorver idéias estrangeiras ou imitar as instituições liberais ou parlamentares de outros países. Sabemos que a elite brasileira deseja mostrar um Brasil que aos olhos de Sílvio não existia, e o escritor dava bastante importância às raças consideradas inferiores, como negros e índios. Mais importante do que salientar a vergonha que a elite brasileira tinha em relação ao que considerava subraças, trazendo com isso a imagem daquilo que não era - expressão de Sílvio -, é lembrar a importância que o escritor sergipano atribuía à cultura do povo e às heranças indígena e africana.

A pobreza mental causada pelo desconhecimento da crítica por nossa classe dirigente causava a megalomania, sendo indispensável descrever o Brasil Social. Na recepção a Euclides da Cunha na Academia Brasileira de Letras em 1906, respondia ao autor de Os Sertões, que acusava Romero de pretender uma reforma pelas cimalhas, ou seja, de pretender reformar o quadro social brasileiro de maneira superficial. Em revide, o escritor sergipano arrola os reais problemas do país. Os males brasileiros não seriam resolvidos com a abertura de ruas e avenidas à beira mar, com a criação de academias de luxo diante de uma sociedade analfabeta, com a construção de palácios e teatros monumentais que ficarão fechados enquanto a maioria da população mora em cortiços e sofre de uma miséria geral. De que adiantava sediar o Brasil um Congresso Pan-Americano para sedimentar e fazer crer sua ilustração quando se presenciava assassinatos de deputados e senadores à luz do dia?

"Não consta em todo o correr da História de mais de dez mil anos, que alargamentos de ruas e aberturas de avenidas numa cidade qualquer, mero luxo a que nações se entregam quando,

${ }^{384}$ Ibidem. p.108 
cansadas da riqueza, entram a caducar, tivessem sido meio de solver os fundos males sociais, as gravíssimas inquietações de um povo! Despediu-se e deixou-me triste" 385

Sílvio criticava toda e qualquer postura por parte da elite brasileira que, segundo ele, não mencionava as raízes dos males brasileiros. Esses problemas só se agravavam porque os dirigentes da nação não levavam a política a sério e o povo analfabeto só reforçava tal estado de coisas. Nem a maioria do povo nem os políticos se interessavam pelos problemas brasileiros. Para reforçar toda esta situação alarmante, os literatos eram os grandes responsáveis pela vigência do quadro social brasileiro em razão do desconhecimento dos livros dos escritores constituintes da Escola de Le Play.

Hora, os críticos brasileiros creditavam o atraso brasileiro ao fato de não ser o imperador Pedro I ou seu sucessor, Pedro II, a raiz dos problemas nacionais, hora depositavam no elemento servil o mal brasileiro. Mas, para Sílvio, as causas desses problemas reduziam-se à falta de amor ao país que, como consequêncial , causava o desconhecimento e o desinteresse pelos verdadeiros assuntos políticos que, mesmo com a instauração da república, não foram sanados:

\footnotetext{
"No caminho da disciplina intelectual e moral, da consciência de um alto destino a realizar nobres Direitos a reivindicar e de grandes deveres a cumprir, a nação não tem dado um passo. Acabou-se a escravidão, desapareceu o Império; mas não findou a nossa incurável leviandade, a nossa clássica covardia, a nossa falta de ideal, a ausência em que temos vivido do senso do que é ousado e grande, do que é justo e nobilitante.

A alma brasileira depois de um ano e meio de República tem a mesma forma e conserva a antiga atitude. Nenhum instinto novo revelou, nenhuma aspiração nova abriu para o lado do porvir.

Um só vezo, que andava oculto, despertou rapace e furibundo: - o vejo do jogo, a ânsia mórbida do ganho barato e rapidíssimo.

Foi a aquisição única feita pela Psicologia nacional!"... 386 (grifos nosso)
}

Pensava Romero que os problemas brasileiros eram decorrentes de uma ordem bem maior, " $a$ teima de julgar política, e sanável por meios políticos, uma questão orgânica, étnica, de Psicologia popular, uma questão profundamente, essencialmente, unicamente da estrutura social do povo". ${ }^{387}$ Num país onde se fazia politiquice e não política, onde a única maneira de sobrevivência era buscar emprego público ou fazer da política meio de vida, onde os políticos se perdiam em sua própria vaidade, onde o povo sequer se interessava pelas reais questões nacionais por falta de amor a pátria, onde a própria Imprensa jornalística reduzia-se a meras disputas partidárias, onde os intelectuais sofriam de cegueira frente à presença de doutrinas novas e imparciais como rezava a Crítica, os cernes dos problemas nacionais eram de ordem estrutural orgânica ligada à raça, ao meio, e à Educação, formadora do caráter nacional brasileiro. Crente na existência de uma índole dos povos, explicava

\footnotetext{
${ }^{385}$ Ibidem. p. 101

${ }^{386}$ ROMERO, Sílvio. Estudos de Literatura contemporânea. Op.Cit.p.359.

${ }^{387}$ Ibidem. p. 109
} 
Romero às causas do atraso brasileiro atinando para os aspectos sociais, econômicos e políticos, onde somente com as idéias do Evolucionismo e da escola de Ciência Social francesa, seria possível a formação de um caráter enérgico para alterar toda a estrutura social, cultural, e política brasileira:

"É assim ainda hoje e sê-lo-á por todo o sempre, enquanto por seguros meios de seleção sociológica, de Educação moral e, até certo ponto, de instrução científica, devidamente generalizados, se não modificar - para melhor - a índole, o caráter intrínseco de nossas gentes.

Já por diversas vezes tenho chamado a atenção para esse fato de fundamental alcance no estudo de nossos destemperos políticos, no intuito de mostrar onde se encontrava a verdadeira raiz do mal", 388

Toda a série de corrupção política por parte dos dirigentes nacionais ao longo da História brasileira, as promessas sempre anunciadas e nunca cumpridas, os discursos políticos onde predominava a verborragia demagógica dos dirigentes da nação eram os principais problemas causadores do atraso do país. Mas os brasileiros eram assim por formação - vinha das raízes, da herança dos povos ibéricos. A ilusão dos dirigentes da nação em sempre representarem um Brasil inventado, bem conformada com a mania de grandeza, não possibilitava conhecer os reais problemas nacionais, dando lugar à vaidade política e às exposições baratas, custeando viagens de escritores brasileiros para fora do país.

Mesmo com a implantação da República no Brasil, o país sequer avançou ou alterou sua estrutura social e econômica instituída ao longo dos quatrocentos anos de sua História. Com a instauração da República, o Brasil só "teve a vantagem de revelar este grande querido povo brasileiro tal qual é, entregue a si próprio ou a seus naturais diretores, o que vem a ser a mesma coisa" ${ }^{389}$. Os problemas nacionais eram decorrentes da formação comunária responsável pela apatia do brasileiro, sem iniciativa para o progresso. Sílvio justificava o atraso brasileiro sempre remetendo à índole nacional, responsável pelo afrouxamento do caráter, pela tendência ilusionista, pela megalomania, pelo mal do funcionalismo público e por toda a sorte de corrupção política do Brasil, onde reinavam de norte a sul e de leste a oeste as oligarquias estaduais. Todo comportamento social e político das classes era equivalente a sua índole e aqui reside o cerne da visão de Sílvio no que tange aos problemas nacionais:

\footnotetext{
"o maior defeito de nossa Psicologia nacional, tenho-o dito milhares de vezes e não canso de o repetir, é não querermos ir ao fundo das questões políticas e sociais em que nos debatemos, não queremos ter a coragem de reconhecer que a raiz do mal está em nós mesmos, na inconsistência de nossa índole, na nossa pelo menos atual, incapacidade para as grandes organizações, as conquistas reais e duradouras

Julgamo-nos aptos para tudo, sem o preliminar preparo de nós mesmos Pensamos que basta copiar as instituições alheias".
}

\footnotetext{
${ }^{388}$ Ibidem. p. 106

${ }^{389}$ Ibidem.
} 
A Alemanha, a Inglaterra, a França, os Estados Unidos, possuem belas instituições políticas e sociais....

Por que não havemos de tê-las também?

É copiar as leis desses países e basta". ${ }^{390}$

Era Sílvio Romero um ardoroso seguidor do Evolucionismo orgânico do mestre Spencer, desdobramento de seu Culturalismo sociológico iniciado com Tobias Barreto. A Ciência Social francesa foi sua grande inspiração e modelo para interpretar o país, somado à crença no arianismo de Ammom, Lapouge e seu grande mestre Gobineau. Mesmo preterindo o Positivismo, Romero aceitou a lei dos três estágios, admitindo ser este um grande feito de Comte. Os problemas brasileiros caminhavam da barbárie à civilização, sentido de seu Evolucionismo em que os órgãos progridem do mais simples ao mais complexo. Quando analisa os problemas nacionais, descreve as diversas áreas do país, não esquecendo os esquemas explicativos de Buckle e Taine, embora tenha divergido destes dois teóricos em alguns aspectos.

Outro problema, segundo Sílvio, era a ausência durante os quatro séculos como colônia portuguesa de movimentos sociais afirmando a existência no Brasil, "senão revoluções e movimentos políticos que longe de facilitarem a constituição social do povo, embaraçam-na ao invés consideravelmente" ${ }^{391}$. Em nada contribuiu para a consciência nacional ter o país abolido a escravidão, seguindo-se imediatamente a proclamação da república, abortando uma possível formação da consciência nacional. Os escravos deveriam ter sido preparados para serem proprietários ou operários agrícolas. Lembremos que, para Romero, era preciso ordenar hierarquicamente cada classe social para só então ser possível uma possível revolução, acarretando uma mudança de estrutura. Democrata, privilegia Sílvio uma forma de representação que fale a língua do povo, e somente classificando hierarquicamente as classes sociais no Brasil seria possível se pensar em futuras mudanças políticas. Tinha conhecimento das idéias de Marx e Engels, afirmara que o Socialismo ou a formação de um partido proletário no Brasil era inviável, mais importante seria classificar a população a par das estatísticas demográficas do país.

Outro problema brasileiro e que muito preocupava Sílvio era a vinda de imigrantes justamente no momento de formação da identidade nacional. O Brasil dispunha de mão de obra suficiente e possuía natureza riquíssima, mas nunca teve uma Economia assegurada, a não ser ciclos econômicos, tornando o país sempre dependente do capital estrangeiro, contraindo empréstimos e mais empréstimos. Não fazia sentido a dupla corrente de imigrantes composta de frades e anarquistas, que só aumentava a ilusão brasileira, uma vez que estes participavam de greves num Brasil sem indústrias e eram desprovidos das condições necessárias para formação de um partido operário. Era de fundamental

\footnotetext{
${ }^{390}$ Ibidem. p.139

${ }^{391}$ Ibidem. p.95
} 
importância receber povos estrangeiros sim, mas de maneira racional e distribuídos não apenas em regiões específicas, como o sul do Brasil. Os povos alemães não poderiam se instalar somente numa região, era essencial o contato com o brasileiro para que este processo de imigração se tornasse benéfico a ambos os povos. No fundo, almejava Sílvio sedimentar os pilares da identidade nacional brasileira, defendendo a língua e as tradições como ponto central para a formação da identidade do país.

Chamava atenção para a imigração alemã, "De vinte e cinco a trinta anos a esta parte, não perco o ensejo de despertar dos brasileiros e dos poderes públicos da nação para esse gravíssimo assunto". ${ }^{392}$ Preocupado com o futuro do Brasil, mesmo adepto da cultura germânica por valorizar o critério etnográfico e acreditar na superioridade da raça ariana, entendia que a imigração no Brasil precisava se processar de forma racional até porque os alemães seriam indiferentes às questões brasileiras indispensáveis à formação nacional

\begin{abstract}
"Existem em cerca de 380.000 pessoas de origem germânica residentes no Brasil, seis ou oito que para confirmar a regra de abstenção de seus patrícios em tudo que é puramente brasileiro, se metem nas lutas partidárias locais.

São raros moços, filhos das cidades, ordinariamente nascidos dos raríssimos consórcios de alemães com brasileiras, desviados em parte do pensar genuinamente germânico, que se deixam atrair por ambição política. É exceção singular, que nada vale". 393
\end{abstract}

Preocupado com o futuro do Brasil e almejando ver seu país como uma verdadeira nação moderna, salientava os aspectos culturais, dentre estes, a importância da língua e das tradições do país: “Destarte, o erro gravíssimo, o erro inexpiável dos governos brasileiros, o erro que nos há de trazer a perda das belíssimas regiões do sul, foi haver-se consentido na formação lenta, por oitenta dilatados anos, de fortes grupos de população que ficou irredutivelmente germânica, sem a menor fusão com as populações brasileiras" 394

Com relação aos aspectos econômicos, sustentava que a elite brasileira havia perdido os ciclos do açúcar, do minério, do café, fazendo do Brasil um país dependente do capital estrangeiro. A vinda de imigrantes, sobretudo dos alemães localizados na região sul, causara um desequilíbrio entre as regiões norte e sul, dificultando o despertar de um sentimento nacional. Era necessário dividir tais imigrantes de forma igualitária para que os costumes brasileiros não se perdessem.

Mesmo com o advento da ordem republicana, "a alma brasileira depois de um ano e meio de republica tem a mesma forma e conserva a antiga atitude. Nenhum instinto novo revelou, nenhuma

\footnotetext{
392 Ibidem. p. 40

${ }^{393}$ Ibidem. p. 148

${ }^{394}$ Ibidem. p.156-157
} 
inspiração nova abriu para o lado do porvir" ${ }^{395}$. A esperança de Sílvio por uma ordem que falasse a voz do povo ao longo da História não sofreu mudanças com o regime republicano, que, em seu entendimento, só consolidara o atraso do país, uma vez que "a nação não tem dado um passo”. Os problemas brasileiros e as estratégias políticas de homens que pretenderam a instalação da república sem sequer esboçarem qualquer forma de projeto político comprovavam a tentativa de traiçoeiros sebastianistas de reconquistarem o poder. Assevera os inúmeros disparates políticos datados desde a proclamação da república até o governo provisório, salientando as manobras política do Barão de Lucena, que pôs fim às poucas conquistas dos tempos imperiais, resultando um cenário brasileiro com "as mesmas questiúnculas, os mesmos vícios, os mesmos interesses pessoais, as mesmas chicanas, as mesmas pepineiras e, para tudo dizer numa só palavra, a mesma desengraçada comédia representada quase pelos mesmos atores" 396

Nessa perspectiva, a ordem republicana em nada alterou a conjuntura social, só agravou os problemas brasileiros de outrora. Traçando um paralelo entre a nova ordem republicana e a política brasileira dos tempos imperiais, alertava Sílvio para a volta do Sebastianismo, afirmando que " $a$ República não está feita desde que não está plenamente constituída e consolidada”. Combatia o perigo do Sebastianismo, salientando que o país "precisa de idéias, de doutrinas, de opiniões firmes, de boa fé, de patriotismo, de todas as qualidades intelectuais e morais que possam vir em auxílio das instituições combatidas pela propaganda vulpiana do Sebastianismo". 397

Os sebastianistas eram os piores inimigos da república e Sílvio os combatia veementemente porque a solução dos problemas nacionais não seria a volta à monarquia. Segundo ele, Jacobinos e puritanos foram posturas políticas compostas por pessoas oportunistas e sem amor a pátria, sem o conhecimento necessário para dirigir a nação brasileira, a começar pelo desconhecimento do próprio Brasil, pois "nem estudam com seriedade, nem possuem a plasticidade mental precisa para assimilar os árduos problemas da vida política em sua realidade" ${ }^{398}$. Somado ao oportunismo dos puritanos e jacobinos na participação do golpe republicano, menciona o desconhecimento dos preceitos da Ciência política, chamando atenção para a necessária presença de um caráter sério na lide para enfrentar os problemas brasileiros: "o país precisa ser dirigido por homens de caráter severo, de patriotismo provado, de ilustração larga, de estudos sólidos. Não basta ter sido declamador de rua ou de gazeta para pretender um posto na direção dos negócios; é mister inspirar confiança por produções sérias" 399

\footnotetext{
${ }^{395}$ Ibidem. p.360

396 Ibidem. p.371

${ }^{397}$ Ibidem. p.374

${ }^{398}$ Ibidem. p.363

${ }^{399}$ Ibidem. p.364
} 
Opondo-se aos grupos puritano e jacobino, Sílvio se diz um reacionário, esboçando seu nacionalismo quando analisa o comportamento dos políticos mantenedores da péssima condição da nação brasileira. Afirma que questões como o casamento civil, a reforma do Ensino e a separação entre a Igreja e o Estado foram fortemente manipuladas. A situação dos estados brasileiros e os cargos do funcionalismo público ficaram nas mãos de poucos politicadores, só reforçando a situação de pobreza social e material da nação, alimentando cada vez mais o predomínio das oligarquias. Diante de tantos problemas arrolados, pugnava Romero pela descrição de um Brasil real e sem ilusões, declarando-se um homem que não bajulava nem concordava com a elite política e intelectual brasileira.

Perguntava, diante de tantos problemas, qual o caminho a seguir, e mais uma vez afirmava que um destes caminhos era "planos, doutrinas, ideias, sistemas, orientação, eis o que é indispensável como arma da oposição”. ${ }^{400}$

\section{Oligarquias no Brasil}

No Rio Grande do Sul os funcionários públicos, do inferior ao superior, são todos de nomeação do presidente do estado, mas este, pela organização interna, ali estabelecida, apenas manda lavrar o decreto e assina: quem nomeia e demite funcionários do estado e de todos os municípios é o Dr. Medeiros, e se o presidente recalcitrar vai para o livro negro e se não se submeter, porque a submissão é a base do aperfeiçoamento, está irremissivelmente condenado, como já esteve o Dr. Carlos Barbosa, que chegou a ver em palácio o Dr. Juvenal Muller, vice-presidente do estado, para insinuar-lhe que lhe devia passar o governo e recolher-se a Jaguarão para tratar da saúde. ${ }^{401}$

Para um bom patriota, crítico e nacionalista, não passaria despercebido o predomínio das oligarquias no Brasil. Apaixonado pelas coisas do Brasil, Sílvio se posicionou criticamente contra os clãs oligárquicos do país. Assim como criticou veementemente os escritores do Romantismo brasileiro e personagens como José Veríssimo, Machado de Assis, Araripe Júnior, Capistrano de Abreu, Carlos Laet e tantos outros, os trabalhos de Filosofia de cunho retórico empreendidos por Monte Alverne, influenciado por Cousin, esclarecendo a inexistência de um pensador brasileiro, não deixou de se posicionar de forma contundente quanto à presença das oligarquias no Brasil. Munido de suas enciclopédias britânica e alemã, cobriu-se de farto manancial teórico para avaliar os principais dirigentes da nação, apoiando-se no conhecimento científico europeu ao longo de seus quarenta anos

\footnotetext{
${ }^{400}$ Ibidem. p.376

${ }^{401}$ Ibidem. p. 211
} 
de atividade literária. Tal patriotismo ficava bastante claro quando tratou de analisar pontualmente a presença das oligarquias no país: "sou do número dos que adoram a terra, amam ardentemente o povo e detestam a chamada classe dirigente, em cujo número avultam incompetentes ou criminosos em qualquer grau", 402

Sílvio classificava em quatro tipos os modelos de oligarquia que eram respectivamente.

\begin{abstract}
"Abrem a fieira as que mais propriamente se poderiam denominar olikoarchias, ou oikocracias, porque não passam de reproduções do obsoleto familismo primitivo, meros communarismo de família, conhecido em remotos tempos, da há muito desaparecido dentre gentes cultas, formula bastarda de organização político-social, cujo exemplar mais completo entre nós é o que se poderá apelidar - o aciolismo - cearense. Neste caso - a família, com todos os parentes, faz o açambarcamento dos postos da governança, da administração e dos mais rendosos negócios. Alonga tentáculos por toda a extensão do estado, suga diretamente dos cofres públicos grossas somas, sob a forma de ordenados, e outras maiores, disfarçadas em arranjos vários. Nesta fórmula a família governamental, a tribu dirigente assume feições de casa reinante; o chefe, o tuxaua, rebento atávico evidente de caciques indígenas, dá-se ao luxo de fazer substituir no trono durante as ausências, em viagens de recreio, pelo príncipe herdeiro" 403
\end{abstract}

Embora tenha salientado a presença das oligarquias em todo o Brasil, uma vez que a federação brasileira havia se transformado em vinte e duas oligarquias, ${ }^{404}$ constituída por estados do Piauí, Rio Grande do Norte, Paraíba, Pernambuco, Alagoas, Sergipe, Bahia, Goiás, Mato Grosso, Sílvio se detém de maneira pormenorizada na oligarquia maior de Pinheiro Machado, reinante no Rio Grande do Sul e com influências em todo o país. Romero atina para a influência de Pinheiro Machado e de seu amigo Procópio Peçanha, motivo do célebre caso de Sergipe, no qual o crítico teve participação direta, conclamando a população a tirar do poder homens como o oligarca José Luís, o senador Leandro Maciel e o vigário Olímpio ${ }^{405}$.

Arrolando de maneira breve as práticas políticas dos inúmeros chefes oligarcas de cada estado, detém-se de maneira pormenorizada no Castilhismo no Rio Grande do Sul. Talvez um dos motivos da atenção votada ao comando de Pinheiro Machado resida no fato de que o próprio Sílvio fora perseguido por ter contestado o caráter oligárquico deste estado. Romero afirmava ter sofrido reveses ao longo de seus quarenta anos de luta por não aceitar as descomposturas de Pinheiro Machado, mostrando com sua linguagem direta a existência inquestionável da forte influência da oligarquia desse político quando certa vez surgiu nos jornais gaúchos Federação e Jararaca, salientando sua posição: "Tiveram ali a coragem, filha de crassíssima ignorância, de contestar o caráter oligárquico do governicho do desventurado estado". ${ }^{406}$ Não havia exemplo maior de oligarquia num regime onde "um chefe incontrastável e meia dúzia de mandarins trazem pela gola a população, sufocando-lhe

\footnotetext{
${ }^{402}$ ROMERO, Sílvio. Geografia da Politicagem: o norte e o sul do Brasil. S.N., 1912.p. 8

${ }^{403}$ ROMERO, Sílvio. Provocações e debates. Op. Cit. p.412-413

${ }^{404}$ Ibidem. pp. 412-413

${ }^{405}$ Em Introdução a Doutrina contra Doutrina Sílvio narra seu envolvimento na política local de Sergipe. Op.Cit.

${ }^{406}$ ROMERO, Sílvio. O Brasil social. p.198
} 
todas as liberdades" ${ }^{407}$. O bacharel não se conformava com o poder que tinha Pinheiro Machado, manipulando a política nacional com a conivência dos próprios personagens políticos

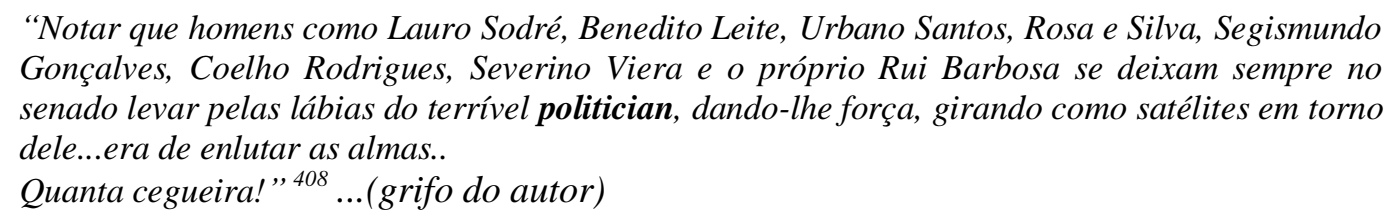

Para um lutador combatente, espírito crítico e, acima de tudo, nacionalista, como era Romero, era inadmissível o poder ilimitado de Pinheiro Machado em todo o país, "Ora é mais que tempo de acabar com isto e reduzir o Sr. Pinheiro Machado ao ser nenhum valor, onde quer que se apresente, no Rio Grande do Sul, em São Paulo, em Caldas, ou no Egito". ${ }^{409}$ Sílvio responsabilizava Gaspar Martins, homem educado de maneira romântica, de 1855 a 1860, em São Paulo, por toda a credibilidade que tinha o líder gaúcho responsável pelo medo dos demais políticos: “Como deputado, como senador, como ministro, na oposição ou no governo, entre 1868 e 69, o jogo de Gaspar Martins foi sempre o mesmo: meter medo com o Rio Grande, mostrar na corte a influência que tinha ali e ali a influência que tinha na corte”. ${ }^{410}$ A situação era tão grave que o oligarca chegou até a alterar a geografia do país para favorecer seus aliados, "a coisa tem chegado ao ponto de até a geografia do país andar alterada, ao sabor das perigosas habilidades do Sr. Pinheiro". "411 Após relevar brevemente a presença das oligarquias em todo o país, reclamava da situação do governo federalista brasileiro. Findava o pequeno artigo Geografia da Politicagem salientando que

\begin{abstract}
"E é a um regime que deveria ser de igualdade, e está, assim, deturpadíssímo, onde o centro pratica diariamente contra a maior parte de seus membros tão grosseiras prepotências e tão terríveis despotismos, que se ousa em desacordo ao mais comezinho bom senso, irriozoriamente denominar de Regime Federalista?!.. Reação, reação, srs. Representantes do norte, em nome do senso comum!"... ${ }^{412}$
\end{abstract}

No artigo O Castilhismo no Rio Grande do Sul, ${ }^{413}$ aborda especificamente aquilo que considera a maior anomalia da república brasileira, a oligarquia do senador Borges de Medeiros. Se o patriotismo de Sílvio ficava evidente no opúsculo Geografia da Politicagem, aqui, a argumentação do

\footnotetext{
${ }^{407}$ Ibidem. p. 198

${ }^{408}$ ROMERO, Sílvio. Geografia da politicagem. Op.Cit.p. 4

${ }^{409}$ Ibidem. p.5

${ }^{410}$ Ibidem. p. 6

${ }^{411}$ Ibidem. p.7

412 Ibidem. p.14.

${ }^{413}$ Este artigo é transcrito integralmente em $O$ Brasil Social faltando apenas os oito primeiros parágrafos. Acompanhamos em nossas leituras os dois documentos. ROMERO, Sílvio. O castilhismo no Rio Grande do Sul. Porto: Oficina do comércio do Porto, 1912.
} 
bacharel se processa "Como preito a verdade, movido pelo patriotismo e o amor a ideias sans, venho neste opúsculo, relembrar algumas extravagâncias da politiquice daquele estado, que deve ser a guarda avançada da democracia brasileira”. ${ }^{414}$ Conforme o crítico, é fácil explicar porque os políticos manipulados por Medeiros são a "gente mais odienta de todo o Brasil". ${ }^{415}$ Antes de começar a citar os inumeráveis casos de corrupção envolvendo a figura de Medeiros, releva Romero de maneira sutil a influência de uma sociedade comunária explicadora das oligarquias,

\begin{abstract}
"Almas semibárbaras de egressos do regime pastoril, envenenadas pelas doutrinas e manhas ditatoriais de um meio Positivismo grosseirismo, - essas da classe hoje dirigente no Rio Grande do Sul -, não trepidam no manejo no manejo dos atos mais violentos, na repressão daqueles que se desviam das normas de seu estreito politicar, e menos ainda em cobrir de insultos e baldões quem quer que não diga amém a todas as suas tresloucadas pretensões" ${ }^{416}$
\end{abstract}

Sílvio chamava atenção para o fato de que não existiam oligarquias somente no norte do Brasil e que o Rio Grande do Sul, em tempo algum, presenciara ares democráticos. Apontava não apenas a existência de verdadeiros clãs espalhados por todo o país como propunha estratégias para acabar com esses pequenos grupos políticos do Brasil. Nessa perspectiva, o Rio Grande do Sul jamais presenciou um regime democrático, alimentado por mentes como Félix da Cunha, Gaspar Martins e Assis Brasil. Sílvio desejava entender os porquês da instalação da ditadura castilhista, explorando rapidamente a situação de outros estados como São Paulo. Analisando a situação colonial de alguns estados brasileiros como Amazonas, Minas Gerais, Mato Grosso e Goiás, conclui que a formação do Rio Grande do Sul como fronteira explica em parte sua História política. Divide o Rio Grande do Sul em três zonas para explicar a presença da oligarquia maior de Borges de Medeiros.

Para Romero, o caráter do povo do Rio Grande do Sul, estado mais novo da federação brasileira naquela época, surgido no século XVIII, pode ser explicado por sua formação comunaria, tendo por base a família instável, de acordo com os preceitos teóricos de Demolins, Poinsard e Preville. Presenciam-se no Rio Grande do Sul, exceto nas pessoas das cidades, dois tipos de população: os agricultores (das encostas da serra e de acima) e os criadores (dos campos e coxilhas e das chapadas do planalto). São pessoas sem iniciativa, que dependem sempre de um patrão, só favorecendo o surgimento de caudilhos como Júlio de Castilhos, Pinheiro Machado, João Francisco e Carlos Barbosa. Povo apto à criação, alimentado pelo mate, desorganizado, os criadores dos campos, das encostas e dos planaltos favorecem o surgimento do castilhismo no sul do Brasil.

\footnotetext{
414 Ibidem. p. 1

415 Ibidem..p. 2

${ }^{416}$ ROMERO, Sílvio. O Brasil social. p.198
} 


\begin{abstract}
"Acostam-se sempre a um patrão, não cultivam a autonomia da vontade, a iniciativa de viver por si, traçando-se uma carreira, não cultivam a liberdade civil no sentido moderno.

São uns patriarcas instáveis, eles e os seus chefes, estirpe desses caudilhos que pululam na terra gaúcha, dos quais tantas dúzias surgiram nos dias da revolução federalista.

Alguns, mais desprendidos, ou mais dignos, ou almas mais alevantadas, abraçaram a causa da revolução como Gumercindo Saraiva; outros, temperamentos de truculentos sequazes, abraçaram a causa dos pica-paus, a causa do déspota Castilhos, como esse ultrafomoso João Francisco, hoje repudiado pela própria oligarquia que se apoderou do estado.

Esses são o esteio-mor do castilhismo". ${ }^{417}$
\end{abstract}

Conforme a divisão das zonas e dos tipos de população no Rio Grande do Sul, exceto a população citadina, descendente de colonos e da velha estirpe nacional, por sua vez, subdividia-se em funcionários públicos, profissionais liberais, negociantes e empregados ou do comércio ou das indústrias. Nos dois últimos grupos é que residia a oposição entre pica-paus e maragatos. Mas chegava à hora de "desfilar às pressas as contas deste rosário" 418

Pontuando as disputas locais entre os seguidores de Júlio de Castilhos, no caso, Borges de Medeiros, e João Francisco e Pinheiro Machado, no que presenciou o jesuitismo manhoso que evitou um confronto direto entre estes dois grupos políticos, salienta Sílvio a presença do Positivismo: “ $A$ organização do Rio Grande do Sul, aberta do sistema americano, é toda ela calcada, a força de marreta e malho, nas aspirações da política positiva de Augusto Comte, que em parte nenhuma do globo teve aplicação, nem na Groelândia, nem no arquipélago de Lafoden". ${ }^{419}$ As origens do povo brasileiro e seus antecedentes históricos eram tomados como causas para compreender a existência da maior oligarquia no país,

\footnotetext{
"Quanto as nossas origens étnicas, aquela organização desmente e contraria absoluta e fundamentalmente as tradições brasileira e rio-grandense, através das quais passam sempre o sopro animador e vivificante e a vibração da liberdade, como os efetivos das correntes de alta frequêncial com que a darsonvalização agita e modifica milagrosamente as condições do organização do organismo humano, ao passo que na atual modelação do Rio Grande do Sul o que predomina é a intolerância insolente e a tendência manifesta para o absolutismo czarista." 420
}

Tais elementos justificavam a presença das oligarquias no Brasil, favorecendo a existência do chefe do clã, o mandão, o caudilho. Chamou atenção para a raça colonizadora, já em estágio degenerativo devido à mistura responsável por um caráter meio selvagem, atávico, frouxo, e uma série

\footnotetext{
417 Ibidem. p.203

${ }^{418}$ Ibidem. p. 204

${ }^{419}$ Ibidem. p. 206

${ }^{420}$ Ibidem. p.206-207
} 
de corrupção política: "é uma loucura procurar conhecer a política de um povo, sem estudar o estado real da Psicologia desse povo" ${ }^{421}$. Afirmava que em nenhum lugar do mundo, nem nos antigos Impérios como os da Assíria, Babilônia, Pérsia, divididos em satrápias, ou mesmo na Roma antiga, Rússia, China e no Japão, a situação política de corrupção era tão caótica como no Brasil. Sílvio não pensava apenas em enumerar as oligarquias com seus respectivos chefes políticos, mas em identificar soluções para eliminar o povo brasileiro da miséria econômica e cultural. A forte presença das oligarquias no Brasil era somente um dos resultados da influência ibero-latina, resultante da formação comunaria.

Nesse sentido, a presença das oligarquias no Brasil refletia bem o caráter de um povo herdeiro de uma raça inculta, onde o meio geográfico por vezes influenciava. Não é estranho que momentos antes afirmava não ser o brasileiro apto ao federalismo e agora salientava que esta forma de representação política desmentia e contrariava absoluta e fundamentalmente as tradições brasileira e rio-grandense. Seria esta mais uma das contradições de Romero? Mais uma vez, vale salientar que a política brasileira era compreendida por Sílvio Romero de maneira ampla e estrutural, sempre ligada a uma organização complexa, à imagem e semelhança de um grande organismo. Em meio a esta estrutura social, relevava o bacharel a influência de elementos com o meio, a raça, trabalhando sempre com as leis históricas determinando o quadro político nacional. Mais uma vez, ressaltava o caráter de um povo inculto, atávico, formado sob uma Educação comunária, aspecto somado ao atavismo da raça refletida em toda a política corrupta dos chefes políticos brasileiros ao longo do processo histórico. Justificava a presença das inúmeras oligarquias agenciada por políticos corruptos que se mantinham no poder sempre por meio de discursos que mascaravam a realidade brasileira. Entendia a existência das oligarquias no Brasil a partir de alguns teóricos da Escola de Le Play e da Antroposociologia: "Só os ensinamentos da Antroposociologia de um Lapouge ou de um Ammom, adjuntos aos processos de Ciência Social de um Tourville ou de um Rousiers, e ao critério histórico de um Freemann ou de um Taine poderiam mostrar ao vivo, porque é que o Brasil é esse produto amorfo, originalíssimo, que se não se parece de todo com algum outro povo conhecido... " 422

Presenciava no Brasil uma situação em que poucos eram os que governavam e muitos os que dependiam da política meio de vida, da empregomania que favorecia o desconhecimento de talentos que bem poderiam ser empregados em suas devidas profissões, a extorsão, o emprego do dinheiro público em obras suntuosas, mas que não elevavam a alma do povo; as roubalheiras crônicas, a alta carga tributária desmantelando a Educação e o abatimento de todas as forças ideais "que não seja

\footnotetext{
${ }^{421}$ Ibidem. p. 182

${ }^{422}$ ROMERO, Sílvio. Provocações e debates. Op. Cit.p. 404
} 
pedir dinheiro para gastar e mentir para fascinar". ${ }^{423}$ Mais uma vez, recorria com um dos fatores da corrupção política no país o desconhecimento das idéias científicas responsável pela existência das oligarquias no Brasil, "politiqueiros, como genuínos ratés, postos a margem dos altos lavores das ideias, terríveis e disfarçados inimigos dos verdadeiros intelectuais, não são gente para se preocupar com coisas sérias e fazer estudos que passem além do alinhamento de frases para pintalgar discursos, como as cortesã arrebicão as faces com as tintas e cosméticos adequados" 424.

O desconhecimento por parte dos dirigentes políticos das diversas áreas do país, a confusão que faziam entre política e politiquice e, sobretudo, a ausência de um conhecimento generalizante, segundo Romero, eram as causas das oligarquias no Brasil, resultando nos poucos que governavam e no resto da população miserável que "ou trabalham mal ou vivem da mendicidade ou da rapina; com a sua política meio de vida" ${ }^{425}$. Concluía que

"O Brasil de hoje, como foi organizado por certos fantasistas sem cultura real, sem plasticidade orgânica de talento e de doutrinas, confundidores famosos de phrases com idéas, e como tem andado ao sabor e sob o tacão de criminosos exploradores,-É uma desarticulada dictadura, de joelhos perante o exercito, repartida em vinte oligarchias fechadas, feudos escusos, pertencentes a vinte bandos de sicarios..." 426

Desse estado de coisas foi que surgiu a série de práticas corruptas, como o filhotismo político e os déficits orçamentários, sustentados por duas forças: uma delas se deu sob a forma de empréstimos estrangeiros, hipotecando as rendas brasileiras; e a outra se realizara gerenciada por bandidos protegidos e aliados dos chefes oligarcas. Ressentia-se Sílvio de nada terem feito os dirigentes nacionais para alterarem o panorama das oligarquias no Brasil, não possuindo o país novas riquezas, uma nova forma de Educação, uma nova moral, enquanto a situação continuava a mesma "A novidade única a destacar no Brasil hodierno, adrede inventada para contrastar a negra realidade que o oprime, são os melhoramentos da capital..." ${ }^{427}$. Não seria com garridices nem derriços que se educaria um povo. Preferia a verdade, o dever, a justiça e a seriedade para educar e disciplinar as massas. Enquanto a capital federal abria suas ruas e avenidas e São Paulo reclinava-se na verdejante coxilha, "a verdade é que estamos divididos em clãs, com seus donos, sem grupos, com seus chefes, em bandos, com seus cabecilhas: política, social, economicamente - é esse o espetáculo geral" ${ }^{428}$.

Esta é a estrutura social onde se abrigava o castilhismo positivóide que inquietava Romero e que considerava preciso combater porque podia se espalhar pelo resto do Brasil "É, pois, no elemento

\footnotetext{
${ }^{423}$ Ibidem. p.406

${ }^{424}$ ROMERO, Sílvio. pp. 403-404

${ }^{425}$ ROMERO, Sílvio. Provocações e debates. Op.Cit.p.405

${ }^{426}$ Ibidem. p.407

${ }^{427}$ Ibidem. p. 409

${ }^{428}$ Ibidem. p. 410
} 
semibárbaro do regime pastoril que se abroquela o castilhismo positivóide”. ${ }^{429}$ Para esta gente, era impossível um regime democrático como nos moldes do Liberalismo americano porque o estágio de cultura do povo brasileiro ainda não era compatível com o regime parlamentarista. Nas cidades, presenciavam-se pessoas herdeiras dos imigrantes que viviam do trabalho nas indústrias ou do comércio e os descendentes da elite nacional compondo parte do funcionalismo público, das profissões liberais, sejam negociantes ou empregados nas indústrias.

Ardoroso defensor do sistema político onde fizesse falar a voz do povo, pode-se afirmar que Romero, mesmo argumentando a favor de um regime unitário em detrimento da situação de corrupção no Brasil, defenderia tempos depois o federalismo no Brasil, "Nem se pense ser absurdo criar o governo conforme a índole dos menos cultos. Ao contrário: os governos para eles é que se fazem; porque são os que mais precisam da sua direção" ${ }^{430}$.

Para os intérpretes de Sílvio, talvez sua posição política seja só mais uma de suas contradições, mas se lembrarmos sua paixão pelos problemas nacionais, a discussão fica mais clara. Arrolava Romero uma série de casos de corrupção no Rio Grande do Sul. Apesar de ser o Brasil em tese um governo federalista, o que houve no Rio Grande do Sul foi a predominância personalista do senador Pinheiro Machado, influenciando não apenas o cenário local como manipulando toda a política brasileira. Sob o manto do federalismo democrático onde cada província teria de eleger por mérito seus administradores, pairava no Rio Grande do Sul o poder e o personalismo de Pinheiro Machado. Começa Romero a relatar uma série de fatos ou acontecimentos nos inícios do regime republicano que comprovavam o cenário favorável à propagação da corrupção política no Brasil.

Desfalques nas repartições públicas, falseamento nas eleições, protecionismo insensato à indústria de estufa, o funding loan, anomalias esquisitas na estrada de ferro, encomenda de dreadnought sem pessoas especializadas, o caso da Faculdade de Medicina, a desorganização do Ensino público, o banditismo no centro, o aviltamento da justiça, o caso da morte dos estudantes no Largo de São Francisco, a morte de Euclides da Cunha, o contrato das Docas de Santos, os cargos públicos outorgados a parentes, cargos de ministro do Supremo Tribunal oferecidos a políticos do mesmo grupo, a farsa do povoamento do solo, as fitas cinematográficas do Nilo, o fechamento de jornais da oposição acontecendo de norte a sul do Brasil e o calote geral na administração do país são alguns dos exemplos de falcatruas políticas no Brasil. Como se não bastasse esta série de fatos que bem demonstrava a corrupção política pairando em todo o país, Sílvio analisou o ramalhete ${ }^{431}$ ou as

\footnotetext{
${ }^{429}$ ROMERO, Sílvio. O Brasil social. Op.Cit.p.203

${ }^{430}$ Ibidem. p. 189

${ }^{431}$ Ibidem.
} 
manobras políticas do castilhismo positivóide reinante nas terras de Gaspar Martins e Silveira Martins. O personalismo de Borges de Medeiros para ele era patente:

\begin{abstract}
"No Rio Grande do Sul os funcionários públicos, do inferior ao superior, são todos de nomeação do presidente do estado, mas este, pela organização interna, ali estabelecida, apenas manda lavrar o decreto e assina: quem nomeia e demite funcionários do estado e de todos os municípios é o Dr. Medeiros, e se o presidente recalcitrar vai para o livro negro e se não se submeter, porque a submissão é a base do aperfeiçoamento, está irremissivelmente condenado, como já esteve o Dr. Carlos Barbosa, que chegou a ver em palácio o Dr. Juvenal Müller, vice-presidente do estado, para insinuar-lhe que lhe devia passar o governo e recolher-se a Jaguarão para tratar da saúde" ${ }^{432}$
\end{abstract}

Narrando uma série de falcatruas políticas, Sílvio se volta contra o castilhismo no sul do país, corroborado por Borges de Medeiros e seguido por Pinheiro Machado. Toda a série de falcatruas políticas, portanto, tinha por base o castilhismo positivóide instalado no Rio Grande do Sul.

\title{
4. O remédio brasileiro: por uma Educação enérgica e popular
}

Extremamente comprometido com as questões brasileiras, tendo contribuído para a formação de uma visão historiográfica centrada nos fatores de meio e raça que predominaria até à década de 1930, chegava o momento de Sílvio Romero propor quais os remédios para os males brasileiros. Após traçar um quadro nada promissor dos verdadeiros problemas brasileiros ao longo dos quatro séculos da História brasileira, o crítico busca quais os remédios para o país. É no artigo O Remédio, escrito em 1913, discurso proferido na recepção aos calouros e futuros bacharéis da Faculdade de Ciências Jurídicas e Sociais do Rio de Janeiro, que veremos a posição de Sílvio frente aos inúmeros problemas brasileiros. Almejava Romero alterar o quadro da realidade brasileira e não somente apontar os males do país. Se, em inúmeras ocasiões, discutiu os reais problemas do país, chegara o momento do bacharel e crítico literário se posicionar diante desses problemas. E fora para os recém-alunos e futuros bacharéis que Sílvio comentara seu último artigo "Que deve ser o discurso de despedida de um velho lente a jovens juristas, ao retirarem-se da faculdade para a vida prática, para a magistratura, a advocacia, a carreira diplomática, o funcionalismo público, a política? ", 433

No artigo em pauta, vê-se um Sílvio preocupado com os mesmos problemas aludidos em seus trabalhos anteriores, propondo também os mesmos caminhos de outrora. Politicamente, o Brasil atravessava uma difícil situação, uma vez que "Qualquer que seja a opinião que possa formar cada um da situação brasileira, porque, é claro, de nosso país é que devo falar impossível é existir homens de são juízo que não a julgue muito melindrosa do ponto de vista político, e especialmente, do ponto

\footnotetext{
${ }^{432}$ Ibidem. p. 211

${ }^{433}$ Ibidem. p.239
} 
de vista social". ${ }^{434}$ Não vinha o bacharel afirmar a inexistência dos problemas brasileiros nem tão pouco cabia o maniqueísmo de se julgar um bacharel realista ou pessimista, apoiava-se Romero sempre na Crítica que julgava imparcial e denunciava "dos fatos, das ideias e dos homens; sede observadores e confiantes". ${ }^{435}$ Com os mesmos problemas sempre apontados pelo bacharel, o Brasil se mostrava atrasado, caminhava de forma tardia e de maneira errada nas múltiplas direções. Residia aqui o cerne das questões "Que nos falta? Que devemos fazer? ” 436

Escritor engajado e modelo de erudito que nunca pretendeu escrever obras artísticas senão sob o prisma do que ele concebia como Literatura e que, de uma forma ou de outra, representava a Evolução das transformações de seu país, amparado que ele dizia estar na Crítica moderna que servia a suas observações imparciais, sendo indispensável o conhecimento das doutrinas científicas em voga na época, Romero entendia que os problemas brasileiros eram sempre políticos,

\begin{abstract}
"Em um país, como o nosso, onde os maiores, e mais complicados esforços dos soi disant estadistas se resumem na mantença da clientela, e os mais árduos assuntos se reduzem da parte da governança a prática de demitir e nomear; demitir os adversários e nomear os amigos, todos os males são políticos, todas as queixas são políticas, todos os clamores são políticos, todas as necessidades políticas, todos os problemas políticos, e, como consequêncial, todas as medidas políticas, todos os remédios políticos...." (grifos do autor) ${ }^{437}$
\end{abstract}

Sendo todos os problemas brasileiros de ordem política, o remédio também era de ordem política, a solução apontada não seria a favor da eleição pelo voto secreto nem por uma revolução num país sem aristocracia e com uma burguesia totalmente estrangeira. Sem uma classificação hierárquica de alto a baixo da estrutura social do país, favorecendo uma consciência nacional por parte dos pobres em geral porque "a parte nacional tem cunho oficial, por trabalhar quase exclusivamente oficial, por trabalhar quase exclusivamente nas oficinas e obras do estado”, o remédio para o Brasil não estaria em colocar no poder anarquistas, comunistas ou socialistas. Mais uma vez, Romero ressaltava a conivência e o desconhecimento da elite responsável pelo atraso brasileiro,

\footnotetext{
"Numa terra em que a mediocridade letrada passa boa parte do tempo a catar supostas contradições nos homens de mérito, em que existem bacharéis, lentes em institutos de Ensino oficial, que acham contradição em dizer ser a Lógica Ciência e também Arte, e, mais, que trata do descobrimento e também da demonstração da verdade...cincada que não encontra sua igual desde que se descreve no mundo...é uma felicidade poder a gente repetir-se a longos intervalos" 438
}

\footnotetext{
${ }^{434}$ Ibidem. p.239

${ }^{435}$ Ibidem. p. 240

${ }^{436}$ Ibidem. p. 242

${ }^{437}$ Ibidem. p. 243

${ }^{438}$ Ibidem. p. 245
} 
Em busca do remédio brasileiro, discordava daqueles que defendiam o novo povoamento do país, velha cantiga, alertava o malefício de entregar zonas inteiras do país aos povos estrangeiros. A questão étnica surgia pela primeira vez no artigo: “Com japoneses, ramo mongólico ou malaio, truculentos orientais, nunca! Será falta irreparável." ${ }^{439}$ E tudo isto para ajudar à formação do sentimento nacional, algo importantíssimo para Sílvio, uma vez que se os chefes da nação tivessem amor ao país, tratariam o Brasil de maneira diferente os problemas nacionais e descreveriam um país real.

Quanto à colonização dos povos estrangeiros no Brasil, era imprescindível povoar o país de maneira racional: "Povoamento, povoamento...sim! Mas em termos, com elementos seletos $e$ principalmente aproveitando nossas desprezadas gentes, a quem devemos outorgar todos os favores de que cumulamos os estranhos, só porque são estranhos" ${ }^{440}$. Baseando-se em Spencer, um de seus mestres, Romero mostrava o pensador organicista que era citando passagens do filósofo inglês para validar a importância da seleção social, que tanto valorizara. Esta seleção social não deixava de ser racial, acreditando Sílvio na seleção dos mais aptos. O caráter de um povo formado somente com a preocupação de subsistência deveria ser alterado, e para isto fazia-se necessária uma Educação que fomentasse uma formação enérgica.

"De acordo com lições do grande mestre, que é que nos falta?

Gente, gente, e só gente, disciplinada, num sentido superior, pela seleção social.

É preciso ir pondo em prática para a obter?

É um verdadeiro sorites: modificar o nosso caráter de comunário, apáticos, amortecidos, desanimados, no sentido da iniciativa, da ousadia, da coragem dos largos empreendimentos, o que traz a vida econômica e progressiva; o que gera a independência individual e coletiva; o que provoca a morte da política alimentaria, e, com isto, o aproveitamento das nossas populações. O povoamento normal do nosso território principalmente por nós mesmos, sem precisarmos de chins ou japoneses: o que tudo acarreta a abastança e a força, o bem estar e o prestígio, bases dos bons governos, da sã politica e das estruturas sociais escorreitas e duradouras" ${ }^{441}$

Sílvio Romero apenas confirmava o que sempre pensou acerca do caráter brasileiro como sendo o elemento mais significativo, responsável pelo atraso do país, presente nos aspectos sociais, econômicos, políticos e culturais. Após citar Spencer, onde afirmava que "o funcionamento das instituições é fatalmente determinado pelo caráter dos homens", ${ }^{442}$ apontava que o remédio brasileiro seria mudar o caráter apático para um caráter particular, enérgico ou de iniciativa. A visão organicista

\footnotetext{
${ }^{439}$ Ibidem. p. 246

${ }^{440}$ Ibidem. p. 246

${ }^{441}$ Ibidem. p. 247

${ }^{442}$ Ibidem. p. 247
} 
e estrutural que possuía devia-se às leituras de Spencer, de quem citava vários livros, defensor de um caráter enérgico. Concluía que "o filósofo é um autonomista em regra. E nem podia ser de outra forma, dado o caráter de ango-saxão, rebento da gente mais particularista por excelência (Releva não esquecer ser esta palavra empregada no sentido que lhe dá a Ciência Social”." 443

Pensava Romero que os males brasileiros deviam-se à formação comunária, responsável pela mania do emprego público, da megalomania, do ilusionismo, da falta de interesse pelas coisas nacionais e, sobretudo, pela falta de patriotismo dos dirigentes ou chefes políticos nacionais pelas coisas nacionais. À medida que buscava o remédio para o país, valia-se da Ciência Social para identificar a índole da nação, encontrar o caráter ou a Psicologia do brasileiro. Admirava o mestre Le Play e a escola da Ciência Social para justificar o remédio do país, "Mas é principalmente nos valentes escritores da Ciência Social leplayana que, de preferência, aconselho a meus jovens patrícios que vão procurar as lições de que todos nós precisamos. Eles fizeram especialidade do estudo das medidas indispensáveis aos povos denominados comunários, para conseguirem a modificação de sua índole apática e sua transformação particularista” ${ }^{444}$ (grifo do autor)

Desse modo, prosseguiu suas argumentações e apontou o remédio para o país sempre baseando na formação comunaria da sociedade brasileira, só agravada pelo desconhecimento da elite política e intelectual dos teóricos da escola de Le Play. Mais uma vez, incomodava a Sílvio não ser reconhecido como o escritor que primeiro divulgou essa ou aquela idéia no Brasil. Ressentia-se ele da falta de reconhecimento por parte da Crítica brasileira sobre a importância de seu nome como divulgador das dessa nova doutrina no Brasil. Criticava assim os homens de Letras do país, médicos, engenheiros, magistrados, advogados, oficiais de curso de terra e mar pelo desconhecimento dos preceitos da Ciência Social.

Nessa perspectiva, os inúmeros problemas brasileiros eram decorrentes da formação de um estado brasileiro que desde o início não permitiu ao individuo a iniciativa, a liberdade, tendo como preocupação primeira a politique alimentaire. A simples busca pela sobrevivência explicava a pobreza da população brasileira, espalhada nas diversas áreas do país. A dependência em relação aos políticos e aos pequenos comerciantes das vilas gerava a empregomania, o surgimento de clãs, o mal do funcionalismo público, a política como meio de vida que desvirtuava milhares de pessoas para outras áreas profissionais. Toda a organização social e política brasileira era nada mais que produto da formação comunária

\footnotetext{
${ }^{443}$ Ibidem. p. 248

${ }^{444}$ Ibidem. p. 249
} 


\begin{abstract}
"Os partidos, as associações ou agrupamentos quaisquer nas freguesias, nos municípios, nas comarcas, nas províncias, hoje estados, na União, todas as instituições, todos os cargos públicos, em número incalculável, não tem outro destino, não tem outra função: seu fim é fornecer meios de vida a uma clientela infinita. $O$ Estado não tem por fim próprio a manutenção da ordem, a garantia da justiça, ou, se quiserem, ajuda de certos empreendimentos elevados; seu papel preponderante, e quase exclusivo, é alimentar a maior parte da população à custa dos poucos que trabalham $e$ isso por todos os meios, como sejam as malhas dum funcionalismo inumerável.

Quando não são os empregos diretos nas repartições públicos, muitos deles inúteis, são as comissões para os influentes, as pensões, as gratificações sob títulos vários, as obras públicas de toda a casta e milhares de outras propinas.

Nestas condições, não é de estranhar que a política preocupe muito os brasileiros, mas é a política que consiste em fazer eleições para ver quem vai acima e ficará em condições de fazer favores.

O grau de corrupção e abastardamento a que chegaram os costumes eleitorais não é suscetível de descrição por pena do homem.

o geral do povo detesta a vida do campo, e, mesmo no interior, acumula-se nas povoações: - cidades, vilas, aldeias, arraiais, etc. É à cata do chefe para o arrimo, á cata do emprego público, do arranjo político sob qualquer forma.

A propensão que tem os moços para se graduarem, para receberem títulos acadêmicos é notória. É para seguirem a vida das cidades nas profissões liberais, no jornalismo, na Literatura, nos empregos da administração.

Nas classes inferiores os que não conseguem arranjo nos empregos compatíveis com sua falta de cultura, ou nas obras públicas, tem um derivativo nas fileiras do exército que se recruta pelo voluntariado, ou nos corpos policiais e milícias urbanas que são numerosos na capital e nos estados.

É esse o retrato social dos brasileiros de hoje em traços rápidos" 445
\end{abstract}

Cabe aqui uma ressalva: a formação comunária era inseparável da raça. Tanto a formação particularista como a comunária foram equacionadas por "raças diferentes". Para Sílvio, os caracteres étnicos explicavam as diferenças entre o caráter de formação comunária e o caráter de formação particularista. Não era sem razão que todo o quadro social brasileiro de atraso e barbárie, de pobreza econômica e cultural estava intimamente ligado a um caráter nacional apático, por sua vez, inseparável da raça. Neste caso, era indispensável alterar a Psicologia do brasileiro responsável pelas mazelas sociais do país. Mas qual o meio ou como transformar a índole apática do brasileiro?

Romero era defensor da formação particularista, por isto, aposta na Educação enérgica como remédio para alterar a índole apática do brasileiro. Uma vez diagnosticado a raiz dos males do país, discorreu sobre a importância da instrução para o surgimento do caráter de iniciativa, discutindo de que forma se processaria esta instrução. Apontando os teóricos em que se baseava para alavancar o progresso do país, apesar de ser um escritor adepto da Antroposociologia, onde o fator racial era preponderante, discordava de Lapouge que não acreditava na importância da instrução como forma de suscitar o caráter de iniciativa por acreditar que os caracteres adquiridos não eram transmitidos

\footnotetext{
${ }^{445}$ Ibidem. p.58-59
} 
hereditariamente, ao que retrucava Romero: "Se os efeitos do saber não se transmitem individualmente por herança, razão é esta demais para tornar indispensável sua eterna repetição pelo Ensino no decorrer dos séculos". ${ }^{446}$ Acerca da transmissão ou não dos caracteres adquiridos, o crítico literário defendia a Educação enérgica

"Isto, porém, que vos acabo de dizer é um hors-d'ouevre nas minhas palavras - não
venho falar-vos especialmente de instrução, nada tenho com ela, senão na parte em
que possa interessar ao primeiro dos meios propostos para transformar o caráter
brasileiro: a Educação enérgica.
Neste pressuposto, o que se refere aos exercícios físicos e a instrução - não tem valor,
não aproveita, no caso, senão tanto quanto são indispensáveis para ajudar a solução
de nosso problema: a Educação moral, a formação do caráter.
E cumpro, com prazer, o dever de declarar em alto e bom som não ser o que
proponho nada mais do que seguir o conselho da Ciência Social, admitindo hoje
intensamente em França e que se acha consignado nos dois magistrais estudos de
Paul Descamps: As Três Formas Essenciais da Educação e a Educação nas Escolas
Inglesas. E não farei agora mais do que compendiá-lo quase pelas mesmas palavras.
O ponto mais considerável, de maior importância nas escolas inglesas, é a
Educação" 447

Em Ensaios de Sociologia e Literatura (1910), Sílvio trata de maneira específica da questão pedagógica propiciadora de uma Educação diferente que alterasse a índole do povo brasileiro. É justamente pelo conhecimento que diz ter sobre essa índole que inicia o estudo acerca do ensino público. Afirma Romero que o que vai escrever é diferente do que há sido escrito durante os vinte anos no Brasil e baseia-se em sua prática docente. Não pretende basear-se em teóricos ou sustentar-se nos ombros dos outros, mas simplesmente falar a partir de sua prática, visto já estar farto de pedagogices. Mesmo se debruçando de forma específica sobre o ensino brasileiro, não perde Romero a conjuntura social e política em que se assenta a Educação do país. Pensa que

\footnotetext{
“A questão do ensino público entre nós só terá um sentido racional, quando for presa à questão geral de nossa organização política e ainda mais às nossas condições sociais, e for um desdobramento normal de nossas aptidões étnicas e históricas. Fora desse plano, tudo quanto se disser será, talvez muito bonito no papel, mas sem o mínimo valor no terreno maninho da aplicação e da prática". 448
}

$\mathrm{O}$ argumento do bacharel era a defesa de uma índole de iniciativa, como ocorrera na Inglaterra e nos Estados Unidos, viabilizando uma formação ou Educação enérgica que preparasse o ser humano para a luta pela vida. Somente com a Educação enérgica, tornava-se possível alterar o quadro social

\footnotetext{
${ }^{446}$ Ibidem. p. 253

447 Ibidem. p.254.

${ }^{447}$ ROMERO, Sílvio. O Brasil social. Op. Cit.p. 255

${ }^{448}$ ROMERO, Sílvio. Ensaios de Sociologia e Literatura. Op. Cit. p. 128
} 
brasileiro. Combatendo o Determinismo de Lapouge, seguia se apoiando na Educação inglesa, concluindo que "o sistema britânico permite o livre desenvolvimento das capacidades divergentes naturais”. ${ }^{449}$ Esclarecendo a Educação nas escolas inglesas desde a Public School ao Preparatory Scholl, chamava atenção para a formação de valores como honra, retidão, lealdade e dever "porque obediência e mando não passam ali de duas formas do senso da responsabilidade”. ${ }^{450}$ É entre os $12 \mathrm{e}$ os 18 anos que os alunos na Inglaterra formavam seu caráter embutido da lealdade, continuando os valores de liberdade e energia, que mais tarde, se tornariam o modelo de aluno e de ser humano da verdadeira sociedade particularista. Este modelo, que era belo, era triste

"porque bem sentimos que é principalmente o que nos falta. É dessa portentosa Educação particularista, como the chama a doutrina da Ciência Social dinâmica, como a denomina Paul Descamps, e que me parece ficar melhor batizada com o apelido de enérgica que proponho, dessa valorosa antípoda do espírito gregário e comunário que vos aconselho que sejais os pregoeiros em o nosso amado Brasil.,"451

Nos clubes ingleses, presenciava-se a autonomia dos alunos, requisito básico de indivíduos particularistas em que cada pessoa naturalmente incorpora a disciplina exterior, bastante elogiada por Romero:

\begin{abstract}
"Os ingleses acharam o segredo de fugir aos defeitos dos casarões, espécies de quartéis que servem de Internatos e aos vícios daí decorrentes, e também aos males dos externos, colocados nos centros das grandes cidades. Colocam sempre suas escolas no campo, divididas em

casas, onde os estudantes sentem prolongar-se a vida do lar; porque moram nelas sob as vistas das famílias dos professores e do diretor.

Acharam o segredo de, mantendo severa moralidade estimular a simpatia entre os alunos e o corpo escolar, o culto da liberdade, da responsabilidade, o prazer, e só isto vale tudo, o prazer da colaboração consciente na obra comum" 452
\end{abstract}

Prosseguia citando outro pensador da Ciência Social que era Paul Descamps. Podemos ver após a citação de Descamps como este seguira rigorosamente os caminhos trilhados pela Ciência Social:

"Hoje em dia a iniciativa particular já tem fundado no continente europeu muitas escolas baseadas nos princípios da Educação dinâmica, e, além disto, podemos mandar nossos filhos às escolas inglesas. Mas cada um de nós pode indevidamente fazer mais. Cada um pode melhorar sua própria regra de conduta, adquirir uma vontade mais firme, aguçar o senso da observação, querer agir por si mesmo: arranjar o tempo, passar o mais rápido possível das ideias aos atos. Os progressos são rápidos, quando se quer com firmeza. Quanto aos meninos, não é possível adotar de súbito, em França (e muito menos no Brasil) todos os princípios da Educação dinâmica. É indispensável dosá-los, enquanto o meio não for mais favorável. Cada pai de família pode, porém, tratar seu filho como homem responsável; não empregar

\footnotetext{
${ }^{449}$ Ibidem. p. 255

${ }^{450}$ Ibidem. p. 256

${ }^{451}$ Ibidem. p. 259

${ }^{452}$ Ibidem. p. 256
} 
nunca a linguagem pueril, não encorajar seus lamentos e queixumes; não lisonjearlhe a vaidade ou ferir-lhe o amor-próprio; não fatigar-lhe a memória, nem querer fazer dele um menino prodígio; deixá-lo desembaraçar-se por si só. À medida que for crescendo, incutir-lhe na alma que deve criar sua posição por si mesmo, e que deverá partir para formar um novo lar; habituá-lo a saber defender seus interesses e a conhecer o valor das coisas; fazê-lo tomar o prazer dos cuidados higiênicos, o gosto dos jogos em pleno ar. Mas, acima de tudo e mais que tudo, o desdém da política e das posições e empregos oficiais, e, em troca, a estima do trabalho e dos ofícios usuais; e horror da mentira e da preguiça; nunca cercá-lo de um sistema de espionagem mais ou menos oculto; incutir-lhe a ideia de que se pode ser feliz por toda a parte, porque a felicidade está em si mesmo e não nas decorações exteriores; agir sempre em quaisquer circunstâncias conforme sua consciência." ${ }^{453}$

As idéias de Descamps não poderiam ser melhor assimiladas por um personagem e divulgador no Brasil como Sílvio Romero. Buscando eliminar seu país do atraso refletido nas mais variadas esferas, analisou a sociedade brasileira a partir do esquema da Ciência Social, atinando para as várias regiões do Brasil e relevando a importância da família; divulgou e defendeu, de maneira muitas vezes agressiva, as idéias científicas, almejando alterar a Psicologia do brasileiro, apática, frouxa ou sem iniciativa; inúmeras vezes, chamou atenção para a vaidade da classe dirigente do país, que se perdia em meio ás futilidades; inquietava-lhe a corrida aos cargos públicos e a falta de seriedade dos políticos pela verdadeira política do país, mostrando no exterior um Brasil de Haia, ou seja, um Brasil de ilusões construído pela classe dirigente, legitimado por escritores e jornalistas.

Fato relevante é que, apesar de ser Sílvio conhecedor as idéias européias e das Teorias liberais, reconhecia que o cenário brasileiro era completamente diferente da sociedade inglesa: "Mas que temos nós com ingleses sem Educação inglesa e coisas congêneres, nós garfo esplendoroso de rutilante trono latino?" ${ }^{454}$ Quando toda a Europa acompanhou as transformações culturais, principalmente da Inglaterra e da Alemanha, seguindo celebridades como Sterne, Richardson, Fielding, Scott, Byron, Lessink e Kant, qual a situação de um Brasil onde se presenciava a inconsciência iletrada? Preso às ideias de Descamps e de outros escritores da Ciência Social que apontavam a importância da Educação enérgica como meio indispensável à superioridade dos povos saxões, mencionou uma passagem do livro de Demolins intitulado A quoi tient la supérioté des anglo-saxons?: "Como complemento da obra educativa, como elementos e fatores dela, deveremos pôr em prática os outros três meios indicados - estudos dos grandes povos diretores da atualidade ou instituição das Humanidades contemporâneas; criação do Ensino superior sistematizado para os operários; orientação particularista ou, melhor, energética da vida..." 455

\footnotetext{
${ }^{453}$ Ibidem. p. 259

${ }^{454}$ Ibidem. p. 260

${ }^{455}$ Ibidem. p. 262
} 
Analisando a Educação inglesa, referendou as ideias de Jean Périer, de quem elencava cinco elementos indispensáveis ao triunfo da vida porque percebia o escritor francês uma corrida aos diplomas, o que chamava atenção do crítico, pois no Brasil a busca pelos diplomas marcava toda a atividade literária dos jovens e futuros bacharéis. De acordo com Périer, face à concorrência estrangeira, é de suma importância tomar conhecimento do que acontece no mundo. E o que tem feito o Brasil nesse sentido? Nada, porque sempre nos passamos por aquilo que não somos, causando uma dupla ilusão: primeiro de enviar retóricos brasileiros ou para a Academia de Paris, conferências ou congressos que ali ocorrem; e importarmos moços inteligentes à vol d'oiseau que chegam em meio a banquetes, festas e passeios, seja em Tijuca, Petrópolis ou São Paulo.

Sílvio descreveu o caso do Japão, que não enviou sabichões eloqüentes, onde o país fora influenciado não apenas pelo modelo de Educação, como no sistema monetário, no sistema postal, na organização dos telégrafos, na telefonia e nas estradas de ferro. Continuava enaltecendo a Educação enérgica, citando agora exemplos de Herni Labroué na sua obra L'Imperialisme Japonais. Na verdade, Romero queria chamar atenção para a Educação popular, ressaltando o esforço dos alunos japoneses que estudavam nos Estados Unidos e, que para custear suas despesas, se sujeitavam ao cargo de criado nos intervalos das aulas. No Brasil, o quadro era totalmente diferente porque o aluno já sabia o que faria com o diploma ou a carta, origem do mal do emprego público e da falta de seriedade de políticos, jornalistas e escritores, que não possuíam amor ao país,

"Por isso marcamos passo, já não digo há quatro séculos, mas há mais de cem anos, a contar desde que esta terra foi elevada a Reino, e para cá se transladou o governo da Metrópole e começou, de fato, a nossa independência; por isso marcamos passo, mexidos e remexidos nas garras da mais estafante politicagem, e vimos, tontos, sem saber mesmo do que se tratava, em menos de quarenta anos, a transformação assombrosa do Japão, e em nossa infantilidade de ibéricos que têm vivido nesta porção da América de explorar os índios, os negros e os colonos, oriundos de países fracos, chegamos à tonteria de pensar que também os exploraremos a eles, a esses homens terrivelmente singulares, que hoje causam temores aos seus mestres, - os U.S.A - e a própria Inglaterra, que lhes deu, pelo mais singular erro político da História, mão forte contra a Rússia, essa Inglaterra que eles andam a molestar no Canadá, na Austrália, na Nova Zelândia e a atraiçoar na Índia... ${ }^{456}$

Para os países que almejam o progresso, só resta adotar os métodos da Educação enérgica. Por fim, cita Pernotte no escrito Un essai enseignement, relevando a Educação popular, novo gênero "que nem é a aula primária rudimentar, nem os cursos médios a antiga, nem as conferências, e outros meios postos em prática sem apreciáveis vantagens, nem ainda o pesado aprendizado das universidades, próprio das classes abastardas" ${ }^{457}$. O interesse deste novo modelo de instrução não seria a mesma pedagogia formadora de doutores, médicos, advogados, e professores. Se os indivíduos

\footnotetext{
${ }^{456}$ Ibidem. p.266-267
}

${ }^{457}$ Ibidem. p. 267 
não podiam aspirar à condição de médicos ou bacharéis, nem por isso deixariam de se envolver nos negócios nacionais, ou seja, a Educação particularista seria tão importante como a Educação universitária. Defende a Educação das massas, pois, na medida em que se processa a transmissão do conhecimento, surge o sentimento nacional.

Neste artigo, Pernotte se refere ao Ensino popular superior experimentado na Inglaterra, salientando a figura de Walter Wrooman, que chegava a afirmar "que cada vez mais o operário se sente um votante, um legislador, um criador de futuras condições sociais (a maker of future social conditions)” 458 . Falava Wrooman sobre a consciência política dos operários das lojas, minas e fazendas inglesas, onde "Sente-se investido de um poder que ciumentamente quer exercer. Cabe à sociedade esclarecê-lo e instruí-lo, se não quer que o seu braço de gigante faça desabar o templo em cima de nossas cabeças" ${ }^{459}$. Defendia Sílvio a instrução popular, capacitando o indivíduo para a área condizente a sua aptidão.

Em $O$ Remédio, Sílvio Romero só reforça o que escreveu anteriormente acerca da Educação enérgica como meio para atingir o caráter de iniciativa, alcançado pela Educação particularista. Continuava a citar os teóricos da Ciência Social, preocupando-se com a seleção social, suscitando questionamentos sobre a imigração dos povos estrangeiros. Enaltecia figuras como Ammon, Live, Woltmann, Lapouge e Niceforo, a favor da Eugenia, e concluía o artigo ressaltando as ideias da Ciência Social e da Antroposociologia:

"Causa ou efeito, ou simultaneamente, causa em uns casos, efeito em outros, a severa seleção energética que tem nas gentes particularistas e eugênicas por excelência seus melhores modelos, é que nos convém, se nos queremos regenerar, se aspiram especialmente matar a politicagem e seus inqualificáveis perniciosíssimos efeitos. É a tarefa do futuro. Ainda creio nele.

Abençoados os que vão chegando e os que hão de chegar, porque verão a grande obra e deles será o reino da Terra, na glorificação deste portentoso Brasil. Trabalhai por isto, e é este o meu último conselho!" 460

No capítulo Notas sobre o Ensino Público ${ }^{461}$, Sílvio analisa o Ensino no Brasil em meio aos antecedentes étnicos e históricos, investigando a participação do mesmo na formação de índole do brasileiro:

\footnotetext{
"Um tal ou qual conhecimento da índole do povo, que presumimos ter, por have-lo estudado sob formas várias, quer parecer-nos, às vezes, que nos habilita a dizer alguma coisa que não é de todo para desprezar.

E pois, vamos ao assunto e sem mais preâmbulos" 462
}

\footnotetext{
${ }^{458}$ Ibidem. p. 268

${ }^{459}$ Ibidem. p. 268

${ }^{460}$ Ibidem. p.271-272

${ }^{461}$ Este artigo encontra editado na revista com a seguinte referência. ROMERO, Sílvio. Notas sobre o ensino Público. História da Educação FAE/UFPEL. V.1, Abril, 1997. pp. 275-302.

${ }^{462}$ ROMERO, Sílvio. Ensaios de Sociologia e Literatura. Op. Cit.p. 128
} 
Dividido o Ensino público brasileiro em seis categorias, discute qual Ensino deve sofrer a intervenção do estado para a divulgação de uma Educação nacionalista. Para Sílvio, o Ensino primário é de responsabilidade do estado, como acontece em toda e qualquer sociedade democrática. Caberia aos países desenvolvidos o Ensino superior, sendo necessário a priori um conhecimento da cultura em geral sob a tutela do estado. Este Ensino deveria surgir de modo espontâneo em razão da organização social e política, contemplando disciplinas como Religião e Filosofia. Com relação ao Ensino secundário, defendeu a presença da união frente à administração deste Ensino. Quando a discussão gira em torno do Ensino primário, presencia-se a defesa do bacharel da obrigatoriedade do mesmo,

"O Ensino primário é a paga inadiável que o Estado deve a todo o cidadão brasileiro, como cidadão, desde que o priva de votar quando é analfabeto. (Art.70, $\$ 2 .^{\circ} d a$ Const.). $O$ Ensino primário é a arma que toda sociedade moderna é forçada a dar, como ponto de partida, na luta tremenda da organização econômica da atualidade, onde o trabalho é cheio de terriveis exigências impostas pelo capital" 463

No caso do Brasil, era inevitável a preocupação com e a obrigatoriedade do Ensino primário pelo estado, Ensino indispensável à formação de uma índole enérgica. Romero defendeu a seriedade do Ensino primário sob a fiscalização do estado para que não houvesse falcatruas administrativas locais. Sabendo da importância deste para a formação da índole responsável pela superioridade dos povos saxões, releva a capacidade do professor, caso da Alemanha, em detrimento da falta de capacidade dos congêneres brasileiros, que se preocupam apenas com a decoração de fórmulas. Apesar da obrigatoriedade do Ensino primário por parte da união, defendeu a liberdade no que dizia respeito ao conteúdo porque somente assim seria possível a formação do espírito de iniciativa "Procuremos desenvolver o espirito de iniciativa neste ramo da atividade nacional". ${ }^{464}$ Apoiou ainda a liberdade do Ensino porque sabia da existência dos 18 milhões de analfabetos que precisam de uma Educação básica. Caberia ao estado se preocupar com o espírito nacional, sendo o Ensino primário uma das conquistas da civilização moderna. O Ensino primário era indispensável à Educação popular, ponto mais importante para o bacharel que tomava a Prússia como modelo de seu pensar. A situação de analfabetismo da sociedade brasileira provinha dos tempos coloniais, quando sequer existiam livros sobre o tema, bastando olhar a Literatura a respeito da questão, onde sobressaiam somente nomes como os de Rui Barbosa, Herculano Bandeira, José Veríssimo e Artur Orlando - "o resto deve ir para o fogo em sua quase totalidade", 465.

\footnotetext{
${ }^{463}$ Ibidem. p. 131

${ }^{464}$ ROMERO, Sílvio. Notas sobre o ensino público. História da Educação. Op. Cit.p. 281

${ }^{465}$ ROMERO, Sílvio. Ensaios de Sociologia e Literatura. Op.Cit.p.144
} 
Notemos aqui algumas contradições por parte do escritor sergipano. No início do capítulo, escrevia Sílvio que não iria apoiar seu olhar pedagógico nos ombros dos outros, dispensando assim prováveis idéias européias ou simplesmente a mera repetição de autores; em seguida, citou o crítico literário paraense José Veríssimo como um dos nomes importantes para a discussão brasileira, certamente devido ao seu trabalho A Educação Nacional, publicado em 1890. Lembremos que Zeverissimações Ineptas da Crítica é um acerto de contas entre Romero e Veríssimo, acusado por aquele de desconhecer os mestres da Crítica moderna, fruto de sua desconsideração ou ignorância em relação às leituras germânicas desenvolvidas no Recife. Nessa perspectiva, o Brasil vivia naquele momento um período de anarquia mental, de assimilação pura e simples das Teorias pedagógicas européias, que não bastavam para o conhecimento da História brasileira.

Percebemos em Romero a interelação de um pensamento sempre preso a uma estrutura que somente se explica a partir das leis e sua racionalidade. A Educação ou instrução, para Sílvio, não se desvinculava dos elementos raciais formadores da população brasileira, onde aquela estava ligada ao desenrolar da História. Quando Romero pontuava um determinado tema a ser discutido, sempre vinha este acompanhado de outros elementos, montado sob uma estrutura e não era diferente quando tratava de analisar a Educação. Mesmo afirmando a falta de estudos pertinentes sobre o tema, responsável pela anarquia pedagógica reinante no Brasil, era necessário, na base da discussão, grandes estudos históricos e geográficos sobre o país, encomendados pelo governo. No mais, de nada adiantaria uma reforma no Ensino sem atinar para a base na qual ela se assentaria.

Quando insistiu no conhecimento do Brasil, Romero assim agia para escolher a partir do conhecimento de cada zona social a forma mais adequada de Ensino para as diferentes populações. Daí, o sentido de dividir o Ensino, o que servia também para pensar o entendimento das ideias europeias a serem aplicadas ao Brasil com relação à melhor forma de representação política, no que tangia a sua postura filosófica, enfim, quando analisava a cultura brasileira de uma forma geral. Ele entendia ainda que a situação do atraso brasileiro datava dos tempos coloniais ou já no período imperial, quando cronistas como Saint Hilaire e Buckle, citados por Sílvio, descreveram o grande atraso das populações sertanejas. De nada adiantaria apresentar diversas reformas teóricas numa sociedade que cortejava títulos, buscando sempre a carta de bacharel. O culto do ornamento por parte dos intelectuais brasileiros era salientado por Romero: "nós possuímos uma instrução barata, avariada e enfeitada com palavras bonitas, ou que o supõem ser" 466.

Nos seis tipos de Ensino, o atraso brasileiro, conforme sua análise, era patente. Chamava a atenção para o retrocesso do Ensino secundário e profissional no Império brasileiro por considerar que

\footnotetext{
${ }^{466}$ Ibidem. p. 149
} 
estes eram "os mais valorosos como força estimulante e propulsora na vida progressiva de uma nação" ${ }^{467}$. O Império brasileiro ficou distante diante dos tempos coloniais, marcados por nomes como os de Alexandre de Gusmão, Rodrigues Ferreira, os Câmaras, os Velosos e vinte outros. Com relação aos tempos coloniais, "os pigmeus de hoje, que sabem frases e fórmulas, mas não sabem pensar; que tem palavreado, porém não tem ideias; que são mestres em basofias e charlatanices, mas andam aí atordoados, sem saber dar solução a série intérmina de desacertos que os afoga" ${ }^{468}$, problemas que caracterizaram as quatros últimas décadas do Ensino brasileiro na época em que ele escreveu.

O Brasil era refém de uma Educação restrita à preparação para os exames e a busca dos diplomas, responsável pelo atraso do país porque não permitia ao brasileiro um conhecimento amplo da cultura clássica desinteressada, não facultava o conhecimento do país para que surgisse amor pelo mesmo. Clamando pelo progresso porque defendia a Educação popular, combate arduamente a americanização da Educação, o projeto daqueles obcecados por um Ensino prático, baseando-se em Du Bois-Reymond, reitor da Universidade de Berlim, por ter proferido, há 16 anos, um debate sobre a instrução moderna que serviu de referência para o livro de Alfred Fouillée denominado L'enseignement au point de vue National, afirmando que "tanto a conferência de Du Bois-Reymond como o livro de Fouilée deveriam constituir o programa de quem no Brasil se quisesse ocupar com a instrução popular" ${ }^{469}$.

Contrário a todo o processo de americanização da Educação, resultado do industrialismo moderno, responsável pelo caos do Ensino, defendeu o retorno da instrução clássica e de seus métodos, cultura esta que elevava o espírito, Ensino totalmente contrário ao que capacitava à mera busca do emprego e da obtenção da carta de bacharel:

"Somos adversários da instrução terra a terra, sem elevação, sem ideal,
industrialística, interesseira, visadora do fim próximo, do ganha pão imediato,
reduzida a uma aptidão mecânica, no intuito do ofício, alguma coisa de pré-
determinado, de preparado em doses, como uma receita de bolos, ou um rol de
compras ao mercado. Essa instrução não dar cultura a ninguém, porque não toca na
alma, nem fala ao coração; não melhora a índole nem desanuvia o espírito, lançando-
a, desassombrado, desinteressado e entusiasta em busca das grandes causas e dos
maiores ideais" 470

Fervoroso adepto da Educação enérgica, da Educação popular, rondavam na cabeça de Sílvio os modelos educativos de Alemanha, Estados Unidos, Suíça, Dinamarca e Inglaterra. Parece contradição, mas salientava que não foi em função da obrigatoriedade do Ensino que se deu o triunfo alemão, e sim devido ao modelo de Educação adotado pelo país. Esboçando o modelo de Educação francesa,

\footnotetext{
${ }^{467}$ Ibidem. p. 150

${ }^{468}$ Ibidem. p. $151-152$

${ }^{469}$ Ibidem. p. 159

${ }^{470}$ Ibidem. p. 160
} 
escrevia que foi-se o tempo em que à Educação cabia a formação dos príncipes, hoje visava à formação popular, facultando o amor à pátria. Atinava para a anarquia pedagógica que tomou conta de escolas e liceus brasileiros e entre a velha e a nova Educação, não pensando em tomar o modelo de Educação antigo como parâmetro, pois as "viagens retroativas são sempre estafadoras e prejudiciais aos povos" ${ }^{471}$.

\title{
5- O revoar das idéias novas: contextualização e política.
}

\begin{abstract}
"Enquanto no Rio de Janeiro os espiritos se diluíam nas divagações das Cartas de Erasmo, a mocidade do Recife fremia sob o impulso das tentações republicanas, democráticas, abolicionistas, patrióticas. A expressão desse aspirar tumultuário e intenso era natural que, em almas juvenis, se manifestasse pela Poesia e mais natural ainda era que ela tomasse o tom e a coloração dos grandes mestres que no tempo falavam mais alto aos instintos generosos do coração francez, Vitor Hugo e Edgar Quinet.

Eis a razão do que se veio a chamar o condoreirismo, o qual se veio a chamar condoreirismo, o qual deve ser apreciado no sentido íntimo das ideias que espalhou, dos sentimentos a que espalhou, dos sentimentos a que deu expressão, do ardente lirismo que poz em voga. Castro Alves foi o apóstolos andante das novas intuições.

Na Bahia, Rio e São Paulo apareceu sucessivamente como alguma coisa de inédito.

A Poesia mudou logo de tom em toda a linha.

Deixados os primeiros exageros de forma, dali tinham de partir as escolas naturalista, a científica, a parnasiana, que se sucederam nos últimos tempos. Mas, só e quase sempre acontecer, os bem aventurados das margens de Guanabara esqueceram facilmente o ponto de partid, o centro provinciano, onde as primeiras ideias tiveram a ousadia de brotar ${ }^{, 472}$
\end{abstract}

O movimento intelectual de renovação literária e filosófica “inaugurador" das idéias novas, surgido no Recife, revelando personagens importantes como Tobias Barreto e Sílvio Romero, e que se irradiaria depois para o resto do país, nos estados de São Paulo, Rio de Janeiro e Cearáa ${ }^{473}$, é, de acordo com Romero, parte integrante de uma nova forma de interpretar a cultura brasileira. A criação do grupo de intelectuais em torno da Faculdade do Recife se confundiu com a própria imagem do polêmico Sílvio Romero em meio a sua trajetória intelectual. Para Veríssimo,

"A escola do Recife não tem de fato existência real. O que assim abusivamente chamaram é apenas um grupo constituído pelos discípulos diretos de Tobias Barreto, professor decerto e, sobretudo, ultrabenévolo, eloqüente orador literário e poeta

\footnotetext{
${ }^{471}$ Ibidem. p. 143

472 ROMERO, Sílvio. Provocações e Debates. Op.Cit.p.351.

473 Sobre as leituras realizadas pelos jovens da Academia Francesa e a "independência" das idéias européias consultar. AZEVEDO, Sânzio de. A Academia Francesa (1873-1875). Fortaleza: Casa de José de Alencar/Universidade Federal do Ceará. COSTA FILHO. Cícero João da. Padaria Espiritual: cultura e política em Fortaleza no final do Século XIX. Dissertação de Mestrado defendido no Programa de Pós Graduação de História Social da Universidade de São Paulo. 2007. Para uma investigação sobre a presença das idéias novas no Brasil, ver. PAIM, Antônio. História das idéias filosóficas no Brasil. Londrina: UEL, 1997.
} 
fecundo, mais do que Tobias pensador e escritor. Cumpre, aliás, repetir que esse grupo, salvo imigrações individuais posteriores, restringiu-se ao norte, donde era a máxima parte de seus alunos, e mais exatamente a Pernambuco". ${ }^{474}$

A primazia das idéias novas defendida por Sílvio Romero é apenas um dos acontecimentos da face polêmica do bacharel. O ineditismo clamado pelo crítico sergipano tem motivação política onde diversas vezes criticou a centralização literária do Rio de Janeiro e como conseqüência o esquecimento do que se passava nas distantes províncias do país. Importante núcleo econômico do país durante o período colonial em função do cultivo da cana de açúcar o Recife foi o primeiro estado a abrigar uma Faculdade de Direito onde somente os mais assistidos estavam em condições de se manterem na província e assim serem alunos do curso. No Ceará, por exemplo, se desenvolveu um grupo leitor de Comte, Buckle, Spencer, denominado Academia Francesa integrada por nomes como Rocha Lima, Xilderico de Faria, Tomás Pompeu, Capistrano de Abreu, se dirigiram para o Recife em busca da carta de bacharel. Nomes importantes da historiografia cearense mais respeitada como Sânzio defendem a autonomia do grupo cearense com relação ao grupo liderado por Sílvio Romero e Tobias Barreto. Falamos da Academia Francesa para mostrarmos que o grupo cearense possa ter sido precursor das ideias novas tão defendidas por Sílvio. O que se sabe é que segundo Sânzio de Azevedo os integrantes da Academia Francesa tomaram conhecimento das idéias novas de maneira independente do grupo do Recife.

Para além de uma discussão em torno de escola literária onde prevaleça a homogeneidade de idéias, o que não existiu, de uma associação em torno de classe e idéias ou de uma mera assimilação das idéias estrangeiras, estamos preocupado em elucidar pontos decisivos para a compreensão cultural do novo Brasil a partir de Sílvio Romero. A Geração de 1870 é parcela atuante de uma nova ordem econômica, social e cultural que começava a se configurar desde 1850 e que, com a ampliação das camadas médias, será responsável por uma nova maneira de interpretar o Brasil. Antonio Candido bem lembrou a pretensão de Sílvio de submeter toda a cultura ao modelo de Crítica moderna. Caio Prado Júnior caracterizou o ano de 1850 como "o ponto de partida de toda a Evolução posterior brasileira" ${ }^{475}$. Essa conjuntura acolheu as novas idéias científicas e filosóficas com a qual se deparou a geração de Silvio Romero, dando origem ao bando de idéias novas tão mencionas pelo mesmo. Para Cruz Costa,

"Pela primeira vez a nossa pátria via um movimento intelectual que procurava abarcar a totalidade dos aspectos humanos. Até ali, quanto a ideias gerais e sistemas filosóficos, só conhecíamos a mistura pueril da Teologia e da Metafísica ensinada nos colégios, não passando o mais de divagação literária com que alguns pedantes

\footnotetext{
${ }^{474}$ VERISSIMO, José. História da Literatura brasileira. São Paulo: Letras e Letras, 1998.p. 344.

${ }^{475}$ PRADO JR, Caio. Evolução Política do Brasil. Colônia e Império. 4a . Ed. São Paulo: Brasiliense, 2007, p.50.
} 
solitários ou em candidata recreavam os seus ócios dando pasto a verdade ou à cobiça" ${ }^{476}$

Os moços bacharéis integrantes da Geração de 1870, na maioria, se contrapunham a toda mentalidade imperial. As idéias do Determinismo e do Evolucionismo serviram para compreender o novo Brasil que se anunciava e era representação mediatizada das transformações econômicas, sociais e culturais do momento. Assim como o pensamento espiritualista carreado pelo pensador católico Monte Alverne, representação do Espiritualismo de Vitor Cousin, expressava em grande parte o perfil cultural brasileiro da monarquia, agora as novas idéias do Positivismo, do Evolucionismo e do Determinismo anunciavam a sociedade que estaria por vir. Toda a agitação das idéias novas disseminada pela nova geração propunha uma renovação cultural baseada nos paradigmas do Naturalismo europeu.

Sem termos a pretensão de simplificar ou associar o advento das idéias novas às transformações econômicas e sociais da segunda metade do século XIX, é indispensável salientar a conjuntura que agora se abria a partir de 1850, com a lei que impedia o tráfico de escravos, tornando a Economia brasileira cada vez mais próxima do Liberalismo econômico norte-americano e inglês. Passados quatro séculos apoiado na Economia do trabalho escravo, o Brasil era concebido pela nova geração de intelectuais, bacharéis, médicos, jornalistas e funcionários públicos como um país atrasado e sem mais razão de ser dentro daquele perfil.

No primeiro Império, o estado brasileiro se mostrou sob as vestes de um Liberalismo patrimonialista, excluindo a maioria da sociedade; o dono de terra e os comerciantes de escravos dominavam amplamente todas as estruturas do poder. Todo o status quo sofreu duras Críticas dos escritores da Geração de 1870 em razão das dificuldades de se adentrar no funcionalismo público, das fraudes eleitorais e toda sorte de desmandos políticos, juntamente com a cooptação da opinião pública em benefício das relações "cordiais". A nova geração clamava por um regime político republicano/democrático, em que o "povo" não ficasse alijado das decisões políticas. Os estabelecimentos de saber como IHGB, faculdades de Direito e de Medicina eram a representação simbólica da sociedade patrimonial, fechada e conservadora do Império brasileiro. Mas, abrigavam razões e projeto de ruptura, como se observa nos pares da Escola do Recife.

Assim como a geração do Romantismo brasileiro, protegida pelo mecenas imperador, buscava conquistar as repartições do funcionalismo público, a geração de Sílvio Romero criticava o exclusivismo desse estado de coisas, elaborando um discurso prontamente acabado, alicerçada nas

\footnotetext{
${ }^{476}$ COSTA, João Cruz. Contribuição a História das idéias no Brasil. 2a . Ed. Rio de Janeiro: Civilização brasileira,
} 1967.p. 151 
doutrinas do cientificismo europeu. O novo método dessa geração era buscar nas ideias da Ciência da época os argumentos para a elaboração de um discurso sólido que explicasse a realidade de então.

Se a sociedade conservadora, estamental e de corte fora legitimada simbolicamente pelo Romantismo, os preceitos naturalistas do Determinismo, do Positivismo e do Evolucionismo serviram de base para apontar e identificar o atraso cultural e promover o progresso rumo a uma sociedade brasileira civilizada. A contestação das estruturas data da época em que o grupo dos liberais radicais se opunha aos liberais moderados, simpatizantes do governo do monarca, para implementar as reformas. Diante do predomínio saquarema vigente durante toda a História imperial, surgiu um momento em que nomes como os de Zacarias de Góes e Vasconcelos, Nabuco de Araújo, Sinimbu, Saraiva Cotegipe, e Paranaguá romperam com a ala conservadora para fundarem a Liga Progressista. O Império brasileiro agonizava e o regime republicano não tardaria.

Anos depois, em 1870, surgia o Manifesto do Partido Republicano, segundo Antonio Candido 477 um quase Socialismo, exibindo os anseios democráticos em nome de uma soberania popular que mais não era que a voz da nova geração representante dos emergentes grupos sociais, contestando a centralização do poder, defendendo a extinção do senado vitalício e clamando por lisura nas eleições. O momento político e social brasileiro era ímpar, um verdadeiro ponto de inflexão da História em que se presenciava a emergência de novas camadas sociais que assimilariam as idéias do Positivismo, do Evolucionismo, e do Determinismo racial e geográfico.

As escolas militares receberiam e irradiariam as idéias do Positivismo, figurando como principal nome o de Benjamim Constant; o Evolucionismo não tardaria a adentrar na Faculdade de Direito do Recife e na Faculdade de Direito de São Paulo. Nos institutos históricos e museus nacionais, o Evolucionismo era a tônica principal porque explicava o atraso do país tendo como referência a civilização européia, propondo a solução para o progresso e civilização num país considerado atrasado culturalmente devido à mestiçagem do espetáculo racial do país ${ }^{478}$. As idéias naturalistas caíram como uma luva na elite letrada brasileira e não tardaria a derrubada do regime imperial.

As idéias novas eram bem a representação de um grupo de intelectuais em busca de respostas para o atraso brasileiro, recorrendo à solução que supostamente só os preceitos das Ciências Naturais ofereciam para identificar o atraso do país de maneira incontestável e a resposta para os mesmos a partir dos paradigmas naturalistas. Foi o início de um novo momento formador da intelligentsia brasileira. Tornava-se indispensável recorrer aos preceitos naturalistas oriundos da Europa para interpretar o "novo" Brasil, almejado por estes homens tão crentes na civilização européia, identificar

\footnotetext{
${ }^{477}$ CANDIDO, Antonio. Introdução ao Método Crítico de Sílvio Romero. Op. Cit.

${ }^{478}$ SCHWARCZ, Lilia Moritz. O espetáculo das raças: cientistas, instituições e questão racial no Brasil, 1870-1930. São Paulo: Companhia das Letras, 2008.
} 
os elementos constituintes do atraso do país e somente assim apontar novos rumos em busca do progresso.

São exaustivos e recorrentes por parte de toda a produção ensaística literária e política e até mesmo panfletária deste período, os conceitos de civilização e progresso. Nos romances naturalistas, sob a influência de Zola, tais termos são recorrentes. Em meio à complexa estrutura social que o Brasil experimentava, as idéias de fora foram assimiladas, selecionadas e instrumentalizadas para preterir toda a História brasileira "manchada" pela presença da escravidão, que atravancava o progresso do país. Foi com o conhecimento das Teorias da Evolução e do Determinismo que esta mocidade preteriu a antiga ordem imperial e elaborou uma nova leitura do país. Foi à geração de Sílvio engajada e preocupada com os destinos da "nação" que

"Por meio do engajamento intelectual, a "geração de 1870" procurou intervir nas transformações históricas que resultaram na Abolição da escravidão e na proclamação da república, trazendo o despontar de uma sociedade urbana de tipo moderno. Essa concepção empenhada, em que o escritor intervém no espaço público, foi continuada por Euclides da Cunha e Lima Barreto na Primeira República". ${ }^{479}$

Mas era com o arsenal teórico europeu que o Brasil seria analisado. Sevcenko sintetiza bem a importância desta nova geração e sua nova maneira de pensar o Brasil,

"Toda essa elite europeizada esteve envolvida e foi diretamente responsável pelos fatos que mudaram o cenário político, econômico e social brasileiro: eram todos abolicionistas, todos liberais democratas e praticamente todos republicanos. Todos eles trazem como lastro de seus argumentos as novas ideias europeias e se pretendem os seus difusores no Brasil. Tomemos apenas alguns exemplos dentre alguns dos mais notáveis desses homens. Tobias Barreto, o sergipano em torno do qual iria se aglutinar a chamada Escola do Recife e cuja influência marcaria a obra de intelectuais de relevo como Sílvio Romero, Clóvis Bevilacqua, Arthur Orlando, Araripe Junior, Capistrano de Abreu e Graça Aranha, dentre muitos outros", 480

O lema da geração de Romero era condenar a sociedade atrasada, regida pelo cancro da servidão, responsável por todos os males do país. Não iremos adentrar a discussão de que a instauração do regime republicano foi mera consequência da Abolição, como incorre grande parte dos estudos. Pretendemos somente apontar que a questão da escravidão, para grande parte da geração cientificista, era responsável pelo atraso do país. Parte da elite brasileira estava preocupada com a imagem do país no exterior e a grande questão tratava da substituição do trabalho escravo pelo trabalho livre, o temor

\footnotetext{
${ }^{479}$ VENTURA, Roberto. Estilo tropical. Op.Cit.p. 72.

480 SEVCENKO, Nicolau. Literatura como missão: tensões sociais e criação cultural na Primeira república. $4^{\mathrm{a}}$. Ed. São Paulo: Brasiliense, 1995. p.79
} 
de uma onde negra ${ }^{481}$, como acontecera na Ilha de São Domingos e no Haiti, e não com as condições de vida do escravo. O Brasil foi o último país ocidental a abolir a escravidão e o imaginário de república representava não apenas um regime democrático calcado na alegada soberania popular, mas era equivalente para estes homens ilustrados ao estágio positivo tão ambicionado pelos republicanos inspirados na Filosofia comteana. Na Escola Militar, divulgava-se o catecismo positivista, objetivando o estágio republicano/positivo, como rezava a cartilha de Comte.

Elaborou-se um discurso prontamente acabado e bem urdido por parte da elite intelectual, que ia de encontro ao imaginário de atraso e de barbárie incrustado sob a sociedade imperial brasileira acobertada pelo manto da Economia escrava. Não estamos afirmando que os escritores da geração cientificista de Sílvio Romero tenham se limitado a temas como a escravidão, porque foram, em boa parte, escritores e políticos preocupados com os rumos da nação que cada qual, a sua maneira, elaborou, "projetos nacionais" que transcendiam a mera Crítica do regime escravo vigente no país. Preocupavam-se com vários problemas nacionais e tanto provinham de classes apenas remediadas, devido ao declínio da Economia açucareira, como eram herdeiros de famílias ainda bem estabelecidas economicamente. Dentre os novos grupos sociais integrantes da geração de Romero que, em parte, não mais se vinculavam a antiga classe senhorial reinante durante toda a sociedade imperial, existiam aqueles que advogavam a favor da Abolição da escravidão de maneira lenta e gradual, com ou sem indenização aos fazendeiros, defendendo a "civilização dos costumes" para não causar um corte abrupto com a sociedade de corte, e outras camadas desta elite defendiam a Abolição a "toque de caixa", mesmo sem nenhum projeto que incluísse o negro na sociedade futura.

Personagens deste momento histórico de transição são Nabuco de Araújo e José de Alencar. A par de um Liberalismo civilizador, Joaquim Nabuco chamava atenção para o "cancro" da escravidão, que manchava a imagem do país e assim obstava o desenvolvimento do mesmo numa sociedade ávida por alcançar o estágio do progresso e da Modernidade. Por outro lado, José Martiniano de Alencar era um escravocrata que mostrava em sua peça teatral Mãe as ambigüidades de uma sociedade que se rogava moderna, mas que em seu íntimo não ultrapassava as teias de costumes mal formados, carente de uma língua nacional.

Mais do que meras questões pessoais e de simples posições partidárias, vinham à tona duas formas de pensar o Brasil enquanto nação. Se Alencar ainda não percebia uma sociedade preparada para acolher as novas idéias científicas, atinando para os costumes bárbaros, chamando atenção para a elite brasileira, já o filho de Nabuco de Araújo era a personificação de muito do que acontecia de mais

${ }^{481}$ AZEVEDO, Celia Maria Marinho de. Onda negra, medo branco: o negro no imaginário das elites século XIX. São Paulo: Annablume, 2008. 
moderno no plano da cultura européia. Ficamos nestes dois exemplos para traçarmos de forma geral duas interpretações divergentes nas formas de pensar o Brasil enquanto nação.

Se simbolicamente Alencar fora uma figura das mais proeminentes por legitimar todo o estatuto colonial com a elaboração de seus romances indianistas, que elevaram o índio a símbolo nacional, Joaquim Nabuco era um homem moderno, cosmopolita e, portanto, adepto de um projeto nacional caudatário dos novos preceitos científicos. O Romantismo de Alencar, com seus índios civilizados, seus Peris e suas Cecis, era combatido por um escritor que buscava uma sociedade onde a Literatura e a política não fossem as únicas alternativas para os polígrafos.

Os intelectuais do Império brasileiro estavam sempre a comparar o cenário nacional com a realidade francesa. Um homem como Nabuco de Araujo se encantava por pensadores da Monarquia de Julho, como Guizot, Montalembert, Royer-Collard, Thiers, De Broglie, Lamartine, D’Alembert, Fenelon, Bossuet, de Bonald, Lamennais, de Maistre, Cousin; ao passo que José de Alencar se inspirava em Chateaubriand e Dumas para dar subsídios a sua imagem de nação brasileira. A elite intelectual brasileira tomara por espelho uma realidade que não podia ser mais díspar econômica e socialmente de seu próprio país. O certo é que a elite brasileira precisava buscar elementos plausíveis, adequar as Teorias de fora à realidade nacional e somente assim utilizá-las em benefício de suas mudanças. No país, alguns momentos da História foram batizados a partir da História política francesa.

A conjuntura que se abre a partir de 1850, no que pesem as transformações econômicas, sociais e políticas e as infinidades de idéias divulgadas pelos escritores bacharéis, continuava a forjar a identidade do país recorrendo ao repertório de leituras européias. É tema já superado pela historiografia brasileira das últimas décadas do século XX perceber as idéias adotadas pela elite brasileira como fora de lugar, sem chão, sendo instrumentalizadas para fins políticos. Mais do que se resguardar sob as idéias estrangeiras, é a infelicidade de não saber ler a realidade nacional, seduzido pelo charme da Ciência ${ }^{482}$. Mais importante do que buscar a originalidade ou não das idéias é perceber que as Teorias importadas sempre serviram de instrumento para preterir uma ordem anterior, considerada arcaica em nome do sempre almejado progresso europeu, sedimentado pelos argumentos inabaláveis da Ciência européia.

Os paradigmas científicos, ao mesmo tempo em que forneciam um critério inabalável de verdade porque carregavam consigo a certeza das leis, nem por isso deixaram de sofrer manipulações estrategicamente políticas por parte da elite intelectual brasileira. Os ensaístas da geração de Romero viveram o conflito de terem que adotar idéias provenientes de fora para interpretar a realidade

${ }^{482}$ BRESCIANI, Maria Stella. O charme da Ciência e a sedução da objetividade: Oliveira Vianna entre intérpretes do Brasil. São Paulo: UNESP, 2007. 
nacional, em nome da identidade nacional do país. Paradoxal é que a caminho do processo de criação da identidade do Brasil, o "atraso" do país ficava sempre evidente quando comparado às nações européias. Ao mesmo tempo em que a elite intelectual brasileira buscava uma identidade recorrendo às idéias de fora, sempre aparecia um Brasil "atrasado", fosse em decorrência da presença ou da herança da escravidão, das forças do meio que impediam qualquer possibilidade de "civilização nos trópicos", e, o que mais inquietava a elite simbólica da época: a presença do cadinho de raças que levaria à degeneração moral e cultural.

A assimilação das idéias de fora só fazia sentido porque o quadro brasileiro era de completo "atraso" com relação às nações européias, carecendo atingir o nível da civilização e do progresso. Dentre os parâmetros de análise para avaliar o grau evolutivo do país, aparecia basicamente a categoria racial, acompanhada da categoria mesológica. Foi com estas categorias que os cientistas brasileiros pensaram a nação para avaliar o grau civilizatório dos grupos humanos. Dessa forma, as leituras sociais ou as interpretações brasileiras de todos os ensaístas da geração de Sílvio Romero davam-se somente enquanto parte de uma teia de saberes, rigidamente constituídos e fincados na visão da civilização européia. Daí, sempre o conflito destes ensaístas/divulgadores da Literatura cientifica frente a um quadro de mestiços e de forças consideradas hostis do meio ambiente, com suas mentes mais na civilização européia do que no Brasil, o que muito inquietava Sílvio Romero.

Nesse sentido, a mudança do estágio de inferioridade/barbárie para o de civilização, na mente desses ensaístas, parecia questão de tempo, uma vez que a passagem unilateral do caminho evolutivo se dava sempre do mais simples ao mais complexo. Os preceitos do Evolucionismo e do Determinismo racial e mesólogico foram os pilares da nova forma de interpretar o Brasil. As argumentações literárias e políticas dos integrantes da Geração de 1870 justificavam "cientificamente" o atraso do país e ofereciam caminhos para o estágio civilizado. Os integrantes dessa geração se amparavam basicamente nas leis dos três estágios, em defesa da nova sociedade democrática que estaria no porvir. A imagem republicana oferecia acima de tudo uma visão de sociedade de maiores oportunidades políticas. Na mente destes homens, a sociedade imperial não tinha mais razão de ser, no que reside aqui a instrumentalização das idéias do Evolucionismo e do Determinismo.

Somado ao pensamento de Comte, presenciava-se o surgimento dos argumentos da lei do mais apto e da seleção natural, elementos centrais para justificar a defesa da ordem republicana e da posição liberal da Geração 1870. As leis históricas comprovariam e explicariam os fatos sociais, dando a devida avaliação positiva ou negativa dos acontecimentos sociais e políticos da sociedade como um todo: eis o sentido da adoção do Positivismo por grande parte dos ensaístas brasileiros. No caso específico de Sílvio Romero, o crítico, num primeiro momento, aderiu ao pensamento de Comte, 
mas à medida que ia tomando conhecimento das idéias de Spencer, tornou-se um perpétuo defensor do Evolucionismo.

Em sua Obra Filosófica, denso trabalho em que analisa a situação da Filosofia no Brasil, aborda de maneira específica as correntes e seis escritores brasileiros amalgamados nessa ou naquela escola de idéias. Doutrina contra Doutrina: o Evolucionismo e o Positivismo no Brasil é uma análise detalhada em defesa do pensamento de Spencer sobre o perigo da nova Religião da humanidade. $O$ Positivismo em suas idéias Capitais é uma dura Crítica a doutrina de Comte.

"O Positivismo é uma coisa perigosa e deve ser combatido com seriedade. Desde que uma doutrina, qualquer que ela seja, tornou-se o pão espiritual de algumas centenas de homens, essa doutrina constitui um fator social e um estímulo de ação; essa doutrina distribui alento e entusiasmo, aviventa as forças da alma, afirma-se como um incentivo em nome do futuro. E coisas assim tão graves só podem ser tratadas com severidade e compostura. Podemos tomar com elas a nossa parte de divertimento e gracejo; porque tudo nesse mundo tem o seu momento cômico; mas este expediente deve ser passageiro e relegado para o segundo plano.

O Positivismo no mundo, e nomeadamente no Brasil, deve ser combatido larga e sistematicamente, ponto por ponto, idéia por idéia, doutrina por doutrina" ${ }^{483}$.

Defendia Sílvio Romero, sobretudo, a idéia de Evolução social do povo brasileiro para alcançar a tão sonhada civilização alardeada pelos teóricos europeus e bem assimilada por inúmeros escritores brasileiros dos finais do século XIX. Advinha daí grande parte dos ensaístas brasileiros se apegarem às Teorias deterministas do Darwinismo Social, alicerçadas sob as categorias raciais, no que resultava a mera constatação da inferioridade do país. Consciente ou não, fazendo uso de um vasto repertório de leituras estritamente europeu para validar as argumentações acerca da situação do país, os demais escritores da geração de Silvio se embrenharam na missão intelectual de gerir um discurso consistente que não deixasse margem a dúvida, daí o apelo à Ciência como estratégia discursiva.

A Europa fora o modelo de sociedade celebrada e que servira de espelho para a elite brasileira, mesmo que a distância entre esta idealização e a realidade política, social e cultural do país receptor saltasse aos olhos. ${ }^{484}$ A elite intelectual brasileira esteve a comparar a realidade nacional tendo como parâmetro os países europeus, na maioria das vezes, estas idéias estrangeiras eram absorvidas sem o conhecimento mínimo da realidade nacional. O resultado da assimilação dessas idéias seria uma leitura desencontrada devido à inexistência estrutural para a adequação e futura aplicação das mesmas, ocasionando a mera instrumentalização em benefício de atitudes políticas por parte de intelectuais e políticos do país.

483 ROMERO, Sílvio. Obra Filosófica. Op.Cit. 314

484 PINTO, Ricardo M. Silvio Romero: contribuições à formação do pensamento racial no Brasil (1870-1914). Dissertação de mestrado defendida no Programa de Pós Graduação da Universidade de São Paulo, 1996. 
O novo Brasil pensado pela geração de Sílvio seria um país moderno, regenerado da Economia escrava e que se preparava para receber levas de imigrantes europeus, propiciando tanto a depuração étnica num país mestiço - fator considerado causa maior do atraso do país - como a formação liberal da nova Economia do país. Embora um escritor como Antonio Paim chegue a perceber em uma das fases do pensamento de Sílvio Romero uma feição marxista porque o crítico sergipano investigara diversas zonas sociais do país, esmiuçando o quadro de extrema pobreza, que ia do chefe de clã às populações sertanejas, era a partir de uma estrutura orgânica que o crítico literário pensava o Brasil. As leituras assimiladas pelos ensaístas brasileiros eram de pensadores regeneradores sociais, figurando como expoente máximo Comte, mais Darwin, Spencer (preterindo verdadeiros "revolucionários" como Nietzsche ou Marx), autores que, quando muito, advogavam uma reforma de valores e não uma mudança das estruturas sociais. A assimilação do Positivismo e do Evolucionismo é bem a comprovação de que a elite brasileira buscava alterar as nuances sociais sem mexer na estrutura orgânica do país, na legitimação do status quo.

Sílvio Romero tinha conhecimento de Marx e cita o pensador alemão quando discute a viabilidade do surgimento do partido operário no Brasil. Mais significativo que apontar o conhecimento das leituras de Marx, Engels e Nietzsche é perceber que toda a elite brasileira adotou um modelo explicativo contra-revolucionário. Grupo de intelectuais comprometidos com os rumos da nação, a geração de Sílvio assimilou e produziu farta Literatura concebendo a vindoura sociedade, tendo por base a nascente Sociologia sob os ares do Naturalismo europeu no século da Biologia. ${ }^{485}$

Romero foi um árduo defensor do Evolucionismo, como grande parte dos polígrafos de sua geração, e mais que isso: foi com sua maneira de aderir ao Evolucionismo de Spencer que sempre lutou contra a mera imitação das idéias, que em nada contribuía para o progresso brasileiro. Que tenha Sílvio adotado o Evolucionismo como a mais importante base para sua leitura de Brasil e assim prover os caminhos da futura nação, não nos resta dúvidas, mas é preciso admitir que, ao mesmo tempo em que acolhia as leituras de escritores regeneradores, analisava os problemas brasileiros que corriam paralelos a sua Crítica científica.

Para Romero, antes de adotar essa ou aquela Teoria, fazia-se necessário o conhecimento real dos problemas brasileiros. Entre a Crítica e a apologia destas idéias, pesam sobre Sílvio dois fatores: assimilar e interpretar erroneamente as idéias estrangeiras sem antes atentar para o cenário interno do país. Sílvio Romero é um escritor ambíguo, polêmico, agressivo, nacionalista, ressentido, que buscou nas mais diversas áreas do conhecimento embasamento científico tendo em vista eliminar seu país do quadro de atraso social, político e cultural.

${ }^{485}$ CANDIDO, Antonio. A Sociologia no Brasil. Tempo Social, 271/301, V.18, na . 1, 1959. Ainda. IANNI, Octávio. A Sociologia e o mundo moderno. São Paulo: EDUC, 1988. 
Mais prejudicial do que a mera imitação das idéias, como argumentava Sílvio, é o ilusionismo surgido em decorrência da beleza visionária européia. Romero censurou a História brasileira sempre de imitação, chamando atenção dos dirigentes do país pelo desconhecimento da Crítica científica, a seu ver, imprescindível para o conhecimento do verdadeiro país na constituição deste como nação moderna.

A tentativa se criar uma Literatura própria surge no Brasil com a geração do Romantismo, numa espécie de nacionalismo literário. Dois personagens são fundamentais para a formação da identidade brasileira: Wolf e Denis. Principalmente este foi a principal figura para criação de uma identidade nacional. De forma geral, estudiosos da Literatura brasileira como Sotero dos Reis, Pinheiro dos Reis, Cunha Matos, Joaquim Norberto, Santiago Nunes Ribeiro e Varnhagen concebiam a tal Literatura como apêndice da portuguesa. Mesmo com a configuração de um sistema literário e sua consolidação, os escritores brasileiros sempre imitaram no afã de erigir uma identidade nacional a partir da realidade européia. Lembremos da dissertação "premiada" do bávaro Von Martius, intitulada Como se deve escrever a História do Brasil, em que coube ao naturalista esboçar um quadro de onde partiria o início da História brasileira, relevando uma sociedade escravocrata, estamental e de corte. Documento dos mais significativos não somente porque esclarece e identifica a História oficial e positivista que via o documento como verdade, mas porque traz inúmeros elementos que servem para nossas análises como, por exemplo, a de ter sido o Brasil sempre concebido a partir de uma visão de fora. $\mathrm{O}$ Romantismo brasileiro, que seria duramente criticado por Sílvio Romero, revestiu-se de um caráter fortemente nacional e mais não foi que um movimento transfigurador não apenas da imagem do índio brasileiro, como de todo um cenário que aumentava a fauna e a flora brasileira, pouco se preocupando com a maioria da população brasileira. Fora o Romantismo brasileiro o primeiro momento em que o Brasil expressava carecer de uma identidade. Para os escritores românticos, foi mais interessante erigir uma imagem idílica do Brasil do que retratar os conflitos internos do Império e a situação de miséria do povo. Os conflitos internos supostamente se apaziguavam sob o manto pacificador do monarca brasileiro. É bom que se diga que o movimento liderado por Gonçalves de Magalhães e Gonçalves Dias em torno da revista Niterói tem início com esses jovens brasileiros residindo na França. A nação brasileira como vimos fora sempre elaborada à imagem e semelhança da sociedade do velho mundo onde não havia espaço para os reais elementos que constituiriam mais tarde tal unidade nacional. Respaldado simbolicamente pelo Romantismo brasileiro, que estilizou a realidade nacional, e por um Catolicismo hierárquico, que legitimou toda uma sociedade de corte do Império Brasileiro, toda esta sociedade seria duramente criticada pela nova visão naturalista de Romero, donde seus duros ataques ao projeto nacional desses escritores. 
A falta de uniformidade de idéias da Escola do Recife se explica, em parte, pela nova conjuntura política iniciada em 1850 e se volta sobre uma complexidade difícil de esmiuçarmos devido às várias vertentes e fases pelos quais passou o movimento. A tão apregoada renovação literária e filosófica pretendida por Sílvio contrapõe-se a toda ordem de um Brasil considerado arcaico e mesmo com o advento do regime republicano, persistiram os problemas denunciados pelo escritor. Não há uma homogeneidade de corrente ou mesmo uma associação de idéias e classe social, onde um perfil sociológico facilite a análise do movimento. A heterogeneidade das Teorias e a inconsistência da idéia de "geração" explicam os desdobramentos das correntes evolucionistas e deterministas, justificando o predomínio do Darwinismo Social.

É mais vantajoso identificar a postura teórica de Sílvio Romero reconhecendo a importância do movimento ideológico e político que não apenas contestava a ordem brasileira como um todo, buscando adentrar as instituições públicas, do que buscar identificar os variados grupos que traçaram planos para o futuro do país. O certo é que os inúmeros integrantes desse movimento literário e filosófico participaram da fé num Brasil moderno e civilizado.

O cenário nacional é o que nos interessa e a visão de cada integrante não se reduz aos elementos há pouco aludidos. É consenso por parte de uma historiografia bastante conhecida, apoiada em nomes como João Cruz Costa, Nelson Werneck Sodré, Antônio Candido, Wilson Martins, Maria Isaura Pereira de Queiroz, Renato Ortiz e Roberto Schwarz, dentre outros, o argumento das "ideias fora do lugar”, discussão que não iremos adentrar porque não contribui para os fins da pesquisa. Outro argumento é que o conhecimento do país sempre se deu a partir da teia dos saberes europeus. O caso de Sílvio é sintomático porque munido por este saber ilustrado, mostrou ser um intérprete de seu país não perdendo de vista os problemas nacionais, denunciando tais problemas de maneira clara e combatendo todos que discordassem de sua maneira de pensar.

Se apelarmos para a leitura do crítico literário Roberto Schwarz, veremos que a assimilação das Teorias liberais era aplicada num cenário sem elementos compatíveis à recepção das mesmas. Fora de seus devidos lugares e sem chão, as idéias européias eram como que letra morta porque encontravam pela frente o "Liberalismo" baseado na escravidão. Na Europa, as Teorias liberais tinham sentido porque iam de encontro à centralização dos países sob as mãos absolutistas dos reis. Mas isso não pode nos fazer esquecer de duas questões: 1) O Capitalismo se constituiu internacionalmente e a escravidão não é um dado das colônias isoladamente, pelo contrário, é parte fundamental dos interesses econômicos das metrópoles onde a escravidão não mais existia. 2) O Liberalismo é tão Ideologia na América escravista quanto na Europa do assalariamento generalizado. 
Se nos debruçarmos sobre o estudo de Renato Ortiz, veremos que o autor afirma que no Brasil as idéias do Positivismo, Naturalismo e Darwinismo Social estavam sim em seus devidos lugares, chamando atenção para o teor prático por parte de toda produção ensaística dos idos de $1870 .{ }^{486}$

Para além de uma análise acerca das idéias assimiladas na época e empreendidas pela Geração de 1870, parece-nos exaustivo investir na falta de coerência de leituras adotadas pelos ensaístas dos finais do século XIX no Brasil. No fundo, embora saibamos da ausência de homogeneidade teórica, as leituras predominantes foram as do Positivismo, do Evolucionismo e, sobretudo, do Determinismo racial e mesológico. Nesse sentido, cabe perceber somente o sentido da assimilação destas vertentes e enxergar até que ponto tais idéias respaldaram e viabilizaram a nova maneira de interpretar o Brasil. O que nos interessa não é apenas elencar nomes e mais nomes, como os de Darwin, Buckle, Taine, Spencer, Gobineau, Letorneau, Scherer, Lapouge e uma infinidade de autores, mas sim entender o sentido da aplicação de tais leituras para apreender a nova maneira de interpretar o Brasil.

Não basta meramente admitirmos ou tomarmos uma postura que conflua e, portanto, corrobore com boa parte da historiografia literária brasileira, afirmando que as ideias estavam fora de lugar, deixando de lado a realidade brasileira, como também não é suficiente compreender a assimilação das ideias atinando apenas para o lado instrumental, suscitando a ideia de que toda e qualquer ideia fora adotada no Brasil sem sentido algum.

Grande parte dos estudos que compõem uma História das idéias está atenta ao lado instrumental das idéias importadas da Europa e dos EUA pela geração de Sílvio Romero. Mas sabemos que essa falta de coerência da Escola do Recife tem implicações políticas como, por exemplo, o anseio em adentrar as repartições públicas, tornando indispensável o combate ao exclusivismo literário dos escritores quando comparados com o grupo liderado por Tobias Barreto e Sílvio Romero. Alguns dos trabalhos dão mais ênfase ao surgimento e à recepção das diversas Teorias no Brasil, esquecendo-se da infinidade de idéias como estratégia política onde o cenário nacional se torna o principal fator explicativo. Nossa postura é não pender para nenhum dos dois lados: não conceber a absorção das idéias por parte da geração de Romero atinando somente para o lado prático das mesmas, pois assim perdemos de vista a razão ou o sentido do próprio movimento onde existia uma seleção das idéias; e nem defendemos um simples teoricismo das idéias, como se estas fossem pura abstração sem relação alguma com a situação do Brasil. As idéias importadas sofriam um processo de seleção e instrumentalização, inaugurando uma nova forma de interpretar o país.

486 ORTIZ, Renato. Cultura Brasileira \& Identidade Nacional. São Paulo: Brasiliense, 1994. Ainda. FRANCO, Maria Sylvia Carvalho. As idéias estão no lugar. Cadernos Debate, 1. São Paulo: Brasiliense, 1976. 
O bando de idéias novas a que se referia Sílvio marcou o início de uma nova era nas leituras brasileiras: a partir de então, o país passou a ser analisado tendo por base as leis do Evolucionismo e do Determinismo racial e mesológico. Nesse sentido, sustentamos a mesma hipótese de autores como Antonio Candido, Maria Isaura Queiroz, Roberto Schwarcz, Mariza Correa, Lilia Schwarcz, Renato Ortiz, Otavio Ianni, e que Ângela Alonso amplia ao nível máximo.

Desconstruindo uma História das idéias, Ângela Alonso defende que a atenção apenas para adoção das idéias perde de vista o cenário nacional em que precisam se realocar para somente assim impulsionar as estratégias políticas legitimadoras de toda a movimentação do pensamento na derrocada da ordem imperial brasileira. Alonso percebe o revoar das idéias novas carreadas pela Geração de 1870 como movimento político, uma vez que idéias e prática não se separam. A razão maior e o sentido de toda a agitação das idéias novas se davam somente porque nela estavam às ferramentas para a Crítica às instituições do Império. As idéias da Geração de 1870 foram instrumentalizadas na critica as instituições imperiais deitadas nas mãos da antiga camada senhorial que, agora, sofria a concorrência das nascentes classes médias e de novos setores dominantes. O teor pragmático é salientado pela autora:

\begin{abstract}
"Essa situação relativa em relação às instâncias de poder do Segundo Reinado, tendo insistido, é a causa principal da mobilização "intelectual" dos anos 1870. E é também, vou agora argumentar, o que explica sua forma, o caráter para institucional de suas manifestações. O movimento da geração 1870 inicialmente procurou os meios canônicos de exprimir demandas no Império: a publicação de obras de interpretação da conjuntura, o ingresso nos partidos, a redação de panfletos e manifestos. Malograda esta via, começaram atividades paralelas para auto expressão e difusão de suas teses fora do mundo estamental. Fundaram sociedades, clubes e pequenos jornais. Organizaram eventos, efemérides, intervenções públicas, comícios, banquetes, recitais, passeatas, viagens de propaganda" 487
\end{abstract}

Ângela Alonso estuda toda a influência e utilização das idéias assimiladas pelo movimento intelectual e político da Geração de 70, em sua multiplicidade de projetos na contestação da ordem imperial. O que chama nossa atenção neste trabalho é a inserção das ideias europeias e sua instrumentalização no cenário nacional por parte da geração de Sílvio. Vendo a autora a adoção das idéias pela geração de Sílvio como recurso de contestação ao Brasil imperial, explode a separação entre Teoria e prática, entre obra e práxis. Alonso pontua a mobilização dos grupos contestadores surgidos nas faculdades de Direito de São Paulo e Recife. Com relação a Sílvio, afirma que Romero não é típico do ponto de vista de sua posição social. Embora tenha se cristalizado a associação entre a Escola de Recife e a emergência de uma "pequena burguesia" com base no estudo clássico estudo de

${ }^{487}$ ALONSO, Ângela. Idéias em movimento: a geração 1870 na crise do Brasil - Império. São Paulo: Paz e terra, 2002. 
Antonio Candido (1988), o ponto pede especificação. Como tenho argumentado, há uma diversidade de extração social entre os membros do movimento intelectual da geração de 1870. Sílvio Romero (1851-1914) só com muita condescendência pode receber o qualificativo de pequena burguesia ou classe média. Rigorosamente, filia-se à camada senhorial decadente. O pai, português comerciante, casou-se numa família típica do norte em fim do Império: os Vasconcelos, donos de engenho de açúcar. Foi no ambiente da casa-grande senhorial dos avós que cresceu, muito à feição de Joaquim Nabuco." 488

O trabalho da socióloga nos faz rever toda a adoção das idéias européias e da instrumentalização das mesmas por parte de Sílvio como forma de superar o atraso brasileiro, e neste ponto, concordamos com a autora. Mais relevante do que reconhecer a instrumentalização das idéias pelo jovem bacharel é reconhecer toda a Crítica de Sílvio ao passado nacional. Em várias frentes, Romero teve posições claras e bem sedimentadas. Fosse com relação ao regime de governo, se presidencialismo ou parlamentarismo, a formação de um partido operário, a melhor maneira de colonizar o país, a questão de terra, a Crítica no que diz respeito às posturas políticas das inúmeras oligarquias que campeavam de norte a sul do Brasil, lá estava Sílvio com uma posição bem definida. Não basta reconhecer que as idéias assimiladas por Romero eram sim parte de um Brasil em transição, adotada pela nova burguesia, em que as transformações selariam a morte de um Brasil do passado e inaugurariam um novo Brasil, causando a idéia de que o autor partia de um fim já pré- estabelecido, ou gerando a sensação de um mero agitador. É simplismo demais conceber Sílvio como um mero agitador, embriagado por simples idéias alienígenas. A farta produção de Sílvio evidenciam seu amplo conhecimento, numa incessante busca para encontrar a melhor vertente científica para solucionar os problemas nacionais. Se Sílvio elencou nomes em penca, em nenhum momento nos autoriza a tirar o mérito ambicioso de sua História literária. Reconhecer que as idéias adotadas por Romero respondiam às exigências ou necessidades do Brasil dos idos de 1870 é situar o contexto em que essas idéias se moveram, e contribui para a compreensão da História literária criada por ele. Saber que o revoar das idéias novas tão alardeadas por Sílvio atendia às necessidades das transformações sociais que enfrentava o Brasil, isso muito já se falou, mas leva a uma visão determinista do autor, cuja principal consequência é o racismo do mesmo. Sílvio conhecia sim as Teorias do Determinismo, mas deixou espaço para uma leitura relativista, o que consideramos ser de vital relevância. As contradições de Romero evidenciam as idas e vindas do autor, as polêmicas em que se envolveu, divergindo da superioridade dos escritores do Rio, as duras Críticas aos inúmeros políticos brasileiros, o apelo em prol dos milhões de brasileiros totalmente desassistidos, espalhados pelos mais distantes recônditos do país, são provas de que não basta ver Sílvio como um

${ }^{488}$ Ibidem. p. 135 
escritor determinista. É claro que em algumas de suas obras deixava explícita sua convicção nas leis evolucionistas e deterministas, mas por vezes mitigava seu Naturalismo.

O modernismo ${ }^{489}$ a que se referiu José Veríssimo com relação a toda movimentação das idéias novas era faceta de uma nova conjuntura econômica, em que a idéia de um imaginário republicano confundiu-se diretamente com a idéia de democracia, onde as oportunidades seriam maiores e o povo viveria melhores dias. Para João Cruz Costa, Wamireh Chacon, Nelson Werneck Sodré e Antônio Candido, dentre outros, as idéias do Evolucionismo e darwinismo europeu faziam parte das significativas transformações econômicas atravessadas no momento. Para Cândido, o movimento crítico empreendido por Sílvio Romero "foi a primeira manifestação orgânica e flagrante do processo de aburguesamento refletindo-se nas esferas mentais" ${ }^{490}$.

Coube aos divulgadores da Ciência da época hostilizar toda a sociedade de corte, estamental e de cunho patrimonialista, que somente favorecia e beneficiava as famílias abastadas, em detrimento de uma imagem de Brasil-República, mais democrático e, acima de tudo, com a possibilidade de maiores oportunidades políticas. Para além da simples identificação de idéias ou de pensadores, é preciso perceber as mudanças pelas quais atravessavam a Economia e a sociedade brasileira, motivadoras da adoção e reelaboração de tantas idéias européias.

A assimilação das idéias modernas não se coadunava com um Brasil escravo, num momento em que emergiam nos centros urbanos camadas médias que passavam a conhecer os preceitos naturalistas, possibilitando uma nova visão de mundo. A nova geração não fora agraciada com os títulos expedidos pelo mecenas imperador, protetor das Artes e Ciências, nem participou das tertúlias e saraus literários em torno do IHGB. Mesmo que remediados, os novos escritores não encontraram a facilidade da geração anterior, herdeiros de uma tradição rural e financeiramente estável, como um Sales Torres Homem ou um Francisco Adolfo de Varnhagen. Foi a dificuldade da geração de Sílvio de adentrar os espaços do funcionalismo público, dentre outros fatores, que fez esse grupo de intelectuais se prender ao novo método para contrapor-se ao menos discursivamente à Retórica dos antigos bacharéis e dos políticos da geração anterior: escritores economicamente estáveis, de famílias bem estabelecidas, sempre agraciados pelo imperador e aceitos numa verdadeira sociedade de corte. Se a geração de escritores e artistas do Romantismo encontrou proteção sob o manto imperial, a geração de Romero contestou todo este cenário e criticou as instituições imperiais.

A geração de Romero fora antes de tudo parcialmente excluída e marginalizada politicamente, e lutava agora por novos espaços no funcionalismo público. As nascentes classes urbanas buscariam agora por meio das atividades letradas (onde era o jornalismo, especificamente, o jornalismo literário,

\footnotetext{
${ }^{489}$ VERÍSSIMO, José. Op.Cit. p. 296.

${ }^{490}$ CANDIDO, Antonio. Introdução ao método crítico de Sílvio Romero. Op.cit.p.181.
} 
o meio mais importante porque era o mais divulgado) elaborar romances, artigos, se agremiar em rodas literárias, como alternativas de ascensão ou mobilidade social.

Vale lembrar que a geração de Sílvio fora marginalizada somente do ponto de vista político e não social. Tanto no Recife como em São Paulo, os alunos das faculdades de Direito vinham de famílias bem estabelecidas, embora, em parte, oriundos da decadente Economia açucareira em crise nas lavouras do nordeste. Tais grupos combatiam as instituições do Império brasileiro porque o regime não acompanhava suas ambições.

Adeptos do Determinismo e do Evolucionismo e oriundos de famílias mais ou menos bem estabelecidas, pertenciam a classes que não podiam ser relegadas politicamente. No Império brasileiro, não havia uma separação entre campo político e literário. Para alcançar a deputação, era necessária a produção de algum ensaio "literário". Não é por acaso que as questões "literárias" versam sobre os problemas políticos nacionais, em busca dos elementos de brasilidade, apelando para as condições do país e para a situação do mesmo frente aos países europeus. Mesmo diante da diversidade de idéias estrangeiras, sobressai um elemento comum na multiplicidade ensaística: a busca pela identidade brasileira. Mesmo diante da importação das idéias européias - o que sempre ocorrera na História brasileira desde o contato do português com os povos nativos - e da infinidade de escritores, era preciso olhar para o Brasil em busca do brasileiro e de seu caráter nacional.

Com a decadência da Economia do açúcar nas lavouras do nordeste durante a primeira metade do século XIX, presenciou-se a emergência da região cafeeira do Vale do Paraíba que, por sua vez, seria suplantada tempos depois pela região do Oeste Paulista, onde veríamos surgir um dos mais eminentes divulgadores do Positivismo no Brasil, que é o médico Luís Pereira Barreto. Seja a favor de uma nova ordem econômica devido às condições de remediados (como fora o caso de Romero, que seguira carreira pública) ou de uma condição econômica estável (como fora o caso de Pereira Barreto), a situação social e econômica foi fator decisivo para explicar o movimento político e intelectual de contestação à ordem imperial. Os grupos insurgentes, como os bacharéis, jornalistas e cafeicultores, eram os maiores interessados no advento da ordem republicana. O grupo de jovens bacharéis e escritores lutava por uma nova ordem política porque almejavam oportunidades que jamais conseguiriam na sociedade fechada e de corte do Império brasileiro.

As duras Críticas de Sílvio Romero em suas diversas frentes atestam a presença de um país coberto por fraudes e toda a sorte de corrupção política, negligência com relação à população em geral, falta de lisura nos concursos públicos, onde o próprio bacharel por duas vezes não conseguiu ser admitido devido, segundo ele, a sua "posição" filosófica. Mais do que a simples Crítica às correntes ecléticas e espiritualistas, as duras falas de Sílvio carregam o peso da centralização literária presidida pelos escritores protegidos dos medalhões, que cada vez mais dificultava as oportunidades para os 
jovens escritores das demais províncias do país. Os ataques de Sílvio aos escritores do Romantismo se davam mais devido à relação entre os pares fincados na corte do que pela simples imagem fantasiosa que tinha com símbolo nacional a figura do índio. As Críticas de Sílvio tinham endereço certo e o próprio Romero era bem a comprovação da crença nas idéias cientificistas, daí seu pragmatismo oriundo de sua paixão pelo Brasil.

Foi Sílvio um pensador pragmático, que buscou conhecer a fundo as idéias que adotava, mesmo diante de suas contradições, de seus acertos e desacertos frente aos inúmeros adversários, para aplicálas ao Brasil e um dia ver o país livre dos inúmeros problemas que denunciou. O certo é que o Brasil não podia ser mais representado, como dizia o escritor, pelos Gonçalves ou pelos Pedros, criadores de uma imagem irreal que jamais permitiria o verdadeiro conhecimento do país, porque desconsiderava os problemas imprescindíveis ao entendimento do Brasil e de sua identidade alicerçada nas raízes populares.

Mais relevante do que tentar encaixar o bacharel nesta ou naquela corrente, levantando o repertório de leituras que conhecia, se interpretou corretamente as idéias européias, se utilizou grandes nomes como recurso de autoridade, é identificar o sentido de seu Evolucionismo e de seu Determinismo, elementos fundantes de sua visão de Brasil. Se é mais difícil encontrar um eixo de análise para entender as inúmeras idéias assimiladas, é fácil entender as razões de seu Evolucionismo e de toda a sua geração. Antes de tudo, é indispensável o conhecimento do Brasil para compreender todo o revoar das idéias novas. É necessário investigar o cenário interno como elemento mais significativo para a recepção e metamorfose das novas idéias.

É mais vantajoso estudar o pensamento e a contribuição de Sílvio Romero sem simplificar sua forma de ver o Brasil nesta ou naquela corrente, mesmo sabendo do ardoroso evolucionista que era e das inúmeras contradições ao longo de sua vasta produção intelectual. Não se pode é desconsiderar a concepção de escritor e a missão literária que dizia ter para com seu país. Mesmo diante de inúmeras idéias, é preciso salientar o modelo de escritor que foi e seu perfil de homem que procurou misturar cientificidade com imparcialidade em nome de uma Crítica sociológica para reparar os males do país e apontar os "melhores" rumos para um Brasil não formado como nação, porque compunha-se de uma população mestiça. O que não se pode é desconsiderar o momento agitado da época que servira de suporte para a assimilação e modificação das Teorias estrangeiras, inaugurando uma nova maneira de interpretar o Brasil do futuro, país camuflado por um discurso liberal burguês mais preocupado em controlar socialmente os futuros libertos, sem oferecer uma estrutura social capaz de garantir as mínimas condições de cidadania à população não-branca.

Não existiu homogeneidade no movimento político da Geração de 70. Os grupos adeptos das idéias novas estavam unidos em função de sua marginalização política e não social, não buscavam 
fundar escolas teóricas, procuravam sim explicar o atraso do país recorrendo aos preceitos do Naturalismo europeu.

Para Ângela Alonso, o segundo reinado não configurou um campo maior de oportunidades políticas para estes grupos marginalizados, eis o sentido de toda a movimentação de idéias de combate à política imperial de pleno domínio saquarema. Os diversos grupos políticos (liberais republicanos, federalistas científicos, positivistas) concordavam apenas quanto à Crítica às instituições do Império brasileiro. Nas Faculdades de Direito do Recife e de São Paulo, na Escola Politécnica e na Escola Militar (Rio de Janeiro), antiga Escola Central, nos jornais, panfletos e sociedades literárias se processou a contestação da ordem imperial. Mais significativo do que apontar o bando de idéias novas é não perder de vista o cenário nacional onde encontramos não apenas o sentido dessas idéias de fora como também a situação de um país saindo de uma estrutura escravocrata fincada na Economia rural, almejando ares modernos e civilizados.

Não estamos a afirmar que a vasta produção ensaística tenha sido motivada pelo mero interesse da busca por cargos públicos ou pela cadeira na Câmara ou no Senado brasileiro porque é desconsiderar o que motivou intelectual e politicamente parte das duras Críticas de Sílvio à geração anterior. Mas também é puro teoricismo achar que Romero e os demais integrantes de seu grupo literário buscavam as idéias estrangeiras por puro deleite, num momento de poucas oportunidades de emprego. Para aqueles escritores que tinham a sorte do apadrinhamento e mantinham relações com um medalhão, restava o jornalismo literário, uma das alternativas para a futura estabilidade, fosse por meio de cargo público, como por exemplo, o colégio Pedro II, ou a tão sonhada consagração para a estabilidade eterna, sendo agraciado com uma cadeira na Academia Brasileira de Letras (fundada em 1897, tendo Romero como primeiro ocupante da cadeira 17).

Não é necessário adentrar neste ou naquele gênero literário, buscar identificar essa ou aquela escola literária para avaliar a qualidade ou a capacidade geniosa do escritor ou artista para dar votos de mérito ou de agraciado a seu cargo profissional. Antes de toda e qualquer produção literária, antes da investigação da capacidade de "vulto literário" ou "mediana" por parte deste ou daquele escritor, cabe relevar o momento histórico atravessado pelo país e ver a relação da adoção dessas idéias e não daquelas, no caso, a primazia das leituras evolucionistas e deterministas para a elite brasileira.

Sintonizado com as idéias do Naturalismo europeu, Sílvio buscava as Teorias que julgava mais adequadas e fundamentassem sua interpretação do Brasil para traçar o melhor caminho para o país. Assim, procurou tantas Teorias para que o país alcançasse o estágio moderno diferente da concepção dos escritores do Romantismo. Combatendo a sociedade arcaica imperial, atrasada para ele, porque não interpretada pelo método do Naturalismo, bárbara porque resguardava uma população analfabeta e indiferente em relação ás questões nacionais, Sílvio Romero partiu da influência do Evolucionismo e 
das Teorias do Determinismo racial e do meio ambiente para interpretar o país e apontar os caminhos para a modernização do mesmo, visando a transformá-lo à imagem e semelhança dos grandes centros europeus.

\title{
6 - Evolucionismo, determinismo racial e climático: identidade nacional.
}

\begin{abstract}
"Se o clima não criou as raças que constituem nossa população, composta de gentes para aqui imigradas, ele as pode modificar e modifica efetivamente. Hoje que este fato empírico está descoberto e estudado, cumpre-nos não caminhar às cegas como hordas selvagens. A política e a Ciência brasileiras tem aí diante um problema a solver e a dirigir." 491
\end{abstract}

Como consequência da concepção científica dos jovens escritores da Geração de 1870, a sociedade brasileira de então passava a ser interpretada de maneira orgânica, os problemas nacionais eram analisados principalmente a partir das categorias do meio e da raça. Divulgadores da Ciência européia, esses intelectuais brasileiros das três últimas décadas do século XIX pensavam conforme o modelo explicativo eurocêntrico: a visão linear da História ocidental feita de estágios, em que os grupos humanos tendiam do mais simples ao mais complexo, num momento de expansão do comércio e da Economia. Não é de surpreender o olhar da elite ilustrada brasileira, moldada por um pensamento em que todos os povos tendiam do estágio bárbaro ao civilizado, tendo que percorrer inevitavelmente as fases dos três estágios anunciados pelo Positivismo. Claude Lévi-Strauss afirma que

\begin{abstract}
"A crença na Evolução unilinear das formas vivas surgiu na Filosofia social muito antes que na Biologia. Mas foi da Biologia que ela recebeu, no século XIX, um reforço que lhe permitiu reivindicar um estatuto cientifico, ao mesmo tempo que esperava conciliar assim o fato da diversidade das culturas com a afirmação da sua desigualdade. Ao tratar os diversos estados observáveis das sociedades humanas como se eles ilustrassem as fases sucessivas de um desenvolvimento único, pretendiase mesmo, na falta de laço causai entre a hereditariedade biológica e as realizações culturais, estabelecer entre as duas ordens uma relação que seria, pelo menos, anaLógica e que favoreceria as mesmas avaliações morais de que se armavam os biologos para descrever o mundo da vida, crescendo sempre no sentido de uma maior diferenciação e de uma mais alta complexidade". ${ }^{492}$
\end{abstract}

A categoria racial, segundo Strauss, aparecia agora aplicada sob bases científicas no século XIX, medindo o grau de Evolução dos inumeráveis grupos humanos. A intolerância etnocêntrica de acreditar numa Evolução linear fazia sentido somente quando perpassada por fases que tendiam da barbárie à civilização. A categoria abstrata de raça ganhou foros de verdade quando da aplicação dos

${ }^{491}$ ROMERO, Sílvio. História da Literatura Brasileira. 6a . Ed. Rio de Janeiro: José Olímpio. p. 96

${ }^{492}$ LEVI-STRAUSS, Claude. Raça e Cultura. In: O olhar distanciado. Lisboa: Edições 70, 1986. p.29 
métodos de indução influenciados pelas Ciências Naturais do século XIX, principalmente pela contribuição da Biologia, pois

\begin{abstract}
"se as Ciências Naturais não foram criadas na segunda metade do século XIX, foi nessa época que se popularizaram e, mais ainda, foi nesse periodo que se tentou a transposição de seus métodos para o estudo do homem. Embora se deva lembrar que já no século XVIII tinha havido algumas tentativas desse tipo - por exemplo, a ideia de magnetismo animal, destinada a êxito tão grande embora efêmero, nas mãos de Mesmer - a verdade é que apenas no século XIX as Ciências começarão a gozar um prestígio que até hoje não perderam. Fundamentalmente, o prestígio das Ciências Naturais e a tentativa de cientifizar o conhecimento do homem decorreram, não do progresso científico, mas da tecnologia científica. Vale dizer, quando as aplicações tecnológicas permitiram a transformação mais eficiente da natureza - seja através do controle físico dos organismos - a Ciência tinha demonstrado sua efiCiência e sua utilidade. E o seu prestígio, fora dos círculos de especialistas e curiosos, decorreu dessas aplicações e, principalmente, da ideia de chegar ao controle do comportamento humano. Nesse panorama, o Evolucionismo de Darwin tem um lugar muito saliente, sobretudo porque permite colocar o homem, definitivamente, no campo das Ciências Naturais". ${ }^{493}$
\end{abstract}

Momento na História brasileira quando a elite política e letrada buscava sustentação teórica para elaborar uma Crítica bem fundamentada ao passado de escravidão e de "barbárie", os ensaístas da segunda metade do século XIX assimilaram as Teorias positivistas, evolucionistas e deterministas na elaboração das interpretações do Brasil, em busca da identidade do país. Juntamente com as argumentações evolucionista e do meio ambiente, surgia a concepção que mais influenciou o pensamento da inteligentsia brasileira, a vertente do Determinismo racial denominada Darwinismo Social, que defendia a superioridade do homem branco em relação a índios e negros. Momento de indefinição política num país mestiço, a elite configurava a identidade brasileira remetendo justamente ao ponto mais frágil da situação que era reconhecer uma identidade num país mestiço recorrendo às Teorias do racismo cientifico para simplificar os problemas nacionais. Uma vez que as leis do Determinismo racial seriam um dos parâmetros para avaliar o grau de progresso do país, a identidade nacional inevitavelmente passava pela questão da raça na configuração da brasilidade.

Para Mariza Correa,

"Antes de ser pensada em termos de cultura, ou em termos econômicos, a nação foi pensada em termos de raça. Dominante, a noção de raça não excluía no entanto uma reflexão a respeito da Economia, da política ou da cultura, mas as subordinava ao âmbito de sua discussão. Talvez justamente por ser dominante, esta é uma noção quase sempre implícita: é difícil encontrar uma definição do que estes autores

${ }^{493}$ LEITE, Dante Moreira. O caráter nacional brasileiro: História de uma ideologia. 4º ed. São Paulo: Pioneira, 1983. p. 192-193 
entediam por raça, a não ser indiretamente, ou através de suas propostas políticas, indiscutivelmente racistas." 494

O advento das Ciências Sociais no Brasil é produto do conjunto de transformações operadas na Europa, especificamente em meados do século XIX. Assim como na Europa em que as idéias liberais e iluministas eram dimensões das novas forças produtivas, da mundialização do mercado, no que acarretaram as revoluções industriais, em contraposição ao pensamento dos tempos medievais, no Brasil, é a partir de 1850, somada à lucrativa Economia do café, responsável por um conjunto de transformações materiais, que as idéias sociológicas em torno das aspirações modernas vêm à tona. Há uma intrínseca relação entre o surgimento das nascentes classes médias, o advento dos centros de saber e as idéias científicas chegadas ao Brasil neste momento. Toda uma rede de saber que começou com a vinda da Família Real para o Brasil que pouco a pouco se fortaleceu e que ganhou foros de verdade com a Geração de 1870 se sedimentara justamente a partir das profundas transformações na no início da segunda metade do século XIX.

Se num primeiro momento a elite brasileira fora treinada nas universidades europeias, de modo especifico, em Portugal, formando a burocracia de estado, com uma base canônica e humanista diante de um quadro intelectual contraditório, quanto mais evidente parecia ser o desenvolvimento das Letras, Artes e Ciências, florescendo nomes ilustres, cada vez mais a população geral encontrava-se despossuída e analfabeta. Com a chegada da corte portuguesa ao Brasil, "rompe-se" formalmente a situação de dependência política e começa a fazer-se necessário o desvendar de uma cultura tipicamente nacional.

Após um período de aproximadamente cinquenta anos, da independência ao advento das idéias novas, onde os letrados brasileiros trabalhavam com os elementos constitutivos da futura unidade nacional, produzindo uma História ideológica que tanto omitiu o massacre físico e cultural das populações indígenas como a espoliação do negro, o que vingou foi uma História produzida por uma sociedade branca, conservadora e católica, influenciada por Cooper e Chateaubriand. No bojo da dança das elites, surgiria outra geração, de bacharéis apegados aos esquemas explicativos oferecidos pelo Evolucionismo na análise da sociedade brasileira.

Não é difícil entender a crença excessiva nos ares modernos por parte de nossos escritores juristas girando em torno da tão festejada civilização e progresso: é que o mito científico era uma cartilha para alcançar a tão sonhada sociedade civilizada. A crença na Evolução linear confundida e somada com a crença positivista caía bem tanto para as classes bem estabelecidas como para as nascentes classes médias, mesmo aquelas remediadas, preocupadas com a estabilidade econômica, o

${ }^{494}$ CORRÊA, Mariza. As Ilusões da Liberdade: a Escola Nina Rodrigues e a Antropologia no Brasil. Bragança Paulista: EDUSF, 1998. p. 53-54. 
que não deixa de ser assunto delicado quando se tenta traçar um perfil sociológico; a elite econômica e intelectual brasileira, que no primeiro momento do Império descendia de famílias estabelecidas, nos idos de 1870, em considerável escala, provinha de famílias decadentes devido ao declínio açucareiro nos estados do nordeste, que combatiam a rigidez hierárquica do Império brasileiro em favor de maior participação política.

Em parte, são estes setores médios em ascensão que adentrarão nas academias, tomarão conhecimento das idéias cientificas e passarão a interpretar a sociedade de maneira orgânica, em concomitância com as necessidades das formulações burocráticas imprescindíveis à formação da nação brasileira. Os ensaístas brasileiros foram conquistados pela linearidade do processo histórico composto por etapas, onde se partia da barbárie para a sociedade civilizada, e do menos diferenciado ao mais diferenciado, idéia tributária da História natural, regida pelas leis. Diga-se de passagem, esta concepção marcou em maior ou menor grau todos os países da cultura ocidental que sofreram a influência da cultura européia.

É por demais conhecido o circuito empírico das idéias do Determinismo e do Darwinismo Social disseminadas nas instituições brasileiras, como museus, academias e institutos históricos, assim como a divulgação do catecismo positivista nas escolas militares, figurando como principal nome dessa tradição Benjamim Constant. A Sociologia no Brasil surge sob os auspícios do Evolucionismo filosófico assimilado nas instituições já citadas, especificamente nas faculdades de Direito, por jovens escritores fascinados pelos mais variados nomes da Ciência e pela Filosofia européia, dentre os principais, Comte e Darwin. Desse modo, o Evolucionismo é o argumento principal para pensar a vindoura nação para a superação de todo o estágio anterior brasileiro que, para a elite política e intelectual, era de puro atraso. Para os predecessores da Sociologia brasileira, o passado do país era vergonhoso, em função da existência de uma sociedade bárbara e quando muito mestiça, que só atravancava o estabelecimento do progresso. A Sociologia no Brasil nasce das mãos de jovens bacharéis pertencentes a camadas sociais bem estabelecidas, por vezes jovens de famílias remediadas que pensam o Brasil conforme o olhar europeu, contribuindo para a institucionalização da ordem. Conforme escreve Antonio Candido,

"O jurista foi o intérprete por excelência da sociedade, que o requeria a cada passo e sobre a qual estendeu o seu prestígio e maneira de ver as coisas. Mas como as Teorias dominantes na segunda metade do século se achavam marcadas pelo surto científico de então, notadamente a Biologia, que saiu dos laboratórios para se divulgar de maneira triunfante, os juristas mergulharam na fraseologia científica e se aproximaram, neste terreno, dos seus pares menos aquinhoados, médicos e engenheiros, que com eles formavam a tríade dominante da inteligência brasileira. Vemos então, na Sociologia, os juristas inaugurarem uma orientação cientificista - 
como se dizia - que contou desde logo com a cooperação de engenheiros e, sobretudo médicos." 495

Não era difícil compreender o sentido da empolgação pela idéia da Evolução social: o Brasil precisava se adiantar na escala do progresso, uma vez que era desprovido dos valores exigidos pelos países europeus civilizados. Para tornar-se uma nação moderna, era preciso antes de tudo elaborar uma idéia nacional, camuflando os ódios de raça e de cultura, e só assim trabalhar dentro das argumentações científicas. Mas a adoção do princípio evolucionista não conseguia nublar nem a barbárie cometida contra os inúmeros grupos indígenas nem a intolerância cometida anteriormente em relação aos milhares de negros ao longo de quatro séculos de História. É claro que no Brasil a leitura sobre Evolução não foi unívoca, ora misturando-se com Crítica à monarquia, devido ao estreitamento das relações de uma sociedade aristocrática, ora incidindo sobre uma população mestiça, com costumes nada condizentes a uma nação moderna coberta por etiqueta. $\mathrm{O}$ certo é que a imagem de índios e, sobretudo de negros estava presente desde as primeiras reflexões brasileiras, mostrando a inferioridade da raça não européia. O que as anotações dos primeiros cronistas e viajantes não conseguiam esconder era a constituição de um país composto por índios e negros. $\mathrm{O}$ racismo impiedoso e por isso mesmo inaceitável de Oliveira Viana, posteriormente ao grupo de Romero, bem pode servir de exemplo à visão de boa parte da elite brasileira que sobreviveu a Império e a escravidão,

"Muito ao contrário do que acontece com os povos europeus e o norte-americano,
entre nós o problema das raças não apresenta, no ponto de vista político, nenhuma
complexidade. Em nenhum país do mundo coexistem, em tamanha harmonia e sob tão
profundo espírito de igualdade, os representantes de raças tão distintas. Homens de
raça branca, homens de raça vermelha, homens de raça negra, homens mestiços
dessas três raças, todos tem aqui as mesmas oportunidades econômicas, as mesmas
oportunidades sociais, as mesmas oportunidades políticas. Está por exemplo, ao
alcance de todos a propriedade da terra. Francos a todos, os vários campos do
trabalho, desde a lavra da terra as mais altas profissóes. Quanto aos Direitos
políticos, não figura em nossas leis, entre as condiçôes da sua investidura, o critério
das raças." 496

O sentido de todo o frenesi da idéia evolucionista era bastante simples: omitir um passado de conflitos entre o colonizador europeu e as duas raças inferiores colonizadas, como da população geral que não deixava de sofrer toda uma forma de controle social. As raças consideradas inferiores, conforme os pressupostos pseudocientíficos, forneciam simultaneamente esperanças de Modernidade e expectativa para o surgimento de uma sociedade menos degenerada, facilitando assim, todo o processo

\footnotetext{
${ }^{495}$ CANDIDO, Antonio. A Sociologia no Brasil. Tempo Social, 271/301, V.18, na ${ }^{\mathrm{a}}$ 1, 1959.

${ }^{496}$ VIANNA, Oliveira. O tipo brasileiro e seus elementos formadores. In: Ensaios inéditos. Apresentação. Marcos Almir Madeira. Campinas: Editora da Unicamp. 1991. p.15.
} 
de constituição da nação brasileira. A mentalidade clássica do pensamento social brasileiro é simplória, pragmática e por isso mesmo, está sempre a serviço das maquinações políticas por mais sutis que sejam.

Uma vez não delimitado cada ramo do conhecimento, corria por baixo uma intuição geral e irredutível, a sociedade a todo custo seria concebida pela infalibilidade das leis e os intelectuais brasileiros do período, estabelecidos nas instituições de saber, tentaram extrair do todo a parte que melhor podia ser trabalhada para identificar os males brasileiros, solvê-los e repará-los em nome do progresso e da tão sonhada civilização. Fosse qual fosse o ramo do conhecimento oriundo da especialização do saber que já se iniciava, a idéia central era o tema da Evolução. Dispensando a farta discussão que gira em torno da primazia do Recife com relação à assimilação das idéias, defendidas por Sílvio, Evolução era tema que estava por todas as partes do Brasil. Em universidades, academias militares, museus e institutos históricos e geográficos, Evolução era o argumento basilar para avaliar o estágio brasileiro frente aos países considerados modernos. Empolgados pelas certezas que só a Religião científica poderia fornecer, os jovens "sociólogos" reverberavam o tema da Evolução sob todas as formas. Na verdade, por nenhum motivo, deve-se omitir a grande teia mascaradora de um passado de dores, horrores e marcas jamais esquecidas num Brasil que na América era o único país que ainda mantinha os horrores da escravidão, onde a qualquer momento poderia explodir a barbárie negra em função da raça, e a manter o regime monárquico. O pano de fundo não poderia ser mais propício para a justificativa evolucionista!

Os conceitos emprestados das Ciências Naturais, que tinham por base a Zoologia e a Botânica, tempos depois, com o surgimento da idéia de Evolução a partir do conhecimento da obra de Darwim, passaram a servir de base teórica para analisar o estágio evolutivo ou de desenvolvimento dos países no Novo Mundo, configurando a maneira de pensar da elite intelectual e política brasileira. A nascente Sociologia surgia parcialmente sob o influxo das Ciências Naturais, nas quais as categorias do meio e da raça eram termômetro de avaliação da civilização ou da barbárie de cada sociedade - os clássicos Max Weber e Émile Durkheim, todavia, não consolidaram a questão racial em seus escritos inaugurais como problemática sociológica e até criticaram sua concepção naturalista. Como prova da crença inabalável nas leis científicas, os campos da Antropologia Física que se estendiam às áreas de Craniometria e Frenologia determinavam as análises das interpretações brasileiras de boa parte da produção ensaística a partir das três ultimas décadas do século XIX. O impacto destes conceitos modelou o pensamento brasileiro até à década de 30 do século seguinte, quando ocorre parcialmente uma virada historiográfica decorrente da influência da Antropologia de Franz Boas no pensamento de Gilberto Freyre (que elogiou aspectos do pensamento de Romero), além dos desdobramentos dos 
debates modernistas envolvendo nomes como os de Mario de Andrade (a rapsódia Macunaíma) e Paulo Prado (o ensaio Retrato do Brasil). Segundo Skdimore,

"Obras social-darwinistas, sobretudo, tinham grande influência no Brasil. Praticamente, todo pensador social brasileiro - antes de 1914 - se viu a braços com o Darwinismo Social. São freqüentes as citações de figuras como Spencer, Le Bom, Lapouge e Ingenieros. Os brasileiros, de regra, aceitavam o Darwinismo Social, em princípio, tentando apenas descobrir como aplicá-lo à sua situação nacional." 497

Incumbidos de gerirem o progresso do país, aqueles ensaístas brasileiros da segunda metade do século XIX voltavam seus olhares para uma sociedade mestiça, que hipoteticamene obstava o desenvolvimento ao estágio civilizado assistido por brancos europeus em função da alegada degeneração social. No fundo, a discussão racial no Brasil era respaldada por uma pseudociência determinista que tolhia toda e qualquer discussão em torno da cidadania dos menos favorecidos, uma vez que, segundo os preceitos do Darwinismo Social, existiam "raças" superiores e "raças" inferiores. O certo é que, com a presença de tantas idéias e Teorias, não deixa de ser simplismo atribuir o atraso brasileiro aos critérios morfológicos como a cor da pele, a forma do nariz, o tamanho da cabeça, tudo isto somado às influências das contingências de um meio que "seria" totalmente inóspito por estar situado abaixo da linha dos trópicos, impedindo qualquer forma de civilização.

Para Mariza Corrêa,

"estes cientistas sociais acusavam a persistência de costumes bárbaros, aborígenes e africanos de serem obstáculos impedindo o Brasil de chegar ao esplendor da civilização europeia. Consideravam-nos assim como uma barreira retardando o encaminhamento do país para a formação de uma verdadeira identidade nacional, que naturalmente embaraçava também um desenvolvimento econômico mais eficiente" 498

Desse modo, o Darwinismo Social ${ }^{499}$ tornou-se a vertente do pensamento científico predominante porque pregava a superioridade do homem branco em detrimento de índios e negros, contribuindo para o processo de identidade nacional brasileira constituída a partir de suas respectivas representações. Chacon é categórico:

"O Darwinismo foi a maior escola presença filosófica no século XIX, não lhe faltando em seguida inúmeros avatares. Até ma hora do sepultamento de Karl Marx, seu fiel amigo Friedrich Engels se sentia na obrigação de evocar uma analogia: "assim como

\footnotetext{
${ }^{497}$ SKIDMORE, Thomas E. Preto no Branco: raça e nacionalidade no pensamento brasileiro. Rio de Janeiro: Paz e Terra, 1976. p. 70.

498 QUEIROZ, Maria Isaura Pereira de. Identidade Cultural, Identidade Nacional no Brasil. Tempo Social; Revista Sociologia, USP, São Paulo, 1: 29-46, 1 sem, 1989.p. 30.

${ }^{499}$ Op.Cit.p.69. Ver. RAEDERS, Georges. O conde de Gobineau no Brasil. Rio de Janeiro: Paz e terra, 1988. SCHWARZ, Lilia Moritz. O espetáculo das raças: cientistas, instituições e questão racial no Brasil, 1870-1930. pp. 43-98.
} 
Darwin descobriu a lei da Evolução da natureza orgânica, assim Marx descobriu a lei pela qual se rege o processo da História Humana" 500

A partir de 1870, segundo Roberto Ventura, as Teorias raciais adentram o universo institucional brasileiro das faculdades de Direito e de Medicina, museus e demais instituições nacionais. Além da escola darwinista-social, outras duas escolas ou correntes estudavam o comportamento humano balizadas em preceitos científicos da época. A escola etnológica oriunda dos EUA nas décadas de 1840-50 sustentava a criação a partir da mutação das espécies, sendo seu maior representante Louis Agassiz. A outra corrente foi à escola histórica que confiava na evidencia histórica argumentando que as diferenças Físicas permanentes haviam sido estabelecidas de modo conclusivo por etnógrafos e anatomistas. O Conde de Gobineau e outros defensores da escola histórica ajudam a propagar na Europa que a raça era o fator determinante da História humana. De acordo com Thomas Skdimore, "quanto mais os brasileiros tomavam conhecimento das últimas idéias geradas da Europa tanto mais ouviam falar da inferioridade do negro e do índio".

Fosse por meios literários, científicos ou políticos, o cenário nacional brasileiro dos três últimos decênios do século XIX era representado e apresentado no exterior tendo como parâmetro a sociedade considerada requintada e fina, com as normas e os padrões da cultura européia que alijavam a maioria da população pobre e mestiça, despossuída dos mínimos direitos de cidadania. Gerou-se, portanto, toda uma política sutil de controle social a partir da construção ideológica das classes perigosas fundamentada por um juízo excludente, que tinha por base a questão racial. ${ }^{501}$ Nas últimas décadas do século XIX, os ensaístas brasileiros trataram de elaborar mais um projeto de identidade nacional. Enfrentando uma ampla diversidade cultural constituída pela rica cultura africana, misturada a credos de um Catolicismo dissidente das superstições da população rural que, paradoxalmente, era presa fácil do Catolicismo oficial, mais o que sobrara de grupos e indígenas e suas culturas, urgia construir a identidade nacional brasileira.

As categorias do meio e da raça serviram estrategicamente para construir o modelo de nação almejada pelas elites política e intelectual do Brasil, sufocando toda a diversidade cultural das raças consideradas inferiores como índios e negros - é agradavelmente surpreendente que um pensador como Romero, tão apoiado naquelas referências, tenha dado atenção a cantos e contos populares, inclusive de negros e indígenas, contribuindo para a legitimação desses grupos no universo da identidade nacional.

No Rio de Janeiro, centro literário brasileiro e até então sede do governo do país, ao mesmo tempo em que os porta-vozes do progresso e divulgadores de uma Literatura científica alardeavam as

\footnotetext{
${ }^{500}$ CHACON, Vamireh. História das Idéias no Brasil. São Paulo, Grijalbo. EDUSP, 1977. p. 47.

${ }^{501}$ CHALOUB, Sidney. Uma História das últimas décadas da escravidão na corte. São Paulo: Companhia das Letras, 1990.
} 
Teorias do Evolucionismo e do Determinismo, a Corte e, depois, Capital Federal recebia não apenas mercadorias, mas também livros sobre as últimas Teorias da época, a elite imperial comprava produtos europeus, como piano, consumia músicas da cultura clássica, e, mais que isto: a introjeção dos costumes e da moda européia era de tal ordem que o público confundia-se com o privado. ${ }^{502}$ Mas, o grosso da população vivia em péssimas condições de higiene, as pestes grassavam por todos os lados, e este era o quadro existente desde a vinda da Família Real para o Brasil. Se por um lado houve um indiscutível impulso cultural com a chegada da corte portuguesa, vale mencionar toda uma condição urbana de insalubridade e de mínima falta de infraestrutura, agravada desde os tempos D. João VI. A Corte e, depois, Capital Federal se confundia ideologicamente com o país inteiro ou com a imagem que a elite queria para o resto do país. Afora tantos modelos teóricos que ecoavam na República das Letras brasileiras, a sociedade carioca, na passagem para o século XX, era um cancro imerso em sua própria aspiração: querer ser uma sociedade moderna e cosmopolita como a francesa, com sua arquitetura art nouveau, seus cafés, teatros, jardins botânicos, praças, ruas em traçado ortogonal, lojas e, sobretudo, com uma Literatura que tinha como referência maior mestres europeus como Emile Zola.

Em meio à grande fachada da belle èpoque carioca, buscou-se o "melhor" modelo de pensamento para condenar a sociedade "atrasada" do Império e instaurar o progresso no país. Reconhecendo que as Teorias científicas adentraram no Brasil a partir de 1870, bem no momento da febre do afrancesamento carioca, é preciso salientar a importância do Rio neste momento no cenário nacional. É somente assim que se compreende o porquê da adoção dos elementos climáticos e raciais como parâmetros para analisar o Brasil, investigar os problemas nacionais, apontar os caminhos para uma sociedade civilizada - equivalência da nova sociedade republicana do porvir - e finalmente construir a identidade nacional. ${ }^{503}$

Almejavam os inúmeros ensaístas, por meio de seus escritos, criar um modelo de sociedade brasileira que tinha por base a europeia, mas para isto fazia-se necessário apontar os elementos fundamentais desta nova sociedade. Se o "atraso" da sociedade ou do povo brasileiro estava ligado à

\footnotetext{
${ }^{502}$ ALENCASTRO, Luis Felipe de. Vida Privada e Ordem Privada no Império. In: NOVAIS, Fernando. História da Vida Privada no Brasil Império. São Paulo: Companhia das Letras, 1977.

${ }^{503}$ As Teorias climáticas assentada sobre os bons ventos num meio favorável ou inóspito eram ao tempo de Sílvio concebida como a mais consistente teoria. Escreve Sodré: "Não nos surpreende, assim, o apreço que Sílvio Romero, há tantos lustros atrás, concedia a Taine, servindo-se ainda de um sub-Taine, o higienista Michel Levy. Era a ciência de seu tempo. Não aceitaríamos, hoje, por exemplo, a repartição do clima brasileiro apresentada por Sílvio, no capítulo que estudamos. Mas isso é naturalmente um detalhe. O principal, o fundamental está nas conclusões, nos conceitos. Estudo do clima, aliás, não oferecia melhores perspectivas, aqui, ao tempo em que o mestre sergipano escrevia. Alimentava-se mais de conceitos, de impressões, do que de elementos colhidos na observação sistemática. Hoje mesmo, quando os postos metereológicos estão espalhados pelo nosso território e as estatísticas estão espalhadas pelo nosso território e as estatísticas correspondentes podem ser levantadas, algumas conclusões a propósito do assunto padecem de dúvida. Que não seria, pois, ao tempo de Sílvio Romero?”. A ideologia do colonialismo. Op. Cit. pp. 85-86
} 
não formação deste povo enquanto uma nação homogênea, como pensava Sílvio, surgia aqui a busca pelo povo brasileiro carente de uma raça homogênea.

Tomava corpo a ânsia nervosa de procurar os elementos constituintes deste caráter nacional. Aqui, o elemento racial é recurso imprescindível para a ideologia do caráter nacional, que é o ponto de partida para a construção da identidade brasileira, somado aos variados elementos desta brasilidade:

\begin{abstract}
"O racismo estava, pois, presentes nos trabalhos destes pesquisadores do século XIX, de envolta, em doses variadas, com o pessimismo pelo futuro econômico e cultural do país, assim como a negação da existência de características especificamente brasileiras, e até mesmo da possibilidade de sua formação um dia. Estes medos ora apareciam em determinadas apreciações, oram permaneciam latentes, mas eram facilmente discerníveis num adjetivo, na construção de uma frase, e sublinhavam a maioria dos raciocínios e das inferências. De qualquer modo, uma pergunta estava sempre presente, explícita ou implícita: chegariam um dia todos os brasileiros, apesar da variedade de seus grupos étnicos e de suas posses a configurar um patrimônio cultural harmonioso e refinado, que seria partilhado por todos, em todas as regiões, em todas as camadas sociais? Pois para estes cientistas, sem harmonia não haveria civilização.", 504
\end{abstract}

Não é sem razão que o Evolucionismo e as Teorias do Determinismo racial e climático são assimilados no Brasil como forma de mostrar o atraso do país, propondo o progresso social e tendo como fundamentação mais significativa o Darwinismo Social, que credita a superioridade cultural às mãos do homem europeu devido a sua "superioridade" racial e biológica, inseparável de suas condições morais e mentais. Para boa parte dos ensaístas brasileiros, o atraso do país residia na mestiçagem que a cada dia levava a elite econômica e política a temer a degeneração do país, o que era posição também de Silvio Romero - que, todavia, abraçou a causa da mestiçagem. Como lembra Lilia Schwarcz, ${ }^{505}$ raça fora um conceito negociado que serviu de estratégia política para a elite no momento em que o país libertava seus negros e caminhava em direção à nova ordem republicana. Entre a idéia de miscigenação e a Teoria do branqueamento, passavam-se os dias e a elite manipulava muito bem, tendo por base os preceitos "científicos", qualquer forma de contestação por parte das raças “inferiores”. Em grande parte dos ensaístas brasileiros dessa época, a solução para livrar o país da degeneração era embranquecê-lo, unir-se a outros povos, criando a idéia de um país verdadeiramente democrático que nunca enfrentou nenhum ódio de raças. Nesse sentido, o problema de assimilação desses grupos era adiado para um futuro indefinido - estratégia semelhante ao adiamento quase secular do fim da escravidão, no Brasil Império.

\footnotetext{
${ }^{504}$ QUEIROZ, Op.Cit.p.

505 SCHWARCZ, Lilia Moritz. Racismo no Brasil São Paulo: Publifolha, 2001. Raça como negociação: sobre Teorias raciais em finais do século XIX no Brasil. Belo Horizonte: Autêntica, 2006.
} 
Para Sílvio, era necessária a mistura das três raças na formação da identidade brasileira, resultando na importante contribuição do mestiço como a maior singularidade do país. Se para grande parte dos escritores da época a causa do atraso brasileiro residia na presença de uma vasta população negra e mestiça, do ponto de vista de Romero, especificamente, a alternativa para se buscar a identidade seria favorecer a imigração européia do homem branco, considerado o trabalhador ideal, de forma racional, espalhando estes imigrantes no meio do povo brasileiro nas diversas áreas do país. A mestiçagem era para boa parte da elite intelectual brasileira a raiz do atraso brasileiro porque era reflexo direto da degeneração social que só provava o caráter bárbaro dos povos. Começava a ganhar corpo no Brasil toda uma vasta produção de saberes que tinha como centro a discussão em torno da origem racial, marcando, delimitando e constituindo o campo da nascente Sociologia no Brasil.

Os estudos de Nina Rodrigues atestam em grau máximo a crença na superioridade do homem branco, resultado das leituras que tinha dos teóricos racistas europeus. Contrário ao livre arbítrio por parte dos seres, baseando-se em autores como Ferri e Tarde, Rodrigues acreditava na diferença das raças e, como desdobramento, na diferença evolutiva dos seres humanos:

"Se de fato a Evolução mental na espécie humana é uma verdade a medida que descemos a escala evolutiva a mais e mais nos deveremos aproximar das ações automáticas e reflexas iniciais. Deste jeito, nas raças inferiores, a impulsividade primitiva, fontes e origem de atos violentos e anti-sociais, por muito predominarão sobre as ações refletidas e adaptadas que só se tornam possiveis nas raças cultas $e$ nos povos civilizados com o aparecimento de motivos físicos de uma ordem moral mais elevada" 506

De acordo com o médico maranhense, a Evolução biológica explicaria o grau civilizatório de determinados grupos humanos. Juntamente com o Darwinismo Social, pode-se afirmar sem receios que a ideia de Evolução social, consoante suas interpretações (uma delas a lei da recapitulação), definiu a visão de mundo dos ensaístas brasileiros até a virada cultural da década de 1930. Analisar a categoria abstrata de raça é trazer para a discussão a questão da desigualdade inata dos homens juntamente com sua triste conclusão: a superioridade do homem branco em detrimento de índios e negros. As Teorias raciais que se esboçaram de maneira explícita e "científica" ao longo da História, são tributárias e se confundiram na era moderna com os argumentos de liberdade, igualdade e fraternidade que, de maneira paradoxal, à medida que se desprenderam da argumentação Metafísica da Igreja, legitimaram a hierarquização entre as mesmas. É aqui que surgem os princípios do racismo dito

\footnotetext{
${ }^{506}$ RODRIGUES, Nina. As raças humanas e a responsabilidade penal no Brasil. Rio de Janeiro: Guanabara, 1957. Ver análises sobre Nina Rodrigues em: BECHELLI, Ricardo Sequeira. Metamorfoses na interpretação do Brasil: Tensões no paradigma racial (Silvio Romeiro, Nina Rodrigues, Euclides da Cunha e Oliveira Vianna). Tese Apresentada ao Programa de Pós Graduação em História Social da Faculdade de Filosofia, Letras e Ciências Humanas. São Paulo: 2009.
} 
científico, que terá seu auge nos meados de 1870, servindo de justificativa colonialista para explorar as populações nativas de diferentes partes do mundo em nome da missão civilizadora do homem branco.

O Darwinismo Social caiu como uma luva nas mãos da intelligentsia brasileira, servindo de justificativa para argumentar sobre a superioridade do homem branco e as vantagens do regime republicano que estaria por vir, equivalência do estágio positivo para a formação do estado nacional. Uma vez existindo diferenças entre as raças e sendo a idéia de Evolução questão central para as análises brasileiras, resultou que aquela concepção, em muitas ocasiões, confundiu-se com a idéia de progresso ${ }^{507}$. Cabe ressaltar que o impacto da idéia de Evolução adentrou também o senso comum e o pensamento acadêmico cientifico até em correntes como o Marxismo e em áreas de conhecimento como a Psicanálise, a Antropologia e a Etnografia. Desse modo, entendia-se que, assim como acontecia com os reinos animal e vegetal, a espécie humana tendia sempre do estágio mais simples ao mais complexo ou do menos diferenciado ao mais diferenciado. Fora esta a grande mudança na maneira de conceber a humanidade. Lembremos que Sílvio muito recorre a Kant para validar seus argumentos acerca de todo o processo de conhecimento. Mas ao mesmo tempo em que a Ciência avançava e colocava o homem como o único ser capaz de produzir cultura, os antropólogos concluíam que quase não existia diferença entre os seres humanos e os grandes primatas como símios e chimpanzés.

Quanto mais se buscava os possíveis antepassados do homem, mais o tema da Evolução inquietava os estudiosos. Lembra Poliakov:

"Bertrand Russel observou que a Teoria de Darwin foi essencialmente uma extensão ao mundo animal e vegetal da Economia política do laissez-faire" ${ }^{508}$. O abalo provocado a partir da ideia evolucionista fora geral porque contrariava a tese criacionista. Segundo Silas Guerriero: "Em meados do século XIX, a humanidade levou um choque. Um cientista inglês, geólogo e naturalista, ameaçou nosso lugar sobre o pedestal dos seres vivos. Charles Darwin colocou-nos na incômoda companhia de todos os outros animais" ${ }^{509}$.

A idéia evolucionista demonstrou ser um excelente argumento para colonizar os países habitados por seres "incapazes", uma vez que habitavam um clima inóspito, onde as forças da natureza eram tamanhas que não favoreciam o alvorecer civilizatório. A Europa era o centro de seres evoluídos e superiores. A ironia sofrida por Darwin logo causou inquietação e suscitou Teorias surgidas das mãos dos mais conhecidos naturalistas europeus e americanos, como Lamarck, Mendel, Buffon, Etinne Serres, Agasiz, Morton, Gliddon, Cuvier, Lyell, Humboldt, os últimos "os três maiores naturalistas do

${ }^{507}$ LE GOFF, Jacques. História e Memória. Campinas: Editora da Unicamp, 2008. Morgan, Lewis Henry $1818-1881$. HERMAN, Arthur. A idéia de decadência na História ocidental. Rio de Janeiro: Record, 1999. Ainda. MORGAN, Lewis Henry. Evolucionismo cultural: textos de Morgan. Rio de Janeiro: Jorge Zahar, 2005.

${ }^{508}$ POLIAKOV, Leon. Op. Cit. 198.

${ }^{509}$ GUERRIERO, Silas. Antropos e Psique: o outro e sua subjetividade. São Paulo: olho d'água, 2008. p.8 
século", marcando os estudos da Antropologia evolutiva, onde também figuravam nomes como os de Tylor e Frazer.

Trilhando os caminhos da cartilha de Comte, a elite brasileira condenou o atraso da sociedade imperial em nome dos ideais modernos padronizados pelas categorias abstratas de meio e raça. Tornou-se imprescindível erigir instrumentos analíticos para avaliar o estágio civilizatório dos países colonizados, sentido maior da adoção da escola do Darwinismo Social. Diante das inúmeras influências de idéias na transição Império/República, a Teoria da Evolução era, para Romero, a principal em sua interpretação brasileira

"O que sabemos ser a lei máxima de todos os fenômenos da História, como a de todos os fenômenos do mundo físico, a lei da Evolução, cuja fórmula mais completa é aquela que é devida ao gênio de Herbert Spencer; os que sabemos que não podem existir fatos sem antecedentes imediatos, sem a passagem de um estado de diferenciação e coerência, não podemos admitir o milagre da existência de instituições, quatro vezes seculares, no ar, sem a menor base na vida nacional.

Tal ideia pode ser de muito efeito na boca de declamadores e ignorantes; mas não tem poder ter apoio da Ciência". 510

O Evolucionismo tornou-se, não apenas para Romero como para a maioria dos ensaístas brasileiros das três últimas décadas do século XIX, a base explicativa para entender o país. Foi pelas teias do Evolucionismo que o crítico preteriu toda uma ordem imperial e atrasada a favor do progresso brasileiro diante da miséria e do analfabetismo do povo de seu país. Como desdobramento do vasto repertório de leituras que conhecia, num primeiro instante, aderiu ao Determinismo climático de Buckle, mesmo discordando de algumas de suas idéias, mas não de sua Teoria climática. Preocupando-se com a influência dos fatores do meio ambiente, procurou explicar o atraso da cultura brasileira responsável pela falta de vitalidade literária do país.

Embora sua concepção de meio não se reduzisse aos fatores geográficos, mostrou a morte precoce dos escritores do país e a falta de talento de nossos primeiros poetas devido aos elementos climáticos e naturais. Discordando do autor da História da Civilização na Inglaterra, que nunca conheceu o Brasil, concluía Sílvio que "Buckle é verdadeiro na pintura que faz de nosso atraso, não na determinação dos seus fatores" ${ }^{511}$. A apatia da Literatura brasileira, sem criatividade, decorria do calor e da umidade "dai um certo abatimento intelectual, uma superficialidade inquieta, uma irritabilidade, um nervosismo, um hepatismo que se revela nas Letras" ${ }^{512}$. As Teorias climáticas e as análises raciais justificavam o atraso brasileiro e, com isso, Sílvio discordava de toda a História do país porque não estudada à luz das novas idéias naturalistas. As categorias raciais e climáticas

\footnotetext{
${ }^{510}$ ROMERO, Sílvio. Obra Filosófica. Op.Cit. p. 269.

${ }^{511}$ ROMERO, Sílvio. História. Op. Cit. p. 87

512 Ibidem. p.91.
} 
passavam a ser a chave para explicar o estágio brasileiro, ao mesmo tempo em que davam suporte cientifico para a modernização das estruturas sociais e políticas do país e explicavam seu atraso.

Passados os acontecimentos que marcaram a segunda metade do século XIX, como a Guerra do Paraguai, na qual o Brasil mostrou sua face escrava (1864-1870) ${ }^{513}$, a Questão Religiosa e, sobretudo, a Abolição, a elite política e intelectual brasileira se avistava com o perigo dos recém-libertos, que enchiam as cidades. A lei de 1850, que em tese punha fim ao tráfico de escravos, não coibiu o comércio de negros entre as províncias brasileiras, fazendo com que a elite temesse a possibilidade de uma onde negra, como acontecera nas ilhas de São Domingo e Haiti. A questão era delicada: o que fazer com a vasta população de ex-escravos que possivelmente iriam se dirigir para as cidades? Nada mais fácil do que transformar o que seria uma discussão meramente restrita ao poder simbólico dos intelectuais brasileiros, em parte pertencentes às classes médias e altas, num problema de cunho maior, suscitando a carência da identidade nacional. Mais uma vez, passados os tempos do nacionalismo literário encabeçado pelos escritores do Romantismo brasileiro, protegidos do imperador Pedro II, urgia a questão de identidade nacional. Mais uma vez, era premente a inquietação: o que era o brasileiro? Era o Brasil um Estado, embora não fosse ainda uma nação, com uma raça ou um povo plenamente constituído, como pensava Sílvio Romero? O que fazia do Brasil um país atrasado ou bárbaro? Quais os caminhos para o progresso?

As categorias raciais e mesológicas estavam em pauta porque subsidiavam a formação da identidade nacional brasileira. Era indispensável identificar a qual raça pertencia o brasileiro. Nesse sentido, fez-se uma radiografia dos elementos integrantes do Brasil, balizadas por questões como: $\mathrm{O}$ que fundava a nação brasileira? Quais os temas abordados pelos polígrafos em seus trabalhos no momento de formação do estado nacional brasileiro? Até que ponto o método adotado pela elite simbólica e política, recorrendo às Teorias raciais e mesológicas, não contribuiu para o não conhecimento do próprio Brasil? Estavam na natureza em geral ou na raça em particular os atributos que dariam as respostas cabíveis, na visão desses homens ilustrados, para esclarecerem as razões do atraso brasileiro?

Com o fim da Economia escrava, urgia encontrar a identidade brasileira centrada não por acaso na questão racial num país possuidor de uma identidade pela falta $^{514}$, caldeado pelo cadinho de raças mergulhado no processo de transformações econômicas e tecnológicas que se processavam desde 1850, com o fim do tráfico de escravos. Foi a era do surgimento dos bancos, assim como dos correios,

\footnotetext{
${ }^{513}$ Com a guerra do Paraguai os escravos serviram a pátria e venceram a guerra e desde então não mais aceitavam a imposição das constantes penas e as humilhações porque passavam. Segundo algumas estatísticas o índice de mortalidade durante a guerra chegou a 90.000 negros. Ver. MUNANGA, Kabengele. Professor Clóvis Moura: o Homem e sua obra. In: O Negro no Brasil: estudos em homenagem a Clóvis Moura. (Org). Maceió: UFAL, 2003. p. 135.

${ }^{514}$ SCHWARCZ, Lilia Moritz. Complexo de Zé Carioca: notas sobre uma identidade mestiça e malandra. São Paulo, 1995. p.49-63.
} 
telégrafos e ferrovias, sob a iniciativa de Irineu Evangelista de Souza, Barão de Mauá, e de outros empresários ou grupos mercantis ligados a diversos ramos do comércio. O Brasil atravessava uma nova fase da expansão capitalista, inserindo-se nas relações econômicas do mercado mundial e no mundo da cultura européia. Em contraposição à elite intelectual do Primeiro Império, assentada na Economia agrária que se formara sob o Ensino canônico, católico e conservador, instruída sob o reformismo da Universidade de Coimbra, não atingida pelo Iluminismo ${ }^{515}$, agora, nas cidades, emergiam os filhos da antiga aristocracia colonial, assimilando as Teorias do Positivismo, do Evolucionismo e do Determinismo. Nas faculdades de Direito e de Medicina do Brasil, nos museus etnográficos, nos institutos históricos, nas escolas militares, os futuros médicos, militares, engenheiros e bacharéis assimilavam as diversas Teorias que chegavam da Europa e dos EUA. As Teorias científicas se transformam numa enorme sedução e charme nas mãos dos ensaístas brasileiros dos fins do século XIX. Estes homens buscavam, por meio de seus escritos, encontrar os porquês do atraso brasileiro, partindo das condições raciais numa sociedade mestiça e recorrendo aos fatores climáticos que pensavam determinar o florescimento de toda e qualquer forma de civilização nos trópicos.

Vale lembrar que quando da chegada do europeu, aqui encontrando o silvícola, atribuiu a este valores de barbárie a partir de uma visão edênica, o que, tempos depois, só se consolidou com o ideal romântico tão combatido por Romero. Frente à gigantesca e exuberante natureza, não havia condições para o florescimento de uma civilização porque os índios não escondiam sequer suas vergonhas, habitando um meio onde as forças naturais lhes eram totalmente hostis. Para a elite intelectual brasileira que presenciara as convulsões ocorridas ao longo da segunda metade do século XIX, o Império não tinha mais razão de ser em decorrência da Economia servil e da imagem negativa do país divulgada no exterior.

Temas como a questão servil e a mudança de representação política estavam na ordem do dia e toda a produção ensaística e romanesca tratava de tais questões. Os meetings ocorridos nas praças públicas, com toda a efervescência panfletária, as discussões em prol do novo regime, pensado como uma nova fase da História brasileira oferecendo maiores oportunidades políticas, na visão da intelectualidade brasileira, atestam a recorrência ao mesmo tema que é o atraso brasileiro devido à Economia escravista ${ }^{516}$. Não é por acaso ou acidente que as Teorias raciais adentram os centros de formação de saber no Brasil a partir de 1870, respaldando e tonificando os discursos científicos de boa parte do ensaísmo brasileiro. De acordo com Roberto Ventura,

\footnotetext{
515 CARVALHO, José Murilo de. A construção da ordem: a elite política imperial. Teatro das sombras: a política imperial. Rio de Janeiro: Civilização Brasileira, 2003.

${ }^{516}$ CARVALHO, José Murilo de. Os bestializados: o Rio de Janeiro e a república que não foi. São Paulo: Cia das Letras, 1987.
} 
"As Teorias das desigualdades raciais se difundiu no Brasil, junto com os ideários naturalistas, cientificistas, positivistas e evolucionistas, nas três últimas décadas do século XIX. A afirmação da existência de etnias inferiores justificava a formação de um novo imperialismo, o que foi percebido por Araripe Júnior e Manoel Bonfim,tornando-se objeto de polêmica com Sílvio Romero,que defendia o caráter científico das ideias racistas" 517

Embora José Veríssimo afirme que as idéias de fora demorassem cerca de 20 anos para chegarem ao Brasil ao longo da colônia e do Império brasileiro, no que concerne ao conhecimento das idéias deterministas e do Evolucionismo, a assimilação parece ter sido muito precisa. Segundo Thomas Skidmore, "Um tal corpo de pensamento racista sistemático não existia, ainda, na Europa de 1800. Por volta de 1860, todavia, as Teorias racistas tinham o beneplácito da Ciência e plena aceitação por parte dos líderes politicos e culturais dos Estados Unidos e da Europa", 518 É o mesmo Roberto Ventura que em sua tese afirma a centralidade da questão étnica no Brasil, enviesando o discurso liberal a partir de $1880{ }^{519}$. Percebe-se a sintonia das idéias de fora quando se tratava do cenário brasileiro. Cabe salientar a enorme discussão (já ultrapassada e talvez superada na historiografia brasileira) sobre o problema do mal da cópia com relação a seus centros de origem, o que foge ao escopo deste trabalho. Apenas é necessário salientar, sem sermos reducionistas, à seleção de idéias e à recodificação destas para a aplicação no cenário brasileiro, no que reside seu caráter de originalidade.

O sentido e a adoção das idéias do Determinismo e do Evolucionismo se confundem com a busca do caráter brasileiro, ou seja: os argumentos oferecidos pelas Teorias do Evolucionismo, do Determinismo racial e geográfico, foram indispensáveis para a criação da identidade nacional. Desse modo, mesmo que reconheçamos que as Teorias e doutrinas européias estiveram fora de lugar, que a imagem que a elite queria para o país era completamente reveladora de um cenário social excludente, seguramente é este o sentido da assimilação das inúmeras idéias cientificistas. À medida que o corpus científico europeu era parâmetro para análise do "atraso" ou do "progresso" dos países, e especificamente, vivia o Brasil uma situação de atraso, a elite forjou um discurso bem urdido de que a involução se dava por conta do não-branco e de mestiços. Este é o sentido da adoção das leituras evolucionistas e deterministas, uma vez que, à medida que estas serviam de critério para analisar o estágio do país, identificando este como "atrasado" e, portanto, inferior em relação às nações modernas, simultaneamente oferecia alternativas para a superação deste atraso. A mudança para o regime republicano e a Abolição da nódoa escrava eram os principais indícios reveladores do atraso brasileiro e esperanças para sua superação.

\footnotetext{
${ }^{517}$ VENTURA, Roberto. Op.Cit. p. 55

${ }^{518}$ SKDIMORE, Thomas. Preto no Branco. Op. Cit. p. 65.

${ }^{519}$ VENTURA, Roberto. Estilo Tropical. Op. Cit. p. 192
} 
De maneira estratégica, a elite confeccionou dois discursos para impedir qualquer forma de protesto social por parte dos não-brancos e dos menos favorecidos: o Brasil estava se degenerando por conta do laboratório racial ${ }^{520}$ e fazia-se necessária a vinda do branco europeu para modernizar o país. Surgia e estava de pé a Teoria do branqueamento em função da mestiçagem da sociedade brasileira, reforçando cada vez mais não apenas a imigração do estrangeiro como a idéia de superioridade do mesmo. O Evolucionismo oferecido pela leitura de Darwin, juntamente com a contribuição de Comte, permitiam a interpretação de que as sociedades percorrem inevitavelmente sempre o mesmo caminho civilizatório, que sempre tende do mais simples ao mais complexo, sendo a república confundida com o estágio moderno.

Enfim, estava em pauta pensar o Brasil com um patrimônio cultural homogêneo ${ }^{521}$ na busca pela identidade nacional e pelos elementos constituintes desse brasileirismo. Desse modo, os ensaístas brasileiros se detinham na investigação sobre a singularidade do país, no que resultava um saber puramente prático. Como lembra Renato Ortiz, analisando os precursores das Ciências Sociais no Brasil de raiz durkheimeana e seus respectivos cientistas sociais, "O que se propõem os intelectuais do período é a construção de uma identidade de um Estado que ainda não é" 522.

Como se depreende da citação, o que estava por detrás de todo um aparato baseado nas categorias analíticas do meio e da raça era esboçar o Brasil como nação e para isso era indispensável à busca por sua identidade. Raça e meio se tornaram um verdadeiro fetiche nas leituras sociais brasileiras. Os homens de Ciência proporão uma análise evolutiva da sociedade, dando margem não somente à idéia do atraso brasileiro, mas, ao mesmo tempo, à condição para solucionar este problema frente às sociedades modernas ou civilizadas. As estratégias de criação para a identidade brasileira eram forjadas nas faculdades, nos museus e institutos históricos, veículos de produção e divulgação do saber. A adoção das Teorias do meio e da raça não escondia o maior problema brasileiro: abolir gradativamente a escravidão e substituí-la pelo trabalhador ideal branco, sem causar rupturas na estrutura social vigente. Os ditames científicos capacitaram todo o processo de formação da identidade nacional brasileira.

A questão da identidade nacional brasileira já era tema central quando do surgimento do Romantismo brasileiro e da fundação do IGHB, em 1838. Criado justamente para forjar uma História brasileira e, por conseguinte, uma identidade nacional a partir de suas efemérides no mais alto teor positivista, bem condizente com uma sociedade estamental e de corte, a questão das três raças já era

\footnotetext{
${ }^{520}$ SCWARCZ, Moritz Schwarcz. O espetáculo das raças: cientistas, instituições e questão racial no Brasil, 1870-1930. São Paulo: Companhia das Letras, 2008.

${ }^{521}$ QUEIROZ, Maria Isaura Pereira. Identidade Cultural, Identidade Nacional no Brasil. Tempo Social: Rev. Sociologia, USP, São Paulo, 1(1): 29-46, 1.sem. 1989.

${ }^{522}$ ORTIZ, Renato. Cultura Brasileira e Identidade Nacional. Op. Cit. p.34
} 
preocupação da elite imperial brasileira quando dos encontros dos poetas e escritores protegidos do mecenas, amante das Letras e das Artes D. Pedro II ${ }^{523}$. Ganhador da melhor dissertação intitulada Como se deve escrever a História do Brasil? e elaborada sob encomenda de Pedro II, a monografia do bávaro Von Martius já trazia a questão sobre a participação das forças diagonais ${ }^{524}$ embutindo a fábula das três raças ${ }^{525}$ que nada mais era do que a concorrência entre elas. Nessa perspectiva, vivendo uma democracia racial, o povo brasileiro era um povo mestiço e de uma identidade também mestiça.

Tempos depois, Sílvio Romero iria se contrapor à imagem do índio como símbolo nacional e discordaria da identidade brasileira levantada por Von Martius:

\begin{abstract}
"Em uma palavra, a Teoria de Martius é puramente descritiva; ela indica os elementos; mas falta-lhe o nexo causal e isto seria o principal a esclarecer. É uma concepção incompleta". ${ }^{526}$ Ainda se detendo sobre a representação brasileira erigida por Martius, o crítico literário pontua: É mister desconhecer completamente o trabalho de Martius para levantar fantasias, como essa, sobre ele.O famoso botanista, no escrito citado, dá apenas um conselho e faz uma enumeração meramente exterior dos elementos que entraram em nossa população.Não os estuda;não os aprecia em sua ação mútua; não os mostra fusionando-se e reagindo uns sobre os outros ; não tenta a determinação, nem ao menos vaga, do que devemos a cada um dos três fatores principais de nossa nacionalidade em seu particular $e$ a todos eles em conjuntamente.Deixa, o que é fundamental na questão, em completo esquecimento o ponto saliente do problema - o mestiço, sobre quem peculiarmente deveria insistir, estudando, repetimos, o especial quinhão de cada fator e definindo o caráter do resultado, 527
\end{abstract}

Coube aos escritores românticos e do IHGB produzir uma narrativa historiográfica condizente à sociedade imperial, que elegera o índio como símbolo nacional enquanto grupos indígenas continuavam a ser exterminados. Livre do jugo colonial português, quando a Literatura brasileira era mero apêndice ${ }^{528}$ da Literatura da mãe pátria, o projeto romântico se incumbiu de averiguar quais elementos serviriam de base para narrar o início da História brasileira, erigir a memória nacional e assim suscitar o sentimento pátrio do país. O surgimento de uma narrativa literária estava ligado ao projeto de formação de uma identidade nacional que, em nenhum momento, colocou em xeque a

\footnotetext{
${ }^{523}$ SCHARCZ, Lilia Moritz. As barbas do imperador: Dom Pedro II, um monarca nos trópicos. São Paulo: Companhia das Letras, 1998. pp.

${ }^{524}$ ROMERO, Sílvio. Autores Brasileiros. Rio de Janeiro: Imago Ed.; Aracaju, SE: Universidade Federal de Sergipe, 2002. p. 562. Nesta obra encontramos as Zeverissimações Ineptas da Crítica que apesar de ser endereçada ao crítico paraense José Veríssimo, Sílvio Romero desenvolve de forma detalhada a monografia de Martius apontando os desacertos do escritor bávaro no que diz respeito a contribuição dos índios, negros e do português para a formação do povo brasileiro. pp. 551- 587

${ }^{525}$ DAMATTA, Roberto. Relativizando: uma introdução a Antropologia social. Rio de Janeiro: Rocco, 1987. p.70

${ }^{526}$ ROMERO, Silvio. História da Literatura Brasileira. Op. Cit. p. 61.

${ }^{527}$ Ibidem. p. 312

${ }^{528}$ Ibidem.
} 
questão da escravidão em função da superioridade do homem branco ${ }^{529}$. Em meio aos títulos conferidos aos escritores do IHGB e aos trabalhos que celebravam o imperador, os escritores amigos de D. Pedro II buscavam as vantagens naturais da fauna e da flora para forjar a identidade do país. Escondendo um passado (e um presente!) indígena, negro e de escravidão, os elementos da identidade nacional residiam nas belezas das matas, nas florestas e em todo o território brasileiro.

Sílvio Romero, assim com boa parte dos escritores de seu tempo, interpretou o Brasil tendo em vista os preceitos naturalistas para, a partir de então, construir seu modelo de representação nacional e de identidade. Era inerente a sua geração não somente o engajamento dos intelectuais, apontando os rumos que a nação deveria tomar, como buscar os porquês do atraso do país frente aos congêneres europeus, considerados evoluídos e já civilizados.

Não restam maiores dúvidas sobre a interpretação de que as sociedades consideradas modernas eram as européias, uma vez que já haviam se formado como nações ao longo do século XIX ou mesmo antes e isso pressupunha a homogeneidade de um povo ou de forma apressada de uma raça plenamente constituída. O que favorecia a constituição dessas sociedades modernas era o longo processo histórico que haviam atravessado, possuidoras de uma História documentada, que só as sociedades civilizadas foram capazes de construir, em detrimento das populações bárbaras e recém-descobertas do Novo Mundo. Não deixa ser esta uma visão eurocêntrica e excludente porque desconsidera a farta cultura elaborada pelas sociedades ágrafas como inferior!

Ainda que Sílvio afirmasse a inexistência de documentos para narração da História brasileira, como também não ser o Brasil uma nação homogeneamente formada, grande parte dos ensaístas nacionais de fins do século XIX partiam das categorias raciais e mesológicas para explicar o atraso da sociedade brasileira decorrente de um paraíso racial ou de um verdadeiro espetáculo das raças. Soma-se a isto o fato de ter o Brasil experimentado por quatro séculos, como bem pontuava Romero, o peso do regime escravista, que mostrava aos países modernos a imagem de um país mestiço/atrasado.

À luz das Teorias evolutivas e deterministas, a elite política e letrada brasileira respaldou seus argumentos científicos na ânsia de modernizar as estruturas do país e assim se distanciar cada vez mais do resto da população pobre e analfabeta. Esse o sentido da caracterização do homem não-branco como inferior e de um Brasil atrasado em função da forte presença de negros e mestiços. Foi recorrendo aos ditames e pressupostos científicos e extrapolando as leituras evolutivas e deterministas do pequeno espaço restrito ao reduzido campos de saber que o processo de definição de uma identidade nacional se desenrolou. Foi devido à transformação das simples leituras de escritores

529 ODALIA, Nilo. As formas do mesmo: ensaios sobre o pensamento historiografia: de Varnhagen e Oliveira Vianna. São Paulo: Fundação Editora da UNESP, 1997. 
racistas e evolucionistas aplicadas aos problemas brasileiros que se forjou todo o processo da identidade do país.

Manipulados estrategicamente pelas elites, os interesses destas se transformam em interesse de todo o país. Assim, a vinda de imigrantes dessa ou daquela nacionalidade, "caracterizando" o trabalhador ideal, se transforma em interesse não apenas da classe burguesa e sim de toda a nação brasileira. Interesses específicos das classes proprietárias agora se tornam interesse nacional, suscitando um verdadeiro problema de identidade. Para Roberto Ventura, "Torna-se a questão étnica de central importância no Brasil em termos de implantação do Liberalismo e do trabalho assalariado, sendo o racismo científico assumido pela elite intelectual e política de forma praticamente unânime a partir de 1880" 530. Uma conquista de Romero foi problematizar essas questões - raça, miscigenação, imigração européia.

A miscigenação era apresentada como o maior entrave para a constituição de um Brasil como nação, somada à ação de um meio inóspito que se, por um lado dificultava o florescer de uma civilização nos trópicos ${ }^{531}$, por outro, seria, para Romero, o agente diferenciador para formar o genuíno brasileiro, no caso, a figura do mestiço. Sendo o conceito de raça um conceito negociado num país amplamente negro e mestiço, Romero resolvia o impasse do caldeamento étnico brasileiro tendo em vista a figura do mestiço, aquele que não era nem português, nem indígena, nem escravo. Era o mestiço o genuíno brasileiro, formador da Psicologia nacional. O mestiço "é aquele que não se confunde mais com o português e sobre o qual repousa o nosso futuro" ${ }^{532}$. Ainda acrescentando o caráter mestiço da sociedade brasileira, afirmava: "O mestiço é o produto fisiológico, étnico $e$ histórico do Brasil; é a forma nova de nossa diferenciação nacional. Nossa Psicologia popular é um produto desse estado inicial, 533

Em que pesem as inúmeras contradições e o relativismo do polígrafo sergipano que ora partia de um extremo Determinismo, baseando-se em Buckle e Taine, e ora flexionava a categoria racial por meio do momento e dos antecedentes históricos, advindos daí seu Evolucionismo, e da seleção natural não somente biológica como também nas ideias, influenciado por Spencer, Sílvio via o Brasil como um país totalmente miscigenado não somente com relação ao caráter étnico, como dos aspectos culturais. As instituições políticas brasileiras sofriam o peso de uma índole mestiça, sob a influência direta do meio, de um caráter mal formado, apático, mórbido e sem vida. Em Raças que Constituíram

\footnotetext{
${ }^{530}$ VENTURA, Roberto. Escritores, escravos e mestiços em um país tropical: raça e natureza na cultura brasileira (18251933). p. 192. Tese apresentada a Faculdade de Filosofia, Letras e Ciências Humanas, em 1988.

${ }^{531}$ GUIMARÂES, Manoel Luis Salgado. Nação e Civilização nos trópicos: o Instituto Histórico e Geográfico Brasileiro e o Projeto de uma História Nacional. Rio de Janeiro, Estudos Históricos, n.1, 1988.pp.5-27.

${ }^{532}$ ROMERO, Sílvio. História. Op. Cit. p. 120

${ }^{533}$ Ibidem. p. 120
} 
o Povo Brasileiro - O Mestiço, Romero elencava dez consequências do caráter mestiço da sociedade brasileira.

\begin{abstract}
" $1^{a}$ - O povo brasileiro não corresponde a uma raça determinada e única;
$2^{a}$ - É um povo que representa uma fusão; é um povo mestiçado;

$3^{a}$ - Pouco adianta por enquanto discutir se isto é um bem ou um mal; é um fato e basta;

$4^{a}$ - A palavra mestiçagem aqui não exprime somente os produtos diretos do branco $e$ do negro e do índio; expressa em sentido lato todas as fusões das raças humanas e em todos os graus no Brasil, compreendendo também as dos diversos ramos da raça branca entre si;

$5^{a}$ - Esta característica é verdadeira no presente e no futuro, quer predomine sempre a atual mescla índio-áfrico-portuguesa, quer venham a predominar, mais ou menos remotamente, os elementos italiano e germânico, trazidos por uma colonização até hoje mal dirigida e pior localizada;

$6^{a}$ - $O$ elemento branco tende em todo o caso a predominar com a internação e o desaparecimento progressivo do índio, com a extinção do tráfico dos africanos e com a imigração europeia, que promete continuar;

$7^{a}$-Comparando-se o Norte e o Sul do país, nota-se já um certo desequilíbrio, que vai tendo consequêncial econômicas e políticas : ao passo que o Norte tem sido erroneamente afastado da imigração, vai esta superabundando no Sul, introduzindo os novos elementos, fato que vai cavando entre as duas grandes regiões do país um valo profundo , já de si preparado pela diferença dos climas;

$8^{a}$ - $O$ meio de trazer o equilíbrio seria distribuir a colonização regularmente $e$ cuidadosamente por todas as zonas do país, facilitando as nossas populações a assimilação desses novos elementos;

$9^{a}$ - Se o não fizerem, as três províncias do extremo Sul terão, em futuro não muito remoto, um tão grande excedente de população germânica, válida e poderosa, que a sua independência será inevitável;

10 - Como quer que seja e em todo o caso, a população do Brasil será sempre o resultado da fusão de diversas camadas étnicas ${ }^{534}$
\end{abstract}

A categoria racial tornava-se assim elemento de primeira ordem para a formação nacional e compreensão de toda a História brasileira devido à associação com toda carga de valores morais daí brotada.

É preciso ressaltar que apesar de seu vasto conhecimento enciclopédico, fruto da época em que assimilou conceitos das Ciências Naturais, acreditava o polígrafo num Algeist para compreender os fenômenos morais. Embora contrário a toda uma geração romântica em decorrência de visão fantasiosa oferecida que exagerou o tamanho das matas e dos rios brasileiros, recorreu ao mesmo berço de origem do Romantismo brasileiro, no caso, o Romantismo nacionalista alemão. Pensava na existência de um elemento maior que escapa ao arbítrio do sujeito e que por isso mesmo o transcendia. Buscava o bacharel uma essência que fundamentasse e que servisse de base para a formação nacional brasileira, responsável pela Psicologia nacional.

${ }^{534}$ Ibidem. p.120-121 
Se por um lado creditava ao mestiço a singularidade brasileira, sofrendo a influência do meio, o agente diferenciador, na formação da identidade nacional, acreditava na superioridade dos povos anglo-saxões. O meio era juntamente com a raça os elementos explicativos para a formação da Psicologia nacional. Buscou estudar as diversas zonas sociais do Brasil porque acreditava na influência diferenciada do meio em cada uma das regiões. Em seus inúmeros trabalhos, não perde de vista a Psicologia do nacional. Em Fatores da Literatura Brasileira, justifica o objetivo de sua obra mestra História da Literatura Brasileira "Neste terreno buscará permanecer este livro, por mais lacunoso que ele possa vir a ser. Seu fito é encontrar as leis que presidiram e continuam a determinar a formação do gênio, do espírito, do caráter do povo brasileiro" 535.

Mesmo discordando do autor inglês Henri Thomas Buckle e sua célebre obra História da Civilização na Inglaterra, onde o filósofo britânico dedicava apenas oito páginas ao Brasil sem sequer ter conhecido o país, após analisar sua Teoria, é enfático: “Buckle é verdadeiro na pintura que faz de nosso atraso, não na determinação dos seus fatores. " ${ }^{536}$ Para Sílvio, o escritor inglês teria sido vítima dos exageros dos escritores românticos, decorrência das "narrações fantasiosas dos viajantes, sedentos de maravilhas e despropósitos" ${ }^{537}$, no que arrolava seus inúmeros equívocos. Pretendendo justificar o atraso brasileiro por meio de sua História da Civilização da Inglaterra, Buckle traçava de forma minuciosa um cenário assustador em que as inclemências do meio impediam qualquer forma de civilização, fosse a mais imperfeita possível. O primeiro elemento tomado pelo escritor inglês para justificar o atraso brasileiro seriam os ventos alísios, causadores do calor e da umidade, responsáveis pelo não florescimento da civilização. De forma detalhada, o escritor inglês chega à conclusão de que por serem estes ventos gerais obstados pela "gigantesca cadeia dos Andes" ${ }^{538}$, acabam deixando sua umidade no território brasileiro, facultando assim "destruidoras torrentes" ${ }^{539}$, daí a razão da riqueza e imensidão da fauna e da flora brasileira. A partir de então, Buckle traça a exuberância da riquíssima fauna e flora brasileira, donde conclui:

\begin{abstract}
"As forças que se lhe opõem são tão formidáveis que ele nunca foi apto a lhes fazer frente, nunca foi capaz de resistir à sua acumulada pressão. O Brasil todo, a despeito de suas inúmeras vantagens aparentes, tem permanecido inteiramente inculto, vagando seus habitantes selvagens e impróprios para resistir aos obstáculos que a generosidade da natureza pôs em seu caminho". ${ }^{540}$
\end{abstract}

Para Buckle, o atraso brasileiro devia-se à exuberância e imensidão da flora e da fauna, resultado do excesso do calor e da umidade, que tornavam o homem incapaz sequer de raciocínio, tornando-se

\footnotetext{
${ }^{535}$ Ibidem. p.55

${ }^{536}$ Ibidem. p. 87

${ }^{537}$ Ibidem. p. 85

${ }^{538}$ Ibidem. p.80

${ }^{539}$ Ibidem. p.81

${ }^{540}$ Ibidem. p. 81
} 
um verdadeiro bárbaro. Romero concorda com o pensador inglês quando afirma "que só os patriotas desajuizados poderão contestá-lo" 541 com relação ao estado de barbárie ou atraso da população brasileira, mas discorda dos elementos que constituem sua hipótese. Não possuía o Brasil grandes matas, rios, montanhas e grandes mamíferos, nem tão pouco vulcões, tremores de terra e furacões, como escrevia Buckle. Mesmo discordando do pensador inglês apenas em suas idéias e não em Teoria, Sílvio sofrera a forte influência do escritor na medida em que assimilou a categoria mesológica em suas análises sociais para interpretar o Brasil, buscar compreender a formação do povo brasileiro e, por conseguinte, sua identidade. Concebera o meio como um conceito amplo com relação à concepção deste:

\begin{abstract}
"O meio, e por esta expressão se deve entender o aspecto geral da natureza, o clima, a temperatura, a constituição geológica e geográfica do país e seus conseqüentes imediatos - o trabalho, a alimentação e as condições fisiológicas e sociais da população, o meio tem operado entre nós como agente diferenciador em toda a direção da vida nacional, pelos fatos e circunstâncias que se vão enumerar

A marcha do povoamento do país, as condições políticas da nação, as relações econômicas, jurídicas, sociais, todas estas coisas, até as intuições Estéticas tem sido, em grande parte, ajeitadas e modificadas pelo meio" ${ }^{542}$.
\end{abstract}

A influência de pensadores deterministas como Buckle e Taine faria com que o bacharel valorizasse a participação do meio físico (clima, temperatura, geologia, geografia) como "agente diferenciador" 543 na formação da identidade do brasileiro. Dizia: “a ação do clima tem contribuído para nossa integração nacional; na Literatura, ela tem ajudado a efusão sentimental de nosso lirismo mais doce, suave e ardente do que o lirismo herdado dos portugueses" ${ }^{544}$. O meio ambiente era de inteira importância para explicar porque

"não temos Filosofia, nem Ciência, nem a grande Poesia impessoal dos grandes gênios europeus. Temos o palavreado da carolice, a mística ridícula do beatério enfermo e fanático, de um lado, e de outro, os devaneios fúteis da impiedade impertinente e fácil; na Poesia, o lirismo subjetivista, mórbido, inconsistente, vaporoso, nulo" 545

O meio era responsável não apenas pelo atraso do Brasil, como tinha participação direta na formação da identidade nacional. As causas do atraso do país eram de três ordens: primárias ou naturais, secundárias ou étnicas e terciárias ou morais. Aqui, entrava a influência da raça, integrando os fatores secundários não levantados por Buckle. Para o escritor inglês, a influência da umidade e do calor eram os principais responsáveis pelo surgimento da civilização, explicando a exuberância da natureza brasileira, do que discordava Sílvio. Segundo Romero, outro fator não salientado por Buckle

\footnotetext{
${ }^{541}$ Ibidem. p.83

${ }^{542}$ Ibidem. p. 268

${ }^{543}$ Ibidem. p. 268

${ }^{544}$ Ibidem. p. 96.

${ }^{545}$ Ibidem. pp.93-94.
} 
era os antecedentes históricos refletidos na política, na legislação, nos usos e costumes. Parece contraditória a visão de Sílvio, uma vez que concebe o meio como um agente não apenas físico, motivo de ser considerado por boa parte da historiografia um escritor determinista, mas para o bacharel existe uma relação de causa e efeito em reciprocidade, ou seja, ao mesmo tempo em que o meio influenciava a identidade nacional, por sua vez, ele era alterado a partir desta identidade.

A explicação da interação do meio na criação da identidade nacional propiciou um relativismo cultural, fomentando difíceis e confusas conclusões, segundo grande parte dos interpretes de Sílvio. Sua Crítica a Buckle advém justamente por seu Determinismo a partir de duas variantes explicativas que eram a umidade e o calor. Nas Conclusões Gerais de sua História da Literatura Brasileira, retoma a influência da umidade e do calor recaindo sobre a Fisiologia do brasileiro. Mesmo admitindo em parte a Teoria de Buckle assentada sobre tais elementos, releva o vasto território brasileiro, com mais de quarenta zonas, justamente por conceber o meio como um conceito amplo e de agir de forma diferente, dependendo da forma de vida de cada população. Mais do que a importância do clima, era de fundamental urgência levar em consideração o vasto território nacional, que colocava por terra a idéia de Buckle, para quem o calor e a umidade eram os elementos mais importantes para o surgimento de uma sociedade civilizada. Sílvio prioriza o aspecto fisiológico, um dos elementos fundantes da Psicologia nacional, o que, para alguns de seus interpretes, é só mais uma de suas contradições. Analisando as diversas zonas sociais do Brasil, cada uma com seu meio geográfico específico, as forças despendidas pelo homem eram diretamente proporcionais às dificuldades que estes encontravam para o desenvolvimento de seu trabalho. Não por acaso, considera os sertanejos do norte homens resistentes,

"Fracos de aparência e de aspecto, são pertinazes, enérgicos, resistentes em grau notável. São um tanto tristes, mas confiantes, resignados, afeitos ao trabalho aprendido diretamente da áspera luta com a natureza. Não são dissimulados nem fingidos; tem a rude sinceridade do sol de seus sertões, duro e severo como eles" 546

Era clara a visão que possuía Romero, tendo em vista o estudo do homem a partir das mesmas leis que regiam as Ciências Naturais. Somente com a visão naturalista das Ciências Sociais, regida pelos métodos que orientavam as verdadeiras Ciências, se entende suas convicções acerca da influencia do meio e da raça no conhecimento do verdadeiro Brasil e da formação da identidade nacional brasileira. Não se cansava de aludir aos avanços da Ciência, desde os gregos às inovações da Crítica naturalista baseada em nomes como Buckle, Gervinus, Taine, Renan, que não mais se baseava

${ }^{546}$ Ibidem. p. 286 
em regras eternas do bom gosto, mas sim sob a influência do meio e da raça nas criações religiosa e artística.

Em História da Literatura Brasileira, pretendia traçar a Evolução cultural do país em todos os seus aspectos, influenciado pela Crítica naturalista e pelo Evolucionismo, delineando os fatores condicionantes da manifestação da inteligência humana. Embora sua concepção literária seja contrária aos críticos anteriores, introduziu a Crítica moderna responsável pela sistematização da obra, o que não significa afirmar que a Crítica tenha surgido com Romero ${ }^{547}$.

Buscava as leis que presidiam o curso da História ao longo do tempo. Do Positivismo, buscou inspiração para analisar a classificação das Ciências de Comte, mesmo com as dissidências de E. Littré e P. Lafitte, com a finalidade de escolher qual a melhor Teoria para pensar o Brasil. Buscou por meio de sua visão científica saber essa Teoria, procurando eliminar o atraso do país e vê-lo à imagem e semelhança das nações civilizadas, de onde emanavam as Teorias do Evolucionismo e do Determinismo. Se existiam leis que explicavam o aperfeiçoamento do organismo, do mais simples ao mais complexo, buscava os nexos causais para interpretar o Brasil e identificar os elementos de brasilidade.

${ }^{547}$ CANDIDO, Antonio. O método crítico. Op.Cit. 


\section{V - A IMAGEM DO ÍNDIO BRASILEIRO.}

\section{Monogenismo e poligenismo: os apologistas das diferenças.}

A discussão em torno da unidade do gênero humano fomentou desde os primórdios da existência humana calorosos debates na busca pelo centro de criação acerca das diferenças raciais. Se o homem surgiu num único centro, qual a razão para as diferenças? O que explica e como se explica que seres da mesma espécie ao longo da História se diferenciem de tal modo que se torna impossível encontrar o ponto de partida deste surgimento? Quais são os fatores que interferem na diferenciação entre as espécies, segundo os cientistas? As espécies já nascem diferentes ou é a interação entre estas e as forças naturais que explicam as variações entre as raças? As raças constituem espécies separadas ou são apenas variações de uma espécie?

O debate acerca das diferenças raciais está diretamente ligado ao problema de identificar o(s) centro(s) de criação da espécie humana, isso porque o primeiro argumento elaborado para justificar as diferenças entre as raças se dava pelo fato de terem surgido em locais diferentes. Buscando localizar o berço de onde teria surgido a espécie humana, os estudiosos enfrentaram a difícil missão de identificar a origem de homens e mulheres para solucionarem o problema das diferenças. Inquietava aos naturalistas - botânicos, zoólogos, anatomistas - investigarem os porquês das diferenças raciais donde surgiam várias inquietações: era o homem descendente da mesma árvore da dos outros seres? Por que determinados grupos humanos eram diferentes? Por que alguns seres possuíam uma pigmentação da cor do bronze ao passo que outros eram de cor amarelada? Por que alguns eram de cabeça arredondada e cumprida - dolicocéfalos - ao passo que outros eram donos de uma cabeça pequena - braquicéfalos? Qual a razão do homem - parente próximo dos grandes primatas como gorilas e orangotangos - ter adquirido ao longo do processo evolutivo uma postura totalmente ereta, com a capacidade de pensar e falar e, sobretudo, de raciocinar, diferente das demais espécies do reino animal?

As argumentações sobre as diferenças são muito antigas. Na Política de Aristóteles, encontramos a imagem de que os homens eram escravos por natureza. Os romanos designavam por bárbaro todo aquele que habitava além de seus domínios e não falava o latim, sendo por eles considerados povos de capacidade inferior. Já na alta Idade Média, o pensamento cristão retomava o pensamento aristotélico de que os escravos seriam desprovidos de alma, corroborando a escravidão de homens considerados inferiores. Nos tempos modernos, tempos de Iluminismo e de Revolução Francesa - filho direto do racionalismo enciclopedista de fundamentação cartesiana -, os divulgadores das luzes pensam na origem humana buscando uma Lógica das diferenças, trazendo no bojo a questão da origem das raças 
apenas para endossar a diferença e a hierarquização das mesmas. Assim como a Mecânica celeste ou dos corpos tinha suas leis e a Biologia experimental seu método de indução, os seres humanos careciam de ser classificados conforme a Histoire Naturelle de Buffon. Poliakov resume bem: "ora, a França buscava novidades. As elites da nova geração não queriam outra coisa senão conciliar amigavelmente o Deus do Sinai e a Deusa Razão" 548.

Mais uma vez, estava em voga a discussão em torno da origem do gênero humano. O racismo científico, que floresceu no século seguinte, tendo em Gobineau, amigo de Pedro II, seu maior arauto, já tinha raízes sólidas em todos dos enciclopedistas franceses. Pensadores como Montesquieu, Rousseau e vários os outros enciclopedistas discutiram a questão da origem humana e sua consequência inevitável: a desigualdade entre as raças. A começar por Montesquieu que, em seu Espírito das leis, apontava que o clima influenciaria determinadas formas de pensar e seria causa da diferença entre determinadas raças.

Rousseau pensava num homem em seu estágio natural, sem o contato da civilização regida pelas leis. Mesmo que as interpretações acerca do homem no estado de natureza sejam inúmeras, o que nos interessa é ressaltar a existência de duas maneiras de pensar que é a concepção desses ilustres intelectuais a partir do surgimento de uma cultura. E como concebem estes mesmos intelectuais os demais povos num contato bem próximo com a natureza? Se as normas concebidas por civilizadas corrompem os costumes como afirma Rousseau no Discurso das Artes, percebe-se que a imagem de outros povos sendo construída a partir do universo de valores das sociedades europeias. As noções do que seja bárbaro ou selvagem só ganham sentido quando imersas e assim confrontadas com a ideia de civilizado/civilização que só remetem à imagem de superioridade do homem branco.

Hegel, filósofo alemão e professor de Tubbingen, depois de Montesquieu e Rousseau, dividia a sociedade e os outros povos a partir da experiência europeia. Sua História universal tinha por base a presença do espírito que nada mais era do que uma forma de conceber a História mundial a partir da História da civilização europeia e teleológica. Acreditava que uma razão, Wolksgeist, se desenvolveria ao longo da História tornando inteligível todo o processo histórico.

O modelo de homem e de sociedade no qual a ideologia de superioridade das raças se enquadra é sempre a sociedade do homem branco e europeia, concebendo o resto dos povos como inferiores e carentes da ajuda civilizatória para subtraí-los da situação de barbárie. Até Marx e Engels não duvidavam da superioridade do homem branco, "supunha-se que a raça branca, portadora do progresso, era mais dotada do que outras raças. Em sua Dialética da Natureza, por exemplo, Engels escrevia que "os selvagens mais inferiores" podiam recair num estado bastante próximo ao do

\footnotetext{
${ }^{548}$ POLIAKOV, Léon. O mito ariano: ensaio sobre as fontes do racismo e dos nacionalismos. São Paulo, Perspectiva, Ed. da Universidade de São Paulo, 1974.p.182.
} 
animal; mais adiante, um raciocínio mais preciso, durante o qual se referia a Hegel e a Lamarck, fazia-o". 549

Mas sabemos ser a discussão em torno das raças antes de tudo uma discussão que carrega relações de poder, cujo discurso só beneficia a quem se sente pertencendo à raça superior como parecia aos apologistas da Ciência.

A França viu surgir um Gobineau, considerado figura máxima do racismo científico porque a História francesa está intrinsecamente ligada a um conflito político territorial com a Alemanha, que até hoje clama por identidade. Temeroso com a aproximação das massas ao poder, onde presenciou a revolução de 1848, o assíduo leitor, diplomata e escritor francês buscou comprovar sua superioridade para se enobrecer cada vez mais por conta de problemas pessoais e pela frustração de não possuir leitores. Escreveu a História de sua própria linhagem para legitimar sua nobreza e a ideia de superioridade das raças muito bem serviu aos seus próprios interesses, mas não dos das populações africanas e dos indígenas do Novo Mundo. É sempre em momentos de crise política que emerge a discussão em torno da identidade. Como afirma Michael Banton,

\begin{abstract}
"Os que pregaram o nacionalismo no século XIX estavam ansiosos por juntar em unidades políticas singulares os povos que eles pensavam ter uma origem comum. Os grupos intermédios e as minorias nacionais destruíram este esquema.Em vez de serem eliminados de um ou outro modo, estes grupos multiplicam-se e tornaram-se mais significativos. As transformações revolucionárias nos transportes e no custo da viagem tornaram possivel ao homem mudar-se para outros continentes em busca de trabalho. Os membros das minorias podem agora manter durante muito tempo o pensamento de regressar ao país natal e não são obrigados a contemplar um futuro em que a única alternativa é a assimilação. Da importância decrescente da nacionalidade nestas circunstâncias deriva o aumento do significado da etnicidade. Se as nações são populações que convergiram ou que estão dispostas a convergir em Estados-nações, as minorias étnicas são grupos que, possuindo atributos nacionais, desejam viver em estados que não têm como base os seus costumes, língua, Religião e valores. As noções de raça vieram a envolver-se tão estreitamente com os problemas das minorias étnicas que é frequentemente improdutivo tentar demarcar o estudo das relações raciais no respeitante ao estudo das relações étnicas. A investigação da História de muitas minorias mostra que é impossível separar a influência de fatores como raça, etnia, classe, Religião, e assim por diante, como se fossem fatores de uma equação algébrica. A História humana não é assim tão simples". ${ }_{550}$
\end{abstract}

Percebe-se que é no processo de formação dos estados nacionais que reside o sentido de aplicação da temática racial. É bem verdade que ao mesmo tempo em que o conceito de raça servia para dar identificação às minorias nacionais, excluía de forma inevitável diversos grupos humanos considerados bárbaros no processo de formação das nações. Dentre os vários elementos integrantes da nação, como a língua, o território, costumes, raça, cultura, a tipologia racial confundiu-se com nacionalismo e permeou todo o processo de identidade de boa parte dos países europeus. Identificar a

\footnotetext{
${ }^{549}$ Ibidem. p. 229

${ }^{550}$ BANTON, Michael. A idéia de raça. Lisboa: Edições 70, 1977.p. 17.
} 
raça de determinados grupos equivalia a identificar a priori qual era nação, com seu território, sua cultura e sua língua. A noção de raça, como esclarece Banton, se torna nesse momento inseparável de outros fatores como os de classe e Religião. Razões não faltavam para elucidar as diferenças entre as raças. A razão maior que inquietava os etnólogos e antropólogos era identificar quais as causas que tornavam os seres humanos diferentes dos outros seres da cadeia zoológica, tornando indispensável um argumento que justificasse as possíveis diferenças citadas. O primeiro argumento para explicar as diferenças advogava a tese monogenista baseada na idéia criacionista, onde todos os homens eram filhos do mesmo pai. Mas o pecado original teria sido o responsável pela degeneração das raças justificando a diferença entre as mesmas.

Os monogenistas defendiam que a causa para a variação das raças devia-se ao fato de algumas delas terem partido em tempos diferentes em direção ao estágio civilizado, mas que derivavam de um único centro de criação; já os poligenistas defendiam o surgimento da espécie humana em locais diferentes, combatendo o argumento diferenciador dos monogenistas. Acreditavam que os grupos humanos haviam surgido num local que não os da Europa ou do Cáucaso, considerados o berço da humanidade, o que permitia a superioridade residir nos povos surgidos nos mais variados locais.

A tese do monogenismo, de início, fora a que mais convencera aos divulgadores dos preceitos científicos que tomavam a experiência do Gênesis. O criacionismo bíblico narrava que todos os seres descendiam do mesmo pai, no caso, Adão. Personalidades católicas como Bonnet e Maier, defendiam que os germes para as futuras gerações já estavam contidos num primeiro homem. Mais tarde, grandes classificadores como Lineu, Cuvier e Agassiz deram suas contribuições para identificar e localizar o homem em escala zoológica com relação a seus possíveis ancestrais, como os símios e hotentotes. Todo este esforço residia em buscar os porquês das diferenças entre as raças. Bem antes do advento da Antropologia Física, corporificada sob a área da Craniometria ligada aos nomes de Morton e Paul Broca - defensores da diferença entre as raças, - um pesquisador como Camper já investigava o tamanho do cérebro, num claro prelúdio ao surgimento da Antropometria.

Contrariamente a um único ponto de surgimento da humanidade, as argumentações dos poligenistas surgiam com mais facilidade, pregando os juízos mais variáveis. Se a humanidade não surgira de um único Adão, era preciso forjar outros centros para a criação humana. A ideia de degeneração tornou-se o mais popular argumento porque o pressuposto de um único pai ainda prevalecia. Os poligenistas defendiam não apenas o surgimento da criação humana em vários locais, mas acreditavam "cientificamente" na superioridade do homem branco. Homens como Prichard, David Hume, Charles White, Louiz Agassiz, George Morton, etc., não duvidaram da superioridade do branco com relação a negros e índios. Todos fazem parte de um contexto compartilhado, todos defendem a escravidão, todos temem a miscigenação e não é sem razão que a escola que prega a 
superioridade do branco surge nos Estados Unidos: "todos os heróis da cultura norte-americana adotaram atitudes radicais que poderiam causar embaraço aos fabricantes de mitos escolares". 551

A Coroação da tese monogenista viria com Buffon porque justificava as diferenças a partir da degeneração. Se a humanidade surgira num único centro, a razão para as diferenças entre os grupos se dava em razão do clima, o que mais tarde influenciaria Montesquieu, sendo o clima o responsável pelas possíveis diferenças, dadas as condições adaptativas de cada raça. Antes do surgimento das célebres tipologias raciais, que cientificamente justificariam a superioridade do europeu em detrimento de negros e índios, o debate se tornava insolúvel porque o conceito de raça era insustentável. Diante de tantos teóricos e suas respectivas argumentações acerca da desigualdade racial, a discussão sempre se misturou a objetivos políticos, que quando não buscavam escravizar negros para a Arte da guerra como acontecera em Grécia e Roma, visavam operacionalizar essa desigualdade para fins expansionistas. O termo raça sofreu ao longo da História várias conotações, obtendo primeiramente a idéia de linhagem, uma vez que, "No princípio da controvérsia, o termo raça nem sequer apareceu. No século XIX houve uma forte tendência para ordenar todas as coisas do mundo - objetos minerais, vegetais e animais, dos mais baixos aos mais elevados -, constituindo como que uma enorme cadeia do ser. Argumentava-se que cada forma se refletia imperceptivelmente na seguinte, pelo que era arbitrário e enganador separá-los em diferentes categorias." 552

Face às várias interpretações que o termo raça propicia, a noção de tipo é a que nos interessa porque a mais específica é tributária da nova concepção de raça oferecida pelas áreas da Anatomia e da Craniometria, eliminando a visão bíblica do criacionismo. Para comprovar se as raças eram iguais ou se descendiam de um mesmo berço de origem, foi preciso classificar o homem dentro do critério racial que, na maioria das vezes, confundia raça com espécie. Apesar da confusão que o termo raça causava, foi a noção de tipo que num primeiro momento se aplicou como categoria explicativa para justificar a diferença entre as raças e a superioridade do homem branco,

"Não há no século XIX qualquer ideia clara e definida de raça. Havia muitas classificações e Teorias, e bastantes controvérsias. Foi a doutrina dos tipos humanos permanentes, refletida nas palavras de Abraham Lincoln, que, como concepção simples, conquistou a atenção popular e conduziu a noção de relações raciais. Esta doutrina foi construída lentamente na primeira metade do século e alcançou a sua mais sistemática exposição num livro chamado Types of Mankind, que foi publicado em Filadélfia, em 1854". 553

Era imprescindível identificar, segundo os ideólogos da raça, quais fatores diferenciavam uma raça da outra: estava, portanto estabelecida, a idéia dos tipos raciais. Mesmo que a antiguidade clássica

\footnotetext{
${ }^{551}$ Ibidem. p. 20

552 BANTON. Michel. A idéia de raça. 40-41.

${ }^{553}$ GOULD, Stephen Jay. A falsa medida do homem. 2a . Ed. São Paulo: Martins Fontes, 1999.
} 
não tenha produzido Teorias sobre as tipologias raciais, "o preconceito racial pode ser tão antigo quanto o registro da História humana, mas a sua justificação biológica impôs o fardo adicional da inferioridade intrínseca aos grupos menos favorecidos e descartou a sua possibilidade de se redimir através da conversão ou da assimilação" 554

O debate acerca da diferença entre as raças não esperou o alvorecer da Ciência moderna em sua ânsia de objetividade para formular de maneira "científica" as ideias acerca das tipologias raciais para conferir os graus de superioridade e inferioridade dos grupos humanos. Na crença da existência de seres superiores, cabia então apontar qual a referência a ser tomada para validar "cientificamente" esta superioridade, responsável pela capacidade mental portadora de valores morais que definiriam o nível de civilização ou barbárie. Desse modo, cada raça era detentora de um caráter e possuidora de certos valores morais e mentais. Estabelecia-se assim a noção de caráter indissociável a idéia de raça. Embora só nos tempos modernos se formulasse "cientificamente" a noção de caráter, devido o surgimento de disciplinas como a Antropologia física, a Craniometria e a Frenologia, relacionando aspectos morfológicos internos e externos, certas características Físicas já representavam para os pensadores gregos e romanos uma forma de avaliar a diferença entre as raças. Reside aqui o ponto nevrálgico de toda a discussão em torno da gênese racista: as transformações de cada sociedade poderiam ser explicadas tendo em mente estes traços biológicos?

Desde a antiguidade, gregos e romanos chamavam atenção para a influência do clima, da posição geográfica, caracterizando e formando diferentes tipos humanos. Não pretendemos esmiuçar um proto-racismo existente entre os povos mongólicos, mas somente apontar momentos que consideramos indispensáveis para a compreensão da crença na superioridade da raça ariana, da qual Silvio Romero fora um fervoroso adepto.

As argumentações sobre a diferença entre as raças é muito antiga. Bem antes dos gregos, populações melanodérmicas e leucodérmicas se confrontavam na Europa e no Oriente Médio. Na índia e na Ásia, a argumentação para determinados confrontos recaía sobre a imagem negativa do um negro bestial, maléfica, perigosa, diabólica, canibal, que só seria reforçada nos tempos medievais, com a conivência dos letrados católicos. A imagem negativa ou pejorativa do negro sempre fora estabelecida ${ }^{555}$. Em síntese, os inúmeros e mais díspares argumentos ao longo da História da humanidade sobre a diferença racial buscam comprovar a inferioridade dos seres de pigmentação diferente da branca,

"Na simbologia de cores da civilização europeia, a cor preta representa uma mancha moral e física, a morte e a corrupção, enquanto a branca remete a vida e a pureza.

\footnotetext{
${ }^{554}$ Ibidem. p. 18

${ }^{555}$ MOORE, Carlos. Racismo e sociedade: novas bases epistemológicas para entender o racismo. Belo Horizonte: Mazza Edições, 2007.
} 
Nessa ordem de ideias, a Igreja Católica fez do preto a representação do pecado e da maldição divina. Por isso, nas colônias ocidentais da África, mostrou-se sempre Deus um moleque preto com chifrinhos e de rabinhos" 556

O Rig-Veda - livro sagrado do povo indiano, - escrito entre 1000 e 500 anos A.C, descreve a invasão dos povos de pele nobre denominados árias, dominando e se impondo sobre os daysu (povos negros) e amasha (povo de nariz chato), ordenando guerra a favor da eliminação desses povos concebidos como inferiores. A Grécia, com uma população 95\% escrava, foi um excelente cenário para o surgimento dos argumentos em benefício da diferença entre as raças e sempre concebeu o negro como inferior. Nomes como os de Sócrates, Platão e Aristóteles - para ficarmos apenas com estes traçaram um quadro de hierarquização entre as mesmas. Mas, não necessariamente o argumento para as diferenças estava relacionado a uma superioridade biológica, como nos moldes apontados por Aristóteles em sua tese sobre a escravidão por natureza. Dada a existência de raças diferentes tendo como parâmetro alguns aspectos morfológicos como a cor da pele, o tamanho e a forma do cérebro (braquicéfalo e dolicocéfalo), o tipo de cabelo, estava firmada e fundada a diferença entre as raças e a hierarquização entre as mesmas.

A Revolução Francesa não foi apenas um movimento de oposição ao Ancien Regime contra o absolutismo dos reis e a visão teológica da Igreja, foi acima de tudo o ponto de inflexão para a nova visão científica que resultaria no racismo científico nos tempos de Samuel Morton e Paul Broca. Os filósofos enciclopedistas, com uma forma generalizante de pensar, se mostraram inquietos acerca do berço e da unidade do gênero humano, das diferenças entre os povos, cada vez mais reforçados pelo contato expansionista das nascentes nações modernas. Em nome dos ideais de liberdade, igualdade e fraternidade, toda uma visão secular da Igreja fora quebrada, dando margem ao desenvolvimento de diversos campos do saber em que o homem desde então se tornara o centro dos debates científicos. Todo o conhecimento humanístico era agora especializado, marcando uma nova era do conhecimento. Se anteriormente ao racionalismo do século XVIII era patente as explicações de ordem Metafísica, tributária do pensamento de gregos e romanos, é com a geração dos filósofos iluministas que os problemas acerca da unidade do gênero humano e a hierarquia entre as raças se cristalizam sob as vestes científicas. Se, por um lado, a busca pelo conhecimento se laicizou em função da nova visão baseado nos ideais de igualdade e fraternidade decorrente da inquietação da unidade do gênero humano, de forma paradoxal foi a partir de então que as diferenças foram manipuladas para a cristalização da hierarquia entre as raças. Neste momento, as argumentações para a diferença entre as raças confundem-se com a própria História européia e são manipuladas em benefício da expansão de mercados nos países então desconhecidos, sendo o homem branco considerado superior a negros e

\footnotetext{
${ }^{556}$ MUNANGA, Kabengele. Negritude: usos e sentidos. Belo Horizonte: Autêntica, 2009. p. 29
} 
índios. Consequência dos avanços técnicos que, de uma forma ou de outra, resultarão no racionalismo das luzes, cada vez mais exigidos pelo século da Biologia, a inquietação acerca do berço da humanidade carecia de argumentos científicos.

A tese monogenista ainda vingava, alimentada que era pela visão cristã, aporte teórico na colonização e estereotipação dos povos do Novo Mundo, concebidos como inferiores carecendo, assim da missão civilizatória para alcançarem a verdadeira sociedade civilizada. Mas, simultaneamente, a visão cristã do criacionismo bíblico começara a ser questionada em função das diferenças. Homens cobertos de pelos, mais parecidos com monstros, misturas de homem e animal, e acima de tudo seres bestiais que não escondiam suas vergonhas por habitarem uma natureza que influenciava até sua capacidade mental, que se encontravam no degrau mais inferior da escala evolutiva. Este é o momento de inflexão no imaginário das diferenças da Modernidade porque se não era nenhuma novidade a visão de uma Antropologia monstruosa reinante em toda a idade média, sustentada pelos humanistas, agora seriam os escritores ligados à História natural que conceberiam estes homens tão diferentes para explicar suas diferenças,

\begin{abstract}
"O espírito crítico humanista, de um lado, a exegese protestante, de outro, mas, sobretudo, a descoberta de um Novo Mundo, multiplicam os problemas insolúveis, que nos tempos modernos acarretam o descrédito das genealogias da Bíblia. As genealogias propostas para substitui-las são fruto da revolução geral das ideias e se valem da Ciência: seus contornos se definem com o nascimento, no século XVIII, das chamadas Ciências do homem. A doutrina do arianismo só pode se constituir, no século XIX, na base das grandes divisões entre raças, estabelecidas pelo pensamento das Luzes; antes de explorar esta Antropologia, foco de convergência de todos os novos conhecimentos, observemos os sucessivos avatares da Teoria pré-adamita, o último dos quais, como se verá, não é o menos significativo" 557
\end{abstract}

Na primeira metade do século XIX, a corrida em busca de novos argumentos para justificar as diferenças entre as raças só reforçou e se fez cada vez mais presente para legitimar a expansão de mercados onde os avanços técnicos permitiam e asseguravam o domínio do homem sobre a natureza, inquietando os estudiosos sobre a origem humana. Mas só havia sentido em buscar o centro de criação do gênero humano na medida em que esta busca trouxesse elementos que tornassem possível sustentar de maneira plausível a diferença buscada, ou seja: só se buscou legitimar a diferença entre as raças a partir de um único centro ou não de criação para argumentar que a raça branca era superior às outras. Antes de esboçarmos de maneira geral os argumentos básicos daqueles que acreditavam na diferença entre as raças, cabe ressaltar que eles só fazem sentido na medida em que se associa esta superioridade à idéia de um caráter.

\footnotetext{
${ }^{557}$ POLIAKOV, Léon. Op.Cit. p. 106. Sobre um olhar mais detido acerca do imaginário antropológico presente nos finais da idade média e inicio da Modernidade. HOLANDA, Sérgio Buarque de. Visão do paraíso: os motivos edênicos no descobrimento e colonização do Brasil. São Paulo: Companhia da Letras, 2010.
} 
O sentido de se buscar a superioridade de uma raça em detrimento de outra reside no fato de se buscar justificativas a serviço de determinados estratos sociais numa certa ordem social e política. Uma vez que, conforme pensamento de alguns pensadores, o elemento para a identificação da diferença repousasse no campo biológico, baseado nos caracteres morfológicos, o que remonta às análises fisionômicas desde os tempos de Hipócrates e Galeno, tais argumentações serviram para legitimar o escravismo e a expansão colonialista em favor das classes dirigentes. Sendo o homem "negro" um escravo por natureza, como pregava Aristóteles, bem próximo da besta restava-lhe senão a escravidão. A classificação de Lineu só retoma a visão aristotélica que não apenas engendrou a Teoria clássica dos monogenistas como cristalizou a diferença entre as raças numa escala zoológica, que ia da espécie dos artrópodes à espécie humana. Não insistiremos em provar que algumas Teorias sobre a desigualdade entre as raças remontam à antiguidade clássica, mas apenas apontaremos de maneira breve personagens importantes que defendiam a diferença entre as raças, buscando ao menos clarear a confusão de um debate não apenas longo, mas talvez insolúvel.

A primeira inquietação reside sobre a concepção de raça. Com o avanço da Biologia moderna, sabemos hoje não ter sentido algum o conceito operacional de raça para designarmos determinados grupos humanos, embora boa parte dos defensores das diferenças entre as raças refiram-se a traços físicos como sendo, "um grande grupo de homens, que possuem em comum certas características Físicas determinadas por hereditariedade" ${ }^{558}$. Com o surgimento da Biologia molecular, da genética das populações, é insustentável que o termo raça sirva de categoria analítica ou conceito operacional para explicar as transformações entre os povos, uma vez que a variação entre as culturas é tamanha que cada vez mais se torna difícil associar as transformações culturais ao elemento raça. Para Munanga,

"Os progressos realizados na Genética Humana, na Biologia Molecular e na Bioquímica levaram os próprios cientistas contemporâneos dessas áreas do conhecimento a desacreditar na raça como fato e realidade, considerando-a apenas como um conceito, aliás, cientificamente inoperante. Por isso que se diz hoje que, biologicamente, a raça não existe. Por isso que o conteúdo dessas palavras é etnosemântico, político-ideológico e não mais biológico, 559

O debate em torno das possíveis diferenças raciais se torna mais problemático quando sabemos que os grupos humanos são, sim, resultado de um processo cultural, onde "a seleção natural" é determinada pelas práticas culturais e não pela "superioridade" biológica, ou melhor: são as maneiras

${ }^{558}$ KLINEBERG, Otto. As_diferenças_raciais. São Paulo: Companhia Nacional, 1966. p.18

${ }^{559}$ MUNANGA, Kabengele. Professor Clóvis Moura: o Homem e sua Obra. In: ALMEIDA, Luiz Sávio de. O negro no Brasil: estudos em homenagem a Clóvis Moura. Maceió: UFAL, 2003. p.139. Ainda do autor. Uma abordagem conceitual das noções de raça, racismo, identidade e etnia. In: BRANDÃO, André Augusto P. Programa de Educação sobre o negro na sociedade brasileira. Rio de Janeiro: EUFF, 2004. 
de viver e as regras de cada sociedade, composta pelos inumeráveis grupos humanos, que explicam a permanência ou não de traços responsáveis pela variação das espécies. Lévi-Strauss mostrou muito bem que são os fatores ou as práticas culturais que agem na determinação das diferenças entre os grupos humanos. Por exemplo, o antropólogo descreve a presença de relações incestuosas entre tribos do mesmo grupo, o que de forma ambígua, fez variar a reserva genética, e assim ter um potencial maior de defesa contra certas infecções. Desse modo, conforme Munanga e Antônio Sergio, raça é simplesmente um conceito operacional, uma categoria abstrata. Mesmo que os argumentos antirracistas reprovem o conceito operacional de raça defendido pelos teóricos que advogam a superioridade européia dos brancos, a ideologia racista alimentou infindáveis discursos só revigorando os inúmeros argumentos desta superioridade,

"no entanto, o conceito continua sendo utilizado em Ciências Sociais apenas como
uma construçáo sociológica por causa do seu conteúdo político e ideológico
relacionado com a estrutura de poder de cada sociedade multirracial". ${ }^{560}$ Para o
antropólogo: "Alguns biólogos antirracistas chegaram a sugerir que o conceito de
raça fosse banido dos dicionários e dos textos científicos. No entanto, o conceito
persiste tanto no uso popular como em trabalhos e estudos produzidos na área das
Ciências Sociais. Estes, embora concordem com as conclusões da atual Biologia
Humana sobre a inexistência cientifica e a inoperacionalidade do próprio conceito,
justificam o uso do conceito como realidade sociológica e uma categoria social de
dominação e exclusão". s6l

É infrutífero tentar localizar um ponto de partida de uma raça original e pura de onde surgiriam as demais sub-raças ao longo do processo evolutivo. Ainda, baseando-nos em Lévi-Strauss, sendo a raça um produto da cultura, é insustentável aceitar esta nomenclatura em razão da complexidade dos grupos humanos. Aos que defendem a existência de seres superiores em função de "uma melhor carga genética," não é possível estabelecer um método seguro dado o desconhecimento da carga genética, uma vez que esta, segundo alguns etnógrafos, seria responsável pela capacidade de determinados seres superiores. Portanto, é preciso lançar mão de outro elemento para avaliar a possível diferença entre as raças.

Com os estudos de Darwin e sua contribuição da lei da Evolução, estava descartada a hipótese de que a humanidade era originária de um único centro, inquietando cada vez mais os cientistas que partiriam para os estudos de caráter morfológico, suscitando as áreas da Craniologia, da Craniometria e da Frenologia. A segunda metade do século XIX deu subsídios para uma argumentação "cientifica" consistente sobre a diferença entre as raças,

\footnotetext{
${ }^{560}$ MUNANGA, Kabengele. Professor Clóvis Moura: o Homem e sua Obra. Op.Cit.p.139.

${ }^{561}$ Ibidem.p.23
} 
"A segunda metade do século XIX não foi apenas a era da Evolução na Antropologia. Outra corrente, igualmente irresistivel, contaminou o campo das Ciências humanas: a fascinação pelos números, a fé em que as medições rigorosas poderiam garantir uma precisão irrefutável e seriam capazes de marcar a transição entre a especulação subjetiva e uma verdadeira Ciência, tão digna quanto a física newtoniana. A Evolução e a quantificação formaram uma temível aliança; em certo sentido, sua união forjou a primeira Teoria racista "cientifica" de peso, se definirmos "Ciência" erroneamente, como muitos o fazem, como sendo toda a afirmação aparentemente respaldada por cifras abundantes. Os antropólogos haviam apresentado dados numéricos antes de Darwin, mas a rusticidade da análise de Morton invalidada qualquer pretensão de rigor. Por volta do final do século de Darwin, técnicas generalizadas e um crescente corpo de conhecimentos estatísticos produziram um dilúvio de dados numéricos mais fidedignos". ${ }^{562}$

Nos últimos decênios da primeira metade do século XIX, são dados os mais importantes passos que culminarão nas análises da Craniologia e da Frenologia. Coroando a ideia de superioridade do europeu em detrimento da inferioridade de índios e negros. Aqui, cabe um pouco mais de cautela, pois alguns cientistas da escola americana de Antropologia, defensores da poligenia e da diferença entre as raças, acabaram por influenciar a visão etnográfica de Sílvio Romero. Tributária do longo conhecimento europeu, a escola americana de Antropologia trazia nomes como Louis Agassiz, Samuel George Morton, George Gliddon. Outros defensores da diferença entre as raças eram Knox, James Hunt, Karl Vogt, Paul Broca e o expoente máximo, considerado o pai do racismo, Artur Gobineau.

Não é sem razão que a escola do poligenismo, preocupada em hierarquizar as raças em prol da manutenção da escravidão de negros, surja justamente nos Estados Unidos. As condições históricas marcadas pelo processo de independência e a guerra civil entre a elite industrial, situada no norte e a elite escravista dependente da mão de obra dos negros deu sustentação aos argumentos que detratavam negros e índios. Discípulo do grande naturalista Cuvier, o suíço e professor de Havard, a imagem que o naturalista Agassiz tinha do negro não era nada positiva,

"Foi em Filadélfia que tive pela primeira vez um contato prolongado com os negros; todos os empregados de meu hotel eram homens de cor. Mal posso lhe experimentar a dolorosa impressão que experimentei, particularmente porque a sensação que eles me inspiraram vai contra todas nossas ideias a respeito de confraternização de todo tipo [genre] e da origem única de nossa espécie. Mas a verdade deve estar acima de tudo. Não obstante, senti piedade à vista dessa raça degradada e degenerada de homens. Contudo, é-me possível reprimir a impressão de que eles não são feitos do mesmo sangue que nós. Ao ver suas faces negras com lábios grossos e dentes disformes, a carapinha de suas cabeças, seus joelhos torcidos, suas mãos alongadas, suas grandes unhas curvas, e principalmente a cor lívida da palma de suas mãos, não pude deixar de cravar meus olhos em seus rostos em seus rostos para mandá-los se conservarem a distância. E, quando estendiam aquelas mãos horrendas em direção a meu prato a fim de me servir, desejei ter a coragem de me levantar e sair à procura de um pedaço de pão em qualquer outro lugar, em vez de jantar servido por gente como essa. Que

${ }^{562}$ GOULD, Stephan Jay. Op. Cit. pp. 65-66 
desgraça para a raça branca ter ligado sua existência tão intimamente à dos negros em certos países! Que Deus nos livre desse contato! ${ }^{563}$

Ainda que a citação acima seja referente aos negros, na tipologia racial de Agassiz, o índio é concebido como inferior na sociedade completamente mestiça dos Estados Unidos da época. Temia o fundador do Museu de Antropologia Comparada a miscigenação, defensor que era da diferença inata entre as raças, legitimando a hierarquia racial onde o homem branco se encontrava no topo da pirâmide. Outra figura ímpar é Morton. Aristocrata e cientista muito reputado nos Estados Unidos, que morava na Filadélfia, o colecionador de crânios iniciou seus estudos de medição de crânio influenciando e marcando época no mundo inteiro. Embora se saiba hoje que não existe relação alguma entre o grau de superioridade com o tamanho e volume do crânio, como acreditava Morton seus experimentos eram senão o prenúncio ou a própria base do racismo científico.

Morton colecionava mais de 600 crânios e dentre suas obras, a que analisa a capacidade mental e o caráter do índio é Crania Americana, publicado em 1839. É desnecessária uma análise detida sobre o método utilizado por cientista, enchendo primeiramente os crânios com sementes e depois com balinhas de chumbo para averiguar o tamanho do órgão como parâmetro de avaliação da superioridade entre os seres humanos.

Em 1839, surgia a Sociedade Etnológica sediada em Paris. Já estabelecida a relação entre valores morais e a capacidade cognitiva (QI) dos tempos de Galton e Alfred Binet, oito anos após a morte de Morton, surgia a Sociedade Antropológica de Paris, tendo como maior expoente a figura de Paul Broca, que não apenas analisou os métodos e as técnicas de Morton como desenvolveu e criou uma nova área, a Craniologia. A partir de então, os estudos anatômicos casariam com as explicações mais esdrúxulas sobre o desenvolvimento ou não das sociedades. Uma vez delimitada a área que serviria de baliza para as análises raciais, no caso, o tamanho do cérebro, restava analisar de maneira pormenorizada os elementos da inferioridade das raças. Não apenas Broca, mas Bean, Tiedemann, Gratiolet, Huscke e Spitzka relacionavam aspectos morfológicos, na maioria das vezes o tamanho e a forma do crânio, a forma do nariz, dos lábios e do ângulo facial, com a capacidade evolutiva do homem.

Tempos depois, os estudos americanos da escola poligenista - influenciados pelos mais variados pensadores europeus - influenciaria a escola italiana de Criminologia, que tinha em Lombroso, Ferri e Garófalo as figuras principais. Medindo a massa cefálica do indivíduo, o tamanho dos dedos, a forma do nariz e a distância entre as têmporas acreditava-se encontrar o criminoso antes do crime. ${ }^{564}$

\footnotetext{
563 Ibidem. p. 32-33

${ }^{564}$ DARMON, Pierre. Médicos e assassinos na Belle Époque: a medicalização do crime. Rio de Janeiro: Paz e Terra, 1991. CORRÊA, Mariza. Raimundo Nina Rodrigues e a "garantia da ordem social". REVISTA USP, São Paulo, n.68, p. 130139, dezembro/fevereiro 2005-2006. Ainda. COSTA, Jean Carlo de Carvalho. Nação, raça e miscigenação no Brasil
} 
Quando se fala na crença nas diferenças entre as raças e na hierarquia das mesmas, não se esquece a figura do Conde Arthur de Gobineau. Quanto ao surgimento do gênero humano, conclui Poliakov, "que era monogenista em Teoria, e poligenista na prática" 565 . Contrário ao espírito democrático dos ideais da Revolução Francesa, Gobineau alertava para os efeitos negativos da mistura entre as raças. Pensava Gobineau que cada raça é detentora de qualidades e valores adaptativos, compreendendo o processo histórico a partir da ideia de progresso ou de decadência ${ }^{566}$. Por mais que um escritor do porte de Poliakov afirme que "seria errôneo, no entanto, acreditar que os homens de cor fossem para Gobineau seres desprezíveis, brutos; ao contrário, os juízos que emite sobre eles surpreendem por sua moderação" ${ }^{567}$, uma vez que o diplomata francês aludia não a seres inferiores como negros e índios, mas sim a grupos humanos. Não foi bem essa a impressão que o assíduo leitor e amigo ilustre do imperador D. Pedro II teve quando esteve no Brasil. Aqui, fica claro a figura de Gobineau como o mais importante teórico da hierarquização das raças, sendo considerado o pai do racismo científico. Nada no Brasil lhe inspirara diante de um cenário nada animador,

"os brasileiros não despertam nenhum interesse e não tem costumes nacionais nem nada de particular a não ser uma excessiva depravação com a qual se pode fazer um livro muito duro, mais não uma novela; e gosto demais do imperador para escrever uma só palavra contra este povo infame. Todos mulatos, a ralé do gênero humano, $e$ costumes condizentes. Estão pervertidos pela escravidão dos negros, e os negros pervertidos por...espere!" 568

Marcado por problemas pessoais de infelicidade, nunca conseguiu fazer sucesso editorial, o diplomata francês no Brasil não podia ver o país onde residiu de abril de 1869 a maio de 1870 de forma mais pejorativa. Sarcástico e irônico falava que, "o brasileiro é um homem que sonha em viver em Paris" ${ }^{569}$. O diplomata logo se tornou indesejável pelos brasileiros. Numa sociedade de mulatos onde os homens mais pareciam macacos ${ }^{570}$, Gobineau atribui a mestiçagem como o principal fator para o atraso do Brasil. Nas questões tangentes à política brasileira, o fato de ser o Brasil um país mulato aparecia em primeira ordem. Com relação à escravidão, ressaltava:

"Os brasileiros são sensíveis a esse fato evidente, e o são talvez mais a uma outra observação que não apenas afeta seus interesses, mas fere sensivelmente seu amor-

moderno: uma análise hermenêutica dos ensaístas da formação da nacionalidade brasileira, 1888-1928. Tese de doutorado apresentada ao Programa de Pós Graduação em Sociologia da Universidade Federal de Pernambuco. 2003. BECHELLI, Ricardo Sequeira. Metamorfoses na interpretação do Brasil. Tensões no paradigma racial (Sílvio Romero, Nina Rodrigues, Euclides da Cunha, Oliveira Viana). Op. Cit.

${ }^{565}$ POLIAKOV, Léon. Op. Cit. p. 218

${ }^{566}$ HERMAN, Arthur. A idéia de decadência na História ocidental. Rio de Janeiro: Record, 1999.

${ }^{567}$ Ibidem. p. 218

${ }^{568}$ RAEDERS, Georges. O Conde de Gobineau no Brasil. Rio de Janeiro: Paz e Terra, 1996. p.77

${ }^{569}$ Ibidem. p.41

${ }^{570}$ SCHWARCZ, Lilia Moritiz. O espetáculo da miscigenação. Rio de Janeiro: Editora Fiocruz, 2003. p. 165-180 
próprio. É preciso reconhecer que a maioria dos que chamamos brasileiros compõem-se de sangue mestiço, sendo mulatos e filhos de caboclos de graus distintos. Eles estão em todos os escalões sociais. O Sr.Barão de Cotegipe, atual ministro das Relações Exteriores, é mulato; no Senado há homens dessa categoria; em uma palavra, quem diz brasileiro diz, com raras exceções, homem de cor. Sem entrar no mérito das qualidades Físicas ou morais destas variedades, e impossivel desconhecer que elas não são laboriosas, ativas ou fecundas." 571

Ainda que Gobineau admita não entrar na idéia de caráter, justifica o quadro brasileiro da época recorrendo à mistura entre as raças,

"A grande maioria dos fazendeiros, cuja desagradável situação econômica expus-lhe ainda agora, vive num estado muito próximo da barbárie, no meio de escravos, $e$ deles não se diferenciam nem por gostos mais sofisticados, nem por tendências morais mais elevadas. O resultado disso é que o comércio, os interesses e todas as fábricas, grandes ou pequenas, estão nas mãos de estrangeiros" ${ }^{572}$

Esta fala não poderia ser mais parecida com a de vários escritores brasileiros, crentes nos valores morais decorrentes do poder das raças para explicar o atraso brasileiro em função da degeneração da raça latina que colonizou o Brasil em contato com as raças inferiores aqui estabelecidas. A argumentação de que da mestiçagem resulta todo o atraso político e cultural do país serve de equivalência ao grau de Evolução social. É resultado do Determinismo racial que fora adotada no Brasil a partir de 1860-1870, operacionalizando as discussões sociais e políticas brasileiras, cujo objetivo era explicar a situação de involução do país nos mais variados âmbitos. Sem adentrar de maneira pormenorizada nas vertentes dos ideólogos da desigualdade entre as raças, hoje sabemos que estas Teorias são destituídas de qualquer consistência científica. Se, como afirma Gould, num primeiro momento, os cientistas não produziam resultados de maneira deliberada a fim de manter o predomínio das elites nos Estados Unidos, embora partissem de conceitos prévios, no que resultava a inconsistência de seus métodos de medição e formatação de crânios; num segundo momento, o pressuposto da diferença entre as raças se alastrou sob forma de raciologia desprovida que era de qualquer base científica, chegando ao extremo de defender a pureza das raças - eugenia - que seria a

\footnotetext{
${ }^{571}$ Ibidem. p.53. Com sua visão romântica o que despertava Gobineau era a admiração por D. Pedro II não só por ser um homem vasto conhecimento, mas por ser este um ariano puro sendo o povo brasileiro gente das mais reles possível. "Uma população toda mulata, com sangue viciado, espírito viciado e feia de meter medo......Nenhum brasileiro é de sangue puro; as combinações dos casamentos entre brancos, indígenas e negros multiplicam-se a tal ponto que os matizes da carnação são inúmeros, e tudo isso produziu, nas classes baixas e nas altas, uma degenerescência do mais triste aspecto...Já não existe nenhuma família brasileira que não tenha sangue negro e índio nas veias; o resultado são compleições raquíticas que, se nem sempre repugnantes, são sempre desagradáveis..as melhores famílias tem cruzamentos com negros e índios. Estes produzem criaturas particularmente repugnantes, de um vermelho acobreado...A imperatriz tem três damas de honra: uma marrom, outra chocolate-claro, e a terceira, violeta. RAEDERS. Op.cit.pp.39-40. Sobre este debate ver. MACIEL, Maria Eunice de S. A eugenia no Brasil. Anos 90, Porto Alegre, nº. 11, Julho de 1999.

${ }^{572}$ Ibidem
} 
bandeira do nazismo. É lamentável que ainda hoje, as argumentações "científicas" sirvam de instrumento político. Michel Paty lembra que

\begin{abstract}
"A ignorância ou o erro poderiam até ser permitidos, mas não a vontade de enganar. Essa é a diferença entre os primeiros antropólogos dos séculos XVIII e XIX e os socio-biólogos de hoje: os primeiros poderiam acreditar de boa fé em sua Ciência ainda balbuciante, sem ter consciência de que não faziam mais que hipostasiar num pretenso conhecimento científico os prejuízos raciais, ou seja, racistas, da sociedade de seu tempo; mas os conhecimentos adquiridos hoje não permitem um tal retorno e o desigualitarismo científico é uma impostura". ${ }^{573}$
\end{abstract}

Para Kabengele Munanga, "tanto o conceito de raça quanto o de etnia são hoje ideologicamente manipulados" ${ }^{574}$. Passada a época do darwinismo social, uma das vertentes do Determinismo biológico, fundamentando "cientificamente" a legitimidade das hierarquias raciais e colocando o branco no topo da pirâmide, índios e negros sofreram a invasão e foram dizimados em nome da chegada da missão civilizadora. Fosse para legitimar a expansão colonial dos povos americanos do Novo Mundo, concebidos como bárbaros em nome da "civilização" e do "progresso" desses povos, fosse para prover os movimentos de cunho nacionalista, como se presenciou nos grupos separatistas da Iugoslávia e da Espanha, dentre outros, mantinha-se de pé a crença na superioridade da raça branca europeia a partir da ideologia das diferenças inatas. A "besta imunda" iria levar às últimas consequências o que tinha começado na era moderna com o racionalismo dos filósofos das luzes. O massacre de quase toda a população indígena nas Américas, a perseguição e morte de milhões de judeus, o regime de segregação racial experimentado na África, e, sobretudo a crença na pureza de uma raça em nome da eugenia de Galton deixam claro até que ponto chega à espécie humana por tanto acreditar na Ciência.

\title{
2. Nacionalismo e caráter nacional brasileiro
}

A ideologia de um caráter nacional está intrinsecamente ligada ao longo processo de formação das nações modernas, responsável pelos diversos nacionalismos, em que a língua e a raça surgem como justificativa para estas manifestações políticas. Estudando o novo nacionalismo moderno, diferente do nacionalismo de tradição clássica, a partir da era das revoluções (1830), Hobsbawm aponta os elementos constituintes do principio de nacionalidade ${ }^{575}$ como ponto principal da diferença. Sendo a nação moderna correspondente a um "povo", dar-se-á a equação nação=estado=povo, em que se tornava indispensável identificar critérios de identidade nacional como língua, território, Religião

\footnotetext{
${ }^{573}$ PATY, Michel. Os discursos sobre as raças e as Ciências. São Paulo: Estudos Avançados (12) 33, 1998. p.161

${ }^{574}$ MUNANGA, Kabengele. Op.Cit. p.30

${ }^{575}$ HOBSBAWM, Eric J. Nações e nacionalismo desde 1780: programa, mito e realidade. Rio de Janeiro: Rio de Janeiro: Paz e Terra, 1990.p.31.
} 
ou raça. Mas a onda nacionalista que mais tarde varrerá a Europa só tem sentido uma vez se presencie a equação nação=povo. Com base em Hobsbawm, "a crescente significação da questão nacional nos quarenta anos que precederam 1914 não é medida simplesmente por sua intensificação nos velhos Impérios multinacionais austro-húngaro e turco. Havia se tornado uma questão importante da política interna de quase todos os estados europeus" ${ }^{576}$.

O interesse folclórico pela busca das tradições é senão resultado da crença da língua como um dos possíveis critérios do que pode caracterizar uma nação. Mas, é sob a influência do conceito de Evolução social, confundido com o impacto do Evolucionismo biológico, que a questão etnográfica torna-se central para o nacionalismo moderno, misturando-se com o racismo científico iniciado nas três últimas décadas do século XIX. Uma vez sendo o estado (política) correspondente à nação (povo), o fator etnográfico se confunde com a questão nacional e o racismo se instaura. Não é demais lembrar que o critério linguístico já era instrumento indispensável para o surgimento da consciência nacional em função das necessidades do capitalismo e que, dentre certos fatores, aparecia o vernáculo a serviço da centralização absolutista dos reis, contra a supremacia do latim. O protestantismo esboçado por Lutero, onde o latim - então a única língua falada nos meios eruditos da Europa - era agora acompanhado pelo vernáculo que, embora não representasse um protonacionalismo, significava que o elemento língua estava em voga. Conforme Anderson, "o que tornou possível imaginar as novas comunidades, num sentido positivo, foi uma interação mais ou menos causal, porém explosiva entre um modo de produção e de relações de produção (o capitalismo), uma tecnologia de comunicação (a Imprensa) e a fatalidade da diversidade da linguística humana" ${ }^{577}$. É na busca pelos critérios de identidade com a língua, a Religião e a raça, que paradoxalmente não sustenta nacionalismo algum, que emerge a argumentação étnica dos teóricos racistas das últimas décadas do século XIX.

"As línguas multiplicaram com os Estados, e não o contrário.

O que dizer sobre a etnicidade? No uso comum, é sempre ligada, de modo inespecífico, a origem e descendência comuns, das quais se alega derivarem as características comuns dos membros do grupo étnico. "Parentesco" e "sangue" têm uma óbvia vantagem em ligar membros de um grupo e excluir estranhos, e, portanto são centrais ao nacionalismo étnico". (grifo do autor) ${ }^{578}$

O nacionalismo moderno, na medida em que confunde nação com estado, carece de um discurso étnico. Sob a influência do Evolucionismo social em que, da língua, se infere uma raça, é que a etnicidade se torna instrumento indispensável para se pensar o conceito de caráter nacional. Este

\footnotetext{
${ }^{576}$ Ibidem. p. 128

${ }^{577}$ ANDERSON, Benedict. Nação e consciência nacional. São Paulo: Ática, 1989.p.78

${ }^{578}$ Ibidem. p.78-79
} 
caráter nacional não deixa de ser uma forma racista que exclui determinados grupos humanos em detrimento de outros, sempre oriundos de uma relação de poder,

"A preservação cultural, o medo do desconhecido e, acima de tudo, a manutenção de um status quo político-econômico estão entre as razões apresentadas por aqueles que apoiam o racismo. $O$ uso de estereótipos contribui para o que é apresentado como uma distinção precisa entre os indivíduos classificados, aos quais é atribuída uma série de características positivas e negativas que dependem das raças" ${ }^{579}$.

Giralda Seyferth, analisando o conceito de raça ao longo da História na legitimação da superioridade biológica do europeu, afirma que,

"Essas breves referências mostram que o conceito de raça foi desenvolvido na Europa para interpretar novas relações sociais no interior do Estado-nação e, usado pelos nacionalismos, ajudou a demarcar pertencimentos nacionais e excluir minorias incomodas. As inúmeras Teorias, doutrinárias ou não, que surgiram ao longo do século XIX não são, portanto, produto do capitalismo ou do colonialismo, mas foram úteis aos seus ideólogos para impor a dominação política e econômica aos povos colonizados" 580

Cabe salientar, como aponta Hobsbawm, que categorias como língua e raça não possuem relação alguma com os movimentos nacionalistas, apenas são operacionalizadas pelas classes médias e altas que compõem o estado objetivando fins políticos precisos: "o nacionalismo e o racismo exibem oposições fundamentais, mas é óbvio que certas formulações do nacionalismo foram associadas no passado, e ainda o são, com o racismo" ${ }^{581}$. Com relação ao lado obscuro do nacionalismo, Guibernau afirma que

"Esse tipo de nacionalismo possui um podo particular de encarar as relações básicas
entre "nós" e "eles", e utilizá-los na construção da identidade nacional. O "outro"
não é alguém que nos torna cônscios de nossas próprias particularidades, alguém
com que possamos aprender, respeitar, conviver e tomar como ponto de referência de
nossa própria identidade. Esse nacionalismo vê no "outro" um inimigo potencial ou
real mas, antes de mais nada, alguém inferior. Isso acontece quando o racismo é
incorporado a um discurso nacionalista.

No Brasil, a questão nacional veio pela primeira vez à tona com a obra de Ferdinand Denis e Garret clamando por uma Literatura brasileira distinta da portuguesa, despertando uma consciência de

\footnotetext{
579 GUIBERNAU, Guibernau. Nacionalismos: o estado nacional e o nacionalismo no século XX. Rio de Janeiro: Jorge Zahar, 1997. p.97

${ }^{580}$ SEYFERTH, Giralda. O beneplácito da desigualdade: breve digressão sobre o racismo. In: Racismo no Brasil. Vários Autores. São Paulo: Peiropólis; ABONG, 2002.p.26.

${ }^{581}$ Ibidem. p. 100

${ }^{582}$ Ibidem. p.100
} 
autonomia $^{583}$ e influenciando, anos depois, a geração dos escritores do Romantismo brasileiro. A relação entre os temas nacionais com o estado oficial não podia ser mais clara quando das discussões artísticas da SAIN, de onde surgiu, em 1838 o IHGB, encarregado de procurar, narrar e dar subsídios à identidade nacional. A ligação entre os escritores e o estado oficial não podia ser tão óbvia para despertar a nacionalidade brasileira, depositando no índio e nos elementos da natureza o ponto de partida da História brasileira. Com a independência política, que formalmente e burocraticamente se fez com a vinda da corte portuguesa para o Brasil em 1808, os intelectuais se deparavam com um cenário propício para a busca dos elementos fundantes do caráter nacional. Visando dar um caráter de homogeneidade decorrente da descentralização política, o que seria responsável pelos diversos conflitos nativistas no período regencial, a simbolização personificada sobre o índio camuflava um passado de escravidão negra, a espoliação de brancos livres, todas as disparidades sociais e políticas eram esquecidas sob o manto parasidíaco das imagens, alegorias, poemas e dedicatórias dos escritores românticos a D. Pedro II.

Erigindo o índio como símbolo nacional, mesmo que de forma estilizada, buscando uma língua nacional onde nomes importantes merecem destaque, como José de Alencar e Capistrano de Abreu, e acima de tudo, atribuindo um caráter mestiço para a recém fundada nação, estava montado o quadro conjuntural do caráter brasileiro. O nacionalismo embutido na produção intelectual dos romancistas brasileiros deriva do Romantismo alemão, que buscava nas raízes folclóricas a identidade do país. O Romantismo que Sílvio Romero tanto combatera não podia ser tão próximo da visão folclórica de Herder, priorizando as raízes de formação deste caráter nacional,

"De fato, a identificação mística de uma nacionalidade como uma espécie de ideia platônica da língua, existindo atrás e acima de todas suas variantes e versões imperfeitas, é muito mais que uma criação ideológica de intelectuais nacionalistas, dos quais Herder é o profeta, do que uma característica dos reais praticantes comuns do idioma. É um conceito erudito e não vivido" 584

Sílvio Romero acreditava tenazmente na idéia de caráter nacional, à qual dedica no primeiro volume de sua História da Literatura Brasileira todo um capítulo. Seja recorrendo ao meio físico, à raça ou em último caso, aos fatores culturais e históricos, era indispensável identificar que caráter era este. Momento agitado da História brasileira, decorrente do embate entre uma nova História que estaria por vir e uma estrutura considerada obsoleta pela elite da época, em meio às transformações econômicas e políticas, os ensaístas brasileiros tentaram não apenas entender o Brasil, mas buscaram identificar o que caracterizava o brasileiro frente às outras sociedades.

${ }^{583}$ CANDIDO, Antonio. O Romantismo no Brasil. São Paulo: Humanitas/FFLCH, 2004. p.21

${ }^{584}$ HOBSBAWM, Eric. Nações nacionalismos desde 1780: programa, mito e realidade. Rio de Janeiro: Paz e Terra, 1990.p. 74 
A idéia de caráter nacional é resultado do imperialismo simbólico nas formas de perceber, sentir e representar, motivadas que são, de uma maneira ou de outra por questões políticas e territoriais. Motivado pelo agitado momento histórico e influenciados principalmente pelo Romantismo alemão, Sílvio Romero se incumbia de encontrar o caráter nacional brasileiro. Seu desejo supremo ${ }^{585}$ de escrever a História literária brasileira incidia de maneira inevitável sobre a busca pelo caráter nacional brasileiro.

Sofrendo influências de escritores franceses que presenciaram o temor das massas, como Fouillé e Burke - donde a cristalização da idéia de caráter nacional -, acreditava calorosamente no conceito de Psicologia nacional. Todo seu projeto literário, que se confunde com sua forma de ver e pensar o Brasil, só tem sentido em razão de sua ânsia de encontrar os fatores que implicavam na formação do caráter brasileiro em detrimento do caráter singular de outros povos. Acreditava Sílvio na idéia de alma nacional responsável por uma Poesia popular -, o que há de mais íntimo numa nação - servindo de esteio e explicando o atraso das diversas áreas do conhecimento e a situação do país de maneira geral. Bradava Sílvio:

"Pelo que toca á nação brasileira, os documentos não se acham coligidos, nem utilizados de forma alguma. Os nossos costumes públicos e particulares, nossas tendências literárias, artísticas e religiosas, todas as ramificações, enfim, da atividade popular, não tem sido objeto de um estudo particular e aturado. Nós desconhemo-nos a nós mesmos". ${ }^{586}$ (grifos nosso)

Mesmo com a ausência de documentos para escrever a História literária brasileira, Sílvio Romero explicava a apatia do brasileiro, a falta de criatividade, o desânimo, o ilusionismo dos dirigentes do país como decorrentes de um “espírito geral, um espírito popular, subjetivo a nação” 587 que mais não seria do que o caráter nacional brasileiro. Admira é que, sendo Sílvio um crente em torno da ideia de caráter nacional presidindo as origens mais íntimas da nação, afirmasse que o "o caráter nacional não está em se falar em maracás e tangapemas, tão pouco está em se lembrar o xiba, o bumba-meu-boi, o samba, etc. Deve estar no sentimento original, no sentir especial do brasileiro" ${ }^{588}$. É indispensável, para a compreensão da idéia de caráter nacional, pontuar o que no parágrafo seguinte escreve o crítico:

"O nacionalismo não há de, pois, ser uma tese objetiva de Literatura, a caçada de um título; deve-se antes de estudar o nosso povo atual em suas origens, em suas

\footnotetext{
${ }^{585}$ ROMERO, Sílvio. Introdução a História da Literatura Brasileira. Rio de Janeiro: Tipografia Nacional, 1882. p. 6. Esta introdução seria o primeiro capítulo da primeira edição da História da Literatura Brasileira que surgiria seis anos depois denominado Fatores da Literatura Brasileira.

${ }^{586}$ ROMERO, Sílvio. História. Op. Cit. p.145

${ }^{587}$ Ibidem. p. 148

${ }^{588}$ Ibidem. p.148
} 
produções anônimas, definindo a sua intimidade emocional, a sua visualidade artística.

Deve-se proceder ao estudo de nossa Poesia e crenças populares, com a convicção do valor dessa contribuição etnológica, desse subsídio anônimo para a compreensão do espírito da nação.

Em Filosofia não se há de supor toda a Ciência humana contida nos livros do Espiritualismo, do Ecletismo ou do Positivismo franceses.. ". ${ }^{89}$ (grifos nosso)

Inspirado no Romantismo alemão donde seu interesse pelo folclore brasileiro, na busca pela gênese da História brasileira, incumbia-se Sílvio de clarear qual o espírito nacional brasileiro, afirmando que, "Importa por certo definir, a traços largos, em várias esferas essa intuição anglogermânica em relação ao Brasil" ${ }^{590}$. Sua visão folclórica é resultante da crença neste caráter nacional e, ao mesmo tempo, produto de sua visão ambígua - reconhecer o peso e a importância das tradições populares, como salientavam as cantigas que saiam da boca dos tangedores de bois e pescadores, no tempo que passara no engenho Moreira, - sempre tangenciada pelo olhar rigoroso da Ciência européia.

Inicia seus estudos folclóricos em busca do caráter nacional munido do critério etnográfico, arregimentando as raças que participavam e formavam a Psicologia do brasileiro. Era em busca da alma nacional que almejava Sílvio encontrar o princípio maior que servira de base à identidade brasileira, inseparável do conhecimento do país. Se por um lado ressaltava a importância das três raças para a formação da Psicologia nacional, regidas pela lei evolucionista e pela lei da seleção natural, onde a raça branca superior venceria as duas raças inferiores, a raça negra e a indígena, é lamentável que Sílvio, depois de tanto empenho em favor do reconhecimento das tradições populares e da contribuição indígena, afirme sobre esta que

\begin{abstract}
"Umas tribos desgarradas pelos desertos e matas, vivendo da caça e, guerreando-se, e outras reunidas em paupérrimas palhoças, sem a menor indústria assinalável, usando da pedra para utensílios como o homem das cavernas, sem tradições, sem heróis, sem historia, não podiam possuir a noção da individualidade, do ser superior, como não podiam ter uma Poesia " ${ }^{591}$.
\end{abstract}

Em O Caráter nacional e as Origens do povo Brasileiro (1871), Sílvio contextualiza de forma breve o estágio do índio frente à chegada do conquistador europeu. O que se percebe é que, após lutar pelo reconhecimento da cultura indígena diferente da imagem romântica, combate a imagem esboçada de viajantes e cronistas, "porque estavam no grau de atraso, o homem da idade da pedra, não podendo ser muitos numerosos. Esqueceu-lhes que não podiam ter-lhe uma Religião, que reconhecesse um ser supremo; tão pouco uma Poesia, como assoalham "592.

\footnotetext{
${ }^{589}$ Ibidem. p. 148

${ }^{590}$ Ibidem. p. 147

${ }^{591}$ ROMERO, Sílvio. O caráter nacional e as origens do povo brasileiro. Recife: Tipografia da Província, 1875. p.42

592 Ibidem. p.42
} 
Percebemos que a imagem do índio é construída a partir do mundo e da cultura do homem civilizado. Seus estudos folclóricos - se assim pudermos delinear, como se fosse possível separar o caráter etnográfico da visão etnográfica de Sílvio - diante de seus estudos de Crítica, Filosofia, Poesia, etc., deixam clara a relação direta entre Psicologia ou caráter inseparável do critério racial balizador dos grupos humanos. Falava Sílvio que

"Pois bem, se procurarmos numa fórmula genérica e exata definir a Psicologia do povo brasileiro; se intentarmos, segundo a velha frase consagrada, penetrar na consciência nacional, para apreender-lhe os contornos e a moldura, muito atilados seremos, se conseguirmos o nosso anelo.

Povo que descendemos de um estagnado e corrupto ramo da velha raça latina, a que juntara-se o concurso de duas das velhas raças mais degradadas do globo, os negros da costa e os peles vermelhas da América, nós ainda não nos distinguimos por uma só qualidade digna de apreço, a não ser o fraco lastimável de mascarar-nos de grandezas que não nos assentam, imitando, macaqueando sem alvo nem critério todos os vícios e loucuras que trazem uma etiqueta de Paris!

$O$ servilismo do negro, a preguiça do índio e o gênio autoritário e tacanho do português produziram uma nação informe, sem qualidades fecundas e originais. $O$ brasileiro se distingue por um certo desleixo moral, o culto do laissez faire, laissez aller, certo abandono por tudo quanto se refere aos mais vitais interesses da ordem pública. E não é, nem precisamos dizê-lo, por falta de patriotismo que assim nos expressamos. Nós amamos ardentemente a pátria, e é esse o motivo porque lhe profligamos os desvarios; os falsos patriotas são os que mentem ao povo endeusando-lhe os vícios. As três raças que constituíram o povo brasileiro ainda não se embeberam de todo entre si.

Além de ser ainda tosca a formação do mestiço, os três povos distintos, como no primeiro século da conquista, ainda acampam um ao lado do outro". 593

Mesmo reclamando da ausência de documentos para traçar a História da Literatura brasileira, o ensaísta é inteiramente convicto sobre a existência de um caráter nacional. Em História da Literatura Brasileira encontramos passagens como essa: "Há um espírito geral que os compreende, que os domina; é o espírito popular, subjetivo a nação, que não se pode fabricar, que deve ser espontâneo".. 594

Se considerarmos uma possível mudança de concepção folclórica primando pelas mais profundas manifestações, com relação ao índio brasileiro e sua contribuição para a formação do caráter nacional, é inadmissível a noção do escritor não somente com relação às influências indígenas como também das manifestações culturais por parte das populações rurais brasileiras, responsáveis pelo bumba meu boi e pelo xiba. Em Cantos Populares Brasileiros (1883), presenciamos um Sílvio preocupado com a influência das festas populares das pessoas residentes nas praias, nas margens dos grandes rios, nas matas, nos sertões e nas cidades: "Deixemos este lado curioso, mas sombrio de nosso povo, que é

\footnotetext{
${ }^{593}$ ROMERO, Silvio. Estudos sobre a Poesia popular do Brasil. 2a . Ed. Petrópolis: Vozes, 1977. p.266.
}

${ }^{594}$ ROMERO, Sílvio. História. Op.Cit.p. 148 
comum aliás as nações até as mais cultas, e vejamo-lo expandir-se em suas festas". É ainda as populações rurais que devemos ir pedir as nossas informações", 595

Como vemos Sílvio é por vezes vacilante quando se trata de referir-se aos elementos que ele mesmo confere como indispensáveis na formação do caráter nacional ou Psicologia do brasileiro. Ainda no artigo citado traça a importância da natureza e do contato entre as raças na formação da Psicologia do brasileiro. Neste artigo podemos observar algumas incoerências do crítico. Embora não fundasse uma raça, o meio servia como agente diferenciador diante da influência estrangeira, dos constantes cruzamentos que se refletiam tanto no plano biológico como no plano cultural que singularizava e respaldava o caráter nacional brasileiro. Tais elementos influenciavam a constituição do caráter brasileiro e não é sem razão que só figurariam em sua História da Literatura Brasileira aqueles escritores que contribuíram para a diferenciação do país: "tanto mais um autor ou um político tenha trabalhado para a determinação de nosso caráter nacional, quanto maior é o seu merecimento. Quem tiver sido um mero imitador português, não teve ação, foi um tipo negativo". 596

A medida para avaliar este ou aquele escritor e assim incluí-lo em sua História da Literatura, conforme seu método naturalista, só teria sentido na medida em que o escritor houvesse contribuído para a diferenciação nacional, despertando e reforçando a existência deste caráter. Salientando mais uma vez a concepção literária de Ślvio, que não se reduzia às Belas Letras e às particularidades Estéticas da capacidade criadora, o crítico sergipano buscava perceber as relações maiores oriundas do contato entre as raças na formação da sociedade brasileira,

\begin{abstract}
"Para tanto é antes de tudo mister mostrar as relações de nossa vida intelectual com a História política, social e econômica da nação; será preciso deixar ver como o descobridor, o colonizador, o implantador da nova ordem das coisas, o português em suma, foi-se transformando ao contato do índio, do negro, da natureza, americana, $e$ como, ajudado por tudo isso e pelo concurso de ideias estrangeiras, se foi aparelhando o brasileiro, tal qual ele é desde já e ainda mais característico se tornará no futuro". 597
\end{abstract}

Segundo Sílvio, o caráter nacional brasileiro era resultado da concorrência das três raças, apontando dessa forma uma sociedade brasileira mestiça, tanto no plano biológico como cultural. Para Sílvio, não bastava apenas identificar as raças responsáveis pela Psicologia do brasileiro - citava como exemplo a concepção de Martius -, era necessário apontar o que coube a cada uma delas, visto que, "Indicar no corpo das tradições, contos, cantigas, costumes e linguagem do atual povo brasileiro, formado do concurso de três raças, que há quatro séculos, se relacionam; indicar o que pertence a cada um dos fatores, quando muitos fenômenos já se acham baralhados, confundidos, amalgamados;

\footnotetext{
${ }^{595}$ ROMERO, Sílvio. Folclore brasileiro. Cantos populares. V.I. Rio de Janeiro: José Olimpio, 1954.p.51.

${ }^{596}$ ROMERO, Sílvio. Op.Cit. p.7

${ }^{597}$ Ibidem. p. 8
} 
quando a assimilação de uns por outros é completa aqui e incompleta ali, não é coisa tão insignificante, como a primeira vista pode parecer". 598

Sua maneira de conceber e trabalhar os elementos deste caráter, como veremos, é contraditória e inconsistente. Discordou do naturalista bávaro Martius justamente porque julgava que não basta "dizer pura e simplesmente que devem ser estudadas na História brasileira as três raças que formaram a nação atual; dizê-lo quando nem ao menos se indicam as linhas gerais da contribuição de cada uma delas é enunciar um conceito perfeitamente estéril". ${ }^{599}$ É crucial, para nossas análises, transcrevermos parte da dissertação de Martius citada por Sílvio, premiada pelo IHGB, intitulada Idéias Gerais sobre a História do Brasil transcrita na íntegra por Sílvio.

"Qualquer, proclama Martius, que se encarregar de escrever a História do Brasil,
país que tanto promete, jamais deverá perder de vista quais os elementos que aí
concorreram para o desenvolvimento do homem. São porém estes elementos de
natureza muito diversa, tendo para a formação do homem convergido de um modo
particular três raças, a saber: a de cor de cobre ou americana, a branca ou caucasiana e enfim a preta ou etiópica.

Do encontro, da mescla, das relações mútuas e mudanças dessas três raças, formouse a população, cuja História por isso mesmo tem um cunho muito particular.

Pode-se dizer que a cada uma das raças humanas compete, segundo a sua índole inata, segundo as circunstâncias debaixo das quais ela vive e se desenvolve, um movimento histórico característico e particular. Portanto, vendo nós um povo novo nascer e desenvolver-se da reunião e contato de tão diferentes raças humanas, podemos avançar que a sua História se deverá desenvolver segundo uma lei particular das forças diagonais. Cada uma das particularidades Físicas e morais, que distinguem as diversas raças, oferece a este respeito um motor especial: e tanto maior será a sua influência para o desenvolvimento comum, quanto maior for a energia, número e dignidade da sociedade de cada uma dessas raças.

Disso necessariamente se segue o português, que, como descobridor, conquistador e senhor, poderosamente influiu naquele desenvolvimento; o português, que deu as condições e garantias morais e Físicas para um reino independente; que o português se apresenta como o mais poderoso e essencial motor. Mas também de certo seria um grande erro para todos os princípios da historiografia pragmática, se desprezassem as forças dos indígenas e dos negros importados; forças estas que igualmente concorreram para o desenvolvimento físico, moral e civil da totalidade da população. Tantos os indígenas, como os negros, reagiram sobre a raça predominante.

Sei muito bem que brancos haverá, que a uma tal ou qual concorrência dessas raças inferiores taxem de menoscabo à sua prosápia; mas também estou certo que eles não serão encontrados onde se elevam vozes para uma historiografia filosófica do Brasil. Os espíritos mais esclarecidos e mais profundos, pelo contrário, acharão na investigação da parte que tiveram, e ainda têm, as raças índia e etiópica no desenvolvimento histórico do povo brasileiro, um novo estímulo para o historiador humano e profundo. Tanto a História dos povos quanto a dos indivíduos nos mostram que o gênio da História do mundo, que conduz o gênero humano por caminhos, cuja sabedoria sempre devemos reconhecer, não poucas vezes lança mão de cruzar as raças para alcançar os mais sublimes fins na ordem do mundo. Quem poderá negar

${ }^{598}$ ROMERO, Sílvio. Folclore brasileiro: contos populares do Brasil. Belo Horizonte: Ed.Itatiaia; São Paulo: EDUSP, 1985. p. 15.

${ }^{599}$ ROMERO, Sílvio. Autores brasileiros. p. 565 
que a nação inglesa deve sua energia, sua firmeza e perseverança a essa mescla dos povos céltico, romano, dinamarquês, anglo-saxão e normando?

Coisa semelhante, e talvez ainda mais importante, se propõe o gênio da História, confundindo não somente povos da mesma raça, mas até raças inteiramente diversas por suas individualidades e índole moral e física particular, para delas formar uma nação nova e maravilhosamente organizada.

Jamais nos será permitido duvidar que a vontade da providência predestinou ao Brasil esta mescla.

O sangue português, em um poderoso rio, deverá absorver os pequenos confluentes (?) se, das raças índia e etiópica. Na classe baixa tem lugar esta mescla, e como em todos os países se formam as classes superiores dos elementos das inferiores, $e$, por meio delas se vivificam e fortalecem, assim se prepara atualmente na última classe(?) da população brasileira essas mescla de raças, que daqui a séculos influirá poderosamente sobre as classes elevadas, e lhes comunicará aquela atividade histórica para qual o Império do Brasil é chamado.

Eu creio que um autor filosófico, penetrado das doutrinas da verdadeira humanidade $e$ dum cristianismo esclarecido, nada achará nessa que possa ofender a suscetibilidade dos brasileiros. Apreciar o homem segundo o seu verdadeiro valor, como a mais sublime obra do Criador, e abstraindo da sua cor ou seu desenvolvimento anterior, é hoje em dia uma conditio sine qua non para o verdadeiro historiador. Essa filantropia transcendente, que aprecia o homem em qualquer situação em que o acha destinado para obrar e servir de instrumento à infinitamente sábia ordem do mundo, é o espírito vivificador do verdadeiro historiador. E até me inclino a supor que as relações particulares, pelas quais o brasileiro permite ao negro influir no desenvolvimento da nacionalidade brasileira, designa por si o destino do país, em preferência de outros estados do novo mundo, onde aquelas duas raças inferiores são excluídas do movimento geral, ou como indignas por causa do seu nascimento, ou porque o número, em comparação com o dos brancos, é pouco considerável e sem importância. Portanto devia ser um ponto capital para o historiador reflexivo mostrar como no desenvolvimento sucessivo do Brasil se acham estabelecidas as condições para o aperfeiçoamento de três raças humanas, que nesse país são colocadas uma ao lado da outra, de uma maneira desconhecida na História antiga, e que devem servir-se mutuamente de meio e de fim.

Esta reciprocidade oferece na História da formação da população brasileira em geral o quadro de uma vida orgânica.

Apreciá-la devidamente será também a tarefa de uma legislação verdadeiramente humana. Do que até se fez para a Educação moral e civil dos índios e negros, e do resultado das instituições respectivas, o historiador poderá julgar no futuro, e tornando-se para ele a História uma Sibila profetizando o futuro, poderá oferecer projetos úteis.

Com quanto maior calor e viveza ele defender em seus escritos os interesses dessas por tantos modos desamparadas raças, tanto maior será o mérito que imprimirá à sua obra, a qual terá igualmente o cunho daquela filantropia nobre, que em nosso século com justiça se exige do historiador. Um historiador que mostra desconfiar da perfectibilidade de uma grande parte do gênero humano autoriza o leitor a desconfiar que ele não sabe colocar-se acima das vistas parciais ou odiosas" ${ }^{600}$ (grifos nossos)

Lendo a fala de Martius com relação à formação da sociedade brasileira da época, percebemos sua preocupação em apontar a influência das três raças responsáveis pelo caráter brasileiro, do que discordava Sílvio porque pensava que o botânico alemão simplesmente colocava lado a lado cada uma

${ }^{600}$ ROMERO, Sílvio. Zeverissimações Ineptas da Crítica - Repulsas e Desabafos. Porto: Oficina do Comércio do Porto, 1909.p 133-138. 
dessas raças. É nítida a importância que Martius atribui às raças inferiores, os valores inatos a cada uma dessas raças, a natureza que mais não é do que "as circunstâncias debaixo das quais ela vive e se desenvolve”, e, sobretudo, a interação entre negros, índios e portugueses. Já está presente de maneira clara a miscigenação, que influenciaria de maneira significativa diversos escritores brasileiros, como Varnhagen, Sílvio Romero, Euclides da Cunha, Oliveira Viana, Gilberto Freyre, Jorge Amado, etc.

Alegava Sílvio que Martius simplesmente apontava quais as raças formadoras do caráter brasileiro, sem descrever o que coube a cada uma delas, somado ao fato de que o vencedor do concurso promovido pelo IGHB não tocava na miscigenação, "corre a galope sobre o fenômeno do mestiçamento a que liricamente consagra duas outras linhas incertas; não estuda, nem define os pontos principais do problema" ${ }^{601}$ Sílvio acabava por concluir que "Dizer pura e magramente que devem ser estudadas na História brasileira as três raças que formaram a nação atual; dizê-lo quando nem ao menos se indicam as linhas gerais da contribuição de cada uma delas é enunciar um conceito perfeitamente estéril. Martius não fez outra coisa" 602

Acreditando nas particularidades brasileiras não mais sob o jugo português ao longo de três séculos, esboçava Sílvio sua imagem de Brasil e sua representação de brasilidade. Embora saibamos que a conclusão do bacharel seria a afirmação de um caráter nacional mestiço, tanto no plano biológico como cultural, cabe cautela no proceder de sua crença e investigação deste caráter nacional. Em sua vasta produção ensaística, inúmeras vezes, utilizou-se Sílvio de termos como caráter nacional, Psicologia nacional, índole de um povo, espírito de um povo, alma nacional, acreditando num princípio maior regendo a sociedade brasileira. Concluía a respeito de uma dada Psicologia dos povos:

"Vem a ser o complexo de tendências e intuições do espírito nacional; alguma coisa que o indivíduo só por si não explica, que só o povo em sua amplitude genérica deixar notar claramente. Assim como há um espírito da época (Zeitgeist), que domina um momento dado da História, há um espírito comum (Algeist), que determina a corrente geral das opiniões de um povo". ${ }^{03}$

Sílvio é guiado pelo espírito de uma época (Zeitgeist) e por um espírito comum (Algeist), influência de sua admiração pela cultura germânica, que começou em seus preparatórios e só se solidificou com o encontro de seu conterrâneo e amigo Tobias Barreto, escritor que lia em alemão e que chegara até a publicar um jornal em alemão em sua terra natal. Somado isso a sua crença nas leis do Determinismo racial e do meio ambiente, seria pelas teias da cultura germânica que o crítico literário se apoiaria para investigar o caráter brasileiro, muito embora não apontasse características positivas deste caráter.

\footnotetext{
${ }^{601}$ ROMERO, Sílvio. Autores brasileiros. p.565

${ }^{602}$ Ibidem. p.565

${ }^{603}$ ROMERO, Sílvio. História. Op.Cit.p. 145
} 
Sílvio atribuía todo o atraso do Brasil no que tange aos mais variados aspectos ao caráter ou a Psicologia do brasileiro. Era o brasileiro apático, sem iniciativa, desanimado, imitação do estrangeiro, abatimento intelectual, irritabilidade, nervosismo, hepatismo, talentos precoces e rápida extenuação, facilidade para aprender, superficialidade das faculdades inventivas, mais contemplativo que pensador, mais lirista, mas amigo de sonhos e palavras retumbantes que de idéias cientificas e demonstradas, sem Filosofia, sem Ciência, sem Poesia impessoal, palavreado da carolice, mística ridícula o beatério enfermo e fanático, devaneios fúteis da impiedade impertinente e fútil, lirismo subjetivista, mórbido, inconsciente, vaporoso, nulo. ${ }^{604}$

\section{Interesse pelo índio}

Estudioso e preocupado com a cultura brasileira, um dos grandes objetivos de Sílvio era investigar as origens culturais do país. Influenciado pelo movimento político e ideológico do Romantismo alemão, buscava Sílvio as raízes da identidade nacional, apontando o mestiçamento biológico da sociedade influenciando a cultura do país. Árduo defensor da participação do índio na constituição da alma nacional porque sabia da importância deste, Sílvio denunciaria a estilização do índio no projeto literário e político dos escritores do Romantismo brasileiro. Sua Crítica à identidade nacional elaborada pelo Romantismo se dava não apenas porque o índio sofrera a estilização, influenciada principalmente por Cooper e Chateaubriand, mas porque, para Sílvio, o conhecimento por parte dos protegidos e agraciados de D. Pedro II se estendia a todo o Brasil, mascarando a realidade do país.

Parece ambiguidade o fato de Sílvio se opor á imagem do índio como símbolo nacional e tanto ter procurado a influência deste na cultura do país. Mas é que, além de ser o índio figurado de maneira idílica, mascarando a realidade e o conhecimento do Brasil, a imagem ilusória era estendida a todo o país. Homem de visão ampla, para Sílvio, a imagem romântica não podia se restringir ao campo estético defendido pelos protegidos do imperador e tão combatido pelo bacharel. Dessa forma, mesmo se opondo ao índio fabricado pelos escritores românticos, era indispensável averiguar a importância do mesmo na formação da sociedade brasileira. Buscaria a origem do selvagem americano e mesmo afirmando ser o índio a raça que menos contribuiu para a formação do caráter nacional brasileiro, de forma alguma poderia deixar de analisá-lo. Após comentar, em sua Análise dos escritores que trataram da nossa Poesia popular, com relação à visão de Couto Magalhães, ressaltava que

${ }^{604}$ LEITE, Dante Moreira. O caráter nacional brasileiro: História de uma ideologia. $4^{\text {a }}$ ed. São Paulo: Pioneira, 1983. pp. 209-210. 
Ele negou como seu viu quase completamente a influencia índia em nossas tradições. Trabalhos posteriores ao seu tiraram a limpo este ponto. $O$ índio influiu e deixou vestígios em nossa língua, costumes, lendas e tradições. Adiante teremos ocasião de reconhecê-lo.

O moço crítico foi neste ponto vítima de um exagero reacionário. Sabe-se que o Romantismo nacional, com o seu gentilismo, deificara o caboclo pelo órgão de nossos poetas e romancistas, atribuindo-lhes grandezas que nunca tivera!... ${ }^{605}$

Mesmo convicto da superioridade da raça branca, não duvidou de que o índio pudesse ter sua Poesia, sua língua e suas tradições, "Fala-se muito de uma decantada Poesia dos índios dos três primeiros séculos da conquista; poucos são os fragmentos coligidos". 606 Embora a Evolução, juntamente com a seleção natural, selecionasse somente as ideias mais fortes, num processo de fusão biológica, moral, e cultural, num primeiro momento, Sílvio acreditava na contribuição da raça indígena diante de sua inferioridade com relação ao branco e ao negro. Em um país formado por uma civilização transplantada, como aponta Sérgio Buarque, carente de alma própria, era indispensável recorrer aos antecedentes históricos em busca do caráter para formação de sua identidade. Pedaço da França, Inglaterra, Suíça e Inglaterra falava Sílvio que

\begin{abstract}
"Perturbar a auto idolatria de sublime prosápia desses arianos puro-sangue é, perante eles, praticar um ato da maior indiscrição, do mais acentuado desazo...

Em que pese, porém, as alterosas pretensões desses despeitados praguejadores, creio ser possivel ainda afirmar não ter sido a Ciência inventada para lisonjear-lhes a vaidade; tem ela outros desígnios.

É ainda lícito para conhecer um povo, sondar-lhe as origens, máxime se o problema a solver é o da exata determinação de sua estrutura social". ${ }^{607}$ (grifos nossos)
\end{abstract}

Admirador da cultura da raça germânica, uma cultura superior, porque afirma "creio ser possível ainda afirmar não ter sido a Ciência inventada para lisonjear-lhes a vaidade; tem ela outros desígnios?", se privilegiava nomes como os Gobineau, Lapouge e Ammom, e reconhecia a superioridade da cultura alemã, o que teria levado o mesmo a compreender a cultura indígena na formação da sociedade e da cultura brasileira? Crente na superioridade do europeu, não bastava apenas apontar o caráter mestiço do brasileiro, mas sim descrever o que coube ao índio na formação da identidade do país. Embora tenha sido influenciado por escritores racistas e integrantes da Antroposociologia, como Lapouge, Ammom, e Gobineau, que primavam pela seleção social dos melhores povos, encontramos um Sílvio que não está a legitimar a autoidolatria dos povos considerados superiores, mas sim um escritor que pretende analisar cientificamente a importância da

\footnotetext{
${ }^{605}$ ROMERO, Sílvio. Estudos sobre a Poesia popular no Brasil. Op.Cit. p. 59.

${ }^{606}$ ROMERO, Sílvio. Folclore brasileiro. Op.Cit.p.15.

${ }^{607}$ ROMERO, Sílvio. O Brasil social. Op.Cit.p.196
} 
raça indígena para compreender a formação do povo brasileiro, e assim, explicar a estrutura social de seu país.

Antes de esmiuçarmos a importância e contribuição indígena em sua obra, vale lembrar mais uma vez a influência europeia sofrida pelos escritores brasileiros da Escola de Ciência Social e da Antroposociologia. Inúmeras vezes, chamou atenção para a participação do índio na identidade nacional, não o índio civilizado e estilizado dos românticos, embora fosse Sílvio um escritor de olhar etnocêntrico, mas sim o índio que portava suas lendas que bem poderiam servir de ponto de partida para o conhecimento do país capaz de fornecer os elementos de sua identidade. Raça que menos contribuiu para a "identidade" do país, era indispensável tomar conhecimento do índio em seu meio e sua cultura. Pensava Sílvio que era relevante estudar o contato entre europeus e índios para entender o processo de mestiçamento não apenas biológico, mas moral e cultural. Sua tese da mestiçagem, que a priori supõe a superioridade do europeu, é totalmente equivocada num país completamente mestiço. Sua hipótese de que a população brasileira tendia a embranquecer dentro de três a quatro séculos, em função dessa tal superioridade, é inconsistente porque as Teorias racistas que adotou, mesmo naquele período histórico, já não possuíam solidez científica.

Pensando que a concorrência ou a existência das três raças explicava o estágio evolutivo ou a situação atravessada pelo Brasil, travou renhidas discussões acerca da contribuição do índio brasileiro, tendo que arrolar os estudiosos que se preocuparam com o mesmo. Dessa forma, recorreu aos cronistas e viajantes Gabriel Soares, Fernão Cardim, Martius, Von Den Steinem, Ehrenreich; aos escritores ligados ao campo da etnografia e das Letras, respectivamente como Rodrigues Peixoto, Batista Caetano, Capistrano de Abreu, Gonçalves Dias, Gonçalves de Magalhães, Couto de Magalhães, Goeldi, Francisco Lisboa, Varnhagen. Reconhecia que o grande problema era o problema das origens, quando buscava avaliar a contribuição do índio na formação da cultura brasileira.

Mas Sílvio coligiu e esboçou somente vinte e um contos ligados a toda a tradição indígena. Outra grande questão motivadora de suas constantes arengas literárias com os diversos pesquisadores estrangeiros e nacionais seria concernente à origem do índio americano- "brasileiro". De sua ânsia por querer investigar a contribuição exata de cada uma das raças, amparando-se nas leis científicas, veio a se contradizer quando afirmou que o índio não tem uma Poesia. Mas fora justamente de sua crença nos preceitos naturalistas, sempre afirmando ter sido o primeiro escritor a ter introduzido no Brasil o método etnográfico, que Sílvio buscou incessantemente averiguar o que coube a cada uma das raças na formação do povo. Como não poderia ser diferente, Sílvio olhou o índio dentro de uma visão europeia, amparado em nomes distintos e mais variados campos, que iam da Filologia à Crítica mitológica. Concebeu o índio dentro dos quadros do Positivismo e do Evolucionismo 


\begin{abstract}
"Por mais exatas que lhes pareçam as primeiras narrações de imaginosos cronistas sobre o numeroso e adiantado da população tapuia, os fatos as desmentem.

Esqueceu-lhes que os selvagens de nosso país estavam no grau de atraso do homem, geológico, o homem da idade de pedra, não podendo ser muito numerosos.

Esqueceu-lhes que não podiam ter uma Religião, que reconhecesse um Ser-Supremo; tão pouco uma Poesia, como assoalham!

O contrario é desdenhar ou desconhecei- os achados da critica moderna, que assinala os diferentes períodos da formação das mitologias, das religiões e da Poesia.

Umas tribos desgarradas pelos desertos e matas, vivendo da caça e, guerreando-se, $e$ outras reunidas em paupérrimas palhoças, sem a menor indústria assinalável, usando da pedia para utensílios como o homem das cavernas, sem tradições, sem heróis, sem historia, não podiam possuir a noção da individualidade, dó Ser - Superior, como não podiam ter uma Poesia.

Estavam pouco além da época de puro Naturalismo em que o terror faz crer o que as nuvens, os trovões (tupan), as tempestades são seres terriveis que se combatem, entidades ferozes, que se devem respeitar. Então o homem é bastante selvagem para criar uma Poesia. Só nos períodos seguintes: no em que os deuses estão quase n'altura de heróis, e os heróis n'altura de deuses, tempo, do antropomorfismo e da apoteose, e no da concepção de um Ser - Superior, é ela possivel". ${ }^{608}$ (grifos nosso)
\end{abstract}

Admitindo ter sido o índio o que menos contribuiu em função de sua inferioridade biológica, sempre reclamava da ausência de visão científica dos escritores românticos, acobertados pelo mecenato do dito ilustre admirador das Letras e Artes brasileiras, o imperador Dom Pedro II. Utilizava sempre o mesmo argumento para se defender de seus inúmeros opositores: a falta do critério científico, que só ele parecia ter em mãos quando analisava a "realidade" brasileira num cenário de inteira barbárie. Contrário à imagem romântica do índio como símbolo nacional porque não condizia com o Brasil real, nunca deixou de reclamar pelas origens onde o verdadeiro índio fosse descoberto e estudado de maneira científica. Sílvio muito mais atacara e reprovava seus adversários do que comentara os poucos contos indígenas que coligira,

\begin{abstract}
"Os missionários e colonos inteligentes do século XVI, que deixaram notícias escritas dos nossos selvagens, eram demasiado incompetentes para uma observação regular, capaz de surpreender os mais íntimos fatos nacionais e a fundamental Psicologia dessas gentes rudes.E, todavia, é onde se encontram hoje as notações de maior valia acerca de tudo que lhe diz respeito. Fizeram meras descrições; mas neles vai hoje o investigador sociólogo achar os materiais mais ou menos adequados para suas conclusões. ${ }^{609}$ (grifos nossos)
\end{abstract}

Buscava adentrar a vida social dos grupos indígenas, influenciados por Le Play e seu discípulo maior, Edmond Demoulins “A Ciência Social chegou neste ponto a conclusões certas, cujo valor $e$ veracidade tenho confirmado nos escritos das melhores autoridades existentes acerca dos costumes dos selvagens brasileiros". ${ }^{610}$ Para confirmar seu método de análise, que era senão o método da Ciência Social ancorado em Demolins, até mandava consultar os estudos de Gabriel Soares, Fernão

\footnotetext{
${ }^{608}$ ROMERO, Sílvio. Etnologia Selvagem. Op.Cit.p.42.

${ }^{609}$ ROMERO, Sílvio. História. Op.Cit. p.201.

${ }^{610}$ Ibidem. p.204
} 
Cardim, Francisco Lisboa, Varnhagem, Couto de Magalhães e Capistrano de Abreu para comprovar que suas convicções estavam corretas. Reproduzia um fragmento do livro de Crevaux Voyages dans l'Amérique du Sud acerca dos selvagens "americanos", lido por Demoulins, onde o discípulo de Le Play apontava os critérios de superioridade da mocidade em face da velhice, o desenvolvimento do individualismo, a limitação dos meios de existência, a necessidade e dificuldade das migrações periódicas. Apoiava-se em Demolins para concordar com a leitura que este faz de Crevaux. Sílvio abre discussões que não finda, sempre argumentando de forma generalizante. Se num primeiro momento se preocupava em identificar quais os grupos indígenas existentes no Brasil, concluía sem perder de vista o caráter nacional implicando diretamente no atraso do Brasil em todos os seus aspectos. Retomou em sua História da Literatura Brasileira a interpretação que Demolins fazia de Crevaux,

\footnotetext{
"Sua descrição, porém é aceitável como o retrato das raças mais adiantadas dentre os índios brasileiros. E como muito dos traços de nossa Psicologia nacional de hoje estão ali em gérmen! E como somos levianos em não estudar as nossas origens para conhecer donde partem nossos defeitos e procurar corrigi-los!

E como somos superficiais em buscar fora a fonte de nossos males, atribuindo-os aos governos, quando ela está em nós mesmos, e aqui de alto a baixo, governos e doença: o vício originário e constitucional!" ${ }^{611}$
}

Lembremos que o bacharel iniciou sua carreira literária escrevendo artigos nos jornais do Recife, divergindo dos escritores que corroboravam com a representação de que era o índio o símbolo nacional, quando ainda era aluno do curso da Faculdade de Direito do mesmo estado. A Crítica que moveu aos escritores do Romantismo brasileiro sempre tinham como causa a falta do critério científico, gerador da visão fantasiosa que só aumentava o tamanho dos rios e da floresta brasileira, responsável pela índio-mania.

Desse modo, partia Sílvio em sua busca folclórica para identificar as origens do país e somente assim encontrar a alma nacional. Buscou coligir as manifestações culturais dos índios para saber a real contribuição destes quando analisava o quadro social, político e cultural do Brasil. Adentrou a Poesia, compilou contos e lendas para saber o que coube a cada uma das raças. Mas, reclamava sempre não apenas da falta de estudos sobre o selvagem brasileiro, como também dos erros ou incoerências devido à falta de critério científico por parte dos escritores brasileiros. Sem a especialização de áreas como a etnografia, a Etnologia, a linguística, a Craniometria, a Filologia, áreas dos pesquisadores com quem dialogava, reclamava sempre da falta do critério científico nos estudos antropológicos,

${ }^{611}$ Ibidem. p. 210 


\begin{abstract}
"Os grandes estudos antropológicos e a Crítica religiosa desfizeram as trevas sobre aquelas inexatidões entre os que sabem pensar, e é bem certo que a sua luz não chegou até cá.

Se não temos ideias seguras sobre a maior parte das grandes indagações da Ciência contemporânea, não nos é lícito a nós americanos, admiradores do tapuio, continuar a ser a nação mais atrasada sobre aquilo que constitui o nosso maior enlevo! E esta é a verdade. Aqui na América mesma, há muito, as coisas mudaram de aspecto". 612
\end{abstract}

Desse modo, Sílvio analisou a participação da raça que menos influenciou a cultura brasileira por ser esta biologicamente inferior às raças brancas e negras na constituição da alma nacional, ávido por entender os porquês do atraso do Brasil.

\title{
4. Origem do índio
}

Cabe salientar de início a dificuldade sobre a definição do que seja um índio. O que é um índio? Manuela Carneiro da Cunha nos mostra a dificuldade em torno dos critérios que caracterizam o índio. Trabalhando com o conceito de etnicidade, algo adquirido e não herdado, a cultura do índio, categoria que nos ajuda a buscar o que seja um índio, poderia ser também perdida, no que acabava por resultar numa questão insolúvel. A autora sustenta que a categoria étnica pode ser instrumentalizada, uma vez que se trata de uma ideologia, argumentação de Fernando Henrique. Enfim, "comunidades indígenas são, pois aquelas que, tendo uma continuidade histórica com sociedades pré-colombianas, se consideram distintas da sociedade nacional. E índio é quem pertence a uma dessas comunidades indígenas e é por ela reconhecido". 613

A Literatura sobre a temática indígena surge do olhar do homem europeu, civilizado, branco e conquistador, que imagina e representa o índio a partir de seu mundo. Mundo este formado pela presença autoritária do Estado que rege uma Economia cada vez mais de mercado e que deprecia o nativo por este não se preocupar em acumular. Desse modo, o índio é visto como bárbaro, primitivo, em que todo um olhar se estende a partir do horizonte europeu. Como se não bastasse o imaginário pejorativo elaborado pelo europeu com relação ao índio, pouco se sabe da História indígena, das reais populações indígenas presente no momento da invasão europeia, ou melhor: não se sabe a certo o que aconteceu. Para Manuela Carneiro da Cunha,

"a maior dessas armadilhas é talvez a ilusão de primitivismo. Na segunda metade do século XIX, essa época de triunfo do Evolucionismo, prosperou a ideia de que certas sociedades teriam ficado na estaca zero da Evolução, e que eram portanto algo como fósseis vivos que testemunhavam do passado das sociedades ocidentais. Foi quando

\footnotetext{
${ }^{612}$ ROMERO, Sílvio. Etnografia Brasileira: estudos críticos sobre Couto de Magalhães, Barbosa Rodrigues, Teófilo Braga e Ladisláo Neto. Rio de Janeiro: Livraria Clássica de Alves, 1888. p.7

${ }^{613}$ CUNHA, Manuela Carneiro da. Antropologia do Brasil: mito, História, etnicidade. São Paulo: Brasiliense: EDUSP, 1986. p. 111
} 
as sociedades sem Estado se tornaram, na Teoria ocidental, sociedades "primitivas", condenadas a uma eterna infância. E porque tinham assim parado no tempo, não cabia procurar-lhes a História. Como dizia Varnhagen, de tais povos na infância não há História: há só etnografia". ${ }^{614}$

A fala de Manuela Carneiro sintetiza bem o olhar que se tem sobre o índio. Para o olhar europeu tratava-se de povos ingênuos com costumes primitivos, no que atestava o estágio infantil das populações indígenas. As infinitas representações elaboradas desde a chegada dos colonizadores até a vinda dos cientistas da Missão Francesa só comprovam o olhar pejorativo com relação às populações indígenas. Como muito já se sabe as inúmeras representações sobre o índio chamam a atenção para o canibalismo, para a violência, enfim, para o modo de vida das populações indígenas, "inferior" ao modo de vida do homem branco, uma vez que "a chegada num continente Novo, inaugura uma tradição narrativa e pictórica" 615

Se não bastasse o imaginário pejorativo do índio "brasileiro" donde as infinitas representações, o critério linguístico levado a cabo pelo IHGB, tendo Varnhagen como colaborador para identificação das populações indígenas não foi menos embaraçoso. Em busca das raças constituintes do povo Brasileiro, o IHGB somente continuou o imaginário de antigos cronistas, viajantes e naturalistas, uma vez que este era constituído por homens de mentes “europeizadas", "estupidez, barbaridade, inaptidão para civilizar-se eram, pois, as características traçadas sobre os índios com os quais teve contato, distantes da imagem sonhada dos índios guerreiros que um dia haviam expulsado os primeiros colonizadores". 616

Sem História, conforme visão de Varnhagen, a análise remetia ao estudo etnográfico e não histórico, o que significa afirmar que o índio era visto a partir do olhar excludente proposto pelo conhecimento racional. Na leitura elaborada pelo IHGB o índio era visto conforme o olhar bíblico, onde todos os seres eram filhos do mesmo pai e surgidos do mesmo centro de criação. O mais sério era a representação do índio imersa no projeto nacional brasileiro forjada por uma meia dúzia de pessoas comprometida com a viabilização da política imperial do país. Em síntese, a visão dos escritores do IHGB caracterizava-se pelo parâmetro dos "tipos" raciais que conheceu seu ápice a partir de 1870. As discussões giravam em torno do monogenismo, ficando evidente a superioridade do homem europeu, tudo isso como parte da ideologia imperial brasileira objetivando a construção do Estado nacional. A discussão sobre a constituição da nação brasileira, no que trazia a questão racial como tema inevitável,

\footnotetext{
${ }^{614}$ CUNHA, Manuela Carneiro da. Introdução a uma História Indígena. São Paulo: Secretaria Municipal de Cultura/ Cia das Letras/ FAPESP, 1992. p. 11

${ }^{615}$ GRUPIONI, Luís Donizeti Benzi. Inventário dos Artefatos e obras da exposição "índio no Brasil: alteridade, diversidade e diálogo cultural”. In: Índios no Brasil. Ministério da Educação e do Desporto, 1994. p. 234. Da mesma publicação, BETTENCOURT, Lúcia. Cartas brasileiras: visão e revisão dos índios.

${ }^{616}$ KODAMA, Kaori. Os índios no Império do Brasil: a etnografia do IHGB entre as décadas de 1840 e 1860 . Rio de Janeiro: FIOCRUZ; São Paulo: EDUSP, 2009. p. 129
} 
haurida das mãos dos escritores preocupados com o país se mostrava ambivalente: "os românticos indianistas, por seu lado, caminhavam dentro de uma ambiguidade, pois a princípio exaltavam o papel indígena e criticavam as atrocidades contra eles cometidas, mas ao mesmo tempo exaltavam os feitos dos conquistadores, estes que agora seriam alçados ao posto de heróis da pátria”. 617

Com o surgimento das Teorias raciais, o debate sobre o índio não permitiu um melhor olhar sobre o mundo deste, as bases constituintes de suas vidas e a situação das "nações" indígenas. Aparecia aqui a categoria racial, no que resultava a constatação de um índio vivendo no primeiro estágio da empreitada civilizatória, sempre habitando uma "civilização" que ainda dormia. O índio era visto tendo por base "tipos" raciais avaliados pelos mecanismos da Antropologia Física. O parâmetro era sempre o homem branco e as classificações estendiam as "nações" indígenas, o que acabava por dificultar ainda mais a realidade das coisas. Homens Como Varnhagen, Cunha Matos, Gonçalves Dias, Martius, dentre outros, empreendiam suas análises apostando no caráter nacional, na índole das nações, onde a Etnologia se confundia com etnografia.

Este foi o quadro que Sílvio se deparou. Sílvio Romero dialogou com escritores da área da Antropologia brasileira como Couto de Magalhães, Batista Caetano, Ladislau Neto e Barbosa Rodrigues analisando a participação do índio na formação do povo e da cultura brasileira. Num renhido debate com os mais significativos personagens da Ciência brasileira da época, das áreas de Craniometria, da botânica, da arqueologia, da filologia, da linguística e da geografia, para Sílvio, o maior problema era identificar qual era a origem do selvagem americano. Em meio a uma série de contradições, indecisões, ataques e contra ataques, o ensaísta sergipano iniciava suas análises acerca das origens afirmando, não sem razão, que "Não pode haver maior inconveniência aos olhos dessa gente que lembrar o incômodo problema das origens... " 618

Em 1874, era lançada a obra de Couto de Magalhães Região e Raças Selvagens, onde o etnólogo investigava o índio brasileiro. Sílvio, em o Globo, elabora um artigo comentando a obra de Couto; embora afirmasse que sua Crítica "não foi um estudo caprichoso, e, antes, muito sincero - gratidão, por ter eu de fato ficado sumamente penhorado a maneira delicada e honrosa por que prometeu ao público responder-me" ${ }^{619}$. Tendo lido o artigo de Sílvio e elogiado o mesmo não pelo livro, e sim pelo assunto que se mostrava do mais alto interesse científico, prometia Couto "acompanhar na discussão do assunto desde que ele tenha concluído a sua análise, se trabalhos de outra natureza não o impedirem” ${ }^{620}$. Partia Sílvio para Pernambuco, esperançoso por uma resposta que nunca viria.

\footnotetext{
${ }^{617}$ SPOSITO, Fernanda. Nem cidadãos, nem brasileiros - indígenas na formação do estado nacional brasileiro e conflitos na província de São Paulo (182-1845). São Paulo: Alameda, 2012. p. 114

618 Ibidem. p. 6.

${ }^{619}$ Ibidem. p.7

${ }^{620}$ Ibidem. p.5
} 
Em 1875, era impresso na tipografia do Recife o artigo de Sílvio Romero Etnologia Selvagem Estudo sobre a memória Região e Raças do Brasil do Dr. Couto de Magalhães ${ }^{621}$. O centro do caloroso debate residia em saber se o selvagem brasileiro tinha ou não filiação ariana com as populações do Velho Continente. Para Couto de Magalhães, o índio brasileiro era fruto do cruzamento com alguma raça branca em razão da aproximação da língua do selvagem com o sânscrito.

\begin{abstract}
"Ha, em questões de etnografia, um ponto para mim nimiamente importante, e é o de saber-se se a língua tupi conserva qualquer vestígio do sânscrito.

Eu disse ligeiramente na minha memória-que não. Quando falo em sânscrito, entendo que o vestígio pôde ser provado - quer pela identidade das raízes, tais quais elas se encontram na velha fôrma (que eu não conheço), quer pela identidade das fôrmas modernas, que eu conheço em algumas das atuais línguas da Europa.

Quando eu escrevi a memória, não conhecia senão uma forma das raízes tupis era a fôrma austral. Daí para cá, porém, eu tive ocasião de familiarisar-me com o tupi do norte, em cuja língua eu me posso exprimir com alguma facilidade; recolhi textos de mitos originais em dois dialetos, e por isso disponho de materiais muito mais completos do que os de que então dispunha.

O estudo sobre esses novos materiais confirmou as minhas convicções, e logo que eu disponha do necessário tempo, ei de entrar nessa discussão com muito prazer". "${ }^{22}$
\end{abstract}

Segundo o general Couto de Magalhães, o homem americano era resultado do cruzamento com alguma raça branca, "Couto de Magalhães é sectário da ideia de Fidel Lopes e Charles Wiener de que a língua quíchua é um idioma indo-germânico, e que a língua tupi, muito ao invés, nada contém que a assimile ao grupo das línguas arianas, e pode talvez ser considerada uma língua turana" ${ }^{623}$. A crer na tese de Magalhães, os brancos arianos que cruzaram com as populações do Peru e América Central não foram as que cruzaram com os índios brasileiros justamente pela ausência do sânscrito. Uma das teses de Magalhães, apontada por Sílvio, é a de cruzamentos pré-históricos de nosso caboclo com alguma raça branca, o que, para o escritor sergipano, não era nenhuma novidade. Analisando a obra $O$ Selvagem, Sílvio alude a uma passagem de Magalhães de onde partiam suas conclusões:

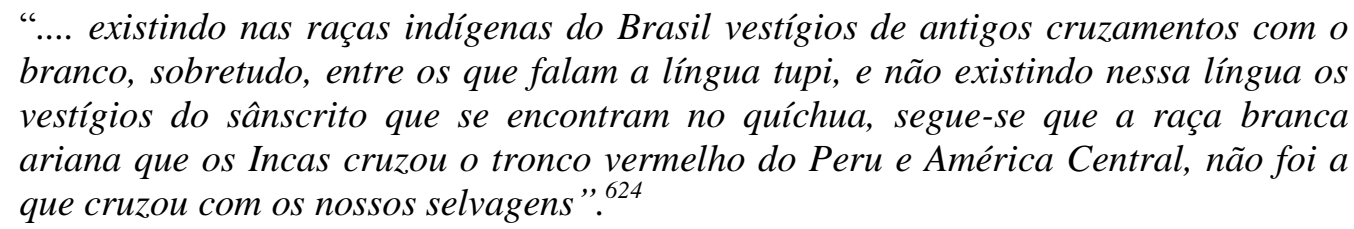

${ }^{621}$ A primeira publicação da obra difere da segunda publicada em 1888 porque não possui a advertência de Couto de Magalhães nem o artigo intitulado $O$ caráter nacional e as origens do povo Brasileiro que se mostra indispensável para as análises acerca do caráter nacional brasileiro. Portanto, a segunda edição consta de seis artigos, ao passo que a primeira somente traz o artigo Couto de Magalhães e os selvagens brasileiros. Utilizamos esta primeira edição para expormos o breve diálogo entre Sílvio e Couto de Magalhães acompanhado do artigo que não consta na segunda edição como já mencionado.

${ }^{622}$ Ibidem p. 6.

${ }^{623}$ ROMERO, Sílvio. Estudos sobre a Poesia popular do Brasil.Op.Cit.p.140

624 Ibidem. p. 10 
Sílvio inicia suas análises apontando de maneira precisa três pequeninas inexatidões sobre a visão de Couto de Magalhães, para concluir sua hipótese acerca da origem do selvagem americano como produto espontâneo do território americano. O fato de não se presenciar no tupi ou no guarani vestígios do sânscrito - apenas uma das línguas arianas -, como ocorrido no quíchua, não invalida a possível origem do selvagem americano com alguma raça ariana. Desenvolvendo suas argumentações, Sílvio recorre ao escritor platino Fidel Lopes, base de argumentação de Couto de Magalhães, para afirmar que este, em seu estudo de "filologia comparada não se limita a mostrar o parentesco da língua dos Piruás só com os dialetos dos vedas" ${ }^{625}$. Embora defenda o cruzamento do selvagem americano com alguma raça branca, afirma Magalhães que "não foi um ramo qualquer ariano que por aqui passou, pois a língua tupi não mostra vestígio algum das línguas indo-germânicas" 626.

Inquietava Sílvio, ao contrário do que pensara Couto, a existência do sânscrito em dialetos como o tupi e o guarani, invalidando a hipótese de ser este dialeto fruto do cruzamento com alguma raça ariana. É que, conforme alega Magalhães, houve em tempos pré históricos o cruzamento entre o índio que habitava o Brasil com alguma raça branca, fazendo com que Sílvio afirmasse: "Não vejo que outra saída possam ter para o problema senão essas mesmas raças arianas que, dizem, se estabelecerem no Peru. E se os vestígios que na língua ficaram são raros, é devido a pequena escala em que, talvez, se dera o acontecimento" 627

Sílvio contra argumentava tendo em vista três hipóteses, quais sejam: não era o sânscrito a única língua turana que pudesse servir de componente comprobatório da possível filiação ariana do tupi; Fidel Lopes - no qual se apóia

Magalhães - não se restringiu a mostrar a possível filiação dos pirhuas apenas com o sânscrito; e nunca Lopes utilizou-se do termo inca para aludir às raças peruanas que, segundo Sílvio, foi somente uma das dinastias do Peru; as raças que habitavam o Peru e a América Central foram diferentes, a basear-se pelos estudos de Brasseur de Bouboung. Informa Sílvio que Magalhães não soube entender o filólogo platino Fidel Lopes porque pensa o etnólogo que a presença de alguns radicais sânscritos na língua tupi ou guarani não significa afirmar a origem do selvagem no velho continente. A segunda inexatidão de Couto, apontada por Sílvio, se dá com relação ao cruzamento da raça branca com relação aos incas. Recorrendo mais uma vez a Fidel Lopes, ressalta que este não utilizou o termo inca para referendar um dos povos indígenas que habitaram o Peru, pois existiam outros grupos como os quíchuas, pirhuás e purhuas. E o último equívoco de Couto, apontado por Sílvio, era a existência dos diversos povos cruzados do Peru e América Central, gerando a falsa ideia de homogeneidade. Mais uma vez, serve-se

\footnotetext{
${ }^{625}$ Ibidem. p. 11

${ }^{626}$ Ibidem. p. 13

${ }^{627}$ Ibidem. p. 13
} 
de Lopes para refutar Magalhães e cita Brausseur de Bourbourg para mostrar a cegueira de Magalhães de "transportar as ideias do México e da América Central para o resto do continente" ${ }^{628}$. Mas as falhas apontadas por Sílvio sobre as hipóteses de Couto de Magalhães não paravam aqui e discorrera sobre a afirmação com relação "a raça branca ariana que com os incas cruzou o tronco vermelho do Peru. " 629

Sílvio não vê qual raça tenha sido senão a dos incas a que cruzou com os quíchuas. Aqui, reside o impasse: alguns povos da América Central, como os quíchuas, descendiam ou não da raça branca ariana? Sílvio continuava a apontar os equívocos de Couto e salientava mais um. A hipótese de Couto de Magalhães era de que, pelo fato de não se encontrarem vestígios do sânscrito no tupi como se encontra no quíchua, a raça branca que cruzara com as populações do Peru e da América Central não fora a que se misturara com o selvagem brasileiro. Salientava que a Etnologia, a filologia e a Ciência das religiões só reconheciam dois grandes troncos linguísticos, no caso: o ariano e o semítico. Para finalizar a Crítica sobre os elementos constituintes da hipótese de Couto, rebatia a ideia de que "não foi um ramo qualquer que por aqui passou" ${ }^{630}$. Significativo é o fato de que, após analisar a passagem já lembrada de Couto, Sílvio conclui com o termo "perfeitamente" e lança sua hipótese de que a língua tupi não possui relação alguma com o grupo linguístico semítico. A discussão se torna ainda mais confusa embora pertinente quando Sílvio lança as bases de oposição a Couto de Magalhães, "Os que não se acham em estado de resolver diretamente se entre as tribos selvagens brasileiras existem amostras de cruzamentos pré-históricos com o branco, porque nunca andaram pelo grande Araxá central, onde fervilha a grei cabocla, admitindo com o ilustre viajante este fato, aliás, pouco provável, não vejo que outra saída possa ter para o problema senão essas mesmas raças arianas que dizem se estabeleceram no Peru. E si os vestígios que na língua ficaram são raros, é devido a pequena escala em que, talvez, se dera o acontecimento”. ${ }^{631}$

Percebe-se que Sílvio não vê outra solução sobre a origem do selvagem americano (brasileiro) senão como sendo fruto de cruzamentos com alguma população ariana. Ao contrário de Couto, que se vale de Fidel Lopes, Nodal e Brasseur para dar validade a sua hipótese de que os índios brasileiros não descendiam da raça ariana que, por sua vez, cruzou com os quíchuas, pirhuas e purhuas, Romero lança um problema: "Como explica o etnólogo a presença de um radical sânscrito, segundo o autor invocado, em nome de países onde se falou o tupi ou o guarani e não o quíchua?” Baseando-se no escritor argentino Fidel Lopes, Sílvio deixa claro que Couto de Magalhães fez uma leitura errada do autor das Races Aryennes du Pérou pois "se aplicasse o seu método ao guarani e ao tupi

\footnotetext{
${ }^{628}$ Ibidem. p. 12

${ }^{629}$ Ibidem. p. 12

${ }^{630}$ Ibidem. p. 13

${ }^{631}$ Ibidem. p. 13
} 
transformava-os de pronto em outras tantas línguas arianas" 632 . Em seguida, alerta que “o avesamento em abusar de certos processos linguísticos como método científico tem contribuído para o descrédito dos estudos americanos conforme o célebre Livro dos Selvagens" ${ }^{633}$. A partir de então, Sílvio recorrerá à linguística para sustentar sua maior hipótese de que o selvagem brasileiro não é produto do Velho Mundo. Provando a origem sânscrita na língua tupi e guarani, afirma que Couto de Magalhães mostrou-se "pouco disposto a conter os exageros" de Fidel Lopes. Logo após, arremata afirmando:

\begin{abstract}
"Porém, note-se, não creio que o quíchua ou qualquer outra língua americana seja ariana; nem até que os povos que as falaram estivessem, em remotas épocas, em contato com as raças daquela origem. Aponto somente a inconsequência do Dr. Couto de Magalhães em jurar nas palavras de Fidel Lopes e não admitir a origem ária de muitas expressões tupis! Ele é significativo em sua opinião e declara o problema da mais instante importância; da solução deste depende, a seu ver, a segurança a respeito da origem dos selvagens que povoaram o Brasil, ou, ao menos, dos povos que com eles se entrelaçaram.

Por maior que seja o comedimento que deva conservar, declaro que não é lícito a um conhecedor exato da Antropologia do indígena brasileiro a simples lembrança do problema: si o tupi é uma língua ariana". ${ }^{34}$
\end{abstract}

Mesmo admitindo que Couto de Magalhães não conteve os exageros de Lopes, o bacharel baseia-se justamente neste escritor para sustentar sua hipótese da presença de vestígios do sânscrito no tupi e no guarani, o que não é suficiente para provar a origem do selvagem americano ao Velho Continente. Recorre à edição francesa da obra do historiador e romancista argentino:

"Le nom que lês tribus emigrantes donnèrent á leur nouvelle patrie fut Peru. Peru, em effet, veut dire em sanscrit l'orient, la mer, le soleil, lês montagnes d'or; et designe par consequent le payssitué à l'est de l'Inde, avec tous sés caracteres principaux. Aussi le même radical se rencontre-t'-il plus ou moins corrompu sur tous lês pointis du continent sud-américain: Paraggay ou Parahuay, Veragua, Beragua ou Pera-hua, Paria, Parina, Brazil ou Para-sil, etc". ${ }^{635}$

Lendo a passagem, percebemos que o nome dado pelas tribos emigradas, mesmo sem uma identidade específica, são tribos oriundas da Ásia e que batizaram a nova terra por Peru, que em sânscrito quer dizer o oriente, o mar, o sol e montanhas. Termos como tupau, taba e o próprio termo tupi deixam clara, de acordo com as reflexões de Sílvio, a presença de vestígios do sânscrito, chegando a comentar que "o caso é para lançar na perplexidade o mais sereno dos espíritos" ${ }^{636}$. Ainda na esteira da origem do selvagem que habitou o Brasil, devido aos vestígios do sânscrito encontrados no quíchua, num certo momento, Sílvio se mostra contraditório. Uma vez discordando da tese de Couto de Magalhães, escrevia:

\footnotetext{
${ }^{632}$ Ibidem. p. 15

${ }^{633}$ Ibidem. p. 15

${ }^{634}$ Ibidem. p. 17

${ }^{635}$ Ibidem. p. 14

${ }^{636}$ Ibidem. p. 15
} 
"Aponto somente a inconsequência do Dr. Couto de Magalhães em jurar nas palavras de Fidel Lopes e não admitir a origem ária de muitas expressões tupis! Ele é significativo em sua opinião e declara o problema da mais instante importância; da solução deste depende, a ser ver, a segurança a respeito da origem dos selvagens que povoaram o Brasil, ou, ao menos, dos povos que com eles se entrelaçaram ",637

Chamava atenção para o fato de Brausseur ter encontrado semelhanças entre as línguas e doutrinas de alguns povos que habitavam México e Guatemala com a presença de alguns idiomas e exemplos culturais indo-europeus que só corroboravam a idéia de filiação dos povos do Novo Mundo aos do Velho continente. Se não se trata de contradição por parte de Sílvio, quando discorda de Fidel Lopes, Brausseur e Magalhães, podemos afirmar que se trata de uma Crítica onde seus fundamentos são por demais sutis e inconsistentes, ou seja: quando Romero inúmeras vezes discorda da infinita gama de autores, lembremos que discorda em grande parte das idéias e não da Teoria. Talvez esta informação explicite a confusão de interpretação acerca de suas idéias. Lançava Sílvio duas vertentes de análise para se identificar, concordar ou não sobre a tese do arianismo das línguas americanas.

Conforme dialogava com o autor de O Selvagem, concluía que "ou deixa de crer tão amplamente na Teoria dos filólogos, Lopes e Nodal, sobre a língua americana que eles estudaram ou chegará a aceitar que o tupi ou guarani tem também resíduos dos idiomas indo-germânicos". 638 Sílvio não acreditava na filiação ariana do quíchua nem de outra língua americana com algum grupo asiático nem concordava com a tese de Couto de que, em tempos pré-históricos, tenha o índio brasileiro cruzado com o branco. Analisando o artigo veremos que Sílvio percebe alguns termos da língua tupi como sendo de raiz ariana. É que o escritor sergipano discorda da origem do homem americano não com relação à filiação da raça ariana, mas apenas em relação ao local de onde tenha esta se irradiado, ou seja: o selvagem brasileiro não é fruto do cruzamento com alguma raça branca que habitou o Peru, como defendia Couto de Magalhães em função da ausência de vestígios do sânscrito no tupi e no guarani. Embora tome posição no debate mais uma vez surgem às contradições de Sílvio. Discordando do argumento de Magalhães sobre o cruzamento do selvagem brasileiro com alguma raça branca aparecida na civilização inca - apenas uma das várias populações que habitou o Peru -, a polêmica só se cristalizava, gerando uma espécie de cadeia. Contrário a possível filiação do tupi ou do guarani por não existir nestes idiomas a presença de alguns radicais sânscritos, argumentava:

"Porém, note-se, não creio que o quíchua ou qualquer outra língua americana seja ariana; nem até que os povos que as falaram estivessem, em remotas épocas, em contato com as raças daquela origem. Aponto somente a inconsequência do Dr. Couto de Magalhães em jurar nas palavras de Fidel Lopes e não admitir a origem ária de muitas expressões tupis! Ele é significativo em sua opinião e declara o problema da

\footnotetext{
${ }^{637}$ Ibidem. p. 17

638 Ibidem. p. 16
} 
mais instante importância; da solução deste depende, a seu ver, a segurança a respeito da origem dos selvagens que povoaram o Brasil, ou, ao menos, dos povos que com eles se entrelaçaram" 639

Não seria esta uma contradição por parte do ensaísta sergipano? Qual seria, portanto a posição de Sílvio Romero? Embora assegurasse que existia a presença de alguns radicais nos dialeto tupi e guarani, admitia que "aquela Ciência, porém, não é só por si um guia seguro para a filiação das raças humanas" ${ }^{640}$, arrematando que "com referência ao tupi, qualquer filólogo, um pouco exercido na Arte do sofisma, levando o seu leitor através de artifícios, irá provar a sua inteira filiação ao grupo dos idiomas indo-germânicos" ${ }^{641}$.

Neste momento, Sílvio recorre aos conhecimentos oferecidos pela Craniometria, pela linguística e acima de tudo, pelo Evolucionismo, que foi a forma de pensamento que norteou profundamente suas análises. Sempre se mostrando sintonizado com as Teorias científicas, adentrava as qualidades anatômicas e psicológicas dos índios americanos para tentar provar a diferença do selvagem do continente investigado pelos pesquisadores da época. Do ponto de vista cultural, Sílvio justifica a diferença do selvagem brasileiro devido seu estágio evolutivo de pura selvageria. O selvagem brasileiro não conheceu os metais, alguns animais domésticos e não possuiu a noção de tempo, de semana, divergindo do pensamento de Magalhães que afirmara que o índio tinha vivenciado este estágio noutro lugar. No fundo, Sílvio Romero está interessado em apontar os elementos constituintes de sua tese de que o selvagem americano é produto do continente americano e não do Velho Mundo.

Mesmo diante da ausência de documentos - argumento sempre levantado por Sílvio - para o conhecimento do índio americano, o que não significava afirmar sua neutralidade, Romero segue analisando o artigo de Couto de Magalhães, causando uma grande confusão. Se por um lado estava sintonizado com as últimas Teorias da Ciência européia da época, recorrendo a autores dessa ou daquela área, por outro lado não se entende suas argumentações quando trata de rebater os adversários. Tomando mais uma vez Fidel Lopes, base de sustentação teórica de Couto de Magalhães, o bacharel defende o escritor argentino para rebater figuras como Garcilazo, Laet, Montesinos, e, sobretudo, Magalhães, numa discussão difícil de ser entendida. Podemos citar uma passagem de Sílvio: "Acho um pouco esquisito que o Dr. Couto de Magalhães, que abraça tão completamente as Teorias novíssimas sobre certas línguas do continente, não houvesse aceito, e mais facilmente, as afirmativas históricas do autor platino, elas que são mais bem firmadas do que as doutrinas filosóficas que as acompanham". ${ }^{642}$

\footnotetext{
${ }^{639}$ Ibidem. pp.16-17

${ }^{640}$ Ibidem. p. 18

${ }^{641}$ Ibidem. p. 18

${ }^{642}$ Ibidem. p. 22
} 
Percebe-se que Silvio diferencia o ponto de vista histórico de Lopes com relação a seu ponto de vista filosófico. Apoiando-se no escritor argentino para refutar Magalhães, discorda da filiação do selvagem americano à raça ariana que cruzou com os quíchuas porque estes povos foram responsáveis por apenas 400 anos da História peruana, o que desconsiderava a existência dos povos mais antigos como os piruás e os amautas. Tudo leva a crer que Sílvio defende a filiação ariana do selvagem americano não a partir dos cruzamentos com os quíchuas, mas como sendo resultado de povos anteriores a este grupo. Desse modo, concluía a análise a primeira parte sobre a obra $O$ Selvagem.

Num segundo momento, avaliava o estágio de atraso do selvagem americano brasileiro mesmo admitindo a ausência de documentos, uma vez que "as raças indígenas da América não poderão ter jamais uma História; não escreviam regularmente e os poucos monumentos do Peru, do México e de Guatemala são insuficientes para tal desideratum”. ${ }^{643}$ Não se entende porque, após longas análises em que recorre a escritores do campo da filologia, da linguística, da Antropologia, em sua busca desenfreada para identificar a origem do selvagem americano, encontramos passagens como esta:

\begin{abstract}
"As diferentes Teorias explicativas da origem e do desenvolvimento das raças americanas estão bem longe de ter um apoio sério da Ciência E a sua classificação é ainda incompleta por mais de uma face. É inexcedivel como prova de vacilação até para aqueles que mais se tem empenhado no estudo do problema, a maneira porque explicam o gênesis das ideias indianas". ${ }^{644}$
\end{abstract}

Nunca é demais lembrar que as conclusões de Sílvio são interpretações suas, que obviamente, podiam ser diferentes de outros estudiosos brasileiros. Após discordar da possível filiação ariana do tupi tendo por base o ponto de vista de Couto, a partir da inexistência de vestígios do sânscrito em alguns radicais dos dialetos tupi e guarani, Sílvio afirma que não é contrário ao método de alguns filólogos na busca da filiação das línguas americanas às línguas asiáticas “.....refiro-me á ideia preconcebida de encontrar aqui na América justamente os mesmos três tipos de linguagem que é costume deparar na Ásia". ${ }^{445}$ Se nem a linguística nem a filologia eram suficientes para comprovar a possível filiação do selvagem americano às raças arianas, nem por isso estava encerrada a discussão. Com a mania generalizante, por onde rumavam seus raciocínios, abria Sílvio uma estrutura metódica dependente de seu Evolucionismo histórico. A simples filiação das línguas com a divisão - já conhecida e que Muller bem conhecia à época de Couto - em arianas, semíticas e turanas, a filiação era mais que um simples nexo casual, era social e cultural: "A filiação dos povos de cada um dos grupos daqueles idiomas asiático-europeus tem uma base, além da linguística, na História. Não assim na América, onde falta este elemento do moderno método" ${ }^{646}$. Percebe-se que Sílvio abre uma discussão

\footnotetext{
${ }^{643}$ Ibidem. p.24-25

${ }^{644}$ Ibidem. p. 25

${ }^{645}$ Ibidem. p. 26

${ }^{646}$ Ibidem. p. 27
} 
e não encerra, busca encontrar de outra forma elementos para justificar suas argumentações e assim gera uma enorme confusão, o que não é necessariamente um mal. Sempre que abre uma discussão em torno dessa ou daquela questão, recorre ao esquema explicativo da Crítica científica da época, mas muitas vezes não chega a avançar as nuances do problema que ele mesmo lança. O que Sílvio pretendia apontar é que uma vez não sendo possível determinar a filiação do selvagem brasileiro à raça ariana misturada ao quíchua, nem por isso o selvagem americano era destituído de filiação ariana. O meio poderia ser a razão da diferença entre as raças, embora admitisse que este não fundasse uma delas:

“.....Uma coisa deve ser aqui dita: para explicar as diferenças das famílias americanas entre si, não é mister somente procurar-lhe uma paternidade algures; preciso observar também que as dessimilhações podem ter sua raiz na simples física das regiões que habitaram. De igual sorte, as similitudes, que de longe em longe mostrarem com as populações do velho mundo, podem ser filhas disso a que chamam os alemães o fator humano, aquilo que constitui o fundo mesmo da espécie. Há quem recorra ao princípio da raça, para explicar as diferenças de civilizações e doutrinas, em uma palavra, para dar o motivo de todas as variedades que apresenta o pensamento humano nos periodos primitivos da História, e depois deles" ${ }^{647}$.

Parece absurdo o fato de Ś́lvio criticar a idéia de que a raça sirva como elemento irrefutável para analisar as diferenças entre os povos, "Teoria nascida com o Romantismo e levada ao cabo aos últimos assentos do exagero" ${ }^{648}$, justamente por se tratar de um escritor com elementos racistas e que nunca deixou de afirmar ter sido ele o primeiro ensaísta a introduzir o elemento etnográfico na maneira de interpretar o Brasil. Entre uma contradição e outra, seguia analisando a obra de Couto de Magalhães, que oferecia a conclusão da filiação do selvagem americano com o selvagem do Velho Mundo. Como lembramos, sempre que Sílvio analisava uma discussão chamava para si os preceitos da Ciência evolutiva, positiva ou determinista, sem adentrar as nuances do argumento de que discordava. Admitindo o problema das origens e sempre se identificando como um extremo naturalista, não avançava as nuances do problema: “A História, a linguística e a Filosofia devem ser precedidas pelas Ciências Físicas e naturais, aconselham os competentes, senão é sempre certo que desnaturam as ideias sãs sobre a humanidade”. ${ }^{649}$

Dois eram os procedimentos de Sílvio para provar a origem das ideias e dos povos americanos. Um é terem filiação com os povos da Ásia e o outro é serem produtos espontâneos do continente americano. Embora a segunda hipótese tenha peso relevante depois dos estudos de Buckle, afirmava Sílvio que os dois sistemas não se excluem, mesmo que sofram com mais de um embaraço. Se por um lado fora possível uma transmigração de povos da Ásia dada a semelhança de alguns dialetos e de

\footnotetext{
${ }^{647}$ Ibidem. pp. $27-28$

${ }^{648}$ Ibidem. p. 28

${ }^{649}$ Ibidem. p. 28
} 
idéias por parte de tribos americanas, "não o é menos a falta das mesmas tendências e, sobretudo, dos mesmos resultados" ${ }^{650}$. Entre idas e vindas, entre contradições e contradições, o certo é que, afirma Sílvio, “os povos americanos, quer os inteiramente selvagens, quer os meio civilizados, seguiram uma Evolução totalmente desacorde com a dos seus supostos irmãos do velho mundo". 651

Para provar sua tese da espontaneidade na origem dos povos americanos, afirma que estes povos não conheceram os metais, ao passo que os povos da Ásia, desde eras remotas, o conheciam, deixando claro seu poligenismo. Para explicar as semelhanças entre os povos americanos com os do velho continente, motivo que levava a alguns cientistas pensarem o selvagem americano como oriundo dos povos asiáticos, afirma que "uma lei geral: o homem, sob as mesmas influências de cultura, produz por toda a parte os mesmos resultados... não é necessária uma só origem de todas as raças para explicar estas normalidades" ${ }^{652}$. Por mais que afirme a autoctonia do selvagem, americano, como “negar a filiação de algumas línguas, talvez, e a repetição de alguns fatos idênticos? ” 653

Sílvio mais nega do que avança em suas argumentações, ao mesmo tempo em que se apoia na Ciência da época, mesmo que seja para discordar "no estado atual da Ciência, porém, é arriscado contestar no todo o fato das descendências da Ásia". ${ }^{654}$ Em suas análises, mais recorre a uma gama de teóricos revestidos de suas Teorias do que adentra aos liames da questão. Se por um lado admite que o estágio da linguística, da Antropologia ou da filologia ainda seja incipiente, não deixa de tirar suas conclusões, o que é no mínimo uma contradição, e mais: sua posição sobre a origem do selvagem americano, após analisar a obra de Couto de Magalhães, é ambígua. Momentos antes, recorria a Simonin em defesa do surgimento espontâneo do selvagem americano para no parágrafo seguinte chegar à conclusão de que "em todo o caso, quer se suponha uma só origem para toda a humanidade, quer se considere que a espécie apareceu espontaneamente em vários pontos da terra, eu julgo que os dois sistemas relativos a América, de que tenho falado, não se excluem, antes devem caminhar unidos". ${ }^{655}$ O que não se entende é que, mesmo afirmando que os dois sistemas não se excluem, persiste Sílvio tentando provar o surgimento espontâneo do selvagem americano no Novo Continente.

Defendendo que as diversas áreas não conseguem oferecer um resultado cientifico devido ao estágio na qual se encontram, Sílvio encontra o argumento de que as populações mais antigas, sempre que emigravam, encontravam uma população mais antiga no local: "é esta a lei: sempre a presença ignota população, qualquer que possa ter sido o concurso posterior de novas raças". 656

\footnotetext{
${ }^{650}$ Ibidem. p.29

${ }^{651}$ Ibidem. p. 29

${ }^{652}$ Ibidem. p.30

${ }^{653}$ Ibidem. p.31

${ }^{654}$ Ibidem. p.31

${ }^{655}$ Ibidem. p. 32

${ }^{656}$ Ibidem. p.33
} 
Assim, aconteceu com as populações do México e do Peru, como também com os povos selvagens dos Estados Unidos. As conclusões de Sílvio sempre se baseiam em nomes importantes da Ciência da época:

"Na incerteza em que laboramos sobre as antiguidades americanas, é necessário, por alguns sintomas, admitir a existência de uma população originária do continente no período do homem geológico, transmigrações talvez do Velho Mundo em épocas posteriores, e, finalmente, algumas transmutações das tribos americanas entre si. Á luz destas ideias, que denunciam a incerteza dos estudos etnográficos do velho mundo e a sua crescente obscuridade para o novo continente e para o Brasil, deve ser apreciada a monografia do Dr. Couto de Magalhães" ${ }^{657}$

Se a Ciência etnográfica ainda não tem condições de averiguar a origem do selvagem americano, Sílvio tem sua posição recorrendo às mesmas idéias desta Ciência que tanto critica. Na terceira parte de sua análise sobre a obra de Couto de Magalhães, continua seus argumentos sempre com generalizações, abrindo problemas e recorrendo sempre à Crítica moderna. Dizia que Couto desconhecia o fato de que sempre que uma população imigrava existia uma população originaria.

Sabendo Sílvio do cerne do problema, articula muito bem suas idéias sem adentrar as nuances da questão, por exemplo: sendo Couto de Magalhães um extremo conhecedor da língua tupi, Sílvio discorda justamente do ponto de vista linguístico adotado pelo general para manter de pé suas convicções: "é sabido, e ele o reconhece, que a simples apreciação morfológica não adianta para a filiação das línguas, quando é certo que idiomas de natureza intrínseca diferente podem pertencer a um mesmo grupo e vice-versa" ${ }^{58}$. Mais adiante, conclui que "em um livro em que se procuram as relações de descendências das raças e das línguas americanas é claro que a divisão dos idiomas em monossilábicos, aglutinantes e de flexão pouco tinha que ver o seu ilustre autor, buscando um alvo a que ela não se presta, não poude aproveitá-la para mais nada”. Recorrendo sempre às Teorias científicas que considerava de maior crédito, dizia que "sem dúvida o nosso ilustre viajante refere algumas vezes estas expressões; mas não tratou dessa Teoria pela luz que dela poderia tirar para o seu alvo". 659

Como se não bastassem os impasses de Sílvio, citava uma passagem de Couto onde este dizia que "o fato de classificar-se o tupi e o guarani no grupo das línguas turanas não quer dizer que ela tenha o menor grau de parentesco com as línguas asiáticas". ${ }^{660}$ Vimos num primeiro momento que Sílvio discorda da filiação do selvagem americano com os povos da Ásia, mas que agora coloca em dúvida suas próprias convicções, afirmando que "será certo que absolutamente, por qualquer outra

\footnotetext{
${ }^{657}$ Ibidem. p.34

${ }^{658}$ Ibidem. p. 35

${ }^{659}$ Ibidem. p.36

${ }^{660}$ Ibidem. p.36
} 
face, entre o tupi e as línguas turanas não existia afinidade alguma?" ${ }^{661}$. Percebem-se os impasses de Sílvio na análise de toda uma obra afirmando, num primeiro momento, a espontaneidade do selvagem americano com relação ao Velho Continente e, que nos momentos finais, se contradiz: "quais as razões do indianólogo nacional para dizer-nos que o tupi não tem parentesco algum com o mongólio, o mantchu, o tibetano...porque?". ${ }^{662}$

Sílvio acusava Magalhães de não ter uma posição:

"O livro de que dou conta não mostra qual a doutrina de seu autor sobre o gênesis dos povos americanos; ele não declarou-se pelo indigenismo das raças do continente, nem pela sua descendência da Ásia. Ainda mais, não aventou sequer essa questão; entretanto, de longe em longe, as páginas de sua Memória dão-nos fragmentos de um ar um pouco absoluto. Percebe-se, de pronto, que o nosso autor tem alguma ideia preconcebida que não delucidou em seu escrito, e que por vezes irrompe e se derrama sobre o papel, ou deixa-se ler entre as linhas", ${ }^{663}$

As argumentações de Sílvio possuem até um tom cômico, afirmando que Couto tem alguma idéia pré concebida, que não chega a explorá-la, embora, por vezes, estas idéias apareçam nas entre linhas. No ponto mais interessante da obra O Selvagem, como afirma o próprio Sílvio, não vemos desenvolvimento algum diante das idéias anteriores. No capítulo O Homem no Brasil, Couto desenvolve o problema do estágio evolutivo do selvagem brasileiro. Segundo leitura de Sílvio, Couto de Magalhães defende a filiação do selvagem americano aos povos do Velho Continente devido à ausência de metais e de alguns animais domésticos, ou seja, do estágio de pastor para o estágio de agricultor, tendo atravessado este estágio num outro lugar. Sílvio discorda da hipótese de Magalhães de que o estágio pastoril, ausente no selvagem americano, tenha sido atravessado num outro local porque se assim fosse, este selvagem teria trazido consigo seus animais e seus metais. Mais uma vez, Sílvio se mostra genérico "para o conhecimento exato da posição das populações primitivas $e$ selvagens, em diferentes estados, é necessário consultar mais de uma Ciência. É preciso encará-las pelo lado psicológico, além do exterior" 664

Sílvio combatia essa interpretação sobre o estágio evolutivo do selvagem americano tendo por base os degraus civilizatórios de Comte, apontando uma contradição de Magalhães: a de que depois de muito tempo é que o selvagem americano atravessou o estágio pastoril na figura do vaqueiro: "ele que proclama que os selvagens conterrâneos eram agricultores, como explica a ausência de animais domésticos, quando não indígenas do país ao menos das regiões em que passaram pela fase anterior". ${ }^{665}$ Sílvio, sempre que pretendia provar a consistência de suas idéias, apontava o

\footnotetext{
${ }^{661}$ Ibidem. p.36

${ }^{662}$ Ibidem. p.37

${ }^{663}$ Ibidem. p.39

${ }^{664}$ Ibidem. p.39

${ }^{665}$ Ibidem. p.41
} 
desconhecimento da Filosofia ou da Ciência por parte desse ou daquele escritor. Era estratégico alegar a falta de conhecimento deste ou daquele pensador e com relação à leitura da obra de Couto de Magalhães não foi diferente
"O nosso autor devia ser também filósofo e não mostrar-se um simples curioso a traçar-nos bibliografias escusadas e a repisar-nos noções linguísticas e geológicas hoje possuídas por todos os espíritos de qualquer cultura! Porque, deixando o lado meramente industrial e exterior do caboclo, não penetrou-lhe no âmago das ideias, $e$ revelou-nos alguma coisa de extraordinário?
Suas asserções são ligeiríssimas e sente-se que ele se acha fora dos assuntos de sua predileção
Ainda assim, deu-nos este pedacinho, hoje vulgar, mas de uma verdade aproveitável...." 666

Concluía a análise de O Selvagem a partir da afirmação de Couto de que "a idéia de um deus todo poderoso e único não foi possuída pelos selvagens ao tempo da descoberta da América" ${ }^{667}$. Em sua contra argumentação, recorria à Crítica moderna que contemplava o Evolucionismo de Spencer e os estágios civilizatórios de Comte: "isto é bom, acorda-se com as idéias da Crítica hodierna sobre a marcha evolucional do pensamento humano". 668 Trazendo para a discussão o poeta Gonçalves de Magalhães que refutara Locke, pensando que os indígenas eram uns teólogos por excelência, Sílvio refutava o autor dos Fatos do Espírito Humano, "acabrunhado por uma Educação romântica" 669 à luz da concepção positiva das leis dos três estágios. Sílvio já havia lançado sua hipótese sobre o estágio de barbárie dos índios no artigo $O$ caráter nacional e as origens do povo brasileiro: "os selvagens de nosso país estavam no grau de atraso do homem geológico, o homem da idade de pedra. Não podiam ter uma Religião que reconhecesse um ser supremo. O contrário é desdenhar ou desconhecer os achados da Crítica moderna que assinala os diferentes períodos da formação das mitologias, das religiões e da Poesia" 670

Mesmo tendo preterido o Positivismo depois do conhecimento das obras de Spencer, Sílvio nunca abandonou a hipótese dos três estágios adotados por Comte
"A grei cabocla, encarada por todas as fases por que pode sê-lo pela Ciência, a luz de ideias sãs e longe do influxo de certos prejuizos, achava-se em um dos mais remotos degraus da escala da civilização
Caçador, ainda hoje no seu descendente, nem sequer estava adiante daquela segunda fase do período fetichico, a idade da astrolatria de que fala Comte". ${ }^{671}$

Antes de encerrar a análise de $O$ Selvagem, afirmara que era preciso "pegar o fio de algumas ideias inaceitáveis que se nos deparam na obra do distinto escritor, tais como o voto de uma

\footnotetext{
${ }^{666}$ Ibidem. p.41-42

${ }^{667}$ Ibidem. p.42

668 Ibidem. p.42

${ }^{669}$ Ibidem. p.42

${ }^{670}$ Ibidem. p.42-43

${ }^{671}$ Ibidem. p.43
} 
continuação de cultivo do indianismo pelo órgão de nossa Poesia”, ${ }^{672}$ assunto que era do mais importante relevo, tendo em vista sua crença nas tradições populares e na busca pela tradição indígena. Não se entende é a maneira como Sílvio conclui a análise de $O$ Selvagem, afirmando que "não o farei para não deturpar a intenção de vistas gerais sobre o indígena, que me propus, deixando a margem tudo aquilo que parece secundário diante das linhas diretas que teve também em vista o ilustre observador", 673

\section{O índio é das Américas: contra o turanismo de Teófilo Braga}

Tratando do lirismo da Europa com relação à Literatura brasileira, Teófilo Braga aludia ao selvagem brasileiro. Acreditava o professor açoriano que o lirismo da Europa meridional teve uma origem comum: era decorrente das populações oriundas da Ásia divididas em dois grupos. Desses dois grupos, um partiu do norte da Europa e o outro pelo norte do continente convergindo para o sul. A tese de Braga, a partir de então, é a defesa da braquicefalia do basco francês e a dolicocefalia do basco espanhol, tendo por base "a suposta dolicocefalia das raças da América do Norte e a pretendida braquicefalia geral das da América Meridional". ${ }^{674}$

Teófilo Braga chama a seu favor figuras como Retzius, Belloguet, Pruner-Bey e Varnhagen. A tese de Braga é a do asiatismo do selvagem americano - argumento que será desacreditado totalmente por Sílvio, recorrendo aos estudos de Broca e Morton. O naturalista Lund já dizia: “a América já era habitada em tempos em que os primeiros raios da História não tinham ainda apontado no horizonte do velho mundo, e os povos que nessa remotíssima época habitavam nela eram da mesma raça que os que no tempo do descobrimento ai habitavam". 675

Continua Sílvio a combater a tese de Braga recorrendo ao grande naturalista Lund. O fato de ter em sidos encontrados no Amazonas Artefatos cerâmicos como a nefrite e jadeite - objetos encontrados somente na Ásia - não significa aceitar a tese do asiatismo do selvagem brasileiro porque tais Artefatos bem poderiam ser resquícios dos povos residentes no Peru, na América Central ou nas Antilhas. Diante da incipiência dos estudos de Craniologia, Linguística, Arqueologia artística e industrial, ironiza Sílvio:

"já temos dúzias de Teorias para explicar a origem dos tupi-guaranis" e desfere: "eu não quero contestar um tal ou qual conhecimento prático de nossos pretendidos savants sobre um ou outro assunto referente aos selvagens; mas é tal a falta de senso crítico, tal a ignorância dos processos de linguística, de etnografia, de mitografia,

\footnotetext{
672 Ibidem. p.44

${ }^{673}$ Ibidem. p.44

${ }^{674}$ Ibidem. p.86

${ }^{675}$ Ibidem. p.87
} 
etc., tal a incapacidade filosófica de alguns desses savants, que os seus escritos merecem ir para o fogo", ${ }^{676}$

Poligenista e contrário à redução das raças americanas a um único centro de criação, explica Sílvio uma de suas hipóteses para combater o turanismo de Braga,

"Uma das marchas migratórias dos antigos povos americanos, que parecem mais esclarecidos atualmente, é a de uma corrente de norte a sul, partindo das Antilhas, das costas da América Central e da atual república de Venezuela, e chegando ao interior do Brasil, estacionando vastamente no vale do Amazonas. O estudo comparativo das antiguidades das Antilhas e da região do Amazonas demonstrará talvez ofato" 677

Vale-se de T. Mason, que estuda a antiguidade de Porto Rico, onde encontra objetos semelhantes aos do Pará, para defender a possível filiação dos povos americanos como originária do solo continental: "desprezemos de uma vez as Teorias fantasiosas e que lembram o velho biblicismo. Tal o turanismo do Sr. Teófilo Braga, prova de seu atraso em semelhante assunto”.

No artigo Ainda Teófilo Braga e o turanismo dos indígenas brasileiros é que Sílvio analisa de maneira pormenorizada a tese do português que conheceu o Positivismo por meio de Littré e os estudos etnográficos orientais a partir de Lenormant. Analisando 12 páginas de uma obra do professor açoriano, o crítico pontua as passagens em que Braga defende seu turanismo: "Uma destas civilizações proto-históricas é a das nações Scytho-mongólicas, nome que talvez seja preferível para exprimir as raças turanianas, da mesma forma que os antropologistas propõem o nome de SyroArabes e Indo-Europeus em vez de Arias" 678

Até os tempos de Colombo, que, segundo Braga tratava-se de uma raça colonizadora que chegou à América pela corrente de Gulf-Stream, a civilização turaniana influenciou a cultura no México e na Europa como o povo basco, o turco, o magiar e o francês, que eram senão "restos da primitiva civilização proto-histórica-turaniana” ${ }^{679}$. O próprio conceito de turanismo é, para Sílvio, insustentável como pensava Braga, incluindo todos os povos que não tinham origem semítica nem ariana, não passando assim de "um velho arrojo desajuizado" 680.

Defende Braga a migração de povos provenientes da alta Ásia para a Europa antes mesmo dos povos indo-europeus, razão para pensar que os povos da América do Sul são braquicéfalos, ao passo que os do América do Norte eram dolicocéfalos. Tal hipótese é, para Sílvio, "uma esperteza absurda e irrealizável a redução de tantos povos a uma única raça. Antropólogos, linguistas e naturalistas estão

\footnotetext{
${ }^{676}$ Ibidem. p.89

${ }^{677}$ Ibidem. p.90

${ }^{678}$ Ibidem. p.95

${ }^{679}$ Ibidem. p. 103

${ }^{680}$ Ibidem. p. 105
} 
neste ponto de acordo" ${ }^{681}$. Civilizações da proto-história, como a acádia, a mexicana, a peruana, a etrusca, a chinesa - civilizações improgressivas- são de origem turana. Baseado em Retzius, Braga sustenta suas ideias do asiatismo do selvagem americano, combatido por Sílvio, de acordo com as ideias de Paul Broca. Não apenas personagens célebres do cenário europeu eram mencionados pelo crítico como também nomes da importante escola do momento: a então escola americana de Antropologia,

\begin{abstract}
"Depois de Frederico Muller, Scheicher, Sayce, Whitney, Renan, Hovelacque e trinta outros terem mostrado irrefutavelmente a impossibilidade de reduzirem-se a uma só família todas as línguas extra-semíticas e arianas; depois dos mais ilustres antropólogos terem auxiliados os linguistas nessa demonstração; depois de Morton, de Nott, de Gliddon, de Broca, de Virchow, de Vogt, vir-nos ainda o Sr. Teófilo Braga atormentar com velhas momices, que fizeram o seu tempo, é contristador...." 682
\end{abstract}

Sendo até "mais exagerado do que o próprio Max Muller", uma vez que recorria o professor de Oxford aos fatores humanos para filiar o homem do Novo ao Velho Continente, Broca "mostra-se mais realista do que o rei." ${ }^{683}$. Discorda Braga até mesmo de Muller - criador da linguística comparada, conhecedor da Religião hindu e professor de sânscrito, - advertindo Sílvio que o turanismo de seu adversário não se funda em bases científicas:

"Qualquer que seja o ponto de vista em que nos coloquemos para classificar as raças humanas, ou nos baseemos nas formas cranianas, ou na cor e forma e forma dos cabelos, ou na cor da epiderma, ou na cor dos cabelos, ou na cor dos olhos; ou nos caracteres linguísticos, ou nas qualidades mentaes, sempre e sempre será uma empresa absurda e irrealizável a redução de tantos povos a uma única raça". ${ }^{684}$

Para sustentar sua tese em defesa do poligenismo, tomava as leituras de Broca em detrimento da argumentação de Braga, apoiada em Retzius e Pruner-Bey. Os povos pré-históricos, existentes antes mesmo dos arianos, não eram braquicéfalos. O turanismo de Braga possuía duas faces - o do velho continente e o americano - mas este merece atenção especial "porque os erros formigam aos cardumes”. ${ }^{685}$ Para se contrapor a esta ideia tomava, Sílvio dois artigos de Broca: Sur lês caracterères de l'homme pré-historique e Lês crânes dês Eysies et La théorie esthonienne. A partir de então Sílvio norteará suas análises principalmente nos poligenistas Broca, Morton, Nott e Gliddon. Os dois argumentos levantados por Braga para filiar os povos americanos ao Velho Continente são dois, quais sejam: a ausência na América de grandes primatas, como o gorila e o chimpanzé; e, a presença de nefrite e de jadeite, que são encontrados em seu estado natural somente na Ásia.

\footnotetext{
${ }^{681}$ Ibidem. p. 106

${ }^{682}$ Ibidem. p. 100

${ }^{683}$ Ibidem. p.104

${ }^{684}$ Ibidem. p.105-106

${ }^{685}$ Ibidem. p. 108
} 
Logo, Sílvio descarta estes dois argumentos levantados por Braga, tirado de Prichard. Em primeiro lugar, a não existência dos primeiros mamíferos não significa considerar o selvagem americano oriundo do velho continente, pois "é apenas considerado um parente colateral afastado. Se não é filho, também não é irmão; é um primo em terceiro ou quarto grau" ${ }^{686}$; e outra porque "além de tudo o animal que Darwin supõe ter sido o progenitor imediato do homem não foi ainda encontrado em parte alguma da terra”. ${ }^{687}$ Segundo Romero, se o progenitor do homem como prega a explicação darwinista, nunca foi encontrado na América, também não foi encontrado em nenhum lugar da terra. Com isto, ao contrário de Agassiz, fica de pé a tese de Sílvio da autoctonia dos povos americanos. O outro argumento de Sílvio para contrapor-se a Braga refere-se à presença de Artefatos como a nefrite e jadeite se baseia a partir dos estudos de Meyer, onde mostra que estes Artefatos foram encontrados não apenas na Ásia, mas na Europa e no Alasca, que faz parte do continente americano. Braga ignorava justamente aquilo que Sílvio fazia questão de relevar: os estudos antropológicos de poligenistas como Morton, Nott e Glidon: “o Sr. Teófilo Braga desconhece tudo isto, ignora também radicalmente os trabalhos da escola de Morton, Nott e Gliddon e mete-se a falar da América com os velhos subsidios de Prichard... É singular". ${ }^{688}$

Acompanhando a classificação das raças concernente à América do Sul fixada por d'Orbigny e relevada por Prichard, afirmava Braga que estas raças são braquicéfalas - o que seria semelhante aos povos mongólicos -, ao passo que as da América do Norte são dolicocéfalas. Baseava-se Braga nas conclusões erradas tiradas de Broca com relação aos bascos e nas de Morton, que seriam os povos do norte dolicocéfalos e os do sul braquicéfalos. Pensava Braga que as primeiras raças seriam braquicéfalas, ao que se opunha frontalmente Sílvio por meio das leituras de Morton, "Veio Broca e interpôs o seu juízo fundado na observação. Não há tal, retrucou ele, houve na Europa raças dolicocéfalas anteriores aos arianos, e quanto aos próprios bascos, os do norte são braquicéfalos e os do sul dolicocéfalos; a Teoria não tem razão de ser, por andar em desacordo com os fatos. Tal o resumo das doutrinas do sábio francês " 689.

Para que fique claro, esta seria a hipótese de Braga baseada nas leituras de Broca, contestada por Sílvio. Mas a sustentação maior de Sílvio, para se contrapor ao turanismo de Braga, viria a partir dos estudos de Morton "que estudou o mais que pode os selvagens da América do Norte, reconhecendo neles caracteres que os afastam das raças mongólicas em que são infundadamente filiados" ${ }^{690}$. Embora tenha Morton escrito algumas informações erradas pelo desconhecimento dos selvagens

\footnotetext{
${ }^{686}$ Ibidem. p. 109

${ }^{687}$ Ibidem. p. 109

${ }^{688}$ Ibidem. p. 110

${ }^{689}$ Ibidem. pp.111-112

${ }^{690}$ Ibidem. p. 112
} 
americanos, utilizou-se da classificação de Retzius e jamais afirmara "o erro do predomínio da braquicefalia dos selvagens da América do Sul ${ }^{, 691}$. Para combater a tese de Braga de que os povos da América do Sul eram braquicéfalas e os da América do Norte dolicocéfalas, Sílvio remete a duas figuras brasileiras, discípulos do grande naturalista Lund, que eram Rodrigues Peixoto e Batista de Lacerda. Uma das bases teóricas de Braga que era Prichard revelava-se um péssimo guia diante dos estudos de Morton. Desse modo, para Sílvio não passava Braga do defensor de velharias caducas, ferrenho publicista e "adorador da descendência do fantasiado patriarca Tur; no Mundo Novo achase no ponto de vista dos jesuitas dos séculos XVI e XVII". 692

Para Sílvio, Morton não pensava serem os habitantes da América do Sul braquicéfalos pois "foi justamente o chefe da escola que repele as ideias agora desastradamente advogadas pelo escritor português". ${ }^{693}$ Findava Sílvio sua aversão ao turanismo de Braga relevando oito argumentos extraídos do célebre livro Types of Mankind, de Nott e Gliddon:

$1^{a}$. O continente americano foi desconhecido pelos antigos egípcios, pelos chineses, pelos gregos, hebreus e romanos;

$2^{a}$. Por ocasião do descobrimento este continente era povoado por milhões de homens que se pareciam e mostravam traços característicos, morais e físicos, inteiramente especiais, e em perfeito contraste com os habitantes do velho mundo;

$3^{a}$. Tais raças estavam cercadas por toda a parte de animais e plantas especificadamente distintos dos do velho mundo, e originados indubitavelmente na América;

$4^{a}$. Estas raças falavam muitas centenas de línguas que aproximando-se na estrutura gramatical, distanciavam-se nos vocabulários, e eram radicalmente distintas dos idiomas do velho mundo;

$5^{a}$. Seus monumentos, como se vê pela arquitetura, escultura, cerâmica, bancos de conchas, testemunham uma avançadíssima antiguidade por sua extensão, disseminação e número incalculável;

$6^{a}$. O estado de decomposição dos esqueletos dos tumuli e determinadamente a estrutura anatômica particular do pequeno número de crânios restantes provam que os construtores destas obras eram não só antiquíssimos, como autóctones: porque os crânios americanos antigos e modernos não se parecem com os de qualquer outra raça antiga ou moderna;

$7^{a}$. Os indígenas americanos não possuíam nem alfabeto, nem verdadeiro sistema de escrita fonética; não possuíam nenhum dos animais domésticos, nem a maior parte das Artes do hemisfério oriental; suas plantas eram indígenas;

$8^{a}$. Seu sistema aritmético era único em gênero; seus conhecimentos astronômicos eram sem a menor sombra de dúvida de origem cisatlântica, e seu calendário não se parecia com nenhum dos pertencentes aos povos antigos ou modernos do outro hemisfério. ${ }^{694}$

\footnotetext{
${ }^{691}$ Ibidem. p. 112

${ }^{692}$ Ibidem. pp.113-114

${ }^{693}$ Ibidem. p. 114

${ }^{694}$ Ibidem. pp.115-116
} 
Para concluir de maneira muitas vezes agressiva - o que sempre fez com seus opositores -, acusava Braga de pilhar doidamente notinhas de Broca, causando espanto por suas conclusões com relação ao turanismo: "Não conheço em tudo quanto tenho lido em minha vida igual exemplo de desconcerto e esquisitice" 695

\section{Um romântico diferente: o índio na Literatura brasileira}

Sendo um espírito tão científico e sempre de posse das últimas Teorias oriundas da critica moderna, não podia Sílvio ter maior ojeriza ao Romantismo brasileiro. As duras Críticas que moveu aos escritores da geração romântica e principalmente os da corrente indianista se davam devido à ausência, neles, do método cientifico e positivo, responsável pela imagem fantasiosa do Brasil, $O$ romanticismo inane, desconhecendo a primeira palavra de investigações positivas já muito espalhadas, multiplicou as extravagâncias e fez-no do caboclo um ente formidável e ridículo! Entretanto, lá fora, nos Estados Unidos por exemplo, o índio não era mais assunto de Poesia; tinha entrado plenamente no domínio da Ciência. ${ }^{696}$

A Crítica que moveu aos escritores do Romantismo brasileiro tinha como principal causa a falta do critério científico responsável pela criação de um Brasil irreal, que só aumentava o tamanho dos rios e da floresta brasileira, mas não falava de um Brasil real, como tanto alardeava Sílvio em seus escritos

\footnotetext{
"O que nos apresenta agora como um defeito, nossos românticos, embriagados de prodígios, sempre nos apresentavam com uma excepcional vantagem!

"Os rios mais largos..." É ainda uma abusão romântica. A maior parte dos que figuram em nossas cartas geográficas ou não existem realmente ou não existem realmente ou não merecem tal designação. Não passam de leitos secos quase todo o ano, e apenas cheios na época das chuvas. Quase todos os rios do Norte do Brasil se acham neste caso". ${ }^{697}$
}

Em sua História da Literatura Brasileira, alertava que não era mais tempo de representar o Brasil independente por meio de um caboclinho boçal, pois o momento do país era gravíssimo. Investido da missão social, combatera a imagem divulgada pelos escritores do Romantismo responsáveis pela índio-mania, porque esta

"cresceu por fatalidade e acabou por inconsciência. Vulgarizou ideias incorretas sobre os aborígines que a Ciência ainda não corrigio entre nós. Essa Poesia sublime de que eram dotados, sua meia civilização tão prometedora, a Teoria fecunda,

\footnotetext{
${ }^{695}$ Ibidem. p. 117

${ }^{696}$ Ibidem. pp.5-6

${ }^{697}$ ROMERO, Sílvio. História. Op. Cit. p. 85 ,
} 
resultado de suas cabeças bem formadas, todos estes levianos avanços para o erro, estão por ser desfeitos neste país". ${ }^{698}$

Se a independência do Brasil em relação à ex-metrópole portuguesa fora resultado das constantes lutas travadas entre parte da elite brasileira, constituída também por portugueses e algumas classes reinóis, que defendiam a colonização, coube a geração romântica nacionalizar pelos meios literários a identidade do país, buscando um ponto de partida para iniciar a História do país ${ }^{699}$. O Romantismo brasileiro foi à independência literária do país, não mais visto como mero apêndice ${ }^{700}$ da historia portuguesa divulgada a partir de nomes como Herculano e Garret. A temática do nacionalismo literário $^{701}$ tornou-se indispensável a um país recém liberto, que precisava ter sua História, identificar suas datas mais importantes tendo por base seus heróis nacionais para se adiantar na escala do progresso e da civilização. Se em alguns países europeus o cavalheiro medieval tornou-se o símbolo nacional, no Brasil, o tempo histórico era inferior e coube ao índio ser erigido como símbolo nacional.

Ao longo de três séculos, o Brasil fora visto a partir da imagem portuguesa, ligado que era à metrópole, inviabilizando qualquer modelo de projeto nacional. Surgido de um grupo de jovens brasileiros que estudavam na França, o movimento romântico se dá na medida em que atina para os elementos nacionais, sendo emblemático o lema da revista Niterói "tudo pelo Brasil e para o Brasil". Desse modo, a contribuição maior do Romantismo brasileiro reside em ter se preocupado com os elementos nacionais, mesmo de forma estilizada, influenciado que foi por escritores como Lamartine, Chateaubriand, e Cooper, etc. Atravessando três momentos, a preocupação maior de Sílvio é com os escritores da corrente indianista, como Gonçalves Dias e José de Alencar. Sabia Sílvio da visão e do projeto de identidade dos escritores românticos com sua Niterói em concomitância com os escritores do IGHB frente às reuniões palacianas assistidas pelo imperador. Recai sobre o Romantismo brasileiro a estilização da realidade brasileira constituída pelos elementos naturais como estratégia ideológica. A guerra movida por Romero aos escritores do Romantismo brasileiro se processa na medida em que o Brasil representado por estes se mostra fantasiosa

Para analisar o Romantismo brasileiro, estuda o congênere europeu, sobretudo, o Romantismo alemão, no qual se inspira. A visão romântica de Sílvio diverge de escritores como Rousseau, Hugo, Byron. O Romantismo não podia ser à volta ao Classicismo, mas sim uma nova maneira de interpretar

\footnotetext{
${ }^{698}$ Ibidem. pp.6-7

${ }^{699}$ COSTA, Emília Viotti da. Op. Cit. Da Monarquia a República. Op. Cit. pp. 19-60. Ainda. DIAS, Maria Odila Leite da Silva. A interiorização da metrópole e outros estudos. São Paulo: alameda, 2005.

700 VERÍSSIMO, José. História da Literatura Brasileira. Op.Cit.

${ }^{701}$ CANDIDO, Antonio. Formação da Literatura Brasileira: momentos decisivos. $6^{\text {a }}$. Ed. Belo Horizonte: Itatiaia, 1981.

${ }^{701}$ Ibidem. p. 14
} 
a realidade sem "o predomínio da imaginação, o principado da fantasia" ${ }^{702}$. Com relação a Victor Hugo, afirma que "Por menos que se deseje uma Literatura que seja uma expressão da realidade, uma notação da vida mundana, não é possível desconhecer a falsidade das criações dos romances e dramas do grande lirista francês", 703 .

O Romantismo de Sílvio é um movimento que transcende as teias Estéticas oriundas da prosa ou da Poesia, é um movimento nacionalista e político que somente deve ser apreciado conforme embute o que há de mais profundo numa nação. Sua maneira de analisar a contribuição indígena é reflexo direto da História alemã, que não resumia Literatura a Belas Letras e na qual o modelo de escritor era o modelo de escritor representante do povo. Combatendo os grandes escritores do Romantismo, "Mais profundo, ou antes, profundamente sério, foi o programa traçado à nova escola por Frederico Schlegel em 1796. Sabe-se que os críticos alemães excluem da escola romântica Lessing, Klopstock, Herder, Goethe e Schiller”. ${ }^{704}$ Confrontando o Romantismo francês com o alemão, Sílvio assimila a concepção romântica do último, o que não era nenhuma novidade, haja visto o enaltecimento da cultura germânica desde seus estudos realizados nos preparatórios. Aludia ao manifesto literário de Schlegel por antecipar o cientificismo e "aproximá-la das grandes lutas modernas, sem despi-la, porém, de seu caráter específico”. 705 Traçando o quadro político no qual se inseriam os escritores românticos da Jovem Alemanha, na busca de explicar a índole da Poesia e da Literatura, o que mais interessava a Sílvio era a investigação pelas tradições populares.

"Mais alentada é a ideia de quem como Grim, julga, ser a notação fundamental da
Literatura do século XIX século a volta de todas e de cada uma das naçôes as suas
criaçôes populares.
Foi esta certamente uma das grandes obras do Romantismo. Ajudado pela Crítica,
pela linguítica e pela mitografia, ele penetrou na região encantada das lendas, dos
contos, das cançoses populares. A nativização, a nacionalização da Poesia e da
Literatura em geral foi, talvez, o maior feito do Romantismo. Não o explica de todo".
706

Para Sílvio, a maior contribuição do Romantismo era a atenção votada às tradições populares que correu paralelo ao processo de formação da identidade das nações. Nunca é demais lembrar a concepção literária de Sílvio, os elementos que a fundamentavam e acima de tudo o modelo de escritor que era. Sílvio analisou a imagem do índio na Literatura sempre preso neste esquema de Literatura nacional alemã. Alude as figuras de Domingos José de Gonçalves de Magalhães, Manuel de Araújo

\footnotetext{
${ }^{702}$ ROMERO, Sílvio. História da Literatura brasileira. Transição e Romantismo. 6a. Ed. Rio de Janeiro: José Olímpio, 1960.p.779

${ }^{703}$ Ibidem. p.779

${ }^{704}$ Ibidem. p. 780

${ }^{705}$ Ibidem. p.781

${ }^{706}$ Ibidem. p.781
} 
Porto Alegre, Francisco de Sales Torres Homem, João Manuel Pereira da Silva, Cândido de Azeredo Coutinho em suas respectivas contribuições para a formação da identidade brasileira. Contrário à imagem romântica erigida por nossos escritores, era para o Romantismo alemão que Sílvio estava voltado, embora interessado pelas raízes brasileiras. Percebia apenas uma única qualidade por parte do Romantismo brasileiro: "maior vantagem da romântica portuguesa entre nós, já o disse uma vez e o repito agora, foi afastar-nos da exclusiva influência portuguesa. O Romantismo português possuía um triunvirato, por todos admirado, em que era vedado tocar: Garret, Herculano e Castilho. Tiveram no Brasil admiradores e não tiveram imitadores. Isto é significativo”. ${ }^{707}$

Se por um lado salientava a maior contribuição romântica por fugir da mera imitação dos clássicos portugueses, rebelava-se contra a imagem fantasiosa do Brasil motivada por sua paranoia científica e sedução pela verdade dos fatos. Quanto à imagem propugnada pelo Romantismo brasileiro a partir da produção literária dos escritores nacionais, exasperava-se:

"Esses escritos até agora ficaram impunes e dominam ainda a quase totalidade dos
nossos literatos. Os enganos por estes produzidos dão a prova, e é para notar que o
primeiro motivo debatido, isto é, a inspiração indiana de nossa Poesia, não tenha
feito o mais leve progresso, e as coisas continuem no mesmo pé de antes se achavam".

Os critérios que vai se utilizar para investigar a imagem do índio são senão consequência de seu modelo de Crítica: os elementos de meio, raça, e momento histórico, sempre regidos pela lei evolutiva do consensus, determinando a maneira do escritor representar o índio literariamente. É somente como elemento de um quadro social e político mais amplo que faz sentido a inquietação de Sílvio Romero com relação ao índio erigido como símbolo nacional. Munido por uma visão literária indissociável do plano das transformações culturais, resultado de sua Crítica sociológica esteada no Evolucionismo, onde os elementos devem funcionar harmonicamente, em que as idéias mais fortes vencem as mais fracas, adentra ao tema do indianismo brasileiro. Sílvio analisa mais a figura do escritor do que sua obra, ou seja, não vê a representação indígena em si mesma, mas sempre como determinada pelo caráter do autor. O crítico não investe detidamente nas obras dos escritores indianistas, se detém a elaborar uma análise psicológica ou de caráter do autor. Um dos parâmetros de investigação do indianismo é saber até que ponto trabalhou o escritor para prover a identidade do país, mas para isso é preciso analisar caracteres nacionais presentes na obra deste ou daquele escritor.

Diante de tantos nomes europeus que influenciaram a corrente brasileira identifica-se com o Romantismo mais realista à lá Balzac. De Gonçalves Magalhães, onde "o fundo das idéias é um Espiritualismo à Cousin com laivos de panteísmo", afirma que

\footnotetext{
${ }^{707}$ Ibidem. p. 915

${ }^{708}$ ROMERO, Sílvio. Etnografia brasileira. Op.Cit.p.6.
} 
"deve ser estudado com amor e interesse, porque foi um trabalhador e porque amou este país. Veja-se o poeta e ouça-se o filósofo. Felizmente ele não pertence a certo grupo de charlatães, tão comuns em seu tempo, que julgava estar a grandeza intelectual em multiplicar livros e livros para tormento do público e especialmente da Crítica" 709

Quando trata de analisar o indianismo de Gonçalves de Magalhães, Gonçalves Dias e José de Alencar para a criação de uma Literatura nacional percebe-se que o projeto nacional de Sílvio Romero é bastante diferente do da geração romântica. Ainda com respeito a Gonçalves de Magalhães,

Como representação étnica dos brasileiros, o livro é sem préstimo, por falso e incompleto; falso, porque a pintura dos caracteres selvagens e dos colonos é inexato; incompleto, porque falta ali o elemento negro, sem dúvida, sob o ponto de vista do trabalho, o mais considerável, o mais considerável do Brasil

A falsidade dos tipos indígenas, dos Aimbires, das Iguaçus, dos Pindobucus e outros salta aos olhos. É só abrir o poema e ler ao acaso. São portugueses da classe média com cores selvagens. 710

Quando resolve analisar o pensamento de Gonçalves de Magalhães (Visconde de Araguaia), é sempre de uma forma pragmática que compreende outros autores. Adentra as particularidades da prosa e da Poesia por ser um materialista em que sempre existe algo factível capaz de sofrer a análise das coisas. Pretere qualquer especulação porque sempre acreditou nos critérios da Crítica científica em que para tudo existe uma causa. Gonçalves de Magalhães

"Não passou de um discípulo de Montalverne, desenvolvido por Cousin. Disse ele que
ouviu a Th. Jouffroy, em Paris...Quando dista do pensamento profundo e do estilo
sóbrio do insigne eclético! Foi um escritor quase vulgar, sem elevação de ideias, sem
firmeza de doutrina, sem firmeza de análise, sem habilidade de forma. Girou num
círculo de raio de tão curto, que não pode enxergar os grandes astros que ilustraram
o seu século. Todos os nobres espíritos que esclareceram com sua luz a Alemanha, a
Inglaterra, a Itália e a França em seu tempo, o Visconde de Araguaia os não referiu, e
todavia, veio dizer-nos que expunha as Teorias mais acreditadas e seguia a Filosofia
que mais exalta o espírito humano!... 711

Embora critique os escritores do Romantismo, admitia talentos como Gonçalves Dias e José de Alencar. A Crítica de Ś́lvio na análise dos escritores românticos tem por base seu nacionalismo literário, onde o escritor deveria falar das coisas nacionais para só assim despertar o amor a sua pátria. Desse modo, era somente como propugnador da memória do país que Gonçalves de

709 Ibidem. p.790. De Gonçalves Dias dizia que "Uma Crítica mesquinha e incorreta espalhou aí ter sido o poeta maranhense um exagerado cantor de índios, não se ocupando de mais nada. Não pode haver maior injustiça." Ibidem. p. 920

${ }^{710}$ Ibidem. p.797

711 Ibidem. p.804 
Magalhães devia ser lembrado: "este homem deve entrar para a História, levando consigo o valor exato dos seus trabalhos". 712

A busca pela verdade e a contribuição do escritor para despertar o amor a seu país eram o maior trunfo para Sílvio. Combatendo o indianismo, salientava o que houve de mais significativo:

"Eu não sou e nunca fui indianista: sempre estive na brecha batendo os exageros do sistema, quando das mãos dos dois grandes mestres passou a dos sectários medíocres. Mas esse velho, e por mim tão maltratado indianismo, teve um grandíssimo alcance: foi uma palavra de guerra para unir-nos e fazer-nos trabalhar por nós mesmos nas Letras". 713

Não é novidade alguma Sílvio priorizar os fatores que acreditava condicionar e determinar o desenvolvimento da cultura do país indissociáveis de sua visão literária que jamais se restringiu as regras Estéticas e formais do bom gosto. Ainda com respeito a Gonçalves de Magalhães,

"Como representação étnica dos brasileiros, o livro é sem préstimo, por falso e incompleto; falso, porque a pintura dos caracteres selvagens e dos colonos é inexata; incompleto, porque falta ali o elemento negro, sem dúvida, sob o ponto de vista do trabalho, o mais considerável, o mais considerável do Brasil

A falsidade dos tipos indígenas, dos Aimbires, das Iguaçus, dos Pindobucus e outros salta aos olhos. É só abrir o poema e ler ao acaso. São portugueses da classe média com cores selvagens". ${ }^{714}$

Quando analisa Gonçalves Dias, pouco fala da contribuição indígena, recorre sempre à ação do meio, da raça e do momento histórico. Seu nacionalismo literário vinha acompanhado do nacionalismo político, respaldado pelo modelo de Crítica moderna que tanto defendera

"Há vinte maneiras diversas de estudar e apreciar um escritor. Podem-se procurar as relações gerais que ele teve com a cultura de seu tempo, mostrando o que lhe deveu e em que a adiantou; podem-se, em dadas circunstâncias, indagar o que fez e o que representa na Evolução intelectual de seu país; pode-se-lhe desmontar o espírito, procurando os elementos que o constituíram e qual a tendência que nele predominou Nesta investigação deve-se apontar a ação do meio físico e social, a parte da natura e a parte da cultura, insistir nos elementos hereditários acumulados na raça, e os elementos novos provenientes da Educação cientifica" ${ }^{715}$. (grifos nosso)

Este era o esquema que Silvio utilizou para analisar a "contribuição" do índio. Não chegava a adentrar na possível contribuição presente na obra do escritor, buscava simplesmente os fatores que a condicionavam. Como um bom evolucionista, quando investiga os escritores indianistas, traça as fases e as obras do escritor preso ao modelo de nacionalismo literário e aos fatores condicionantes de

\footnotetext{
712 Ibidem. p. 790

${ }^{713}$ Ibidem. p. 914

${ }^{714}$ Ibidem. p.797

${ }^{715}$ Ibidem. p.916
} 
seu Determinismo literário, não elaborando uma Crítica propriamente literária, mas sim mais sociológica. Com relação a Gonçalves Dias,

...é o autor do que há de mais nacional e do que há de mais português em nossa Literatura, é um dos mais nítidos exemplares do povo, do genuíno povo brasileiro. É o tipo do mestiço físico e moral de que tenho falado repetidas vezes neste livro. Gonçalves Dias era filho de português e mameluca, quero dizer, descendia das três raças que constituíram a população nacional e representava-lhes as principais tendências.

O mestiçamento, como se sabe, é no seu início uma fonte de perturbação e desequilíbrios.

O mestiço é o depositário de tendências, índoles e inclinações diversas, que nem sempre acham um ponto de apoio, ordem e fixidade. Daí o seu caráter inquieto, contraditório, anormal. Tal a razão da constante turbulência das populações americanas. $^{716}$

Analisa a imagem do índio por parte de cada escritor mais em função dos fatores constituintes da clássica tríade taineana, tendo sempre em mente o nacionalismo literário. Sílvio está preso à ideia de caráter responsável pelos valores morais e pelo talento do escritor, não é sem razão que associa diretamente a capacidade do escritor e sua produção como consequências do fator racial e do meio. Este muito explica o indianismo de Gonçalves Dias:

"Juntai a tudo isto fortes impressões de luzes e cores e vida e movimento, fornecidas
pela natureza tropical, que se expande pela região em fora que vai de Caxias a São
Luís, juntai ainda as cenas marítimas da primeira viagem a Portugal, não esqueçais
os quadros da natureza e da vida provinciana no velho reino, e nem tampouco os
panoramas indescritíveis do Rio de Janeiro e região circunvizinha; trazei a esse
concurso de fatos e circunstâncias as leituras dos poetas latinos e modernos, o estudo
das crônicas coloniais, e tereis os elementos predominantes e fundamentais do talento
poético desse valente e mimoso lirista. ${ }^{717}$

O sentimentalismo de Dias só é importante enquanto provocador de um nacionalismo literário que nem todo escritor possui, ou seja, o talento do escritor está não em sua produção e sim nos fatores que o condicionam geradora de desdobramentos. Apela reiteradamente aos fatores tantas vezes mencionados para identificar o nacionalismo literário do talento deste ou daquele escritor. Toca em sínteses generalizantes com uma concepção literária que engloba os mais diversos ramos do conhecimento, recorrendo sempre aos elementos que o condicionam. Esquecia a imagem do índio representada pelo escritor, priorizando a lei da seleção do mais forte presente na Literatura, "As leis da seleção na Literatura e no povo brasileiro dão a perceber que há de vir a triunfar na luta pela vida, neste país, é a raça branca. A raça selvagem e a negra, uma espoliada pela conquista, outra embrutecida pela escravidão, pouco, bem pouco, conseguirão diretamente para si. Os seus próprios recursos vover-se-ão em vantagem dos brancos". 718

\footnotetext{
${ }^{716}$ Ibidem. p.917

${ }^{717}$ Ibidem. p.918

${ }^{718}$ Ibidem. p. 924
} 
Seguia discorrendo acerca das raças formadoras do mestiço brasileiro, concluindo que "o leitor compreenderá a razão de discutir eu insistentemente, tratando de Gonçalves Dias, a questão do indianismo. Foi uma Poesia útil como um tônico, um abalo necessário imposto aos nervos de nossos burgueses para os arredar da mania das imitações europeias; mas não podia ser exclusivista". 719 Para fundamentar suas análises, salientava o lirismo de Gonçalves Dias sem adentrar em sua visão indígena, e quando citava o maior poema do escritor, ressaltava, "Não faço especial menção dos Timbiras, porque não passam eles de um fragmento de poema sem caráter épico, donde se colhem apenas alguns pedaços líricos", concluindo que

"Não é preciso citar trechos e trechos de Gonçalves Dias para comprovar o que tenho avançado; porque suas obras são de fácil acesso; ele é, com Álvares de Azevedo, Casimiro de Abreu, Fagundes Varela e poucos outros, do numero dos poetas mais populares no Brasil. Não me julgo, porém, desobrigado de indicar ainda algumas notações para a boa compreensão do poeta" ${ }^{720}$

Mas, o que mais interessava a Sílvio, como descreve nos momentos finais da análise de Gonçalves Dias é que o poeta "teve, como em parte já disse, perfeita intuição do problema etnográfico em o Brasil”" ${ }^{721}$. Mais à frente, ressalta que "o poeta possuía a intuição histórica e étnica deste país, o que importa um elogio, atenta a ignorância, por assim dizer sistemática, dos nossos homens de Letras em tudo o que se refere a assuntos nacionais” ${ }^{722}$. Quando comenta apenas um verso de um poema indianista, conclui que "é conhecido hoje o valor especial que a Filosofia e a Ciência moderna em geral ligam as crenças dos selvagens e do homem primitivo”. O próprio Sílvio afirma que

\footnotetext{
"Tanto quanto soube fazê-lo, mostrei a formação biológica do talento de Gonçalves Dias, indicando o que ele deveu as raças que oformaram e ao meio em que viveu, isto é, encarei-o no seu desenvolvimento ontogenético e em suas relações com a filogenia dos povos de que descende, não esquecendo a adaptação ao meio de Coimbra, do Maranhão e do Rio, onde viveu principalmente" 723
}

Falando que ainda não estava tudo dito, finaliza suas análises sobre o indianismo de Gonçalves Dias: “o nosso Gonçalves Dias, no seu pugnar pelas idéias, pelo belo e pela glória, não foi nem um derrotado, nem um vitorioso desses que fazem o seu caminho por entre cem batalhas. Ele estava mais ou menos na altura de seu meio e de seu momento histórico, e esse momento era uma época de entusiasmo e esperanças para este país". ${ }^{724}$

\footnotetext{
${ }^{719}$ Ibidem. p.927

${ }^{720}$ Ibidem. p.927

${ }^{721}$ Ibidem. p.927

${ }^{722}$ Ibidem. p.929

${ }^{723}$ Ibidem. p.943

${ }^{724}$ Ibidem. p.944
} 
Com relação ao escritor maior do indianismo brasileiro, José de Alencar, é de admirar que Sílvio não lhe dedique sequer uma lauda. Simplesmente divide os trabalhos de Alencar e afirma que teria sido uma "loucura imperdoável" se o índio tivesse sido esquecido por este escritor para concluir que

"A chamada Poesia puramente indiana é uma Poesia biforme, que nem é brasileira, nem indígena. A raça selvagem, com todos os encantos e alucinações do homem criança, virgem e travessamente agradável, com todos os aparentes eflúvios de Poesia imensa, é hoje vulto mudo a esvair-se no centro de nossa vida, no marulho de nossa civilização. Não quis ou não pode sentir as agitações de um outro viver, escutar os ruídos de outras formas de anseios, de liberdade, de crenças, de lutas, que a turba, as vezes tirânica, dos conquistadores, lhe quis fazer entender. A raça selvagem está morta; nós não temos nada mais a temer ou a esperar dela. O colono europeu não teve que dar grandes batalhas a um inimigo tenaz: teve que presenciar o desfilar triste e compungidor da multidão selvaticamente boa e simpática dos adoradores de Tupã..". 725

Se, por um lado, o Romantismo surgido na Alemanha é consequência de uma nação sem povo, Sílvio é influenciado por essa fantasiosa criação do gênio nacional habitando a alma das nações. A importância que dava ao folclore é prova cabal da influência do nacionalismo literário encabeçado pelos escritores da Jovem Alemanha. Acreditando na seleção natural das idéias, almejava mapear a contribuição de cada raça por meio de estudos folclóricos. Para isso, buscava a origem da Poesia indiana, das lendas e canções dos povos mais humildes, que jamais poderiam ser esquecidas

"As tradições populares não se demarcam pelo calendário das folhinhas; a História não sabe do seu dia natalício, sabe apenas das épocas de seu desenvolvimento.

O que se pode assegurar é que, no primeiro século (XVI) da colonização, portuguezes, indios e negros, acharam-se em frente uns dos outros e diante de uma natureza esplêndida, em luta pela vida, tendo por armas o obuz, a flecha e a enxada, e por lenitivo as saudades da terra natal.

O portuguez lutava, vencia e escravisava; o índio, defendia-se, era vencido, fugia ou ficava captivo; o africano trabalhava, trabalhava...

Todos deviam cantar, porque todos tinham saudades; o portuguez de seus lares, d'além mar, o indio de suas selvas, que ia perdendo, e o negro de suas palhoças, que nunca mais havia de ver" 726

Não se entende porque Sílvio quase nada fala sobre o maior escritor da corrente indianista, uma vez que foi um ensaísta que tanto acreditou na contribuição indígena. Sua "justificativa" vem do fato de que o índio brasileiro não representava o mesmo que na França, o Terceiro Estado, responsável pela revolução: "embalde se procurará um sério e profundo princípio social e civil deixado por ele. Em pouco modificou o gênio, o caráter dos nossos conquistadores", 727

Sendo Sílvio alimentado pelas ideias da seleção natural, pelas leis históricas, e sobretudo pela lei do consensus, o índio não podia representar o gênio, a alma nacional devido a sua inferioridade ou seu estágio civilizatório, comprovado, como ele mesmo aponta desde o momento da conquista da

\footnotetext{
${ }^{725}$ Ibidem. p.921

${ }^{726}$ ROMERO, Sílvio. Estudos... Op. Cit. p. 39

${ }^{727}$ ROMERO, Sílvio. História. Op. Cit. p.921-922
} 
América. Por não ter resistido à invasão do europeu, não foi possível, por parte do índio, uma contribuição que futuramente resultasse no gênio brasileiro ou na alma nacional. Vemos aqui que Sílvio pensa numa mistura e fusão não apenas biológica, mas moral e cultural, onde, do contato entre o português e o negro, do meio e do clima brasileiro, surja o caráter brasileiro por excelência que é o mestiço, o genuíno nacional.

\begin{abstract}
"São, pois, o gênio, a força primeira do brasileiro, e não os do gentio, que devem constituir a Poesia, a Literatura nacional.

$O$ índio não deixou uma História por onde procurássemos reviver sua fisionomia perdida. Não nos pode dá, por exemplo, o romance histórico ou o romance de costumes propriamente tais. Não conhecemos sua vida intima. E que no fundo hão revelado sobre ele quantos os tem estudado nos seus romances e nos seus poemas? O que tem dito se reduz a uma exposição de usanças meramente exteriores, conhecidas desde o século XVI, e que todos trajam de um só modo em rigor " ${ }^{728}$.
\end{abstract}

Quando Sílvio combatera a imagem romântica que tinha no índio a representação nacional, não desconsiderava este como de fundamental importância para a cultura do país, discordava apenas do exagero dos Gonçalves e da mania tupiniquim que mascarava a realidade nacional de um país bárbaro, comparado às nações europeias, só dificultando o encontro da verdadeira alma nacional, "Bem claramente é aí expresso que eu procurava então reagir contra uma dupla exageração do Romantismo: que temos um povo em tudo capaz de ombrear com os mais distintos do velho mundo, $e$ que possuímos uma Poesia popular das mais brilhantes que se conhecem". ${ }^{729}$

O escritor sergipano deu importância ao folklore brasileiro influenciado que fora pelo Romantismo alemão, formado por nomes como Schelling, Goethe, Herder e a contribuição mais importante dos estudos dos irmãos Grimm sobre a cultura popular. O Romantismo, movimento político, ideológico e libertário, permitiu o relativismo cultural em contraposição à visão eurocêntrica reinante até a Idade Média e que agora estava ligada a todo o processo de formação das nações modernas. Ultrapassando uma conjuntura de crise econômica e vivendo significativas transformações que culminariam com o regime republicano, o Romantismo de Sílvio fora um conceito não de esteta ou do escritor diletante, preso a sua torre de marfim, mas um Romantismo de libertação de um passado histórico atrasado - mesmo que desse passado se extraíssem bons elementos para a História futura, para só assim pensar nas raízes da identidade brasileira.

É somente enquanto movimento político em que a representação maior é o escritor militante, engajado, consciente de sua missão que o Romantismo brasileiro é analisado pelo crítico literário. Para avaliar a contribuição do índio a partir da imagem traçada pelos escritores nacionais, servia-se Sílvio da Crítica moderna em que inúmeras vezes se amparou para enfrentar seus adversários, acusando-os

\footnotetext{
${ }^{728}$ Ibidem. p. 922

${ }^{729}$ ROMERO, Sílvio. Estudos sobre a Poesia popular no Brasil. Op. Cit.p.32.
} 
do desconhecimento da mesma, somado ao desconhecimento da Filosofia. Se da França vinham os melhores exemplos da Crítica moderna, como um Taine ou um Balzac, era da conturbada Alemanha, vivendo disputas de política territorial e carente por uma identidade, que recorria Sílvio a nomes como Lessing e Herder, para identificar as raízes do país que levassem a e assim facultassem o surgimento de sua identidade.

A preocupação maior de Sílvio é identificar quais são os elementos nacionais a par de sua concepção etnográfica, daí sua constante busca pela origem do país, recorrendo ao folclore. Arrolava nomes e mais nomes de escritores desta ou daquela escola, esboçava fases de seu pensamento, os momentos de sua vida e de seu meio, mas a maior contribuição do Romantismo brasileiro foi olhar para o Brasil, "O Romantismo brasileiro, em seu acanhado círculo, asilou os mesmos debates que o seu congênere europeu. Seu maior título, a meu ver, foi arrancar-nos em parte da imitação portuguesa, aproximar-nos de nós mesmos e do grande mundo", 730

O índio equivalia ou era correspondente a ultrapassada sociedade imperial. Para um homem de espírito geométrico, acusado de não ter o estilo indispensável à criação Estética, em que a intuição científica modelava todas as criações do espírito humano, inclusive a Poesia, o ataque aos escritores do Romantismo brasileiro se mostra indispensável em sua denúncia social num Brasil analfabeto e miserável, repleto de vícios e defeitos. Não é estranho que tenha começado sua carreira literária criticando a imagem fantasiosa de Brasil, esboçada pelos escritores românticos, e que sua Teoria do mestiçamento colocaria para o plano futuro a resolução dos problemas brasileiros. Desse modo, a sociedade tendia ao embranquecimento: o impasse entre o velho e novo Brasil foi resolvido pela figura do mestiço, que não era nem português, nem índio e nem negro. $\mathrm{O}$ mestiço era acima de tudo a representação, no plano simbólico, de um país sem povo (nação), que carecia do estado em busca de Modernidade européia para, somente assim, entrar na História universal. Resultado da Teoria da mestiçagem respaldada nas leis e na Filosofia da História do progresso, o embranquecimento mediou o alvorecer da nova conjuntura que se abria, representação direto de Modernidade e cosmopolitismo e que acima de tudo, entorpecia o ânimo dos mosqueteiros intelectuais do país.

O índio equivalia à ultrapassada sociedade escravocrata, hierárquica, e, sobretudo, regida por uma mentalidade católica, eclética, baseada no Direito natural que impedia o alvorecer da nova sociedade, que era senão representação do Evolucionismo e da comprovação de que toda a Filosofia da História que tendia do mais simples ao mais complexo era uma argumentação inviolável e infalível. No fundo, foi a partir da Filosofia de Comte, que ditava os degraus das sociedades civilizadas tão bem aceita pela elite brasileira, que se fomentou o interesse pela questão nacional, indissociável da questão

${ }^{730}$ ROMERO, Sílvio. História... Op. Cit. p.787 
racial, surgindo daí a idéia de um caráter nacional num país mestiço e atrasado não apenas do ponto de vista cultural como no plano econômico. Legitimado simbolicamente ao longo do Império brasileiro pela Metafísica representada pela Retórica presente nos seminários e centrada na figura do índio ingênuo e participando da missão civilizadora, surgia a imagem futura do novo Brasil, moderno e cosmopolita, construído e produto direto das idéias emanadas da Europa, principalmente da França.

Não é estranho o ataque de Sílvio aos escritores sob o mecenato do segundo imperador, num período em que o país sofria profundas mudanças, favorecendo cada vez mais o advento da ordem republicana e que o crítico relata de maneira emocionante, no momento em que lançava sua obra mestra, depois de vinte anos de tanto empenho: "troa por toda a parte o ruído das festas da Abolição" 731.

Queria Sílvio encontrar o gênio, aquilo que há de mais íntimo na alma das nações, influenciado que foi pelos estudos folclóricos dos irmãos Grimm. Seja em prosa ou em verso, busca o crítico o ponto de partida onde residam os elementos identitários, sempre se apoiando nos critérios da Crítica moderna. Discorda da identidade brasileira elaborada pelos escritores românticos porque não admite que o índio possa servir de ponto de partida, defendendo as lendas e as canções populares que constituem a verdadeira alma da nação. O sentido de suas duras Críticas à visão romântica se dá porque, para Sílvio, existe uma relação direta entre raça, meio e cultura, determinando o caráter do escritor que, de uma forma ou de outra, reflete o estágio de civilização ou de barbárie em que vive, representando de uma forma ou de outra o conjunto das transformações de seu país.

${ }^{731}$ Ibidem. p. 37 


\section{VI - IMAGEM DO NEGRO (OU AFRICANO) NO BRASIL.}

\section{Escravidão: base das representações do Império brasileiro}

A população brasileira do Império sofreu com o alto grau de exclusão, em uma sociedade extremamente aristocrática e palaciana, onde muitos caminhos eram vedados aos princípios de cidadania. Recém independente, o país necessitava traçar sua nova forma de organização política, sendo estratégica a elaboração de uma Constituição que, ao menos retoricamente, amalgamasse todas as classes - contanto que as aspirações populares, estimuladas pelos princípios de soberania popular e de vontade geral, não pusessem em xeque a ordem e abalassem o mandonismo da elite agrária e dos comerciantes. Não fora fácil reger princípios formalmente universais, surgidos com o grande modelo $^{732}$ de revolução liberal das bandeiras tricolores, quando esses princípios permitiam diversas interpretações, em um Brasil ocupado pelos mais variados estratos sociais - dentre os quais, os escravos, destituídos de direitos.

Se, por um lado, parte dos estratos inferiores foram arregimentados pelos ideais liberais, até manipulados pela elite política e intelectual, por outro lado, o Liberalismo, pelo olhar da elite, apontava, a qualquer momento, um possível levante das massas ou mesmo uma revolta alimentada pelos escravos, tendo em vista suas péssimas condições de existência. Havia uma sociedade extremamente fechada, agraciada por títulos e mais títulos sob o gerenciamento maior dos Pedros, voz dos interesses da elite agrária e dos comerciantes que se beneficiaram com a independência, uma vez que o monopólio português foi abolido; mas também existia uma população despossuída que, antes mesmo do movimento político da independência, já sentia toda forma de exclusão social com a presença da violência e da miséria vivenciadas por boa parte dela.

O imaginário de uma república de maiores oportunidades teve seus primeiros ecos nas revoluções liberais influenciadas pelas idéias ilustradas do enciclopedismo francês. Não foi sem razão que, ao longo do Império Brasileiro, uma série de motins populares ocorreu, sobretudo no período regencial, misturados aos movimentos encabeçados pela elite imperial conservadora, racista e nobiliárquica. Em uma sociedade de traço proeminentemente elitista, os intelectuais brasileiros, que tanto alardearam os ideais liberais, esbarravam sempre numa realidade onde não fazia o menor sentido adotar o ideário abstrato das clássicas formas de representação, à la Rousseau.

Em um cenário onde o poder do chefe político, geralmente o dono de terra, era o próprio poder do Estado, agenciador das mais diversas formas de corrupção e abuso, em que uma das formas de

${ }^{732}$ HOBSBAWM, Eric. A era das revoluções. Rio de Janeiro: Paz e Terra 2009. 
sobrevivência era a condição de agregado, era quase dispensável tanto ornamento frente um público analfabeto. Num mundo onde predominava toda forma de violência política e se instaurava a troca de favores, em um Brasil onde o dono de terra tinha o poder de vida e de morte sobre seu agregado, a adoção de belas fórmulas abstratas parecia até dispensável. Seja analisando o Liberalismo do ponto de vista econômico, ideológico, ou político, no Brasil, essa doutrina mais não foi do que violência, perseguição, corrupção, empastelamento de jornais, brigas de famílias e rodízio entre conservadores e liberais, destituídos de um projeto ideológico que efetivamente os distinguisse ${ }^{733}$.

No Brasil, conservadores e liberais não ultrapassavam a linha de discussão em torno da centralização, em que o poder do monarca não deixava de ser um entrave ao domínio das oligarquias regionais. Frente às utopias democráticas de Raynal, Mably, Rousseau, neste país, aconteceu o movimento inverso, com a instrumentalização bem urdida do Liberalismo. O Brasil não era a Europa, onde essa doutrina se voltava politicamente contra a centralização do poder e que, no plano econômico pregava o fim dos privilégios econômicos, no caso, o Pacto Colonial, umas das práticas do Estado moderno e do Mercantilismo. Na Europa, havia toda uma conjuntura social e política que dava outro sentido à adoção do Liberalismo, com a contestação do Ancien Regim e, no Brasil, as formas representativas de poder estavam nas mãos de homens conservadores, beneficiados com a Economia rural, dependente do braço escravo.

Um olhar historiográfico permite perceber que o Brasil imperial caminhava com muitas das mesmas amarras do período colonial, em que o objetivo principal dos políticos e dos homens de Letras era livrar o país do jugo português. A tese central de Emilia Viotti da Costa elucida não apenas a influência do ideário das Luzes nos movimentos anteriores e imediatamente posteriores à independência, sobretudo os de 1817 e 1824, o que já é relevante, por mostrar a presença do espírito de contestação anterior à ruptura formal com Portugal, caracterizado, a seguir, com a vinda da Corte para o Brasil e com a ruptura definitiva consolidada oficialmente com a independência do país, como também mostra as facetas do Liberalismo brasileiro, no processo de ruptura com a ex-metrópole, gerado, concomitante, ao processo de elaboração da nação brasileira. Nossos princípios liberais esbarravam, assim, em um cenário completamente diferente do cenário europeu, mas logo tal questão seria solucionada como num passe de mágica.

Antes mesmo de 1822, a História brasileira configurava-se conflituosa: era preciso livrar-se da exploração metropolitana, num momento de ampliação dos mercados, quando não seria interessante que boa parte dos lucros brasileiros ficasse à disposição de Portugal. A elite brasileira do Primeiro Império, composta por latifundiários, comerciantes, traficantes de escravos, carecia de um discurso

${ }^{733}$ CARVALHO, José Murilo de. A construção da ordem: a elite política imperial. Teatro das sombras: a política imperial. Op. Cit. 
que arregimentasse outros setores da população em função da necessidade de se construir o novo Brasil independente, mas, ao mesmo tempo, esse Estado excluía inevitavelmente setores sociais que, de uma forma ou de outra, participaram das manifestações ilustradas da independência.

Pode-se dizer que o início da História do Brasil recém independente é a História que une para separar: em nome da nação, teoricamente e retoricamente, todos os setores sociais integram essa simbologia, mas o predomínio do primeiro momento da monarquia brasileira foi de centralização do poder, mandonismo político e uma Constituição em nada democrática. A nação brasileira independente foi, em larga escala, o prosseguimento da mesma política portuguesa, apenas com um diferencial: livre o Brasil da metrópole, carecia-se de uma elite para fundamentar as leis que regessem o país do futuro.

Mas, reger o país carecia ser possuidor de um arsenal teórico que nossa elite fora buscar em universidades estrangeiras, principalmente em Portugal, para onde se dirigiu a elite rural e de onde vieram políticos e letrados defensores do Liberalismo europeu e responsáveis pela instalação dessa estratégia política. Instruídos sob os princípios do direito canônico e conservador da sagrada Universidade de Coimbra que, segundo José Murilo de Carvalho, não fora contagiada pelo Iluminismo francês que varreu boa parte da Europa, diferente da educação processada na Espanha, a primeira geração da burocracia brasileira formou-se nessa Universidade, dada a ausência dos cursos de Direito no país.

Talvez seja essa a razão de um tal Liberalismo que, no Brasil, confundiu-se com democracia, como mostra Emilia Viotti. Parece sem sentido, mas as ideias liberais, das quais a elite brasileira tomou conhecimento nas universidades europeias, contagiaram outros setores da população, facultando as mais díspares interpretações, desde a instrumentalização de teorias liberais que a todo o momento, nas mãos de setores dominados, transformaram-se em uma aberta revolução de escravos, até em um extremo Socialismo, por parte de revoltosos que eram os mais despossuídos, configurandose, então, os limites do Liberalismo no Brasil.

Em seu estudo, Maria Odila Silva Dias mostra a trajetória de ares separatistas, sob as vestes de um Liberalismo nada democrático e tributário da Revolução Francesa, deixando claro o cenário corporificado por uma elite regional, mandatária no plano político, somada a comerciantes locais e portugueses. Mais do que lembrar a autoria da antiga tradição das ideias liberais nos movimentos que favoreceram a independência do país, é importante olhar o cenário da sociedade geral da época. Nessa ótica, para Maria Odila, "A fachada liberal construída pela elite europeizada ocultava a miséria, a escravidão em que vivia a maioria dos habitantes do país. Conquistar a emancipação definitiva e real 
da nação, ampliar o significado dos princípios constitucionais foram tarefas relegadas aos pósteros". 734

Não fora tarefa fácil para a elite brasileira, nessa fase de formação do país independente, utilizar um discurso em que a união era utopia: o primeiro império caracterizou-se pelo Absolutismo do imperador, pela criação de um quarto poder - no caso, o poder moderador -, pelo voto censitário e, sobretudo, pela corrupção nas províncias. Tarefa conflituosa arregimentar os setores desfavorecidos sabendo o Liberalismo que pairava no Brasil. Afinal, os dominantes eram homens prendados com os títulos $^{735}$ de viscondes e marqueses, formados, em grande parte, na Europa, principalmente na Universidade de Coimbra, em um Brasil imperial constituído por um lado por homens educados sob os princípios do ensino retórico e humanístico; e de outro lado, por uma população analfabeta. Seriam aqueles homens os responsáveis por legitimarem toda a organização social e política do país, sustentando a base do Império que residia na Economia do açúcar - depois, café - mantida sob o braço escravo, uma vez que eles eram a própria elite fundiária.

Numa sociedade de base escravista, as teorias da soberania popular e da vontade geral refletiam o grau de elitismo, em todos os níveis do Império brasileiro. Se na Europa a adoção do Liberalismo político e econômico tinha um determinado sentido, no Brasil era sustentado pela elite conservadora, agrária e, acima de tudo, escravista "O escravismo desmente as idéias liberais; mais insidiosamente o favor, tão incompatível com elas quanto o primeiro, as absorve e desloca, originando um padrão particular. O elemento de arbítrio, o jogo fluido de estima e auto-estima a que o favor submete o interesse material, não podem ser integralmente racionalizados. Na Europa, ao atacá-los, o universo visara o privilégio feudal. No processo de sua afirmação histórica, a civilização burguesa postulara a autonomia da pessoa, a universalidade da lei, a cultura desinteressada, a remuneração objetiva, a ética do trabalho etc.- contra as prerrogativas do Ancien Regime "736

Contrariando as monarquias centralizadas dos tempos modernos, onde predominavam o poder absoluto do rei, o monopólio e as restrições do comércio, no Brasil, todo esse cenário esbarrava na escravidão que, estrategicamente, sofria manipulação por parte da elite e contagiava a maioria de nossos letrados no afã de mascarar a realidade nacional. Concluímos com Schwarz: "de modo que o confronto entre esses princípios tão antagônicos prevaleciam com facilidade, ou melhor, adotávamos sofregamente os que a burguesia européia tinha elaborado contra arbítrio e escravidão; enquanto na prática, geralmente dos próprios debatedores, sustentado pelo latifúndio, o favor reafirmava sem

\footnotetext{
${ }^{734}$ COSTA, Emília Viotti da. Da monarquia à república. Op. Cit. p.60

735 Para uma breve leitura da sociedade nobiliárquica imperial, ver Rodrigo Ricupero. A formação da elite colonial. São Paulo: Alameda, 2008; Lilia Moritz Schwarcz. As barbas do Imperador: D. Pedro II, um monarca nos trópicos. São Paulo: Companhia das Letras, 2007.

${ }^{736}$ SCHWARCZ, Roberto. As idéias fora do lugar. In: Ao vencedor as batatas. São Paulo: Duas Cidades, $1977 . p .16$
} 
descanso os sentimentos e as noções em que implica. O mesmo se passa no plano das instituições, por exemplo, com burocracia e justiça, que embora regidas pelo clientelismo, proclamavam as formas $e$ teorias do Estado burguês moderno" 737

A adoção dos princípios liberais ocorreu à medida que respaldava teoricamente o fim do Pacto Colonial. As utopias do possível Socialismo, antes mesmo da independência do país, nunca ultrapassaram o estatuto colonial. O Liberalismo adotado no Brasil é tão somente fruto da independência do país que não rompeu com as particularidades da política portuguesa, um movimento de independência cunhado por José Honório Rodrigues como contra-revolucionário, o que leva o historiador a afirmar que "o Liberalismo do começo do século XIX não trazia a democracia, nem em Portugal, nem no Brasil, porque como já dissemos, conviveu com a escravidão e limitou as concessões liberais a certos grupos sociais. Uns eram mais "iguais" que outros, e por isso houve sempre discriminação política, reflexo da discriminação social.", 738

No plano da cultura, alguns de nossos importantes escritores, preocupados com o Brasil, como Francisco de Adolfo Varnhagen e João Francisco Lisboa, mostravam uma visão elitista elaborando uma História oficial, uma História ideologicamente "neutra", coberta pelos grandes heróis, pelos grandes acontecimentos rigidamente marcados por datas e fatos, uma História vista de cima, História que mascarava as diferenças sociais no intento de buscarem uma identidade ao país. Todas as diferenças se diluíam em nome do ideal maior do nascente Estado brasileiro, glorificado pela História oficial elaborada pelos escritores, a partir de fatos importantes, cujo objetivo maior era a criação da memória nacional,

Pertencentes à nata imperial e amigos íntimos do imperador, esses escritores eram a própria realização das estratégias políticas de um Brasil que, desde suas raízes, confundiu público com privado camuflando os interesses da classe escravocrata. Um homem como Varnhagen, agraciado com o título de Visconde de Porto Seguro, sagrado pai da História brasileira, o "Heródoto brasileiro" 739, erudito que se tornou conhecido devido a sua metodologia histórica, por sua "neutralidade" e pelo apuro no tratamento das fontes, defendia a violência sobre as classes inferiores, mascarando sua argumentação histórica no discurso maior da História nacional. Para além da erudição de Varnhagen e do amplo quadro de problemas abertos no momento de "fundação" da História nacional, cabe estreitar as relações entre os escritores - parcialmente responsáveis pela manutenção do Estado escravocrata - e os representantes diretos da classe senhorial, equacionadas pela força maior do imperador.

\footnotetext{
${ }^{737}$ Ibidem. p. 17

${ }^{738}$ RODRIGUES, José Honório. Independência: revolução e contra-revolução. Rio de Janeiro: Francisco Alves, $1975 . p .32$.

${ }^{739}$ REIS, José Carlos. As identidades do Brasil: de Varnhagen a FHC. Rio de Janeiro: FGV, 2009.
} 
Os homens que não eram brancos sempre inquietaram os políticos e os escritores brasileiros, sem os quais os discursos viabilizadores do progresso e da civilização jamais teriam sentido. De maneira sutil, sem as nuances que depois iríam florescer, sustentadas por argumentos em nome da Ciência, quando do alvoroço de idéias assimiladas pela Geração de 1870 e reflexo das idéias naturalistas, surgia um quadro de elementos que seriam orquestrados ao longo da História brasileira. No quadro maior das inquietações desse recém independente Brasil, era de primeira ordem encontrar o brasileiro, o tipo nacional, de onde surgia a identidade do país, em que estavam ligados elementos morais, como por exemplo, o atraso, a violência e muitas vezes a barbárie. Tal terminologia nada mais era do que o brasileiro, um povo novo, diferente do europeu e habitando um espaço totalmente diferente. Mesmo que os conflitos não fossem aparentes, tanto Varnhagen como toda uma geração de escritores, nesse momento, tratavam da nação, buscando encontrar uma homogeneidade que só na aparência e em suas representações existia. Para além da erudição desses letrados, a razão maior dos estudos brasileiros era diminuir as diferenças, omitindo a realidade conflituosa das classes, num país marcado pela ausência de rígida hierarquia e sem o estatuto de uma nobreza baseada nos laços de sangue que caracterizava os países europeus.

Uma vez que os princípios liberais indispensáveis ao estabelecimento das novas bases sociais do Brasil independente estavam restritos à elite agrária, cabia a ela a conclamação ao povo, em nome dos ares liberais, que equivalia à esperança de melhores dias e mais oportunidades políticas: chegará um momento em que a união das várias classes sociais tornará insustentável, e só um ideário nacional poderá ordenar e apaziguar as diferenças e divisões reais do Brasil. A distância entre a "enorme" erudição dos nossos homens de Letras e o analfabetismo das massas era patente, a ponto daqueles acreditarem que o país não tinha povo, contradição que jamais se admite quando o discurso principal desses intelectuais era o de soberania popular.

Assim, a nobreza imperial brasileira, os barões do café, estendia sua teia no campo econômico, militar, burocrático, e, sobretudo político, fechando o restrito círculo da "boa" sociedade branca, civilizada e cristã, "para manter o prestígio e aumentar a riqueza, essa elite brasonada buscou sempre o casamento entre as famílias, abastadas e "distintas". As uniões eram realizadas, preferencialmente, entre filhos de grandes proprietários de terras e de escravos, de comerciantes enriquecidos, de militares de alta patente ou de homens com projeção na vida pública, embora fossem raros os casamentos consanguíneos. Essa estratégia matrimonial, preocupada em ampliar o patrimônio, por meio de heranças, e em conservar o status, típica de uma nobreza, reforçava-se em 
função da exigência do consentimento paterno, bem como da aprovação pelo imperador, para a realização dessas uniões". ${ }^{740}$

Toda essa realidade social, integrada de uma forma ou de outra, estava nas discussões do Instituto Histórico e Geográfico Brasileiro (IHGB), mascarando a realidade hierárquica da sociedade brasileira. Foi essa a visão dos nossos primeiros letrados do Brasil, pois, conforme Manoel Luiz Salgado Guimarães, "Ao definir a Nação brasileira enquanto representante da idéia de civilização no Novo Mundo, esta mesma historiografia estará definindo aqueles que internamente ficarão excluídos deste projeto por não serem portadores da noção de civilização: índios e negros. O conceito de Nação operado é eminentemente restrito aos brancos, sem ter, portanto, aquela abrangência a que o conceito se propunha no espaço europeu. Construída no campo limitado da academia de letrados, a Nação brasileira traz consigo forte marca excludente, carregada de imagens depreciativas do "outro", cujo poder de reprodução e ação extrapola o momento histórico preciso de sua construção". 741

Para criar a sensação de um país sem conflitos, erigia-se, como objetivo maior, a nacionalidade e o amor ao país, discurso dos primeiros homens de Letras preocupados em analisar o Brasil, como a geração romântica, que depositou na Literatura o papel de despertar o sentimento nacional, do qual, até os dias de hoje, boa parte da Literatura nunca se eximiu. Tanto a História oficial elaborada pelos homens de Letras do IHGB quanto a ideologia dos escritores românticos trataram de legitimar a sociedade de corte do Império, uma sociedade hierarquizada, num Brasil temerário a setores sociais desfavorecidos, como negros e indígenas, embora não existissem as teorias hierárquicas do racismo científico que excluía e controlava socialmente esses setores. Como aponta Guimarães, os escritores brasileiros formularam seus projetos nacionais, a serviço da nova nação branca, católica e civilizada, num Brasil de negros e índios que foram excluídos de um processo histórico, do qual, a priori, participaram.

Todo o discurso do IHGB girava em torno da criação e legitimação de um Brasil branco “civilizado". Nessa ótica, ser "civilizado" equivalia a ter costumes europeus, ser cristão e, acima de tudo, branco. Mais que isso, tal visão era uma maneira sutil de dotar o Brasil não apenas de tais costumes civilizados, mas de explorar o país no plano econômico. Fazia-se necessária a crença na evolução histórica, como alguns escritores da época pensavam, tendo que, para isso, se apegarem a uma verdade documental, a todo um trabalho de erudição que encontrou no Instituto o maior centro de criação de saber da época. Tais homens eram influenciados por uma tradição iluminista, herança do

\footnotetext{
${ }^{740}$ NEVES, Lúcia Maria Bastos Pereira das. O Império do Brasil. Rio de Janeiro: Nova Fronteira, 1999. p. 272

${ }^{741}$ GUIMARÃES, Manoel Luis Salgado. Nação e civilização nos trópicos: O IHGB e o projeto de uma história nacional. Estudos Históricos. Rio de Janeiro, n. 01, 1988. p.7
} 
Instituto de Paris e, se elaborarmos um breve perfil sociológico, veremos o mundo "civilizado" do projeto nacional do Brasil independente. Dada essa exclusão acima salientada, se não encontramos racismo num Visconde de Porto Seguro, como afirma Odália, a associação entre raça e cultura é por demais clara.

Em nossos primeiros cronistas, pertencentes aos quadros da Igreja ou não, percebemos de maneira acintosa a associação entre raça e barbárie. Nesses primeiros ensaios acerca da História do Brasil, predomina a associação entre raça "inferior" e cultura "inferior", ou seja, coexiste a idéia de que as raças indígenas e africanas são culturalmente inferiores. Fossem ou não da cor de cobre, o certo é que essa associação favorecia, de maneira sutil, a interpretação de um país multirracial escalonado por níveis de superioridade.

Assim é que, em meio a milhões de índios e negros africanos, tratou o Estado brasileiro de dissipar toda e qualquer impressão de ódio entre as raças, de homogeneizar a História nacional dividida entre tantas Histórias regionais, de aglutiná-las sob o manto divino de Pedro de Alcântara, o maior ícone da História brasileira da segunda metade do século XIX. Os intelectuais, em nome do Estado, fazendo uma História dos evenements, baseada nos grandes homens e nos grandes feitos, legitimavam não apenas a política imperial, como essa própria História nacional.

Para além do debate historiográfico, positivista, conservador e elitista dos intelectuais envoltos na elaboração desse Brasil, o objetivo maior desses primeiros escritores era a narrativa de uma História de um país que se libertou da mãe pátria sem ruptura violenta ou crises políticas, em nome de um ideal maior e geral que era a nacionalidade.

Mas não era difícil encontrar, por todos os lados, o caráter elitista dos ilustrados brasileiros pautados pelo modelo de História produzida pelo Instituto Histórico Francês ou pela ideologia civilizadora iniciada pelos primeiros escritores românticos, nos primórdios do movimento de independência literária, que residiam fora do Brasil. Se já não bastassem mais de três séculos de exploração pela metrópole do imaginário brasileiro elaborado por cronistas, alguns que sequer estiveram no país, seguidos de uma "Literatura de viagens" e, mais tarde, por uma prosa ficcional ainda presa ao imaginário fantástico, os líderes do Romantismo brasileiro introduziram uma nova visão de país, com os pés fincados no berço fino francês.

Se a grande contribuição do Romantismo foi olhar para dentro do país, com uma visão estilística composta pelos elementos da fauna e da flora brasileira, ele não deixou de mascarar e mitificar a História nacional, dando a idéia de homogeneidade e de harmonia nos mais variados campos do olhar. O próprio lugar de onde fala o historiador é por si só excludente devido à dificuldade de adentramento por parte da maioria da população. Segundo Certeau, "antes de saber o que a História diz de uma sociedade, é necessário saber como funciona dentro dela. Esta instituição se inscreve num complexo 
que lhe permite apenas um tipo de produção e lhe proíbe outros. Tal é a dupla função do lugar. Ele torna possíveis certas pesquisas em função de conjunturas e problemáticas comuns. Mas torna outras impossíveis; exclui do discurso aquilo que é sua condição num momento dado; representa o papel de uma censura com relação aos postulados presentes (sociais, econômicos, políticos) na analise. Sem dúvida, esta combinação entre permissão e interdição é o ponto cego da pesquisa histórica e a razão pela qual ela não é compatível com qualquer coisa. É igualmente sobre esta combinação que age o trabalho destinado a modificá-la. ", 742 (grifos nosso)

A fala de Certeau exprime a visão e as intenções dos letrados brasileiros na configuração da nação. Quando da adoção do método crítico da Ciência histórica, percebe-se o caráter ideológico e excludente dessa vertente historiográfica. Influenciados pelo Positivismo de Ranke, os letrados brasileiros superestimam as fontes documentais e o processo linear onde não cabem rupturas. Trata-se de uma leitura social que não permite questionamentos, no que acarreta a passividade do historiador frente à História passada: os documentos falam por si e os liames da investigação giram dentro deste processo hermenêutico.

A argumentação dessa História positivista era bastante óbvia: a política imperial do Brasil era a continuação da política dos Bragança. Nessa nação, não apenas o processo histórico era linear e evolutivo, como o centralismo predominava sobre o provincial, a igualdade sobre as diferenças, o Catolicismo sobre os vários ritos e crenças, a união sobre as guerras de raças, tudo parecendo ser homogêneo, confluindo, construindo e cristalizando o ideal patriótico. Elucidativo é o último capítulo de História Geral do Brasil: "Bem longe estamos de acreditar que a verdade histórica se aquilate pelo número das autoridades; não sendo estas, aliás, às vezes, mais que reprodução ou plágio umas das outras; e antes pelo contrário todos sabem que, conforme o mais judicioso critério histórico, casos há em que o depoimento de uma só testemunha presencial, conscienciosa, pode completamente destruir invenções e calúnias que se tiverem ido repetindo por um chorrilho de escritores de pouca autoridade; chorrilho, com razão comparável às armadilhas das cartas de jogar dobradas ao meio, que servem de divertir as crianças, quando a primeira, que cai, arrasta consigo a queda de todas as demais. Mas é também sem dúvida que o que sobra não prejudica; e que é somente reunindo todas as testemunhas e acareando-as entre si, e com certos fatos conhecidos, que se atina com a verdade histórica". ${ }^{743}$

Nesse sentido, Varnhagen é figura singular por ser representação direta da elite brasileira abrigada e confundida com Estado, em extrema aversão aos estratos menos prestigiados que foram

${ }^{742}$ CERTEAU. Michel de. A Escrita da história. Rio de Janeiro: Forense Universitária, 1982. p. 76.

743 VARNHAGEM, Francisco Adolfo. Escritores, viajantes, letras e imprensa periódica no reinado. In: História Geral do Brasil: antes de sua separação e independência de Portugal. Rio de Janeiro: H.Laemmert. p. 
envolvidos por um modelo de Liberalismo conservador, somente continuador da política portuguesa dos Braganças a que, no Brasil, resumiu-se a ruptura colonial, mantendo as mesmas estruturas econômicas e políticas, deixadas durante um bom tempo sob as mãos do monarca. O barão e depois Visconde de Porto Seguro é produto de todo um contexto onde era necessária a busca pela identidade nacional brasileira, dando-lhe validade somente enquanto categoria abstrata aurida pelas falácias do constitucionalismo europeu.

Mencionar Varnhagem só faz sentido quando se atina para todo um quadro estrutural do momento, clareando a intrínseca relação entre o cenário político e econômico, revelador das idéias do constitucionalismo francês repercutidos no Brasil de então. Entende-se, portanto, a bagagem iluminista de Varnhagen ao neutralizar os conflitos sociais em nome da unidade harmônica, objetivando a manutenção de um status quo.

Enaltecedor da colonização portuguesa nos trópicos, Varnhagen destaca-se não só pela quantidade de informações que forneceu, pois antes dele existiram outras Histórias do Brasil. Sua importância deve-se a ser um escritor a serviço da monarquia brasileira, de uma nação que mesmo independente pouco alterou de sua política de estatuto colonial. A História contada por Varnhagen é a História da formação do Estado nacional, um Estado que se formava sob as bases do patriotismo, do conservadorismo, do racismo e do catolicismo "Varnhagen defende a presença portuguesa, ele faz o elogio da colonização portuguesa, é compreensivo com os seus erros e despotismo. A independência não foi prejudicial porque garantiu a continuidade do Brasil colonial no nacional: um Brasil português. A independência não interrompeu o passado, melhorou-o. O Brasil continuava português, imperial e ainda por cima independente! A nação brasileira seria construída racionalmente pelo Estado imperial, autoridade indiscutível, absoluta. A independência não foi problemática porque o Estado não foi comprometido: continuava nas mãos da dinastia de Bragança. O Estado brasileiro será construído sobre o modelo do Estado português. A unidade deverá ser preservada a qualquer custo. O Estado funcionará como um imã da nação gigantesca: assegurará a ordem, a lei, a religião, a unidade. Ele continuava a ação civilizadora da Europa branca. O novo Estado nacional garantirá o conservantismo, a continuidade. O cristianismo sustentará o regime monárquico". ${ }^{744}$

Diplomata, viajado pelos países da América do Sul e da Europa, apaixonado pelas informações contidas nos arquivos por onde andou, amigo de D. Pedro II, o amante e mecenas das Letras e das artes, Varnhagem se insere numa conjuntura, onde a História se liga às estratégias políticas do Brasil independente. Com vínculo estreito com a monarquia portuguesa, pode-se falar claramente de Varnhagen sem perder de vista sua devida importância quando do momento histórico no qual se

\footnotetext{
${ }^{744}$ REIS, José Carlos. As identidades do Brasil. Op.cit.p.46.
} 
buscava constituir a identidade do país. Informa Temístocles Cezar que "Varnhagen escreveu, segundo ele, a História da colonização portuguesa no Brasil. Uma História da vitória da civilização sobre a barbárie. A História da construção da nação brasileira. Uma História, portanto, dos vencedores. Mas o próprio Varnhagen seria um vencedor? Sua luta para ser reconhecido, em primeiro lugar como brasileiro, após como historiador e diplomata, finalmente como nobre, não foi exatamente um empreendimento pessoal bem-sucedido. É preciso lembrar que Varnhagen é brasileiro por decreto imperial. Sua carreira diplomática, pelos postos que ocupou, é aparentemente um sucesso, mas tanto na América Latina como na Europa ele lamenta as atribulações e dificuldades, que, mesmo inerentes à diplomacia, são encaradas por ele muitas vezes como um fardo que o desvia do principal: suas pesquisas". 745

Identidade de que carece e que se forma, como pontua Hobsbawm, a partir de uma mesma língua, de costumes, de um mesmo território partilhado, de grupos oriundos de um mesmo grupo étnico, traço mais marcante de um Brasil, como lembrava Sílvio, em vias de formação, e como tal, constituída pelas diversas raças que, ao mesmo tempo em que faziam parte do grande "processo civilizador", por outro eram excluídas deste mesmo processo, pelas características do projeto em que se constituiu a instauração da independência no Brasil. Ao mesmo tempo em que múltiplas raças, crenças e credos participavam desse país recém independente, o que vingou foi um Brasil aristocrático, ilustrado e excludente, tanto socialmente como politicamente, o que não deixou de ser um processo ambíguo e autoritário.

O processo que buscava encontrar o brasileiro, em que o patriotismo e o sentimento nacional se faziam presentes, cada vez mais, alijou a maioria do povo brasileiro. A estratégia política, encapada sempre por um discurso nacional, fora bem urdida: o Estado era a representação direta da nação, o que era a consciência nacional, pátria, ou melhor, era o sentimento e a aspiração do próprio povo brasileiro. Ou seja, o projeto nacional brasileiro se consumou, enquanto parte desse discurso nacional, em que a maioria da população não percebe interesses particulares, por ser indispensável aos projetos políticos tanto de liberais como de conservadores, que no Brasil partilhavam das mesmas práticas políticas, permeadas por interesses econômicos e disputas intelectuais, os quais definiam até a própria escrita historiográfica.

Nesse sentido, Varnhagem é figura extremamente relevante por ter sido "um dos maiores trabalhadores da História do Brasil, para cuja bibliografia contribuiu decisivamente, criando um modelo de síntese que seria muito adotado e repetido; e informa ainda a versão oficial, às vezes até

${ }^{745}$ CEZAR, Temístocles. Varnhagen em movimento: breve antologia de uma existência. TOPOI, V.8, $\mathrm{n}^{\circ}$ 15, Jul-Dez. 2007.p.193. 
em aspectos convencionais e contestáveis". ${ }^{746}$ Escrevendo à luz da erudição, que tem por base os fatos históricos, amparado sob a verdade documental, influenciado pelo modelo crítico-histórico que teve em Ranke o maior nome, Varnhagen celebrava e legitimava simbolicamente a unidade histórica do império brasileiro. Há de se perguntar por que Martius, ganhador do concurso em 1843, no IGHB, acerca da melhor História do Brasil, reconhecido como o primeiro escritor a ter esboçado o brasileiro como fruto da concorrência das três raças, pouco é lembrado como responsável por uma teoria brasilianista, recorrendo o leitor sempre ao Martius que apontou a concorrência das três raças, chamadas pelo botânico de forças diagonais.

Vale ressaltar, também, que a História de formação do império brasileiro se confunde com a própria História de Pedro de Alcântara, desde os tempos de infância até o período em que o moço já estava na hora de casar. Schwarz analisa detidamente todo o processo de como se deu a "monarquia nos trópicos”, que girava em torno da inviolabilidade imperial de Pedro II. A autora descreve todo o processo de transformação e de transplante da monarquia, agora fincada nos trópicos, dotados de população composta de negros e índios, tendo que se adaptar a um cenário, onde os padrões finos da cultura europeia agora encontravam um cenário completamente diferente.

"Não havia como esquecer a existência da escravidão, que por sua vez tornava a monarquia brasileira absolutamente singular. Na época, 45,6\% de um total de 79321 pessoas eram escravos no Rio de Janeiro, dando às ruas um colorido especial. Nesse Império, o universo do trabalho resumia-se ao mundo dos escravos. Vendedores ambulantes, negras quituteiras, negros de ganho oferecendo-se como pedreiros, barbeiros, alfaiates, funileiros e carpinteiros eram figuras obrigatórias nas ruas da cidade.

Mas a vivacidade das ruas não correspondia à estrutura da sociedade, hierarquizada, violenta e desigual. Aí se apresentava a grande contradição, que não se limitava ao traço de Debret: como afirmar a imagem civilizada e constitucional dessa monarquia ao lado da realidade escravocrata?

Não obstante, nas imagens oficiais era a mistura de elementos que dava colorido à jovem nação que se emancipava. Cem anos depois, um artista popular anônimo mostrava como era forte o imaginário desses momentos inaugurais. No quadro a seguir, d. Pedro I aparece ao lado de José Bonifácio, o artista Debret logo atrás. Trata-se da elaboração dos emblemas do novo país, mas o que mais interessa é a união de personagens. Perto das figuras oficiais uma negra escrava (ajoelhada) e um indígena com expressão pensativa observam a grande cena. Bela imagem de congraçamento, nessa releitura popular de inícios do século $X X{ }^{\prime \prime}{ }^{747}$

Além da análise minuciosa que faz a autora, esmiuçando os elementos constituintes do imaginário não apenas do imperador, que era a própria imagem do Império brasileiro, por meio do farto material iconográfico de propriedade do próprio monarca, como também da criação de telas a óleo e gravuras que

\footnotetext{
${ }^{746}$ IGLESIAS, Francisco. Os historiadores do Brasil: capítulos de historiografia brasileira. Rio de janeiro: Nova fronteira; Belo Horizonte, MG, IPEA, 2000.p.91.

${ }^{747}$ SCHWARCZ, Lilia Moritz. As Barbas do Imperador. Op.cit. p. 60
} 
só estilizavam a realidade brasileira, no processo de construção da "monarquia nos trópicos", é mais vantajoso perceber a realidade daqueles que não integravam o círculo do imperador, perscrutar o mundo em que viviam as pessoas que não integravam os círculos da corte, para compreendermos tanto o processo construtivo da maior figura do Segundo Reinado do país, o ilustre erudito, baseado no modelo dos grandes monarcas europeus, como também a conjuntura maior do Brasil de então.

A moda à européia, todo o processo simbólico construído pelos escritores da época, cada vez mais tornava o imperador um mito ou o grande herói da História brasileira, onde os reais problemas do momento eram mascarados, como por exemplo, a existência da escravidão na monarquia tropical e as péssimas condições de higiene que a própria corte presenciou quando de sua chegada em 1808, entre outros aspectos. Com tantos problemas, o atraso do país era associado de maneira mais ou menos sutil à barbárie das raças inferiores, dando sentido a um discurso homogêneo: "uma intenção muitas vezes abertamente expressa de construção de uma representação de porte nacional, por meio da oficialização e proliferação de rituais, da criação de monumentos e de um "passado" cuja continuidade temporal levaria ao Império —, já na releitura das festas populares o que está presente é a imagem mítica do rei, de um rei sagrado e religioso que nesse sentido não tem data nem lugar". 748

As inúmeras representações aludidas pela autora, dentre elas a iconografia, confundindo-se com a auto-imagem que o monarca queria ou idealizava do império, não é gratuita. Era fruto de um imaginário europeu que em nada correspondia à monarquia tropical, constituída por milhares de escravos, onde ao mesmo tempo em que se celebrava um "padrão de comportamento que molda o país", predominava o Reino de Obá, tamanha era a presença do homem de cor, o que dá sentido à fala de Luiz Felipe de Alencastro: "Tamanho volume de escravos dá à corte as características de uma cidade quase negra ena seqüência do boom do tráfico negreiro dos anos 1840 - de uma cidade meio africana. No núcleo urbano do município, formado pelas nove paróquias centrais, as percentagens eram menores, mas o impacto da presença escrava parecia maior, na medida em que envolvia o centro nervoso da capital, sede dos principais edifícios públicos, as praças e as ruas e o comércio mais importante do Império. Do total de 206 mil habitantes que moravam na área nos anos 1850, 79 mil (38\%) eram cativos". 749

Não sendo tão tropical a monarquia no Brasil, era discrepante a situação da Capital do Império que de um lado aspirava ares de "civilidade" e de outro mostrava um cenário nada promissor: no censo de 1849, de cada três habitantes da Corte, um provinha da África. Mais do que simples aferições de cor a recém-formada elite do país construía a ideologia de um temor em relação ao negro, ou seja: a monarquia brasileira era ameaçada pela presença do escravismo presente não apenas na Corte, como nas demais

\footnotetext{
${ }^{748}$ Ibidem. pp. 26-27

${ }^{749}$ ALENCASTRO, Luiz Felipe de. Vida privada e ordem privada no Império. NOVAIS, Fernando A. In: História da Vida Privada no Brasil. São Paulo: Cia das Letras, 1997.p.25.
} 
províncias: "Na tentativa de garantir e criar uma nova nação, desvinculada da "pátria", as elites do sul do país apostaram claramente, portanto, na monarquia e na conformação de uma ritualística local. A realeza aparecia, em tal contexto, como o único sistema capaz de assegurar a unidade do vasto território e impedir o fantasma do desmembramento vivido pelas ex-colônias espanholas. É nesse sentido que a monarquia se transforma em um símbolo fundamental em face da fragilidade da situação. Transcendendo a figura humana do rei, as representações simbólicas do poder imperial evocavam elementos de "longa duração" que associavam o soberano à idéia de justiça, ordem, paz e equilíbrio". ${ }^{750}$

Essa História camuflava, então, os embates sociais e as diferenças regionais de uma sociedade por demais excludente. A nação que se gerava referendava índios e negros somente para excluí-los do processo civilizador, autorizando ao branco "civilizado", representante de "melhor" cultura, o papel de ditar os caminhos do Estado brasileiro, à época. Elaborado a partir das normas abstratas do constitucionalismo francês, fundamentado pela soberania popular e pela vontade geral, influência do Liberalismo europeu, nossos primeiros escritores e políticos manipularam e transformaram o que seria ares de melhores dias em autoritarismo e violência. Os mais proeminentes políticos e os mais ilustres homens de Letras brasileiros, alguns de linhagem européia, instrumentalizaram os ideais enciclopedistas no afã de legitimar as manobras políticas do presente e as do futuro. Recorriam, para isto, aos acontecimentos "mais" importantes e aos heróis incontestes da História nacional, na busca fremente para a formação do país como nação. As palavras de ordem eram homogeneidade, unidade, harmonia, para que só então se tornasse possível a identificação do caráter brasileiro, elemento indispensável não apenas para a busca de acontecimentos singulares da História nacional, como também da legitimidade de um sentimento de amor ao país. Odália, em estudo sobre Varnhagen e Oliveira Lima, é categórico quando pontua o sentido dessa homogeneidade, que tem como causa a questão do branqueamento defendida pelo primeiro, o que fomenta seu projeto de Brasil:

\footnotetext{
"Finalmente, em quarto lugar, temos o problema de que o homem não é apenas um ser cultural; ele também possui uma origem étnica, freqüentemente diversificada, que, no caso de Varnhagen, implica a busca de uma unidade idealizada, pela projetada predominância dos grupos raciais tidos e havidos como mais fortes e superiores. Neste último caso, um problema suplementar surge para ser resolvido: o estabelecimento do critério para a aferição da superioridade de uma etnia sobre a outra. Como na História geral do Brasil não existe estritamente uma teoria racial em termos biológicos, que decidisse em favor de uma etnia em detrimento de outras, seu critério é o mais simples e o menos sofisticado: de um lado, a civilização, encarnada no homem branco, conquistador e cristão; de outro, a barbárie, indígena ou negra. Disso tudo resulta que o homem branco brasileiro nasce de uma rede de relações ideais e históricas, cuja realização final é ainda expressão da mesma vontade racionalizadora que projeta a nação. Descendente do conquistador branco, o homem branco brasileiro deve manter, em si, preservados e acarinhados, os valores que fizeram daquele o vencedor".
}

${ }^{750}$ SCHWARCZ, Lilia. As Barbas do Imperador. Op. Cit. 22 
A idealização do vencedor é feita pela contínua referência à civilização superior que impôs seus padrões, incluindo-se aí os traços característicos de seu portador, o homem branco, ele mesmo produto de condições históricas e de concepções idealizadoras de seu ser e de sua atuação na História.

Termo de uma evolução, o homem branco europeu, ao conquistar uma nova terra, cujos habitantes chafurdam na mais grosseira barbárie, deve encontrar forças na civilização da qual se origina para superar as novas condições históricas em que deverá realizar sua missão de conquistador. Dessa maneira, se é impossível descartar-se a presença incômoda dos naturais da terra, porque eram eles os primitivos donos dela, e se é impossível remediar um erro histórico constituído pela escravidão negra, a solução está em assinalar ao emergente homem branco suas raízes históricas, mostrar o que o diferencia e o aproxima do indígena e o que o distancia do negro". ${ }^{751}$

No processo de formação do Brasil pós-independente, os inúmeros discursos recaíam sobre a inferioridade das raças, pois havia a associação entre raça e cultura. Narrando inúmeras batalhas, onde fica evidente a violência do homem civilizado diante de índios e negros, o objetivo maior do Visconde de Porto Seguro, assim como tantos outros letrados preocupados com a História do Brasil, era a consolidação da unidade do país. Embora reconhecendo à precariedade de elementos constitutivos para formação de uma Literatura nacional, escrevia Gonçalves de Magalhães: "Nós pertencemos ao futuro, como o passado nos pertence. A glória de uma nação que existe, ou que já existiu, não é senão o reflexo da glória de seus grandes homens. De toda a antiga grandeza da pátria dos Cíceros e dos Virgílios, apenas nos restam suas imortais obras e essas ruínas que tanto atraem os olhos do estrangeiro, e, no meio das quais, a moderna Roma se levanta e se enche de orgulho. Que cada qual se convença do que diz Madame de Stael: "a glória dos grandes homens é o patrimônio de um país livre, depois que eles morrem, todos participam dela". ${ }^{752}$

Não tão diferente era a fala do Visconde de Porto Seguro: “Entretanto, por mais que corram os séculos, não ha país, embora blazone de mui republicano, que não aprecie a sua aristocracia; isto é a nobreza hereditária; - sendo que a tradição das famílias vem, com o andar do tempo, a constituir a historia da pátria. A nação acata nos filhos, e ainda mais nos netos, os nomes e a sombra, digamos assim, dos indivíduos que lhe deram ilustração e glória, como nós em sociedade veneramos até as suas relíquias; e não só o cadáver, como a espada do herói, que morreu pela independência da pátria; a pena do escritor que a ilustrou pelas Letras; o anel do prelado que foi modelo de saber e virtudes. Além de quê, a experiência prova que as aristocracias, sustentáculos dos tronos, são ao mesmo tempo

\footnotetext{
${ }^{751}$ ODALIA, Nilo. As formas do mesmo... Op. Cit. p. 90.

752 MAGALHAES, Gonçalves de. Discurso sobre a história da literatura do Brasil. Revista do Instituto Histórico e Geográfico Brasileiro. V.1
} 
a mais segura barreira contra as invasões e despotismos do poder, e contra os transbordamentos tirânicos e intolerantes das democracias", 753

Estas duas falas revelam muito bem a preocupação dos primeiros polígrafos do Império brasileiro. Se não podemos associar que a escrita historiográfica do Brasil de então manteve relação estreita com as necessidades do Estado, não podemos também esquecer que a vertente historiográfica fabricada pelo IHGB bem atendeu aos interesses das elites regionais, nas primeiras décadas da independência do país até o término da monarquia.

Desse modo, é recorrente, tanto nos trabalhos históricos como literários, a busca irrefreável pelo sentimento nacional, o que norteou umas das maneiras de representar o país, a Literatura brasileira. Não é gratuita a ligação entre a tradição historiográfica de cunho estritamente conservador, fornecida pelos homens de Letras agremiados no IHGB que, ao mesmo tempo, transitava com alguns escritores do Romantismo brasileiro: de um lado, a confecção de um discurso oficial diretamente influenciado pelo modelo de História francesa, fundamentado nos grandes acontecimentos e amparado pela verdade histórica; de outro, a postura "civilizada" transmitida pelos romances que concebiam índios e negros como raças inferiores e "bárbaros", quando não idealizavam os primeiros e ignoravam os outros.

$\mathrm{Na}$ construção do projeto nacional, fazia-se presente a existência de pelo menos um esboço literário, objetivando dotar o país de aspectos singulares que, como consequência, resultariam na própria identidade nacional. Assim, os letrados do momento recorrerão à fauna e a flora, classificando as espécies e utilizando-se de conhecimentos taxonômicos como estratégia de validação na construção de uma imagem de um Brasil real que sequer deixava dúvidas. Florescem, neste momento, os primeiros discursos literários, os primeiros compêndios, os florilégios, os bosquejos, as diversas Histórias da Literatura de um país oficialmente livre, uma vez que nenhum Estado se forma sem idéias, sem uma argumentação teórica que legitime ou se volte contra a organização social de onde brotam tais particularidades.

Seja por meios literários ou históricos, o arsenal teórico europeu cada vez mais foi moldando o Estado Nacional, sendo indispensável o apelo à noção de nacionalidade. Um olhar mais atento revela que, ao contrário das diversas formas de representar o Brasil, seja pelos meios literários, históricos, ou pela farta contribuição iconográfica, a realidade em que vivia a grande parte da sociedade brasileira era bem diferente com relação à visão oferecida pelos escritores, pintores e artistas. Contra as várias formas de corrupção, numa política onde os partidos não possuíam projetos mais densos, onde pairava o embuste e a dissimulação, reflexo do que se fazia na política portuguesa, e acima de tudo, contra o despotismo do imperador devido à criação do poder moderador, Manoel Bonfim salienta:

\footnotetext{
${ }^{753}$ VARNHAGEN, Francisco Adolfo de. Historia geral do Brasil antes da sua separação e independência de Portugal. $2^{\mathrm{a}}$.
} Ed. Rio de Janeiro E. \& H. Laemmert, 1876. p.152. 
"Liberal, Pedro II deixou inexoravelmente cativar as províncias, naquela monstruosa centralização, pior que o cativeiro dos dias coloniais; liberal, ele ostentava o Liberalismo, reduzindo-o, finalmente, a um favor com que trazia os brasileiros à condição infamante de escravos...e de bom senhor. E era este o fim do Liberalismo destacar o mérito de quem o concedia. Justo, ele permitia que a justiça pública fosse descarada mentira, pois que nunca houve poderoso punido, qualquer que fosse o crime: justo e liberal, ele abusava do seu privilégio para negar a Otttoni e Alencar aquilo que o eleitorado manifestamente queria conferir-lhes. Bom, generoso, ele guarda rancores imperecíveis; bom, ele suportava o espetáculo doloroso do cativeiro como indústria; bom, ele fez exterminar, nos campos do Sul, centenas de milhares de brasileiros moços e válidos; bom, ele quis e fez aniquilar, por longos anos, uma nação americana, sempre amiga do Brasil, guerreando-a ineroxavelmente, até o extermínio completo de todos os seus homens válidos. Amante das Letras, ele negava acintosamente o Senado a um dos mais legítimos representantes da Literatura brasileira, assim como consentia passasse fome, na Europa, o primeiro e glorioso poeta brasileiro - Gonçalves Dias; cultor da Ciência, propugnador do progresso intelectual, ele deixava abandonada a verdadeira prática científica, sem um estabelecimento de desinteressada e alta cultura, sem meios, para os que pretendessem dedicar-se a investigações orientadoras; propugnador do progresso intelectual, o seu governo condenava as sucessivas gerações de brasileiros, inválidos no analfabetismo, aviltados, na ignorância profunda. Probo, ele dirigia um governo de deslavados esbanjamentos; probo, ele fazia da probidade ostentação, como virtude rara, e que desmoralizava o ambiente político. Honesto, ele aceitou a corrupção política, cultivou-a, explorou-a, em proveito do seu poder pessoal; honesto, ele presidiu aqueles decênios de vida pública, para os dias de desmoralização definitiva em que tudo acabou. Patriota, ele converteu a soberania da nação em soberania do trono, e reduziu o Brasil à mera expressão da sua onipotência pessoal; patriota, assim onipotente, ele nada fez do muito bem que poderia ter feito, e o seu reinado foi, somente, de efeitos negatíficos, ou explicitamente, maléficos - conservação monstruosa da escravidão, sistematização da corrupção política, guerras injustas com os vizinhos, destruição final de tudo que o movimento de 1831-32, havia trazido às instituições nacionais, resistência a tudo que era verdadeiro progresso... Não é que faltasse, ao imperador, boas intenções, convencionalmente definidas; mas porque eram de convenção; porque faltava, a um Bragança aqui abandonado, a efetiva correspondência com os sentimentos e as necessidades do Brasil. A verdade é que as boas intenções dele não combinavam com o verdadeiro bem desta pátria. E assim se explica que, apesar de não odiado, foi o imperador o motivo mais forte na campanha pela República. Como ideologia, todos o sabem, a propaganda de 1870-89 nada valeu; para mover a opinião, só se notam, de substanciais, argumentos concretos - que o governo imperial se concentrava no poder pessoal. E como eram os políticos e chefes monárquicos, os mais veementes, contra esse mesmo personalismo do governo, sendo também, os mais autorizados para dar testemunho do fato, foram eles, os monarquistas, os mais eficientes propagandistas da República." 754

Os mais proeminentes homens do país declaravam suas hostilidades ao Liberalismo brasileiro, existente num país patrimonialista, administrado por donos de terra e por uma elite portuguesa que era auto gerida, a partir das relações de favor. Falava Alencar:

${ }^{754}$ BONFIM, Manoel. O Brasil nação: realidade e soberania nacional. 2a . Ed. Rio de Janeiro: Topbooks, 1996. pp. 238-239 
"Não contesto que exista em nosso paiz uma grande massa de liberdade, mais avultada do que na própria Inglaterra. Não fallo dos Estados-Unidos, porque ali reina o despotismo da multidão.

De tão enorme volume de liberdade, porém, a máxima parle jaz ainda em bruto, como a natureza de nossas regiões magníficas; o resto constitue o monopólio de um pequeno numero.

A liberdade no Brasil está, como dizia Nodier, na mão dos forles e na bolsa dos ricos. Dos sobejos, que elles repartem, ou das migalhas que ficão pelo chão, vivem os fracos e os pobres; por outra, a maior parte da nação". ${ }^{755}$

José Bonifácio cognominado patriarca da independência, lamentava uma "constituição em papel”. Exclamava, "de que serve uma constituição em papel? A constituição deve estar arraigada em nossas leis, estabelecimentos e costumes. Não são comissões militares e medidas ditatoriais que deviam restabelecer a ordem, e sossegar as províncias, mas sim a imediata convocação das câmaras, e um novo ministério sábio, enérgico, e de popularidade”. 756

Alfredo Bosi é categórico quando em sua Dialética da Colonização pontua:

"Nada haveria, a rigor, de excêntrico, deslocado ou postiço na linguagem daqueles políticos brasileiros que, usando o termo Liberalismo em um sentido datado, pro domo sua, legitimaram o cativeiro por um tempo tão longo e só restringiram sob pressão internacional. Uma proposta moderna e democrática sustentada pelas oligarquias rurais é que teria sido, nos meados do século XIX, uma idéia extemporânea. Mas esse projeto não se concebeu nem aqui, nem em Cuba, nem nas Antilhas inglesas e francesas que viviam o mesmo regime de plantation, nem no reino do algodão do Velho Sul americano. Em todas essas regiões, políticos defensores do Liberalismo econômico ortodoxo velaram pela manutenção do trabalho escravo". ${ }^{757}$

Mas era nesse cenário que surgiam as "idéias de Brasil”, como lembra Carlos Guilherme Mota, “matrizes e formas de pensamento, modos de ser e tipos de comportamento social e político que passariam a ser progressivamente identificados como nacionais", ${ }^{758}$. Vasta historiografia aparece, sob as mais diversificadas formas, amparada sob esta ou aquela vertente, defendendo esta ou aquela posição, mantinha estreita ligação com a conjuntura do Brasil recém independente.

Flora Sussekind pontua detidamente a constituição da prosa de ficção brasileira elaborada pelos inúmeros relatos de viajantes, quando de sua formação, na primeira metade do século XIX. Mais do que a busca exacerbada de classificar, de perceber o fundamento de verdade por parte desses relatos, de confrontar o narrador com a realidade enquanto tal, eles são o primeiro momento da identidade nacional: "Tratava-se de descobrir ângulos, mapas, telescópios capazes de homogeneizar, numa

\footnotetext{
${ }_{755}^{75}$ ALENCAR, José de Alencar. Ao povo: cartas políticas de Erasmo. Rio de Janeiro: Tipografia Pinheiro, 1866. p.10

${ }^{756}$ SILVA, José Bonifácio de Andrada. Projetos para o Brasil. São Paulo: Companhia das Letras; Publifolha. p.122.

${ }^{757}$ BOSI, Alfredo. Dialética da colonização. São Paulo: Companhia das Letras, 1996.p.202.

${ }^{758}$ MOTA, Carlos Guiherme. Idéias de Brasil: formação e problemas (1817-1850). In: Viagem incompleta. A experiência brasileira (1500-2000). Formação: histórias. São Paulo: SENAC, 2000.p. 201. Organizado pelo autor; 1822: Dimensões. São Paulo: Perspectiva, 1972.
} 
grande paisagem natural atemporalizada, de um lado, tantos materiais literários diversos, e, de outro, tantas divisões internas do país. E, de posse de uma Ciência "interessada" na observação, tratava-se de desenhar mapas e álbuns de vistas do Brasil e de sua gente, semelhantes ao pano de boca de Debret, e capazes de se sobrepor ao ruído de chicotadas caseiras, aos confrontos provinciais, rebeliões de escravos, conflitos entre fazendeiros e índios no interior". ${ }^{759}$

Não restam dúvidas sobre o caráter ideológico de toda esta vasta produção ensaística comprometida com os anseios das classes dirigentes interessadas na formação do Estado nacional brasileiro. Pode até parecer sem razão de ser, face à elevada taxa de analfabetismo de grande parte da população, mas o temor de possíveis movimentos de insatisfação popular era patente aos olhos da incipiente elite nacional. Antonio Candido reitera que, "a partir de 1834, surgem alguns fatos que, vistos de hoje, denotam o início de novo período, em que a Literatura apareceria transformada, marcada por um ritmo muito mais vivo e adequado às transformações da sensibilidade e da sociedade". ${ }^{760}$

Como Varnhagen, este erudito e apoiado no rigor das fontes, os primeiros cronistas viajantes que estiveram ou não a serviço de suas nações estilizaram o Brasil e não deixaram de corroborar com falsas representações, em nome da identidade do país, em um processo muito mais ligado ao campo político do que ao conhecimento e à arte. Era sempre um Brasil estilizado, dado que o foco de análise sempre residia na fauna e na flora, omitindo o que havia de mais relevante, que era o extermínio das populações indígenas, a brutalidade e a coisificação contínua dos escravos. Homens de formação europeia e setecentistas, formados sob a amplitude do saber europeu, possuidores de uma visão que estreitava cada vez mais a realidade, devido à concepção que tinham da História, ligada à História natural, o traço mais significativo dos letrados agrupados no IGHB e dos escritores do Romantismo foi a tomada de consciência para a nacionalização literária.

A historiografia literária brasileira confunde porque ela própria cheira a nacionalidade sem atinar antes para a realidade, posto que seu fim era o despertar do sentimento nacional. Não se destacava como bom escritor aquele trabalho mais condizente com as transformações sociais e políticas do momento, mas sim aquele escritor que tinha a capacidade de despertar e provocar a nacionalidade literária. Escritores de gabinete ou não, homens realistas ou românticos, era indispensável conhecer o Brasil e, para isso, era inevitável recorrer à fauna e à flora do país. De fundamental importância, era mostrar "que o Brasil existia e que estava se aproximando a passos rápidos da meta traçada pelo processo da civilização. Para tanto, como também se viu, era preciso escrever a História Nacional,

\footnotetext{
${ }^{759}$ SUSSEKIND, Flora. O Brasil não é longe daqui: o narrador, a viagem. São Paulo: Cia das Letras, 1990. p.123.

${ }^{760}$ CANDIDO, Antonio. A literatura durante o império. In: Reações e transações. História da civilização brasileira. $\mathrm{O}$ Brasil monárquico. Tomo II, 3ª V (org) Sérgio Buarque de Holanda 5ª Ed. São Paulo: Difel, 1985. p. 344.
} 
por um lado e, por outro, levantar mais e mais fontes que lhes permitissem corrigir os erros tão difundidos a respeito deste Quinto Império." 761

A fala de Maria Helena Rouanet sobre Ferdinand Denis, considerado por boa parte da crítica como fundador dos estudos sobre a Literatura brasileira, é pertinente porque sintetiza e dá sentido à vasta produção literária do momento. Quando o Brasil torna-se independente de Portugal, sua História, transmitida pelos meios literários, não pode ser mais escrita a partir da extensão da metrópole, a História do país não pode ser mais mero apêndice da História de Portugal, deve partir de elementos que "caracterizam" o país, de elementos nacionais. Como Varnhagen, Gonçalves Dias, Gonçalves de Magalhães e tantos outros, esses primeiros construtores da identidade brasileira eram homens viajados, eruditos a serviço e às ordens do Estado brasileiro.

Resume bem Antonio Candido, ao afirmar que "Os homens que escrevem aqui durante todo o período colonial são, ou formados em Portugal, ou formados à portuguesa, iniciando-se no uso de instrumentos expressivos conforme os moldes da mãe-pátria. A sua atividade intelectual ou se destina a um público português, quando desinteressada, ou é ditada por necessidades práticas (administrativas, religiosas, etc). É preciso chegar ao século XIX para encontrar os primeiros escritores formados aqui e destinando a sua obra ao magro público local. " 762

Cândido chama atenção para uma Literatura prática ligada aos interesses das classes dominantes, no que resultou na visão transfiguradora do real, mesmo que fora justamente essa visão que suscitou os anseios para uma investigação sistemática da realidade nacional. No que pese a pluralidade estética das formas, não se pode eliminar a nova conjuntura política de um país livre onde, de uma forma ou de outra, as idéias evidenciavam as estratégias da preocupação maior dos escritores nacionais, no caso, com a unidade nacional. Arremata Antonio Candido que "Estas considerações visam sugerir que, no período em questão, houve entrosamento acentuado entre a vida intelectual $e$ as preocupações politico-sociais" 763

Sem rigor de análise ou abordagem determinista, o entrosamento aludido pelo autor resulta em pragmatismo, o que verificamos antes mesmo da independência do Brasil, não apenas quando voltamos o olhar para a diversidade das academias e grêmios literários, como também pela seleção e releitura de personagens libertários como Raynal, Rousseau e Mably que, no Brasil, iriam de encontro ao próprio cenário da colônia. Escritores e leitores conservadores, ligados à elite fundiária, pregando leituras liberais, Liberalismo este que se opunha apenas ao jugo colonial, e não ao Liberalismo democrático, baseado na soberania popular.

\footnotetext{
761 ROUANET, Maria Helena. Eternamente em berço esplêndido: a fundação de uma literatura nacional. São Paulo: Siciliano, 1991.p.147.

${ }_{762}$ CANDIDO, Antonio. Literatura e sociedade. 9a . Ed. Rio de Janeiro: Ouro sobre Azul, 2006.p. 100.

${ }^{763}$ Ibidem. p. 100
} 


\section{O negro na historiografia Brasileira}

Não é nenhum reducionismo afirmar que o negro tem sido visto predominantemente, ao longo da História brasileira, de maneira pejorativa, devido a sua condição de escravo. Último país a libertar os escravos, o Brasil carrega a enorme marca de algoz de suas vítimas. A condição de mera mercadoria impossibilitou aos escravos toda e qualquer possibilidade de cidadania.

Os primeiros trabalhos, elaborados pelos jesuítas acerca do país recém descoberto, mostram a defesa do índio na viabilização do processo colonizador, sendo os aldeamentos não apenas, o instrumento da conversão de "povos bárbaros" em "povos civilizados", mas a defesa dos povos indígenas, por parte da Igreja, ao contrário do negro, a quem coube a escravidão. Do combate pelo índio e contra sua escravização feito pelos homens da Igreja, emerge a defesa da escravidão inconteste ao negro. Nessa perspectiva, a escravidão legitimada na própria natureza era herança de alguns relatos bíblicos, devia-se ao pecado de Caim, por quem os negros expiariam toda sorte de sacrifício.

Esta historiografia privilegiou o homem branco, escamoteando o negro como agente do processo histórico, uma vez que este era visto a partir do olhar etnocêntrico, sufocando toda e qualquer forma de manifestação como agente da História. Remontam às primeiras informações acerca da terra brasilis, como crônicas, autos, as primeiras explicações envolvendo a natureza da escravidão. Discutida num segundo momento, o que não deixa de ser paradoxal, em parte devido ao combate contra a escravidão do índio, a escravidão negra passa a ser o centro da discussão em meados do século XVII, em função do conjunto de transformações econômicas, sobretudo, a partir da decadência da lavoura açucareira e da emergência do ouro. É nesse quadro complexo que cada vez mais se acirram os antagonismos sociais, cristalizando a temática da escravidão negra. Desse modo, os debates sobre a escravidão do homem de origem africana no Brasil estão articulados às significativas oscilações dos ciclos econômicos no país.

Mesmo que, durante os dois primeiros séculos, não tenha surgido nenhuma produção literáriohistórica trazendo a escravidão para o centro da discussão, do bojo da escravidão indígena surgem às raízes da escravidão também do africano, cavando uma ruptura semântica e um ponto de inflexão a partir do século XVII. Ronaldo Vainfas aborda, assim, o tema da escravidão presente nos trabalhos dos letrados coloniais:

"No Brasil colonial do século XVI e inícios do XVII, não houve um só tratado preocupado com a escravidão africana. A questão era apenas referida e constatada em obras de cunho geral, e só raramente apareceu como problema. É certo que houve queixas, como a de Fernão Cardim, que reclamava das grandes perdas que tinham os senhores com a escravatura de Guiné, destacando as mortes dos escravos e os gastos 
grandes com a manutenção do plantel. E o Padre Jacome Monteiro indignava-se, em 1610, com a conduta dos escravos nos domínios da Companhia: "Os negros, além de roubar, gostar de roubar, gastam infinito... o que tudo sai das contas do Colégio". Essas e outras eram queixas menores, não chegando, ao que se vê, a um dimensionamento social da situação escravista". ${ }^{764}$

Diferentemente da escravidão sofrida pelo índio, a escravidão do africano nunca fora colocada em discussão. Excetuando vozes isoladas como as de Cristovão Gouveia e Anchieta, foi do seio da Igreja que partiram as premissas legitimadoras para a escravidão do negro. As vantagens naturais outrora narradas pelos primeiros cronistas com relação à terra de Santa Cruz, com seus bons e salutares ventos, afora as descrições exuberantes da fauna e da flora, agora cediam lugar à temática da escravidão negra. Aqui aparecem nomes significativos na fundamentação ideológica como Antonio Vieira, João Antonio Andreoni, Jorge Benci, Nuno Marques Pereira e Manuel Ribeiro da Rocha. Assim, nas palavras de Vainfas:

\begin{abstract}
"O retrato da escravidão nas primeiras Letras coloniais não rompeu, no mais das vezes, os horizontes estreitos da observação, alentado pela consCiência idílica e pela intenção propagandística do colonialismo e da fé católica.

Os letrados do século XVI e inícios do XVII, ocupantes de uma posição de classe escravista, não atentaram para a dimensão social da escravidão, embora a concebessem como o sustentáculo da riqueza na terra. Ao compor o quadro econômico da colônia - seus requisitos e potencialidades -, indicavam o escravo como mercadoria, ou associavam-no aos animais de que careciam os trapiches. Atribuíam-lhe, ainda, a exclusividade do trabalho nas fazendas e engenhos. O ser escravo oscilava, assim, entre a idéia de coisa e a de trabalho indispensáveis ao êxito da colonização-idealização confirmada na semântica do discurso, na imprecisão de fronteiras entre as duas idéias. Classificar os escravos significou, ainda, aludir à sua cor ou a origem: pretos de Angola ou negros da Guiné, naturais do gentio ou índios da terra. Ampliava-se assim, o campo semântico do ser escravo, compondo-se, no quadro, a representação etnográfica da divisão do trabalho colonial ${ }^{, 765}$
\end{abstract}

As justificativas ideológicas para a escravidão negra surgem dos pensadores e doutores da Igreja que ora defendem a escravidão natural porque os negros da Guiné são os responsáveis pelo pecado original, herdeiros de Caim; ora identificam no negro a personificação de Jesus Cristo, o Salvador, sendo os negros imbuídos de salvar a humanidade, o que marca assim o início de uma era. Entre uma explicação e outra, repousam as argumentações bíblicas tributárias de dois dos maiores ícones do pensamento cristão que São Agostinho e São Tomás de Aquino: a escravidão logo se transforma em salvação, compreendendo todo o processo de mortificação e pureza da carne. Assim, pelo sacrifício que mortifica a carne se alcança a redenção, uma vez que, de acordo com o pensamento cristão, o prazer sexual é pecado, sendo o sexo aceito somente como meio de reprodução e não como fonte de prazer e, como responsáveis pelo pecado original, os negros são condenados à escravidão.

\footnotetext{
${ }^{764}$ VAINFAS, Ronaldo. Ideologia \& Escravidão: os letrados e a sociedade escravista no Brasil Colonial. Petrópolis: 1982.p.82.

${ }^{765}$ Ibidem. p. 84
} 
Outra premissa legitimadora da escravidão do negro advém de sua caracterização como peça ou coisa, devido à inserção da Economia brasileira no jogo maior da acumulação de capital, norteada pelas leis e transformações do mercado mundial. Ao conceber o negro como mercadoria, o que fazia deste uma valiosa fonte de riqueza, no Brasil, esta visão se adequou à propriedade do senhor. Enfim, entre um discurso e outro, a escravidão foi legitimada pelos escritores católicos, também responsáveis pela "catequização" dos índios. Se, com relação ao índio, o argumento era inseri-lo na cultura civilizada por meio dos sermões, da conversão das almas, dos aldeamentos, substrato integrante do cânone cristão, estereotipando-o como dócil, o que levava a desconsideração da pluralidade dos ritos simbólicos, sobretudo, a prática do canibalismo, com relação ao negro, associada à condição de peça, surgia a imagem de belicosidade que a qualquer momento podia se tornar evidente.

Vale lembrar, como informa Vainfas, que os jesuítas, em grande parte, defensores da escravização do negro e não do índio, eram senhores de escravos. Nessa ótica, o trabalho, ao mesmo tempo em que purificava a alma, causava desonra. Se num primeiro momento, presenciamos as preocupações por parte de missionários e cronistas em relevar a riqueza natural da fauna e da flora brasileira, erigindo a docilidade do índio, num segundo momento, presenciaremos como resultado das transformações econômicas já aludidas, a preocupação com a mão de obra. Se num primeiro momento foram os índios de fundamental importância para a implementação do projeto catequético, viabilizando o processo eurocêntrico na terra de Santa Cruz, num segundo instante, os negros não ultrapassaram a categoria de peça ou coisa imersa no quadro mais amplo das relações do Capitalismo mundial.

Mesmo que se reconheça a multiplicidade das populações africanas que vieram ao Brasil - dentre estas, dois grupos maiores, bantos e sudaneses -, é indiscutível o interesse pelo lucrativo negócio gerado pelo próspero mercado no tráfico desses seres humanos que, muitas vezes, sequer chegavam a seus lugares de destino.

Não é de maneira gratuita que, posteriormente, surgiria a versão tardo-romântica que só denota cordialidade entre senhores e escravos. A senzala nada mais era que a extensão da casa grande, a "docilidade" das mucamas e das sinhás revelava uma relação sem conflitos, onde a influência dos negros se estendia na linguagem, no uso dos diminutivos, na gastronomia, nos costumes de modo geral, e, sobretudo nas relações sexuais: “conhecem-se casos no Brasil não só de predileção, mas de exclusivismo: homens brancos que só gozam com negra". ${ }^{766}$

Clóvis Moura, realizando um balanço historiográfico, analisou o pensamento dos mais significativos escritores e apontou uma visão do negro concebido como inferior e bárbaro, visto como

\footnotetext{
${ }^{766}$ FREYRE, Gilberto. Casa-Grande \& senzala: formação da família brasileira sob o regime da economia patriarcal. $48^{\mathrm{a}}$. Ed. São Paulo: Global, 2003.p. 368.
} 
uma peça. Dentre os nove autores abordados por Moura, todos estão presos à visão etnocêntrica, base explicativa da concepção do negro como inferior, legitimando sua condição como mercadoria.

Percorrendo as páginas de Moura, percebemos as visões dos polígrafos sobre a imagem do negro. Vicente do Salvador alertava para os perigos das possíveis rebeliões por parte dos negros, principalmente os da Guiné. Considerava-os massa amorfa. Rocha Pita, referindo-se a uma peste de bexiga acontecida na Bahia, queixa-se não pela morte dos negros, mas sim pela perda do lucro advindo necessariamente da mão de obra escrava. O inglês Southey, erudito atento ao tratamento com as fontes, continuava o raciocínio dos dois escritores anteriores, vendo o negro como mercadoria. Alertava, ainda, para a ferocidade dos negros, considerando-os selvagens, bárbaros e canibais. Palmares é visto sob a frieza britânica, uma vez que não podiam negros canibais, bárbaros e selvagens, criar uma organização como a dos quilombos. Como bom anglicano, repudiava todas as manifestações culturais dos negros, considerndo-os seres semibárbaros.

Abreu e Lima, em seu Bosquejo histórico, político e literário do Brasil, analisando o quadro social brasileiro, ainda conforme Moura, traz à tona a questão da luta de classes. Monarquista e tendo analisado o Brasil sob um olhar de classes, isso não significa que o escritor pensasse numa harmonia entre as diversidades étnicas existentes no país.

Momento ímpar na concepção historiográfica brasileira vem com Varnhagen. Atento às fontes, concebia a História como factual e elaborada com base nos grandes feitos históricos, derivando daí sua visão aristocrática. Para Moura "toda a estrutura teórica da sua obra fundamenta-se nesta visão $e$ podemos dizer que, por essas razões, elaborou um trabalho no qual esses atores anônimos ficaram na penumbra, quando entram em cena, ou são estigmatizados, criticados ou mesmo condenados" ${ }^{767}$. Por sua visão elitista e aristocrática, em Varnhagen já aparece o pensamento sutil do branqueamento; uma vez concebendo o negro como inferior, a escravidão era natural. Não apenas para Varnhagen como para vários escritores, o fato de o negro ser escravo no Brasil, justificava sua condição, por que a continuarem em seus países de origens, enfrentariam uma escravidão ainda mais forte. Conservador, branco, ilustrado e católico, assim como tantos outros escritores, a justificação da escravidão devia-se à Natureza que estava, intrinsecamente, ligada à raça dos escdravizados.

O inglês Armitage escondeu os milhares de negros que encontrou na Corte, palaciano por ser um monarquista e homem ligado ao comércio: "a seleção étnica para Armitage acompanha a seleção técnica. Os ingleses eram a eficiência, enquanto os vagabundos brasileiros e os negros constituíam o

767 MOURA, Clóvis. As injustiças de Clio. As injustiças de Clio: o negro na historiografia brasileira. Belo Horizonte: Oficina de Livros, 1990. p. 94 
elemento negativo como componente militar. Os nativos e os negros levaram o almirante mercenário a mudar de tática". ${ }^{768}$

Handelmann continua a ver o escravo como mão de obra e, de forma semelhante aos escritores anteriores, o negro é concebido por ele como massa amorfa e bárbara. Mesmo que, em tese, chegue a condenar a escravidão, curva-se ao rentável trafico de negros. Estratificando a sociedade a partir do caráter de cor, pensa o citado escritor que somente com a imigração européia seria possível encaminhar o Brasil para a formação da nação. Insiste sempre na imigração e no povoamento do Brasil, para solucionar o problema da mão de obra do país. Anuncia também a imigração de povos "superiores" como os alemães, em detrimento dos chineses. O projeto de colonização que privilegiava imigrantes alemães - idéia tenazmente defendida por Sílvio, com algumas ressalvas - já era esboçado por Handelmann. Como seria visto tempos depois, especificamente em meados das décadas de 1860, a discussão acerca da desigualdade entre as raças, acompanhada da definição da raça mais forte, gerou acalorados debates políticos em defesa da imigração do trabalhador ideal, no caso, o homem branco, superior e apto às normas civilizadas, em contraposição à inaptidão dos orientais, sobretudo, os chins. Pensa o autor que só com a vinda do imigrante europeu seria possível o progresso do país.

Euclides da Cunha, experimentando um novo momento em que as teorias "científicas" eram parâmetro de avaliação da civilização e da barbárie, aponta as três raças formadoras do tipo brasileiro, ramificando-as em sub-raças, sendo o negro inferior ao branco. Quando estuda a figura de Antonio Vicente Mendes Maciel, o Conselheiro vê um homem doente, dominado pelas categorias atávicas, resultado que era de uma raça inferior. Nesse sentido, o meio onde nasceu o pregador fora determinante, fazendo de Conselheiro apenas um dentre tantos outros integrantes da "turba nevrótica". Imerso numa modalidade de "psicose progressiva", as pregações e o fetichismo de Canudos eram reflexos desta raça:

\begin{abstract}
"Todas as crenças ingênuas, do fetichismo bárbaro às aberrações católicas, todas as tendências impulsivas das raças inferiores, livremente exercitadas na indisciplina da vida sertaneja, se condensaram no seu misticismo feroz e extravagante. Ele foi, simultaneamente, o elemento ativo e passivo da agitação de que surgiu. $O$ temperamento mais impressionável apenas fez o absorver as crenças ambientes, a princípio numa quase passividade pela própria receptividade mórbida do espírito torturado de revezes, e elas refluíram, depois, mais fortemente, sobre o próprio meio de onde haviam partido, partindo da sua consciência delirante". ${ }^{769}$
\end{abstract}

Mesmo reconhecendo a falta de estudos científicos com relação aos negros, não deixa Euclides de concebê-los como inferiores: "Qualquer, porém, que tenha sido o ramo africano para aqui transplantado trouxe, certo, os atributos preponderantes do homo afer, filho das paragens adustas $e$

\footnotetext{
768 Ibidem. p. 132

${ }^{769}$ CUNHA, Euclides da. Os Sertões: campanha de Canudos. $3^{\text {a }}$. Ed Corrigida. Rio de Janeiro/São Paulo: Laemert \& C, 1905. p. 150
} 
bárbaras, onde a seleção natural, mais que em quaisquer outras, se faz pelo exercício intensivo da ferocidade e da força". ${ }^{770}$ Cabe realçar, todavia, como a narração da Guerra de Canudos finda destacando grande capacidade de luta entre esses negros e mestiços, o que redirecionou a presença do conceito de raças no pensamento de Cunha. ${ }^{771}$

Oliveira Viana, influenciado por Sílvio Romero e Euclides da Cunha, mas escrevendo já num outro momento histórico, leva às últimas consequiências a questão racial em sua interpretação de Brasil. Para ele, todo o processo histórico é por assim dizer determinado pelas raças no que origina a luta entre elas, explicando e dando sentido à evolução do povo brasileiro. Seu esquema teórico baseia-se em Spencer, somado ao temor da degeneração. Fortemente influenciado por alguns dos escritores que marcaram Sílvio, teóricos da Escola de Le Play e teóricos racistas, Viana encara a ideologia racial, desconsiderando, no entanto, as raças inferiores, em que destoa de Sílvio. Para ele, a elite brasileira criava a idéia de uma "onda negra", justificada pelo contato entre as raças:

\begin{abstract}
"Entre nós, por toda a área de dispersão do tipo vicentista, a seleção da classe superior se faz, para a nossa felicidade, num sentido ariano. São os melhores exemplares da raça lusa, da nobreza nacional e da massa mestiça, que entram na sua composição. Mesmo nas minas, são os emboabas que tomam a dianteira à plebe rural e ocupam o lugar, que a legislação da metrópole abre, de súbito, no seio da aristocracia paulista.

Esse caráter ariano da classe superior, tão valentemente preservado na sua pureza pelos nossos antepassados dos três primeiros séculos, salva-nos de uma regressão lamentável. Fazendo-se o centro de convergência dos elementos brancos, essa classe, representada principalmente pela nobreza territorial, se constitui entre nós no que poderíamos chamar o sensorium do espírito ariano, isto é, num órgão com a capacidade de refletir e assimilar, em nossa nacionalidade, a civilização ocidental e os seus altos ideais. $O$ negro, o índio, os seus mestiços, esses não nos podiam, na generalidade dos seus elementos, dar uma mentalidade capaz de exercer essa função superior.

Toda a evolução histórica da nossa mentalidade coletiva outra coisa não tem sido, com efeito, senão um contínuo afeiçoamento, por meio de processos conhecidos de lógica social, dos elementos etnicamente bárbaros da massa popular à moral ariana, à mentalidade ariana, isto é, ao espírito e ao caráter da raça branca. Os mestiços superiores, os mulatos ou mamelucos, que vencem ou ascendem em nosso meio, durante o largo período da nossa formação nacional, não vencem, nem ascendem como tais, isto é, como mestiços, por uma afirmação da sua mentalidade mestiça. Ao invés de se manterem, quando ascendem, dentro dos característicos híbridos do seu tipo, ao contrário, só ascendem quando se transformam e perdem esses característicos, quando deixam de ser psicologicamente mestiços porque se arianizam. ${ }^{772}$
\end{abstract}

Para Viana, qualquer que seja a tipologia mestiça, é impossível a evolução social do Brasil devido à presença das raças e sub-raças inferiores, destituídas do conjunto de valores formadores do tipo

\footnotetext{
${ }^{770}$ CUNHA, Euclides da. Os sertões. Rio de Janeiro: Laemmert C., 1905. p. 66

${ }^{771}$ SILVA, Marcos A. da. “'A Terra' d' Os Sertões (Literatura como História)”, In: CARDOSO, Heloísa Helena Pacheco e PATRIOTA, Rosângela (Org.). Escritas e narrativas históricas na contemporaneidade. Belo Horizonte, Fino Traço, 2011, pp $177 / 188$.

${ }^{772}$ VIANA, Oliveira. Populações meridionais do Brasil. Brasília: Senado Federal, Conselho Editorial, 2005. p.179
} 
civilizado, somente existente na raça européia. Sua teoria aristocrática baseia-se em critérios de seleção étnica similares aos adotados por Sílvio Romero, a partir de autores da Antropossociologia como Gobineau, Ammon e Lapouge. Afirma Nelson Werneck Sodré:

\begin{abstract}
"Vimos os mestres, os Gobineau, os Ammon, os Lapouge, homens do século XIX, com veleidades científicas, cujas teses, hoje, nem sequer são mencionadas senão a título de curiosidade, e para mostrar a que extremos pode chegar o erro, e a que descomedimentos pode atingir a audácia do leigo, nos cursos sistemáticos. Vimos como Oliveira Viana elaborou suas idéias e as adotou. Qualquer principiante de antropologia sabe que tudo são frases destituídas de qualquer fundamento; qualquer universitário de sociologia pode, sem nenhum esforço, verificar como a armadura analítica do escritor fluminense carece de solidez; qualquer estudioso de genética humana está em condições de avaliar o enorme disparate das conclusões apresentadas. " 773
\end{abstract}

Segundo Clóvis Moura, "O problema racial, para ele, sobrepõe-se a todos os outros. Essa biologização da História, via antropologia física, tão em voga no Brasil daquela época, era uma forma fácil e simplificadora, mas ao mesmo tempo, revestida da respeitabilidade de "Ciência”, para escamotear os elementos econômicos, sociais, políticos e culturais que nos subalternizavam como nação. Estabelecia-se um critério de classificação racial analógica e anticientífica, e daí se inferia, dentro da escala de valores que esta classificação estabelecia a causa de desenvolvimento elou atraso dos povos. "774

Mesmo que um escritor relevante como Gilberto Freyre, em Casa Grande e Senzala, pontue detidamente a importante contribuição dos negros na formação da cultura brasileira de base agrária, com sua forma "adocicada", omitia as duras penas e o cotidiano brutal do negro, a idéia de um caráter indissociável às raças ainda persiste de maneira sutil em boa parte de sua obra. Parte da crítica acadêmica vê em Freyre um ponto de ruptura, introduzindo um novo olhar na historiografia brasileira, por não ser um autor determinista, crendo na diferença inata das raças. Assim mesmo, ele corrobora com os preceitos naturalistas dos escritores anteriores que sempre associavam um certo caráter ao elemento racial. Por outro lado não deixa, em sua vasta obra, de atribuir predisposições a cada uma das raças. Em Nordeste presenciamos de maneira muito sutil uma predisposição para a raça branca, a negra e a indígena, diferente da visão exposta em Casa Grande e Senzala. Dessa forma a imagem racial-mestiça aparece no ensaio de Freire, embora o escritor não veja a mestiçagem como um fator negativo a exemplo de ensaístas brasileiros como Nina Rodrigues, Euclides da Cunha, Monteiro Lobato, Oliveira Viana. Com relação ao cabra, tipo mestiço do nordeste brasileiro descreve as palavras do folclorista paraibano Rodrigues de Carvalho "raramente o cabra ... tem a dedicação afetuosa do

\footnotetext{
${ }^{773}$ SODRÉ, Nelson Werneck. Ideologia do colonialismo. Op.Cit. p. 183

${ }^{774}$ MOURA, Clóvis. Op.Cit.p.183
} 
africano ou a carinhosa estima do mameluco, ou do branco” ${ }^{775}$. Em seu ensaio não há alusão a nenhum teórico racial ou pensador que aponte a influência do meio geográfico para formação de uma índole regional explicando o desenvolvimento ou o atraso da sociedade patriarcal do nordeste brasileiro, pelo contrário, Freire combate pensadores importantes do cenário nacional que acreditavam na inferioridade biológica na fundamentação teórica para interpretação do "atraso" ou "subdesenvolvimento" brasileiro como Nina Rodrigues, Silvio Romero, José Veríssimo e Oliveira Viana. O sociólogo se exime dos preceitos naturalistas e parte seu olhar para as relações sociais entre o português, o negro, o cabra, o mameluco, aludindo ao indígena na construção da identidade regional nordestina. Reconhece a condição social espoliativa por parte do senhor de engenho em sua exploração da natureza humana e geográfica onde o cultivo da cana não apenas afastou animais desequilibrando todo um ecossistema como também não permitiu uma variação da cultura agrícola afetando na precária alimentação do nordestino privando-o até da farinha de mandioca, dieta básica do mestiço nordestino. Em função da monocultura do açúcar há um mau uso da terra como também um

${ }^{775}$ FREIRE, Gilberto. Nordeste: aspectos da influência da cana sobre a vida e a paisagem do Nordeste do Brasil. $7^{\mathbf{0}}$ Ed. Rev. São Paulo: Global, 2004. p. 172. Publicado em 1937, o estudo ecológico Nordeste - Aspectos da Influência da Cana sobre a Vida e a Paisagem do Nordeste do Brasil de Gilberto Freire, como o próprio sociólogo denomina, trata de analisar a cultura nordestina que se estende do extremo nordeste (Pernambuco) ao recôncavo baiano a partir dos reflexos e influências da instalação da civilização do açúcar no nordeste brasileiro. Segundo Freire, o nordeste que pretende analisar não é o nordeste de Djacir Menezes fincado no sertão, mas sim o "nordeste agrário, hoje decadente, que foi por algum tempo, o centro da civilização brasileira" (p. 37). O nordeste levantado por Freire seria um outro nordeste, rico em massapê e sempre oleoso, que nunca falta uma mancha de água, do húmus gorduroso, da terra melada, espaço onde se ergueu a civilização moderna. O nordeste impressionista retratado por Freire traz elementos regionais, agrários, onde o massapê sustenta a monocultura e o latifúndio da cana-de-açúcar, embora essa mesma atividade seja o principal fator de destruição da natureza como acentuará mais tarde o sociólogo em sua obra. Aqui surgem duas inquietações interessantes: a primeira é a de Freire ter apontado a cultura como variante explicativa para analisar a civilização nordestina deslocando a compreensão da sociedade brasileira do parâmetro racial para o cultural; a segunda é a de que o escritor pernambucano generalizou suas análises para criar uma identidade regional nordestina a partir de um espaço geográfico específico, o nordeste agrário e pastoril do senhor de engenho da casa grande e senzala do sertão pernambucano. Se Freire não esboça claramente uma diferença inata entre as raças aceitando, pois, uma hierarquia entre as mesmas como nos moldes dos escritores integrantes da Geração de 70, credita de maneira muito sutil uma predisposição para a raça branca, a negra e a indígena, o que em nenhum momento se verifica a presença da cultura num primeiro instante em sua compreensão. Assim, a imagem racial-mestiça aparece sim no ensaio de Freire, embora o escritor na tenha esta como um fator negativo a exemplo de ensaístas brasileiros como Nina Rodrigues, Euclides da Cunha, Monteiro Lobato, Oliveira Viana, mas salienta o caráter biológico de certa maneira. Por exemplo, com relação ao cabra, tipo mestiço do nordeste brasileiro, descreve as palavras do Folclorista paraibano Rodrigues de Carvalho "raramente o cabra ... tem a dedicação afetuosa do africano ou a carinhosa estima do mameluco, ou do branco". Freire segue analisando tipos raciais como o mameluco e o cabra, sempre associando características morais-psicológicas a tais tipos. A miscigenação aparece sim na obra de Freire. Seguindo o ensaio podemos descrever uma fala de Freire onde se presencia a variante raça como elemento explicativo na análise da civilização do açúcar estabelecida em Pernambuco. Com relação à mestiçagem pontua Freire: "mas aqui insistiremos no que já sugerimos em trabalho anterior sobre certos aspectos da miscigenação que se relacionam mais intimamente com a formação social do Brasil: muito do que se atribui a miscigenação resulta do desajustamento psicológico e social desajustamento de classe e, até certo ponto, de raça (este principalmente pela persistência de evidências de raças ligadas aos traços de classe) - em que se encontra o mestiço. A lealdade, a conformidade e a constância de subordinados não são qualidades que se possa esperar que existam em um elemento social e psicologicamente flutuante, indeciso e insatisfeito como é geralmente o mestiço, no mesmo grau em que existe no índio puro e principalmente no negro retinto. Figuras mais definidas e mais integradas no estado de subordinação de que a pele - como nariz, o cabelo, os pés - é como se fosse insígnia de trabalhador sempre de eito, de soldado sempre raso. É como se fosse um uniforme insubstituível, grudado ao corpo para sempre. Um macacão eterno" 
desequilíbrio completo da mata nordestina, uma vez que o cultivo da cana cada vez mais se expande e exige assim maiores espaços de terra. Se por um lado Freire reconhece que certas condições sociais espoliativas contribuem para o não desenvolvimento moral de alguns "tipos" do nordeste açucareiro, em pontos isolados e de forma muito sutil alude a questão racial-biológica tanto para explicitar elementos positivos ou negativos na forma de conceber o estabelecimento e as influências da civilização do açúcar que se estende do extremo nordeste ao recôncavo baiano. Freire reconhece a condição de negros explorados e desenraizados de sua cultura, mas nas entrelinhas a tônica era tão somente a de dois tipos raciais que contribuíram para o estabelecimento da civilização do açúcar. Conforme se lê: "grandes massas de gente da melhor, da mais capaz, da mais eugênica; e não os indesejáveis do ponto de vista da moralidade das tribos, como já houve quem ensinasse. Aliás, podiase dizer a esse respeito o mesmo que a respeito dos criminosos, portugueses deportados para o Brasil: nem todos eram desterrados por crimes que hoje consideraríamos crimes, mas vários por pecadilhos de amor e de heresia" ${ }^{776}$. É explícita a ligação que o autor atribui a uma raça boa seja por parte do português ou de negros transplantados para o Brasil na formação da sociedade patriarcal do nordeste. Mais adiante o autor combate justamente a idéia de raça e salienta o fator cultural como elemento de análise. Com relação aos negros, afirma "Querer ligar não só o desinteresse atual do preto ou do mulato pobre pela lavoura, como a deserção dos campos pelos trabalhadores negros - deserção que de fato se verificou aqui, nas Antilhas e no sul dos EUA, às primeiras notícias de abolição e artes, por grupos revoltados, pelos quilombolas e mucambeiros - a uma questão de raça, a um ódio especial da raça africana ao trabalho agrícola, é que seria torcer um fenômeno de causas nitidamente sociais para acomodá-lo a um "racismo" muito suspeito, quase sem nenhum cheiro de Ciência e com um odor cada dia mais carregado de intenção política. A verdade é que ainda hoje os xangôs afrobrasileiros do nordeste recordam em alguns dos seus cantos mais doces e dos seus movimentos de dança mais expressivos os velhos gestos de semear e de colher, o culto da terra, a alegria no trabalho agrícola, o regozijo pelo fruto ou pela espiga madura e toda uma mística do trabalho agrícola" 777. Lendo a fala de Freire percebe-se o forte caráter ideológico da fala de Freire. Aqui reside o que os críticos de Freire chamam mais atenção: a relação harmônica entre as raças, sem nenhum ódio, a democracia racial onde o branco escorregava nas coxas da negra agenciando a monocultura escravista do açúcar. A idéia central sutilmente apregoada na fala acima é a predisposição da raça negra africana que muito contribuiu para a instalação da civilização do açúcar ao trabalho agrícola. Se os negros da lavoura das Antilhas e do nordeste brasileiro segundo Freire se rebelaram não foi devido a nenhum ódio racial e nem devido ao desamor desta raça ao trabalho agrícola porque além de uma possível

\footnotetext{
${ }^{776}$ Ibidem. p. 158

${ }^{777}$ Ibidem. pp. 162-163
} 
predisposição do negro ao labor existia uma estrutura condicionante culturalmente a esta atividade constituída em "velhos gestos de semear, cultuar a terra, alegria ao trabalho agrícola e toda uma mística ao trabalho agrícola", 778

Percebemos a forte marca da visão etnocêntrica presente desde o início da colonização européia que, nesse momento inaugural, não manifestava claramente a justificativa escravista a partir de uma teoria das raças, que surgiu, em nome da Ciência, bem depois. A escravidão era, pois, justificada ora com punição ao pecado original ora como sendo o homem da "cor de cobre" escravo pela própria natureza. $\mathrm{O}$ negro por ser inferior não apenas serviria de peça, mera extensão da riqueza dos senhores de terra, como era portador de uma cultura menor. Bárbaro que era, muitas vezes a violência se constituía em traço singular deste caráter.

Nessa perspectiva, o homem de cor é possuidor de um conjunto de práticas e costumes intrinsecamente ligado a sua raça, equivalência direta de barbárie e inferioridade, sendo sua escravidão justificada tanto moralmente como legalmente. Quando a justificativa para a escravidão não aparece de maneira clara, surge à idéia de que a escravidão do negro no Brasil foi menos dura do que se ele tivesse continuado na África. Quando o negro não é concebido como mercadoria, é visto como uma grande massa que causa temor à elite, em função de sua potência de ferocidade ou barbárie.

Perante a visão dos letrados do período colonial, a resistência dos negros se dilui porque está relacionada a uma concepção de classe, em uma visão, no mínimo, ambígua e sem nenhum sentido para os milhares de africanos, de várias etnias e culturas, que tinham plena consciência da espoliação e assim buscavam a libertação da condição de escravo. Na visão de alguns desses escritores, os negros tinham consciência de sua própria espoliação, mas querer trazer a opressão sofrida por eles para as relações maiores do capital é questão dispensável. Daí, para eles, o motivo da resistência dos negros ter se dado por uma questão muito simples: "desterrados de seu continente, separados de seus laços de relação pessoal, ignorantes da língua e dos costumes, os recém chegados se transformavam em boçais. Entendido como propriedade, uma peça ou coisa, o escravo perdia sua origem e sua personalidade. Servus non habent personam: "o escravo não tem pessoa, é um sujeito sem corpo, sem antepassados, nomes ou bens próprios". 779

Em nome de uma missão civilizadora, todo o processo escravocrata, nas mais recônditas áreas do mundo, só foi possível por causa do importante papel da educação católica na expansão da "cristandade". Responsável não apenas pela formação da sociedade agrícola brasileira, com participação na forte Economia do açúcar e em várias ocupações, o negro contribuiu para a formação da cultura brasileira, tanto no campo como nas cidades

\footnotetext{
${ }^{778}$ Ibidem. p. 162.

${ }^{779}$ SCHWARCZ, Lilia. Racismo no Brasil. Op. Cit. p. 39
} 


\section{3 - Interesse pelas manifestações do povo brasileiro.}

O interesse informal de Sílvio pelas tradições populares data dos tempos de meninice, quando morou no engenho do avô. Lembrava que sua capacidade já vinha de outrora e que este era o "primeiro ato" de sua vida espiritual, logo, para conhecer o Brasil e a formação de seu povo e, assim, apontar a contribuição das raças então consideradas inferiores, era inevitável que recorresse às manifestações culturais de negros e índios. Influenciado pelos estudos do Romantismo alemão, que preconizava a relevância da alma nacional na identidade dos países, Sílvio foi profundamente marcado pela experiência que teve, na infância, que jamais sairia de sua mente. Criado até os cinco anos no engenho dos avós, Antônio Luís Vasconcelos e D. Rosinha, nas proximidades do rio Piauí, permaneceu até essa idade ouvindo e sentindo a natureza, os tangedores de boi, nos tempo de moagem de cana. Esse período foi crucial para seu interesse pelas manifestações das pessoas mais simples com suas taieras, juntamente com as contadoras de Histórias.

É o período mais marcante para o menino Romero, que tempos depois viria a recordar as fortes impressões que teve do sertão, onde brincou da maneira mais natural, ouvindo sempre os escravos cantadores que estavam a serviço de seu avô. Recordando os tempos de moagem diante do ruído dos cavalos, ficaram gravadas as cantigas

\section{"Pomba voou, meu camarada Avôou, que hei de fazer? Quem de noite leva á boca De dia que há de comer?",780}

De acordo com Sílvio, "tudo que sinto do povo brasileiro, todo meu brasileirismo, todo meu nativismo, vem principalmente dẩ ${ }^{781}$. O interesse pelas manifestações populares provém das lembranças de Histórias ouvidas ao cair da noite, ao iniciarem sempre a narrativa de era uma vez. Mais tarde, quando chegara ao Recife em 1868, estava impregnado de contos, romances, lendas, cantigas de cheganças e reisados aprendidos outrora. Afora as fortes recordações, outro traço lembrado por Sílvio era a religião "que nunca mais houve crítica ou Ciência que dali me extirpasse" 782 devido à negra Antônia, que dormia em seu quarto: todas as vezes que acordava, lá estava à negra de joelhos, rezando.

Na simples vila de Lagarto, presenciou manifestações populares de São João e se deixou saturar por elas. O próprio Sílvio falava numa certa predisposição hereditária, originando seu folclorismo nortista. Quando chegou ao Recife para cursar Direito, onde teria contato com a infinidade de autores

\footnotetext{
${ }^{780}$ Ibidem. p. 220

${ }^{781}$ Ibidem. p. 220

${ }^{782}$ Ibidem. p. 220
} 
da tão celebrada intuição moderna, principalmente, Comte, Darwin, Taine, Spencer, Haeckel, trazia consigo o amor por todas estas tradições absorvidas nos tempos de meninice. Mesmo diante da empolgação pelas novas idéias, dizia que toda a sua propensão para a crítica fizera apenas despertar o que já trazia desde os tempos de engenho e das aulas primárias do ensino no Ateneu Fluminense.

As leituras feitas no Recife só consolidaram as velhas tendências do escritor: "as influências ali recebidas não fizeram senão desenvolver o que em mim já existia, desde os tempos do engenho, da vila, da aula primária e dos preparatórios" ${ }^{783}$. Recordava, de modo específico, de Emilio de Lavelley e seu estudo sobre os Niebelungen, antiga poesia popular germânica, de Pedro Lerroux e seu estudo a respeito de Goethe, e Filósofos Franceses Contemporâneos, de Eugênio Poitou.

Lavelley partira para as análises do folclore, da Crítica Religiosa, da Mitologia, da Etnografia, e das tradições populares, que tanto despertariam Sílvio para a busca de experiências similares. Lerroux adentrou pelos caminhos da crítica literária moderna, campo de atuação que marcaria e destacaria posteriormente o nome de Sílvio Romero. Poitou explorava a Filosofia. Diante de tantas influências, lembrava Romero que sua capacidade já vinha de outrora. Esse era o primeiro ato de sua vida espiritual. Face a tais influências, ao longo de sua atividade literária, falava que cabia à crítica indígena a tarefa de descobrir e refazer sua formação, caso fosse interessante.

Embora conhecedor de tantos autores, livros e teorias da Ciência europeia, Sílvio jamais esqueceu as tradições e os gestos simples das pessoas de sua terra natal. Diante de sua enciclopédia alemã ou francesa, alegava que as impressões sentidas quando criança foram responsáveis por seu interesse pela cultura popular. Em O Momento Literário, pontuava as três influências sofridas, de modo específico, Emilio de Lavelley e a antiga poesia popular germânica em sua produção. Citava os Lusíadas, que só aumentou seu sentimento nativista. Não esquecia dois livros, base de ensino do seu último professor de primeiras Letras: Epítome da História do Brasil de J. P. Xavier, que retratava o cenário brasileiro, tendo em vista a descrição de Rocha Pita. Afirmava a respeito dessas duas obras “ $O$ Brasil da descrição de Pitta ficou sendo o meu Brasil de fantasia e sentimento; e a poesia de Camões ainda hoje é uma das mais elevadas manifestações da arte no meu ver e sentir, e, com seu ardente amor da pátria, fortaleceu o meu nativismo" ${ }^{784}$.

Um conjunto de fatores, dentre estes os maus tratos sofridos a partir da ação dos próprios irmãos, despertou o interesse do bacharel pela crítica $^{785}$, associada ao interesse pelas manifestações populares.

\footnotetext{
${ }^{783}$ Ibidem. p. $225-226$

${ }^{784}$ ROMERO, Sílvio. Op.Cit.p. 224

${ }^{785}$ Sílvio afirmara que escolhera a crítica porque era o gênero que melhor se ajustara ao seu temperamento "Existem em mim, encerram os germes de minhas tendências de analista e crítico. Aliadas as que tiveram origem no engenho Moreira, explicam em grande parte, toda a minha vida e toda a minha obra". Valeu-se da crítica naturalista alicerçada sob os paradigmas das ciências naturais em voga na Europa para delinear sua forma de ler o Brasil submetendo a cultura de seu país a um processo de renovação mental nos mais variados campos de observação "É preciso que nos entendamos: eu
} 
O amor por essas manifestações, tantas vezes aludido em seus trabalhos, é conseqüência da vida simples que conhecera antes de ingressar na Faculdade de Direito do Recife em 1863, com seus 17 anos, onde tomaria conhecimento da intuição moderna. Daí, sua concepção de poesia esteada sob a nova intuição crítica que despertou-lhe o interesse pelas lendas e canções colhidas da boca das pessoas mais humildes. Não é de maneira gratuita que relevava a importância das tradições populares, pois quem quisesse poesia que fosse buscar na boca do povo,

"Este sol que não se cansa de nos dar beleza e fartura e dengue às nossas mulheres, palavra que, às vezes, tenho vontade de o adorar porque é verdadeiramente um deus. Nós não prestamos para nada. Qual Literatura! Toda essa versalhada que por aí anda não vale o canto de um boiadeiro. Se vocês querem poesia, mas poesia de verdade, entrem no povo, metam-se por aí, por esses rincões, passem uma noite num rancho, a beira do fogo, entre violeiros, ouvindo trovas de desafio. Chamem um cantador sertanejo, um desses caboclos e peçam-lhe uma cantiga. Então, sim. Poesia é no povo. Eu criei-me na largueza, livre, correndo campinas, varando cerrados, comendo o que me ofereciam as árvores, bebendo nas fontes vivas, e quando o calor abafava, despia-me, pendurava a roupa num galho e atirava-me n'agua, nadando contra a corrente. Poesia para mim é água em que se refresca a alma e esse versinhos que por aí andam, muito medidos, podem ser água, mas de chafariz, para banhos mornos em bacia, com sabonete inglês e esponja. Eu, para mim, quero águas fartas, rio que corra, ou mar que estronde. Bacia é para gente mimosa, e eu sou caboclo, filho da natureza, criado ao sol" 786

Poesia para Sílvio era o que há de mais espontâneo em um povo, o substrato de onde as coisas partem e que, por isso, refletem toda e qualquer manifestação. Mesmo "por ser velha, por ser primitiva mesmo, nem por isso ela há de morrer". Mesmo carregando todo o lirismo subjetivista que deu a tônica aos poemas lamurientos dos poetas românticos, a poesia tinha como pano de fundo a nova intuição aplicada às diversas áreas do conhecimento: a evolução do espírito linear acompanhada pela intuição científica. Confia Sílvio na poesia popular porque pensa que esta revela o caráter dos povos. Conhecedor de todo o quadro social brasileiro, nas suas variáveis material, social e cultural, buscou, diante de tantas ideias e teorias, analisar a formação do povo brasileiro.

Mesmo com sua nova forma de pensar baseada na crítica moderna, não concebia a poesia sem relação alguma com o espírito de um povo ou de uma época, uma vez que a poesia revelava o caráter dos povos. O Romantismo não havia compreendido a verdadeira alma nacional, que só a análise das tradições populares poderia fornecer. Seu anti-Romantismo assumia, por vezes, uma face de Romantismo passado a limpo...

também suponho ser naturalista, quero também a verdade dos fatos, e é justamente por isto que julgo estreita a fórmula de Zola". Crítica para Romero era senão um instrumento por assim dizer metodológico, de analisar todo um estágio de cultura preocupando-se com os fatores condicionantes, para ele, responsáveis por toda e qualquer forma de produção artística emanada do espírito humano. Influenciado por mestres como Taine, Scherer, Saint-Beuve, a crítica de Sílvio ultrapassa a crítica descritiva, a seu ver, refém a estética, a metafísica e a retórica.

786 “A poesia é o produto da vida simples, espontânea, da comunhão com a natureza, da impressão imediata das coisas, e estas condições, próprias da humanidade em sua infância, desaparecem necessariamente todos os dias diante do progresso científico e industrial das sociedades”. ROMERO, Sílvio. Novos Estudos de Literatura Contemporânea. Rio de Janeiro: Garnier".p. 21. 
Conforme leituras acerca da contribuição racial, quando este ou aquele escritor privilegiava o elemento indígena, como fora o caso dos escritores românticos responsáveis pela índio-mania, inviabilizava o conhecimento do país, supervalorizava a participação do branco e esquecia os negros, o que negligencia uma justa análise da formação do povo brasileiro. Todo o esforço de Sílvio de estudar, conhecer e descrever o Brasil, com a visão que a crítica naturalista lhe ofereceu, resultou em seu intento de entender a contribuição de cada raça, no processo de formação do povo, assim sintetizada por Sílvio Rabelo: "Na verdade, o que pretendeu Sílvio Romero foi mais do que colecionar lendas, toadas, costumes, superstições e modos de dizer - a tradição popular do Brasil: foi alcançar o processo da formação brasileira, pela análise introspectiva das suas origens". ${ }^{787}$

Foi a ausência das "justas" contribuições de cada raça - segundo avaliações de Sílvio - que fez o polígrafo se interessar pela Literatura oral, tornando-o um extremo conhecedor da cultura popular. O mesmo comportamento de Sílvio quando de suas inúmeras arengas literárias que sempre se apoiou na incipiente crítica moderna, acusando seus adversários ora pelo desconhecimento da nova arte de Taine e Scherer, ora pela ausência de espírito filosófico, aqui se mostrava: o polígrafo tinha sempre uma posição e se julgava com a missão de dar uma espécie de veredicto, que só ele parecia ter em mãos. Sua série de artigos contra o Romantismo brasileiro, no início de carreira acadêmica, estendida ao longo de seus longos quarenta e cinco anos de produção literária, é uma reivindicação não apenas pelo negro, mas por outras raças e pela interação com o meio, enquanto partícipes da formação do povo brasileiro.

Deste momento, podemos datar o artigo O Caráter Nacional e as Origens do Povo Brasileiro, onde Sílvio investiga as raízes constituintes da formação de nosso povo: "Está ainda por escrever a História brasileira dos séculos coloniais. Em lugar da narrativa das direções que foram tomando as diversas camadas da população e da ordem futuras, em vez do desenho do pensamento de um povo que ia crescendo, temos o mote, sempre mal glosado, das virtudes dos Governadores e do numero dos Jesuítas que chegavam "788.

Em Romero, o interesse pela cultura popular confunde-se com o interesse folclórico devido à cultura livresca, onde tomou conhecimento do caráter etnográfico, contemplado por pensadores racistas como Lapouge, Gobineau, e Ammon. O conhecimento de tais autores "embora tenha feito de elucubrações mentais para poder ter chegado a alguns resultados menos drásticos quanto à gente

\footnotetext{
${ }^{787}$ RABELO, Sílvio. Op. Cit. p. 74

${ }^{788}$ ROMERO, Sílvio. Etnologia Selvagem. Op. Cit. p.48.
} 
brasileira" 789 incidiu diretamente sobre sua forma de analisar o processo de formação étnica do Brasil.

Fosse pelos meios literários ou pelas mais variadas manifestações do espírito, a cultura popular/folclórica tinha raízes étnicas avaliadas sempre a par do Evolucionismo e da lei do mais forte. Foi a influência conjunta da escola de Le Play e da Antropossociologia, que considerava ser a forma mais científica, que levou Sílvio aos estudos de formação do povo brasileiro.

Vale lembrar que Sílvio não fora o primeiro escritor a se interessar por este processo de formação. Couto e Celso de Magalhães já haviam contribuído com seus estudos acerca da contribuição do selvagem que mais tarde seriam analisados por Sílvio. Com relação a Couto de Magalhães, Sílvio ficou sem resposta, possivelmente devido a seu temperamento quando da publicação de Raças Selvagens, em que a questão do momento era a filiação ariana do tupi. Tempos depois, analisaria em seus Estudos sobre a Poesia Popular do Brasil o que coube a cada uma das raças, tendo em vista a leitura que Couto realizou de umas das obras de Teófilo Braga.

Por mais que, no Sílvio Romero folclorista, não desapareça o temperamento agressivo de um homem sempre preparado para a luta, às vezes, cometendo injustiça com vários escritores dos quais ele se apropriou para estudar a vasta contribuição das tradições populares, não deixou de ser um lutador por querer delinear a participação dos povos do interior, das vilas e cidades. Mesmo coberto da teoria científica européia, Sílvio não esqueceu das tradições populares, a ponto de ler sobre as tradições folclóricas da Itália e da França, perto de sua morte.

Câmara Cascudo aponta em Romero um escritor que, ao mesmo tempo em que era extremo conhecedor das últimas teorias emanadas da Ciência européia, preocupou-se com as tradições culturais das pessoas mais simples:

"Notável é que Sílvio Romero, devoto de livros e da Ciência oficial do tempo, amigo de
Tobias Barreto, fosse preferir estudar a Ciência do social através do Folclore que era
apenas uma curiosidade e uma pilhéria para a inteligência da época. Em 1873, quando
ele começa a interessar-se pelas próprias predileções promovendo-as a motivos de
análise, nada possuímos como utilização folclórica. Apenas artigos de jornais e
pequeninos estudos de aspectos parciais sem uma aproximação notória e corajosa do
assunto popular na plana grave dos volumes sociológicos efilosóficos". 790

Se um escritor do nível de Câmara Cascudo afirma ser notável o interesse de Sílvio pelo Folclore, sabemos o porquê de seu interesse pelas lendas e a canções populares. O Romantismo alemão fora o fator que mais contribuiu para o interesse e a grande contribuição da formação da nação brasileira, no caso, as tradições populares deitadas no folk-lore. Daí sempre o "problema das origens"

\footnotetext{
${ }^{789}$ MORAES FILHO, Evaristo de. Medo à utopia: o pensamento social de Tobias Barreto e Sílvio Romero. Rio de Janeiro: Nova Fronteira; [Brasília]: INL, 1985. p.268.

${ }^{790}$ CASCUDO, Câmara. In: Folclore Brasileiro: cantos populares do Brasil. Tomo I. Rio de Janeiro: José Olimpio, 1954. p. 24.
} 
que despertava Sílvio, levando-o, antes de tudo, a identificar quais os agentes do processo de formação do gênio ou da alma nacional.

\section{4 - Um triste passado.}

O tema da emancipação da escravidão, do ponto de vista econômico, acompanhado pela questão do aproveitamento da mão de obra dos futuros libertos e da organização do trabalho, assim como a discussão sobre a melhor forma de representação política, tangente a questões sociais como a colonização estrangeira, a grande naturalização e a reforma do ensino, carecia de um posicionamento, não apenas de Sílvio, mas de todos os escritores e políticos de sua época. Embora fosse o Brasil, como afirmava Sílvio, um país etnicamente em vias de formação, o escritor denunciou as mazelas e a situação da raça africana perante às imposições do europeu, quando de todo o processo de colonização. Base econômica do Brasil, o negro não poderia deixar de ser lembrado porque "alimentou o branco, deu-lhe dinheiro durante quatro séculos e agora por último dá fama aos gananciosos de nomeada fácil, dá glória aos espertos que não se pejam de declamar! Singular destino em verdade!" 791

Contrário a grandes estadistas brasileiros como José do Patrocínio e Joaquim Nabuco, dentre tantos outros, Sílvio Romero não elaborou nenhum discurso pomposo coberto pelas mais célebres divindades poéticas para falar sobre a condição do negro escravo no Brasil. Se era comum a celebração dos ilustres poetas e escritores clássicos quando da fundação dos grêmios literários ou mesmo quando se tratava de validar a argumentação do atraso do país, o escritor brasileiro não precisou aludir a clássicos como Dante e Camões para ver a importância do negro na formação do país.

Ao recorrer a uma gama de nomes europeus dos mais variados campos do saber para fundamentar sua visão, a crítica moderna, fosse ou não com a pretensa busca de autoridade, como chegam a apontar alguns de seus leitores, quanto à condição do negro no Brasil e sua espoliação e futura abolição, o bacharel era bastante objetivo e realista em um país que ele bem conhecia e do qual já havia apontado infinitos males.

Causa da involução ou do atraso do país, pode-se dizer que, segundo argumentação da elite política e intelectual do momento, os problemas sociais e políticos do Brasil recaíam sobre a questão da escravidão. Último país do mundo a libertar os cativos, o país trazia o peso do íorte contato entre as três raças, de onde uma sociedade fortemente marcada pela miscigenação, um verdadeiro "espetáculo das raças", somado ao fato que poderiam os negros se sublevar como acontecera nas ilhas

${ }^{791}$ ROMERO, Sílvio. História da Literatura Brasileira. Op. Cit.p. 37. 
de São Domingos e do Haiti. Era incoerente para um país que aspirava à condição de nação moderna resguardar em sua estrutura o "cancro" que só manchava os ares civilizatórios. Não é gratuita a imagem de atraso do Brasil, aludida pelos escritores brasileiros da época ligada à questão racial: era um novo país que se anunciava e passava a ser a primeira preocupação do Estado "lidar" com possíveis padrões desviantes. As teorias científicas assimiladas pelos homens de Letras e de Ciência da época foram bem instrumentalizadas pelos políticos a serviço de um novo Brasil. Nessa perspectiva é que "O mesmo contexto que encontra em um projeto liberal a solução para a nova configuração política, procura, nas teorias deterministas, subsídio para transformar diferenças sociais em barreiras biológicas fundamentais. Ante a liberdade prometida pela abolição e a igualdade oferecida pela nova Constituição, parecia imperativo repensar a organização desse novo país. Como dizia o artigo, de 21 de dezembro de 1920 do Correio Paulistano," os homens não nascem iguaes absolutamente, suppõe-se uma igualdade presumida pela lei sem o que não haveria lei...". ${ }^{792}$

Todo o discurso científico alimentado pela geração de Sílvio recaiu de maneira estratégica sobre duas temáticas: a escravidão e a monarquia. As diversas abordagens colocavam fora de dúvida a inferioridade do negro, tão bem assimilada pela elite intelectual, e buscavam sedimentar a idéia da incapacidade do negro em relação à nova sociedade, que se abria regida pelos valores mais recentes importados da Europa. O véu ideológico oriundo do tema da escravidão se dava pelo simples fato da obtenção de uma mão de obra forjada como ideal tributário do racismo científico.

É difícil entender que a crença na inferioridade do negro tenha surgido das mentes mais prestigiadas do mundo e que só ganhou força com os ares de liberdade, igualdade e fraternidade processados pela movimentação político-ideológica da Revolução Francesa. Difícil também é deglutirmos que o ideário liberal, em vez de conferir cidadania plena à população no Brasil, foi símbolo de autoritarismo, legitimado por nossos homens de Letras e de Ciência.

Toda a situação brasileira, na mente de nossos ensaístas, divulgadores da Ciência européia, era explicada a partir de uma pequena bolha, o mundo científico, tão excludente e que os próprios intelectuais interpretavam a sua maneira. De qualquer modo, o Brasil era visto por esse reduzido número de escritores a partir do olhar europeu, diante de um país composto por uma população miserável e analfabeta, conforme apontava Sílvio, espalhada nas mais distantes zonas do país e somente preocupada com a subsistência, ao passo que a Corte, enquanto centro do poder político, se

\footnotetext{
792 ANDREWS, George Reid. Negros e brancos em São Paulo. Op. Cit. AZEVEDO, Célia Maria marinho de Azevedo. Onda negra, medo branco. Op. Cit. ANDREWS, George Reid. Negros e brancos em São Paulo. Op. Cit.
} 
referendava enquanto tal, enviando escritores brasileiros ao exterior e se utilizando do dinheiro público na abertura de ruas e avenidas, conforme o estilo inebriante da arquitetura Art Nouveau.

Motivo do atraso brasileiro, a nódoa escrava ou a lepra social, como costumava ser designada, era responsável pelo atraso do país. Mas entre os inumeráveis discursos a favor ou contra a abolição, fosse ela lenta ou gradual, com ou sem indenização aos proprietários, alguns deles, pais de jovens da geração de Silvio, como Nabuco de Araujo, recorriam à necessidade da nação, cobertos pelos teores patrióticos, aferidos pelos intelectuais e políticos brasileiros, em Sílvio, a importância do negro na formação da sociedade brasileira era posta fora de dúvida. Em nada interessava adentrar as minúcias de que era o negro o responsável pela desmoralização do país ou pelo atraso, quando na verdade, para Sílvio, fora este negro, depois do português, o elemento que, no Brasil, fincou mais larga influência.

Entre a idéia de degradação moral causada pelo cativeiro da escravidão, proclamada por Joaquim Nabuco, e a frustração de durante três séculos ter sido o Brasil o último país a abolir a escravidão no mundo, o escritor pernambucano concluía que

\begin{abstract}
"A História da escravidão africana na América é um abismo de degradação e miséria que se não pode sondar, e, infelizmente, essa é a História do crescimento do Brasil. No ponto a que chegamos, olhando para o passado, nós, brasileiros, descendentes ou da raça que escreveu essa triste página da humanidade, ou da raça com cujo sangue ela foi escrita, ou da fusão de uma e outra, não de vemos per der tempo a envergonhar-nos desse longo passa do que não pode mos lavar, dessa hereditariedade que não há como repelir. Deve mos fazer convergir todos os nossos esforços para o fim de eliminar a escravidão do nosso organismo, de for ma que essa fatalidade nacional diminua em nós e se transmita às gerações futuras, já mais apagada, rudimentar, e atrofiada." 793
\end{abstract}

O escritor baiano, ainda que incorra no discurso sobre a prática da escravidão, tentando nublar a inferioridade do homem de cor, não consegue rejeitar o argumento do prejuízo acarretado pela raça negra no Brasil:

\begin{abstract}
"Se, multiplicando-se a raça negra sem nenhum dos seus cruzamentos, se multiplicasse a raça branca por outro lado mais rapidamente, como nos Estados Unidos, o problema das raças seria outro, muito diverso - talvez mais sério, e quem sabe se solúvel somente pela expulsão da mais fraca e inferior por incompatíveis uma com a outra; mas isso não se deu no Brasil. As duas raças misturaram-se e confundiram-se; as combinações mais variadas dos elementos de cada uma tiveram lugar, e a esses juntaram-se os de uma terceira, a dos aborígenes. Das três principais correntes de sangue que se confundiram nas nossas veias - o português, o africano e o indígena - a escravidão viciou sobretudo os dois primeiros. Temos aí um primeiro efeito sobre a população: o cruzamento dos caracteres da raça negra com os da branca, tais como se apresentam na escravidão; a mistura da degradação servil de uma com a imperiosidade brutal da outra.",794
\end{abstract}

Se o aumento da população negra no Brasil tornara-se, segundo a elite, um problema nacional devido ao aumento desproporcional com relação à população branca, surgiam dois fatores que só reforçavam o prejuízo causado pela escravidão: a degeneração que cada vez mais crescia, pondo em

\footnotetext{
${ }^{793}$ NABUCO, Joaquim. O abolicionismo. London Abraham Kingdon, 1883. p .143.

${ }^{794}$ Ibidem. p. 138
} 
risco a sociedade regida pelo branco, parâmetro das normas aceitas legalmente, portanto, ditas "civilizadas". O que parecia ficar restrito ao plano biológico acabava por normatizar as práticas e os valores sociais, no inicio do regime republicano. Se o negro "cientificamente" era inferior ao branco, a escravidão só os tornava inapto à condição civilizatória. Ressente-se Nabuco da qualidade racial que veio ao Brasil, as fezes sociais, criminosos, e, sobretudo, espíritos aventureiros incapazes da luta pela vida. Mesmo que Nabuco reconheça a influência do negro na cultura brasileira - "Suprima-se mentalmente essa raça e o seu trabalho, e o Brasil não será, na sua maior parte, se não um território deserto, quando muito um segundo Paraguai, guarani e jesuítico” -, não deixa de percebê-lo, assim como Silvio, num Estado de "barbárie intelectual".

Se Nabuco reveste seus argumentos a partir de um nacionalismo libertário, não esquece a ideia de escravidão ligada à submissão divina, sendo os negros o cordeiro de Deus. Alega Nabuco que, além de não existir ódio de raças entre senhores e escravos, a espoliação do negro se dilui no sentimento patriótico, ou seja, assim como os negros se libertavam porque eram servos de uma força maior, no caso, a boa relação que tinham com seus senhores, libertavam-se da própria condição de não mais serem escravos em suas terras e sim escravos brasileiros de nascimento. A justificativa é sutil e Nabuco altera uma ideologia por outra, sem pensar na libertação do negro: ser escravo no Brasil é diferente da escravidão de cor.

Nas nuances do discurso, percebe-se que a cor é que dá a tônica ao fenômeno da escravidão, tributária do pensamento católico, por sua vez pretenso herdeiro da fonte bíblica, a favor de uma escravidão negra por natureza. Diferente de uma sociedade birracial como a norte-americana, rigidamente delimitada pela linha de cor e sem nenhuma condição de ascensão social para o negro, no Brasil, foi justamente por essa ausência que os discursos raciais se impuseram.

Manchando toda a História brasileira, ao longo de três séculos Nabuco abordava o "cativeiro da escravidão" como fator de vergonha e imoralidade do país, que impedia o progresso material e moral, obstando o caminho da civilização. Mesmo condenando o cativeiro, o escritor pernambucano encara a escravidão como um processo natural, se preocupando assim como Sílvio com o futuro dos libertos na vindoura ordem social. Alguns pontos da argumentação do autor de $O$ Abolicionismo são semelhantes aos de Sílvio Romero. A grande diferença de Sílvio com relação a Nabuco, no que tange à escravidão, é a importância que o crítico literário atribui ao negro na formação do caráter nacional brasileiro. Sílvio referenda a importância de Nabuco no processo abolicionista, porque o escritor pernambucano "chegou onde brasileiro algum ainda subiu tão alto".

A louvação de Sílvio ao filho de Nabuco de Araújo ocorre por ter sido o autor de Minha Formação um "homem de Letras, o homem da palavra sobre todas as outras qualidades que ele por ventura possa revelar". A figura de Joaquim Nabuco é digna de apreço em função das lutas patrióticas 
e, conforme Sílvio, de sua participação na História literária do país. Todo escritor engajado nas lutas nacionais encantava e merecia os aplausos de Sílvio. No capítulo que escreve sobre Joaquim Nabuco, Sílvio chama atenção para o papel desempenhado por aquele nas questões nacionais sem realizar uma análise minuciosa sobre o escritor elogiado, o que não desmerece a fundamental importância do bacharel. Tal ponto é apenas parte integrante do nacionalismo de Sílvio, do modelo de escritor que tinha em mente. Para o escritor sergipano, é de maior valia salientar o espírito combatente do escritor, um modelo que sempre fez questão de ressaltar que não escrevia para agradar e nem deveria se poupar, ante o que ele mesmo considerava verdade. Assim a figura de Joaquim Nabuco se destacava:

"Não é que desconheça o grande valor de sua ação de hoje; é que os seus feitos de agora, por mais brilhantes que sejam, e o são em alto grau, funcionam principalmente como a dourada moldura dos seus feitos da mocidade

Ele está bem em seu lugar, no seu posto de Embaixador da civilização brasileira perante o mundo.

A cultura nacional não poderia encontrar mais distinto representante". 795

Apoiado no Darwinismo social, Sílvio se opõe à escravidão, imposição da colonização portuguesa, e aos vícios acumulados, devido à raça colonizadora, durante os quatro séculos de dominação, somava-se uma cultura "bárbara", oriunda de tipos mestiços existentes no Brasil. Ao passo que os escritores do império brasileiro tratavam e concebiam o negro como fator que obstava a chegada a uma sociedade de costumes civilizados, Sílvio ia muito além: não deixou de inserir o negro no discurso patriótico indispensável à modernidade do Brasil. Diferente de grande parte dos homens de Letras e dos políticos que justificavam as mais autoritárias práticas políticas, convictos da hierarquia racial e preocupados coma legitimação do sistema, Sílvio não apenas destacava na História brasileira a importância de significativos homens negros no campo intelectual como pensava em dias melhores para a raça africana.

Como tantos outros escritores de seu tempo, a imagem do negro, embora inferiorizada, biologicamente, não é de rejeição. Reconhecer o grau de barbárie do negro não significa afirmar que Sílvio mantinha uma posição negativa perante o elemento negro. Era a leitura e resultado do corpus teórico que tinha a sua frente. Mesmo conhecedor dos livros racistas daqueles que considerava seus mestres, Sílvio combate a escravidão, parte integrante do processo colonizador, porque o colono não soube tirar proveito racionalmente do negro sem o escravizar. Se nossos políticos e escritores argumentavam que o atraso do país dava-se pela presença de milhares de negros, Sílvio opunha-se à prática da escravidão, fosse ela indígena ou negra.

${ }^{795}$ ROMERO, Sílvio. Op. Cit. p. 65 
Diferente de diversos escritores que justificavam a inferioridade do negro para forjar uma imagem negativa deles, Súlvio em nenhum momento o concebe de maneira pejorativa. O maior discurso elaborado pela elite brasileira do momento era a associação negativa da escravidão com a imagem do país, manchando o imaginário de um país inferiorizado pela presença de milhares de negros. Contrário a tantos escritores que advogavam que a "inferioridade" do negro, com seus instintos bárbaros, entravava a empreitada civilizatória, justificando assim a escravidão, Sílvio transforma a imagem negativa do negro na importante contribuição deste para a formação social, econômica, política e cultural do país. Se a maioria dos demais políticos e escritores brasileiros aludia ao negro somente para excluí-lo da História, Sílvio introduzia um movimento diferente: apegando-se às teorias "científicas" da época, propugnadoras da hierarquia racial, buscou a contribuição do negro na cultura brasileira. O racismo de Sílvio é um racismo diferente, que merece o olhar atento aos nossos antepassados, homens que influenciaram demasiadamente nossos costumes.

A constante revolta de Sílvio a favor do reconhecimento da contribuição do negro é uma clara demonstração da importância desse contingente humano na formação social, cultural e política brasileira. $\mathrm{O}$ fato de o autor acreditar nas teorias racistas européias não invalida o olhar bastante atento à raça que, segundo suas palavras, depois do português, mais contribuiu para a identidade nacional. Não se pode deixar de reconhecer o esforço de Romero em ralação à contribuição cultural do negro. Se o escritor sergipano esteve envolvido com os mais variados temas pertinentes à nação, por vezes construindo argumentações prolixas quando se tratava de sua visão artística, isso não nos autoriza a admitir uma desatenção com relação aos negros. Pelo contrário, a par do mundo ilustrado que tão bem conhecia, pensava Sílvio num mundo melhor para o negro, temendo que após a abolição, a raça enfrentasse piores condições do que no regime servil.

Sílvio aborda o tema da escravidão dentro de uma estrutura ampla e racional, para além da temática onde a raça européia era superior - o que poucos escritores seus contemporâneos fizeram - e busca encontrar o mundo do negro para inseri-lo no Brasil moderno. Primeiramente, a escravidão por parte do colonizador português foi um erro que, somado a outros fatores oriundos dessa colonização, resultou em um quadro pior da situação brasileira. Por isso, o escritor aponta a importante contribuição do africano para a formação do Brasil, combatendo a escravidão e o esquecimento do negro. O que pode parecer mais uma dentre as possíveis ambiguidades de Sílvio, conforme chegam a apontar alguns de seus leitores, é apenas uma análise precavida com relação à temática da escravidão. Entre a louvação do movimento abolicionista e o surgimento de algumas sociedades libertárias, o crítico colocava-se na dianteira do movimento em nome dos preceitos científicos:

"A solução que preguei, a que dei o nome de emancipação autonômica e popular, foi a única que se pôs em pratica. Nada de deixar dependendo do governo geral uma 
questão de caráter social e econômico, disse eu. E acrescento que o individuo, a família, o município, a província fossem libertando os seus escravos, os nossos irmãos de cor, ao que eram impelidos, além de motivos morais, pelo fato do escravo começar já então a ser um trambolho, uma desvantagem diante do trabalho livre.

Apesar de não terem sido estas idéias declamadas da tribuna das conferências ou da Câmara dos Deputados, constituíram a solução que praticamente foi posta em execução pelos heróis populares da abolição no Ceará, Amazonas, Rio Grande do Sul, São Paulo, Bahia, Paraná, Pernambuco, Minas e Rio de Janeiro, durante oito anos. Foi a solução posta em prática pelos homens do povo, os fautores mais valentes, os obreiros mais meritórios do abolicionismo, Nascimento, João Cordeiro, João Ramos, Antônio Bento, Carlos de Lacerda e vinte outros". ${ }^{796}$

Não se pode simplificar sua análise por ser Romero um adepto da inferioridade biológica do africano, diante do homem europeu, tendo em mente as premissas teóricas do racismo europeu. Entre a constatação da inferioridade do negro respaldada pela lei da seleção natural, cerne da ideologia evolutiva, e a defesa da escravidão, há uma grande distância. O ponto nevrálgico do pensamento de Sílvio com relação à escravidão não se reduz meramente à presença da raça "inferior" no país, mas sim, por ter sido o Brasil colonizado pela raça portuguesa, acostumada à colheita e que só se desorganizou com a abolição, tornando-se uma "sociedade pratiarcal instável", porque nem o negro nem o índio foram preparados para o trabalho agrícola. Melhor seria, nessa perspectiva, se a colonização tivesse se processado sem escravização negra.

Nas entrelinhas do pensamento de Sílvio, o que se combate é a escravidão e não a inferioridade do negro, porque tal inferioridade é senso comum entre os ensaístas da época. Seu ponto de vista dá margem a uma visão romântica, resultado que é de sua defesa na hierarquia das raças. O negro bem se relacionava com o senhor por ser "muito mais dócil ao trabalho colonial do que o índio, muito mais assimilável e mais prolífico" ${ }^{797}$. Com isso, Sílvio não quer legitimar a colonização, apenas deseja ressaltar que o desenvolvimento social do Brasil torna-se mais fácil com o contato do colono com o negro, não com o índio, diante de seu grau evolutivo. Embora sendo contra a escravidão do negro, não vemos duras críticas por parte de Sílvio movida a fazendeiros e traficantes, mesmo que reconheça a espoliação do escravo. A crítica de Sílvio dirige-se mais uma vez à escravidão, mas não se sabe qual o mundo que o escritor propõe para o africano, daí emerge uma leitura talvez continuada por Gilberto Freyre.

Muito mais significativo para Sílvio é conhecer quais as bases sociais deixadas pelos portugueses para as raças negras e indígenas. Romero possui uma idéia de colonização "condizente" a índios e negros, ou melhor, se a colonização tivesse se processado de outra maneira, outra seria a História do Brasil. É que a velha família portuguesa, com seu modo de vida "patriarcal absoluto", logo caiu num

\footnotetext{
${ }^{796}$ ROMERO, Sílvio. História da Literatura Brasileira. Op.Cit.p.41

${ }^{797}$ ROMERO, Sílvio. Estudos sobre a poesia popular brasileira. Op.cit.p. 150
} 
partriarcalismo desorganizado devido à "transmissão da parcela das heranças e domínios", tornando-se uma família de base instável, que só se desorganizou em razão da ausência de uma "colonização geral sistematizada", agravada ainda mais com a extinção da escravidão.

Mesmo sendo um apóstolo da inferioridade do negro diante do branco, Silvio entendia que o sistema patriarcal não logrou êxito nem com a escravidão do índio nem com a do negro, o que não significa contradição ou ambigüidade por parte do escritor. Romero é um pensador organicista, suas diretrizes contemplam cada um dos elementos analisados, daí a precisão de análise onde cada raça deve se encaixar na estrutura que "melhor" a resguarde. O colonizador não soube extrair da melhor forma a potencialidade do negro num Brasil formado por uma educação comunaria preocupada somente com a política alimentar, o que exclui um possível Determinismo por parte dessa ou daquela raça na justificativa da condição social e política do país.

Para todas as questões, Sílvio é possuidor de um esquema de pensamento criterioso e isso dificulta uma interpretação unilateral, embora se trate de um autor convicto sbre a existência de uma hierarquia racial. Quando analisa o processo da abolição da escravidão no Brasil, adentra sua cultura, seus hábitos, sua organização de trabalho, seus costumes, sua língua etc. Daí, o interesse em conhecer a cultura do negro, salientando a potencialidade deste. Nessa ótica, é buscando a herança do negro que Romero acaba por conhecer sua importância, visando a adequá-lo a uma organização social condizente.

Sílvio analisa a herança do africano à luz das teorias européias, especificamente, da escola de Ciência social, estudando-os de maneira objetiva conforme tais preceitos, para os quais a forma da organização social familiar era indispensável, "o que havemos mister é conhecer, à luz dos novos processos da Ciência social, o Estado exato das sociedades africanas que enviaram representantes ao Brasil e parte com que entraram na formação da nova nacionalidade aqui fundada. Esta é a questão; o mais é esgrimir no ar". 798

Admirador inconteste de Préville, Sílvio elabora uma análise minuciosa acerca dos locais de origem das populações africanas, seus modos e costumes porque "felizmente, na falta de estudos brasileiros, existe o admirável, e magnífico livro de A. de Preville: - Les Sociétés Africaines. Leur origine: ler évolution; Leur avenir, que derrama uma luz intensíssima no assunto". 799

Percebe-se a análise minuciosa de Sílvio indo muito além da suposta inferioridade do negro, elaborando uma análise sociológica. A partir do trabalho do escritor francês, Romero vai estudando o modo de vida de populações africanas, sua forma de organização social na identificação do tipo de família, visando a contribuir para um mundo melhor para os negros. Não é sem razão que, atinando

\footnotetext{
${ }^{798}$ ROMERO, Sílvio. História da literatura. V. I. Op. Cit. p. 212

${ }^{799}$ Ibidem. p. 212
} 
para a forma de colonização processada pelo português, Sílvio era cauteloso no que diz respeito à abolição da escravidão: do que adiantava libertar os milhões de escravos sem uma estrutura que lhes resguardasse as mínimas condições de sobrevivência? Temia, assim, o mesmo quadro ocorrido na antiguidade:

"Refiro-me à negação pelo Brasil dada à lei histórica, observada na milenária evolução do Ocidente, quando se deu a transformação dos escravos e servos em homens livres. Em todo o Ocidente, a maior porção daqueles transmudou-se nessa massa de pequenos proprietários agrícolas, presos ao solo pelos mais sólidos interesses, e que veio a constituir o cerne, o âmago, o nervo das nações modernas; a outra porção transformouse nesse corpo de operários rurais também ligados à terra e que é também uma das bases firmes das nações fortes e futurosas" 800

Sílvio pensava o tema da abolição de maneira precavida, sempre salientando o tipo de organização social dos portugueses. Chama atenção para a desorganização contínua dessa população, que, de "patriarcal-absoluta", transformara-se em "patriarcal-desoganizada" devido a suas heranças e domínios, que se desestruturaram ainda mais em razão da ausência de uma colonização geral sistematizada. As boas qualidades do colono só desapareceram com o contato com índios e negros. Se Sílvio combate a escravidão tanto indígena como negra, mantém bastante cautela com relação à abolição, embora reconheça que "A escravidão operou como fator social, modificando nossa psicologia, nossos hábitos, e nossos costumes. Habilitou-nos por outro lado a arrotear as terras e suportar em descanso as agruras do clima. Desenvolveu-se como fator econômico, produzindo as nossas riquezas e o negro foi assim um robusto agente civilizador. " 801

Sendo a escravidão um meio degradante tanto materialmente como moralmente, impossibilitou o que de melhor poderia ser extraído do negro. Na verdade, como um dos apóstolos da hierarquia racial, num primeiro momento, Sílvio "parece” não combater a escravidão, uma vez que se posiciona a favor de outros meios de aproveitamento da mão-de-obra escrava por parte do colonizador português. Entre a defesa da superioridade branca em detrimento das raças inferiores, Romero combate o fenômeno da escravidão, afirmando ter seguido o processo evolutivo acompanhado pelo desejo da nação brasileira. O que parece duvidoso e ambíguo logo se clareia: o sergipano conclui que é preciso o contato do negro com o branco para a solução de sua barbárie.

Se Sílvio considera o negro como raça inferior, de acordo com suas leituras de Spencer e outros admirados teóricos racistas, apontou a contribuição dos negros e combateu a escravidão imposta pelo português. Podemos perguntar, de acordo com Romero, qual seria a melhor maneira de o português colonizar o Brasil sem ter escravizado o negro. Se o escritor apontou o caráter espoliativo da

${ }^{800}$ ROMERO, Sílvio. O Brasil Social. Op.cit. p. 91

${ }^{801}$ ROMERO, Sílvio. Estudos sobre a poesia popular brasileira. Op.cit.p. 230 
escravidão no Brasil, nem por isso deixou de reconhecer a importância desta na formação da cultura brasileira. Sílvio ora assume uma postura romântica por creditar ao processo evolutivo a base explicativa das coisas, eximindo-se assim de clarear os reais fatores da existência da escravidão no Brasil. Fora a nação brasileira que libertara os negros e pela lei fatalista da História, não tardaria a emancipação do africano "E a maior prova é que, se os recém chegados do gabinete atual demorassem mais três ou quatro anos meses a apresentação de seu projeto, não encontrariam mais a quem libertar!... A abolição progressiva, espontânea, popular teria chegado ao último representante da escravidão, o meu sistema teria vencido em toda a parte." 802

Sílvio vai além de sua crença nas teorias raciais que advogam a inferioridade dos negros. Antes de tudo, toda a organização social é pensada por ele na leitura que faz sobre a escravidão, que só faz sentido enquanto parte de suas análises maiores, que repousam sobre a organização social brasileira, que tem como célula a base familiar. Desse modo, o africano possui um lugar na organização social rigidamente constituída, deve participar e se beneficiar do processo histórico do Brasil, da evolução do país, ao mesmo tempo gerindo-se enquanto negro que contribui para o desenvolvimento social e político do país sendo por isso contemplado pelos serviços prestados pelo aparelho de Estado.

Diante dessa estrutura social rigidamente pensada, Sílvio criou o impasse da miscigenação, apontado pela crítica como sua contradição maior, apostando no desaparecimento no negro, fosse pelo fim do tráfico ou pela superação-assimilação biológica deste por parte da raça superior branca, que chegara ao Brasil nas províncias do sul do Brasil. Ao mesmo tempo em que releva a importância do negro na formação da sociedade brasileira, esquecida por inúmeros escritores, arrematava Sílvio concluindo pelo desaparecimento deste. Impasse que mostrava sua agonia, bem lembrado por Thomas Skdimore:

\begin{abstract}
"No fundo, naturalmente, Silvio estava inseguro. Pois: "Se é certo que a mistura de povos diversos é um garante de geração vigorosa, nenhum mais que o brasileiro pode oferecer maior vantagem". A cláusula condicional epitomiza sua incerteza. Era irredutivel em declarar que a miscigenação estava no centro da História do Brasil. Mas suas conclusões sobre a significação disso dependiam da sua estimativa do progresso contemporâneo do país e da sua tendência muito pessoal de confundir análise histórica com futurologia. Esse equívoco não é de surpreender. O pensamento científico sobre híbridos mudava rapidamente ao tempo dele. A Ciência européia continuava a renegar sangues humanos misturados como fracos e potencialmente estéreis. Sílvio Romero pensava que isso era, provavelmente, uma tolice, mas ainda não tinha base científica para proclamá-lo. ${ }^{, 803}$
\end{abstract}

Sílvio não era profeta nem desconhecia as teorias raciais da época. Diversas vezes tinha aludido a que a Ciência não estava em condições de confirmar esta ou aquela tese, mas seu espírito geométrico o impelia a buscar sempre uma fundamentação teórica. Positivista e evolucionista, atinava para as leis

${ }^{802}$ ROMERO, Sílvio. História... Op. cit.p. 42

${ }^{803}$ SKDIMORE, Thomas. Preto no branco: raça e nacionalidade no pensamento brasileiro. Op.cit.p. 53 
históricas baseando-se nos modelos de escravidão ocorridos na Antiguidade Clássica, em que os escravos passaram para a condição de homens livres, tornando-se depois pequenos proprietários agrícolas. Não adiantava de uma hora para outra libertar o negro sem pensar numa estrutura que o acolhesse de maneira humana. Não é difícil pensar o mundo encontrado pelos negros após a lei de 13 de maio de 1888, que não lhes ofereceu as mínimas condições de cidadania, relegando-os a trabalhos marginais, com todo o peso da discriminação no Brasil republicano. As apostas num mundo melhor, defendidas pela geração de Sílvio, se transformaram em utopia.

O ex-escravo, que não tinha sido preparado pelo colonato, nem pela descrição ao solo, devido à solene incapacidade da famosa elite de bacharéis palreiros que têm sido sempre governo nesta terra e têm tido nas mãos os destinos do Brasil, o ex-escravo deu em geral na calaçaria e emigrou para os povoados... Aí vive aos trambolhões nuns empregos reles. Aí, nas cidades, como nesta capital, nenhuma aspiração elevada e nobre lhes despontou n'alma.

Aumentaram apenas a nota cômica que nos cerca por todas as faces da existência. Uma das mais características dos dois últimos decênios é o sério com que distintas e grandes damas de cor imitam os trajes, os gestos, os cacoetes das mais finas arianas européias ou fluminenses, ou a doce ternura com que se tratam - de Excelências... ${ }^{804}$

Segundo Lilia Schwarcz,

"O resultado imediato dessa versão organizada e pretensamente cordata de nossa libertação dos escravos foi jogar uma imensa população, despreparada e pouco instruída, num processo de competição desigual, sobretudo com a mão-de-obra imigrantes que afluía ao país desde os anos 1870. De toda maneira, atrasada ou não, o certo é que a abolição era vendida como um presente e, enquanto tal uma dádiva nãonegociada. O problema foi que dissimilou um processo de confronto, para se investir numa imagem de superação lenta, ordenada, gradual e controlada pelo Estado”. ${ }^{805}$

Sabedor da situação de espoliação do negro no Brasil, concluía Sílvio em O Problema Brasileiro em 1891 que "acabou-se a escravidão, desapareceu o império; mas não findou a nossa incurável leviandade, a nossa clássica covardia, a nossa falta de ideal, a ausência em que temos vivido do senso do que é ousado e grande, do que é justo e nobilitante". 806

\section{Esqueceram do negro}

Ao mesmo tempo em que Sílvio considerava o elemento negro inferior com relação ao homem europeu, tendo por base os preceitos darwinianos, a participação do homem negro cada vez mais despertava sua atenção. Era de fundamental importância analisar "um dos elementos essenciais $e$

\footnotetext{
${ }^{804}$ ROMERO, Sílvio. O Brasil social. Op.cit.p. 92.

${ }^{805}$ SCHWARCZ, Lilia Moritz. As barbas do imperador: D. Pedro II, um monarca nos trópicos. São Paulo: Companhia das Letras, 1998.

${ }^{806}$ ROMERO, Sílvio. Estudos de Literatura Contemporânea. Op. Cit.p.359.
} 
predominantes na formação brasileira" ${ }^{807}$. Por ser o negro, depois do português, o elemento que mais participou no caráter e na formação da psicologia nacional brasileira, segundo Romero, era imprescindível analisar o que coube a um sujeito que tanto influenciou a cultura brasileira, tanto no plano biológico como nos planos moral e das idéias.

Dentre as inúmeras querelas em defesa desta ou daquela temática concernente aos rumos do Brasil, o principal objetivo de Sílvio era pontuar o que coube a cada uma das raças na formação do país. Acompanhado da preocupação em descrever a realidade Brasil, denominada por Romero de "Brasil social" ou de "Brasil sem ilusões", incumbiu-se o escritor de pontuar o que coube a cada uma das raças na formação do povo brasileiro. Fosse pelos meios "literários", sociais e políticos, alguns destas consideradas obras sociológicas ou, partindo de sua grande aposta, a vertente folclórica, surgia em Sílvio o interesse em apontar a grande contribuição do negro, esquecida pelos escritores nacionais e estrangeiros. O combate de Romero aos escritores do Romantismo se deu em razão do esquecimento dos negros por parte daqueles escritores, que deificaram o caboclo, o que fazia Sílvio afirmar "ter descoberto o motivo histórico e moral deste silêncio voluntário". ${ }^{808}$ Dizia eleo que o desinteresse pelo africano se dava por conta de uma possível postura de classe. Conhecedor do quadro social e material do Brasil, Sílvio jamais duvidou da inferioridade do negro,

\footnotetext{
"A raça negra nas suas pátrias de origem, na África e na Oceania, não se civilizou, não passou da selvageria, não caminhou, não progrediu. Nas terras, para onde se deixou transportar, como a América, ao contato com os seus ex-senhores, pouco tem avançado em massa, não passando de uma semibárbara característica. Não é só. Os restos da gente vermelha da América andam talvez em piores condições; como que apostaram em desmentir a lei do famoso progresso indefinido e as sonhadas maravilhas da razão inenarrável. Não é tudo.... Eram quase todos do grupo banto. São gentes ainda no período do fetichismo, brutais, submissas e robustas, as mais próprias para os árduos trabalhos de nossa lavoura rudimentar. ${ }^{, 809}$
}

Mas, o maior objetivo de Sílvio era relevar a extrema importância do negro diante da ausência de documentos "A pobre raça escravizada não teve nunca o direito de entrar na História; seu trabalho intelectual foi anônimo, bem como o seu trabalho físico. Ainda mesmo em fatos altamente épicos, em fenômenos extraordinários, como o Estado dos Palmares, a História é anônima. Como se chamava o herói negro, o último Zumbi, que sucumbiu à frente dos seus nos Palmares? Ninguém sabe”. 810

E mais: "é uma vergonha para a Ciência do Brasil que nada tenhamos consagrado de nossos trabalhos ao estudo das línguas e das religiões africanas" ${ }^{811}$. Dialogando com Celso de Magalhães,

\footnotetext{
${ }^{807}$ ROMERO, Sílvio. História da Literatura Brasileira. Op.Cit.p. 210

${ }^{808}$ ROMERO, Sílvio. Estudos sobre a poesia popular Brasileira. 2a ${ }^{\text {a }}$ Ed. Petrópolis, 1977. p. 60

${ }^{809}$ ROMERO, Sílvio. História. Op. Cit. p.119

${ }^{810}$ Ibidem. p. 128

${ }^{811}$ ROMERO, Sílvio. Estudos... Op. Cit.p. 34
} 
Couto de Magalhães, José de Alencar, Araripe Junior, José Antônio de Freitas, Carlos de Koseritz, Sílvio irá buscar a influência do africano na formação do povo brasileiro.

Cabem aqui algumas ressalvas. Foi por meio das tradições populares ou folclóricas, representação direta da "inerrância popular", concepção de Jacob Grimm, que Sílvio acreditava repousar a alma nacional. Não se pode esquecer o apelo e a importância de Romero no que tange ao estudo das criações anônimas. Vale lembrar que por mais louvável que seja seu interesse pelas tradições populares seu ponto de vista é estritamente folclórico e etnocêntrico, ou seja, Sílvio é um escritor que analisa a cultura pensando na luta das idéias, como sempre afirmou. Era a presença da luta do mais forte no plano das idéias. Aqui, reside o ponto principal nos estudos folclóricos de Sílvio que é sua avaliação da contribuição das raças a partir das leis transformadoras, sempre acompanhadas pela lei do mais forte. Não é sem razão que bradava sobre a inexistência de estudos folclóricos por parte dos escritores nacionais, "Um olhar lançado sobre nossa História, não sobre a História escrita por A ou B, por Varnhagen ou Pereira da Silva, velhos declamadores retóricos, mas a História não escrita, a tradição flutuante e indecisa de nossas origens e ulterior desenvolvimento, num olhar ali lançado irá descobrir com alguma dificuldade os primeiros lineamentos de nossas lendas e canções populares, 812

Em Estudos sobre a poesia popular Brasileira, Sílvio não somente mostrou a ausência de estudos sobre a "devida" contribuição de cada uma das raças como também pontuou de que forma os polígrafos brasileiros concebiam a poesia popular do país. O objetivo do crítico é claro: apontar no corpo das tradições brasileiras o que devemos a cada uma das raças, mesmo diante da inexistência de documentos para tal estudo. Assim como faltavam documentos para escrever a História literária do país, o que sempre salientava em seus estudos, as dificuldades só aumentavam quando se tratava de delinear as lendas e canções populares brasileiras. Sentindo-se com a missão de tratar de maneira justa a condição e a relevância do negro, Sílvio buscou investigar sua contribuição depositada nos estudos populares.

A busca pela poesia popular e o sentido de sua concepção folclórica não se separam da importância racial enquanto parte de um processo maior que é a reflexão sobre o caráter nacional brasileiro. Somente a partir da idéia de caráter, conjunto de valores "inerente" a cada uma das raças, é que reside o sentido e a relevância simultânea da investigação folclórica na busca por essa identidade acompanhada da ânsia pelo conhecimento do verdadeiro Brasil. Desse modo, o interesse de Sílvio em relação ao que coube a cada uma das raças é parte integrante da busca de seu Brasil sem ilusões, que

${ }^{812}$ Ibidem. p. 38 
não era grande como queriam os políticos e literatos e que foi a razão para as intensas polêmicas na descrição de um tal objeto.

Sua ânsia em querer mapear as lendas e as canções populares reveste-se de uma moldura folclórica tributária do Romantismo alemão, em busca da alma nacional residente nas criações do "povo". Por meio de um enorme esforço em que coligiu uma gama de quadrinhas, sobretudo, lendas e canções populares, é que Sílvio mapearia a contribuição das raças, pois para ele, "A poesia popular revela o caráter dos povos... Ao lado, pois, de peças antigas, ainda hoje cantadas em nossas festas de Natal e Reis, como a Nau Catarineta de origem portuguesa e que dá uma idéia de um povo navegador, ouvem-se entre nós os verdadeiros cantos que nos definem e individualizam" ${ }^{813}$.

Em busca da justa contribuição do africano ancorada sob as manifestações populares, algumas vezes não se entende a maneira de Sílvio conceber essa poesia, uma vez que a priori só relevaria a contribuição cultural das raças puras num país onde ele mesmo afirmava que as diversidades de tipos superam as "variedades de gatos que habitam nossos telhados, para repetir a frase de Quatrefages". 814

Em alguns momentos, a tese de Sílvio mostra-se confusa porque se por um lado apontava a singularidade do Brasil, que residia no mestiço, somado a sua concepção de meio, que se não fundava uma raça singularizava a identidade do país dando possibilidade ao surgimento de uma raça diferente, iniciava suas análises a partir de raças puras representadas pelo português nato, o negro da costa e pelo índio selvagem, e aqueles dois primeiros grupos tinham origens estrangeiras. Dada à inexistência do africano puro, a influência da raça africana seria constatada no mestiço, o "genuíno nacional", a singularidade brasileira. Não bastasse a dificuldade em averiguar a contribuição do africano, o olhar de Sílvio era amparado pela visão folclórica formada pela lei do mais forte, pelo Evolucionismo fincado na Crítica Religiosa, esteio dos estudos da religião e Mitologia, em que sofreu considerável influência. Daí, a razão de sua aversão a Metafísica e a incessante busca de cientificidade aplicada aos estudos populares.

Não deixava de ser conflituoso estudar as tradições populares seguindo os estágios evolutivos de Comte, as teorias raciais que influenciaram fortemente Sílvio, e acima de tudo sua compreensão do que era popular. De acordo com Claudia Neiva Matos

"os pensadores do Sturm und Drang assumiram o espírito religioso como componente de uma visão de mundo que desejavam ampla e elevada, e no interior da qual procuravam conectar-se com o universo cultural popular. No Brasil, um século mais tarde, eruditos como Sílvio Romero são compelidos pela própria pretensão de

\footnotetext{
${ }^{813}$ Ibidem. p. $31-32$

${ }^{814}$ Ibidem. p. 40
} 
cientificidade a rejeitarem de sua visão de mundo todo misticismo e mesmo toda Metafísica. E, quando consideram historicamente a função religiosa nos quadros classificatórios evolucionistas e positivistas, situam na cultura popular as formas consideradas inferiores e indefinidas de religião. Isto também contribui para que o povo e sua poesia sejam vistos sob o signo do "atraso", só podendo ser culturalmente resgatados enquanto objetos do discurso cientifico que os preserva, ao mesmo passo que expulsa de si mesmo toda e qualquer veleidade religiosa e/ou poética" 815

Como nenhum outro escritor de seu tempo, sabia Sílvio do caldeamento étnico presente no país espalhado pelas mais pobres e mais distantes vilas e cidades,

\begin{abstract}
"Aí inscreve-se, no meio da lista, a população brasileira de hoje, que é o objeto de análise. À primeira vista parece que o povo do Brasil é dos mais adequados agora para o estudo da poesia e das crenças populares, por conter nada menos de três distintos ramos de procedências. O caboclo, o negro e o branco... que belo ensejo oferecem para apreciar-se o cruzamento das idéias a par do cruzamento das raças! $O$ engano desaparece, considerando-se de perto o Estado da população atual e a primitiva situação dos povos que para ela concorreram" 816
\end{abstract}

A tarefa de Romero era extremamente difícil, haja vista a ampla variedade de "tipos" mestiços, como pardos, mulatos, cabras, mamelucos, caburés. Ao mesmo tempo em que Sílvio reconhece a importância do africano na cultura brasileira, seu interesse é ambíguo: buscar no mestiço a contribuição do homem que não é branco porque, conforme o próprio Romero, não existia o elemento em estágio de pureza e sim tipos mestiços, formados parcialmente pelo elemento africano. O crítico se estendia e se alongava, mas aparentemente não avançava. Sua teoria acabava voltando ao velho Determinismo racial das raças fortes e mais numerosas superando moral e biologicamente as raças fracas. O que sobra em suas análises e vai além desse retorno teórico é a idéia de mestiçagem consolidando a visão de um caráter brasileiro formado pelos mais variados tipos de mestiços.

Sílvio abre uma discussão de suma importância do ponto de vista cultural, o que não podemos esquecer, mas não se desvencilha plenamente de uma das maiores ideologias do momento que é a associação entre raça e caráter. Trabalha a contribuição do africano sempre tendo por base a rigidez de seu caráter, elemento portador de um conjunto de valores morais aptos ou não à inserção numa sociedade civilizada. Na verdade, podemos perceber que o sentido da longa discussão em torno da concepção de raça só faz sentido quando, de uma forma ou de outra, elabora uma hierarquia não apenas racial, mas social, pronta para validar ou não "cientificamente" a inserção do homem na sociedade onde surge tal discussão. No caso do negro, mesmo sendo Sílvio um apóstolo de sua inferioridade e um escritor que por vezes se posicionava abertamente nos limites deterministas, suscitou toda uma discussão sobre a importância do elemento africano, influenciando posteriormente

\footnotetext{
${ }^{815}$ MATOS, Claudia Neiva de. A poesia popular na república das letras: Sílvio Romero folclorista. Rio de Janeiro: FUNARTE, UFRJ, 1994. p.70.

${ }^{816}$ ROMERO, Sílvio. Estudos sobre a poesia popular. Op. Cit. p. 33
} 
vários escritores. O "Determinismo" de Sílvio avança na medida em que é somente compreendendo a superioridade do branco sobre os vários tipos de mestiços que o ensaísta se motiva para encontrar os tipos esquecidos por nossa Literatura e só assim descobrir a potencialidade destes tipos esquecidos antes do embraquecimento, resultado da vitória do mais forte.

Se por um lado está Sílvio ciente da dissolução biológica e cultural do negro colonizado devido ao contato com o homem de raça e cultura que o escritor considerava superior, seu interesse em descobrir o potencial do negro, embutido no mestiço, foi de uma relevância sem precedentes. E não raras vezes pode falar Sílvio sobre a conquista de posições confortáveis por parte de alguns mestiços. Não aceitava que a elite nacional mascarasse suas raízes africanas, pois afirmava que o mestiço representava 2/3 da população brasileira. Em vários segmentos da sociedade brasileira, aparecia a importância do negro, fosse na ordem econômica, na História política, civil, literária, artística. Mas toda essa enorme influência só podia ser notada na figura do mestiço,

"Na História política, civil, literária, artística, sua colaboração foi de todos os tempos,
por intermédio principalmente de seus parentes mestiços, com seus jornalistas, seus
oradores, seus jurisconsultos, seus poetas, seus artistas, bastando só citar um Cruz e
Souza, um Luís Gama, um Natividade Saldanha, um Justiniano da Rocha, um Ferreira
de Menezes, um Guedes Cabral, um Silva Alvarenga, um Visconde de Jequitinhonha, um
José Maurício, um Caldas Barbosa, um Henrique de Mesquita, um Gonçalves Dias, um
Lívio de Castro, um Eunápio Deiró, um André Rebouças e tantos outros. Claro é que
nesta incompleta lista de mortos ilustres estão incluídos mestiços de todas as gradaçães,
desde os mais escuros até os que se podiam perfeitamente confundir com os melânios do
Sul da Europa." 817

$\mathrm{Na}$ verdade, o grande nó causado por Sílvio reside não por ter sido o primeiro escritor que introduziu o método etnográfico na interpretação do Brasil, como sempre fazia questão de salientar, mas sim a maneira como concebia a mestiçagem. Entre concordar com as teorias científicas darwinistas e evolutivas, que consideravam o colono indígena e o escravo negro inferiores, e simplificar toda a contribuição cultural desses povos a essas mesmas teorias científicas, há uma lacuna enorme.

A figura de Sílvio, por si mesma, é ambígua, trata-se de um homem ilustrado que concebe a cultura popular a partir do ideário romântico fundamentado pela concorrência ou luta entre as idéias. Paralelo ao conhecimento e à importância dados pelo escritor às tradições populares, sua visão sofria da ação das leis evolutivas. Era o mundo de Sílvio, a visão de um homem ilustrado interessado pela cultura popular, por isso, sua visão valoriza o folclore. Para além das possíveis e inúmeras críticas que possamos dirigir a Sílvio, sobretudo, sua visão sobre folclore, como bem lembra Michel de Certeau,

${ }^{817}$ ROMERO, Sílvio. História da Literatura. Op. Cit. p. 302-303 
abrindo uma séria discussão, não devemos desconsiderar o esforço de Sílvio para coligir farto material por onde passou.

Se não pairavam dúvidas sobre a inferioridade do negro com relação ao europeu e sobre a circunstância de que, com a escravidão, não se pode dar aos negros a forma de trabalho condizente a sua capacidade, extrair de maneira racional sua força de trabalho, não podemos esquecer todo o interesse de Sílvio pela cultura africana. O diferencial de Sílvio é que mesmo exaltando a superioridade do branco no plano biológico e no cultural, quer o escritor se aproximar da cultura herdada dos negros porque reconhece a importância destes na formação do caráter brasileiro.

Mesmo que seu pensamento seja fundamentado na aplicação das idéias darwinianas ao campo da cultura em seu sentido amplo, tangenciada pelos estágios de Comte, onde pensa toda uma tradição folclórica em estágio de "nascença", influencia de Herder, isso não invalida e nem tira o mérito de ter tentado Sílvio coligir os cantos e os contos.

Seu objetivo era primeiramente identificar o que era manifestação de cada uma das raças para daí conhecer o Brasil. Pensando conforme Sílvio, era preciso conhecer a alma nacional, o que havia de mais íntimo, singular ou específico num povo. Partindo em busca da alma nacional é que Sílvio encontra espaço para "todas" as raças. Nessa perspectiva, ele trabalha a "nação" brasileira que mesmo não formada etnicamente precisava da formação de seu povo. Todo o intento de Sílvio para encontrar lendas, canções e cantos é parte integrante de encontrar a nação que se formava e - por que não dizer? - o próprio Brasil que o escritor tanto buscou conhecer. Não podemos nos antecipar pensando que, pelo fato de Sílvio ser conhecedor das diversas formas de organização social, tanto na Europa quanto em algumas sociedades africanas, o autor estivesse legitimando o sistema espoliativo encontrado pelo negro imerso no leque maior da situação brasileira da época.

Avaliar toda a contribuição de Sílvio por considerá-lo como mais um dentre os inúmeros escritores racistas, como nos faz recordar a leitura de Antonio Candido, é tocar somente numa parte da questão. Não estamos a combater nem tão pouco negar passagens claras no autor de A Filosofia do Brasil, mas sim ressaltar que é justamente de sua crença na importância etnográfica aplicada não apenas a Literatura como a cultura geral que torna Sílvio um personagem importante abrindo uma discussão pioneira no Brasil que é rastrear, classificar e identificar a herança brasileira formada pelas três raças. É somente percebendo Sílvio como homem de seu tempo que podemos entender seu método no resgate da cultura popular, sua visão de Brasil, e acima de tudo, qual o Brasil pensado pelo autor.

Um dos exemplos é sua visão sobre a mestiçagem, que difere de outros ensaístas brasileiros que combatiam a mistura entre as raças. Sílvio não via o mestiço como um degenerado, mas sim como um elemento indispensável à formação brasileira. Admitia que, pelo fato da mistura não ter se realizado 
completamente, o país encontrava-se na situação de marasmo social, econômico e político. Ao mesmo tempo em que se torna de fundamental importância não desprezar os povos das matas, dos sertões, das vilas e cidades, só fazia sentido estudá-los quando a cultura do mais forte superasse as raças inferiores de índios e negros. Mas, não aceitava Sílvio o esquecimento do negro,

\begin{abstract}
"Nós dissemos que não temos um só homem notável em nossa História de quatro séculos, que tenha sido negro ou caboclo puro. Camarão e Henrique Dias, repetimos, ainda quando ficasse provado que o foram, o que temos por duvidoso, o gênero de atividade em que se desenvolveram é daqueles que não requerem grande discussão. Os nossos homens mais notáveis, nas Letras e na política, ou são brancos, como um José Bonifácio, um Gonçalves de Magalhães, um Marquês de Olinda, ou mais ou menos mesclados, como um Gonçalves Dias, por exemplo, tenha possuído mais talento e ilustração do que Gonçalves de Magalhães; mas quem contestará que ele foi mais brasileiro, isto é, tinha maior soma de qualidades que o separavam do genuíno espírito português e o aproximavam de um tipo, ainda não bem definido, que nós chamaremos no futuro o verdadeiro nacional." 818
\end{abstract}

Se o caráter brasileiro não estava formado devido à incompleta fusão das determinadas raças, como é que Romero dava importância à mestiçagem, sabendo que dessa fusão iria prevalecer o traço da raça superior? $\mathrm{O}$ índio ficaria quase um retrato do português e o negro iria assimilar os agentes civilizatórios daquele. Parece-nos que ao mesmo tempo em que o escritor tanto salientava a importância do meio e da raça, atinando para os elementos nacionais em busca da identidade brasileira, simplificava demais um amplo quadro de pesquisa que ele mesmo erigia e que era o quadro com que se deparou. Como aponta uma série de estudos sobre o momento histórico em que se processou a assimilação de tais idéias européias, não foi fácil alocar as mesmas no cenário brasileiro.

Se num primeiro momento parecia fácil estudar a poesia e as crenças populares em função da concorrência das três raças, concluía Sílvio que o engano desaparecia quando se observava a participação dos povos na formação dessa poesia. Após essa passagem ambígua, a concepção de Sílvio só mostrava dificuldades quando afirmava que

\footnotetext{
"Bem se compreende que nesta inquirição devem ficar fora do quadro português nato, o negro da Costa e o índio selvagem, que existem atualmente no país, porque não são brasileiros e sim estrangeiros. O genuíno nacional é o descendente destas origens. Semelhante deve ficar de fora desta análise a inquirição da influência que porventura, haja tido na formação total do nosso caráter de hoje a existência de estrangeiros, como franceses, ingleses, chins..., que em épocas anteriores, ou na atualidade, se tenham domiciliado no país. Tal influência é mínima e escapa aos olhos do historiador". 819
}

\footnotetext{
${ }^{818}$ ROMERO, Ś́lvio. História... Op. Cit. p. 232

${ }^{819}$ ROMERO, Sílvio. Estudos... p. 33
} 
O que se percebe é que a análise sobre a participação do africano só deve ser prosseguida quando se trata de negros puros, mas sabemos que foi concebendo a cultura brasileira como mestiça que Sílvio se interessou pela contribuição de cada uma das raças. Como se entende que deveriam ficar de fora de sua análise racial negros da costa, índios selvagens, considerados estrangeiros, e outros grupos mestiços, ao passo que holandeses e, acima de tudo, italianos e espanhóis colonizadores do sul do país eram de extrema importância para o futuro do Brasil? "Pode-se a respeito dela desde já predizer que no sul do Império está se formando um grande núcleo, que dentro de dois ou três séculos nos há de salvar de nossa cada vez mais crescente extenuação de forças e de idéias" ${ }^{820}$.

O esquema explicativo de Sílvio para analisar a formação do povo brasileiro, assim como em vários escritores racistas de sua época, era bastante simples: tomava por base o modelo de análise das doutrinas do Evolucionismo e do Determinismo, somados ao que pregava a Antropossociologia, priorizando escritores racistas que acreditavam na "seleção social". Com todo este aparato teórico, o que estava em sua mente era o modelo das raças superiores misturadas à influência romântica fornecida pelos estudos folclóricos dos irmãos Grimm. Num polígrafo que sempre lutou para que o negro fosse reconhecido não apenas como agente econômico, mas como agente social ao longo da História brasileira, são questionáveis passagens como esta:
"Da colonização bem dirigida das províncias do sul é que depende o bom futuro deste país. Oxalá tivessem podido os neerlandeses perdurar aos milhares, ao menos a titulo de colonos, por uns quatro séculos nas províncias do norte! Teriam então aquelas províncias uma força impulsiva para opor a crescente superioridade das suas irmãs meridionais. Não foi assim, e temos visto os nossos idólatras darem-se os parabéns pela total expulsão holandesa. Olhemos também para o norte". ${ }^{81}$

Sabemos do temor que Sílvio tinha em relação a um novo imperialismo nas colônias do sul do Brasil e se mostrava cauteloso com a colonização e a disseminação desordenada desses núcleos na região, pensava que era necessário que essa colonização se espalhasse também pelo norte do país. O Determinismo de Romero avançou porque mesmo defendendo a superioridade do homem branco, não esqueceu da importância do negro na sociedade brasileira. Queria uma colonização sistematizada, onde a fusão de sangues se desse de maneira harmônica porque fusão biológica equivalia à fusão cultural, o que hoje é designado como assimilação. Nesse sentido, o estudo e o interesse pela contribuição africana se dão somente como parte de um todo em que o pano de fundo é a cultura européia e a consolidação da cultura brasileira.

Trata-se de buscar os desdobramentos que permeiam suas análises sobre a cultura brasileira que inevitavelmente passa pela temática racial. Sílvio sempre foi claro e objetivo no que diz respeito a sua concepção racial, refletindo tanto no plano biológico como cultural de que os mais fracos perecem

\footnotetext{
${ }^{820}$ Ibidem. p. 34

${ }^{821}$ Ibidem. p. 34
} 
quando em contato com as raças superiores. Se tanto lutou para avaliar a contribuição do negro porque nunca aceitou que este fosse concebido apenas como agente econômico, e sim também um agente social, o escritor ainda concebia o negro como uma raça inferior, mas não irrelevante. Não é um paradoxo investir o crítico literário no folclore atinando somente para as raças puras quando ninguém melhor do que ele conhecia a realidade mestiça do país, sabia da existência das sub-raças existentes nas vilas, sertões, matas, e cidades, espalhadas por todo o país? Onde estaria a contribuição da infinita gama de mestiços existentes no Brasil vivendo em situação de extrema pobreza?

Nessas idas e vindas, a singularidade brasileira estava resguardada e se formava na figura do mestiço, a representação brasileira daquilo que temos de "genuinamente nacional". Todo o processo de assimilação, tomado da cultura européia "filtrada" pela ação do meio brasileiro - não apenas físico, mas social -, aparecia cristalizado e representado na figura do mestiço: era o Brasil, país do índio, do negro e do branco.

$\mathrm{O}$ que transformou as influências culturais sofridas pelo brasileiro deveu-se à natureza e ao mestiço. À medida que as três raças se fundiam, a cultura brasileira era corporificada no mestiço, mas neste processo nem todas as raças se fundiam. É um processo em cadeia que só se inicia quando termina, ou seja, Sílvio só começa suas análises a partir do mestiço, mas para isso busca no Brasil a existência ou não de raças puras. Diante de tantas idéias e de uma teoria racial talvez confusa, Sílvio chamou para si a responsabilidade de identificar o que coube a cada raça na História do país. Já tendo em O Brasil Social se preocupado com o caráter nacional brasileiro, caráter apático e não apto paras as lutas pela vida, herança de uma sociedade comunária, agora delimitava o país em quatro seções naturais para investir na contribuição de cada uma das raças.

A análise de Sílvio é tipicamente evolucionista, carreada pela seleção natural e acima de tudo fundamentada na certeza documental. Arrolando as manifestações culturais tributárias dos habitantes das praias e das margens dos grandes rios, dos habitantes das matas, dos sertões e das cidades, é que iremos analisar como o polígrafo concebeu a contribuição de cada uma dessas raças.

Romero trabalha a contribuição de cada raça porque lhe atribui um caráter, o que singulariza e dá sentido à busca por ela. Conclui sobre o brasileiro que "é um povo sem objetivo político, sem consciência social e histórica, falho de Ciência e de elevados incentivos, e, ao mesmo tempo, sem muitos mitos e heróis", porque “aplicando-lhe a lei dos três Estados, formulada por Comte, está ele exteriormente no período teológico, na fase do monoteísmo; mais ainda com pronunciados resíduos da fase do fetichismo e do politeísmo", 822

${ }^{822}$ ROMERO, Sílvio. Estudos... Op. Cit.p. 40 
Seu interesse pelas tradições populares vem acompanhado do processo de seleção cultural, onde os povos europeus são portadores de uma cultura mais significativa com relação às raças inferiores, "O que se diz das raças deve-se repetir das crenças e tradições" ${ }^{823}$. Assim como já havia refutado Couto de Magalhães, autor de $O$ Selvagem, no que diz respeito à origem do índio americano e sua possível filiação turana, agora é chegado o momento de analisar a influência do negro. As causas atribuídas por Sílvio ao esquecimento deste por parte dos escritores nacionais se devem a independência do Brasil, responsável pela deificação do índio, erigido como símbolo nacional, e ao regime escravista que, segundo ele, justificou a exclusão do mesmo. O interesse de Romero pelo africano se dá pelo fato de considerar este, depois do português, o que mais contribuiu para a formação da poesia popular brasileira. Crente nas teorias da evolução processadas pela lei do mais forte $\grave{a}$ Darwin, a importância do negro se verifica, porque, diferentemente das repúblicas espanholas, onde o cruzamento maior fora de portugueses com índios, no Brasil, o negro misturou-se com os negros na composição da formação de nosso povo. Tendo por base as leis da evolução e da seleção natural, a raça africana dera maior contribuição do que o caboclo porque era biologicamente mais forte, embora inferior ao europeu.

"A raça africana tem tido no Brasil uma influência enorme, somente inferior à importância da
portuguesa; penetrou em nossa vida íntima e por ela moldou-se em grande parte a nossa
psicologia popular. É fácil compreendê-lo.
A raça africana entre nós conta-se também como raça invasora, e este fato merece
atenção". 824

Embora Sílvio conceba o africano como uma raça inferior e bárbara, idéia compartilhada por boa parte dos ensaístas de seu tempo, era imprescindível pontuar a contribuição do negro na cultura brasileira. Da mesma forma que havia criticado o botânico Martius, diante de seu posicionamento acerca da contribuição das raças, suas forças diagonais, em sua já citada monografia premiada pelo IHGB, afirmando que não bastava apenas colocar lado a lado cada uma das raças, o argumento era o mesmo com relação a Celso de Magalhães:

"Não basta dizer que o africano era atrasado ou estúpido, e que ele influiu desagradavelmente na formação de nosso povo. É mister mostrar o que lhe devemos: é preciso indicar qual a parte que lhe cabe na compreensão de nosso caráter nacional. $E$ maior falta do Trabalho de Celso de Magalhães, defeito tanto mais lastimável, quanto nenhum dos outros escritores que trataram do assunto fornece dados para preencher-se essa falha, e o moço crítico, se o tivesse querido, tinha competência bastante para acabar de uma vez com a eterna injustiça que pesa sobre os nossos pretos" ${ }^{825}$

Se existe algo a ser questionado é qual o modelo ou concepção de civilização e modernidade que Sílvio possuía. Como boa parte de seus contemporâneos, o caminho que levava à civilização ou ao

\footnotetext{
${ }^{823}$ Ibidem. p. 39

${ }^{824}$ ROMERO, Sílvio. Folclore brasileiro: contos populares do Brasil. Belo Horizonte: Ed. Itatiaia; São Paulo: Ed. Da Universidade de São Paulo, 1985.p. 22.

${ }^{825}$ Ibidem. pp. 59-60
} 
progresso tinha intrínseca relação com a questão étnica, uma vez que, cada raça portava uma série de atributos morais de civilização ou de barbárie. Sabemos que este discurso racial aparatado pelos preceitos científicos camuflava a espoliação sofrida pelo negro na Economia rural brasileira, num momento em que o país sofria a mudança de predomínio de um novo produto na Economia, a emergência do café e com ele todo um universo não apenas econômico como também social, passando pela política. Nesse novo cenário, o homem branco civilizado era considerado "apto" a lidar com os costumes indispensáveis a nova ordem, sobretudo, técnicas de produção. A tônica mais alardeada pela elite nacional recaia sobre a população mestiça, que poderia levar o Brasil à degeneração, um processo de "involução", argumentação dos intelectuais brasileiros defensores de nossa modernidade. Entre esse modelo de civilização européia e a defesa de um trabalhador ideal, os vieses são bastante tênues, como mostram as falas dos reformadores nos jornais da época, sobretudo, em São Paulo. Acontecesse de maneira lenta, gradual imediata, o que não escapava aos argumentos desses reformadores era a imagem de um negro inapto ao trabalho livre, sedimentada pela ideologia da vadiagem, realidade bem diferente do que acontecia nas lavouras de café do Oeste Paulista.

Como Tavares Bastos, Pereira Barreto, Couty, C. E. Amoroso Lima, não deixou Sílvio de se posicionar sobre a melhor forma de trabalho para esse Brasil. O pensamento de Romero é análogo aos dos reformadores sociais da segunda metade do século XIX no que diz respeito à inferioridade do negro, a diferença é que o escritor salienta a importância do negro na sociedade brasileira, ou seja: não basta percebê-lo como inferior recorrendo às teorias racistas em voga no momento, é preciso investigar sua importância no cenário maior pelo qual a sociedade brasileira estava passando neste momento de transição.

Não há dúvida sobre a adoção de Darwinismo social e lei do mais forte por Sílvio quando de suas análises sociais, mas em nenhum momento o autor defende a escravidão como a melhor forma de ter se processado a colonização pelo português. Ele buscava identificar o que coube a cada uma das raças para traçar seu projeto nacional. Germanista por conceber a cultura de maneira bem ampla, influência do conterrâneo Tobias Barreto, e crente na superioridade dos dolicocéfalos, não se vê nos trabalhos do bacharel nenhuma passagem de legitimação da escravidão negra pelo fato de ser o africano pertencente a uma raça inferior. A crença na superioridade da raça europeia, apanágio para a vinda de imigrantes europeus, modelo de homem ideal compartilhado pela elite empreendedora da lavoura cafeeira do Oeste Paulista, em contraposição à suposta indolência e à vadiagem do negro, insere-se num novo contexto que se abre respaldado pelas teorias científicas, possuidoras de ares de verdade. Conforme Seyferth 


\begin{abstract}
"O reinício da colonização com base no agenciamento de europeus foi concomitante com a proibição da escravidão nas colônias - fato não ocorrido na primeira fase. Na prática, ao tomar essa iniciativa, os governos provinciais separaram ainda mais os dois regimes de trabalho quando se avizinhava a proibição do tráfico de africanos para o Brasil. $\mathrm{Na}$ prática, ao tomar essa iniciativa, os governos provinciais separaram ainda mais os dois regimes de trabalho quando se avizinhava a proibição do tráfico de africanos para o Brasil. A promulgação quase simultânea da Lei de Terras e da Lei Euzébio de Queirós marca ainda mais esse distanciamento - a colonização definitivamente vinculada ao trabalho livre". 826
\end{abstract}

Nos debates parlamentares, como bem mostra Célia Azevedo, é patente a instrumentalização das idéias científicas na construção de um trabalhador ideal, em contraposição à inaptidão e indolência do escravo na nova sociedade civilizada e moderna que se abria. Não é sem razão o uso das teorias raciais em nome do progresso do país "De fato, durante toda a década de 1870 os temas do negro livre e do imigrante ideal nortearam os debates dos deputados provinciais. Preocupados com a extinção da escravidão em futuro próximo, os representantes dos interesses paulistas travaram intensas $e$ acaloradas discussões, visando solucionar a questão da substituição do escravo pelo trabalhador livre antes mesmo que ela se tornasse um problema para os proprietários". ${ }^{827}$

No momento de transição para o novo Brasil, abolicionista e republicano, o conceito de raça serviu para camuflar todo o passado de opressão e qualquer forma de manifestação cultural do negro concebido pelas teorias científicas como inferior. Embora se trate de um escritor que usava argumentos de teor racial, não percebemos em Sílvio nenhuma apologia da escravidão e essa questão fica clara quando combate a forma de colonização brasileira empreendida pelo português:

"É pena, pois, que essa raça enérgica tenha sofrido o labéu da escravidão; fazemos aqui também um voto em prol de sua libertação completa e para que se reivindique o seu lugar em nossa historia. Havia outros meios de utilizar o negro sem aviltal-o. $O$ índio, por seu lado, foi também mui cruamente tratado e é admirável que, nestas condições, não tenhamos tido aqui guerra de raças, além dos pequenos episódios dos Emboabas, Mascates e Balaios".

\title{
6 - Resgate do Negro a partir de suas tradições.
}

O primeiro escritor a ser analisado por Sílvio é o maranhense Celso de Magalhães. Como veremos, as análises etnológicas de Sílvio recaem sobre a leitura que o escritor maranhense realiza da obra $O$ Romanceiro do escritor açoriano Teófilo Braga. Sílvio arrola antes de Magalhães escritores como Francisco Lisboa, Varnhagen e Gonçalves Dias que se preocuparam com a formação do povo

\footnotetext{
${ }^{826}$ SEYFERTH, Giralda. Colonização, imigração e a questão racial no Brasil. Revista USP, São Paulo, n.53. pp.117-149 março-maio 2002.

${ }^{827}$ AZEVEDO, Célia Maria Marinho de. Onda Negra. Op. Cit. p. 94
} 
brasileiro, mas segundo suas conclusões, dos onze escritores que chega a mencionar apenas sete merecem suas análises. O quadro traçado por Sílvio não era nada promissor:

"A Literatura nacional é ainda muito pobre de trabalhos críticos sobre a poesia e contos populares. Durante os três séculos em que o Brasil foi colônia das criações anônimas ainda não tinha despertado a intenção dos sábios. Ao nosso século pertence a contribuição definitiva da Lingüística e Mitologia comparadas, da Crítica Religiosa e da Etnografia. Não nos deve, pois maravilhar o silêncio dos escritores coloniais sobre o assunto que nos ocupa. Na própria Europa o fato se dava geralmente, com exceção da Alemanha, que, desde os meados do século passado, começara a perscrutar os segredos das epopéias nacionais. A discussão dos poemas de Ossian agitava também desde aqueles tempos a Inglaterra, superficialmente porém" 828

Convicto na visão oferecida pela crítica moderna, base de análise de seu pensamento, estendida aos vários ramos do conhecimento como a Lingüística, a Mitologia, a Crítica Religiosa, dentre outras, queixava-se Sílvio da ausência de estudos científicos que, no Brasil, teriam começado apenas a partir de 1870. Como se sabe, reclamava Sílvio da ausência do critério etnográfico nas análises sociais brasileiras. Não é estranho que o bacharel inicie suas análises em busca da contribuição de cada uma das raças a partir de Celso de Magalhães, um escritor que "desde os tempos acadêmicos principiara a ocupar-se com as nossas criações populares à luz das idéias positivistas e transformistas" ${ }^{829}$.

Lendo as citações de Magalhães apresentadas por Sílvio, percebe-se a semelhança da visão deste com a do escritor maranhense. O que permeia as análises de Magalhães é a idéia de seleção natural da raça mais forte determinando os traços culturais de cada uma delas. Realizando uma leitura de Francisco Lisboa, Varnhagen e Gonçalves Dias acerca da contribuição da formação do povo brasileiro, apontava Magalhães que

"É uma lei histórica que nas raças puras é necessário o cruzamento com outra raça, para que aquelas se possam consolidar. Não é só isto uma lei histórica. Como é que a raça índia, que se podia considerar como vigorosa, degenerou com o cruzamento dos invasores e extinguiu-se quase totalmente? Como é que o elemento maravilhoso e cavalheiresco, do índio, porque ele o tinha, perdeu-se e desvaneceu-se completamente? Como é que o ideal messiânico da raça conquistada cedeu o passo ao da raça conquistadora? E note-se que o ideal messiânico é uma das leis sobre que se apóia a formação da poesia popular, na hora das grandes aflições do povo. Onde o herói indiano? Onde o seu semideus? Onde o Caapora? Onde o jeropari? Onde a lenda de Some? Onde a teogonia de Thevet? Onde o Tamenduare (Tamandaré)? Tudo isto só conhecem hoje os curiosos. Tudo perdeu-se, tudo se desfez...A razão principal da dissolução indígena foi, nada mais, nada menos, que o principio de seleção natural, o struggle for life. A raça conquistadora era mais robusta, a indígena teve de ceder. No combate entre duas raças que se dispunham o mesmo alimento, o mesmo meio, a vitória será do mais forte". ${ }^{830}$

\footnotetext{
${ }^{828}$ ROMERO, Sílvio. Estudos... p. 54

${ }^{829}$ ROMERO, Sílvio. Estudos sobre a poesia popular no Brasil. $2^{\text {a }}$. Ed. Petrópolis: Vozes, 1977. p. 55

${ }^{830}$ Ibidem. p. 57
} 
Depois de escrever os primeiros trechos da leitura que Magalhães realiza de Braga, conclui Sílvio que "Esta citação foi feita com o fim de fornecer um completo documento da alta capacidade e fino critério do jovem maranhense. Ele era um espírito sem hesitações; daí a segurança dos seus conceitos e também, um certo sentido, o ar absoluto de algumas asserções suas". 831

Conforme a citação, podemos identificar a semelhança entre o pensamento de Magalhães e Romero. Assim como em Sílvio, permeia a fala daquele a idéia de pureza racial e de seleção natural. De visão européia, tanto Magalhães como Sílvio percebem o negro como culturalmente inferior, de acordo com os preceitos das leis evolutivas e do struggle for life. No caso de Romero, a problemática é ambígua porque, ao mesmo tempo em que a inferioridade do negro se mostra fora de dúvida, respaldada pelo Darwinismo social, é a partir do contato deste com o branco que sua importância deve ser considerada. É somente diante de índios e europeus que Sílvio pensa a importância do elemento negro, uma vez que o europeu superior transferiria parte de seus valores civilizados ao mesmo e em contrapartida, este condicionava o europeu às reais condições de aclimatação nas terras tropicais por ser uma raça acostumada às temperaturas quentes - quetões retomadas, ampliadas e redirecionadas por Gilberto Freyre em Casa grande \& senzala.

Iniciando a análise de Celso de Magalhães sobre a obra O Romanceiro, dizia Sílvio que "para o estudo das origens portuguesas o trabalho de Celso é excelente, ainda que ele só trate da poesia e não diga uma só palavra dos contos populares" ${ }^{832}$. Traços semelhantes entre Magalhães e Sílvio podem ser percebidos como a idéia de ser a raça latina, pertencente ao ramo ariano, a mais fraca por conta da degeneração. Segundo Magalhães, "se outra fosse à nação que descobrisse o Brasil, uma nação da raça germânica, da anglo-saxônica, por exemplo, cremos que seria outra a nossa política, a nossa arte, a nossa Literatura e a nossa religião" ${ }^{833}$.

Após descrever os elementos responsáveis pela ausência do romanceiro português no Brasil, Sílvio afirmava que "não se pode dizer melhor: aí estão caracterizadas por mão de mestre a insuficiência portuguesa, a deletéria eficácia jesuítica e as más condições em que se deu a emigração da poesia popular européia para o Brasil" ${ }^{834}$. Seguindo as análises de Celso, Sílvio chamava atenção para o fato de que no Brasil predominam as manifestações líricas e não épicas. Compilando quadras populares espalhadas por todo o Brasil, o objetivo de Sílvio é investigar a origem dos versos. Para isto, é necessário identificar suas variantes, seja em Sergipe, Maranhão, Rio de Janeiro (Parati), Ceará, Rio Grande do Sul, províncias onde o maior número de quadrinhas foi localizado.

\footnotetext{
${ }^{831}$ Ibidem. p. 58

${ }^{832}$ Ibidem. p. 61

${ }^{833}$ Ibidem. p.64

${ }^{834}$ Ibidem. pp. 61-62
} 
Celso de Magalhães percebia a presença dos diminutivos no romance D. Barão, encontrado no Maranhão, variante portuguesa do romance D. Martinho de Avisado, ao passo que, segundo Sílvio, o lugar onde mais se encontrava a tendência para os diminutivos era no Rio de Janeiro, possivelmente por ser a província que, na época, concentrava o maior número de escravos. Para Romero, a presença dos diminutivos refletia o respeito e a timidez dos negros para com os seus senhores. Desse modo, era analisando os romances por meio de suas variantes que Sílvio buscava identificar a contribuição de cada raça. No mesmo romance, surgia a expressão "que era macaco" como sinônimo de astuto, fino, palavra brasileira quem para Romero, sofreu a modificação do caboclo. Quanto à alteração de criado para moleque, que segundo Magalhães tornou o romance português menos nobre, logo inquietava Sílvio. Dizia que, em poesia popular, não existe ser mais ou menos nobre e dessa forma afirmava que “descortinamos nisso ainda um sedimento de romântico atraso no escritor maranhense" ${ }^{835}$.

A razão para o surgimento da variante brasileira devia-se ao mestiço e não ao negro:

"Não foi o português que alterou o romance; não foram também o caboclo e o negro; havia de ser o mestiço, que é no Brasil o agente de transformações: as raças puras fornecem os materiais das lendas e o mestiço os transforma segundo as leis do meio. A adaptação lendária, pois, que executa-se pelos móveis naturais, devia efetuar-se de acordo com os fatos realizados; e, estando o criado português substituído pelo moleque, era lógica, nesse sentido, a alteração do romance" 836

O comentário sobre a participação do negro que, para Celso de Magalhães, tornaria "menos nobre" a poesia popular brasileira, na visão de Sílvio, era não somente injusto como demonstrava a ignorância por parte do colonizador português, que obstou a contribuição do africano devido ao jugo da escravidão. Dentre alguns romances não encontrados por Celso de Magalhães a partir da obra de Teófilo Braga, salientava o autor de $O$ Romanceiro que apenas três variantes existiam no Brasil. Em desacordo com o Magalhães, afirmava Sílvio que possuía treze variantes nacionais.

Passando ao segundo momento da obra de Braga, eram mencionadas romances como Silvana e Bernal Francês. Devido ao maior número de versos com relação ao último romance citado, esclarecia Sílvio que Celso concebia essa característica como uma deturpação, visão diametralmente oposta à do sergipano, "Entendemos por outro modo; reconhecemos no povo a força de produzir e o direito de transformar a sua poesia e os seus contos" ${ }^{837}$. Como tantas vezes aludido, Romero entendia as tradições populares sofrendo a ação das leis transformistas, onde as mais fortes predominavam:

\footnotetext{
${ }^{835}$ Ibidem. p. 67

${ }^{836}$ Ibidem. p. 67

${ }^{837}$ Ibidem. p. 71
} 
"Desde que este processo de transformação, que não passa de uma aplicação das leis da Ciência biológica aos fenômenos sociais, se deixar de executar, teremos aí a prova de que o povo esqueceu as suas próprias criações, e elas irão irremediavelmente morrer. Sabe-se que as leis do Transformismo de Lamarck e da teoria da seleção de Darwin hão tido uma brilhante aplicação quase em todos os ramos dos conhecimentos humanos. Na esfera da morfologia levadas por Hackel, na psicologia e Ciência social conduzidas por Spencer, na filologia por Scleicher, devem também elas no terreno dos estudos mitológicos e especialmente no da poesia popular ter a mais completa verificação. E é que temos notado confrontando os originais das composições populares portuguesas com os seus representantes brasileiros " 838

Sem termos a pretensão de relacionar cultura oral, tradição popular e folclore, hodiernamente já delimitados em função da imposição do Positivismo e do Evolucionismo surgidos no século XIX, não é demais esclarecer o sentido dos estudos folclóricos que tanto preocupou Sílvio Romero. Segundo Renato Ortiz,

"A criação do folclore se realiza sob a égide do pensamento gestado pelas Ciências
Sociais do século XIX. O Positivismo de Auguste Comte e de Spencer tem uma influência
determinante na compreensão dos fenômenos sociais. A crença na possibilidade de se
fundar uma Ciência positiva em todos os domínios do conhecimento, anima o clima
intelectual da época. Os folcloristas acreditam ser apenas um desses grupos, que
aplicadamente levam o esclarecimento científico ao domínio popular. Não se deve
esquecer, que este é o momento em que é publicado o livro de Darwin, A Origem das
Espécies. No século XIX, as idéias de progresso, evolução e Ciência são dominantes, e
praticamente sinônimas. Mas é importante distinguir duas vertentes que incidem sobre a
reorientação do pensamento. Uma, que floresce junto ao mundo acadêmico, outra que se
caracteriza como cientificismo. Evidentemente há uma relação estreita entre elas; seria,
entretanto um equívoco identificar inteiramente os desdobramentos científicos
exclusivamente ao campo da ideologia. Um exemplo disso, na Inglaterra, são os
Institutos de Mecânica, cuja finalidade é esclarecer os trabalhadores sobre o progresso
da humanidade. Na França a doutrina de Allan Kardec integra os ensinamentos de
Comte para positivamente descobrir as leis que regem o universo dos espíritos. Os
folcloristas encontram-se a meio termo entre o universo das Ciências e a popularização
do saber. Ambigüidade que irá acompanhá-los, marcando de maneira indelével a
disciplina que pretendem construir." 839 a

Romero reveste-se da visão ilustrada tomada de empréstimo do Romantismo alemão para nortear seus estudos acerca da formação do povo brasileiro. Sempre em busca do caráter nacional, enfrentando o que dizia ser o problema das origens, podemos afirmar que o interesse de Sílvio pelas tradições culturais africanas enquanto tal se dava por achar esta "morta", por isso mesmo "bela, mas que deve ser resgatada”. O problema étnico é de fundamental interesse para ele porque cada raça embute em menor ou maior grau um potencial "apto" ou não à civilização. Cada elemento étnico carrega valores e aptidões que somadas a fatores como o meio, a influência estrangeira e o mestiço que se formava paralelamente nesse todo, equacionam-se na identidade do brasileiro. Homem nascido nas paragens simples do nordeste brasileiro, cedo respirando e ouvindo o canto da natureza e dos tangedores de boi,

\footnotetext{
${ }^{838}$ Ibidem. p. 71

${ }^{839}$ ORTIZ, Renato. Românticos e folcloristas: cultura popular. São Paulo: Olho D’AGUA, 1999. p. 30
} 
Sílvio uniu a sua propensão analítica para os temas mais eruditos à paixão pelas tradições dos mais simples, que nunca cansou de admirar.

Analisando a contribuição de Alencar sobre a poesia popular, afirmando que a maior contribuição do escritor cearense se deu pela luta em beneficio de uma Literatura brasileira e suas investigações sobre a transformação da língua portuguesa no país, admitia que "Alencar, apesar de todo o seu merecimento como literato, não tinha uma preparação cientifica suficiente para tratar destas matérias. Estudou muito pouco o assunto e os seus cismares românticos o iludiram. O notável escritor não leu, por exemplo, a recomendação dirigida pelos professores Comparetti e d'Ancona aos coletores da poesia popular italiana”, 840

Sobre Couto de Magalhães, Sílvio retoma uma discussão já comentada nesta pesquisa acerca da contribuição do índio na formação do caráter brasileiro, mas nada há para averiguar uma vez que $O$ Selvagem trata da influência deste e não do negro na poesia. Na análise que faz de José Antonio de Freitas, aparece mais uma vez o turanismo do mestre deste, Teófilo Braga. Crente na existência de raças anteriores aos povos arianos e semitas, Sílvio combate o turanismo de Braga, influência recebida de Muller e Lenormant, discordando assim de uma ligação e homogeneidade cultural do índio americano como relação aos povos da grande raça uralo-altaica. Romero quer deixar clara a ausência da contribuição negra na análise elaborada por Antonio de Freitas, que "divaga bejamente sobre a arte e a poesia, escreve umas velharias sobre Camões e não esclarece o seu problema capital. Além de tudo, ele labora numa contradição intrínseca que mina e corrói todo o seu trabalho. A sua tese principal é que em nossa vida atual predomina o elemento europeu”. 841

Quando Sílvio critica o turanismo de Teófilo Braga, traz de maneira implícita uma significativa inquietação que é a contribuição do negro na formação do caráter nacional, elemento indispensável à formação cultural do Brasil. Mais do que combater o turanismo, a maior crítica de Sílvio a Antonio de Freitas é a ausência de estudos que resultariam na identificação da contribuição africana na formação da sociedade brasileira. Isso porque, diferentemente das repúblicas espanholas onde a fusão biológica se deu em maior grau entre brancos e índios, no Brasil, o contato maior fora de brancos com negros. Assim como acontecera com a crítica aos escritores do Romantismo que exageravam a participação do índio na Literatura pátria, Freitas esquecia a participação do negro na formação da poesia popular brasileira "O Sr. Freitas falou-nos de brancos e índios; e sobre a maioria da população do país, que são negros e pardos, nem uma palavra escreveu”. ${ }^{842}$

\footnotetext{
${ }^{840}$ ROMERO, Sílvio. Estudos... p. 104

${ }^{841}$ ROMERO, Sílvio. Estudos.....Op.Cit.p.149.

${ }^{842}$ Ibidem. p. 150
} 


\section{7 - Nunca fui Positivista...!}

As críticas de Sílvio ao Positivismo são freqüentes, inumeráveis e contundentes. Afirmava que passara pelo Positivismo como se fosse um processo de pura evolução mental, defendia- se das acusações sofridas por seus inimigos alegando simples evolução de pensamento. Em sua concepção, o maior problema da doutrina de Comte se dava porque atravancava o desenvolvimento da Ciência devido a seu "círculo de ferro". Afirmava Romero que a doutrina de Comte nada tinha de universal, não podia servir de base explicativa para as questões científicas uma vez que entrava em desacordo com a lei geral da evolução. Um homem como Sílvio, impregnado de tanto cientificismo, jamais aceitaria a nova doutrina universal, a nova "religião da humanidade". Conhecedor das teorias do conhecimento Romero analisava de maneira minuciosa as instâncias positivistas. O interesse do crítico literário era amplo "Refiro-me a necessidade de fazer o quadro completo. Traçar a carta, organizar definitivamente o esquema do conteúdo mesmo da civilização, indicando, sem subterfúgios, quais sejam em definitivo as criações fundamentais da humanidade, qual o ponto de partida de cada uma delas, qual o seu alvo supremo, qual a sua evolução até hoje, qual finalmente, o caráter que tenha presidido ao desdobramento de todas". 843

Queria Sílvio encontrar a base fundamental para as criações humanas, identificar a índole dos fenômenos culturais de onde partem suas análises sobre os mais variados campos do conhecimento. Dizia ele que a base da doutrina comtiana não era original e tão pouco fora interpretada de maneira correta pelos discípulos do engenheiro francês. Um das fragilidades do Positivismo era sofrer de "anarquia mental" na transição dos idos medievais à modernidade, por isso "qual tem sido desde então o ritmo da evolução? Terá sido para a anarquia? Bem longe disso." 844.

A análise elaborada pelo escritor sobre o Positivismo é muita ampla e minuciosa, mas alguns pontos podem ser destacados: buscava o bacharel a base de conhecimento mais segura, que melhor justificasse a ordem das coisas. Dessa forma, recorria ao Criticismo para validar sua visão científica, sempre se apoiando na intuição moderna, que tinha por base a lei evolutiva ancorada no meio, na raça e no momento histórico. Todos os problemas e questões em Sílvio possuem causas, o que motivava sua inquietação frente aos inúmeros "males brasileiros" e sua busca fremente pelo remédio. Fascinavam-no os grandes críticos, homens de saber enciclopédico avessos à explicação metafísica, propugnadores de uma nova maneira de pensar a Ciência, acima de tudo, reformadores sociais. Viveu um momento histórico de laicização do conhecimento, que punha em choque fé x razão, luzes x trevas, ideal x real. Mesmo indo de encontro à boa parte de pensadores que muito lhe influenciaram, como

\footnotetext{
${ }^{843}$ ROMERO, Sílvio. Obra Filosófica. Op. Cit. p. 335

${ }^{844}$ Ibidem. p. 347
} 
Martius, Taine, Buckle e tanto outros, a erudição e o saber enciclopédico de Sílvio formaram-se dentro de um amplo processo de sistematização do conhecimento.

Não fora tarefa fácil para Sílvio tornar-se figura principal de um amplo movimento de ideias, tendo que escolher uma doutrina, uma teoria, uma linha de interpretação que abrangesse ao mesmo tempo todos os ramos do conhecimento, para assim fornecer sua interpretação de Brasil, projetando sua imagem de nação. Depois de Martius e Varnhagen, Romero foi o escritor que conseguiu elaborar mais explicitamente uma teoria do Brasil, pensando todo o processo de transformação social e partindo de um raciocínio preliminar.

Um olhar mais apurado deixa ver um escritor fascinado pelo método organicista que, em parte, é tributário da nova "Física Social" empreendida por Comte e surgida a partir das significativas transformações somente possíveis após a expansão econômica processada pela Revolução Industrial, em que Ciência passa ser a terminologia usada em contraposição a concepção oferecida pela Metafísica - em que as leis explicavam as transformações sociais em função da veracidade dos fatos. A crença inabalável de Sílvio é parte dessa conjuntura estrutural, que deita raízes na transição dos tempos medievais para os modernos. Não bastasse a análise miúda sobre o Positivismo, a distinção entre as duas formas de conceber o mesmo - para Sílvio a parte política estava de acordo com a parte filosófica -, a reflexão sobre a marcha da civilização, tendo por base a lei do desenvolvimento e suas inumeráveis articulações somavam-se o Materialismo e o Transformismo de Haeckel. Não é sem razão que arremata Antonio Candido:

"A obra de Sílvio Romero dá uma certa idéia de turbilhão, no sentido próprio e no figurado. Um movimento forte e agitado, que arrasta idéias e paixões, destruindo pelo caminho; um movimento circular que gira incessantemente sobre si mesmo e progride, parecendo permanecer. Não espanta, portanto, que bem cedo ele tenha parecido aos contemporâneos contraditório, impaciente, injusto, mas apto para a generalização do que para a análise" 845

Embora a análise sobre o Positivismo seja minuciosa, o inimigo precisava urgentemente ser combatido por estar em desacordo com a maneira de análise da marcha da civilização "É preciso submetê-lo ao processo geral da crítica, abrindo mão da espécie de privilégio que os fanáticos querem criar para ele”. ${ }^{846}$

Sílvio Romero é o escritor brasileiro de sua época que maior admiração nutriu pelos escritores naturalistas, admiradores dos avanços da Ciência moderna. Sua maneira de conceber a sociedade expressa o espírito de sua época que tantas vezes afirmou e norteou suas análises fincadas a partir do cientificismo europeu. Sílvio sempre recorreu às grandes sínteses, dimensão da influência de Spencer, Herder, Taine e Comte, para analisar todo o quadro brasileiro e traçar projetos para o melhor Brasil.

${ }^{845}$ CANDIDO, Antônio. Teoria, Crítica e História Literária. Op. Cit.

${ }^{846}$ ROMERO, Sílvio. Obra Filosófica. p. 318 
Tributária da sistematização durkheimiana, em que os fatos eram inquestionáveis, não deixando liberdade para o Relativismo, era inevitável a amplitude do pensamento do crítico; por isso, Sílvio adentra diversas áreas que, a partir de sua visão, tinham em comum um ponto de análise, a intuição moderna formada pelo meio, pela raça e pelo momento histórico.

Posteriormente, consolidou-se a concepção de que cada área possui seu objeto, mas ao tempo de Sílvio a Ciência social começava a se formar quando ele pesquisava um determinado tema, acabava por adentrar noutros, quando tentava analisar uma obra literária fazia-se sociólogo ou historiador, nunca apenas um crítico de Literatura. Eram facetas de sua maneira de conceber a sociedade, sua concepção de cultura transcendia toda e qualquer especificidade do conhecimento. Era sua maneira de análise, sua maneira de ver a Literatura presa ao Culturalismo germânico, influência do conterrâneo e exemplo de escritor combatente Tobias Barreto.

Conhecedor das idéias européias, da lei do consensus, que lhe permitiu interpretasse o Brasil a partir da conjuntura mundial, demonstrando seu esforço para encontrar um quadro teórico que melhor servisse para explicar a situação do país, Sílvio iniciava suas análises visando a elevar as idéias ao ponto máximo em busca de um patamar irredutível na interpretação dos problemas brasileiros. Era necessário tomar conhecimento do ritmo das transformações que aconteciam no mundo, numa atividade muito maior do que propriamente assimilar idéias de fora de maneira aleatória. Para analisar o Brasil conforme as leituras oferecidas por seus mestres era crucial aproximar as Ciências Sociais das Ciências Naturais, o que merece cuidado quando se analisa o surgimento da sociologia no Brasil. Romero se mostra sociólogo quando abre um amplo quadro de análise visando a encontrar um ponto de partida comum a todos os ramos do saber, ponto este que permeia múltiplos campos do conhecimento. Era a fundamentação proporcionada pela influencia das Ciências Naturais, vindo à tona com a contribuição de Comte. Era esta a base maior de Comte, ter anunciado o surgimento da "Física Social”, agora desmembrada das demais Ciências Naturais, mas apoiada no mesmo ponto de análise:

\footnotetext{
"Agora que o espírito humano fundou a física celeste, a física terrestre quer mecânica, quer química; a física orgânica quer vegetal, quer animal, resta concluir o sistema das Ciências de observação, fundando a Física Social. Tal é agora, sob vários aspectos capitais, a maior e a mais premente necessidade de nossa inteligência; essa é, ouso dizer, a primeira meta deste curso, sua meta especial" 847
}

O Positivismo era para Sílvio ao mesmo tempo algo que deveria ser combatido, mas sem o qual jamais teria o bacharel formulado entre tantas influências o princípio do progresso, da "marcha civilizatória”; por isso, reconhecia a maior contribuição do Positivismo, “a razão de ordem, por assim

${ }^{847}$ COMTE, Auguste. Org. Evaristo de Morais Filho. 2a . Ed. São Paulo: Ática, 1983.p. 61 
dizer, o primum móbile do Positivismo está no seu perfil de encarar a marcha da civilização, nomeadamente da civilização ocidental " 848.

Conforme Antonio Paim,

\begin{abstract}
"Sílvio Romero, entretanto, não levava sua crítica à doutrina de Comte até o ponto de invalidar o conjunto do sistema conforme teremos oportunidade de assinalar. Nos três primeiros capítulos (Obra filosófica, p. 7-31) estuda a obra dos ecléticos espiritualistas: o Compêndio de Filosofia, de Monte Alverne, escrito em 1833 e publicado em 1859; Investigações de Psicologia, de Eduardo Ferreira França, editado em 1854; e Fatos do Espírito Humano, de Domingos Gonçalves de Magalhães, editado em 1858 nos tópicos subseqüentes resume-se a apreciação de Sílvio Romero, seguindo-se algumas observações". 849
\end{abstract}

Para Romero, o maior mérito do Positivismo foi à lei dos três estágios, apesar de a Filosofia de Comte entrar em contradição com o princípio evolucionista, mostrando-se perigosa e precisando ser combatida. "Doutrina contra Doutrina é o nosso brado", exasperava-se Sílvio, mas o mesmo ensaísta que inúmeras vezes criticou as interpretações de dissidentes como Littre e Mill reconheceu a importância da lei dos três estágios. A mesma evolução anunciada por Comte formada pelos três Estados históricos aderia, através de Sílvio, ao Evolucionismo de Spencer, uma vez que, para o pensador sergipano, a doutrina de Comte era apenas uma leitura da "revolução" produzida pela lei da evolução. Quanto mais buscava contrariar os princípios positivistas, mais se tornava positivista "Primeiramente, a simples consideração filosófica de que a lei geral da evolução rege também a História, mostra-nos que é uma afirmação fátua, para não dizer estólida, a determinação de um Estado humano final e definitivo". ${ }^{850}$

A problemática e então levantada por Sílvio era que os estágios históricos eram relativos, uma vez que as raças situavam-se em patamares culturais diferentes. Mas lembremos que em alguns de seus escritos etnográficos, como $O$ caráter nacional e as origens do povo Brasileiro, não podia ser o ensaísta mais positivista! Apontava nesse artigo que o índio encontrava-se num estágio pouco além do quadro natural, sendo impossível a noção de individualidade que levasse a crer num ser superior. Quando Sílvio a todo custo move críticas ao Positivismo, não podia ser mais positivista: assim como Comte classificou as Ciências, buscou o autor de A Filosofia no Brasil um princípio universal que servisse de guia explicativo para os variados ramos do saber. A diferença é que aparece em Romero a importância da raça como base explicativa para a evolução mental, influência dos grandes nomes da crítica moderna como Taine, Buckle, Beauve, etc.

Do ponto de vista epistemológico, correntes como o Positivismo, Marxismo e Psicanálise nada são interpretações dos princípios da lei máxima evolutiva aplicada aos mais diversos campos das

\footnotetext{
${ }^{848}$ ROMERO, Sílvio. Op. Cit. p. 319

${ }^{849}$ PAIM, Antônio. A Escola do Recife. Op. Cit. p. 20.

${ }^{850}$ ROMERO, Sílvio. Op. Cit. p. 325
} 
Ciências humanas. Assim como oferecia o Positivismo um princípio universal que explicava a base mental do conhecimento, Sílvio pretere a doutrina de Comte em detrimento do Criticismo, não deixando de ser positivista, "É preciso submetê-lo ao processo geral da crítica, abrindo mão da espécie de privilégio que os fanáticos querem criar para ele”. Mas o ponto chave do desacordo de Romero com relação ao Positivismo se explicava, “Dessa sua maneira de apreciar o desenvolvimento da cultura moderna origina-se o determinado e invencível desacordo em que ele se acha para com a Filosofia critico-naturalista, para com o Evolucionismo em suma”. ${ }^{851}$

Outro ponto crucial para a recusa do Positivismo por Sílvio se dava por conta da idéia da seleção do mais forte, que, somada à influência da crítica moderna, dariam a tônica argumentativa em beneficio do Evolucionismo de Spencer. A passagem para uma nova era em que agora via formar-se as nações acompanhadas da expansão dos mercados, responsável direta pelo aparecimento das idéias novas, marca e delimita a visão de Romero.

Para Sílvio, todos os problemas sociais eram passíveis de análise porque sofriam a participação de elementos exteriores por demais aludidos, postura que tornava o escritor, segundo boa parte da crítica, um autor determinista. De tanto buscar em sua farta enciclopédia européia a resposta cientifica para os inúmeros males brasileiros, Romero caía num "Sociologismo", invadindo outras áreas do conhecimento. Esse traço positivista somou-se ao Evolucionismo, uma de suas bases teóricas para interpretar o Brasil. Não é sem sentido a pretensão de Sílvio de submeter a cultura brasileira a um processo geral de crítica, como lembra Antonio Candido, uma vez que se baseava nos princípios do Evolucionismo fundamentado nos critérios do meio e da raça sempre amparados pela lei do mais forte.

De maneira objetiva, para Romero, toda a cultura brasileira era atrasada e merecia ser pensada à luz do Transformismo, em que sempre se presenciava a vitória do mais do mais forte, tanto no plano biológico como no plano da cultura, onde as idéias mais fortes venciam as mais fracas. No quadro que traça sobre o país em A Filosofia no Brasil, pontua a ausência de espírito científico, constatando a pobreza filosófica do Brasil porque os escritores nacionais se prendiam à Retórica esteada pelo ecletismo de Cousin e pelo espiritualismo de Jouffroy, que tinham como figura principal entre nós o franciscano Monte Alverne.

Do ponto de vista literário, poucos foram os poetas brasileiros que levaram adiante e aprofundaram um projeto mais complexo, em função de um meio totalmente inóspito vitimando prematuramente nossos escritores. No ensino primário e superior, o conteúdo das disciplinas continuava preso aos caducos manuais que bem lembravam documentos de cartório, impedindo toda e qualquer manifestação do pensamento. No plano social, o país sofria do mal do funcionalismo público

${ }^{851}$ Ibidem. p. 325 
por causa da herança de uma raça em estado de decadência, despreparada para enfrentar a luta pela existência. Sofríamos da mania de passar por aquilo que não éramos: a Corte não era o espaço de bons escritores, mas sim reduto ou cortiço de vespas, ocupado por um jornalismo literário patenteado pelas panelinhas e por agraciados oportunistas. Enfim: em todas as questões pertinentes ao Brasil, incidiam o Evolucionismo de Spencer, o Transformismo de Haeckel, e o Positivismo de Comte.

Ao mesmo tempo em que todo um conjunto de fatores condicionava as transformações reverberadas no plano da cultura, esses mesmos fatores condicionantes causavam uma ação contrária, numa espécie de ação e reação. O Determinismo de Sílvio dava margem a um Relativismo porque a partir das transformações sociais, acabava por alterar aqueles fatores condicionantes na medida em que havia a interação direta do produto com a causa.

Adentrando as nuances epistemológicas de Sílvio, presenciamos um escritor que quanto mais tenta tentava fugir do Positivismo, mas se ligava a ele na medida em que nunca abandonou a lei dos estágios históricos. Romero buscava o fundamento de análise para iniciar suas reflexões e numa espécie de vai e vem, não conseguia se desvencilhar das teias do Positivismo. É que se perguntar pelo princípio universal que rege as coisas - no caso, o modelo de crítica que adotou - pode acarretar uma análise sem relação alguma com a ordem externa que a condiciona.

Uma das facetas de Sílvio Romero é seu Materialismo, que repele toda e qualquer base explicativa que não seja o dado ou o concreto e que viabilize o processo do conhecimento. O que importa para Sílvio é partir de um ponto concreto para só então iniciar seu longo e amplo processo de análise. O que foge da concretude é Metafísica, Retórica, por isso deve ser tenazmente combatido.

Conhecedor das teorias do conhecimento, aplaudiu o Criticismo Kantiano que instaurou a nova forma de validar o processo de conhecimento norteador das Ciências modernas. Os "níveis" e as “ordens" do conhecimento, avaliados por Sílvio, eram consequiências do esfacelamento da Metafísica, tantas vezes criticada pelo escritor: mas deixava de ser ele metafísico quando se perguntava pela ordem primeira das coisas, pelo que fundamentava, dava sentido e validade aos fenômenos, ao positivo, ao princípio irredutível dos fatos?

Bem lembra Wehling que a

"Característica epistemológica das mais presentes em toda a construção cientificista,
a concepça do nível único de observação, intrínseca a lógica da explicação ou
claramente definida, encontra sua formulação original no pensamento newtoniano.
Sua radicalização, entretanto, somente ocorre com as extrapolaçães cognitivas dos
séculos seguintes, atingindo sua maior expressão com o cientificismo, naquilo que
Popper cognominou de Determinismo metafísico" ${ }^{852}$

${ }^{852}$ WEHLING, Arno. Sílvio Romero e a consciência modernizadora no Brasil: pressupostos, análises, rumos. Tese de Livre Docência apresentada a Faculdade de Filosofia, Letras e Ciências Humanas da Universidade de São Paulo, 1979.p.58. 
Acompanhando a crítica moderna, Sílvio carregava consigo a nova visão de análise para a construção do conhecimento, tão influenciada por Kant, a grande revolução na maneira de conceber o conhecimento e abordar os mais variados ramos do saber. Personagem pragmático, que deixava claro querer transformar o quadro social a partir das leis científicas e evolucionistas, as diversas leituras de Romero só fazem sentido porque concebia o cenário brasileiro como puro atraso. O escritor buscava a todo o momento um ponto de apoio para legitimar sua hipótese de um país atrasado, mas era um homem das grandes sínteses e não podia conhecer toda a História da civilização mundial, tendo que voltar seu olhar para o Brasil. Era mais fácil revestir-se de nomes ilustres do cenário mundial, almejando transformar o estágio de atraso do Brasil nos mais variados segmentos.

Muitas vezes, ele analisava apenas momentos históricos, pontuando ligeiramente os autores que veio a criticar, sendo seu temperamento polêmico regado por sua vida turbulenta tanto em atitudes como na bagagem intelectual, o que dificulta precisar qual a corrente seguida a cada momento. Primeiramente positivista preterindo a doutrina de Comte quando tomou conhecimento dos livros de Spencer que lhe caíam às mãos nos tempos da Faculdade logo se interessando aos estudos sobre a organização social, Sílvio diversas vezes cita o autor de A crítica da razão pura como ícone, buscando validar suas argumentações. Apoiou-se no Criticismo Kantiano mais para justificar sua concordância com a idéia evolucionista do que para seguir fielmente o filósofo alemão. Aponta Antonio Paim que "Em A Filosofia no Brasil, após ligeira análise da intelligentsia brasileira o Positivismo é caracterizado por uma aceitação parcial do que não é de molde a recusar o seu sentido principal". ${ }^{853}$ As críticas de Sílvio ao Positivismo se processam na medida em que o mesmo não oferece a base explicativa de toda a situação de barbárie do Brasil frente às nações européias. Sia grande esperança era um dia ver o povo brasileiro minimamente conhecedor dos problemas nacionais para só assim ser possível uma mudança na base social, que ligava-se a raça.

Em Doutrina contra doutrina: o Evolucionismo e o Positivismo no Brasil se pode constatar o combate do Positivismo e a apologia do Evolucionismo de Spencer. Em todo o artigo é claro o "brado" de alerta de Sílvio em apoio ao Evolucionismo, chamando atenção para os perigos do Positivismo. Sílvio trata de temas como o advento do regime republicano sob a regência dos militares - regime embutido pelos novos padrões da modernidade ocidental -, o arcaísmo do império, a viabilidade ou não de um partido operário no Brasil, a formação de um Brasil forte, mas não ditatorial. Todos estes fatores à luz do Evolucionismo, que considerava a lei máxima que regia a sociedade. Espírito anticientífico, segundo Romero, o Positivismo feria a liberdade natural das coisas, donde a concepção de que não era possível uma experiência democrática frente ao governo ditatorial, como os

${ }^{853}$ PAIM, Antonio. Op. Cit. p. 24. 
dos primeiros militares presidentes do Brasil. O que interessava a Sílvio era progredir, evoluir, passar de uma situação de "atraso" para uma situação de modernidade. Em todos os aspectos ou temáticas abordadas nesse artigo, é freqüente sua ânsia evolutiva "A crise econômica, para tudo dizer em traço rápido, vem ladeada por outras muitas crises, cada qual mais pavorosa. Aqui, é a velha intuição religiosa, o velho credo cristão, que presidiu à evolução de nossa cultura ocidental, que se esboroa e cai aos pedaços: é a crise religiosa." 854

Nas mais variadas questões, ele elaborava trabalhos sociológicos e com uma concepção histórica calcada na verdade dos fatos e no Evolucionismo, quadros da História literária brasileira perpassada por momentos da História política do país. Nunca se libertou das teias do Positivismo, uma vez que “As grandes leis da História hão de se cumprir também no Brasil; nós também havemos de ter o nosso quarto Estado triunfante. Não há dúvida". 855

Num vai e vem de crítica ao Positivismo, sem se desvencilhar de todo da lei dos três estágios, o escritor sergipano acabava por se desdizer:
"A lei dos três Estados, se fosse uma indução verdadeira, deveria dar conta de todos de todos os fenômenos da atividade humana e deveria aplicar-se a todos os ramos dessa atividade.
Outra cosia não é a lei da conexão e do consensus de todos os fatos, que rege a complexidade dos atos humanos. É princípio geralmente admitido por toda a Filosofia moderna como o daqueles pontos fora de contestação. O próprio Comte o reconhece e proclama, como uma das verdades elementares da Sociologia.
Para mostrar, porém que a teoria dos três Estados infringe esse dogma fundamental do pensamento científico hodierno, não é preciso grande esforço.
Bastante é olhar para o desenvolvimento histórico das cinco fundamentais criações da humanidade: Religião, Arte, Ciência, Política e Indústria, segundo deixamos indicado em $n^{a}$. IV do capítulo I deste livro.
O cabal esclarecimento desta tese prende-se ao que ali ficou demonstrado e não deve ser agora repetido e ao que será dito na explanação dos três defeitos seguintes a este quadro de que ora tratamos. A matéria é conexa". 856

A análise sobre o Positivismo é minuciosa. Cabe ressaltar o pano de fundo do pensamento científico do bacharel, alicerçado em preceitos positivistas. Sílvio buscava um sistema rígido de observação das coisas, donde seu apego ao Positivismo, ao Evolucionismo e à Escola de Le Play, mesmo com divergências a cada uma dessas correntes.

Alguns de seus conceitos mais importantes são mal interpretados, como o de miscigenação. Silvio aludia à assimilação, troca cultural entre as nações modernas e um Brasil atrasado em vias de formação. Sobre o pano de fundo positivista, não deixava se vir à tona a questão racial, contribuição da crítica tão bem assimilada por Romero. Como sempre salientou, a fusão das raças se mostrava de

\footnotetext{
${ }^{854}$ Ibidem. p. 79

${ }^{855}$ ROMERO, Sílvio. Introdução a Doutrina contra Doutrina. Op. Cit. p. 82

${ }^{856}$ ROMERO, Sílvio. Op. Cit. p. 470
} 
primordial importância porque a mistura era não apenas biológica, mas também moral. Onde termina a mistura biológica e se inicia a troca de experiências culturais, nunca se saberá.

O certo é que Sílvio via a sociedade a partir de pontos chaves, mas esses pontos sofriam ação conjunta simultânea dos resultados e acabavam por alterar os fatores condicionantes, dando margem a um Relativismo ${ }^{857}$. Se num primeiro momento parece que conceitos como os de meio, raça, momento histórico e influência estrangeira sempre explicavam as transformações sociais, esses mesmos elementos davam margem para em nada condicionarem ou explicarem o que acontecia na sociedade brasileira, a começar pela diferença da situação do país, que em nada se parecia com alguns países da Europa. Discordava de algumas idéias de ambientalistas, mas não da teoria. Quando Sílvio cita autores como Buckle e Taine, autores que apontavam a importância do meio na evolução da cultura, ao mesmo tempo os contradiz, amparando-se na diferença do Brasil. Toda a gama de teóricos que chegou a citar, dessa ou daquela corrente, ao mesmo tempo em que facultava uma análise determinista, não o fazia esquecer jamais das diversas regiões do país. Eis o sentido da adoção do Determinismo, mas um Determinismo com alguma margem de liberdade, que não se fechava na simples identificação de suas causas. Desse modo, realizava Sílvio um trabalho sociológico de fôlego, diante de um Naturalismo que avançava mirando identificar as singularidades do país.

Determinista sim, mas um escritor determinista que considerava a diferença da capacidade geniosa do artista, aquele que em seu meio incute a missão de falar a partir do caráter de seu povo, relevando a importância de fatores como a raça, o estágio de seu país e da interseção combinada da assimilação e simultaneamente da transformação de todos os fatores condicionantes. Romero buscou ao longo de sua trajetória partir de uma base sólida que servisse como alicerce às criações humanas. Saber onde Sílvio queria chegar nem sempre é possível, muitos problemas brasileiros são por ele lançados para o futuro, e toda uma organização social é pensada a partir dos esquemas explicativos de Comte, Spencer, dos seguidores de Le Play que primavam pela base familiar, pelos teóricos da Antropossociologia como Ammom, Lapouge e Gobineau. Com tantas idéias e teorias, com inúmeras críticas ao Positivismo ancoradas no Evolucionismo e o Darwinismo, Sílvio se justificava na conclusão ao quadro da Filosofia do Brasil que "o meu sistema reduz-se a não ter sistema algum; porque um sistema prende e comprime sempre a verdade," 858.

Concluía Sílvio que

"era sectário convicto do Positivismo de Comte, não na direção que este lhe deu nos últimos anos de sua vida, mas na ramificação capitaneada por Émile Littré, depois que travei conhecimento com o Transformismo de Darwin, procuro harmonizar os dois sistemas num Criticismo amplo e fecundo.

${ }^{857}$ CANDIDO, Antonio. Método Crítico. Op. Cit

${ }^{858}$ ROMERO, Sílvio. Obra Filosófica. Op. Cit.p .146 
Não é isto alguma novidade esquisita, quando a tendência filosófica principal na Alemanha, Inglaterra, França, Itália e Espanha na atualidade é justamente este Criticismo independente, firmado nos dados positivos, espécie de neokantismo, não por ir pedir idéias a Kant, mas por tomar-lhe o espirito. Neste sentido moderno, "é preciso voltar a Kant" é verdadeiro". ${ }^{859}$

É inadequado julgar Romero, no que pese sua agitada vida literária, à delimitação do campo sociológico. Homem de pensamento orgânico e de sínteses generalizantes, o que lhe cabia em seu tempo era o domínio da visão do todo, a partir de uma base que engendrou, ao menos num primeiro momento, a maioria dos intelectuais brasileiros da época - o Evolucionismo e Darwinismo.

${ }^{859}$ Ibidem. p. 146 


\title{
VII - O BRASIL É PORTUGUQ̂S?
}

Esta terra, Senhor, parece-me que da ponta que mais contra o sul vimos, até a outra ponta que do norte vem, de que nós deste porto houvemos vista, será tamanha que haverá vinte ou vinte e cinco léguas de costa. Traz ao longo do mar em algumas pArtes grandes barreiras, umas vermelhas, e outras brancas; e aterra de cima toda chã e muito cheia de grandes arvoredos. De ponta a ponta é toda praia...muito chã e muito formosa. Pelo sertão nos pareceu, vista do mar, muito grande; porque a estender os olhos não podíamos ver senão terra e arvoredos terra que nos parecia muito extensa.

Até agora não pudemos saber se há ouro ou prata nela, ou outra coisa de metal, ou ferro; nem lha vimos. Contudo a terra em si é de muito bons ares frescos e temperados como os de entre Douro e Minho, porque neste tempo de agora assim os achávamos como os de lá. Águas são muitas; infinitas. Em tal maneira é graciosa que, querendo-a aproveitar, dar-se-á nela tudo; por causa das águas. (Pero Vaz de Caminha)

\section{1 - Brasil: objeto da cobiça do Estado patrimonial português}

A chegada às terras brasileiras do homem português é parte integrante de um todo, um processo de expansão do capital. Junto com a quebra do monopólio do mercado das especiarias pelas cidades italianas, como Veneza e Genebra, o que mais despertava a elite portuguesa era a possibilidade de encontrar ouro, prata e outros tipos de materiais preciosos.

A ânsia que fez Portugal se lançar aos mares nunca dantes navegados, responsável pelos descobrimentos marítimos, é parte do amplo processo de transição entre o mundo limitado das trocas realizadas na era feudal e o alvorecer das camadas burguesas dos tempos modernos. Evento integrante do Capitalismo mundial, é dentro dessa conjuntura que vemos surgir as primeiras representações brasileiras.

\begin{abstract}
"A expansão marítima dos países da Europa, depois do séc. XV, expansão de que o descobrimento e colonização da América constituem que particularmente nos interessa aqui, se origina de simples empresas comerciais levadas a efeito pelos navegadores daqueles países. Deriva do desenvolvimento do comércio continental europeu, que até o séc. XIV é quase unicamente terrestre, e limitado, por via marítima, a uma mesquinha navegação costeira e de cabotagem.Como se sabe, a grande rota comercial do mundo europeu que sai do esfacelamento do Império do Ocidente é a que liga por terra o Mediterrâneo ao mar do Norte, desde as repúblicas italianas, através dos Alpes, dos cantões suíços, dos grandes empórios do Reno, até o estuário do rio onde estão as cidades flamengas" 860
\end{abstract}

Contando com fatores indispensáveis à primazia na empreitada expansionista, como o conhecimento da arte náutica, Portugal se adiantou no negócio das grandes navegações "Portugueses, ou treinados por portugueses foram todos os grandes navegadores dos séculos XV e XVI" ${ }^{861}$. A investida comercial portuguesa rumo ao Oriente estreita os laços entre o antigo Estado patrimonial

\footnotetext{
${ }^{860}$ PRADO JÚNIOR, Caio. Formação do Brasil Contemporâneo. 18ª . Ed. São Paulo: Brasiliense, 1983.p. 21.

${ }^{861}$ BETTENCOURT, Lúcia. Achados do escrivão no achamento do Brasil. In: Luis Donizete Benzi Grupioni (org.), A carta de Pero Vaz de Caminha - Documentos e ensaios sobre o achamento do Brasil. São Paulo, DBA, 2000.p.105. 105
} 
português e o surgimento de uma burguesia sediada em Lisboa e interessada na exploração de novas fontes de riqueza.

O Estado patrimonialista português delega a particulares a participação nas grandes navegações, na ânsia de obter proveitosos lucros no Novo Mundo. Era Portugal um Estado patrimonial de caráter burocrático que, com a incumbência da Igreja e todo o seu corpo clerical, recebera a concessão para catequizar e salvar seu próprio povo dos mouros infiéis e estender a civilização à linha dos Trópicos. De um lado, a fundamentação para a colonização recaía sobre o infiel; de outro, a alegada barbárie e selvageria dos povos que viviam abaixo dos Trópicos justificavam a expansão da fé aos mesmos.

Junto à sede de riqueza, encontrava-se o alicerce teórico bem urdido e elaborado pelas mãos dos pensadores e escritores cristãos. A certidão de nascimento do Brasil, no caso, a carta do escrivão Pero Vaz de Caminha, funcionário a serviço da Coroa portuguesa, burocrata, escritor marcado pelos ares renascentistas, "coloca-se em pé de igualdade com o cronista do Gênesis, ou mesmo o supera, já que ele tem a posição privilegiada de testemunha ocular". ${ }^{862}$ Não fosse a argumentação letrada extraída da Igreja, outorgando simbolicamente o direito de Portugal para a colonização dos países ultramarinos, todo o processo de exploração do Novo Mundo estaria menos justificado. Maria de José Goulão, analisando as representações em torno da figura do homem selvagem, meio gente e meio animal, em Portugal, no campo das Artes, na iluminura, na escultura tumular, nos romances, antes dos grandes descobrimentos é enfática:

\begin{abstract}
"Não podemos esquecer que o desejo de espalhar o evangelho foi uma importante força norteadora da empresa dos descobrimentos, desde o tempo do infante Dom Henrique. A inclusão do rei índio simbolizará, assim, a confiança na possibilidade de conversão dos habitantes do novo continente, para além de um simples apontamento exótico tão ao gosto desse período. Não há dúvida de que o artista procurou também mostrar o conhecimento crescente acerca dos novos mundos e povos relacionados com as viagens dos marinheiros portugueses" 863
\end{abstract}

A empreitada expansionista portuguesa surge de um Estado português nobre que não confunde aristocracia com elite e nem tão pouco mistura estamento com classe dirigente, dispensando a participação do povo em detrimento da tão alardeada vontade geral, o que só torna inevitável a discussão em torno da participação popular na constituição do Estado nacional brasileiro. Mas, a aristocrata nobreza portuguesa, alicerçada nos laços sanguíneos, arregimenta uma elite surgida nos tempos modernos, surgida no novo panorama histórico de formação dos Estados nacionais, partícipe do grande negócio das especiarias. É da união desse Estado patrimonial português, que delega economicamente poderes a elite comercial sediada em Lisboa que se empreenderão as grandes

\footnotetext{
${ }^{862}$ Ibidem. p.109

${ }^{863}$ GOULÃO, Maria José. Do homem selvagem ao índio brasileiro: a construção de uma nova imagem da humanidade na

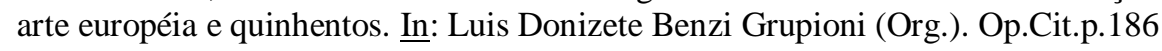


expedições marítimas em busca de ouro e prata. É a partir de um Estado português patrimonial dos tempos de Dom Manoel, o mercador da pimenta, que toda uma estrutura burocrática da Coroa portuguesa processará a colonização das terras brasileiras.

Se, por um lado, essa rigidez assentada na nobreza serve para excluir as demais camadas sociais numa Lisboa "acanhada, suja e feia", habitada por "um povo empobrecido e áspero" ${ }^{864}$, é de seu próprio caráter patrimonial que surge a elite mercantil como nova classe social, produto que é dos tempos modernos. Se mais tarde o Estado patrimonial português morrerá de velho devido a sua falta de renovação, é justamente porque uma elite de financiadores apostou nas grandes expedições marítimas. Não encontrando num primeiro momento ouro e prata, estabeleceu na colônia portuguesa bases mercantis que serviam simultaneamente para vigiar a costa brasileira contra concorrentes internacionais e corsários como se mostravam pontos de apoio para a realização de trocas de mercadorias antes da efetiva colonização, tendo o pau-brasil como primeiro produto a ser explorado até o início do cultivo de açúcar nas lavouras do nordeste. Para Faoro,

"no seu conjunto, e vista no plano mundial e internacional, a colonização dos Trópicos toma o aspecto de uma vasta empresa comercial, mais complexa que a antiga feitoria, mas sempre com o mesmo caráter que ela, destinada a explorar os recursos naturais de um território virgem em proveito do comércio europeu. É este o verdadeiro sentido da colonização tropical, de que o Brasil é uma das resultantes; e ele explicará os elementos fundamentais, tanto no econômico como no social, da formação e evolução históricas dos Trópicos americanos" 865

Conhecedores do cultivo da cana de açúcar experimentado nas ilhas do Atlântico e com os estabelecimentos comerciais na salvaguarda e no comércio do pau-brasil, buscavam os portugueses encontrar ouro e prata. O processo de fixação e as expedições colonizadoras são estabelecidos na crença da existência de riquezas minerais, que o olho português jamais perdeu de vista. Sequer um olhar desinteressado e mais abstrato fora possível por parte de homens que se agarraram as mulheres, mesmo que as considerassem vil gente, somente para vincularem-se à terra e no dia seguinte as trocavam ou vendiam ${ }^{866}$. A denominação índio não incidia somente para aqueles que habitavam as Índias, destino de Portugal, mas para todos aqueles que residissem nas terras descobertas; Terra de Santa Cruz, logo ganhou o nome de Brasil devido à madeira avermelhada que lembrava brasa que era o pau brasil, produto logo exportado para o mercado italiano. Em tudo enxergava o português a avidez

\footnotetext{
${ }^{864}$ BETTENCOURT, Lucia. Achados do Escrivão no Achamento do Brasil. In: A Carta de Pero Vaz de caminha. Op. Cit. p. 107

${ }^{865}$ FAORO, Raimundo. Os Donos do Poder: formação do patronato político brasileiro. $3^{\mathrm{a}}$. Ed. Rev. São Paulo: Globo, 2001.p.136.

${ }^{866}$ HOLANDA, Sérgio Buarque de. Raízes do Brasil. 26a . Ed. São Paulo: Companhia das Letras, 1995. p. 49
} 
gerada pelo lucro "o descobridor antes de ver a terra, antes de estudar as gentes, antes de sentir a presença da religião, queria saber da presença de ouro e prata". ${ }^{867}$

O homem português, em seu espírito aventureiro, buscava a geração de proveitosos lucros porque "selvagens" eram mesmo negros e índios que viviam da natureza, onde o atendimento às mínimas necessidades de sobrevivência lhes bastava para a sobrevivência, restando-lhes tempo necessário para a realização de suas crenças e rituais. Para alimentar o consumo de uma elite sediada em Lisboa, de gosto suntuoso e coberta de luxo, o Brasil só podia mesmo parecer um lugar de bárbaros ou de selvagens, mas de uma futura promessa. Financiou-se, assim, o empreendimento das grandes expedições marítimas. A sede de encontrar ouro e prata até erigiu a terminologia de um "espírito" ibérico, homens em busca de riqueza fácil sem nenhum projeto racional de colonização e objetivando uma riqueza como que aos saltos. Afirma Sérgio Buarque que

\begin{abstract}
"O que o português vinha buscar era sem dúvida, riqueza, mas riqueza que custa ousadia, não riqueza que custa trabalho. A mesma em suma que se tinha acostumado a alcançar na Índia com as especiarias e metais preciosos. Os lucros que proporcionou de início, o esforço de plantar a cana e fabricar o açúcar para mercados europeus, compensava abundantemente esse esforço - efetuado de resto com as mãos e os pés dos negros -, mas era preciso que fosse muito simplificado, restringindo-se ao estrito necessário ás diversas operações". 868
\end{abstract}

A vida dos povos do Novo Mundo não poderia ser mais estranha ao europeu ávido por riqueza. Caminha narra momentos em que é clara a preocupação em saber como seriam a forma de viver dos índios, seres assustados, embora passivos, enquanto o conquistador demonstra, desde cedo, o interesse na existência de ouro na Terra de Santa Cruz.

"Eles não lavram, nem criam. Não há aqui boi, nem vaca, nem cabra, nem ovelha, nem galinha, nem qualquer outra alimária, que costumada seja ao viver dos homens. Nem comem senão desse inhame, que aqui há muito, e dessa semente e frutos, que a terra e as árvores de si lançam. E com isto andam tais e tão rijos e tão nédios, que o não somos nós tanto, com quanto trigo e legumes comemos". ${ }^{869}$

O interesse na existência de produtos de valor comercial mostra o conquistador em primeiro plano, e incomoda-lhe a ausência de acumulação derivada da concepção mercantil europeia. Descorteses, desprovidos que eram das regras viciosas que só a civilização permite, os nativos não beberam vinho, não comeram de suas comidas, se assustaram com a presença de animais como o papagaio frente ao gracejo dos tripulantes, mas olharam atentamente para o suntuoso colar de Pedro Álvares Cabral no que gesticulavam rumo à terra, atitude interpretada como clara alusão à possível existência do metal "Nela, até agora, não pudemos saber que haja ouro, nem prata, nem coisa

\footnotetext{
${ }^{867}$ FAORO, Raimundo. Op. Cit.p. 116.

${ }^{868}$ HOLANDA, Sérgio Buarque de. Op.Cit. p.49

${ }^{869}$ CAMINHA, Pero Vaz de. A carta de Pero Vaz de Caminha - Documentos e ensaios sobre o achamento do Brasil. Op.Cit. 1999. p. 72
} 
alguma de metal ou ferro; nem lho vimos. Porém a terra em si é de muitos bons ares, assim frios e temperados, como os de Entre Douro e Minho, porque neste tempo de agora os achávamos como os de lá." 870

Homem a serviço da Coroa portuguesa, personificada em Dom Manuel, o Venturoso, coube ao escrivão informar sobre as possíveis riquezas existentes no Brasil. É latente a visão utilitária do escrivão, justificando todo o rigor de narrar somente aquilo que viu, o que exige mais análise. Por mais que seu relato seja um canto épico em louvor da paradsisíaca natureza da terra descoberta, sua maneira de narrar é resultado da visão utilitária de um burocrata da Corte a serviço da Coroa portuguesa. Caminha ficou de passagem nove dias, narrando um Brasil que desconsiderava todo um passado e a riqueza cultural dos indígenas. Eivado da ânsia e expectativa do que aqui buscava encontrar, reflexo da fome ou da ambição da Coroa portuguesa, desconsidera toda a pluralidade cultural do aborígine, prioriza a sede de lucro, quando a preocupação com a fauna e com a flora merece atenção primeira, por ser a própria riqueza.

Caminha mais fantasia do que descobre a realidade das coisas, por conta de uma imagem idílica que permitia as mais esdrúxulas representações humanas: uma que "o índio não é uma realidade objetiva e permanente, mas uma construção mental, uma pura imagem criada pelos europeus. Os europeus inventaram os índios, mais do que o descobriram, da mesma forma que a América não foi descoberta, mas inventada pelos europeus do século XVI" ${ }^{871}$. Mas, a realidade dos povos daqui não foi tão paradisíaca, como deixam ver os primeiros escritos acerca da terra recém descoberta. Apostando na existência de preciosos minérios, não era estranho ver seres humanos fora de seus mundos.

Não é correta a tese de que os portugueses tenham chegado ao Brasil de forma acidental ${ }^{872}$, visto serem hábeis conhecedores da Geografia da época. Mais significativo do que a chegada acidental ou não é a constatação do olhar "civilizatório" acobertado por uma racionalidade surgida justamente do olhar pragmático, ligeiro e artificial, que não deixa espaço para a criação desinteressada decorrente da "inaptidão de ver fora das viseiras douradas do comércio e dos metais preciosos". 873 Aqui estabelecido, o português se misturou com índios e negros, aprendeu o tupi, bebeu e mascou fumo, dormiu em suas moradas, copulou com as mulheres indígenas, escorregando-se nelas, e comeu de suas comidas. Tudo para prover o processo colonizador!

\footnotetext{
${ }^{870}$ Ibidem. p.77

${ }^{871}$ GOULÃO, Maria José. Op.Cit.182

${ }^{872}$ CORTEZÃ̃O, Jaime. A expedição de Pedro Álvares Cabral e o descobrimento do Brasil. Lisboa: Imprensa. NacionalCasa da Moeda, 1994.

${ }^{873}$ FAORO, Raimundo. Op.Cit.p.116.
} 
Para além da cobiça e avareza, buscava o português a riqueza fácil sem um plano colonizador metódico e racional, diferentemente dos colonizadores da América do Norte, não se fixando em nenhuma atividade econômica, como aponta Sérgio Buarque de Holanda ${ }^{874}$. O traço mais significativo do português com relação às culturas aqui encontradas foi esquecer-se de si e retratar as culturas dos povos da América, a partir de seu espelho, o que é bem lembrado por Serge Gruzinski:

"As mestiçagens desencadeadas pela conquista do Novo Mundo parecem
indissociáveis de dois outros fenômenos maiores na América do século XVI: de um
lado o que costuma se chamar "o choque da conquista"; e, de outro, o que chamei de
ocidentalização, essa empreitada multiforme que levou a Europa Ocidental no rastro
de Castela, a fazer a conquista das almas, dos corpos e dos territórios do Novo
Mundo. O fato de as mestiçagens americanas terem se inscrito numa fase de expansão
da Europa e num contexto de colonização impede que sejam reduzidas a um fenômeno
cultural. Se queremos compreendê-las, não podemos abstrair seus laços com a
Conquista e a ocidentalização que as acompanham. Resta esclarecer a natureza
desses laços." 875

É do contato entre colonizador e colono que emerge a necessidade de ver o outro não a partir de seu mundo, mas a partir de uma visão totalitária e negadora de todos os símbolos culturais dos povos conquistados. Cabe salientar que é da cobiça européia que surge um corpo documental bastante conhecido, de onde emanam as primeiras imagens do Brasil. Não se pode esquecer que, ligado ao interesse material do português, estava sua maneira de gerir politicamente toda uma estrutura estatal e é dessa estrutura que emanavam as normas ou imposições a serem seguidas, fosse por parte de homens saídos da Igreja ou de pesquisadores a mando da Coroa, preocupados com os mais variados ramos do saber. O que se presenciará mais tarde, nos fins do século XVII, e de modo mais significativo, no século XVIII, no Brasil, com o alvorecer das Academias e escolas de Medicina, só faz sentindo em razão da busca de um conhecimento utilitário que gere resultados materiais, mascarado por um ideal maior em torno da identidade do país. Toda uma geração de escritores, desde os tempos de Caminha, passando pelos inúmeros viajantes que no Brasil estiveram em suas missões, até o momento propício ao surgimento de uma Literatura pátria, no império brasileiro, reunindo personagens empolgados com as idéias de um Liberalismo nada democrático, só dá continuidade a uma visão iniciada desde os tempos da invasão portuguesa no Brasil. Homens para quem a Literatura, espécie de recurso de autoridade, balizava suas visões de mundo, entremeada ao rigor das Ciências Naturais como estratégia discursiva e inabalável frente a qualquer argumentação contrária.

Em seu estudo sobre a Ilustração brasileira, Maria Odila Silva Dias sustenta que “A mentalidade pragmática dos iluministas foi-se enraizando entre os brasileiros. O conceito dos que tinham as Artes

\footnotetext{
${ }^{874}$ HOLANDA, Sérgio Buarque de. Raízes do Brasil. 26 Ea Ed São Paulo: Companhia das Letras, 1995.

${ }^{875}$ GRUZINSKI, Serge. O pensamento mestiço. São Paulo: Companhia das Letras, 2001. p.63.
} 
como hierarquicamente inferiores as Ciências parecia refletir o alvitre geral da época". ${ }^{876}$ Conclui a autora que

\begin{abstract}
"Tinham a consciência de uma grande obra a realizar para o progresso de sua terra; continuar o trabalho de exploração e devassamento de enormes tesouros que permaneciam ignorados no interior do Brasil, a existência dos quais não era posta em dúvida pelo seu otimismo: "Seria do maior interesse que tão digno desejo de conhecer as produções do mais rico dos países se propague e que não deixemos ignorados, $e$ nos privemos a nós e ao resto do mundo das vantagens e riquezas, de que somos possuidores ${ }^{, 877}$
\end{abstract}

Sérgio Buarque de Holanda, com a imagem de "desterrados em nossa própria terra”, herdeiros de uma tradição oriunda de uma nação avarenta, que antes mesmo do contato já sentira o lucro nas entranhas, apontou o traço de continuidade que se iniciou desde a chegada do português, marcando de maneira significativa todo o processo de formação do Brasil, continuando pelas inúmeras Academias literárias. Tomemos como exemplo o surgimento do IHGB, surgido das discussões literárias da SAIN (Sociedade Auxiliadora da Indústria Nacional), onde vieram juntar-se escritores e políticos, amalgamados pela tutela do Estado brasileiro, personificado na Ilustração de D. Pedro II.

Do espírito de aventura do português, derivou-se no Brasil uma elite agrária que buscava prestígio utilizando-se de meios ornamentais, principalmente recorrendo ao bom uso da palavra, que as Ciências e as Artes oferecem, em suas relações baseadas no favor - o que caracterizaria na visão do autor a cordialidade - em detrimento das mínimas regras de cidadania que um Estado burocrático pode ofertar. Decorre daí o patriarcalismo do Estado brasileiro, onde a esfera pública confunde-se com o privado, sendo não mais que o espaço para a concretização de seus interesses. As regras e normas sociais originam-se não da racionalização que exige o sério Estado burocrático, mas das relações cordiais onde ambos os lados saem favorecidos.

\title{
2- Um discurso nada catequizador.
}

Da ânsia de encontrar ouro e prata, surge a idéia de um paraíso terreal, habitado por seres puros e inocentes, à espera das mãos catequizadoras para civilizarem os povos do Brasil descoberto. A visão de paraíso despertada no português é produto da ganância pelo que buscavam encontrar nas terras recém descobertas, o que se manifestou num argumento contraditório: não existia certeza alguma da existência de ouro e prata ou outros metais, mas se percebe a insistência a todo custo em afirmar a riqueza das novas terras ao invés de relatar um discurso coerente acerca de Brasil com o que já se sabia. A idealização de um paraíso terreal é uma estratégia bem urdida da empreitada colonial para

\footnotetext{
${ }^{876}$ DIAS, Maria Odila. Op.Cit. p.79.

${ }^{877}$ Ibidem. pp. 79-80.
} 
esconder o que de real acontecia no Brasil e no cenário europeu. $\mathrm{O}$ discurso fantástico e sedutor de uma terra harmônica, paralelo às Utopias de Morus e Campanella ${ }^{878}$, tornara-se argumento indispensável para viabilizar o processo de exploração brasileira, de onde a visão edênica é estratégia para colonizar os povos que habitavam abaixo da linha dos Trópicos. Com o choque da conquista provocado pelo contato de seres auto-designados como civilizados, que habitavam os climas temperados da Europa, com seres vistos como bestiais, habitantes de zonas tropicais de forte calor, vai emergir todo um discurso centrado na influência das forças climatológicas, fundamentando as representações do olhar exótico direcionando os novos grupos humanos.

O Paraíso Terreal, imagem fantasiosa e maravilhosa, é tributário dos tempos bíblicos, quando acreditavam os homens num jardim do Éden, crentes na existência de uma Idade do Ouro, só revigorada ao longo da Idade Média. Esse imaginário precipuamente conservador se alimenta e reforça cada vez mais na hierarquização dos grupos humanos. A visão nostálgica de um paraíso perdido, agora transplantado para a América, norteia a maneira de conceber índios e negros do Novo Mundo.

Nos relatos de Cristovão Colombo, Diários da Descoberta da América, Álvaro Coelho, Roteiro da viagem de Vasco da Gama as índias, Américo Vespúcio e Cabral, influenciados pelo livro de Marco Pólo, Livro das Maravilhas, é patente a esperança num Eldorado ou numa terra proveitosa, onde tudo se dava. Ao primeiro contato com o Novo Mundo, ante o fascínio e encantamento, sentiu o português uma natureza exuberante, responsável pela presença de seres ingênuos, destituídos dos mínimos padrões de vivência que somente o homem civilizado podia fornecer. Por aqui existiam seres tão inocentes que sequer incomodava o fato de mostrarem suas vergonhas, com seus corpos pintados de cima a baixo e com suas cabeças raspadas, no que relatava o escrivão de que "Assim, Senhor, a inocência desta gente é tal, que a de Adão não seria maior, quanto à vergonha", 879

Essa forma idílica e parasidíaca de ver o Novo Mundo esconde muito mais do que a realidade das coisas: o olhar selvagem e bárbaro é o do português, em uma constante visão utilitária, e não dos índios e negros, que desconheciam as normas impostas pela civilização européia e viviam uma realidade completamente diferente da avidez e da acumulação do homem branco. Criando uma imagem a partir do mundo europeu, que tem por base a acumulação e o trabalho racional, para o português, reinavam aqui seres ingênuos, inocentes, descrentes de um Deus, que bem serviriam de matéria prima para a conversão Católica encabeçada por jesuítas. Concebendo esses novos seres sem a

\footnotetext{
${ }^{878}$ MORUS, Thomas. Utopia. Rio de Janeiro: Ouro, 1966. CAMPANELLA, Tommaso. A cidade do sol. São Paulo: Ícone, 2002.

${ }^{879}$ CAMINHA, Pero Vaz de. Op.Cit.p.76
} 
presença monstruosa do Estado, traço peculiar desses homens ilustrados, não é estranho que navegantes e cronistas estereotipassem de maneira negativa as populações do Novo Mundo. ${ }^{880}$

Instaurou-se o imperialismo civilizador que sempre buscou justificar a presença de seres ingênuos e inocentes, ou seja, de seres inferiores com relação à mente do homem europeu. Esse europeu, em seu olhar ilustrado e utilitarista, fantasiou e criou representações também negativas acerca dos seres aqui presentes. Toda uma imagem construída pelos letrados católicos, reanimando particularidades clássicas, recaía sobre o homem selvagem, muito próximo da besta, inclinado a realizar aquilo que mandavam seus extintos primários, incide agora sobre os povos recém descobertos. É durante a Idade Média que surge uma Antropologia fantástica baseada no homem selvagem habitante das matas, coberto de pelos, e acima de tudo, desprovido da mínima capacidade racional que somente as normas sociais civilizadas capacitavam. Com a circulação do relato de Caminha sobre a descoberta do Novo Mundo na Europa, esse imaginário é direcionado para os povos americanos aqui encontrados.

Este imaginário serviu de pano de fundo para o surgimento de um discurso colonial destituído de alteridade. Podemos inserir a Literatura dos viajantes e dos cronistas num discurso colonial ambivalente, fruto do desejo de querer ver os povos encontrados de maneira fixa, sob a angústia psicanalítica do poder, alicerçados, pois, em categorias como a raça e o sexo. Para a confecção desse discurso colonial, coube aos homens letrados estereotipar os seres abaixo da linha dos Trópicos, baseados na fixidez de seus próprios mundos, sem perceber o outro em sua totalidade. Homi Bhabha esmiúça a ambivalência do discurso colonial como aparato de poder, afirmando que se trata de

\begin{abstract}
"um aparato que se apóia no reconhecimento e repúdio de diferenças raciais/ culturais/ históricas. Sua função estratégica predominante é a criação de um espaço para "povos sujeitos" através da produção de conhecimentos em termos dos quais se exerce a vigilância e se estimula uma forma complexa de prazer/desprazer. Ele busca legitimação para suas estratégias através da produção de conhecimentos do colonizador e do colonizado que são estereotipados, mas avaliados antiteticamente. $O$ objetivo do discurso colonial é apresentar como uma população de tipos degenerados com base na origem racial de modo a justificar a conquista e estabelecer sistemas de administração e instrução. Apesar do jogo de poder no interior do discurso colonial e das posicionalidades deslizantes de sues sujeitos (por exemplo, efeitos de classe, gênero, ideologia, formações sociais diferentes, sistemas diversos de colonização, e assim por diante), estou me referindo a uma forma de governamentalidade que, ao delimitar uma "nação sujeita", apropria, dirige e domina suas esferas da atividade. Portanto, apesar do "jogo" no sistema colonial que é crucial para seu exercício de poder, o discurso colonial produz o colonizado como uma realidade social que é ao mesmo tempo um "outro" e ainda assim inteiramente apreensivel e visivel. Ele lembra uma forma de narrativa pela qual a produtividade e a circulação de sujeitos e signos estão agregadas em uma totalidade reformada e reconhecível. Ele emprega um sistema de representação, um regime de verdade, que é estruturalmente similar ao realismo." 881
\end{abstract}

${ }^{880}$ CLASTRES, Pierre. Arqueologia da violência: pesquisas de antropologia política. São Paulo: Cosac \& Naify, 2004.

${ }^{881}$ BHABHA, Homi. Op.Cit.p. 111 
Esse discurso colonizador, responsável pela criação fantasiosa, teme as mudanças da História, por isso pensa num mundo fixo como o local da cultura. Nesse sentido, os seres habitantes das novas terras seriam inferiores porque desprovidos das regras que só o mundo civilizado é capaz de gerar, resultando daí sua inocência e pureza. O Novo Mundo causa espanto, fascinação, do que decorre a visão exótica e maravilhosa como forma de fuga e frustração, temerosa das possíveis mudanças e contestações que ofereceriam índios e negros. O olhar parasidíaco é constituído por uma série de elementos que se misturam para dar sentido à justificativa colonizadora. Este olhar pode se assentar em função da nudez do índio, de suas línguas não compreendidas pelo homem colonizador, de seus rituais, de seus costumes, sempre como parte integrante de uma argumentação maior que é o discurso colonizador.

Há de se ressaltar que o burocrata que por aqui esteve era um homem do Estado e a serviço da Coroa portuguesa que concebia o gentio a partir das normas coercitivas impostas por uma sociedade civilizada. Desse modo, é pelas necessidades em si mesmo exploratórias que letrados, sejam viajantes ou cronistas, homens a serviço de suas respectivas Coroas, concebem o índio com a imagem selvagem e bárbara de um ser poligâmico e comedor de carne humana.

Nessa perspectiva, na Terra de Santa Cruz, reina o pecado, a descrença, a inocência, a pureza e a mansidão de um índio condescendente com os ideais de instalação de um projeto civilizador. A concepção dos cronistas é eurocêntrica porque não considera as diferenças culturais, negando e desconhecendo o quadro riquíssimo das representações simbólicas de negros e índios. O bem maior seria salvar essa gente do pecado da poligamia e da antropofagia. A argumentação por parte do colonizador sobre a pouca capacidade do gentio, oriunda de sua bestialidade, é parte integrante da ideologia maior do invasor, que despreza conhecer o gentio dentro de sua própria cultura.

O certo é que índios e negros não viviam conforme as regras do mundo capitalista do branco europeu ansioso por riquezas. Pisando o solo brasileiro, os missionários logo assinalam o pecado do índio. Segundo o padre Manoel da Nóbrega,

"Espero em Nosso Senhor fazer-se fructo, posto que a gente da terra vive em peccado mortal, e não há nenhum que deixe de ter muitas negras das quaes estão cheios de filhos e é grande mal. Nenhum delles se vem confessar; ainda queira Nosso Senhor que o façam depois. $O$ irmão Vicente Rijo ensina a doutrina aos meninos cada dia e também tem eschola de ler e escrever; parece me bom modo este para trazer os Índios desta terra, os quaes têm grandes desejos de aprender e, perguntados se querem, mostram grandes desejos". ${ }^{882}$

Pouco depois, denunciava o missionário que

"Nesta terra há um grande peccado, que é terem os homens quasi todos suas negras por mancebas, e outras livres que pedem aos negros por mulheres, segundo o costume da

\footnotetext{
${ }^{882}$ NOBREGA, Manuel da. Cartas do Brasil (1549-1560). Rio de Janeiro: Oficina Industrial Gráfica, 1931.p.33
} 
terra, que é terem muitas mulheres. E estas deixam-nas quando lhe apraz, o que é grande escândalo para a nova egreja que o Senhor que fundar. Todos se me escusam que não têm mulheres com que em tanto que uma mulher, ama de um homem casado que veiu neste armada, pelejavam sobre ella a quem a haveria por mulher, e uma escrava do Governador lhe pediam por mulher e diziam que lh'a queriam jorrar". 883

Por aqui, reinava o pecado e somente com o processo de evangelização seria possível converter esses seres selvagens em seres civilizados. Tratava-se de uma argumentação eurocêntrica, elaborada pelos homens da Igreja, que serviu para alavancar o discurso colonial, em que a visão edênica se mostrou ser o "primeiro capítulo da invenção da América". ${ }^{884}$ Nos relatos de viagens, tantas vezes aludidos, nem sempre se presencia uma fauna rica ou os ventos possuem bons ares, contrariando parte da Literatura encorpada por cronistas e viajantes e a idéia de uma terra perfeita, onde nada faltava. Quando da visão edênica do espírito português com relação à ilha de Santa Cruz, esta se dá mais em razão de um espírito pragmático, de maneira paradoxal, "pouco afeito as transformações que, em muitos outros países, se operam simultaneamente com a grande obra dos navegadores do Reino", ${ }^{885}$, sedento pela busca de um Eldorado, obstando a análise coesa da realidade dos mundos colonizados.

Assim, as primeiras representações brasileiras elaboradas pelos navegantes e jesuítas caracterizam-se pelo olhar fantasioso e maravilhado, visão do homem ilustrado ligado ao Estado português. Estas representações por figuras como Caminha, Gandavo, Anchieta, Nóbrega, Cardim, Gabriel Soares e tantos outros podem ser sintetizadas, como bem observou Sérgio Buarque, a partir de uma visão edênica, de um paraíso terreal, onde existia um paraíso perdido, integrado por uma fauna e por uma flora perfeitas. Semelhante ao jardim do Éden dos tempos bíblicos, imaginário reforçado ao longo da Idade Média por Isidoro de Sevilha, São Tomás de Aquino, Boaventura Soares, os cronistas retrataram o Brasil de maneira fantástica. Nesse sentido, o exotismo por parte do olhar civilizador repousa nos fatores naturais, dando início e direcionando o olhar "para dentro", muito tempo depois reforçado e reorientado pelos escritores românticos, pela Geração de 1870 e finalmente, pelo Modernismo.

$\mathrm{Na}$ ausência de ouro e prata, não deixava o recém-descoberto Brasil, com seus salutares ares, traço legitimado pelos tratados e crônicas do período, de mostrar muito proveito: “Águas são muitas;

\footnotetext{
${ }^{883}$ Ibidem. p.79

${ }^{884}$ FAORO, Raimundo. Op.Cit. p.121. Ver também as reflexões de Fernando Novais sobre a importância ideológica desses argumentos, associados ao interesse mercantil pelas terras descobertas e colonizadas: NOVAIS, Fernando A. Condições da privacidade na colônia. In: SOUZA, Laura de Mello e (Org.). Cotidiano e vida privada na América portuguesa. São Paulo: Cia. das Letras, $\overline{19} 97$, pp. 13/39.

${ }^{885}$ HOLANDA, Sérgio Buarque de. Visão do Paraíso: os motivos edênicos no descobrimento e colonização do Brasil. São Paulo: Brasiliense; Publifolha, 2000. p. 5

${ }^{885}$ CAMINHA, Pero Vaz de. Op.Cit.77
} 
infindas. E tal maneira é graciosa que, querendo-a aproveitar, dar-s, por bem das águas que tem”. 886 O imaginário sobre o Novo Mundo, formado por suas representações literárias e artísticas, era agora transmutado da Europa e os grupos indígenas são concebidos à luz da portentosa natureza, não sendo capazes do despertar a capacidade humana. Habitantes de uma esplendorosa flora, coberta por uma fauna abundante, é somente como produto deste paraíso terreal que a imagem do silvícola se consolida.

Homens como Caminha, Gandavo, Pero Lopes de Souza, Cardim e Anchieta, em seus apontamentos acerca da terra recém descoberta, esboçam as primeiras representações brasileiras a partir de um quadro exótico da natureza e dos seres aqui presentes. A visão exótica dos cronistas acerca do Brasil, possível paraíso perdido antes mesmo da queda de Adão, pode ser sintetizada como bem observou Sérgio Buarque a partir de uma visão edênica, onde a fauna e a flora seriam elementos inseparáveis. Semelhante ao jardim do Éden dos tempos bíblicos, imaginário reforçado ao longo da os cronistas retrataram o Brasil de maneira fantástica. Portanto,

\begin{abstract}
"Desde Gandavo, e melhor, de Pero Vaz de Caminha até pelo menos Frei Vivente do Salvador é uma curiosidade relativamente temperada, sujeita, em geral, a inspiração prosaicamente utilitária, o que dita as descrições e reflexões de tais autores. A extravagância deste ou daquele objeto que ameaça desafiar o costume ou ordem da natureza, pode ocasionalmente acarretar, é certo, alguma vaga sugestão de mistério. De que nos serve porém querer penetrar a todo transe esses segredos importunos? Muito mais do que as especulações ou os desvairados sonhos é a experiência imediata o que tende a reger a noção do mundo desses escritores e marinheiros, e é quase como se as coisas só existissem verdadeiramente a partir delas. A "experiência que é madre das coisas, nos desengana e de toda dúvida nos tira" assim falou um deles nos primeiros anos do século XVI." 887
\end{abstract}

Para além da pretensão de buscar compreender o sentido da fantasia edênica, do gosto pelo maravilhoso, típico dos “descobridores” com sua visão de paraíso, vale elucidar que foi somente em meio a este imaginário que se tornou possível a colonização não apenas do Brasil como de vários outros países. Desse ponto de vista, as primeiras representações sobre o Brasil retratam a riqueza da fauna e exuberância da flora, sendo o índio produto de um cenário exótico ligado à exuberância natural. Cumpre destacar que a História produzida no momento é uma História Natural, intrinsecamente ligada ao conhecimento das potencialidades das colônias. Como bem lembra Roberto Ventura,

"Até o século XVIII, a História apresentava diversos objetos e empregos, que não tem relação com a disciplina que se conhece hoje sob este nome. A História encerrava toda uma coleção de objetos, que podia conter a descrição da flora, fauna e recursos naturais de uma região, dos costumes de seus habitantes, do modo de vida e governo. Incluía,

${ }^{887}$ HOLANDA, Sérgio Buarque de. Op.Cit.p. 5 
com freqüência, a África e a América, como na Historia natural y moral de las Índias, do padre Acosta, ou na Histoire des deux Indes, de Raynal." 888

Os primeiros cronistas tratam de representar à fauna e a flora presos à noção de História Natural, o que perdurará até o momento do Iluminismo, facultando um novo olhar, uma nova maneira de conceber o gênero humano. Nas crônicas, vemos sempre emergir a grandeza dos rios, a salubridade dos ventos, a exuberância vegetal, para justificar um futuro promissor da nova terra. Para Gandavo,

"As fontes que há na terra sam infinitas cujas agoas fazem crescer a muitos e muy grandes rios que por esta costa, assi da banda do Norte, como do Oriente entram no mar Oceano. Alguns delles nascem no interior do sertam, os quaes vem por longas $e$ tortuosas vias a buscar o mesmo oceano: onde suas correntes fazem avastar as marinhas agoas por força, e entram nelle com tanto ímpeto, que com muita deficuldade e perigo se pode por elles navegar. Hum dos mais famosos e principaes que há nestas pArtes he o das Amazonas, o qual sae ao Norte meio grau da Equinocial para o Sul e tem trinta legoas de boca pouco mais ou menos" 889

Preocupados com a existência de ouro e outros metais no Brasil, homens católicos, muitas vezes ligados a senhores de terra e donos de escravos, tratam sempre de apontar as riquezas da Terra de Santa Cruz,

\begin{abstract}
"Esta Província Santa Cruz alem de ser tam fértil como digo, e abastarda de todos os mantimentos necessários para a vida do homem he certo ser também muy rica, e a ver nella muito ouro e predaria, de que se tem grandes esperanças. E a maneira com isto se veo a denunciar e ter por cousa averiguada foi por via dos índios da terra.....Além da certeza que por esta via temos há outros muitos índios na terra, que também ver no sertão muito ouro, os quaes posto que sam gente de pouca fee e verdade, dasse-lhe credito nesta parte, porque acerca disto os mais delles sam contestes, e falam em diversas pArtes por um boca. Principalmente he publica fama entre elles que ha huma lagoa muy grande no interior da terra donde procede o Rio de San Francisco, de que já tratei, dentro da qual dizem aver algumas ilhas e nellas edificadas muitas povoações, $e$ outras orredor della muy grandes onde também há muito ouro, e mais quantidade, segundo se afirma, que em nenhuma outra parte desta Província. Também pela terra dentro nam muito longe do Rio da Prata descobriram os Castelhanos huma mina de metal da qual se tem levado ao Peru e de cada quintal delle dizem que se tirou quinhentos e setenta cruzados e de ouro trezentos e tantos: o de mais que della se tira he cobre infinito." 890
\end{abstract}

Não apenas era de vital importância salientar a grandeza e riqueza das terras brasileiras, como também a localização geográfica exata das novas terras, era muito mais que representar: tratava-se de demarcar limites e fronteiras na garantia das possíveis riquezas que a ilha de Santa Cruz podia oferecer. Em direção ao extremo oriente Caminha avista de longe um "grande monte, mui alto $e$

\footnotetext{
${ }^{888}$ VENTURA, Roberto. Estilo tropical. Op.Cit. p. 28

889 GANDAVO. História da Província Santa Cruz. Lisboa que vulgarmente chamamos Brasil: Tipografia da Real Academia das Ciências, 1858. p. 6

${ }^{890}$ Ibidem. p.67
} 
redondo; e doutras serras mais baixas ao sul dele; e de terra chã, com grandes arvoredos: ao monte alto o capitão pôs nome - o MONTE PASCOAL - e a terra - a TERRA DA VERA CRUZ" 891.

Era crucial, uma vez que o que estava em jogo era a busca por novas riquezas matérias, conhecer a exata localização das novas terras,

"E assim seguimos nossos caminhos, por esse mar, de longo, até que, terça feira das Oitavas de Páscoa, que foram vinte e um dias de abril, estando da dita ilha obra de 660 ou 670 léguas, segundo os pilotos diziam, topamos alguns sinais de terra, os quais era muita quantidade de ervas compridas, a que os mareantes chamam Botelho, assim como outras a que dão o nome de rabo-de-asno. E quarta-feira seguinte, pela manhã, topamos aves a que chamam fura-buxos." 892

Gandavo, quando trata de escrever as qualidades do Brasil, situa a Terra de Santa Cruz,

"Esta província Santa Cruz esta situada naquela grande América, huma das quatros partes do mundo. Dista o seu princípio dous graus da equinocial para a banda do Sul, $e$ daí se vai estendendo para o mesmo sul até quarenta e cinco grau. De maneira que parte dela fica situada debaixo da temperada. Esta formada esta Província a maneira de uma harpa, cuja costa pela banda do Norte corre do Oriente ao Ocidente e esta olhando direitamente a Equinocial; e pela do Sul confina com outras Províncias da mesma América povoada e possuídas de povo gentílico com que ainda nem temos comunicaçam. E pela do Oriente confina com o mar Oceano Áfrico, e olha direitamente os Reinos de Congo e Angola ate ao Cabo de boa esperança, que e o seu opposito". ${ }^{893}$

Já José de Anchieta registrava que

"esta parte do Brazil (assumpto em que apenas toquei nas passadas cartas) que se chama S.Vicente, dista da Equinocial vinte e três gráos e meio, medidos do Aquilão para o Áfrico, voltado para o Austro, onde qual é o adiantamento do sol, ou motivo de regresso; qual o curso dos astros; que declinações de sombras; quaes sejam as minguantes e as crescentes da lua; não me é fácil explicar: porque me não parece que jamais as possa attingir, e também porque é assumpto estranho ao que aqui se emprehende" 894

Em sua densa obra em que trata de descrever a divisão do Brasil com suas respectivas capitanias hereditárias, situando geograficamente todas elas, falando de suas riquezas e da presença das diversas nações indígenas, o senhor de engenho na Bahia, Gabriel Soares, no Tratado Descritivo do Brasil em 1857, além de situar a província do Brasil "alem da linha equinocial da parte do sul, debaixo da qual começa ela a correr junto do rio que se diz das Amazonas; onde se principia o norte da linha da

${ }^{891}$ CAMINHA, Pero Vaz de. Op.Cit.p. 52

${ }^{892}$ Ibidem. p.52

${ }^{893}$ GANDAVO, Pero de Magalhães. Op.Cit. p. 4

${ }^{894}$ ANCHIETA, José de. Cartas inéditas. Instituto Histórico e Geográfico Brasileiro. Edição comemorativa do 4 a . centenário. São Paulo: Tipografia Eclética, 1900. pp. 4-6 
demarcação e repartição; e vai correndo esta linha pelo sertão d'esta província até 45 gráos, pouco mais ou menos $"{ }^{895}$ logo trata de anotar a riqueza da Bahia.

Na segunda parte da obra intitulada Das Grandezas da Bahia de Todos os Santos, de sua fertilidade e das notáveis partes Que tem esclarece que:

\begin{abstract}
"Dos metaes de que o mundo faz mais conta, que é o ouro e prata, fazemos aqui tão pouca, que os guardamos para o remate e fim d'esta historia, havendo-se de dizer d'elles primeiro, pois esta terra da Bahia tem d'elle tanta parte quanto se pode imaginar; do que nunca vieram das Índias occidentaes, se S. Magestade for d'isso servido, o que se póde fazer sem se metter n'esta empreza muito cabedal de sua fazenda, do que não tratamos miudamente por não haver para que, nem fazer ao caso da tenção d'estas lembranças, cujo fundamento é mostrar as grandes qualidades do Estado Brasil, para se haver de fazer muita conta d'elle, fortificando-lhe os portos principaes, pois tem tanto commodo para isso como no que toca á Bahia está declarado; o que se devia pôr em effeito com muita instancia, pondo os olhos no perigo em que esta de chegar á noticia dos Lutteranos parte do conteúdo n'este tratado, para fazerem suas armadas, e se crem povoar esta província, onde com pouca força que levem de gente bem armada se podem senhorear dos portos principaes, porque não há de achar nenhuma resistência n'elles, pois não tem modo de fortifivação, donde os moradores se possam defender nem deffender a quem os quizer entrar" 896
\end{abstract}

Várias são as passagens em que Gabriel Soares afirma a riqueza da terra. A idéia de um paraíso terreal em que se verifica a longevidade dos índios, a presença dos bons e salutares ventos, com a presença de rios enormes como o São Francisco e o Amazonas, o que "se enlaça estreitamente aos motivos edênicos, tão populares durante as grandes navegações da época". ${ }^{897} \mathrm{~A}$ visão edênica elaborada pelos letrados a respeito dos povos americanos surge como justificativa colonizadora na construção de seres passivos, puros, ingênuos, como se estivessem a esperar a chegada civilizadora dos padres católicos da maneira mais passiva possível. Bem sintetiza Faoro que

\footnotetext{
"A visão paradisíaca, criada pelo grupo dominante, filtrada da imaginação dos letrados, servia para calar os ódios guardados. Longe, em outros hemisférios, fora do caldeirão das cobiças, havia terras virgens, habitadas de bons selvagens, onde a vida se oferece sem suor, para glória de Adão antes do pecado. Esta a imagem que desenha Pero Vaz de Caminha, em consonância com o quadro que seria o mesmo de Pero de Magalhães Gandavo, setenta anos depois pintado, de modo mais consciente, como o mesmo seria o de Montaigne, ainda no século XVI". ${ }^{898}$
}

${ }^{895}$ SOARES DE SOUZA, Gabriel. Tratado descritivo do Brasil em 1587. Rio de Janeiro: Tipografia Universal de Laemmert. p. 15

${ }^{896}$ Ibidem. p.364

${ }^{897}$ Ibidem.

${ }^{898}$ FAORO, Raimundo. Op.Cit. p.118 


\title{
3- Mundos diferentes: civilização x barbárie
}

Das inúmeras representações surgidas a partir do contato entre o homem suposto civilizado europeu e os seres vistos como bestiais do Novo Mundo, muitas são delineadas a partir de um imaginário que podemos chamar de olhar civilizatório. Dos elementos constituintes daquilo que se considera civilização, surge sua antípoda ou negação: seres selvagens ou bárbaros, desprovidos das regras e costumes impostos por aquela civilização. Uma idéia intrinsecamente associada à evolução e progresso que gregos e romanos conheciam, tomando por base sua concepção de tempo linear e teleológico. Gregos e romanos acreditavam na decadência histórica guardada em mãos da Fortuna. Acreditando os gregos na roda da fortuna, no telos em que a História se revelaria, os romanos não foram menos providenciais quando concebiam a História como a mestre da vida onde mais uma vez o tempo histórico carregaria consigo a providência. Mas para conhecer a História era necessário ver e narrar os fatos para que só assim fosse esta digna de verdade.

Com o advento do Cristianismo, segundo Le Goff, uma religião de "historiadores", ocorreu ainda mais a valorização do tempo e das datas com fundamento da verdade histórica. A História já estava traçada em traços providenciais de maneira teleológica se consumando ou se realizando após a morte. Mais uma vez, o tempo seria elemento imprescindível para a construção da idéia de civilidade que mais tarde se acentuaria no confronto com os povos colonizados,

\begin{abstract}
"Gregos e romanos afirmaram face aos "bárbaros" o valor da civilização mais ou menos concebida um processo evolutivo e a "Antropologia comparativa" colocou-os, por vezes no limiar da idéia de progresso. Mas tudo por outras razóes os desvia de tal idéia. Por exemplo, o papel atribuído a deusa Fortuna, persistente na realização dos seus projetos, mas volúvel nas suas intervenções pronta a manifestar a instabilidade de todas as coisas-humanas. Quando o grego Polibio, o mais "racional" dos historiadores antigos declara: "Reunirei para os leitores, num só quadro, todos os meios pelos quais a Fortuna executa as suas intenções "introduz uma lógica bem caprichosa na Ciência histórica." ${ }^{899}$
\end{abstract}

Um dos elementos justificadores da civilização ocidental com sua História descritiva, fatual e linear era a noção de tempo. A História a ser contada e a ser seguida era a História de Grécia e Roma, donde a caracterização de que os demais povos estavam num estágio infantil como criança à espera da ajuda civilizada. Com o advento da modernidade, aparece a idéia de evolução e progresso, não mais apelando para um tempo linear e escatológico, mas enraizada numa Ilustração racional, que bem servia para justificar a colonização do Novo Mundo. Filha das Luzes, a noção de civilização recaía acintosamente sobre as características fenotípicas do gênero humano. Se antes bárbaro era aquele que estava fora das fronteiras de Roma e que não falava o latim, fosse da cor de bronze, de prata ou de

${ }^{899}$ LE GOFF, Jacques. História e Memória. Campinas, São Paulo: Editora da Unicamp, 1990.p. 236. 
ouro, agora bárbaro seria aquele em que uma série de valores não condizia com os costumes europeus referendados pelos critérios da ciência moderna oriunda do enciclopedismo das Luzes. São homens ilustrados a serviço de suas majestades como letrados, viajantes, missionários e conquistadores os maiores defensores da civilização européia, que concebem a civilização dos povos abaixo dos Trópicos num estágio infantil, exótico, exuberante, prova cabal de todo um quadro de cultura visto a partir de outra, donde a concepção de povos selvagens. Homens encantados com as maravilhas do Novo Mundo, pensavam que essa população encontrava-se apenas em seu estágio infantil, donde o imaginário maravilhoso coberto por uma concepção de inferioridade dos povos encontrados. Montaigne, que teve ao seu lado por doze anos um homem que conheceu a França Antártica, analisou o Novo Mundo conforme as particularidades deste. O que é era barbárie e ingênuo era um mundo completamente diferente das normas sociais criadas pelo homem europeu. Em Dos Canibais, afirma que

"Esses povos não me parecem, pois, merecer o qualificativo de selvagens somente por não terem sido senão muito pouco modificados pela ingerência do espírito humano senão haverem quase nada perdido de sua simplicidade primitiva. As leis da natureza, não ainda pervertidas pela imisção dos nossos, regem-nos até agora e mantiveram-se tão puras que lamento por vezes não as tenha o nosso mundo conhecido antes, quando havia homens capazes de apreciá-las. Lamento que Licurgo e Platão não tenham ouvido falar delas, pois sou de opinião que o que vemos praticarem esses povos, não somente ultrapassa as magníficas descrições que nos deu a poesia da idade de ouro, e tudo o que imaginou como suscetivel de realizar a felicidade perfeita sobre a terra, mas também as concepções e aspirações da Filosofia. Ninguém concebeu jamais uma simplicidade natural elevada a tal grau, nem ninguém jamais acreditou pudesse a sociedade subsistir com tão poucos artifícios.

Podemos, pois, achá-los bárbaros em relação às regras da razão, mas não a nós, que os sobre passamos em toda a espécie de barbárie. Sua guerra é toda nobre e generosa e tem tanta desculpa e beleza quanta se pode admitir nessa calamidade humana; seu único fundamento é a emulação pela virtude. Não lutam para conquistar novas terras, pois ainda desfrutam dessa liberdade natural que, sem trabalhos nem penas, lhes dá tudo quanto necessitam e em tal abundância que não precisam de alargar seus limites. Encontram-se ainda nesse estado feliz de não desejar senão o que as suas necessidades naturais reclamam; o que for além disso é para eles supérfluo. Geralmente, entre os da mesma, idade, chamam-se irmãos; filhos, os mais novos, e os velhos consideram-se pais de todos. Estes deixam a seus herdeiros a plena posse dos seus bens em comum, só com o título todo puro que a natureza concede a suas criaturas ao depositá-las no mundo. Se seus vizinhos transpõem as montanhas para os atacar e são vencidos, o único lucro do vitorioso é a glória e a mercê de os haver dominado em valor e virtude; aliás, de nada lhe serviriam os bens dos vencidos, porque quando regressa ao seu país nada lhe falta do que necessita, nem mesmo essa grande qualidade de se saber felizmente conformar com a sua condição e viver contente com ela. O mesmo se dá com os outros. Para o resgate dos prisioneiros exigem-lhes apenas a confissão e o reconhecimento da derrota; mas não se encontrou um em todo um século que não preferisse a morte a quebrantar, de ânimo ou palavra, um só ponto da grandeza da sua invencível coragem, ou que não preferisse ser morto e comido a pedir clemência. Dão-lhes todas as comodidades imagináveis para que a vida.lhes seja mais grata, mas, ameaçam-nos frequentemente com a morte futura, com os tormentos que os esperam, com os preparativos feitos para tal fim, com a destruição dos seus membros e o festim que celebrarão à sua custa. Fazem tudo isso para lhes arrancar da boca alguma palavra de fraqueza ou de humilhação, ou 
os induzir a fugir, vangloriando-se então de os terem amedrontado e quebrantado a sua firmeza." 900

Jean de Lery, viajante francês e calvinista que no Brasil esteve por quase um ano, escreve suas impressões de viagem informando as condições para os povos de sua terra aqui exilados. Em História de uma viagem feita à terra do Brasil publicada em 1578 anotava que

"Tanto os homens como as mulheres estavam tão nus como ao saírem do ventre materno, mas para parecer mais garridos tinham o corpo todo pintado e manchado de preto. Os homens usavam o cabelo cortado na frente à maneira de Coroa de frade e comprido atrás, aparado em torno do pescoço como entre nós as pessoas que usam cabeleira. Ainda mais: todos tinham o lábio inferior furado ou fendido e cada qual trazia no beiço uma pedra verde e polida, como que engastada, do tamanho de uma moeda e podia ser tirada ou colocada, como bem entendiam. Usam por certo tais coisas para se enfeitarem, mas, na realidade sem a pedra a fenda do lábio inferior se assemelhava a uma segunda boca, o que os afeia grandemente." 901

Conclui o viajante francês:

\begin{abstract}
"Essa boa gente que não fora avara, ao chegar, de mostrar-nos tudo quanto trazia no corpo, do mesmo modo procedeu ao partir, embora já vestisse camisa. Ao sentarem-se no escaler os índios arregaçaram-se até o umbigo a fim de não estragar as vestes e descobriram tudo que convinha ocultar, querendo, ao despedir-se, que lhes víssemos ainda as nádegas e o traseiro. Agiram sem dúvida como honestos cavalheiros $e$ embaixadores Corteses. Contrariando o provérbio comum entre nós de que a carne é mais cara do que a roupa revelaram a magnificência de sua hospedagem mostrandonos as nádegas, na opinião de que mais valem as camisas do que a pele". ${ }^{902}$
\end{abstract}

O olhar civilizador sobre os seres infantis do novo mundo era hierarquizador, colocando no topo da pirâmide o homem branco. Agora, todas as representações de barbárie estavam localizadas nas terras quentes e tropicais da América, produto de um meio incapaz de garantir o florescimento de qualquer traço de civilização. No calor dos Trópicos, existia uma raça de seres dominados pelas forças naturais que impedia toda e qualquer forma de raciocínio por parte do homem que nela habitava. Afora esta visão fantástica, o que mais incomoda a este olhar civilizador é a barbárie do gentio, formada por sua maneira de viver: andam nus, com seus corpos tingidos de cima a baixo, sua língua é incompreensível, são descrentes de um Deus previdente, como defendem os homens da Igreja, desconhecem a noção de tempo linear, são desprovidos de escrita, habitam em simples moradias, dormindo em redes, e o que mais incomoda ao olhar totalitário do explorador europeu: o rito do gentio de comer carne humana.

\footnotetext{
${ }^{900}$ MONTAIGNE, Michel de. Dos canibais. Tradução de Luiz Antonio Alves Eva. São Paulo: Alameda, 2007.

${ }^{901}$ LÉRY, Jean de. Viagem à terra do Brasil. Tradução integral e notas de Sérgio Milliet; segundo a edição de Paul Gaffarel com o colóquio na língua braílica e notas tupinológicas de Plínio Ayrosa. São Paulo: Biblioteca do Exército Editora, 1961.p. 61

${ }^{902}$ Ibidem. p.62
} 
Se num primeiro momento Caminha denunciava a ingenuidade do índio que não se incomodava em mostrar suas vergonhas, depois o traço característico dos escritores missionários foi delinear claramente a selvageria dos indígenas. Jesuítas partem da descrença do Deus católico para justificarem seus atos de etnocídio. Lendo o relato de Caminha, percebemos a mansidão do gentio, que embora assustado, se torna de fácil conquista para a missão de conversão, objetivo central da catequização, ao passo que em Anchieta, Gandavo, Cardim e Nóbrega vamos encontrar um índio valente e sobretudo pecador, bárbaro. Afirmava Caminha a respeito dos índios que

"Estiveram assim conosco até acabada a comunhão; e depois de acabada a comunhão, comungaram esses religiosos e sacerdotes; e o capitão como algum de nós outros. E alguns deles, por o sol ser grande, levantaram-se enquanto estávamos comungando, e outros estiveram e ficaram. Um deles, homem de cinqüenta ou cinqüenta e cinco anos, se conservou ali como aqueles que ficaram. Esse, enquanto assim estávamos, juntava ali aqueles que tinham ficado, e ainda chamavam outros. E andando assim entre eles, falando-lhes, acenou-se com o dedo para o altar, e depois mostrou com o dedo para o céu, como se lhes dissesse alguma coisa de bem; e nós assim o tomamos!" 903

Várias são as passagens em que se presencia um índio manso, que em nenhum momento resistiu à dominação do branco e até trocou gestos com o português, tamanha era sua passividade,

"Ao outro dia seguinte saiu Pedro Álvares em terra com a maior parte da gente na qual de disse logo missa cantada e houve pregação: e os índios da terra que ali se ajuntaram ouviram tudo com muita quietança usando de todos os atos e cerimônias que viam fazer aos nossos e assim se punham de joelhos e batiam nos peitos como se tiveram lume de fé, ou que por alguma via lhes fora revelado aquele grande, e inefável mistério de Santíssimo Sacramento no que mostravam claramente estarem dispostos para receberem a doutrina cristã a todo o tempo que lhes fosse denunciada como gente que não tinha impedimento de ídolos, nem professava outra lei alguma que pudesse se contradizer a esta nossa, como adiante se verá no capítulo que trata de seus costumes." 904

Nesse testemunho, percebemos a imagem de um índio complacente à dominação da cultura européia, comungando com os ritos católicos. A adentrarmos a carta do escrivão, temos a impressão de um via de mão única, tamanha é a passividade do gentio. Caminha faz questão de mencionar o momento em que um gentio se encanta com o colar do capitão e gesticula para a terra, caracterizando, portanto, a imagem de um índio por demais complacente. Do relato de Caminha aos que surgirão nas primeiras décadas do século XIX, dentre os inúmeros textos de viajantes e missionários, iremos perceber ao mesmo tempo uma linearidade como uma enorme discrepância no que tange à imagem de barbárie do aborígene anunciada por estes homens. Se ora Caminha delineia um gentio num estado de inocência ou pureza, onde a conversão destes seria bastante fácil bastando que para cá logo acorressem padres católicos na missão catequizadora a mando da Coroa portuguesa, percebe-se um gentio que se

${ }^{903}$ CAMINHA, Pero Vaz de. Op.Cit.

${ }^{904}$ Ibidem. p. 
esquiva frente à aproximação com o europeu, não sendo nada cortês. Tem-se a impressão de que os próprios índios se mostram mais amigos do colonizador do que propriamente de sua própria gente, mas olhando de forma menos apressada veremos que se trata apenas de uma Literatura ficcional. Coberto de contradições, oscilando ora entre um índio passivo fabricado que é por um olhar civilizado, podemos perceber o cenário em que o olhar etnográfico está em voga. Quando Caminha alude aos costumes indígenas, não é sem base alguma, mas sim pensa tendo como parâmetro o raciocínio que tem a cultura do homem civilizado e branco como centro, olhando a si mesmo esquecendo-se do outro.

Toda e qualquer descrição por parte destes escritores burocratas a serviço da Coroa portuguesa mais não são do que meros desdobramentos de uma forma de pensar que concebe a cultura de índios e negros como menor. O termômetro de análise para comentar as infinitas representações dos seres abaixo dos Trópicos é sempre o do mundo racional, baseado nas leis eurocêntricas. Tão importante como admitir que a cultura dos seres aqui existentes vista era sob este espelho civilizador é compreender que essa forma de ver esteve subjacente ao processo de colonização no Brasil, daí a enorme preocupação dos cronistas em serem imparciais, narrando somente aquilo que viram, presos que estavam a concepção de uma História Natural onde até o comportamento dos seres poderia ser medido.

É certo que a diversidade de grupos indígenas espalhados ao longo da costa brasileira, como nos informa Darci Ribeiro em O Povo Brasileiro é muita variada, não sabemos exatamente a qual nação indígena pertenciam os primeiros índios quando do contato da esquadra de Cabral na Terra de Santa Cruz, mas sabemos que as nações dos tupinambás e aimorés habitavam os sertões baianos e não eram tão passivos como descrevia Caminha, agora considerados por Gandavo como os mais violentos guerreiros,

\footnotetext{
"Estes índios tem sempre grandes guerras huns contra outros e assi nunca se acha nelles paz nem será possivel, segundo saõ vingativos e odiozos, vedaremse entre elles estas discórdias por outra nenhuma via, senam for por meios da doctrina christã, com que os Padres da Companhia pouco a pouco os vam amançando como adiante direi. As armas com que pelejam sam arcos e frechas nas quaes andam tam exercitados que de maravilha erram a couza a que pontem, por déficit que seja d'acertar. E no despedir dellas saõ muy ligeiros em extremo, e sobre tudo muy arriscados nos perigos, e atrevidos em gram maneira contra seus adversários. Quando vaõ a guerra sempre lhes parece que tem certa a victoria e que nenhum de sua companhia ha de morrer, e assi em partindo dizem, vamos matar,sem mais outro discurso, nem consideraçam, enam cuidam que também podem ser vencidos. E somente com esta sede de vingança sem esperanças de despojos, nem doutro algum interesse que a isso os mova, vã̃ muitas vezes buscar seus immigos muy longe caminhando por serras, matos dezertos e caminhos muy ásperos... ${ }^{905}$
}

905 GANDAVO, Pero de Magalhães. História da Província Santa Cruz a que vulgarmente chamamos Brasil. Lisboa: Tipografia da Academia Real das Ciências, 1858. p. 50 
“...chamam-se aimorés, a língua deles é diferente dos outros índios, ninguém os entende, são eles tão altos e tão largos de corpos que quase parecem gigantes; são muito alvos, não tem parecer dos outros índios na terra nem tem casas nem povoações onde morem,vivem entre os matos como brutos animais; são muito forçosos em extremo, trazem uns arcos muito compridos e grossos conforme sua força e as frechas da mesma maneira. Estes índios têm feito muito danos aos moradores depois que vieram a esta costa e depois mortos alguns portugueses e moradores, porque são inimigos de toda a gente...". ${ }^{906}$

Em meio às incoerências do escrivão, com relação à mansidão do gentio, podemos pensar em outras questões que se inserem na idéia de barbárie, como por exemplo, a descrença do gentio no Deus católico e como conseqüência, numa vida após a morte,

"Este gentio não tem conhecimento algum de seu Creador, nem de cousa do Ceo, nem si há pena nem gloria depois desta vida, e portanto não tem adoração nenhuma nem ceremonias, ou culto divino, mas sabem que tem alma e que esta não morre e depois da morte vão a uns campos onde há muitas figueiras ao longo de um formoso rio, $e$ todas juntas não fazem outra coisa senão bailar; e tem grande medo do demônio, ao qual chamam Curupira, Taguaigba, Machachera, Anhanga, e é tanto o medo que lhe tem, que so de imaginarem nelle morrem como aconteceu já muitas vezes; não no adoram, nem a alguma outra creatura, nem tem ídolos de nenhuma sorte, somente dizem alguns antigos que em alguns caminhos tem certos postos, aonde lhe offerecem algumas cousas pelo medo que tem delles, e por não morrerem. Algumas vezes the $\underset{907}{a}$ arecem os diabos ainda que raramente, e entre elles há poucos endemoninhados"

Os índios acreditavam em deuses como parte integrante de seus ritos simbólicos, não sem razão tanto incomodavam o missionário Fernão Cardim, que os encarava como adeptos de feiticeiros ligados que estavam em seus mundos, no que

\begin{abstract}
"Usão de alguns feitiços e feiticeiros, não porque creião nelles, nem os adorem, mas somente se dão a chupar em suas enfermidades, parecendo-lhes que receberão saúde, mas não por elles parecer que há nelles divindades, e mais o fazem por receber saúde que por outro algum respeito. Entre elees se alevantão alguns feiticeiros, a que chamam Caraíba, Santo ou Santidade, e é de ordinário algum índio de ruim vida: este faz algumas feitiçarias, e cousas estranhas á natureza, como mostrar que ressuscita a algum vivo que se faz morto, e com esta e outras cousas semelhantes traz após si todo o sertão enganando-os e dizendo-lhes que não rocem, nem plantem seus legumes, $e$ mantimentos, nem cavem, nem trabalhem, etc, por que com sua vida é chegado o tempo em que as enxadas por si hão de cavar, e os panicús ir as roças e trazer mantimentos, e com estas falsidades os traz tão embebidos, e encantados deixando de olhar por suas vidas, e grangear os mantimentos que, morrendo de pura fome, se vão estes ajuntamentos desfazendo pouco a pouco, até que a Santidade fica só, ou a matão" 908
\end{abstract}

\footnotetext{
${ }^{906}$ Ibidem. pp. 60-61

${ }^{907}$ CARDIM, Fernão. Do princípio e origem dos índios do Brasil e de seus costumes, adoração e cerimônias. Rio de Janeiro: Gazeta de Noticias, 1881. pp.1-2

${ }^{908}$ Ibidem. pp. 2-3
} 
É notório o esforço do missionário para negar a crença em alguma divindade por parte do gentio. Mesmo recorrendo a deuses, o gentio a ele se dirigia por uma crença em busca de cura. No segundo momento, a intolerância não poderia ser maior. $\mathrm{O}$ feiticeiro no qual o gentio deposita suas crenças, argumento desconsiderado por Cardim, se volta contra a própria condição de subsistência do índio na medida em que pede para que este não lavre suas terras. Desse modo, é diante de um olhar unilateral e totalitário, produto da busca irrefreada por possíveis riquezas, onde presenciamos a estilização do nativo e do país conquistado, como fruto de uma exuberância e uma ingenuidade extrema.

Quando não é o traço mercantil provenientes de possíveis e futuras riquezas, o que sobressai nos relatos, cartas e tratados é por vezes, de maneira contraditória, a violência de populações que para o mundo do homem branco não podia parecer maior. Pero de Magalhães Gandavo, em seu Tratado de Terra do Brasil, dedicado ao príncipe e cardeal Dom Henrique, chega a comentar sobre os índios:

\begin{abstract}
"Vivem todos entre os matos como brutos animais, sem terem povoações, nem casas em que se recolham. Sam muy forçosos em extremo, e trazem uns arcos muy compridos e grossos conformes a suas forças, e a frechas da mesma maneira. Estes alarves tem feito muito damno nestas Capitanias depois que desceram a esta costa e mortos alguns portugueses e escravos, porque sam muy bárbaro-, cinda agente da terra lhe-heodioza: nam pelejam em campo nem tem animo pera isso: põem se entre o mato junto de algum caminho, e tento que alguém passa aliramlhe aocoraçam ou a parte onde o matem, e nam despedem frecha que nam na empreguem. " 909
\end{abstract}

A idéia dos missionários é representar um gentio que vive como animais brutos, que somente com a conversão podem ser amansados. No capítulo Do Gentio que há nesta Província, da condição e costumes dele, e de como se governam na Paz, onde Gandavo se detém especificamente em traçar os costumes das várias nações indígenas, ele acredita que apesar da diversidade, existam traços em comum, conforme recorre o cronista à língua para justificar a barbárie do gentio. Com uma língua "falada pelas costas", onde existia entendimento entre as várias nações indígenas até à "altura de vinte e sete graus", não se encontram as Letras F, R e L, fazendo crer numa sociedade sem Fé, sem Lei e sem Rei, onde tudo parece ser possível. Estas nações indígenas "vivem desordenamente sem terem, além disto, conta, nem peso, nem medida" ${ }^{910}$. Segue-se daí a imagem de incredulidade dos povos nativos no que tange a um Deus e numa vida após a morte. Mais que isso: toda a cultura indígena é concebida de forma negativa como de um gentio que não deve regras a nenhum chefe e quando obedece é tão somente pelo desejo ou vontade e jamais pela força. Pudemos perceber de maneira

\footnotetext{
909 GANDAVO, Pero de Magalhães. Tratado da terra do Brasil. Op. Cit.p

${ }^{910}$ GANDAVO, Pero de Magalhães. História da província de Santa Cruz a que vulgarmente chamamos Brasil. Op. Cit. pp. 44.
} 
isolada numa das passagens de Gandavo uma fala que bem parece esboçar traços deterministas do racismo científico, onde a categoria raça embutiria valores morais e físicos:

"Estes índios são de cor baça, e cabelo corredio: tem o rosto amassado, e algumas feições dele a maneira de Chins. Pela maior parte são bens dispostos, rijos, e de boa estatura: gente muito esforçada, e que estima pouco morrer, temerária na guerra, e de muito pouca consideração: são desagradecidos em gram maneira, e muy desumanos e cruéis, inclinados a pelejar, e vingativos por extremo. Vivem todos muy descansados sem terem outros pensamentos senão de comer, beber, e matar gente, $e$ por isso engordam muito, mas com qualquer desgosto pelo conseguinte tornam a emagrecer, e muitas vezes pode deles tanto a imaginação que se algum deseja a morte ou se alguém lhe mete em cabeça que há de morrer tal dia ou tal noite não passam daquele termo que não morram. São muy inconstantes e mudáveis: crem de ligeiro tudo aquilo que lhes persuadem por dificultoso e impossível que seja, e com qualquer dissuação facilmente o tornam logo a negar. Sam muy desonestos e dados a sensualidade e assim se entregam aos vícios como se neles nam houvera razão de homens: ainda que toda via em seu ajuntamento os machos as fêmeas tem o devido resguardo, e nisto mostram ter alguma vergonha." 911

A cor, equivalência direta de uma série de atributos morais, caracterizava os habitantes do Novo Mundo, vistos como inferiores, onde todo e qualquer traço de alteridade lhes era negado, impossibilitando o conhecimento da cultura aborígine. Quando o europeu em seu olhar colonizador com sentido de colonização avista os seres que por aqui se encontravam, definiria os valores morais classificando os índios a partir dos atributos de civilização e ou de barbárie. Mas sobre o gentio recaiu uma imagem negativa e negadora de todos os valores humanos. Gandavo enaltece sua obra dando um tom sagrado que somente pelos meios misteriosos da Ciência tornasse imortal a imagem de Leonis. É de tal forma que ainda no prólogo da mesma obra, o cronista associa a noção de barbárie remontando as civilizações gregas e romanas com relação às outras nações que não possuíam História pelo simples fato da inexistência de documentos escritos que servissem de memória. Pensa numa História magistae vitae após afirmar que "somente procurei esta na verdade por um estilo fácil, e tal, como meu fraco engenho me ajudou, desejoso de agradar a todos os que delas quiserem ter notícias. Pelo que devo ser desculpado das faltas que aqui me podem notar: digo dos discretos, que com são zelo o costumam fazer, que dos idiotas e mal dizentes não hei de escapar, pois está certo não perdoarem a ninguém”. 912

Assim como Caminha representava pela primeira vez um índio manso de maneira talvez incoerente com a realidade, a verdade é que preocupava aos primeiros homens que visitaram o Brasil a tarefa de manter as missões nos sertões das capitanias hereditárias. O que vamos presenciar por parte de uma Literatura dos viajantes elaborada por cronistas e depois cientistas das mais variada áreas a mando de seus países são nem sempre verossímeis com o cenário brasileiro. Toda essa Literatura,

\footnotetext{
${ }^{911}$ Ibidem. pp. 43-44

${ }^{912}$ Ibidem. p.XX
} 
formada por cartas geográficas, relatos e anotações de viagens, era resultado da ambição maior do colonialismo nascente. Cabia antes de explorar conhecer as riquezas do país para só assim investir de maneira segura. Toda a Literatura informativa processada é sintoma não apenas da baixa qualidade literária feita nos primeiros momentos do Brasil colonial, como reflexo do utilitarismo incutido nas obras "literárias", desfilando nomes e mais nomes, num quadro de pobreza que o homem europeu queria rico e exuberante. A base de apoio para o discurso histórico incidia na visão parasidíaca em que a fauna e flora adentravam nos mais variados aspectos da vida humana.

Mais importante do que a constatação da ausência de verossimilhança entre o cenário descrito por Caminha e a realidade do Brasil de então é a visão pitoresca que desce as teias do idílico e do pitoresco. Os relatos de viajantes posteriores à Carta até certo ponto guardam visões análogas, denotando posição diferente, onde o caráter de mansidão por parte do gentio se torna o elemento mais significativo na construção da imagem brasileira. Em História da Província de Santa Cruz a que vulgarmente chamamos Brasil, o mesmo Gandavo escrevia em reconhecimento ao heróico Dom Leonis por suas vitórias e conquistas no Oriente, afirmando até que sua vida não seria suficiente para tal reconhecimento. Nesse testemunho, percebemos a imagem de um índio até complacente à dominação da cultura européia no momento de consagração dos ritos católicos frente ao processo de catequização.

Ainda no prólogo da mesma obra, o cronista associa a noção de barbárie remontando às civilizações grega e romana com relação às outras nações que não possuíam História. Como Caminha, Gandavo preocupava com a imagem de um gentio que vivia nas matas virgens, à imagem e semelhança de seres irracionais, animais ferozes cujas mãos civilizadoras lhes eram necessárias. Essa imagem só era reforçada devido aos inúmeros conflitos entre as tribos espalhadas pelo sertão brasileiro. O olhar europeu consolidava a imagem infantil dos grupos humanos nas nascentes terras tropicais. Desse modo, o que vamos presenciar nos primeiros relatos dos cronistas, funcionários a mando da Coroa portuguesa, são imagens resultantes mais da vontade ou dos desejos europeus, donde resulta a visão fantástica e parasidíaca, de que a fauna e a flora seriam as maiores fontes de comprovação.

\section{4 - Contribuição cultural portuguesa}

A tarefa de Sílvio era árdua na busca pelo caráter nacional brasileiro. Para ele, foi à raça portuguesa a que mais contribuiu para a cultura brasileira por ser biologicamente a mais forte que quando em contato com o meio brasileiro, com negros, índios e mestiços, saiu vencedora. Essa 
contribuição seria constatada a partir dos estudos folclóricos, onde Sílvio pontuou o que coube a cada uma das raças. O objetivo de Sílvio era de grandes proporções: foi por meio de toda uma tradição folclórica composta por crenças, lendas, cantos e contos que situou a contribuição de cada raça. Dessa forma, acreditava Romero encontrar uma fundamentação à possível identidade nacional, a alma do brasileiro. Esta foi a grande tarefa tentada por Sílvio e diagnosticada em seus trabalhos folclóricos. Pensava ele em tipos em que cada raça carregava seus costumes singulares e que, dessa forma, tornavam possível a identificação do caráter nacional brasileiro. A maneira que o crítico utilizou foi coligir o que seriam possíveis variantes num determinado meio unido à raça para identificar qual tinha sido o grupo responsável pela alteração.

Antes de delinearmos alguns pontos indispensáveis sobre a contribuição portuguesa, cabem algumas explicações. O grande agente diferenciador era o meio brasileiro ímpar, uma vez que era a flora brasileira desprovida de matas fechadas e de grandes primatas, somado ao que tínhamos de singular, o mestiço. A cultura brasileira era mestiça, uma vez que éramos mestiços no sangue e nas idéias. Sua teoria da mestiçagem é talvez o grande impasse, o maior problema para aqueles que reduzem o escritor a um simples racista. Mas a teoria de Sílvio era embaraçosa, pois se o mestiço era o resultado do português, do índio, do negro, do meio, não seria este mestiço superado biologicamente, como no plano da cultura, pelo branco que era superior? Como pode a singularidade brasileira ser mestiça, mas que caminhava ao branqueamento, na medida em que, de acordo com a lei do mais forte, a raça resultante seria a branca? A conclusão de que a sociedade caminhava para o branqueamento não significava a própria negação do mestiço, uma vez que o resultado final seria a vitória do mais forte, como entendia Romero?

Não resta dúvida de que este foi o maior dilema que ele enfrentou, sendo alvo de diversas críticas e visto como um racista, suas idéias reduzidas à condição de um pensador determinista que justificava a colonização no Brasil de povos europeus. Sílvio nunca duvidou da superioridade do branco europeu na formação da sociedade e da cultura brasileiras. Mas sua tarefa: buscou coligir a vasta tradição para saber de maneira minuciosa o que cabia a cada raça, "Aos portugueses devemos a colonização por uma raça européia, seu sangue e suas idéias, que nos prendem ao grande grupo de povos da civilização ocidental. Pertencente, porém, ao grêmio dos povos íbero-latinos, trouxe-nos também seus prejuízos de toda a casta, políticos, sociais, religiosos, econômicos, e tantos males crônicos que lavram na alma daqueles povos.". 913

Aos portugueses devíamos nossas crenças religiosas, as instituições civis e Políticas, a língua e acima de tudo, tinha sido da maior relevância ter contado com uma colonização de um povo europeu,

${ }^{913}$ ROMERO, Sílvio. História. Op.Cit. p. 107 
embora em estágio de degradação. O resultado do contato português seria de duas ordens: continuava a raça portuguesa com seus hábitos, uma vez que não podiam alterar as duas raças inferiores, e influenciava biologicamente e culturalmente as demais raças. De cantos e contos buscava Sílvio coligir, em províncias brasileiras, como Sergipe, Rio de Janeiro, Rio Grande do Sul, possíveis variações e ver qual tipo era o responsável por estas. A tese de Romero era a vitória do mais forte na formação do caráter brasileiro e o desaparecimento de maneira irremediável de negros e índios. Lembremos a admiração dele pela cultura germânica, não apenas do ponto de vista literário, como no campo da cultura, servindo de base para sua visão que era não só literária como social.

O que Sílvio não conseguiu foi separar rigidamente a origem de cada gênero, pois à medida que identificava vários contos como de origem européia, na maioria das vezes, esses contos eram de origem popular. Somado a isto, Silvio sempre salientava em suas observações, especificamente como um historiador da Literatura, o problema das origens que, para ele, era indispensável resolver, como base para análises futuras acerca da constituição da cultura brasileira. A formação da cultura brasileira estava intrinsecamente ligada à questão racial responsável pelo caráter brasileiro que, por sua vez, era ligado ao passado, às nossas origens, àquilo que havia de mais íntimo de uma nação. Quando Sílvio identificava um conto como de origem européia, simultaneamente negava sua própria origem, porque muitas vezes o que predominava era a participação popular. Mais uma vez, de maneira implícita, Romero trazia para a discussão a influência do meio, da raça, da influência estrangeira, dos antecedentes históricos e do mestiço, elementos que eram a própria cultura brasileira.

Vale lembrar todo o esforço de Silvio em sua investida na coleta de uma tradição baseada no que havia de mais íntimo em uma nação. Tinha Romero momentos de uma fixação no teor racial duro e inconteste ao chamar a atenção para o processo histórico que interferia nos fatores primeiros, no caso, o meio e a raça. Embora defendesse a existência de uma grande raça, o que tornava diferentes as "raças" eram as condições históricas e Políticas que permitiam a variabilidade dos inúmeros ramos. Nesse sentido, Sílvio atina para as condições históricas, ao mesmo tempo em que permite uma interpretação social e não racista.

Em alguns estudos, o autor mostra porque ramos da grande raça se tornam tão diferentes ao longo da História. Para Sílvio, assim como para vários escritores de seu tempo, o conceito de raça, vez por outra, extrapolava mera delimitação dos caracteres físicos, portava um conjunto de valores rigidamente delimitados. 


\section{5 - Futuro do povo brasileiro.}

Apesar de Sílvio nutrir uma empolgação pela raça portuguesa, o escritor esquadrinhava as localidades brasileiras onde a imigração portuguesa poderia ser viabilizada. Primeiramente, mencionava a grande região do Vale do Paraíba, onde o português criou pouco núcleo de população, deixando a região entregue ao selvagem. A população da república não conseguira ocupar toda a vasta região, num futuro próximo populações estrangeiras ou mesmo a população dos Estados Unidos iriam misturar-se com os selvagens, fazendo com que o português brilhe pela ausência. Outra região é o Far-West brasileiro, no caso, o vastíssimo vale amazônico. A terceira região que cada vez mais vai escapando das mãos portuguesas é a dos Estados do sul do Brasil, acompanhado do Estado de São Paulo. Por último, sobra o que Sílvio chama de Brasil intermédio, que vai do Maranhão ao Espírito Santo: "este será ainda por muito tempo o Brasil português". 914

De maneira irônica, se essa é a região das secas, da miséria e ruína, diz Sílvio que ela foi a região onde o mestiçamento alcançou seu maior nível, produzindo de um lado, mulatos, e de outro, caboclos. É a região para onde o imigrante não vem, zona tórrida, em que está localizado o São Francisco, a cobrir todo o "Sergipe, minha pátria". Após traçar as áreas que podem ser aproveitadas em beneficio da imigração portuguesa, lança Sílvio a questão da discussão: ou o velho Brasil receberá o elemento estrangeiro, diminuindo cada vez mais a população igual à de São Domingos, ou verá o predomínio do estrangeiro, neste caso, o elemento português diminuirá. O futuro do elemento português está, segundo ele, no meio mais adequado da colonização.

O problema da imigração, em seu entendimento, tinha recebido duas soluções contraditórias: uma positiva e a outra negativa. A primeira reduz-se aos povos estrangeiros colonizarem nos Estados do sul do Brasil, o que não agradava Sílvio, uma vez que colocava em risco a integridade do país e não facultava a criação da consciência nacional. Já vimos que, para Romero, os Estados do sul do Brasil corriam sérios riscos de se transformarem em verdadeiros Estados alemães, por conta da existência da língua e da cultura saxônicas.

A outra possibilidade considerada como negativa para Sílvio é a imagem sobre os Estados do norte do Brasil, que para o europeu significavam mortalidade.

A consequência dessas duas possíveis formas de fixar o imigrante no Brasil foi, em primeiro lugar, a continuação do depauperamento do norte do país, haja vista não ter sido povoado por nenhum povo; e em segundo, a presença marcante das raças inferiores no norte do país, formando uma população que morrerá de marasmo, devido justamente à existência de tais raças. Mais tarde, poderão

${ }^{914}$ ROMERO, Sílvio. A Imigração e o Futuro do Povo Brasileiro. In: Ensaios de Sociologia e Literatura. Op. Cit. p. 220 
vir povos dos Estados Unidos ou da Europa para a região norte, “alastrarão o país e suavemente o engolirão". ${ }^{915}$

O que Sílvio quer dizer é que por mais que no norte do país, assim como por todo o Brasil, predominem as raças inferiores, elas são indispensáveis para a viabilização da melhor forma de imigração. Nessa ótica, fica bastante clara a importância das raças inferiores na formação do Brasil. Aqui, aparece a teoria do mestiçamento, mesmo que índios, negros e mestiços sejam povos considerados inferiores com relação ao europeu, contribuem do ponto de vista biológico e moral para a vitória da raça superior. O negro contribuiu para a aclimatação do europeu ao meio brasileiro, embora não fundasse uma raça que diferenciava nosso povo, nossa natureza era singular, em uma estrutura que sacramentava a vitória do mais forte. Sílvio quer pontuar a importância das raças inferiores, no que concluímos que a superioridade do europeu não faz sentido algum, sem a observação destas raças.

Embora seja o Brasil constituído por essas raças vistas como inferiores, só tem sentido para Sílvio a imigração se levarmos em conta a importância das mesmas. Ele não defende uma imigração onde predomine apenas uma raça, daí a razão de seu combate tanto com relação à presença do português nos três Estados do sul do Brasil, como à possível presença de estadunidenses e europeus na região norte do país: "seria possível encaminhá-la metodicamente para todas as zonas do país, espalhá-la, difundi-la, habilitá-la a produzir novas populações, que sejam absorvidas, incorporadas às nossas populações nacionais e assimiladas por elas. Nada de hipertrofias por um lado e esgotamentos por outro". 916

A situação brasileira jamais poderia ser comparada com a dos Estados Unidos, dotado de uma população enérgica, que não perdeu suas tradições culturais quando da colonização. É que, como sempre fazia questão de aludir, a imigração não se realizou ali em apenas um ponto do país, razão de que "a nova população formou-se e cresceu, sem mudar de aspecto. Todos são americanos e falam inglês". 917 A realidade brasileira também não podia ser comparada com a da República argentina, porque seu território era bem menor do que o do Brasil e a colonização ali espalhou-se. Devoto dos preceitos indiscutíveis da Ciência, Sílvio mais uma vez nele buscava argumentos: "Aqui nada se tem feito com plano e sob a direção de idéias justas e científicas". 918

Após este erro, Romero falava que muitos eram os políticos que faziam falsas promessas para atraírem as populações estrangeiras, com o duplo intuito de fazerem figurar o Brasil na Europa e conseguirem vaga no Parlamento, contando com o apoio dessas populações estrangeiras. Isso aconteceu ao longo do Império brasileiro. Tais ambiciosos políticos não queriam jamais que se

\footnotetext{
915 Ibidem. p. 222

${ }^{916}$ Ibidem. p. 224

${ }^{917}$ Ibidem. p. 224

${ }^{918}$ Ibidem. p. 225
} 
alterasse o sistema de imigração e ficavam possessos quando se falava numa imigração espalhada por todo o país. Para eles, a colonização pensada por Sílvio significaria impedir o surgimento de uma sociedade que já vinha intervindo na vida Política do país e, dentro de pouco tempo, iria dar "o grito da rebelião separatista, desmantelando assim aquela famosa peça de arquitetura Política, de que falava o grande Andrada". 919

Para Romero, tais políticos eram terroristas que estavam preocupados com a vaidade nacional e levavam a todos os brasileiros a velha mania de passarmos por aquilo que não somos. Dentre os três sistemas de colonização, o escritor optava pela colonização integral e progressiva, "é o único apto a garantir o futuro da raça portuguesa nestas regiões da América; por ser o único que pode preencher as lacunas da antiga colonização pelos descobridores, encaminhando convencionalmente o problema do moderno povoamento com elementos estrangeiros". 920

Sílvio arrolava os pontos do sistema de colonização que a seu ver era o ideal para o Brasil:

$1^{a}$. A antiga colonização do Brasil pelos portugueses foi lacunosa, especialmente no alto norte e grande oeste do país;

$2^{a}$. Mesmo no sul e leste a sua influência tende a diminuir, ali pela introdução de fortes elementos estranhos, e aqui pela super abundância dos mestiços de sangue indio e africano;

$3^{a}$. O meio de formar no Brasil uma nação forte é atrair a colonização estrangeira por modo inteiramente diverso daquele que tem sido até agora praticado;

$4^{a}$. Deve-se acabar com o sistema de cuidar só do sul, deixando o norte e o centro em completo esquecimento;

$5^{a}$. É indispensável acabar, uma vez por todas, com o descrédito estultamente lançado sobre o clima do norte e do oeste do país, reconhecendo que em todo planalto brasileiro existem zonas perfeitamente apropriadas à colonização européia;

$6^{a}$. Este sistema de colonização integral do país, assimilando os elementos estrangeiros, é previdente e patriótico, sem ser por forma alguma hostil aos europeus; $7^{a}$. Muito, pelo contrário, é contar sempre e sempre com eles para aorganização e engradecimento da nossa pátria;

8. Não de devem, porém, desprezar os elementos nacionais, que podem ser aproveitados para a colonização do país. ${ }^{921}$

O elemento nacional ou o brasileiro era o principal na análise do sistema de colonização defendido por Sílvio. Não tinha sentido algum contar o Brasil com milhões e milhões de estrangeiros desconhecedores de suas tradições culturais e da língua do país. Romero nem defendia a presença de milhares de seres inferiores no norte do Brasil, como também não advogava a vinda de milhares de europeus - no caso, alemães, no sul do país. É que, no caminho da vitória da raça mais forte, esta não deixava de incorporar elementos da mais fraca, que contribuíam tanto no plano biológico como no

\footnotetext{
${ }^{919}$ Ibidem. p. 226

${ }^{920}$ Ibidem. p. 226

${ }^{921}$ Ibidem. p. 227
} 
cultural para a vitória daquela. Se Sílvio nunca duvidou da superioridade do europeu, não deixa de ser marcante sua atenção às raças inferiores, sobre as quais ele tanto falou para provar sua importância, na formação do povo brasileiro.

\section{6 - Colonização Portuguesa: um bem ou um mal?}

Em A América Latina, título igual ao de um dos livros de Manoel Bonfim, Sílvio analisava a obra do seu conterrâneo e médico sobre a situação social do Brasil. Para compreender a sociedade brasileira, partia Sílvio do modelo de organização social empreendida pelos seguidores de Le Play que tinha por base o modo de viver das famílias, os meios de trabalho adotados pelos grupos divididos nas diversas regiões do país. Como sempre agiu diante de seus adversários, Sílvio não poupou a visão de Bomfim, afirmando que "tal a razão pela qual, tiradas as divagações, o livro se reduz a cinza e nada". 922

Não bastassem as duras críticas ao livro de Bomfim, acrescentava Silvio que além da leitura elaborada pelo médico sergipano não ser nenhuma novidade, uma vez que já tinha sido abordada por Oliveira Martins, afirmando até que das quais 2.276 páginas do livro, 1.444 foram parasitadas do escritor português, e em menor parte da obra de Rocha Pombo.

Publicado em 1905, A América Latina: males de origem trazia uma leitura da realidade e da espoliação das colônias pelas metrópoles latinas. A leitura de Bomfim não estava restrita, como indica o próprio nome, ao Brasil, alcançando a situação dos países colonizados em toda a América Latina por suas metrópoles, tema de extrema relevância para o Brasil. Bomfim oferece uma nova leitura de Brasil, baseada na Educação como meio de superação do atraso.

Por ter formação médica, em que a História estava ligada à História Natural, Bomfim toma metaforicamente o fenômeno do parasitismo presente nos reinos animal e vegetal para constatar a espoliação das colônias, detectando onde ela repousou. Se a teoria do parasitismo na História, como pensava Bomfim,

"produziria a exploração predatória e o gosto pela vida sedentária, que levariam ao esgotamento dos recursos e à decadência das sociedades. A eterna luta entre parasita e parasitado seria, portanto, o principal fator das transformações históricas", Sílvio combatia tal teoria afirmando que, "o parasitismo social, no que tem de real, é sempre a exceção num povo dado; absurdo é supô-lo estendido por

\footnotetext{
${ }^{922}$ ROMERO, Sílvio. A América Latina (Análise do livro de igual titulo do Dr. Manoel Bomfim). Porto: Chardron, 1906. p. 53.

BOMFIM, Manoel. http://www.do.ufgd.edu.br/MarioJunior/arquivos/BOMFIM_A_America_Latina_Males_de_origem.pdf Ver o comentário sobre essa polêmica em: SILVA, José Maria de Oliveira. Da Revolução à Educação - Radicalismo republicano em Manoel Bomfim. Dissertação de Mestrado em História Social da FFLCH/USP. São Paulo: digitado, 1991.
} 
uma nação inteira. Não poderia ela subsistir e menos ainda representar uma função histórica distinta". 923

A teoria do parasitismo de Bomfim mostrava, segundo a análise de Sílvio, uma linha de investigação falha, uma vez que o conceito de parasitismo era utilizado de maneira desproporcional e tinha um sentido metafórico, algo que para o crítico literário acabava por ir de encontro à própria História Natural, tornando evidente que, "esse pretenso qualificativo não pode servir de base para a explicação da vida Política, econômica, cientifica, histórica, em suma, de povos quaisquer" ${ }^{24}$, redundando num profícuo empirismo. Num momento em que se buscava ver a Sociologia a partir de leis, dada a existência destas no amplo quadro das Ciências naturais, a causa da pobreza das colônias residia sobre o fato do caráter depredador da raça ibérica. Desse modo, "Foi mister transcrever longamente; transcrever e repetir. Repetições propositais para deixar bem evidente o caráter da conquista portuguesa: saquear, sem nenhum outro objetivo - a rapina, a pirataria, o parasitismo depredador". 925

A questão central para Bomfim era a idéia de parasitismo, fenômeno existente tanto nos reinos das formigas quanto no das abelhas, impedindo, pois, o desenvolvimento das sociedades colonizadas. Fundamentado em Nordau e Schaeffle, autores de que Sílvio tomou conhecimento, para interpretar o Brasil, Bomfim baseava-se justamente neles para se contrapor a idéia de lei abreviada da História de que a filogênese reproduz a ontogênese, a par da teoria da evolução. $O$ médico sergipano explicava o principal motivo da pobreza das colônias: devia-se ao caráter depredador das metrópoles. O luxo e a ostentação eram parte integrante da ganância, dos ataques fortuitos seguidos pelo gosto da depredação; tudo isso levou, segundo Bomfim, à degeneração das colônias. Diante deste quadro, "Como se poderão desenvolver e apurar os sentimentos altruísticos, de justiça e eqüidade, de cordialidade e amor, numa sociedade que sucede viver, justamente, de uma iniqüidade - do trabalho alheio?.... "926

À imagem e semelhança de um organismo vivo, para Bomfim, a sociedade possuía leis assim como a Biologia, só que "As sociedades obedecem a leis de uma Biologia diversa da individual nos aspectos, mas em essência idêntica”. 927

Formado em Medicina na Bahia, o historiador e político mereceu elogios de Darci Ribeiro como um dos mais originais pensadores brasileiros, chegando a ocupar o cargo de secretário da Educação do Distrito Federal, de diretor e redator da revista pedagógica Educação e Ensino, além de ter produzido obras de cunho psicológico e didático. A teoria de Bomfim é construída pela noção de parasitismo,

\footnotetext{
${ }^{923}$ ROMERO, Sílvio. A América Latina. p. 40

${ }^{924}$ Ibidem. p. 47

${ }^{925}$ BOMFIM, Manoel. A América Latina: males de Origem. Rio de Janeiro: centro edelstein de pesquisas sociais, 2008.p. 58

${ }_{926}$ Ibidem. p. 24.

${ }^{927}$ Ibidem. p. 17
} 
onde o médico sergipano analisa as consequiências do processo nos países espoliados - as colônias latino-americanas. Alegava Sílvio que a pretensão da obra de Bomfim era semelhante à sua, com o único diferencial de que aquela perscrutava um quadro mais vasto. O historiador sergipano explicava a pobreza dos países colonizados pelo parasitismo, o que impedia a evolução de determinados órgãos. Sofrendo, pois, de leis semelhantes às dos reinos animal e vegetal, a sociedade era regida por leis inevitáveis, concluindo que

\begin{abstract}
"Se a marcha do progresso e da evolução é a mesma nos organismos biológicos e nos sociais, é fatal que as circunstâncias capazes de entravar esse progresso nos primeiros há de forçosamente produzir os mesmos efeitos nos segundos. Demais, o simples exame do fato em si é bastante para mostrar que um grupo, um organismo social, vivendo parasitariamente sobre outro, há de fatalmente degenerar, decair, degradar-se, evoluir, em suma. Em que consiste, em última análise, o progresso social? No desenvolvimento da inteligência, pelo esforço contínuo para aproveitar do melhor modo possível os recursos havidos da natureza, da qual tiramos a subsistência, e no apuro dos sentimentos altruísticos, que tornam a vida cada vez mais suave, permitindo uma cordialidade maior entre os homens, uma solidariedade mais perfeita, um interesse maior pela felicidade comum, um horror crescente pelas injustiças e iniqüidades... Ora, uma sociedade que viva parasitariamente sobre outra perde o hábito de lutar contra a natureza; não sente necessidade de apurar os seus processos, nem de pôr em contribuição a inteligência, porque não é da natureza diretamente que ela tira a subsistência, e sim do trabalho de outro grupo; com o fruto desse trabalho ela pode ter tudo. Não há mais necessidade de ver, observar, guardar a experiência e manter-se em contato com a natureza. Deriva daí que não há o esforço íntimo para conhecer as coisas e os fenômenos, pois que as necessidades são satisfeitas; nem há o estímulo contínuo, vivaz e eternamente novo, da natureza sobre o nosso entendimento, visto como vivemos dela afastados. Em tais condições, é lógico que a inteligência não poderá progredir, decairá." 928
\end{abstract}

Assim como na vida orgânica dos seres pertencentes aos reinos animal e vegetal, a sociedade era regida pela inevitabilidade das leis fatais integrantes do processo evolutivo-histórico. Bomfim lançava um olhar à História pelo menos num primeiro momento de sua América latina atinando para a relação entre o explorador e o explorado, composto o último grupo por milhares de negros e ignorantes, produtos do parasitismo que se operou nas colônias. Tratava-se, como designava Roberto Ventura e Flora Sussekind, de uma teoria biológica da mais valia ${ }^{929}$.

Em seu estudo sobre radicalismos, onde busca identificar o que faz de um escritor um radical, Antonio Candido lembra a injustiça cometida ao médico sergipano,

"Creio que foi o primeiro a elaborar um modo inconformado e desmistificador de ver a nossa Independência, assim como a natureza e o papel das classes dominantes, que estudou à luz da sua tradição irremediavelmente conservadora. E terá sido dos primeiros a rejeitar a noção pseudocientífica de superioridade das raças, atribuindo as diferenças e os graus de progresso a fatores de ordem social e cultural". ${ }^{330}$

\footnotetext{
${ }^{928}$ Ibidem. p. 24.

${ }^{929}$ VENTURA, Roberto e SUSSEKIND, Flora. História e dependência: cultura e sociedade em Manoel Bomfim. São Paulo: Editora Moderna, 1984.

${ }^{930}$ CANDIDO, Antonio. Radicalismos. Estudos Avançados, 4 (8), 1988. p. 12
} 
Um dos motivos aludidos por Candido para o esquecimento de Bomfim deveu-se justamente à força da fala de Sílvio que, no momento, exercia grande força. Para além dos revides de Romero contra Bomfim, podemos perceber pontos em comuns entre os dois sergipanos. Trata-se de dois escritores que buscavam encontrar leis que presidiam o desenrolar da sociedade num período marcado pelas certezas oferecidas pela visão evolucionista e pelo Darwinismo social. Embora elabore Bomfim uma leitura por demais científica acerca das sociedades espoliadas, não pensa que seja a raça, e como conseqüência, a mestiçagem, a raiz do atraso dessa ou daquela sociedade. Sílvio é um escritor que coloca na raça o fator do atraso brasileiro, ao passo que Bomfim

"Rebate inclusive o aproveitamento errado da teoria da seleção natural pela luta das espécies, de Darwin, que segundo ele não se referia às sociedades humanas, nas quais são decisivas a solidariedade e a cooperação, sendo curioso que neste passo adota sem citar o ponto de vista de Kropotkin, no livro "O auxilio mútuo", uma das grandes bases teóricas do Anarquismo. Manoel Bomfim diz também que a mestiçagem não é fator de inferioridade, pois não há nela degenerescência de raças pseudopuras". 931

Mas não existiam somente diferenças no olhar de Bomfim com relação ao tempestuoso Sílvio. Em primeiro lugar, esses dois polígrafos pensavam que o conhecimento de causa pudesse trazer a chave para proporem um novo Brasil, daí suas investidas minuciosas nesta ou naquela corrente de idéias em busca dos males brasileiros. Neles, as idéias confundem-se com a busca pelo atraso brasileiro. A mesma paixão pelos problemas nacionais do médico era a característica principal do bacharel. Sempre, no prefácio de suas obras, Sílvio se antecipava diante de seus adversários se justificando em nome de um ideal maior, fosse em nome da justiça ou da verdade, ou em nome do Brasil, eliminando qualquer possibilidade de interesse próprio, enquanto Bomfim falava que " $A$ América Latina era um livro nascido, animado, alimentado e divulgado pelo sentimento; não o sentimento dos interesses pessoais, que obscurecem a razão e pervertem o julgamento, mas um sentimento que só aspira alcançar a verdade - a causa efetiva desses males, dentro dos quais somos todos infelizes; o desejo de subir à civilização, à justiça, a todos os progressos”, Romero afirmava, em sua obra mestra, que "este livro é um livro de amor, feito por um homem que sente há perto de vinte anos sobre o coração o peso do ódio que lhe tem sido votado em sua pátria...". 932

Nas respectivas obras, podemos perceber a busca dos autores pela imparcialidade, no que a priori se justificavam contra toda e qualquer suspeita de interesse pessoal em nome do conhecimento do "verdadeiro" Brasil. Sílvio, numa espécie de apoteose ao seu próprio pensamento, afirmava que os mesmos problemas no que tange à situação brasileira nos mais variados aspectos era o propósito do médico: "Como se vê, é o mesmo problema abordado, por outras vias, por outros processos, por

\footnotetext{
${ }^{931}$ Ibidem. p. 16

${ }^{932}$ ROMERO, Sílvio. História da literatura brasileira. Op. Cit.p.
} 
outras doutrinas, pelo Sr.Dr. Manoel Bomfim em seu livro A América Latina. O seu quadro é apenas mais vasto, porque ele cogita de todo o continente e eu me refiro somente ao Brasil." 933

O argumento de Sílvio pela observação direta dos fatos, almejando sempre a imparcialidade, traço singular assimilado pelos ensinamentos da Escola de Le Play, era também a pretensão do médico. $\mathrm{O}$ amor ao país e a busca de compreender os problemas nacionais em seus mais variados aspectos, para os dois escritores, se mostravam de fundamental importância. Buscavam os dois pensadores compreender a situação de pobreza do país que diziam amar e identificar os males brasileiros. Se Bomfim utiliza o conceito de vício, Sílvio adotava o de males. Mais do que simples conceitos, o que há de significativo é a visão que esses dois ensaístas possuíam sobre a colonização portuguesa, responsável pela herança colonial, que, por sua vez, gerou interpretações de Brasil, o que nos leva a tentar entender como eles encararam a formação brasileira e projetaram o Brasil do futuro.

Vista de maneira positiva ou negativa, a herança colonial, sobretudo, a portuguesa, foi tema bastante relevante para os intérpretes brasileiros que de uma forma ou de outra tiveram que filtrar o que de bom restou da influência portuguesa para formar o Estado nacional brasileiro. O "antilusitanismo" pregado pelos escritores românticos diante de suas representações estilizadas, fosse por meio da prosa ou do verso, mostrando as grandezas e riquezas do país, estava plenamente reconhecido, dado ter sido o Estado nacional brasileiro formado sob o reformismo ilustrado e conservador bem típico de uma sociedade do ancien regime.

Atuando noutro momento histórico do Brasil, buscaram Bomfim e Sílvio compreender o país não mais a partir do quadro gigantesco da fauna e da flora, onde essa natureza falava por si só e confundiase com o amor à pátria, mas a partir de teorias fornecidas pelo Positivismo, Determinismo e Evolucionismo. Se os escritores românticos que transitavam entre o IHGB e mantinham estreita relação com o homem de Letras Pedro II enxergaram um Brasil de maneira idealizada, homens como Sílvio e Bomfim de tudo fizeram para retratar a par de outros olhares um Brasil real, convictos que estavam das certezas oferecidas pela Ciência.

Bomfim e Sílvio, mesmo vivendo num Brasil independente, se inquietaram com antigas temáticas que remetiam à herança portuguesa, uma delas, o temor da restauração. Os dois escritores bem podem nos servir de base para a imagem que tinham do Brasil da época. Bomfim concebe os males brasileiros ou a involução de todo o organismo social decorrente do parasitismo, ao passo que Sílvio, mesmo reconhecendo traços positivos da herança portuguesa em nosso país, não perde de vista aspectos negativos dessa mesma herança, pois foi o Brasil colonizado por uma raça inferior e ao tempo da colonização, em Estado de decadência, o que, para o crítico, explicava a formação de um Brasil

${ }^{933}$ ROMERO, Sílvio. A América Latina. Op.Cit.p. 10 
com a predominância da cultura de jardinagem, onde o colonizador português não soube prover da melhor forma a mão de obra escrava, desagregando cada vez mais a família. Não despreza Bomfim o meio, o tempo e a origem para explicar as doenças sociais. Com precaução, podemos afirmar que Sílvio, por vezes, se posiciona da mesma maneira de Bomfim, utilizando apenas terminologias diferentes.

Assim como Romero, Bomfim pensava a sociedade regida por leis, não as mesmas aplicadas aos estudos das Ciências naturais, mas leis singulares, que avaliavam o progresso ou a decadência da sociedade. Vale lembrar que Sílvio lutou insistentemente para fincar os Estudos Morais, como a História e a Sociologia, sobre bases científicas, donde classificou essa ou aquela disciplina como Ciências e quase Ciências. A grande diferença entre os dois polígrafos é a relevância da raça, bastante explorada por Romero, ao passo que Bomfim descarta o Determinismo racial de toda a geração anterior (e mesmo sua contemporânea), sem perder de vista noções como o meio, o lugar, as condições do tempo, os antecedentes históricos, traços pontuado pelo primeiro. Não seriam os mesmos conceitos muito conhecidos da clássica tríade taineana?

Como médico, Bomfim possui uma visão fisiológica, focando-se nos estudos dos reinos animal e vegetal, buscando compreender a situação de espoliação das colônias ibéricas. Com isso, supõe o escritor que a sociedade humana, assim como outros tipos de sociedades vivas, segue a evolução onde determinadas espécies deixam de evoluir porque encontram o comodismo da sustentação - no caso, a alimentação é o parasitismo. Bomfim explica a pobreza dos países colonizados devido ao parasitismo a partir da não evolução de certos órgãos, no que rebate Sílvio que "não basta dizer que isto aqui foi obra de parasitários e supor que tudo está aclarado, todas as dúvidas resolvidas". 934

Escrevia Romero que a noção de parasitismo era vaga ou mesmo desprovida de rigor conceitual, que não poderia servir de base para a análise da História, da Política e da Economia. Parasita referiase apenas ao predicado, sem deixar claro qual era o sujeito, ou seja: segundo Sílvio, a terminologia poderia funcionar como sintoma e não como causa, por isto que se tratava de um conceito claro e indeterminado. Acrescentava que o conceito de parasitismo "tem ainda hoje um pronunciado sabor metafórico" 935 , daí é que "muitas vezes, dá-se o caráter parasitário a quem não o merece; crer-se artificial o que é natural; acredita-se inútil quem presta reais serviços". 936 O cerne da teoria de Bomfim conforme visão de Sílvio Romero, ficava sem sustentação, uma vez que a idéia de parasitismo era utilizada de maneira metafórica, representando o flagelo da Sociologia. Como sempre se posicionara frente a seus oponentes, alegava Sílvio que faltava a seu adversário base científica. No

\footnotetext{
${ }^{934}$ Ibidem. p. 40.

${ }^{935}$ Ibidem. p. 40

${ }^{936}$ Ibidem. p. 40
} 
caso de Bomfim, faltava consistência etnográfica diante de suas doutrinas capitais, das fontes em que bebeu, daí suas precipitações.

O temperamento de Sílvio não permitia reconhecer mérito em nenhum de seus adversários. Sempre se posicionava de maneira agressiva, e com relação a Bomfim não fora diferente, "verifica-se que a nota preponderante nas acusações que me faz é a da inveja... Em cinco ou seis pontos da furibunda epistola, surge essa insinuação insistente". 937 Alegava Romero que Bomfim era um invejoso, afirmando, “coitado do Invejado! Tanta sandice! Que curto é esse demônio! Como dá trabalho, como é aborrecido lidar com um rapaz tão tapado! Bomfim não sabe nada de Ciência alguma e exatamente nas Ciências Naturais é que ele é completamente zero. Tudo aquilo está errado". 938

Sílvio revidou tenazmente, numa série de vinte e cinco artigos, o livro de Bomfim. Além da acusação de que o livro de Bomfim carecia de base teórica, acrescentou que não passaria este de meros temas já abordados por Oliveira Martins e Rocha Pombo, alegando que o universo tratado em $A$ America Latina não era nenhuma novidade. Mas a grande importância da obra de Bomfim de dava por conta do combate às teorias raciais, as teorias do Positivismo, do Evolucionismo e do Darwinismo social, tão bem conhecidas por Sílvio e sua geração.

A leitura sociológica de Bomfim tinha estrita fundamentação biológica, remetendo aos mundos animal e vegetal das espécies, ao passo que a leitura de Sílvio era balizada especificamente pelo critério racial. O organicismo de Sílvio é parte integrante do cientificismo da época, ao passo que a visão de Bomfim é mais localizada, bem mais específica, mas que se estende pelo menos num primeiro momento à trama social, opondo opressores e oprimidos, e que acima de tudo, suprime o fator racial na constatação do progresso ou da decadência das sociedades. De um lado, um médico escritor que entendia de Fisiologia e Parasitologia; de outro, um bacharel ainda preso à visão científica tributária de uma História Natural. São dois escritores cientificistas, mas de cientificismos diferentes. Percebemos pontos de encontro entre Sílvio e Bomfim. A Educação era tema de suma importância para os dois escritores na aposta ou regeneração do Brasil do futuro. Se Romero deu tanta importância para o conhecimento da crítica moderna, deixando clara sua aposta no que havia de mais recente no plano científico, atinando para a classificação das Ciências, para os diversos tipos de ensino, etc, Bomfim mostrava a importância da Educação para superar o atraso do país, "após a consolidação da República com Floriano, a Educação popular se apresentava como maior problema do país. Tinha a sua atenção voltada, nesse momento, para as dificuldades que representava para a formação do espírito nacional a "massa popular inculta e incaracterizada" que a República tinha como dever

\footnotetext{
${ }^{937}$ Ibidem. p. 24

${ }^{938}$ Ibidem. p. 226
} 
educá-la". 939 Apesar da formação médica, Bomfim afastava toda e qualquer análise apenas fixada na Biologia, acreditando até numa revolução pela Educação, Bomfim tirou conclusões inovadoras de sua análise do parasitismo na História da América Latina. Mesmo sendo o "grande mal" dos países do subcontinente, o parasitismo social não traria, ao contrário do biológico, modificações orgânicas irreversíveis, ficando seus efeitos limitados à ordem moral. Apesar de conceber a sociedade como organismo, procurou investigar as leis não-biológicas, específicas, aos fatos sociais, e acreditava que o parasitismo social poderia ser extipardo pelos explorados por meio do ensino popular ou da rebelião contra as diversas formas de espoliação: "as populações podem refazer a sua Educação social, corrigindo os vícios havidos na tradição parasitária, e entrar para o progresso; é uma questão de reEducação”. Ao colocar limites às analogias entre natureza e sociedade, Bomfim rompeu com o pessimismo e o Determinismo das teorias do meio, da raça e do caráter nacional, concebidos como fatores imutáveis e inelutáveis". ${ }^{940}$

Tanto para Sílvio como para Bomfim a raça colonizadora foi responsável pela conjuntura miserável do Brasil. Cabe aqui uma ressalva: nenhum autor esmiuçou categoricamente os conceitos biológicos como Romero e não é gratuito seu esforço na classificação das Ciências. Se para Bomfim foi o caráter parasita que explicava a situação de miséria das colônias espoliadas por suas respectivas metrópoles, quais eram as causas do atraso brasileiro? O que Sílvio atribui à colonização portuguesa?

A herança portuguesa, segundo ele, tinha pontos positivos e negativos. Reconhecia Sílvio à importância de um Camões, de um Pinheiro Chagas e até da Geração de 70 portuguesa, embora discordasse da geração de Herculano por causa de sua visões românticas. Por mais que considerasse a raça portuguesa inferior quando comparada com as raças do ramo anglo saxão, restava o fato de ter sido o Brasil colonizado por uma raça européia, "aos portugueses devemos a colonização por uma raça européia, seu sangue e suas idéias, que nos prendem ao grande grupo de povos da civilização ocidental. Pertencente, porém, ao grêmio dos povos iberos-latinos, trouxe também seus prejuízos de toda casta, políticos, sociais, religiosos, econômicos, e tantos males crônicos que lavram na alma daqueles povos". 941

Traçando de maneira pormenorizada as regiões mais importantes de Portugal, acompanhado do clima, da Geografia e dos produtos nelas cultivados, o que é de real importância para Sílvio é o caráter dos povos oriundo do tronco ibérico, "gentes comunárias de origem, descendentes fundamentalmente de berberes patriarcais, na dupla forma da família e da propriedade, os algarvios, como todos os

\footnotetext{
${ }^{939}$ SILVA, José Maria de Oliveira. Da Educação à Revolução: radicalismo republicano em Manoel Bomfim. Op. Cit. 2006. p. 22

${ }_{940}$ VENTURA, Roberto. Manuel Bonfim: A América Latina: males de origem. São Paulo: SENAC, 2002. v. 2. pp. 237258

${ }_{941}$ ROMERO, Sílvio. História da literatura brasileira. V. I. Op.Cit.p. 107
} 
portugueses aliás, foram, no curso de História, reforçados em suas tendências originárias do século VIII ao século XII ou melhor XIII, pois que sua reconquista aos árabes foi em 1249, cento e dez anos após a independência do reino". ${ }^{942}$

Para analisar os pontos positivos e negativos da colonização portuguesa, era indispensável realizar uma leitura do enorme território ibérico, o que Sílvio fez, apontando quais eram as regiões por ele consideradas como as mais importantes. Antes de algumas análises, vale dizer que o argumento central de Sílvio para pontuar os pontos positivos e negativos da colonização portuguesa no Brasil recaíam no fato de ser o colonizador oriundo do tronco ibérico e de formação comunaria, o que explicava a forma de legislação civil, a Economia e, sobretudo, a falta de iniciativa. Desse modo,

\begin{abstract}
"ficaram de posse das fraquezas e defeitos da primitiva e persistente constituição social, sem as suas grandes vantagens. Não tem mais o apoio direto e constante do grupo, do clã, da família, que de patriarcal se tornou instável; falta-lhes a iniciativa do tentar, a autonomia do querer, a audácia do empreendimento, a coragem irrefreável da luta, a audácia do empreendimento, a coragem irrefreável da luta, o estímulo do progredir e do avançar, a atração irresistível do grande, a loucura do futuro, quero dizer, a fé inabalável num ideal coletivo, deslumbrante e invejado no mundo. ${ }^{943}$
\end{abstract}

O cerne de sua argumentação envolvia a questão racial, uma vez que os fatos históricos não deixavam dúvidas, "conhecido o Estado português do povo, uma indução, fundamentada pelos fatos, facilitará a apreciação de suas origens étnicas e de seu evolver histórico”. " 944 Era investindo no caráter nacional do ibérico que Sílvio compreendia a situação do país impelindo a buscar as origens étnicas do colono. Baseando-se nos teóricos da Escola de Le Play, mencionando sempre alguns desses autores para provar que suas idéias eram indiscutíveis, o crítico via pontos negativos da colonização portuguesa no Brasil. Sempre em busca da índole dos povos, fundamentado por algum teórico da Escola de Ciência Social, Sílvio desenvolveu análises em que são típicas conclusões como esta: "só assim de descortinará o motivo por que até ilustres sociólogos e economistas, como Basílio Teles, Anselmo se Andrade, Rocha Peixoto, Bento Carqueja, Ripamonti, são tão hábeis e perspicazes em descobrir os males de sua pátria e tão desazados em procurar-lhes as causas, as fontes e os remédios". 945

Mesmo diante de um enorme território português que Sílvio divide em três grandes regiões, por sua vez subdivididas, prevaleceram o bérbere ou os iberos que foram "a base principal, indelével, inapagável das populações históricas de toda a península, tronco primordial e resistente, no qual todos os subsequentes achegos étnicos não passam de enxertos, mais ou menos fecundos e viáveis". 946

\footnotetext{
942 Ibidem. p. 251

943 Ibidem. p. 252

${ }^{944}$ Ibidem. p. 247

945 Ibidem. p. 247

${ }^{946}$ Ibidem. p. 248
} 
Buscando encontrar a índole do berbere, Romero discorre sobre as regiões consideradas mais importantes, como o Algarves, expondo o modo de vida das pessoas, sua organização social, do que viviam, seja da colheita de produtos naturais, da pesca, de frutas, etc. Após descrever a origem do berbere, o que interessa a Sílvio é a índole da raça portuguesa, algo que o clima, a forma de viver, e o país, não conseguem alterar. Somente buscando a índole do íbero ou o berbere é que o escritor pontua os pontos negativos da colonização portuguesa no Brasil: as causas do modo de vida desde as origens deste povo são as causas alegadas para explicar a situação brasileira.

Era sempre a formação de um povo sem iniciativa. Sílvio era categórico com relação à índole da raça portuguesa, "os povos de tronco ibérico, enumerados em Estrabão e cuidadosamente por eles distinguidos dos fenícios, dos célticos, dos romanos e de todos os povos residentes, então, na Península, não eram, nem são, agora, em seus descendentes, dentes de formação particularista, dotadas de forte iniciativa criadora, de audaciosos impulsos de renovação, progresso e riqueza" 947 (grifos nosso)

Após traçar as várias regiões de Portugal e discordar de Alexandre Herculano e Oliveira Martins, remontava ao geógrafo grego Estrabão na busca do caráter português, herdeiro dos bérberes e dos íberos. Ainda que relevasse o clima e as várias zonas sociais, o que tanto chamou atenção para a análise social de cada povo diante da importância de cada região, pensava Sílvio na existência de um sangue português ou espanhol, diferente do celta, do lígure, do romano, do visigodo, etc. O resultado de um território grande, com o predomínio de uma vasta colheita era, "como entra pelos olhos adentro, a gente portuguesa, com tão agradáveis espécies de culturas, não passou, em lavoura, da mera jardinagem e da simples colheita remuneradora, quase sem trabalho" 948

Era em função da índole de formação comunária que Sílvio justificava tanto a situação portuguesa como os pontos negativos da colonização no Brasil. A conclusão desse estado de coisas era que "Na sua passagem, verbi gratia, para a Península Ibérica, ele se desorganiza em conflito com inúmeras condições do meio e da concorrência de elementos estrangeiros e chega à formação desse tipo comunário de Estado, tendo como base a família instável, como se pode ler em Demolins - Les Grandes Routes des Peuples, em Poinsard - La question du Marroc e Le Portugal Inconnu, em de Preville - Les Societés Africaines ${ }^{949 ", ~ . ~ N o ~ q u e ~ c o n c l u i ́ a ~ d e ~ m a n e i r a ~ d i r e t a ~ q u e ~ " T a l ~ a ~ r a i z ~ e m ~ q u e ~ s e ~}$ vai prender a desordem atual da Política portuguesa, que serve de Ilustração da nossa", ${ }^{950}$

Como se não bastasse a falta do espírito de iniciativa da raça ibérica, no brasileiro que habitava desde o extremo norte ao extremo sul, esse caráter ibérico só se desestabilizou devido à passagem da

\footnotetext{
${ }^{947}$ Ibidem. p. $251-252$

${ }^{948}$ Ibidem. p. 265

${ }^{949}$ ROMERO, Sílvio. O Brasil social e outros estudos sociológicos. Op.Cit.p.202

${ }^{950}$ Ibidem. p. 202.
} 
formação da família patriarcal absoluta para a família instável. Era a partir da formação social ou do tipo de Educação, comunaria ou particularista, que Sílvio explicava a importância do trabalho e de toda a organização social, e, sobretudo, o modo de viver de milhares de pessoas chefiadas por um líder local que a ele se submetiam em troca da mera subsistência. Se existia algo de positivo por parte do colonizador português, logo apareciam os problemas, uma vez que "Pode-se até dizer que algumas boas qualidades de que eram portadores os colonos europeus se dissolveram ao contato de índios $e$ negros e do novo meio tropical, que obraram como uma espécie de reagente químico de índole destruidora" ${ }^{951}$.

Romero ora mostrava um apego ferrenho ao fator racial, ora dava margem para a relativização desta leitura determinista. Do ponto de vista político, quando se perguntava pela melhor forma de representação nos países colonizados pelos ingleses, povo formado sob uma Educação particularista, explicava o surgimento do sistema parlamentarista, elemento típico do Estado Moderno, o que não fora possível nas Américas, dada à inaptidão da raça que não saberia viver com a presença de certas instituições. Mesmo reconhecendo o caráter de falta de iniciativa do português, Sílvio percebe uma unidade conjuntural de Portugal e pensa que não existiam no Brasil na época diferenças suficientes para que a colonização tivesse se processado de outra forma.

Após remeter à colonização de alguns Estados modernos, sempre chamando atenção para o espírito particularista ou comunário, comungando com a adoção de um modelo colonizador contemplador das diferenças, Sílvio parece ter postura ambígua com relação à colonização portuguesa no Brasil. Se para países como os Estados Unidos, o mais adequado era uma colonização onde a grande preocupação se referia a possíveis separatismos, com relação ao Brasil, afirmava que "tanto era este o tipo adequado ao novo país que se ia povoar, á nova gente que se ia constituir, que as tentativas dispersivas nunca lograram vingar, por si mesmas definhavam e morriam" 952.

Numa colonização processada pela ação de Companhia de Jesus, Governo Geral, Ordenações do Reino e Conselho Ultramarino, não encontrou Portugal diferenças que pudessem comprometer todo um processo colonizador. Daí, conclui Romero que

\footnotetext{
"Assim, a colonização primordial pelas capitanias hereditárias, que por toda parte caducou; assim, a divisão em dois governos, que nunca se pode manter; assim, a opção feita pelos nossos em prol dos portugueses, preferidos aos holandeses, quando no século XVII foi possível preferir uns ou outros. Durante quase quatro séculos nunca mudou o ritmo da evolução e, por isto, apresenta o Brasil o fenômeno assombroso de ser um tão enorme país, onde as tradições são fundamentalmente as mesmas, os costumes os mesmos, a língua a mesma, sem a deturpação de dialetos locais, o folk-lore o mesmo, a
}

\footnotetext{
${ }^{951}$ Ibidem. p.58

${ }^{952}$ ROMERO, Sílvio. Provocações e debates. Op. Cit.p. 279-280
} 


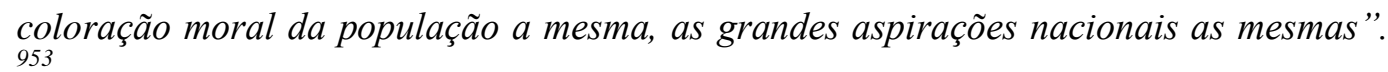

Mesmo com todos os pontos negativos apontados, tinha sido o Brasil colonizado por um país europeu, por uma raça que, mesmo em Estado de degeneração, não era inferior a negros e índios. O fato de Sílvio afirmar que outra não poderia ser a colonização no Brasil, em nenhum momento autoriza a conivência com a colonização portuguesa: é que o ideal seria ter sido o Brasil colonizado por um povo europeu, mas de formação particularista. Assim, o que resta ao ensaísta é descrever a situação política do Brasil, onde imperavam de norte a sul as oligarquias, a Política como meio de vida, a corrida aos cargos públicos, o desinteresse pelas questões nacionais, tudo isso resultado do caráter nacional brasileiro, formado sem iniciativa.

No tempo de Sílvio Romero, era comum analisar o atraso ou o progresso de uma dada sociedade a partir da análise racial, sendo a presença de uma raça inferior, como negros e mestiços, representação direta do atraso. Sílvio era conhecedor do Marxismo e do Anarquismo, mas em primeiro lugar pensava que era indispensável ver a sociedade brasileira hierarquizada para poder ser possível a criação de um partido operário no Brasil.

Se em outros países fora possível a adoção ou assimilação dessa ou daquela corrente Política era porque outra era a estrutura dos mesmos em relação ao Brasil. Sabendo que o Brasil não tinha sido colonizado por outro país, só lhe restava apontar os resultados desse processo. Tratava-se de uma atividade dolorosa, saber que o brasileiro poderia ter iniciativa, viver numa sociedade organizada à maneira dos grandes países europeus dirigidos por políticos comprometidos com as necessidades do país e por uma população interessada pelos problemas nacionais, mas ter que admitir que o caráter nacional brasileiro ainda não estava preparado para abrigar instituições e formas de governo como as existentes nos países que guardavam em seu seio uma raça forte, acompanhados do caráter de iniciativa. Sabendo disso é que Sílvio criticava muito mais a maneira dos políticos gerirem a nação brasileira do que a melhor forma de representação política para o Brasil.

Diferentemente da colonização de outros países, os portugueses encontraram um Brasil homogêneo, onde nenhuma condição punha em risco a estabilidade política do país. Ainda que medrassem motins locais sob a ingerência dos inúmeros déspotas, nunca a ordem política brasileira esteve ameaçada. Sílvio queria chamar atenção para a unidade do país: a forma de governo imposta pelo colono era a correta, errado foi à maneira dos políticos brasileiros conduzirem o governo. Assim, houve no Brasil toda uma estrutura que possibilitou a colonização portuguesa, o grande problema foi o aparecimento das tiranias ou oligarquias que por vezes agitavam o país. Entre a escolha por uma raça colonizadora que não a portuguesa e a falta de condições do caráter brasileiro, apático e produto

${ }^{953}$ Ibidem. p. 280 
da raça ibérica, só restava a Sílvio historiar como se deu a colonização. Seu grande temor era que os possíveis levantes colocassem em risco a integridade do país, uma vez que um de seus grandes desejos era ver um dia o Brasil constituído como uma nação forte, não apenas nas Américas como em todo o mundo. Essa a razão maior para o enaltecimento do gênio de Caxias, por ter o militar pacificado as revoluções do Prata e embutido o gênio do povo brasileiro. Era o general "belo tipo de ariano ocidental transplantado para as regiões brasilicas representa a continuidade da tradição étnica dos Vidais de Negreiros, dos Gomes Freyres de Andrade, a ação civilizadora de coesão do povo, da nação contra as tendências dispersivas da desagregação tribal de índios e africanos que se acham incorporados em nossa vida", 954

No que concluía sobre a figura de Caxias,

$E^{\prime}$ o gérmen da coesão ariana, nomeadamente portuguesa, que devemos acima de tudo fortalecer.

$E^{\prime}$ urgente, sob pena de morte, largar os atalhos do federalismo dissolvente $e$ caminhar com segurança e afoiteza para a unidade. Sejam quais forem os tropeços e embaraços, é preciso deitá-los por terra. ${ }^{955}$

Não poderia ser motivo de maior admiração por parte de Sílvio uma figura como Caxias. Era o gérmen coeso da raça ariana que faltava à raça portuguesa e que, portanto, precisava ser fortalecido, somado ao fato de ser Caxias o pacificador brasileiro. Tudo em nome do Brasil! Mais uma vez salientava Sílvio a admiração pela raça ariana, tantas vezes aludida. Um povo ou uma nação formada sob uma Educação particularista seria o grande diferencial e o ponto chave para explicar o êxito futuro de uma verdadeira nação moderna. Era o que faltara ao Brasil. Para Sílvio, o grande problema era a situação de pobreza dos cerca de 12 milhões de brasileiros espalhados pelos mais recônditos lugares do país. Todo esse Estado de coisas devia-se à Educação comunaria empreendida pela colonização portuguesa, em que a única preocupação era somente com a subsistência. Por aqui, o que sobressaía era a política alimentar, o que explicava dois terços de pessoas trabalhando para manter as regalias de uma meia dúzia de políticos e de uma dúzia de letrados, que viviam dos esforços da população miserável. Diante dessa situação, não era possível a formação de um povo forte e lutador, interessado pelas coisas nacionais do país, esta somente uma das várias características em que diferia o caráter nacional brasileiro dos povos fortes como alemães e ingleses.

No Brasil, predominou uma sociedade que detestava a vida campestre, em que a maior possibilidade de ascensão sócio econômica era migrar do campo para a cidade à procura de cargos públicos. No campo, não existia outra solução para a maioria das pessoas a não ser a dependência em relação aos donos de terras ou aos políticos acobertados pelo filhotismo político, responsáveis pelas

\footnotetext{
${ }^{954}$ Ibidem. p. 332
}

${ }^{955}$ Ibidem. p. 332 
mais variadas formas de corrupção política. Num país onde nem todos podiam ser donos de terras, restava a dependência em relação aos políticos e frente à manutenção das oligarquias espalhadas de norte a sul do Brasil. Todo esse cenário estava intrinsecamente ligado à herança portuguesa, donde a raça ainda se mostrar de grande importância nas análises do polígrafo com relação ao Brasil. A maneira como Sílvio vê a colonização portuguesa se confundia com todo o cenário social descrito, onde a apatia do brasileiro e a falta de interesse pelos rumos de seu país estão ligadas à decadente raça latina. Mas nem tudo era português no Brasil, restavam índios, negros e mulatos...

Sendo o Brasil colonizado por uma raça decadente, restava a Sílvio perceber a "melhor" forma de colonização, e acima de tudo, descrever como esta colonização se processou. Admirador inconteste da raça ariana, Romero traçou momentos significativos da colonização portuguesa no Brasil e de como esta se desenvolveu. A crença de Sílvio na inferioridade de negros, índios e mulatos não significa que o mesmo tivesse sido conivente com a colonização portuguesa, pelo contrário, muitas vezes moveu críticas à maneira como esta se processou. Até mesmo em relação a um país como a Alemanha, ao qual tantas vezes teceu elogios e encantamento por alguns escritores racistas, não deixou de pontuar detidamente como deveria se processar a colonização. Sílvio nunca titubeou quanto à crença na desigualdade racial, mas foi criterioso no que tange ao modo como se processaria a colonização.

Como outra não foi à História de seu país, só restava ao bacharel guardar na memória como se processaram quatrocentos anos de História agenciadora de tantos vícios e infinitos problemas, muitos dos quais insolúveis.

\section{7 - Perigo da imigração alemã}

As idéias assimiladas pelos bacharéis da geração de Sílvio, sobretudo as que sagravam a superioridade da raça européia, assumiram um papel ainda mais destacado quando se tratou da substituição do trabalho escravo pelo trabalho livre. Antes de tudo, a teoria do Darwinismo social serviu para respaldar posicionamentos dos letrados e políticos brasileiros para conformar a situação do momento e prover o Brasil do futuro. Uma das mais importantes questões era abolir a escravidão, motivo para alguns ensaístas que trataram do atraso do país e que suscitava irremediavelmente a temática da melhor forma de colonização.

Mas a temática da imigração trazia consigo o maior entrave que era a absorção do trabalhador livre nacional. Num longo e melindroso processo, parlamentares, políticos, imigrantistas, ensaístas, não deixaram de ser vozes de oligarcas e discutiam como se daria esta imigração. Se não era mais possível a entrada de escravos provenientes da África, desde a lei de 1850, milhares de escravos da decadente lavoura açucareira do nordeste brasileiro podiam agora ser utilizados nas fazendas do 
emergente Vale do Paraíba e do Oeste Paulista. Como se pronunciaram os parlamentares brasileiros? Quais as falas predominantes? Qual a argumentação básica destes representantes diretos dos fazendeiros?

A questão imigracionista nos faz remontar toda a uma conjuntura que há tempos era problemática e só se tornou ainda mais evidente após a resolução de 1850. A discussão da absorção de uma mão de obra existente no próprio país, no caso, quer fossem os então escravos ou os pobres livres, ou a defesa da imigração européia era parte de uma conjuntura anterior a lei que punha fim ao tráfico de escravos, em 1850. Já em 1848, o ministério conservador, integrado por Araujo Lima, Eusébio de Queiroz, Paulino José Soares de Souza e Joaquim José Rodrigues, enfrentou questões da ordem da própria existência do Império brasileiro, como o problema da estrutura fundiária, o incentivo à imigração e se o fim da escravidão seria realizado com ou sem indenização aos proprietários.

Base de todo o império brasileiro, mascarado como um império de etiqueta, a cada momento que era colocado em questão o problema escravo no Brasil, mais premente era a discussão sobre como seria a forma de trabalho após a abolição. Sistemas de parceria foram tentados nas fazendas do interior paulista, pontualmente nas décadas de 1850 e 1860, onde se destaca a fazenda Ibicaba, de propriedade do senador Vergueiro. E os debates se processavam na Assembléia legislativa com duas posições antagônicas: poucos eram os deputados a favor da absorção de negros remanescentes da Economia nordestina, alegando serem pertencentes a uma raça vinculada à barbárie; e a grande maioria defendia a introdução do imigrante europeu.

Discutir a questão da imigração no Brasil é remontar toda a conjuntura imperial do país. A elite brasileira nunca manobrou tão bem politicamente uma questão de interesse "nacional" quanto a questão servil. Só se aboliu a escravidão no país quando as elites (letrada e política) perceberam que não existia o menor risco de por a ordem social em xeque. Os preceitos oferecidos pelas terminologias de civilização e progresso eram acima de tudo parte integrante de um mundo que não concebia a existência do negro e de mestiços integrados em seus quadros. Não é sem razão ou de maneira gratuita que, rente à questão da imigração, subjaz uma teia de atributos morais, sem os quais se torna inviável a inserção do Brasil no mundo civilizado. Tratar da imigração é tratar da escravidão no Brasil, essa processada sob as mais variadas formas de trabalho. Trazer o imigrante num momento de transição do velho para o novo Brasil, em que carecia este construir, dar nacionalidade a seu povo, era de suma importância para solver a situação do escravo.

Era um momento ímpar para se falar de um Brasil republicano, equivalência direta da chegada da modernidade do país, que dava oportunidade a este de ter sua História nacional. Esse novo Brasil era republicano, civilizado e possuidor de seu próprio progresso, com sua independência própria, que não mais carecia da mão de obra escrava. Assim como toda a situação de atraso justificada pela elite 
nacional recaía sobre a falta de condição de índios, negros e mestiços para os padrões civilizatórios pretendidos, o caminho a seguir seria superar a barbárie do negro. Não é estranho que no momento em que se assimilavam as mais variadas teorias emanadas dos Estados Unidos e da Europa, na década de 1870, em que tanto se evocava a superioridade da raça européia, o que norteava as falas dos parlamentares e letrados nacionais era a emigração européia, "de fato, durante toda a década de 1870 os temas do negro livre e do imigrante ideal nortearam os debates dos deputados provinciais". 956

Há uma estreita relação entre o Positivismo - uma Filosofia progressista -, o Evolucionismo, do qual o Darwinismo é fruto direto, e a opção pela raça branca que emigraria para o Brasil. Depois da tão sonhada e alardeada chegada do progresso propagada por nossos políticos e intelectuais, cabia deixar claro que o desenvolvimento do país se daria com a participação do trabalho livre, e, para letrados e políticos, o negro se mostrava incapaz de se inserir numa Economia regida por máquinas orquestrada pelo tempo de trabalho. Não é acidental que na mesma década em que Sílvio anunciava o atraso do Brasil frente à emergência das idéias novas, o alagoano Aurélio Candido Tavares bastos, formado na Faculdade de Direito de São Paulo em 1861, fundava a Sociedade Internacional de Imigração. Os reformadores políticos brasileiros argumentavam que o atraso do país era devido à inferioridade do negro, que, comprovada cientificamente, obstava a chegada do progresso. Essa idéia de progresso passava pela transição do trabalho escravo para o trabalho livre, pela eliminação do trabalho escravo e da monocultura, pela abertura de novas Economias e acima de tudo pela entrada do imigrante branco.

A passagem do trabalho escravo para o trabalho livre exigia esforços na corrida ao desenvolvimento do Brasil moderno. O médico Luis Pereira Barreto, que foi estudar na Bélgica em 1860 e, entusiasmado pela Filosofia de Comte, reprovou a escravidão da raça negra por ser esta uma raça inferior, gente bárbara, explicava o atraso do Brasil a partir desse fator. Mais do que o combate à escravidão, o que se combatia era a presença de uma raça inferior. Em 1840, bem antes da grande entrada de imigrantes no Brasil, o senador Vergueiro criara em sua fazendo o regime de parceria, que contava com o trabalho do imigrante. A partir de 1866, o fluxo migratório intensifica-se. No decênio de 1870, com a emergência do café no Oeste Paulista, trabalhadores livres e escravos do decadente Vale do Paraíba conviviam lado a lado. ${ }^{957}$ Era neste momento que surgia o racismo científico.

O que dizia Sílvio da escravidão e da vinda do imigrante?

Por mais que tenha sido Romero um defensor da raça superior européia, não defendeu a escravidão da raça inferior diante do quadro evolutivo, mas pensava que, como outra não foi à

${ }^{956}$ AZEVEDO, Célia Maria Marinho de. Onda negra medo branco: o negro na imaginação das elites do século XIX. Op. Cit. p. 94

${ }_{957}$ SCHWARCZ, Lilia Moritz. Retrato em branco e negro: jornais, escravos e cidadãos em São Paulo no final do século XIX. São Paulo: Companhia das Letras, 1987. p.34 
colonização por parte do português, não adiantava de um dia para o outro abolir a escravidão sem que os escravos tivessem as mínimas possibilidades de melhores dias. De modo sutil, num primeiro momento, o combate por parte dos ensaístas brasileiros recaía não no regime escravista, mas sim num Brasil composto por milhares de seres incapazes de abraçarem o mundo civilizado dos brancos. Num segundo momento é que se levantam vozes como as de Joaquim Nabuco combatendo os horrores da escravidão. Como Nabuco, outros polígrafos combateram a escravidão sofrida pelo negro, mas não se pense que o posicionamento desses homens vinha a favor de uma nova ordem que desse melhores condições para o ex-escravo, era apenas estratégia de um novo Brasil por parte de reformadores políticos para um país não mais agrário, tornado industrial, urbano e alavancado pela mão de obra branca. É nesse contexto que emerge a tônica racial respaldando a questão da imigração no Brasil. Reconhecia Sílvio a falta de uma nação num Brasil caldeado por diversas raças, donde a precaução pela colonização alemã. Após a primeira grande leva de imigrantes para o Brasil, o país se via agora frente a duas ideologias: a idéia de inferioridade de negros e mulatos e a ideologia da vadiagem. Uma vez que a Economia mudara das lavouras do açúcar nordestino para as emergentes terras cafeeiras do Oeste Paulista, o discurso central agora era a certeza da superioridade do homem branco, o que de uma forma ou de outra guardava estreita relação com as teorias raciais que conquistaram boa parte dos ensaístas da época.

A idéia de uma raça imprestável não ultrapassa as teias de um discurso liberal, uma vez que pairava a imagem de um negro indolente, indisciplinado, não apto ao trabalho e acima de tudo, que podia enfrentar diretamente seu próprio dono, pondo em risco a sobrevivência deste: era o temor da onda negra. ${ }^{958}$ Era a ideologia da vadiagem, que merecia todo cuidado com relação às classes perigosas na passagem do Brasil rural, negro e atrasado ao Brasil citadino, fabril, republicano e moderno. Trazer imigrantes de países distantes é que se mostrou ser o problema principal, mas a questão era resolvida facilmente, uma vez que se tratava de uma raça superior. Giralda Seyfert informa a dificuldade da imigração,

"A missão diplomática de Abrantes não foi bem sucedida pois, em 1859, a Prússia promulgou decreto que dificultava a emigração para o Brasil. Isso foi motivado pelas denúncias acerca das condições precárias das colônias no sul, da servidão associada aos contratos de parceria nas fazendas paulistas e do discurso das autoridades brasileiras sobre a substituição do escravo pelo trabalhador livre imigrante, objeto da crítica de Sturz.

Os planos de colonização dessa sociedade não se concretizaram. Era necessário grande aporte financeiro (que precisava ser captado na Europa) e uma propaganda eficiente que pudesse "desviar" a corrente emigratória que tinha como destino a América do Norte, particularmente os Estados Unidos, num período em que os próprios governos alemães, sobretudo o da Prússia, colocavam entraves ao agenciamento de emigrantes para o Brasil. Além disso, o custo da viagem para a

${ }^{958}$ AZEVEDO, Célia Maria Marinho de. Op. Cit. 
América do Sul era muito maior, e os riscos da longa travessia marítima na primeira metade do século XIX eram grandes, registrando-se altos índices de mortalidade, principalmente entre aqueles que viajavam de forma mais precária". 959

Embora o estudo de Seyfert se concentre no Vale do Itajaí, em Blumenau, é de grande interesse porque fora justamente para a região sul do Brasil que Sílvio dirigira seu olhar, temendo o possível desmembramento do país. Nessa ótica, o estudo de Seyfert é parâmetro para a análise do processo de construção da nação. Regido pelo Deutschtum - caráter nacional germânico e crescimento de suas riquezas e de seu povo -, o povo alemão caminhava sua tendência expansionista. O Brasil e a nação brasileira seriam formados não mais a partir da junção étnica de índios, negros e portugueses, mas sim com uma raça superior, uma raça forte como queria Romero.

Sílvio era admirador inconteste de uma raça de caráter forte por conta da iniciativa, condição de vencer as contingências duras da vida, fruto que era da formação particularista. Nessa ótica, primava o bacharel pela defesa da imigração da raça germânica, porque eram homens de iniciativa. Mas nem por isso a imigração dos alemães seria realizada a toque de caixa, dispensando toda uma reflexão, pois o território e a nação brasileira poderiam estar em risco, sem a assimilação do nacional, uma vez que "existem ai milhares e milhares de patrícios nossos que devem ter a preferência nos favores do governo para a colonização. É um meio de fixar e garantir o imenso proletariado brasileiro". 960

Romero chamava atenção para a presença de emigrantes alemães processada somente na região do sul do Brasil, e advertia: "quanto aos estrangeiros, deve-se fazer com eles o que intitulei a colonização integral. Isto é, que se vão espalhando por todo o país, especialmente o Norte e o grande Oeste. Nada de aglomerá-los as dezenas e centenas de milhares de uma só raça nas quatro províncias do Sul”. 961

Temendo o desmembramento do país, visto que algumas cidades do sul do Brasil como Blumenau foram colonizadas por alemães, onde se falava o alemão, indagava Sílvio: "e por que não quererão eles ocupar o resto do país? O plano é o mais liberal possível: em vez de três ou quatro províncias, damos-lhe vinte. O Brasil aí todo está; espalhem-se e misturem às populações nacionais. Não vejo motivos para não aceitarem este sistema. Nada de privilégio de zonas; o clima do país é todo apto a colonização". ${ }^{962}$

Após a disseminação das teorias raciais que defendiam a superioridade do homem branco em detrimento de negros, amarelos e mestiços, pairava agora a ideologia do trabalhador ideal, o que deu sentido à vinda de imigrantes para o Brasil. Emergindo como principal núcleo da Economia brasileira,

\footnotetext{
${ }^{959}$ SEYFERT, Giralda. A dimensão cultural da imigração. Revista brasileira de ciências Sociais. V.26, na . 77, 2011. p. 49.

${ }^{960}$ ROMERO, Sílvio. História da Literatura Brasileira. Op. Cit.p. 45.

961 Ibidem. p.45

962 Ibidem. p.45
} 
foi no Oeste Paulista e no sul do país que se consumaram os debates sobre a vinda de imigrantes para o novo Brasil. Admirador inconteste da cultura germânica e da raça saxônica em detrimento da colonização processada pela raça íbero latina, Sílvio analisava calmamente como poderia se processar a formação da nação brasileira diante da imigração alemã. Passados os tempos áureos do racismo científico acompanhado pelos primeiros fluxos migratórios da década de 40 e 50 do século XIX, Romero se preocupou com o que, a seus olhos, parecia de fundamental importância, por isso mesmo, um assunto grave para a integridade do Brasil, que era o perigo alemão. No artigo O Alemanismo no sul do Brasil, publicado em janeiro de 1906, Sílvio esmiuçava a situação dos cerca de 350.000 colonos alemães presentes nos Estados Paraná, Santa Catarina e Espírito Santo, impelidos pelas necessidades do Deutschtum - os interesses e a fortuna alemã. Remontava à longa História do expansionismo alemão, uma vez que "a tendência do povo alemão para emigrar, estimulada pela pobreza do solo, é antiga, já deixei ponderado”. 963

De início, era preciso mostrar qual a melhor maneira de processar a imigração. O ponto de apoio de Sílvio mais uma vez recaía sobre a Escola de Le Play, pois seus ensinamentos permitiam averiguar o estado das gentes ou das populações. Nesse caso, o próprio Sílvio arrolava quatro caminhos para viabilizar a imigração alemã no Brasil, sobressaindo, “o quarto sistema, que aliás, deve ser empregado de combinação com os dois anteriores, pode ser chamado o sistema-norte-americano. É salutar, com a condição da inoculação de elementos étnicos de primeira ordem, por todas as regiões do país, de forma que sejam assimilados a nossa gente pelo uso de nossa língua". 964

Uma vez que a primeira entrada de imigrantes no Brasil datava de 1825, contestava Romero a maneira como se dava a imigração, pois poderia ser bom para o alemão, mas não para o brasileiro. No artigo em questão, Romero remontava à História da raça germânica que derrubou o Império Romano e constituiu-se no Império Romano Germânico do Ocidente, apontando desde mil e duzentos anos a tendência expansionista para as terras mais longínquas. Na leitura acerca da História da raça ariana, donde descendiam os germanos, o que mais importava a Sílvio era ver a potencialidade da raça "pois o seu primeiro arranco nesse sentido já é quase histórico e foi quando ocuparam a famosa planície saxônica, onde ramos enérgicos da raça lançaram as bases de seu viver particularista. " 965

A par da influência de escritores pertencentes à Escola de Le Play e outros somente citados nesse momento, como Georges Blondel, Jules Stoecklin, V.A. Malte Brun e Arthur Raffalovich, para Sílvio, a questão da colonização alemã reportava a toda uma estrutura social e política nacional, donde a importância para os elementos como a língua, os costumes e acima de tudo o interesse pelos

\footnotetext{
${ }^{963}$ ROMERO, Sílvio. O Alemanismo no Sul do Brasil. In: Provocações e debates. Op. Cit. p. 124

${ }^{964}$ Ibidem. p. 117

${ }^{965}$ Ibidem. p. 119
} 
problemas nacionais do país colonizado. A admiração pela colonização alemã no Brasil era evidente, mas tratava-se de uma análise minuciosa, visto que
"destarte, as famosas colônias alemães no sul do Brasil nem são simples casos de imigrações, que tenham sido assimiladas pelas populações circunvizinhas, como soe acontecer entre as nações soberanas, nem são por enquanto, colônias no clássico sentido dependências Políticas duma metrópole de além mar. Vão para aí. Constituem, por agora, um caso especial, que merece estudo". ${ }^{966}$

Se nos Estados Unidos o alemão deixava-se assimilar pelo yankee, misturando-se e assim perdendo todos seus costumes e principalmente a língua, no Brasil, acontecia justamente o contrário: existiam localidades no sul do país onde era completo o domínio alemão. Não poderia ser mais desanimador para um nacionalista como Sílvio ver em seu país o pleno domínio de uma raça somente num ponto específico deste, pondo em risco a formosa peça de arquitetura política montada pela fiugura de Andrada,

\begin{abstract}
"os colonos alemães do Brasil meridional gozam de completa liberdade; além de raras autoridades de justiça e polícia, nenhum empregado exerce funções nas colônias...Se no Brasil, como nos Estados Unidos, os colonos alemães não tem mostrado, por enquanto, fortes tendências de se meterem na Política, ao menos no primeiro deste dois países não tem, como no segundo, perdido o uso de sua língua materna". ${ }^{967}$
\end{abstract}

A admiração de Silvio pela a raça ariana se dava na medida em que era uma raça forte e de iniciativa, daí no artigo em questão mostrar o caráter da expansão acontecida entre os anos de 1884 a 1888, sob a política de Bismarck. Mesmo sendo Sílvio um escritor encantado pela cultura germânica e pela raça branca, chamava atenção para a emigração dos alemães para a América do Sul, inclusive o Brasil. Não concordava com uma emigração da forma que vinha se processando, e apontava diversos artigos em que manobras políticas por parte dos alemães vinham se encaminhando para a viabilização da colonização no sul do Brasil. Por meio de artigos traduzidos pelo Jornal do Comércio do periódico Européen, Sílvio esmiuçava o que diziam os jornais alemães sobre o Brasil. Se não bastasse a tendência dos alemães para a expansão, alegava Romero que não tinha sido o Brasil desmembrado por causa da Doutrina Monroe, o que não permitiu à Alemanha a colonização direta no Brasil. Sílvio não apenas traçava a longa História de expansão do Deutschtum em que dos doze milhões de vassalos do imperador Guilherme onze se dirigiram aos Estados Unidos, no que "por todos estes documentos, por todas estas citações, creio que se terá compreendido a gravidade do caso teuto-sergipano”. 968

\footnotetext{
${ }^{966}$ Ibidem. p. 129

${ }^{967}$ STOECKLIN, J. Les Colonies Et E’migration Allemandes. Apud. ROMERO, Sílvio. Ibidem. pp.128-129

${ }^{968}$ Ibidem. p. 140. A expressão "teuto-sergipano" é assim comentada por José Carvalho: "a escola, se de escola merece o nome, que aprouve a literatos fluminenses designar pelo título de teuto-sergipana, com o claro intuito de produzir impressão cômica, pela associação da idéia de Alemanha e da província natal de dois infatigáveis promotores do germanismo em terras brasileiras, mas sem saber que esta arte lhes conferem, bem como a sua terra, uma honra imensa, cujo valor exato só ao futuro é dado conhecer e aquilitar; uma tal escola ainda tem a lutar com dificuldades e embaraços,
} 
O gravíssimo assunto refere-se à colonização dos alemães localizados nos três Estados do sul do Brasil, o que, para Sílvio, poderia levar ao desmembramento do país, uma vez que o colono não se interessava pelas questões políticas locais, e os costumes, a língua e as tradições nessas cidades eram todos de origem alemã. Contrário ao que ocorreu com a leva de imigrantes alemães que se dirigiram para o Chile e a Argentina, onde tentaram se instalar na Patagônia, esses países foram protegidos pela Doutrina Monroe, o que mesmo assim não freou a instalação de milhares de alemães no sul do Brasil, "diversa é a situação do Brasil, no qual o processo de desagregação vai sendo dirigido habilmente, com alguma demora; mas infalivelmente seguro". 969

Mas, o mais grave é que como descreviam alguns jornais alemães o Brasil mostrava uma situação por demais favorável à colonização alemã,
"em particular, o sul do Brasil torna possivel e garante a preservação da língua, costumes e Educação alemães, visto como a sua população é muito pouco numerosa e ilustrada, para poder desviar a emigração alemã da sua nacionalidade, ao mesmo tempo em que o elemento alemão já tem adquirido aí uma poderosa situação. De fato, os 250.000 alemães que atualmente residem nas províncias meridionais do Brasil, conservaram-se até hoje alemães, contraste agradável com os nossos patrícios na América, que rapidamente sucumbem a superioridade do anglo saxônico" 970

Sílvio pontuava passagens onde esboçava o temor pelo ou o perigo do desmembramento do Brasil. O Brasil, ao contrário do que acontecia com os Estados Unidos, não oferecia resistência alguma para a completa dominação da cultura germânica. Sílvio reconhece o caráter expansionista por parte da raça germânica, aponta elementos que justificam essa própria expansão como, por exemplo, merecer o povo alemão colônias para se expandir e disseminar suas riquezas econômicas, mas nem por isto, deixa de refletir sobre o perigo e a ameaça que esta imigração traria. Outra passagem clareia a postura de Sílvio: "no sul do Brasil encontra a prosperidade do emigrante uma garantia no fato de ali ser temperado e salubre o clima e fecundo o solo, de existirem ferrovias fáceis de estender e prolongar, rios navegáveis, além de que não há necessidade de combater os indígenas e a proximidade do litoral facilita o comércio com o mundo inteiro e torna possíveis todas as transações". ${ }^{971}$

O sucesso da estratégia alemã se deu não apenas pela tendência expansionista ligada a raça germânica, mas por conta da conservação da língua, dos usos e dos costumes desta raça o mais importante fator para Sílvio, uma vez que era a partir desses elementos que o escritor avaliava a imigração alemã. Não era benéfico para o Brasil hospedar uma raça que não se assimilava com o nativo. Se no país yankee o alemão acabava por se confundir com o caráter americano, tributária da

que anos e anos de combate não tem podido arredar'(Cf. BARRETO, Tobias. Estudos Alemães. 5a. Ed. Rio de Janeiro/ Aracaju: Record Secretaria da Cultura e Meio Ambiente, 1991. p. 45)

${ }^{969}$ Ibidem. p. 131

${ }^{970}$ Ibidem. p.133-134

${ }^{971}$ Ibidem. p.134 
raça anglo saxônica, esquecendo sua cultura e tornando-se já na segunda geração um verdadeiro americano, no Brasil vários fatores confluíam para a ocorrência de um quadro totalmente diferente. Localizados geograficamente em apenas três estados e distribuídos em grande massa onde a única língua falada era a língua alemã, sem contato algum com o resto do Brasil, a cultura alemã era disseminada pela religião, pelo ensino e pelo próprio povo. O que esperar de um cenário como este num momento em que se buscava dar identidade ao brasileiro?

Romero não hesitava, pontuando a principal conseqüência deste Estado de coisas, "o desprezo que ostentavam por nossa vida pública, da qual não participam de propósito, é outra prova irrefragável" 972. Muito bem informado, citava como prova do perigo alemão alguns artigos traduzidos por jornais como a Gazeta de Notícias e principalmente, pelo Jornal do Comércio, em que tais veículos mostravam o interesse Deustschtum, e como aparecia o Brasil segundo estes. A discussão em torno da invasão de milhares de alemães numa só região é parte da visão de Sílvio no que diz respeito à construção da nação, equivalência de povo, e acima de tudo, da formação de um país já com sua identidade própria. De tal modo a maior crítica de Romero se dava em função da centralização de milhares de alemães numa única região, o que dificultava a valorização da língua e dos costumes do nosso país. O mais grave era que além desses fatores não propiciarem a integridade do país, ao contrário do que aconteu nos Estados Unidos, não houve nenhuma reação por parte dos nativos, pelo contrário, "nessas colônias, os atos oficiais, os processos judiciários, os despachos dos juízes, os editais das câmaras, tudo, tudo é em língua alemã ". 973

Preocupado com a identidade nacional brasileira, alertava Sílvio para a invasão de alemães no Brasil, o que estava acontecendo nos estados Paraná, Santa Catarina e Rio Grande do Sul, impossibilitando a formação da nação brasileira com sua língua, seus costumes e sua cultura. Alertava Romero para o gravíssimo problema, "de vinte e cinco a trinta anos a esta parte, não perco ensejo de despertar a atenção dos brasileiros e dos poderes públicos da nação para esse gravíssimo assunto”. ${ }^{974}$ Entendia Sílvio que a concentração de alemães nos três Estados do sul anos punha em risco a integridade do Brasil obstando a formação de uma consciência nacional. Era inaceitável para um homem que pensou o Brasil dotado de sua identidade própria encarar localidades totalmente tomadas pela cultura alemã, pois “cerca de 380.000 pessoas de origem germânica, residentes no Brasil, seis ou oito que para confirmar a regra da abstenção de seus patrícios em tudo que é puramente brasileiro, se metem nas lutas partidárias locais" ${ }^{975}$. Concluía Sílvio que

\footnotetext{
972 Ibidem. p. 147

${ }^{973}$ Ibidem. pp.148-149

974 Ibidem. p. 140

${ }^{975}$ Ibidem. p. 148
} 
"são raros moços, filhos das cidades, ordinariamente nascidos dos raríssimos consórcios de alemães com brasileiras, desviados em parte do pensar genuinamente germânico, que se deixam atrair por ambição Política. É exceção singular, que nada vale.

Sua aversão, seu desprezo por tudo que é brasileiro, menos a terra que chamam sua,é atestado pelos poucos nacionais que ousam viver no meio deles nas colônias compactas". ${ }^{976}$

Justificando a expansão alemã nos artigos já mencionados, Sílvio deixava claro que o temor do desmembramento do Brasil era patente, "a separação não se fez já, com o auxílio e sob o protetorado da Alemanha, por causa das perturbações que isto acarretaria diante da previdente da doutrina Monroe, freio único que contém o império, conforme os próprios alemães confessam, e mostrarei linhas abaixo". 977

Ainda que a maioria dos artigos sobre o tema datasse da primeira década do século $\mathrm{XX}$, Sílvio chamava atenção para um texto bem anterior onde levantava as fases do expansionismo alemão. O periódico El Tiempo noticiava o interesse alemão pelas Ilhas Carolinas, como se não bastasse, recortava Sílvio artigos reproduzidos pela Gazeta de Notícias, onde procurava deixar claro como procedia a Política expansionista alemã. Nesse artigo, ele chamava atenção para a imagem positiva acompanhada obviamente do interesse alemão por todo um Brasil que não oferecia maiores resistências.

\footnotetext{
"Esses territórios oferecem espaço suficiente, diz a circular que estou traduzindo literalmente, para perceber toda a emigração alemã na sua importância atual, por um período de tempo superior a um século. Tem efetivamente uma superfície dez vezes maior do que a do império alemão, e a densidade da população não chega a oitava parte da nossa pátria.

Em particular, o sul do Brasil torna possível e garante a preservação da língua, costumes e Educação alemães, visto como a sua população é muito pouco numerosa e ilustrada, para poder desviar a emigração alemã da sua nacionalidade, ao mesmo tempo que o elemento alemão já tem adquirido aí uma poderosa situação. "978
}

O que era veiculado no jornal era que o Brasil oferecia vários atrativos para o colono alemão, atinando-se para o aspecto econômico, o que seguramente incomodava Sílvio, haja visto já ter o escritor chamado atenção para a dependência econômica do país durante toda sua História. Um país tão rico de produtos naturais, em função da ingerência dos governantes, ficou ao longo de sua História dependente do capital externo. Afora toda uma estrutura brasileira favorável ao Deutschtum, donde a existência da Associação de defesa dos interesses alemães mediante todo um serviço de propaganda (cartas, relações pessoais), e etc, espalhado por todo o globo, o medo de Sílvio era pela disseminação da cultura germânica não apenas nas três colônias do sul do Brasil, mas em todo o território nacional.

\footnotetext{
${ }^{976}$ Ibidem. p.148

${ }^{977}$ Ibidem. p. 159

${ }^{978}$ Ibidem. pp.133-134
} 
Para um homem apaixonado pelo Brasil, que sonhava um dia ver seu país constituído como nação moderna, os cerca de 300.000 a 350.000 mil colonos espalhados pelos três estados do país não deixavam de ser uma grande ameaça. A integridade do Brasil estava, pois comprometida!

Diante de toda aquela estrutura favorável à disseminação da cultura alemã, da tendência expansionista da raça germânica devido a sua formação particularista, o que fazer para evitar o pior que, segundo Sílvio, era o desmembramento do país?

Romero elencava até medidas preventivas para que não chegasse o Brasil a perder as terras do sul.

\begin{abstract}
$1^{a}$. Seguir o sistema japonês de nos aparelharmos por meio de todos os recursos da Ciência no sentido de prepararmos-nos militarmente para a luta;

$2^{a}$. Mudar a feição comunária de nosso caráter, que tudo espera do Estado, e reformar a nossa Educação no sentido anglo-saxônico da iniciativa pessoal, da audácia no empreendimento, da coragem na ação, da formação dum alevantado ideal de vida e de força individual e coletiva

3. Ajudar a essas grandes medidas com o povoamento do solo por um regime sistemático: imigrantes de nacionalidades diversas espalhados por todas as zonas do nosso imenso planalto, desde as serras do Rio Grande do Sul até as fronteiras do Vale do Amazonas, que será também povoado por gente adequada;

$4^{a}$. Aproveitar, por todos os meios imagináveis, o enorme proletário nacional, que será transformado em elemento colonizador, posto ao lado do estrangeiro para educar-se com ele no trabalho e o ir abrasileirando;

$5^{a}$. Facilitar esse povoamento do país em todas as direções, levando estradas de ferro por toda a parte, que sirvam para articular, por assim dizer, este imenso corpo, facilitando-lhe ao mesmo tempo a defesa. ${ }^{979}$
\end{abstract}

Dentre as medidas preventivas contra o possível desmembramento do país num momento em que Sílvio pensava a formação de um Estado nacional forte, aparecia como cerne a questão racial. Nesse momento é que se notifica a fineza de análise de Romero: mesmo sendo admirador da raça forte e de iniciativa, não adiantava introduzi-la no Brasil sem que sem nenhum elemento nacional estivesse presente. No momento em que o polígrafo rebate a imigração processada a partir de 1825 , deixa em evidência a disparidade entre uma raça de formação particularista, a germânica, e outra de formação comunaria, a brasileira. Sílvio mostrava-se preocupado com o caráter nacional brasileiro. Temendo a grave ameaça do desmembramento do país, indagava sobre o que iria resultar de toda essa conjuntura? Não bastasse a apatia de nosso caráter nacional, produto da colonização da raça latina em estágio de degeneração, formado por milhares de negros e de mestiços, seres inferiores quando comparados ao homem branco, o que fazer para impedir que viesse prevalecer no Brasil o caráter do povo germânico?

Arrolava Sílvio as medidas para evitar o desmembramento do país:

${ }^{979}$ Ibidem. p. 164 
$1^{a}$. Proibir as grandes compras de terrenos pelos sindicatos alemães, máxime nas zonas das colônias;

$2^{a}$. Obstar a que estas se unam, se liguem entre si, colocando entre elas, nos terrenos ainda desocupados, núcleos de colonos nacionais ou de nacionalidades diversas da alemã;

$3^{a}$. Vedar o uso da língua alemã nos atos públicos

$4^{a}$. Forçar os colonos a aprenderem o português, multiplicando entre eles as escolas primárias e secundárias, munidas dos melhores mestres e dos mais seguros processos;

$5^{a}$. Ter o maior escrúpulo, o mais rigoroso cuidado em mandar para as colônias, como funcionários públicos de qualquer categoria, somente a indivíduos da mais esmerada moralidade e de segura instrução.

$\sigma^{a}$. Desenvolver as relações brasileiras de toda a ordem com os colonos, protegendo o comércio nacional naquelas regiões, estimulando a navegação dos portos e dos rios por navios nossos, criando até alguma linha de vapores que trafeguem entre eles e o Rio de Janeiro;

$7^{a}$. Fazer estacionar sempre vasos de guerra nacionais naqueles portos;

8. Fundar nas zonas de oeste, tolhendo a expansão germânica para o interior, fortes colônias militares de gente escolhida no exército. ${ }^{980}$

Lembremos que Sílvio assim como toda a geração de escritores de seu tempo estava preso a ideologia da um caráter nacional. Esse caráter, de maneira genérica, estava ligado à raça, sendo o branco, o negro, o índio e o mulato portadores de singularidades. Não é menos interessante o combate de Romero pela colonização alemã quando sabemos de toda sua admiração pela cultura germânica, influência do pensador e uma de suas grandes admirações, Tobias Barreto. No longo artigo, Sílvio escrevia qual era o germanismo que o atraía, se justificando para aqueles que viam contradição em seu pensamento. Em outros trabalhos, especificamente nos de crítica e História literária, presenciamos as argumentações do escritor e os porquês da admiração pela cultura germânica. Era a visão do todo que contagiava Sílvio, o que justificava a defesa e o apego ao germanismo literário. Sílvio até mencionava o nome de seu amigo de refregas e para os literatos imbecis frisava que "o meu amigo sempre quis, sempre ensinou a este inconsciente povo de ingratos, desnorteado por literateiros imbecis, o que ele pretendia, com uma larga intuição verdadeiramente genial, era que o Brasil fizesse o que o Japão já tinha então começado a fazer". 981

Num momento em que pouco se chamava atenção para o perigo do imperialismo por parte de alguns países europeus, Romero era a favor de uma colonização racional, distribuída em todas as regiões do Brasil. Pensava ele que uma colonização "irracional” não possibilitava o amor ao país e nem preservava a língua, um dos elementos mais importantes para a integração nacional. Mesmo sendo ele um admirador da cultura germânica, caso fosse necessário escolher entre povos germânicos, eslavos ou de origem peninsular - de modo especifico, português -, optaria pela cultura luso-brasileira, uma vez que "não cheguemos ao aviltamento de deixar de ser nós mesmos, de renegar nossas

\footnotetext{
${ }^{980}$ Ibidem. pp. 165-166
}

${ }^{981}$ Ibidem. pp. 166-167 
origens, de apagar nosso passado, de escurecer os altos predicados de nossa raça, de repelir nossos maiores, última das vilanias a que pode descer um povo", 982.

Afirma Sílvio Rabello que:

\begin{abstract}
"Sílvio Romero tinha a antevisão das ameaças do imperialismo do tempo presente imperialismo, apenas esboçado na época em que propunha uma reaproximação com Portugal, não porque Portugal pudesse prestar-nos qualquer auxílio contra as possíveis investidas dos povos de Política colonial desenfreada, contra a Alemanha ou contra o Japão, mas porque dessa aliança resultaria o fortalecimento da unidade e da integridade nacionais por um processo de colonização que tinha quatro séculos de cultura portuguesa em confraternização com as demais raças do país, indígena e africana" 983
\end{abstract}

\title{
7 - Lusismo versus brasileirismo: paixão pelo Brasil
}

Se existe um ponto pelo qual podemos entender o turbulento mas fecundo Sílvio Romero é seu argumento de paixão pelo Brasil. É esse sentimento que o levaria a tentar conhecer o país de norte a sul; a buscar as raízes para os infinitos males brasileiros corroborados pela elite econômica e intelectual; a denunciar as fraudes políticas; a apontar favorecimentos em relação aos escritores que se dirigiam ao Rio em busca de medalhões literários, almejando melhores dias, com o objetivo maior da estabilidade por meio de uma cadeira na Academia Brasileira de Letras; a argumentar que o meio para analisar o Brasil era tomar conhecimento dos elementos que constituíam a crítica moderna; a dar a palmatória a quem merece; a buscar sempre o que era justo.

O brasileirismo de Sílvio se faz presente em suas obras, dando sentido às colocações dessa ampla produção. Nela, é bastante claro o desejo de se conhecer o Brasil, não o Brasil divulgado pela pena dos escritores nacionais do Romantismo e por alguns escritores cobertos de vaidade quando expunham em conferências internacionais acerca do Brasil. Era por causa da paixão pelo Brasil que ele afirmava que o Brasil social merecia todos os esforços. Nessa perspectiva, somente o apaixonado poderia descrever o país em sua real situação, primando pela verdade e assim denunciando o que houvesse de prejudicial a seu desenvolvimento.

Isso levava Romero a voltar os olhos para o Brasil que tanto sonhou um dia constituído enquanto nação e ter sua História contada na América com uma raça já constituída. Essa era a razão da reprovação do crítico com relação à imitação estrangeira, principalmente a francesa. Não é sem razão que ele repele qualquer tipo de imitação, seja no campo das Artes ou da Política, para só assim falar do Brasil real. Em todas as questões concernentes aos destinos de país, lá estava o bacharel como numa arena, lutando em nome do Brasil com uma posição definida. De seu nacionalismo, derivam alguns pontos importantes, como sua concepção de escritor, não o escritor esteta descompromissado com os

${ }_{982}$ ROMERO, Sílvio. Discursos: Porto, 1904. Op. Cit. p.167

${ }^{983}$ RABELLO, Sílvio. Op. Cit. p. 211 
problemas nacionais, mas sim o combatente, aquele que retrata a transformação social. Para reforçar essa missão literária, caracterizava os escritores nacionais como desenhistas de um Brasil irreal. A imagem que os nossos escritores elaboravam no exterior, para Romero, não passavam de mero ilusionismo. Combatendo toda essa situação, vinha à tona o Brasil almejado por ele. Qual Brasil seria este? Quais as bases indispensáveis para a formação deste Brasil não mais atrasado?

Sílvio nunca teve admiração pelo escritor esteta, seus mestres tiveram participação direta na formação de suas nações modernas. Ele queria mudar o Brasil, era-lhe hostil qualquer tipo de escritor que não denunciasse os problemas nacionais almejando transformar toda uma situação de miséria material e cultural. Já bastava de tanta imitação, de tantos planos políticos e tanta demagogia, era interessante conhecer sim a cultura européia não para aplicar ao Brasil, mas sim para, a partir de então, levar ao conhecimento deste. O estudo ou o modelo comparativo de Sílvio ressaltava a importância de saber o que acontecia fora do país, não para imitar, mas sim detectar a situação do país e só assim lutar para que este alcançasse a tão almejada posição de nação moderna,

"Entretanto, o ideal por este lado, o alvo nesta direção, seria acabar com o privilégio francês; ler, estudar os grandes representantes de todas as fortes Literaturas do século, não para repetir o que eles escreveram, mas para saber o que eles pensaram e chegar até onde eles subiram. Fortificar a individualidade, em vez de perdê-la, ao contato dos mestres.

A melhor condição para isto é cultivar os assuntos brasileiros, conhecer a vida deste país. Sua Etnografia, sua História, sua Literatura, sua demografia, seu folclore, não falando já no interesse incomparável do estudo de sua geologia, de sua Geografia, de sua faina, de sua flora, que belos assuntos oferecidos à sagacidade, ao talento, ao patriotismo de nossa mocidade!" 984 (grifo do autor)

Não se pode simplificar o pensamento e a contribuição do escritor sergipano quanto a sua compreensão de Brasil por ter sido mais um dos inúmeros assimiladores das teorias européias. Seu pragmatismo é demonstração cabal de querer ver o Brasil, o verdadeiro Brasil, para só então apontar os melhores rumos a seguir. Em Sílvio, onde termina a assimilação das idéias de fora começa seu olhar para o Brasil, nenhuma assimilação faz sentido sem que antes se tome conhecimento do verdadeiro Brasil. Daí, surge o interesse desmedido de Sílvio por todos os problemas nacionais.

Todo o interesse pelas mais diversificadas áreas do conhecimento, de modo específico, pelas premissas científicas, só tinha sentido para Sílvio se pudesse servir ao entendimento do Brasil, sonhando o escritor com um Brasil grande, donde declarar que "a aplicação ao Brasil é a preocupação constante; as considerações etnográficas, a teoria do mestiçamento, já físico, já moral, servem de esteios gerais; o Evolucionismo filosófico é a base fundamental". 985

\footnotetext{
${ }^{984}$ ROMERO, Sílvio. Movimento espiritual no Brasil no ano de 1888. In: Estudos de Literatura Contemporânea. Op.Cit. p.208.

${ }_{985}$ ROMERO, Sílvio. História da Literatura Brasileira. V.I.Op.Cit.p.48
} 
Responsável, juntamente com Tobias Barreto, pela anunciada renovação mental, literária e filosófica ou movimento espiritual de 1868-9, para Sílvio, o bando de idéias novas só fazia sentido se viesse acompanhado do objetivo de construir um novo Brasil. Todo o passado do país, tanto no campo da Cultura como no da Política, se encontrava numa situação de atraso, não apenas para ele, como para toda sua Geração de 1870. Sua vasta erudição, aparatada pela influência da intuição darwiniana tonificando a nascente Sociologia, fator somado a seu temperamento tempestuoso, fizeram de Romero, como ele próprio afirma, responsável pela missão literária de construir um novo Brasil. Lendo sua extensa produção intelectual, percebe-se a motivação do escritor se colocando na posição de um justiceiro em benefício de um novo país. Este Brasil não podia ser mais o país das oligarquias, da falta de consciência e de interesse do povo pela Política nacional, do desconhecimento da elite intelectual e política com relação às balizas fornecidas pela crítica moderna, da falta de oportunidades para os escritores residentes fora da Corte. Mas toda essa gama de quesitos poderia ser bem formulada se os escritores falassem de um Brasil real que era o Brasil social, o que atraía todos os esforços. Somente descrevendo o verdadeiro Brasil, era possível pensar na construção de um novo país.

Até a primeira década do século $\mathrm{XX}$, a república não havia dado um passo sequer e os problemas do país continuavam os mesmos. No plano da cultura era que se presenciava o atraso do Brasil nas mais variadas esferas do pensamento. Não bastassem as críticas esboçadas em sua obra A Filosofia no Brasil, onde analisava a situação filosófica do país a partir de seis intelectuais, e na série de artigos contra o Romantismo, dentre estes A Literatura Brasileira e a Crítica Moderna, em 1888, realizava Sílvio um balanço, um Retrospecto Literário e Científico da cultura brasileira. Não é de estranhar que mais uma vez as duras críticas com a linguagem ácida de outrora estivessem presentes.

"Vinte anos! Vinte anos de completa esterilidade no terreno das Letras.

Não temos um romancista, não temos um crítico de alta e vasta capacidade. Não apareceu um espírito superior, um vulto que se impusesse à reverência geral" 986

Torna-se mais fácil salientar o que ficava de pé na concepção de Sílvio para o progresso do país, "e ver se há saldo ou déficit em nossa contribuição geral dos povos para a cultura do século". 987 Gonçalves Dias e Alencar estavam presos à Metafísica, caindo nos ditames do absoluto, esquecendose assim da evolução normal dos fenômenos intelectuais. O tema mais importante que impulsionou toda uma geração de escritores, a Abolição, só produziu “declamadores banalíssimos, sem estudos, sem Ciência, sem idéias, sem estilo, sem uma só das qualidades dos escritores, ou dos oradores de

\footnotetext{
${ }^{986}$ ROMERO, Sílvio. Movimento Espiritual... Op. Cit.p. 205

${ }^{987}$ Ibidem. p. 206
} 
mérito" ${ }^{988}$. As duras críticas de Sílvio, com sua linguagem ácida, aos inúmeros escritores e políticos brasileiros são reflexos de seu brasileirismo. No balanço que realizava sobre a situação cultural do Brasil no último ano do Império, aparecia o mesmo escritor polêmico e combatente que começou a carreira nos jornais do Recife:

"Por toda a parte são sempre os mesmos ignorantes sáfaros, adicionados aos declamadores inchados, palavrosos, inanidos de idéias, sem profundeza, sem originalidade, sem espírito, sem uma sombra qualquer de verdadeiro talento. No eterno carnaval da Política e da Literatura do Rio de Janeiro, eles representam um papel de zabumba martelante, atordoador; mas oca e vazia como as geringonças de uma palhaçada africana.

Pode-se-ia fazer exceção para os escritos políticos do Sr. Joaquim Nabuco"” 989

É ambíguo ter Sílvio excluído Nabuco da ignorância dos declamadores em seus Ensaios de Crítica Parlamentar e momentos depois ter elogiado o autor de O Abolicionismo $^{990}$ :

\begin{abstract}
"O Sr. Joaquim Nabuco é um homem de certo talento, porém sem estudos firmes, sem idéias assentadas, sem espírito analítico e perscrutador, sem vistas largas e seguras. O caráter flutuante e indeciso de seus conhecimentos denota ao crítico um espírito móbil e ledor, onde as idéias não se acham, por assim dizer, estratificadas pelo trabalho lento da meditação, mas atrapalhadas, incorretas, confusas, como oriundas de leituras fugaces que são. $\dot{E}$ o mais perfeito tipo de diletante juvenil e vago, que, como crítico e filósofo, fará das sempre um papel medíocre e como orador conseguirá apenas iludir os incautos. Ele é ainda a mais completa encarnação da mediania educada à fluminense. Seu liberalismo é mais um tema para exibições pedantes do que uma conquista do estudo, é mais um predicamento de sua vaidade ainda não saciada do que um apostolado de homem convicto e intransigente. Temo-lo ouvido por vezes para caracterizá-lo e sempre o encontramos elegante, sorridente, luxuoso até, mais frio. Quando expõe suas idéias, abstratas, flutuantes, falo com o desleixo do touriste que desenfastia-se narrando a um companheiro de viagem as cenas que pouco o tocaram. Quando, porém, pressente que se põe um em sua dúvida o seu discernimento e a sua curiosidade de viajante da idéia, anima-se um pouco. Fala todos os dias porque não estuda e não medita para falar. É dizer que ele é mais um ornamento de salão político, um perigoso enganador das turbas que se está ali criando, aéreo, retumbante, bombástico e nada mais. É uma nova sereia mentirosa e falaz. É da pequena raça dos oradores acadêmicos, vaidosos, inanes. Há de ser grande, porque dessa madeira é que se fabricam os robustos esteios deste bem aventurado país. Quando chegarem, porém, as horas amargas, em que a nação, faminta de idéias e crenças, desiludida, alquebrada, abatida, rotos os laços dos velhos enganos e prejuízos, venha pedir aos homens que pensam aos sondadores da verdade, alguma solução, alguma luz para as suas trevas, não contém com o Sr. Nabuco para isso..." 991
\end{abstract}

Ainda sobre Nabuco escrevia Sílvio que "Joaquim Nabuco se me afigura, pois, um distinto homem de letras que sabe falar e escrever adicionado a um pensador político de largo descortino. Quando lhe chamo homem de letras, para bem frisar sua qualidade de intelectual, não pretendo de forma alguma confundi-lo com esses curiosos literatos, que se estacionam nos cafés e nas portas das livrarias; quando lhe noto o característico de escritor político, é para claro mostrar que sua ação

\footnotetext{
${ }^{988}$ Ibidem. p. 207

${ }^{989}$ Ibidem. p. 207

${ }^{990}$ ROMERO, Sílvio. História da Literatura Brasileira. Op. Cit.p.1758.

${ }^{991}$ ROMERO, Sílvio. Ensaios de Crítica Parlamentar. Apud. MENDONÇA, Carlos Sussekind de. Op. Cit.p. $217-218$.
} 
nesta esfera é mais notável no que ele escreveu do que no que fez, ainda levando em conta sua extraordinária ação no abolicionismo. Se eu tivesse autoridade para lhe dar conselho, indicaria que reunisse os seus discursos, artigos e panfletos políticos, porque não há um só dentre eles que não encerre alguma idéia, alguma vista aproveitável. Deste número é, entre outros, o Erro do Imperador. A coleção desses escritos avultará mais do que a presidência do Congresso Pan-Americano. "992

Não se pense que a linguagem simples, objetiva, e muitas vezes agressiva de Sílvio é destituída de sentido. Por mais conhecedor que fosse das teorias estrangeiras, sua forma simples e direta de falar sobre as mais variadas questões regidas pelo princípio regulador da crítica moderna deixa bastante claro seu brasileirismo. Em muitas passagens, é até cômica a fala de Sílvio com relação ao tema que aborda. Colocando-se sempre como crítico imparcial, a par de sua crítica sociológica, nada fica de pé quando de suas análises, quando se sobressai sua auto-estima, em passagens como "Meu fito é mais alto, mais difícil, mais nobre e mais útil: dar a idéia geral, a nota característica do momento espiritual da nação, fazer a diagnose da inteligência pátria pela apreciação das publicações mais valiosas do ano que acaba de desaparecer". 993

Inteligência pátria: é dessa forma que se processa o brasileirismo de Sílvio. Em todas as situações concernentes a esta ou àquela temática que mostrasse ter relação com os rumos do país, partia ele com sua paixão brasileira, apontando os problemas com um linguajar nada convencional a um homem de Letras de seu tempo. Daí, o sentido de sua busca fremente na identificação dos males brasileiros, comportando-se de maneira polêmica, uma cascavel, como nos lembra Araripe Junior, criticando tudo e todos. Para Sílvio, não fazia sentido nenhuma forma de representação que não incorporasse os males nacionais, que não trouxesse os germes para seu projeto nacional. Não sem razão, sua concepção de crítica literária e de escritor destoa da de Veríssimo, Machado e Araripe Junior porque mesmo reconhecendo que a Arte tende ao Absoluto, fruto que é da subjetividade de cada escritor ou poeta, esta jamais pode deixar de se amparar por uma intuição primeira (a intuição geral) que, de uma maneira ou de outra, tem relação com o meio, com a raça e com o momento histórico, e mais que isto: não deve o escritor deixar de lutar por sua pátria.

Sua obra mestra busca muito mais que enfeixar escolas literárias pautadas pelas leis que presidiram a Literatura do país: Historia da Literatura Brasileira analisa a evolução da cultura brasileira até o último ano do Império. Em todos os seus livros, a questão nacional aparece em primeiro lugar. Até mesmo quando elaborou versos, vinha à tona o brasileirismo de Sílvio

\footnotetext{
${ }_{992}^{992}$ ROMERO, Sílvio. História da Literatura Brasileira. Op. Cit.p.1758.

${ }^{993}$ ROMERO, Sílvio. Movimento Espiritual. Op. Cit. pp. 207-208
} 
De perlas, safiras, de mil esmeraldas,

De ricos brilhantes a fronte engrinaldas,

Gigante, orgulhoso, soberbo Brasil.

Na historia dos povos teu nome escreveste, Mil palmas e louros, na infância, colheste,

Colheste-os com gloria, batendo o fusil.

De lindas estrelas, de Luzes brilhantes Teu céu é bordado ; subtis, cambiantes

Destendem-se as nuvens ligeiras no ar,

$\mathrm{E}$ as luas formosas de pálidos lumes,

$\mathrm{E}$ as flores e os dias e os gratos perfumes

São mimos, que a Europa bem pode invejar.

Teus bosques frondentes, teus campos e montes,

$\mathrm{E}$ os mares e os rios, regatos e fontes,

São verbos, são frases, que dizem-valor- .

Não durmas, não tremas, nem curves o eólio,

Que a turba, que passa por sobre o teu solo,

São livres, são moços da idade na flor.

Não és tu a pátria dos grandes Andradas

$\mathrm{Na}$ voz de tribunos plantando as cruzadas

Em prol dos teus foros negados em vão?

Não és o guerreiro, que as hostes imigas,

$\mathrm{Na}$ guerra amestradas, sem custo profligas,

Vencendo os valentes de Ormuz e Ceilão ?

Império orgulhoso; soberbo e gigante, Não pares, caminha, caminha adiante,

Com os olhos no Trono cercado de luz,

Não durmas, nem tremas, não curves o eólio,

Que a turba, que passa por sobre o seu solo,

São fortes, são livres, são filhos da Cruz.

E tu, Mocidade, falange animada,

Que fases o encanto da pátria adorada,

Que além te reserva brilhante porvir;

Consagra os teus dias, teus hymnosà gloria

Da terra dos bravos de eterna memória,

Que a fronte de louros terás de cingir.

Não vês que rutila por sobre as montanhas

O sol de setembro de glorias tamanhas,

Mostrando a alvorada de um bello existir ?

Não ouves no pico das serras o grito

Maior do que as molles vetustas do Egypto,

Maior do que o mundo, maior que o porvir?

E o echo das serras proclama a verdade, Que o filho das mattas bradou - liberdade !-

Do Prata ao Amazonas retumba essa voz.

Quebraram-seosélos da iujusla cadeia, 
São livres os povos, domina-os a idéa, Mimoso legado de nosios avós!

E os lábios dos bravos, ardentes de gloria, Prorompem nos hymnos da excelsa victoria,

Que os filhos de Lisia fizeram tremer!

São livres os povos ! fluclua a bandeira, Que as filas cobrira da gente guerreira,

Que tinha por norte : ser livre ou morrer!

Sejamos unidos, mais fortes seremos:

Dos livres vergintea, si livres nascemos!

Das sacras relíquias guardemos a lei.

Brazil ! minha pátria, serás sempre grande,

Pois guia-te uni Pedro, maior que Alexandre,

Governa-te um subio, quo é mais do que um rei! 994

Apesar de ser um arguto denunciador dos problemas nacionais, Romero nunca se considerou um homem pessimista nem otimista (considera que este "é como o embriagado sorridente, que se julga sempre no melhor dos mundos"). ${ }^{995}$ Essa paixão jamais o deixou indiferente a inúmeros problemas, daí fazer questão de lembrar que não era nem otimista nem pessimista, pois "O pessimista é o doente amuado que tem a visão, mas não tem o entusiasmo nem a coragem: vê o mal, mas não pode ou não sabe arcar contra ele. Quero crer não ser este precisamente o meu caso”. 996

Um dos maiores sonhos de Sílvio era um dia ver a História brasileira contada na América e ver o Brasil como nação forte e homogênea. De seu nacionalismo, surgiam as reflexões acerca de toda a dependência brasileira, tanto no plano econômico como cultural, uma herança colonial que bem evidenciava quatros séculos de completo atraso. Após farta produção intelectual, investindo sob os mais diversificados olhares na análise da sociedade brasileira, Romero concluía que a maior herança do país devia-se ao fato de ser ex-colônia portuguesa. Inúmeras vezes, cometeu sérios equívocos quando num primeiro momento elogiou o estágio esplendoroso da raça portuguesa no plano das Ciências e das Artes para depois afirmar que o atraso brasileiro devia-se ao declínio geral da raça ibero-latina.

O esforço do crítico não fora fácil quando buscava encontrar o ponto de partida para a independência literária de seu país. Sempre que levantava as escolas literárias brasileiras, buscava encontrar o escritor que mais identificava com o caráter brasileiro, aquele que encarnava a alma nacional e que só assim podia lutar pela construção de um Brasil melhor. É que Sílvio via os literatos a partir da dedicação que tinham ao Brasil.

\footnotetext{
${ }^{994}$ ROMERO, Sílvio: Parnaso sergipano. Aracaju: Tipografia do Estado de Sergipe, 1899. pp. 21-22

${ }^{995}$ ROMERO, Sílvio. O Brasil Social..Op. Cit. p. 240.

${ }^{996}$ ROMERO, Sílvio. O Brasil social. p.240
} 
A independência "literária", aos olhos de Romero, precisava contemplar a cultura de maneira geral, dada a abrangência que o termo Literatura carregava, segundo a concepção germânica, mas a evolução da História brasileira sempre esbarrava na mestiçagem, o que impossibilitou Sílvio de desprezar toda a herança colonial portuguesa. Afinal de contas, esquecer a contribuição lusitana seria ignorar a parte mais significativa para a formulação da futura nação brasileira. Contrário a qualquer forma de imitação, principalmente em relação às tradições francesas, tanto no plano da cultura como no da organização social e política, o brasileirismo sempre estava presente em seus escritos.

Desde os primeiros artigos nos jornais pernambucanos, a série de artigos contra o Romantismo Brasileiro, quando ainda cursava Direito, até seu último livro, Minhas Contradições, lançado em 1914, o pano de fundo de tão vasta produção é a vontade de mudar o Brasil, falando e partindo do que via como as principais questões do atraso brasileiro. A paixão que tinha pelo país e a vontade de ver um dia a História do Brasil contada na América tornou Sílvio o tipo de escritor missionário, muitas vezes agredindo e sendo injusto com seus adversários. No prólogo de sua História da Literatura Brasileira, percebe-se o brasileirismo do polígrafo, quando afirmou que "este livro é um livro de amor, feito por um homem que sente há perto de vinte anos sobre o coração o peso do ódio que lhe tem sido votado em sua pátria...”. 997 Espécie de presente ao país, sua História da Literatura era publicada no momento de libertação dos escravos, para a emoção demonstrativa de tanta paixão pelo Brasil.

"No momento em que traço estas linhas troa por toda a parte o ruído das festas da abolição. A lei foi sancionada pela regente há poucos dias, está-se no período dos festejos promovidos pela imprensa da capital

Um fenômeno singular salienta-se já aos olhos do observador independente: cada um já vai puxando para si as glórias do feito e deixando os outros atirados na sombra...",998

Tamanho empenho foi recompensando por ser sua História da Literatura Brasileira o primeiro estudo sistemático da Literatura nacional brasileira. Literatura essa entendida como toda e qualquer manifestação do espírito, contrário à concepção literária restrita às Belas Artes.

Daí é que se entende o lado polêmico de Sílvio e o turbilhão que foi, mas Araripe Junior nos fala de seu espírito bonachão. Quando arrolava os tantos problemas brasileiros, era pensando a todo custo subtrair a situação de atraso que pairava por todo o país. Assim, se o atraso material e cultural do país era evidente; se o ensino retórico propagado ao longo do império e até nas Faculdades ainda persistia, influenciado que era pelo método coimbrão, se a Metafísica ainda reinava quando do surgimento das idéias novas, se a situação literária e filosófica baseava-se na mera imitação, se a Política dos dirigentes nacionais reduzia-se à arte de mentir habilmente, se a situação do país nem mesmo com o advento da

\footnotetext{
${ }^{997}$ ROMERO, Sílvio. História... Op. Cit. p.37
}

998 Ibidem. p. 37 
República havia progredido era porque os políticos e escritores não olhavam para seus problemas tão graves.

Por isso é que analisando a evolução de gêneros como o romance, o drama e a poesia, concluía que "A melhor condição para isto é cultivar os assuntos brasileiros, conhecer a vida deste país. Sua Etnografia, sua História, sua Literatura, sua demografia, seu folclore, não falando já no interesse incomparável do estudo de sua geologia, de sua Geografia, de sua fauna, de sua flora, que belos assuntos oferecidos à sagacidade, ao talento, ao patriotismo de nossa mocidade!" 999

${ }^{999}$ ROMERO, Sílvio. Movimento Espiritual... Op. Cit. p.208. 


\section{CONCLUSÕES}

\section{AINDA FAZ SENTIDO LER SÍLVIO ROMERO “DEPOIS" DAS RAÇAS?}

Depois de passadas as acaloradas discussões que buscavam identificar o brasileiro, num Brasil visto pelas elites como atrasado, devido à economia agrária, aos milhares de negros e mestiços e ao analfabetismo da população geral, é de se perguntar sobre a situação atual do país. Obviamente os tempos são outros e os olhares bem diferentes dos olhares de homens que viveram à época de Sílvio Romero. Mas, na história, há rupturas e continuidades e os antigos parâmetros não mais existem, pois se diluíram e formaram novos olhares, que não perdem de vista a situação do Brasil e ainda trazem de maneira paradoxal as clássicas idéias do Brasil atrasado, pois embora a ciência, cada vez mais se divida, muitas imagens do Brasil são as mesmas que a elite material e intelectual, na passagem do século XIX para o XX, tanto combateu.

Na temática racial aqui abordada, a ideologia da degeneração, resultante do cruzamento de brancos com índios e negros, ainda se mostra muito importante num país cada vez mais mestiço. Se as teorias da desigualdade inata das raças ficaram no passado, vivenciamos hoje as conseqüências de um triste passado legitimado por personagens dotados de saber, alguns confortados na boa posição econômica. Onde andava o povo? Qual a situação social da população geral que sequer era assistida com as mínimas condições de sobrevivência? Eram utópicas as idéias de jovens estudantes fechados no mundo acadêmico em defesa do progresso que marginalizava cada vez mais a população em geral? Até que ponto leituras pautadas no olhar de fora contribuíram para o conhecimento do "verdadaeiro" Brasil, e forjaram a identidade nacional, mas uma identidade que por si só era por demais excludente?

Estas e tantas outras questões inquietaram inúmeros intelectuais brasileiros, confluindo sempre no bem maior, no caso, a "busca" pelo Brasil. País surgido sob a violência do europeu, que para cá se dirigiu almejando encontrar riquezas, o Brasil surgiu sob os olhares dos remanescentes portugueses. A independência nunca significou libertação, ao contrário, somente reforçou a dependência lusitana deitada sob a tutela dos Braganças. Surgia o Brasil forjado pelos letrados instruídos nas universidades européias, que se formavam sob a veste retórica da nação e de seu "povo", excluindo índios e negros. Escritores da geração romântica, letrados assistidos pelo erudito Pedro II, integrantes do IHGB buscaram conhecer o Brasil, tendo que para isso averiguar a raça do índio e do africano, muitas vezes cometendo um injusto critério de análise. O país nasceu do interesse do homem civilizado, branco e católico, excluindo a maioria da população pobre e despossuída. 
Este era o quadro nacional até o aparecimento na arena literária de Sílvio Romero. Os estudos de Sílvio, no que pesem sua intrepidez e arrogância, falam do que era o Brasil dependente, do Brasil que precisava se libertar e criar sua identidade. Para isso, o conhecimento do país e de seu povo mostravase ser da mais alta relevância. Todos os problemas brasileiros foram sentidos pelo autor, através deles, a miséria da população e a corrupção dos políticos nacionais foram denunciadas de maneira nunca vista na história nacional. Todo o passado brasileiro fora posto em xeque, e o país passou a ser visto de maneira nada romântica, sob um Naturalismo sem igual. Fosse no plano político, econômico, social, cultural, o país, conforme as denúncias de Sílvio sofria de profundo atraso. O combatente Sílvio se armou $^{1000}$ do que era na época, a seu ver, a última verdade científica para entender o Brasil e assim analisar quais os pontos pertinentes para preterir todo o passado tupiniquim na inauguração do novo Brasil. Diante de tantas idéias, idéias em penca, o erudito e homem amante da cultura popular, admirador das tradições das pessoas humildes e fiel ao seu universo mental de origem, enfrentou Sílvio o conflito de apreender o Brasil a partir da ilustração e macaqueação européia, o que em vida tanto combateu. Sua paixão pelo país confundiu-se e misturou-se à injustiça diante de nomes importantes das letras nacionais.

Sílvio não escapou a nenhum tema pertinente ao desenvolvimento do país, em quaisquer áreas. A ciência foi seu maior instrumento na reelaboração do Brasil. Em um momento em que o país rumava para o novo e carregava o rótulo de barbárie, o escritor olhou para os povos indígenas e a exploração desumana do negro, embora não se discuta que Sílvio concebia o homem branco como superior e se mostrasse muito convicto do desaparecimento dos povos há pouco aludido, olhou para sua rica contribuição. Mas é preciso antes de lermos as duras críticas que recaem sobre a figura de Sílvio reconhecer que a análise de progresso ou de atraso da sociedade baseava-se nas raças formadoras desta mesma sociedade. Se não há dúvidas, em várias passagens de sua farta produção, que era pela raça que o atraso era diagnosticado, ao contrário de alguns polígrafos de sua época, defendia que o atraso cultural do país poderia ser mudado, pois a interação entre a raça, o meio e o homem possibilitava a inversão de tais elementos. Conhecedor dos mais variados campos do saber, Sílvio fora um usuário do conceito de raça diferente!

A raça formadora da sociedade brasileira num meio inóspito não poderia trazer o progresso, era possível ainda que remotamente, mudar o país. Em Sílvio a questão racial assumia enorme importância. Não estamos a inverter a visão do escritor sergipano, mas a problemática racial em Sílvio vai muito além das raças. Ambiguidades não foram poucas, polêmicas muitos menos, mas tudo em nome do conhecimento do Brasil. O maior argumento de Sílvio foi o Evolucionismo, mas um

${ }^{1000}$ SODRÉ, Nelson Werneck. Ideologia do Colonialismo. Op. Cit 
evolucionismo integrado a um todo, uma visão que ele mesmo definia como orgânica. Toda e qualquer temática levantada por Sílvio trazia em pauta esta vertente, a partir da qual levantou questões e desdobrou seus pensamentos, abrindo, cada vez mais, horizontes, ao ponto de afirmar que sua filosofia era não ter nenhuma Filosofia. Mesmo em sua época, Sílvio abria sua mente para encontrar um ponto de partida, e o que era arte para alguns escritores, era para Sílvio, antes de qualquer coisa, apenas mais um ponto de questionamento. Adentrou no cenário político e foi deputado em seu estado, participando da deposição de um político tradicional, representante das oligarquias locais.

Arrojado e destemido, buscou a fundo identificar os elementos fundamentais para compreender o Brasil. Por vezes, afirmava que era o meio, outras vezes, pontuava o momento histórico, mas não conseguia esquecer a raça latina, raça que mais contribuiu na formação do povo brasileiro. Como se não bastasse o momento histórico e político, fundamental para compreensão de toda a situação de atraso, identificação dos males e a busca pelas soluções, adentrou Sílvio em uma questão não menos embaraçosa, no caso, a problemática das raças, de maneira específica, ponturar rigorosamente o que coube a cada uma das raças. A cada passo que dava em busca do caráter nacional brasileiro, "chave explicativa" para investigar a situação brasileira nos mais variados campos, mais demonstrava a fragilidade desta ideologia dos homens de sua época.

O racismo influenciou Sílvio a ponto de ele reconhecer a superação daqueles que ele mesmo afirmava serem a parte da sociedade que mais havia trabalhado em benefício do país. Era preciso conhecer todos os estratos sociais, dividi-los, para só assim viabilizar o amplo processo de desenvolvimento do país. Só o conhecimento imparcial e verdadeiro possibilitaria subtrair o atraso do país, conhecimento este que acolhia a grande população e que tinha espaço para aceitar a cultura rica não letrada desta. É de admirar que Sílvio com tantas leituras tenha acreditado tanto na força do povo, formado pelos índios e negros, na construção do novo Brasil.

O novo, mais rico Brasil, com sua ampla cultura e suas riquezas materiais, era também o país da diferença, que se fazia a cada passo de sua história. Diferente de tantos outros ensaístas que viam o declínio dos povos pobres, sub-raças, consideradas atrasadas, Sílvio sabia da extrema importância desses povos. Sua concepção inaugurou uma nova era, um novo olhar na busca pela identidade nacional. Sílvio foi a representação direta do Brasil moderno, modernidade essa que ao mesmo tempo em que traria a superação das raças inferiores pela cultura branca civilizada, trazia a possibilidade de um Brasil mais justo e mais digno para as camadas despossuídas. O novo Brasil, ainda que predominasse a supremacia da cultura letrada européia, abria caminho para as manifestações populares, o mais importante era dá o devido valor à herança brasileira. Num país onde desde cedo se presenciou o etnocídio, o genocídio das populações indígenas e a exploração do africano, era de primeira ordem ser justo com a contribuição dessas raças. Jamais o país poderia se desenvolver tanto 
no plano econômico, social e cultural sem que tivesse rigidamente pontuado a contribuição de índios e negros.

Mais interessante do que apreender as conclusões de Silvio com relação aos índios que habitavam o Brasil, vivendo num estado fetichista, e ao negro africano é reconhecer seu esforço para atribuir a devida importância a essas raças. Sem esta ressalva, Sílvio não pode ser compreendido e sua farta contribuição intelectual fica comprometida. Sílvio era o Brasil do futuro, o Brasil moderno, o Brasil que não existiu ao longo da história. A época em que viveu e as teorias que tinha em mãos nos permitem afirmar um escritor cindido: mirou-se nas idéias mais prestigiadas do momento para negar o passado do país e trazer o que nunca tinha sido considerado. Foi um movimento duplo, de vai e volta, buscando e mesmo negando o passado brasileiro. Negou toda a história passada até o aparecimento da crítica moderna, confundida com sua própria pessoa, sendo muito brasileiro. Muito se entende do polemista que foi e da maneira como se colocava se levarmos em consideração sua paixão pelo Brasil. Frente a tantas teorias, escolheu a lei do mais forte e o evolucionismo. Nada mais coerente para um pensador que criticou e não deixou nada em pé do passado nacional, fosse qual fosse a área.

O Brasil e brasileiro eram frutos das três raças e o caráter nacional foi para Sílvio o mais importante elemento para o conhecimento do país. A mestiçagem estava para o Brasil assim como o Brasil estava para a soma das três raças. Era a "chave explicativa" do Brasil. Sílvio ficou reduzido a um olhar determinista, mas é de admirar seu enorme esforço, suas múltiplas leituras, do evolucionismo mais ferrenho ao socialismo mais utópico, na busca para compreender a pobreza de um terço da população que sustentava a elite política e intelectual do país. De tanto querer conhecer o país, afora a crença na superioridade do branco, procurou um ponto de apoio para suas análises. Algumas vezes, Sílvio fugiu da explicação racista, embora nunca tenha perdido de vista a importância da raça na explicação dos fatores sociais e culturais, daí apenas uma de suas várias contradições. Entre um pólo e outro, muita coisa pode ser encontrada na maneira de Sílvio pensar o Brasil. Sua visão por demais esquemática, influenciada pela cultura européia, o fez adentrar a cultura popular, ainda que uma cultura vista sob o olhar da cultura letrada do erudito com sua visão ilustrada formada pela universidade, que concebe a cultura como morta. ${ }^{1001}$

Sílvio sintetizou o que nenhum escritor anterior ao seu aparecimento havia realizado, colocou o povo como parte integrante da identidade brasileira. O povo que Sílvio fez questão de ressaltar era diferente do povo pensando e aludido pelos escritores de antes: os estratos mais humildes participariam dentro de seus mundos do desenvolvimento do país. Apaixonado pelo Brasil, admirador da cultura das pessoas mais simples, seu traço de polemista, mas homem bonachão fez de si um

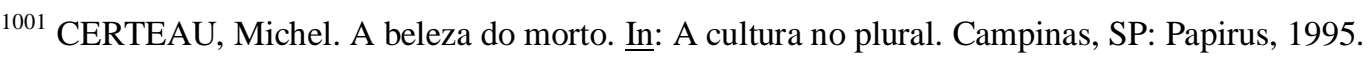


escritor que dava a mão à palmatória, um justiceiro sempre em busca da verdade. Quanta paixão sentida no feitio de seus vários livros, do defensor das pessoas mais simples, dos poetas nunca lembrados do Sergipe, do mais importante amigo e companheiro de refregas, o mulato Tobias Barreto! Era o espírito de Sílvio, fera ferida ${ }^{1002}$, sempre polêmico, justiceiro, leitor de muitos livros e autores, verdadeiro turbilhão que nunca deixou de ter posição quando se tratava de Brasil.

A libertação do país carecia de elementos nacionais. Para isso, Sílvio combateu todo o passado brasileiro, almejando encontrar o Brasil. Foi romântico, destemido, por certo utópico, mas sem sombra de dúvidas, preocupado com seu país. Falou em nome do desenvolvimento do Brasil alertando claramente que não possuía interesse algum diante de suas argumentações, previu de maneira admirável o que seria o Brasil do futuro. Continua o brasileiro desinteressado pelos problemas de seu país, várias são as nacionalidades aqui residentes, o que dificulta a formação do nacional, as elites intelectual e econômica mais se preocupam com a vaidade e o poder do que com os problemas mais urgentes do país. A falta de paixão pelo país continua, o que segundo Sílvio explicava a corrupção espalhada em todo o país. O conhecimento nos dias atuais cada vez mais se especializa e se torna instrumental e mercadoria, tema que se arrasta desde a corrida aos cursos de Direito na história do Império brasileiro. A falta de amor dos professores as suas carreiras salta aos olhos.

E a situação racial do momento?

Sílvio apelou para argumentos raciais, mitigou o naturalismo, mas os pontos ou temáticas abordadas nos fazem reconhecer o fecundo escritor que foi.

Estas conclusões são escritas em 2012, 67 anos após a derrocada do Nazismo, 45 anos depois do fim do Apartheid no sul dos Estados Unidos da América (considerando a declaração pela Suprema Corte daquele país de que era inconstitucional a proibição de casamentos interaciais), 18 anos sem Apartheid na África do Sul. E no Brasil, a Lei Afonso Arinos, de 1951, tratou de criminalizar a discriminação racial.

Tais registros sugerem um mundo sem racismo, um mundo além das raças.

Algumas tragédias como a prática de "limpeza étnica" na ex-Iugoslávia, na última década do século XX, e as grandes tensões e violências entre israelenses e "árabes” (muito mais que árabes, certamente palestinos, talvez muçulmanos do Oriente Próximo e do Oriente Médio), até hoje, lembram que o preconceito destrutivo ainda existe, pode ser que menos poderoso, todavia ameaçador e com grande capacidade destrutiva, evocando terríveis práticas racistas. E o Nazismo, embora derrotado no desfecho da Segunda Guerra Mundial, insiste em tentar sobreviver através do Negacionismo e outros esforços de reabilitação de seus crimes.

1002 DIMAS, Antonio. O turbulento e fecundo Sílvio Romero. Op. Cit 
Apesar disso, a argumentação racista perdeu força a partir de meados do século XX e é mesmo criminalizada mundialmente, com o endosso da ONU. A consolidação dos estudos em Biologia e campos próximos de saberes, evidenciando o caráter social do conceito de raça, demonstrou a absoluta inconsistência argumentativa das teorias racistas que sustentaram Nazismo e outras correntes de extermínio humano ou exclusão social em nome daquele (pre)conceito.

Sendo assim, num mundo quase depois das raças - ou no limiar das raças -, ainda faz sentido ler Silvio Romero?

É uma pergunta que, numa pesquisa histórica, assume um peso apenas retórico. Do ponto de vista do conhecimento histórico, sempre fará sentido ler documentação de qualquer época para explicar as experiências humanas a seu redor. Resta pensar sobre horizontes talvez surpreendentes que a interpretação desses documentos - os escritos de Silvio Romero - revela para o pesquisador e ultrapassam a exclusiva erudição documental. Junto com essa obviedade historiográfica, vale a pena realçar algumas facetas de uma leitura de Romero depois de Nazismo e Apartheids superados - ou, ao menos, enfraquecidos.

O primeiro título desta pesquisa foi Além das raças - Silvio Romero (1870/1914) e ele constou do Relatório para Exame de Qualificação que apresentei ao Programa de Pós-Graduação em História Social da FFLCH/USP, diante de Banca Examinadora formada pelos Profs. Drs. José Maria de Oliveira Silva, Ricardo Bechelli e Marcos Silva (o último orientou este trabalho). Tal título preliminar procurava enfatizar como Romero conseguira ultrapassar o conceito de raça, aparente paradoxo num autor que tanto o utilizava. Comentários dos Drs. Oliveira Silva e Bechelli naquele exame, depois reforçados por meu Orientador em colóquios de pesquisa, permitiram-me entender que havia certo excesso interpretativo de minha parte em relação a um "ir além". O conceito de raça permaneceu na escrita de Romero, embora redirecionado e fortemente vinculado a dimensões culturais e mesmo psicológicas, em termos coletivos.

Finalizando o trabalho, optei pelo título No limiar das raças - Silvio Romero (1870/1914). Entendo que, sem eliminar o conceito de raça, Romero apresenta tensões em relação a seu entendimento estritamente biológico, questão que foi discutida antes por Bechelli e que abrangeu importantes pensadores contemporâneos de Romero ou que se sucederam imediatamente a ele, como Nina Rodrigues, Euclides da Cunha e Oliveira Viana ${ }^{1003}$. A áspera polêmica de Silvio com Manoel Bomfim, muito bem analisada por Oliveira Silva ${ }^{1004}$, revela certa incompreensão de Romero em relação ao que ele mesmo fazia, atitude mesclada a sua vontade de guerrear intelectualmente.

\footnotetext{
1003 BECHELLI, Ricardo Sequeira. Metamorfoses na interpretação do Brasil: Tensões no paradigma racial (Silvio Romeiro, Nina Rodrigues, Euclides da Cunha e Oliveira Vianna). Op. Cit.

${ }^{1004}$ José Maria de Oliveira. Da Revolução à Educação - Radicalismo republicano em Manoel Bomfim. Op. Cit.
} 
Romero alcançou ecos em importantes debatedores brasileiros das questões sociais posteriores àquele grupo estudado por Bechelli. Comentando o Jorge Amado de Tenda dos milagres, Marcos Silva arrolou nomes como Lima Barreto (ainda contemporâneo de Silvio), Monteiro Lobato, Paulo Prado, Mario de Andrade, Luís da Câmara Cascudo (que organizou edição crítica de estudos de Romero sobre cantos e contos populares) e Gilberto Freyre, que adensaram cada vez mais interpretações de "raça" como etnia e cultura ${ }^{1005}$.

Rediscutir Silvio Romero e suas relações com o conceito de raça, portanto, é também rever essa rica tradição de debate sobre culturas no Brasil, que encarou a diversidade de identidades humanas na História, crescentemente, a partir de suas potencialidades culturais. Há um antiracismo que se desdobra dessa valorização das múltiplas culturas e Silvio Romero trouxe contribuições pioneiras para esse debate.

Mais que uma surpresa documental, a leitura dos escritos de Silvio Romero se revela o reencontro com uma voz presente no Brasil do século XX e até hoje através de diversificadas interpretações e novos direcionamentos nos estudos sobre História e sociedade no país, em diálogo com também novas experiências culturais e sociais aqui e noutras partes do mundo, que abrangem o fim do colonialismo na África e os movimentos de afirmação de grupos étnicos secularmente oprimidos em diferentes países.

E Romero nos prova que o pensamento pode ir além de preconceitos até para quem não sabia que estava em seu limiar, prestes a ultrapassá-los.

Nesse sentido, o conhecimento se revela mais que ideologia. Reafirma-se o pioneirismo de Silvio Romero na consolidação das Ciências Sociais no Brasil.

1005 SILVA, Marcos. "Milagres da Literatura - A liberdade zomba da ditadura em Tenda dos milagres". Texto de conferência apresentada no Simpósio Nacional de História Cultural da ANPUH (Teresina, PI). Digitado, 27 pp, 2012. 


\section{Fontes Primárias}

ROMERO, Silvio. Autores brasileiros. (edição comemorativa). Rio de Janeiro: Imago Editora; Aracaju; Sergipe: Universidade Federal de Sergipe, 2002

Castilhismo no Rio Grande do sul. Porto: Comércio do Porto, 1912.

Etnografia Brasileira: estudos críticos sobre Couto de Magalhães, Barbosa Rodrigues, Teófilo Braga, Ladislao Neto. Rio de Janeiro: Livraria Clássica de Alves \& C, 1888.

Estudos de Literatura Contemporânea. (edição comemorativa). Rio de Janeiro: Imago

Editora; Aracaju; Sergipe: Universidade Federal de Sergipe, 2002. (1 ${ }^{\mathrm{a}}$. Ed. 1884)

Estudos sobre a poesia popular no Brasil. Petrópolis: vozes, 1977. (1ª Ed. 1889)

Folclore brasileiro: cantos populares do Brasil: Rio de Janeiro: José Olympio, 1954. (1 ${ }^{\mathrm{a}}$. Ed. 1883)

Folclore brasileiro: contos populares do Brasil. Belo Horizonte: Ed. Itatiaia; São Paulo: Ed. da Universidade de São Paulo. (1 ${ }^{\mathrm{a}}$ Ed. 1885)

Geografia da politicagem: o norte e o sul do Brasil. S.l. S.N., 1912.

História da Literatura Brasileira. I, II, III. Rio de Janeiro: José Olimpio, 1960. (1ª . Ed. 1888)

Doutrina contra doutrina. Sílvio Romero. Companhia das Letras, 2001. (1ª Ed.1894)

Minhas contradições. Bahia: Catilina, 1914.

O Brasil social e outros estudos sociológicos. Brasília: Senado Federal, 2001. (1ª Ed. 1908)

Obra Filosófica. Rio de Janeiro: José Olimpio, 1969.

Provocações e debates. Contribuições para o estudo do Brasil Social. Porto: Imprensa Moderna, 1908.

\section{Bibliografia}

ABREU, J. Capistrano de. Capítulos de História Colonial. 7ª Ed. São Paulo: Editora Itatiaia Limitada; EDUSP, 1988.

ABDALA JUNIOR, Benjamim. Sílvio Romero: História da Literatura Brasileira. In: Introdução ao Brasil. Um banquete nos trópicos. São Paulo: Editora SENAC, 2001. pp. 196-199.

ADORNO, Sergio. Os aprendizes do Poder: o bacharelismo liberal na política brasileira. Rio de Janeiro: Paz e Terra, 1988.

ALENCAR, José de Alencar. Ao povo: cartas políticas de Erasmo. Rio de Janeiro: Tipografia Pinheiro, 1866. 
ALENCASTRO, Luiz Felipe de (Org). Império: a corte e a modernidade nacional: Cia das Letras, 1988.

Vida Privada e ordem privada no Império. In: NOVAIS, Fernando. História da Vida Privada no Brasil. São Paulo: Cia das Letras, 1997.

ALONSO, Ângela. Idéias em movimento: a geração 1870 na crise do Brasil - Império. São Paulo: Paz e Terra, 2002.

Positivismo: uso tópico. O projeto civilizatório de Luis Pereira Barreto. Dissertação de Mestrado. São Paulo: USP, 1994.

ANCHIETA, José de. Cartas inéditas. Instituto Histórico e Geográfico Brasileiro. Edição comemorativa do $4^{\text {a }}$. centenário. São Paulo: Tipografia Eclética, 1900.

ANDERSON, Benedict. Nação e consciência nacional. São Paulo: Ática, 1989.

ANDRADE, Mario de. Macunaíma. www.sabotagem.revolt.org. pdf

ANDREWS, George Reid. Negros e brancos em São Paulo. Barueri, SP: Edusc, 1988.

ARARIPE JUNIOR, Tristão de Alencar. Silvio Romero Polemista. Obra Crítica, Ed. Afrânio Coutinho. Rio de Janeiro, Casa de Rui Barbosa, 1958-70, 5 vols., vol.III, 1963, pp. 271-332.

ARENDT, Hannah. Origens do Totalitarismo. São Paulo: Companhia das Letras, 2004

ARENDT, Hannah. Entre o passado e o futuro. 6a . Ed. São Paulo: Perspectiva, 2007.

ARGEU, Guimarães. Presença de Silvio Romero. Rio de Janeiro: Organização Simões, 1955.

ASSIS, Machado de. Obra completa. V.III. Rio de Janeiro: Editora Nova Aguilar, 2008. pp. 801-836

AZEVEDO, Célia Maria Marinho de. Onda negra medo branco: o negro no imaginário das elites século XIX. $3^{\text {a }}$ ed. São Paulo: Annablume, 2004.

AZEVEDO, Fernando de. A cultura brasileira: introdução ao estudo da cultura no Brasil. 4a . Ed. São Paulo: UNB, 1963.

AZEVEDO, Sânzio de. A Academia Francesa do Ceará (1873-1875). Fortaleza: Casa de José de Alencar da Universidade Federal do Ceará, 1971.

AUERBACH, Erich. Ensaios de Literatura ocidental: filologia e Crítica. São Paulo: Duas Cidades; Ed. 34, 2007

BANTON, Michael. A idéia de raça. Lisboa: Edições 70, 1979.

BARBOSA, João Alexandre. A Biblioteca Imaginária. São Paulo: Ateliê Editorial, 1996

BARREIRA, Dolor. História da Literatura Cearense. Fortaleza: Instituto do Ceará, 1948 
BARROS, FILHO. Indo a Nina Rodrigues: as "premissas" de As Raças Humanas e a responsabilidade penal no Brasil. Caderno Pós Ciências Sociais - São Luís, v.2, na. 4, Julho/ Dezembro, 2008.

BECHELLI, Ricardo Sequeira. Metamorfoses na interpretação do Brasil: Tensões no paradigma racial (Silvio Romeiro, Nina Rodrigues, Euclides da Cunha e Oliveira Vianna). Tese Apresentada ao Programa de Pós Graduação em História Social da Faculdade de Filosofia, Letras e Ciências Humanas. São Paulo: 2009.

BERBEL, Márcia Regina. A nação como Artefato: deputados do Brasil nas cortes portuguesas (1821-1822). São Paulo: Hucitec: FAPESP, 1999.

BERGO, Antonio Carlos. "Darwinismo social" e Educação no Brasil. Tese (Doutorado em Educação). Unicamp, 1993.

BEZERRA, Alcides. Sylvio Romero, o pensador e o sociólogo: conferencia pronunciada, no dia 17 de outubro de 1929, na Sociedade Brasileira de Filosofia. Rio de Janeiro: Oficinas Gráficas do Arquivo Nacional, 1935.

BHABHA, Homi. O local da cultura. Belo Horizonte: Ed. UFMG, 1998.

BODEI, Remo. A história tem um sentido? São Paulo/Bauru: Edusc, 2001

BRESCIANI, Maria Stella. O charme da Ciência e a sedução da objetividade: Oliveira Vianna entre intérpretes do Brasil. São Paulo: UNESP, 2007.

BONFIM, Manoel. A América Latina: males de Origem. Rio de Janeiro: centro edelstein de pesquisas sociais, 2008.

O Brasil nação: realidade e soberania nacional. 2ª Ed. Rio de Janeiro: Topbooks, 1996.

BOSI, Alfredo. Dialética da colonização. São Paulo: Companhia das Letras, 1996.

BROCA, Brito. A vida literária no Brasil 1900. Rio de Janeiro: José Olympio, 2005.

CAIRO, Luiz Roberto Velloso. Do Florilégio a Antologia da Poesia Brasileira da Invenção: uma reflexão sobre o Paradigma da História da Literatura Brasileira. Revista de Estudos de Literatura. Belo Horizonte, V.3, pp. 43-53, out.95. Disponível em http://www.letras.ufmg.br/poslit

CAMPANELLA, Tommaso. A cidade do sol. São Paulo: Ícone, 2002.

CÂNDIDO, Antonio. A literatura durante o império. In: Reações e transações. História da civilização brasileira. O Brasil monárquico. Tomo II, $3^{\text {a }}$. V (Org) Sérgio Buarque de Holanda $5^{\text {a }}$. Ed. São Paulo: Difel, 1985.

A Sociologia no Brasil. Tempo Social, 271/301, V.18, nª 1, 1959. 
Formação da literatura brasileira: momentos decisivos. 6a ${ }^{a}$ ed. Belo Horizonte: Ed. Itatiaia, 1981.

Iniciação a Literatura Brasileira. 5a. Ed. Rio de Janeiro: Ouro sobre Azul, 2007.

Introdução ao método crítico de Silvio Romero. São Paulo: Tese/FFLCH, 1945.

Literatura e cultura de 1900 a 1945, In: Literatura e sociedade. São Paulo: Ouro sobre azul, 2011.

O romantismo no Brasil. São Paulo: Humanitas/FFFLCH, 2004.

Radicalismos. Estudos Avançados, 4 (8), 1988. p. 12

Sílvio Romero: Teoria, Crítica e História literária. Rio de Janeiro: livros técnicos e científicos; São Paulo: Edusp, 1978

CARDIM, Fernão. Do princípio e origem dos índios do Brasil e de seus costumes, adoração e cerimônias. Rio de Janeiro: Gazeta de Noticias, 1881

CARNEIRO, Maria Luiza Tucci. O racismo na História do Brasil: mito e realidade. São Paulo: Ática, 1994

CARPEAUX, Otto Maria. História da Literatura Ocidental. V. 1. Rio de Janeiro: Edições O Cruzeiro, 1959

CARVALHO, José Murilo de. A construção da ordem: a elite política imperial. Teatro de sombras: a política imperial. Rio de Janeiro: Civilização Brasileira, 2003

A formação das almas: o imaginário da República no Brasil. São Paulo: Companhia das Letras, 1990.

Os bestializados: o Rio de Janeiro que não foi. São Paulo: Companhia das letras, 1987.

CASCUDO, Câmara. In: Folclore Brasileiro: cantos populares do Brasil. Tomo I. Rio de Janeiro: José Olimpio, 1954

CAVALLI-SFORZA, Luigi Luca. Genes, povos e línguas. São Paulo: Cia das Letras, 2003.

CERTEAU, Michel de. A Cultura no Plural. Campinas: São Paulo: Papirus, 1995.

A Escrita da história. Rio de Janeiro: Forense Universitária, 1982.

CESAR, Guilhermino. Historiadores e críticos do romantismo: a contribuição européia, crítica e história literária. Rio de Janeiro: Livros técnicos e Científicos; São Paulo: EDUSP, 1978.

CEZAR, Temístocles. Em nome do pai, mas não do patriarca: ensaios sobre os limites da imparcialidade na obra de Varnhagen. História. São Paulo, v. 24, nª 2, pp. 207-240, 2005. 
CHALHOUB, Sidney. Cidade Febril: cortiços e epidemias na corte imperial. São Paulo: Cia das Letras, 1996.

Visões da Liberdade: uma história das ultimas décadas da escravidão na corte. São Paulo, Cia. das letras, 1990.

CHARTIER, Roger. A história cultural entre práticas e representações. Rio de Janeiro: Bertrand Brasil. Lisboa. DIFEL, 1990.

CHAUI, Marilena. Brasil: mito fundador e sociedade autoritária. São Paulo: Ed. Fundação Perseu Abramo, 2000.

CLASTRES, Pierre. Arqueologia da violência: pesquisas de antropologia política. São Paulo: Cosac \& Naify, 2004

A sociedade contra o estado: pesquisas de antropologia política. $5^{a}$ ed. São Paulo: Rio de Janeiro: Francisco Alves, 1990.

COMTE, Auguste. Curso de filosofia positiva São Paulo: Nova Cultural, 1991.

CORRÊA, Mariza. As ilusões da liberdade: a Escola Nina Rodrigues e a antropologia no Brasil. Bragança Paulista, BP: EDUSF, 1988.

Raimundo Nina Rodrigues e a garantia da ordem social. REVISTA USP, São Paulo, n.68, p. 130-139, dezembro/fevereiro 2005-2006.

CORTEZÃO, Jaime. A expedição de Pedro Álvares Cabral e o descobrimento do Brasil. Lisboa: Imprensa. Nacional-Casa da Moeda, 1994.

COSTA, Emília Viotti da. Da Monarquia à República. São Paulo: UNESP, 1999.

COSTA, Jean Carlo de Carvalho. Nação, Raça e Miscigenação no Brasil Moderno: uma análise hermenêutica dos ensaístas na formação da formação da nacionalidade brasileira, 1888-1928. Tese de Doutorado Apresentado ao Programa de Pós Graduação em Social da Universidade Federal de Pernambuco. 2003

COSTA FILHO, Cícero João da. Padaria Espiritual: cultura e política em Fortaleza no final do século XIX (1892-1898). Dissertação de Mestrado apresentada a Faculdade de Filosofia, Letras e Ciências Humanas de São Paulo, 2007.

COSTA, Hilton. Horizontes raciais: a idéia de raça no pensamento social brasileiro 1880-1920. Dissertação apresentada ao Programa de Pós Graduação em História/IFCH da UFRS, 2004. 
COSTA, Sérgio. A mestiçagem e seus contrários: etnicidade e nacionalidade no Brasil contemporâneo. Tempo Social. Revista de Sociologia, USP, São Paulo, 13 (1): 143-158, maio de 2001.

COSTA, João Cruz. Contribuição à História das idéias no Brasil. Rio de Janeiro: Civilização Brasileira, 1967.

Panorama da História da Filosofia no Brasil. São Paulo: Cultrix, 1959.

CUNHA, Euclides da. Os sertões. Rio de Janeiro: Laemmert C., 1905.

DAMATTA, Roberto. Relativizando: uma introdução a antropologia. Rio de Janeiro: Rocco, 1987 O que faz o Brasil, Brasil? Rio de Janeiro: Rocco, 1984.

DANTAS, Carolina Vianna. O Brasil café com leite: história, folclore, mestiçagem e identidade nacional em periódicos. Rio de Janeiro, 1903-1914. Tese defendida em 2007, no Programa de PósGraduação em História da UFF.

DARMON, Pierre. Médicos e assassinos na "Belle Époque": a medicalização do crime. Rio de Janeiro: Paz e Terra, 1991.

DIAS. Maria Odila Leite da Silva. A interiorização da metrópole e outros estudos. São Paulo: Alameda, 2005.

DIMAS, Antonio. O turbulento e fecundo Sílvio Romero. In: BOTELHO, André e SCHWARCZ, Lilia. (Org). 29 intérpretes e um país. São Paulo: Cia das Letras, 2009.

DOMINGUES, Heloisa Maria Bertol. Os intelectuais e o poder na construção da memória nacional. Revista Tempo Brasileiro, 87: 43/57, out-dez., 1986.

A Recepção do Darwinismo no Brasil. Rio de Janeiro: Fiocruz, 2003

ENGELS, Magali. Meretrizes e doutores: saber médico e prostituição no Rio de Janeiro (18401890). São Paulo: Brasiliense, 1989.

FAORO, Raimundo. Os Donos do Poder: formação do patronato político brasileiro. $3^{\mathrm{a}}$. Ed. Rev. São Paulo: Globo, 2001

FERNANDES, Florestan. Circuito Fechado: quatro ensaios sobre o “poder institucional”. 2a. Ed. São Paulo: Hucitec, 1977.

Significado do protesto negro. São Paulo: Cortez, 1989

FERREIRA, Ricardo Franklin \& CAMARGO, Amilton Carlos. As Relações Cotidianas e a Construção da Identidade Negra. Psicologia: Ciência e Profissão, 2011, 31(2), 374-389. 
FRANCO, Maria Sylvia Carvalho. As idéias estão no lugar. Cadernos Debate, 1. São Paulo: Brasiliense, 1976

FREYRE, Gilberto. Casa-Grande \& senzala: formação da família brasileira sob o regime da economia patriarcal. 48ª Ed. São Paulo: Global, 2003

Nordeste: aspectos da influência da cana sobre a vida e a paisagem do Nordeste do Brasil. $7^{\circ}$ Ed. Rev. São Paulo: Global, 2004.

Ordem \& progresso. Rio de Janeiro: Global, 2012.

FRY, Peter. Política, nacionalidade e o significado de "raça" no Brasil. In: Brasil: fardo do passado, promessa do futuro. Dez ensaios sobre política e sociedade brasileira. Org. Leslie Bethell. Rio de Janeiro: Civilização Brasileira, 2012

GANDAVO, Pero de Magalhães. História da Província Santa Cruz. Lisboa que vulgarmente chamamos Brasil: Tipografia da Real Academia das Ciências, 1858

Tratado da terra do Brasil. História da terra da Província Santa Cruz. Belo Horizonte: Itatiaia, 1980.

LÉRY, Jean de. Viagem à terra do Brasil. Tradução integral e notas de Sérgio Milliet; segundo a edição de Paul Gaffarel com o colóquio na língua brasílica e notas tupinológicas de Plínio Ayrosa. São Paulo: Biblioteca do Exército Editora, 1961.

GOULD, Stephen Jay. A falsa medida do homem. 2a . Ed. São Paulo: Martins Fontes, 1999. GRUPIONI, Luís Donizete Benzi (Org). A Carta de Pro Vaz de Caminha: documentos e ensaios sobre o achamento do Brasil. São Paulo: DBA, 2000. (Vários Autores)

GRUZINSKI, Serge. O pensamento mestiço. São Paulo: Companhia das Letras, 2001.

GUALTIERI, Regina Cândida Ellero. O Evolucionismo na Produção Científica do Museu Nacional do Rio de Janeiro (1876-1915). In: DOMINGUES, Heloisa Maria Bertol (Org). A Recepção do Darwinismo no Brasil. Rio de Janeiro: Editora Fiocruz, 2003.

GUIBERNAU, M. Montserrat. Nacionalismos: o estado nacional e o nacionalismo no século XX: Rio de Janeiro: Jorge Zahar, 1997.

GUIMARÃES, Argeu. Presença de Sílvio Romero. Rio de Janeiro: Organização Simões, 1955.

GUIMARÃES, Antonio Sergio Alfredo. Classes, raças e democarcia. São Paulo: Editora 34, 2002.

Preconceito de cor e racismo no Brasil. Revista de Antropologia, São Paulo, USP, 2004, v 47, $\mathrm{n}^{\mathrm{o}} 1$.

Raça, cor, cor da pele e etnia. Cadernos de campo, São Paulo, n. 20, p. 1-360, 2011 
GUIMARÃES, Manoel Luis Salgado. Nação e civilização nos trópicos: O IHGB e o projeto de uma história nacional. Estudos Históricos. Rio de Janeiro, n. 01, 1988.

Uma história da história nacional: textos de fundação. In: LIMA, Ivana Stolze; CARMO, Laura do (Org.). História social da língua nacional. Rio de Janeiro: Edições Casa de Rui Barbosa, 2008. p. 393-414

HASENBALG, Carlos A. Discriminação e desigualdade raciais no Brasil. São Paulo: Brasiliense, 1979.

HERINGER, Rosana. Desigualdades raciais no Brasil: síntese de indicadores e desafios no campo das políticas públicas. Cad. Saúde Pública, Rio de Janeiro, 18(Suplemento): 57-65, 2002

HERMAN, Arthur. A idéia de decadência na história ocidental. Rio de Janeiro: Record, 1999.

História da Educação / ASPHE (Associação Sul-Rio-Grandense de Pesquisadores em História da Educação) FAE/UFPel. n. 25 (Maio/Ago 2008) - Pelotas: ASPHE - Quadrimestral. pp.275-302

HIRATA, Alessandro. Sílvio Romero: o polemista da Escola do Recife. São Paulo, 2011.

HOBSBAWM, Eric J. Nações e nacionalismos desde 1780: programa mito e realidade. Rio de Janeiro: Paz \& Terra, 1990.

HOLANDA, Sérgio Buarque de. Raízes do Brasil. 26a . Ed São Paulo: Companhia das Letras, 1995.

Visão do Paraíso: os motivos edênicos no descobrimento e colonização do Brasil. São Paulo: Brasiliense; Publifolha, 2000.

IANNI, Octávio. A sociologia e o mundo moderno. São Paulo: EDUC, 1988.

Dialética das relações raciais. Estudos Avançados 18 (50), 2004.

O Preconceito racial no Brasil. Entrevista de Octávio Ianni. Estudos Avançados, 18 (50), 2004.

Raças e Classes sociais no Brasil. 3ª. Ed. São Paulo: Brasiliense, 1987.

IGLESIAS, Francisco. História e Ideologia. São Paulo: Perspectiva, 1981.

Os historiadores do Brasil: capítulos de historiografia brasileira. Rio de janeiro: Nova fronteira; Belo Horizonte, MG, IPEA, 2000.p.91.

JANCSÓ, István (Org). Independência: História e historiografia. São Paulo: Hucitec: FAPESP, 2005.

LE GOFF, Jacques. História e Memória. Campinas: Editora da Universidade de Campinas, 1990. 
LEITE, Dante Moreira. O caráter nacional brasileiro: história de uma ideologia. São Paulo: Pioneira, 1976.

LÉRY, Jean de. Viagem à terra do Brasil. Tradução integral e notas de Sérgio Milliet; segundo a edição de Paul Gaffarel com o colóquio na língua brasílica e notas tupinológicas de Plínio Ayrosa. São Paulo: Biblioteca do Exército Editora, 1961.

LEVI-STRAUSS, Claude. O olhar distanciado Lisboa: Edições 70, 1983.

LIMA, José Augusto da Rocha. Silvio Romero: Pensador, Escritor e Mestre. In: Revista de Aracaju, $\mathrm{n}^{\circ}$ 4. Aracaju, 1951.

LISBOA, Karen Macknow. Viagem pelo Brasil de Spix e Martius: Quadros da Natureza e Esboços de uma civilização.

LOWY, Michel e SAYRE, Robert. Romantismo e Política. Rio de Janeiro: Paz e terra, 1993.

KLINEBERG, Otto. As diferenças raciais. São Paulo: Companhia Editora Nacional, 1966.

KODAMA, Kaori. Os índios no Império do Brasil: a etnografia do IHGB entre as décadas de 1840 e 1860. Rio de Janeiro: FIOCRUZ; São Paulo: EDUSP, 2009

MACHADO, Ubiratan. A vida literária no Brasil durante o romantismo. Rio de Janeiro: EdUERJ, 2001

MAIO, Marcos Chor. O Projeto UNESCO e a Agenda das Ciências Sociais no Brasil dos Anos 40 e 50. Revista Brasileira de Ciências Sociais - vol. 14, nº 41, Outubrto/ 1999.

MAIO, Marcos Chor; SANTOS, Ricardo Ventura (orgs). Raça, ciência e sociedade. Rio de Janeiro: Fiocruz / Centro cultural Banco do Brasil, 1996.

MARTINS, Wilson. História da Inteligência brasileira. 2a . Ed.vol. IV. (1877-1896). São Paulo: Cultrix, 1996.

MATOS, Claudia Neiva de. A poesia popular na república das letras: Silvio Romero Folclorista. Rio de Janeiro: Funarte / Ed. da UFRJ, 1994.

MAZZOLENI, Gilberto. O planeta cultural: para uma antropolgia histórica. São Paulo: Editora da Universidade de São Paulo, 1992.

MENDONÇA, Carlos Sussekind de. Silvio Romero: sua formação intelectual (1851 -1880). São Paulo: Ed. Nacional, 1938.

MERQUIOR, José Guilherme. De Anchieta a Euclides: breve história da literatura brasileira I. $3^{\mathrm{a}}$. Ed. Rio de Janeiro: Topbooks, 1996. 
MONTAIGNE, Michel de. Dos canibais. Tradução de Luiz Antonio Alves Eva. São Paulo: Alameda, 2007.

MOORE, Carlos. Racismo \& sociedade: novas bases epistemológicas para entender o racismo. Belo Horizonte: Mazza, 2007.

MORAES FILHO, Evaristo de. Medo a utopia: o pensamento social de Tobias Barreto e Sílvio Romero. Rio de Janeiro: Nova Fronteira; [Brasília]: INL, 1985.

MORGAN, Lewis Henry. Evolucionismo cultural: textos de Morgan, Tylor e Frazer. Rio de Janeiro: Jorge Zahar, 2005.

MORUS, Thomas. Utopia. Rio de Janeiro: Ouro, 1966.

MOTA, Carlos Guilherme. 1822: Dimensões. São Paulo: Perspectiva, 1972.

(Org). Viagem incompleta. A experiência brasileira. Formação: histórias. São Paulo: SENAC, 2009. (Vários Autores)

MOTA, Lourenço Dantas (Org). Introdução ao Brasil: um banquete nos trópicos. São Paulo: Ed. do SENAC, 2001. (Vários Autores)

MOTA, Maria Aparecida Rezende. Silvio Romero: dilemas e combates no Brasil da virada do século XIX. Rio de Janeiro: FGV, 2000.

MOTTA, Roberto. Paradigma das relações raciais no Brasil. Estudos Afro-Asiáticos, $\mathrm{n}^{\circ}$ 38, Rio de Janeiro/Dezembro, 2000.

MOURA, Clóvis. Injustiças de Clio: o negro na historiografia brasileira: oficina de livros, 1990.

MUNANGA, Kabengele. A difícil tarefa de definir quem é negro no Brasil. Entrevista do autor. Estudos Avançados 18 (50), 2004

Algumas considerações sobre "raça", ação afirmativa e identidade negra no Brasil: fundamentos antropológicos. REVISTA USP, São Paulo, n.68, p. 46-57, dezembro/fevereiro 2005 2006.

Diversidade, etnicidade, identidade e cidadania. Palestra proferida no $1^{\text {a }}$ Seminário de Formação Teórico Metodológico - São Paulo.

Mestiçagem como símbolo da identidade brasileira. São Paulo: Cortez, 2010.

Racismo: da desigualdade a intolerância. São Paulo em Perspectiva, 4 (2): 51-54, Abril/Junho 1990 
Rediscutindo a mestiçagem no Brasil: identidade nacional versus identidade negra. Belo Horizonte: Autêntica, 2008.

Negritude: usos e sentidos. Belo Horizonte: Autêntica, 2009.

Preconceito racial de marca e preconceito racial de origem (sugestão de um quadro de referência para a interpretação do material sobre relações raciais no Brasil). Apresentado originalmente ao XXXI Congresso Internacional de Americanistas, realizado em São Paulo, de 23 a 30 de agosto de 1954, no Symposium Etno-Sociológico sobre Comunidades Humanas no Brasil, organizado por Florestan Fernandes. Reprodução da versão apresentada em Porto Rico, em 1957.

Professor Clóvis Moura: o homem e sua obra. Maceió: EDUFAL, 2003. PP. 127-145.

Superando o racismo na escola. 2a . Ed. Revisada. Brasília: Ministério da Educação: Secretaria de Educação Continuada, Alfabetização e Diversidade, 2005.

Uma abordagem conceitual das noções de raça, racismo, identidade e etnia. In: Programa de Educação sobre o negro na sociedade brasileira. Rio de Janeiro: EDUFF, 2004. pp.15-34

MURICY, Kátia. A razão cética: Machado de Assis e as questões de seu tempo. São Paulo: Companhia das letras, 1988.

NABUCO, Joaquim. O abolicionismo. London Abraham Kingdon, 1883

NAXARA, Márcia Regina Capelari. Estrangeiro em sua própria terra: representações do brasileiro, 1870/1920. São Paulo: Annablume,1998.

Brasil e Brasileiros - interpretações cientificistas/Ensaios de caracterização. Revista História, São Paulo, n.129-131, p.31-51, Agosto-Dezembro/93 a Agosto-Dezembro/94.

NEEDELL, Jeffrey. Belle Époque Tropical: Sociedade e Cultura de Elite no Rio de Janeiro na Virada do Século. São Paulo: Companhia das Letras, 1993.

NEMEZIO FILHO, Para além do conceito de "raça". Revista Científica de Información y Comunicación, na. 3, (2006), Sevilha.

NETO, A.L. Machado. Estrutura social da república das letras: sociologia da vida intelectual brasileira. 1870-1930. São Paulo: Edusp / Grijalbo, 1993.

NEVES, Lúcia Maria Bastos Pereira das. O Império do Brasil. Rio de Janeiro: Nova Fronteira, 1999 NEVES, Margarida de Souza. A ordem e o progresso: O Brasil de 1870 a 1910. São Paulo: Atual, 1991.

NOBREGA, Manuel da. Cartas do Brasil (1549-1560). Rio de Janeiro: Oficina Industrial Gráfica, 1931 
NOGUEIRA, Marco Aurélio. As desventuras do liberalismo: Joaquim Nabuco, a monarquia e a republica. Rio de Janeiro: Paz e terra, 1984.

NOGUEIRA, Oracy. Preconceito racial de marca e preconceito racial de origem: sugestão de um quadro de referência para a interpretação do material sobre relações raciais no Brasil. Tempo Social, Revista de Sociologia da USP, v. 19, $\mathrm{n}^{\mathrm{a}}$. 1,

NOVAIS, Fernando Antônio. A independência política do Brasil. 2a . Ed. São Paulo: Hucitec, 1996 Portugal e Brasil na Crise do Antigo Sistema Colonial (1777-1808). 5a . Ed. São Paulo: Hucitec, 1989.

NUNES, Sylvia da Silveira. Racismo no Brasil: tentativas de disfarce de uma violência explícita. Psicologia, USP, 2006, 17 (1), 89-98.

ODALIA, Nilo. Gilberto Freyre: uma interpretação etno-cultural do Brasil. São Paulo: 2001. (Digitado)

As formas do mesmo: ensaios sobre o pensamento historiográfico de Varnhagen e Oliveira Vianna. São Paulo: Fundação Editora da UNESP, 1997.

OLIVEIRA, Lúcia Lippi. A Questão Nacional na Primeira República. São Paulo: Brasiliense, 1990. OLIVEN, Ruben George. Violência e cultura no Brasil. 2ª ed. Petrópolis: Vozes, 1983.

ORTIZ, Renato. Cultura brasileira e identidade nacional. São Paulo: Brasiliense, 2003. Românticos e folcloristas: cultura popular. São Paulo: Olho D’Agua, 1999.

PAES, José Paulo. Canaã. O horizonte racial. Estudos Avançados 5 (3), 1991.

PAIM, Antonio. A Escola do Recife. Estudos complementares à História das Idéias Filosóficas no Brasil. Vol. V. Londrina: UEL, 1999.

A filosofia da escola do Recife. Rio de Janeiro: Editôra Saga, 1966.

Escola eclética. Estudos Complementares a História das idéias filosóficas no Brasil. Vol. IV. 2 a . Ed. Londrina: CEFIL, 1999.

História das Idéias Filosóficas no Brasil. São Paulo: Ed. Grijalbo,1967.

Sílvio Romero, 1851-1914: bibliografia e estudos críticos. Centro de Documentação do Pensamento Brasileiro, 1999.

A Escola do Recife. Estudos complementares à História das Idéias Filosóficas no Brasil. Vol. V. Londrina: UEL, 1999. 
PEREIRA, João Baptista Borges. Diversidade e Pluralidade: o negro na sociedade brasileira. REVISTA USP, São Paulo, n.89, p. 278-284, março/maio 2011

PATY, Michel. Os discursos sobre as raças e a ciência. Estudos Avançados 12 (33), 1998.

PINTO, Ricardo M. Silvio Romero: contribuições à formação do pensamento racial no Brasil (1870 - 1914). Dissertação apresentada ao Programa de Pós Graduação em História Social /FFLCH-USP, 1996.

POLIAKOV, Leon. O mito ariano. São Paulo: Perspectiva, 1974.

PRADO, Paulo. Retrato do Brasil: ensaio sobre a tristeza brasileira. São Paulo: 2006. (Digitado)

PRADO JUNIOR, Caio. Evolução política do Brasil. Colônia e Império. 4a . Ed. São Paulo: Brasiliense, 2007.

Formação do Brasil Contemporâneo. 18ª . Ed. São Paulo: Brasiliense, 1983

QUEIROZ, Maria Isaura de. Identidade Cultural, identidade nacional no Brasil. Tempo Social; Revista Sociologia, USP, São Paulo, 1(1), 1.semestre. 1989. pp. 29-46.

RABELLO, Sylvio. Itinerário de Silvio Romero. Rio de Janeiro: Civilização Brasileira, 1967.

RAEDERS, Georges. O conde Gobineau no Brasil. Rio de Janeiro: Paz e Terra, 1988.

RAMA, Angel. A cidade das letras. São Paulo: Brasiliense, 1985.

REIS, José Carlos. As identidades do Brasil: de Varnhagen a FHC. Rio de Janeiro: Fundação Getúlio Vargas, 1999.

RICUPERO, Bernardo. O romantismo e a idéia de nação no Brasil (1830-1870). São Paulo: Martins Fontes, 2004.

RIO, João do. O momento literário. Rio de Janeiro: Edições do Departamento Nacional do Livro, Fundação Biblioteca Nacional 1994.

RODRIGUES, José Honório. Independência: revolução e contra-revolução. Rio de Janeiro: Francisco Alves, 1975

RODRIGUES, Nina. As Raças humanas e a responsabilidade penal no Brasil. Rio de Janeiro: Guanabara, 1894.

Mestiçagem, degenerescência e crime. Archives d'Anthropologie Criminelle de 1899. Lyon: A.. Storck \& Cie, Imprimeurs Éditeurs. Tradução de Mariza Correa.

ROUANET, Maria Helena. Eternamente em berço esplêndido: a fundação de uma literatura nacional. São Paulo: Siciliano, 1991. 
SANT’ANA, Antônio Olímpio. História e conceitos básicos sobre o racismo e seus derivados.

SANTOS, Mariza Veloso Motta \& MADEIRA, Maria Angélica. Leituras brasileiras: itinerários no pensamento social e na literatura. São Paulo: Paz e Terra, 1999.

SANTOS, Wilmihara Benevides da Silva Alves dos. Povo e raça na formação da nação: o debate entre Manoel Bonfim e Silvio Romero. Dissertação - mestrado em Ciências Sociais. FFC /UNESP, 2006.

SCHAPOCHNIK, Nelson. Como se escreve a história. Revista Brasileira de História. São Paulo: ANPUH/Marco Zero, v. 13, n 25/26, pp. 67-80. set 92/ago93.

SCHNEIDER, Alberto Luiz. Sílvio Romero, hermeneuta do Brasil. São Paulo: Annablume, 2005.

SCHWARCZ, Lilia Moritz. As barbas do imperador: D. Pedro II, um monarca nos trópicos. São Paulo: Companhia das Letras, 1998.

Complexo de Zé Carioca: notas sobre uma identidade mística e malandra. São Paulo, 1995. pp. 49-63. Disponível. http://www.anpocs.org.br/portal/publicacoes/rbcs_00_29/rbcs29_03

Retrato em branco e negro: jornais, escravos e cidadãos em São Paulo no final do século XIX. São Paulo: Cia. das Letras, 1987.

O espetáculo das raças: cientistas, instituições e questão racial no Brasil. 1870-1930. São Paulo: Cia das Letras, 1993.

Raça como negociação. In: FONSECA, Maria Nazaret Soares (Org). Brasil afro-brasileiro 2a . Ed, Belo Horizonte: Autêntica, 2006.

Racismo no Brasil. São Paulo: Publifolha, 2001.

Um enigma chamado Brasil: 29 intérpretes e um país. São Paulo: Cia das Letras, 2009.

SCHWARCZ, Lilia Moritz e QUEIROZ, Renato da Silva (org). Raça e diversidade: São Paulo: EDUSP, 1996.

SCWARTZ, Stuart B. Segredos internos: engenhos e escravos na sociedade colonial, 1550-1835. São Paulo: Companhia das Letras, 1988.

SCHWARZ, Roberto. Cultura e Política. São Paulo: Paz e Terra, 2001.

SEVCENKO, Nicolau. Literatura como missão: tensões sociais e criação cultural na Primeira República. $4^{\text {a }}$ ed. São Paulo: Brasiliense, 1995.

(Org.). Da Belle époque à era do rádio. São Paulo: Cia. das Letras, 1998. 
SEYFERTY, Giralda. A assimilação dos imigrantes como questão nacional. Rio de Janeiro: Mana, v.3, n 1,1997.pp.95-131.

Construindo a nação: hierarquias raciais e o papel do racismo na política de imigração e colonização

Os paradoxos da miscigenação: observações sobre o tema imigração e raça no Brasil. Estudos Afro-asiáticos, na 20, 1991. pp.165-191.

O beneplácito da desigualdade: breve digressão sobre racismo. In: Racismo no Brasil. São Paulo: Editora Fundação Peirópolis, 2002. (Vários autores) pp.17-43

SILVA, José Bonifácio de Andrada. Projetos para o Brasil. São Paulo: Companhia das letras; Publifolha, 2000.

SILVA, José Maria de Oliveira. Da Revolução à Educação - Radicalismo republicano em Manoel Bomfim. Dissertação de Mestrado em História Social da FFLCH/USP. São Paulo: digitado, 1991 SILVA, Marcos A. "A Terra" d'Os Sertões (Literatura como História)", In: CARDOSO, Heloísa Helena Pacheco e PATRIOTA, Rosângela (Org.). Escritas e narrativas históricas na contemporaneidade. Belo Horizonte, Fino Traço, 2011, pp 177/188.

"Milagres da Literatura - A liberdade zomba da ditadura em Tenda dos milagres". Texto de conferência apresentada no Simpósio Nacional de História Cultural da ANPUH (Teresina, PI). Digitado, 27 pp, 2012.

Caricata república. Zé Povo e o Brasil. Sao Paulo: Marco Zero, 1989.

“Cultura como Patrimônio Popular (Perspectivas de Câmara Cascudo)”. Projeto História. São Paulo: PUC, 33: 195/204, dezembro 2006.

"Detrito federal - O vômito e o silenciamento de Lucrécio Barba-de-Bode". História \& Perspectivas. Uberlândia: EDUFU, 40: 179/205, jan/jul 2009 (versão eletrônica: www.historiaperspectivas.inhis.ufu.br).

"Policarpo \& Policarpo (Policarpo Quaresma, Herói do Brasil)”, In: FONSECA, Selva Guimarães e GATTI JR., Décio (Orgs.). Perspectivas do Ensino de História: ensino, cidadania e consciência histórica. Uberlândia: FAPEMIG/Uberlândia, 2011, pp 383/390.

TODOROV, Tzvetan. A conquista da América: a questão do outro. São Paulo: Martins Fontes, 2003.

SIRINELLI, Jean-François. Os intelectuais. In: Por uma história política. Org. REMOND, René. Rio de Janeiro: Editora UFRU, 1996. 
SKIDMORE, Thomas E. O Brasil visto de fora. 2ª Rio de Janeiro: Paz e Terra, 1994

Preto no branco: raça e nacionalidade no pensamento brasileiro. Rio de Janeiro: Paz e Terra, 1976.

Uma história do Brasil. São Paulo: Paz e Terra, 1998.

SOARES DE SOUZA, Gabriel. Tratado descritivo do Brasil em 1587. Rio de Janeiro: Tipografia Universal de Laemmert.

SODRÉ, Nelson Werneck. A ideologia do colonialismo: seus reflexos no pensamento brasileiro. $2^{\mathrm{a}}$ ed. Rio de Janeiro: Civilização Brasileira, 1965.

O Naturalismo no Brasil. 2a . Ed. Belo Horizonte: Oficina de Livros, 1992.

História da Literatura Brasileira: seus fundamentos econômicos. 4a ${ }^{\mathrm{a}}$. Ed. Rio de Janeiro: Editora Civilização Brasileira, 1964.

SOUZA, Francisco Martins de. A questão teórica da cultura na Escola do Recife. Prefácio. In: O Brasil Social. Brasília: Senado Federal, 2001. (1 ${ }^{\text {a }}$ Ed. 1908)

SOUZA, João Mendonça de. Sílvio Romero: o crítico e o polemista. Rio de Janeiro: Emebê, 1976.

SOUZA, Laura de Mello e (Org.). Cotidiano e vida privada na América portuguesa. São Paulo: Cia. das Letras, 1997, pp. 13/39.

SOUZA, Ricardo Luiz de. Identidade Nacional e modernização na Historia Brasileira: diálogo entre Romero, Euclides, Cascudo e Freyre. Tese de doutorado em História, defendida na FAFICH/UFMG. Belo Horizonte, 2006. (Digitado)

SPOSITO, Fernanda. Nem cidadãos, nem brasileiros - indígenas na formação do estado nacional brasileiro e conflitos na província de São Paulo (182-1845). São Paulo: Alameda, 2012.

SUSSEKIND, Flora. O Brasil não é longe daqui: o narrador, a viagem. São Paulo: Cia das Letras, 1990

THIESSE, Anne Marie. A criação das identidades nacionais. Lisboa: temas e debates, 2000.

TINHORÃO, José Ramos. Os romances em folhetins no Brasil: 1830 à atualidade. São Paulo: Duas Cidades, 1994.

VAINFAS, Ronaldo. Ideologia e Escravidão: os letrados e a sociedade escravista no Brasil colonial. Petrópolis, Rio de Janeiro, vozes. 1986.

Yvonne Maggie e Claudia Barcellos Rezende (organizadoras). Raça como retórica: a construção da diferença. Rio de Janeiro: Civilização Brasileira, 2002. 
VELLOSO, Mônica Pimenta. As tradições populares na "belle époque" carioca. Rio de Janeiro: Civilização Brasileira, 1946.

VERÍSSIMO, José. História da literatura Brasileira. São Paulo: Editora Letras \& Letras, 1998.

VENANCIO FILHO, Alberto. Introdução; Cronologia. In: Doutrina contra Doutrina. ROMERO, Silvio. São Paulo: Companhia das Letras, 2001. pp.7-31.

VENTURA, Roberto. Manuel Bonfim: A América Latina: males de origem. São Paulo: SENAC, 2002. v. 2. pp. $237-258$

Estilo tropical: história cultural e polêmicas literárias no Brasil. São Paulo: Companhia das Letras, 1991.

História e Crítica em Silvio Romero. In: História da Literatura: ensaios. Campinas, SP: Editora da Unicamp, 1994. pp.37-54.

Um Brasil mestiço: raça e cultura na passagem da monarquia a república. São Paulo: SENAC, 2000. pp. 331-332

VENTURA, Roberto e SUSSEKIND, Flora. História e dependência: cultura e sociedade em Manoel Bomfim. São Paulo: Editora Moderna, 1984

VIANA, Oliveira. Populações meridionais do Brasil. Brasília: Senado Federal, Conselho Editorial, 2005.

ZILBERMAN, Regina; A fundação da Literatura brasileira. In: Revista brasileira de Literatura comparada. São Paulo: Abralic, (2): 59-68, maio 1994.

ZILBERMAN, Regina/ MOREIRA, Maria Eunice. Porto Alegre: Mercado Aberto, 1998; Críticos e historiadores da Literatura: pesquisando a identidade nacional. Via Atlântica, nª 4, Out, 2000.

WILLIAMS, Raymond. O campo e a cidade. Na história e na literatura. São Paulo: Cia das Letras, 1989.

WEBER, João Ernesto. A nação e o paraíso. A construção da nacionalidade na historiografia literária brasileira. Florianópolis, Ed. UFSC, 1977.

WEHLING, Arno. Silvio Romero e a consciência modernizadora no Brasil: pressupostos, análises, rumos. São Paulo, 1979. Tese - Livre Docência, FFLCH / USP. 
Anexo 
SYLVIO ROMÉRO

(On Acadomite Broslleira)

\section{Provocações e Debates}

(Contribuiç̧ös para o Estedo do Brazil Social)

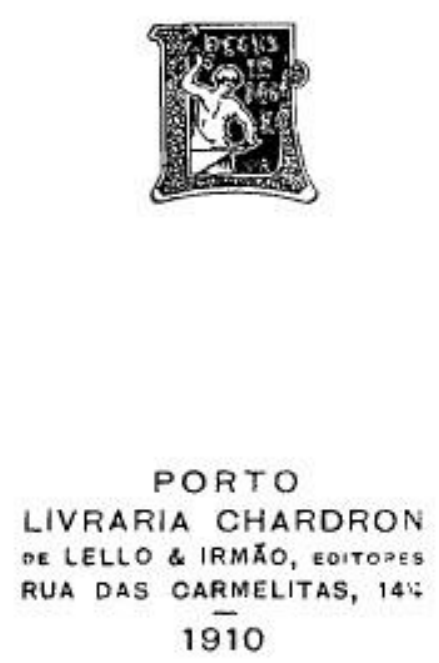




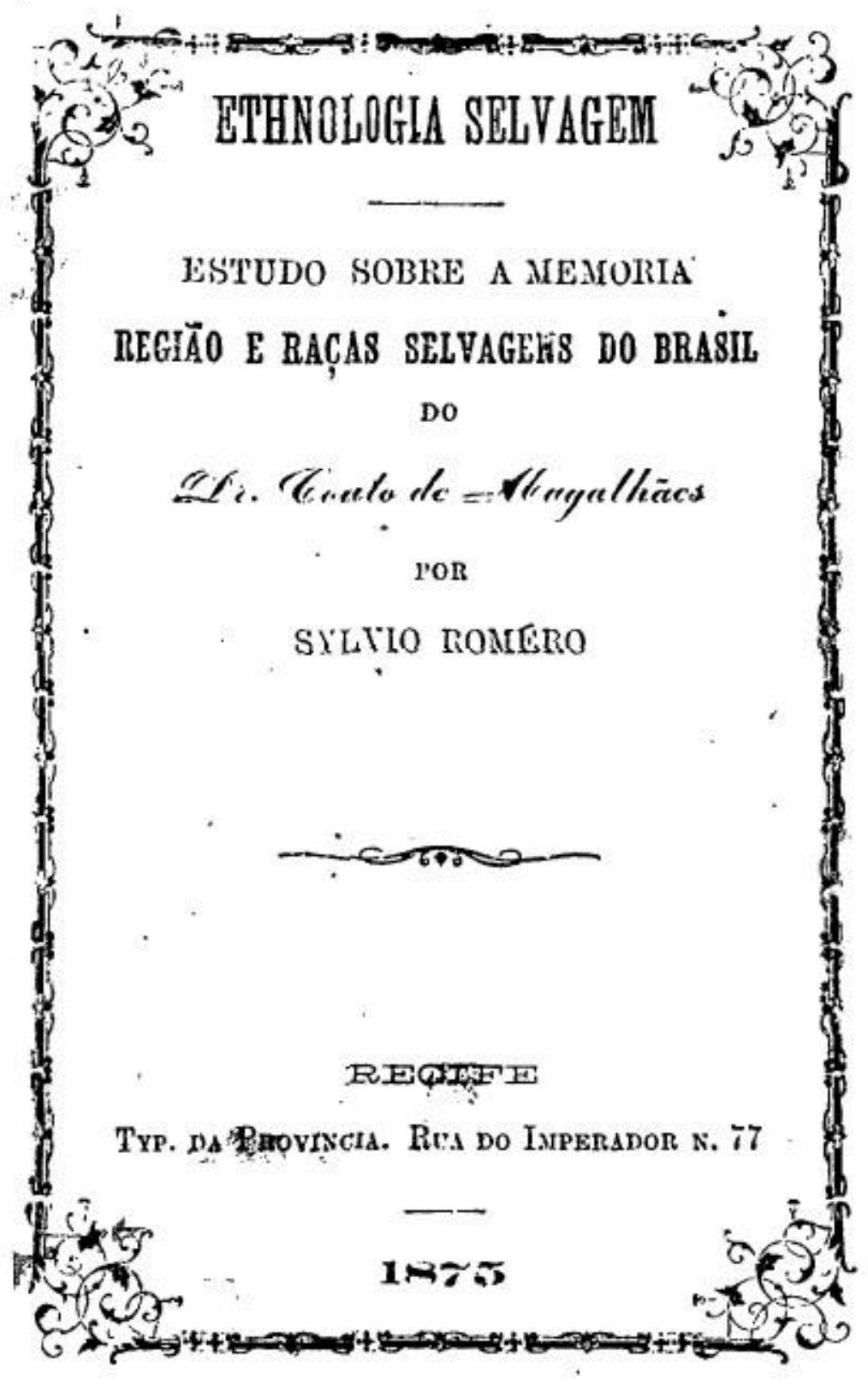




\title{
ETHNOGRAPHIA
}

\author{
BRAZILERRA
}

ESTUDOS CRITICOS

SOBRE

COUTO DE MAGALHAES, BARBOSA RỌDRIGUES, THEOPITILO HRAGA E I.ADISL.KO NETTOO

RIÓ DE JANEIRO

Livraria Classica de Alves \& C: 46 e 45 . Rua de Gonçalves Dias, 46 e 48 1Reg 


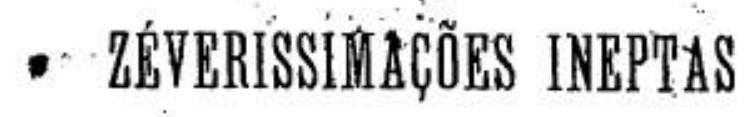

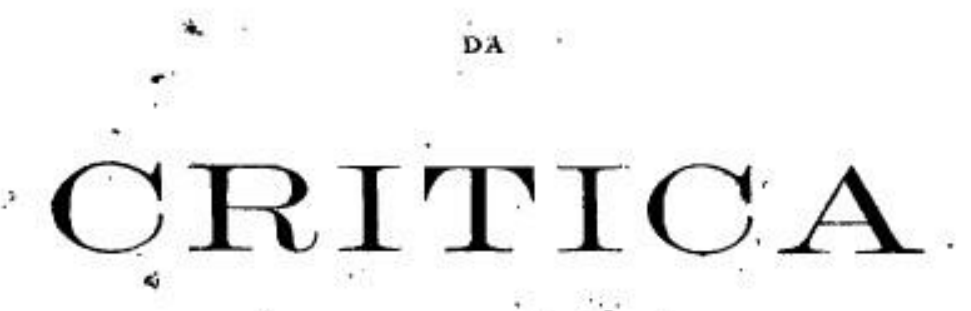

(REPULSAS E DEŚABAAFOS)

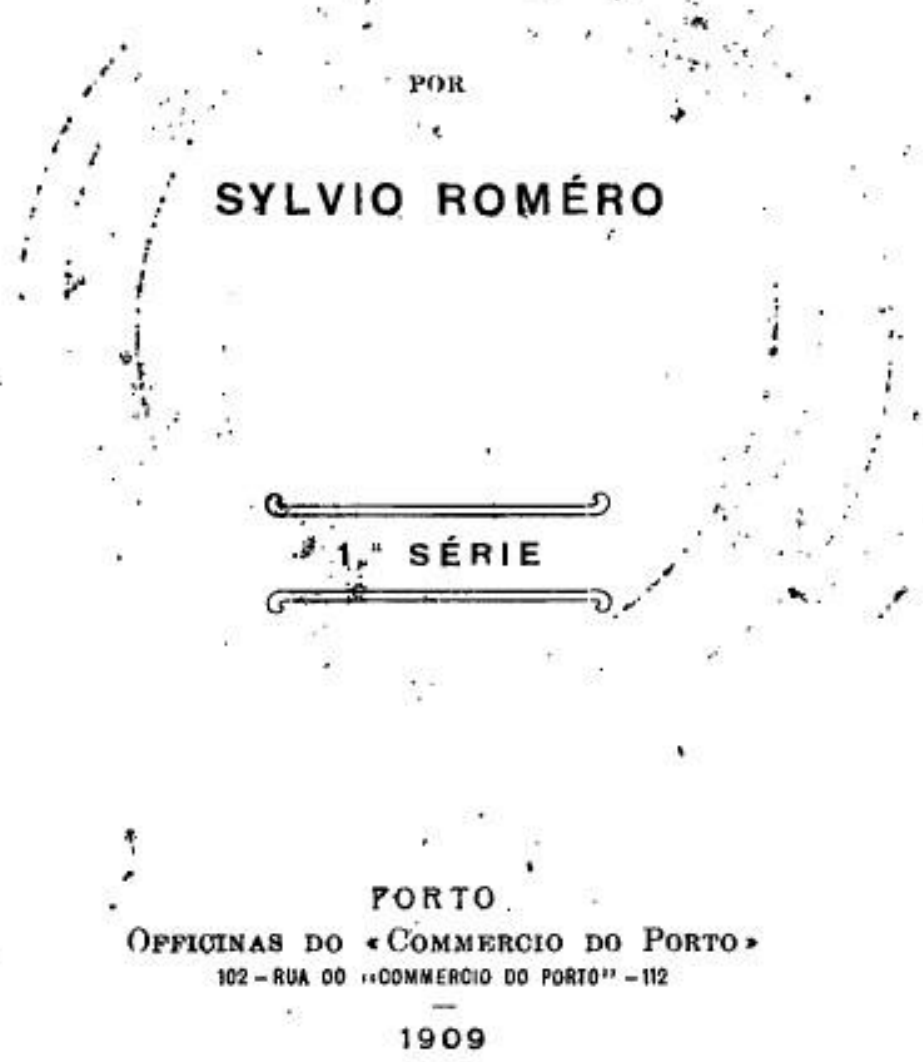




\section{UMA ESPERTEZA}

Os Cantos e Contos Populares do Brazil e 0
Sr. Theophilo Braga

Protesto

POA

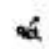

SYLVIO ROMÉRO

RIO DE JANEIRO

TrP. Da-ESCOLA-DE SERAFtu Jost Alvis

83 Rua Sete de Setembro 83

1887 


\section{GONTOS POPULARES}

\section{DO BRAZII \\ COLLIGIDOS}

Pelo Dr. SYLVIO ROMERo

Professor do Cullegio Pedro II

COM UM ESTUDO PRELLINAR E NOTAS COMPARATIVAS

POr THEOPHILO BRAGA

LISBOA

Nova Livraria ISTERAcional - EDitora

96, Rua do Arsenal, 96

$18 \times 5$ 


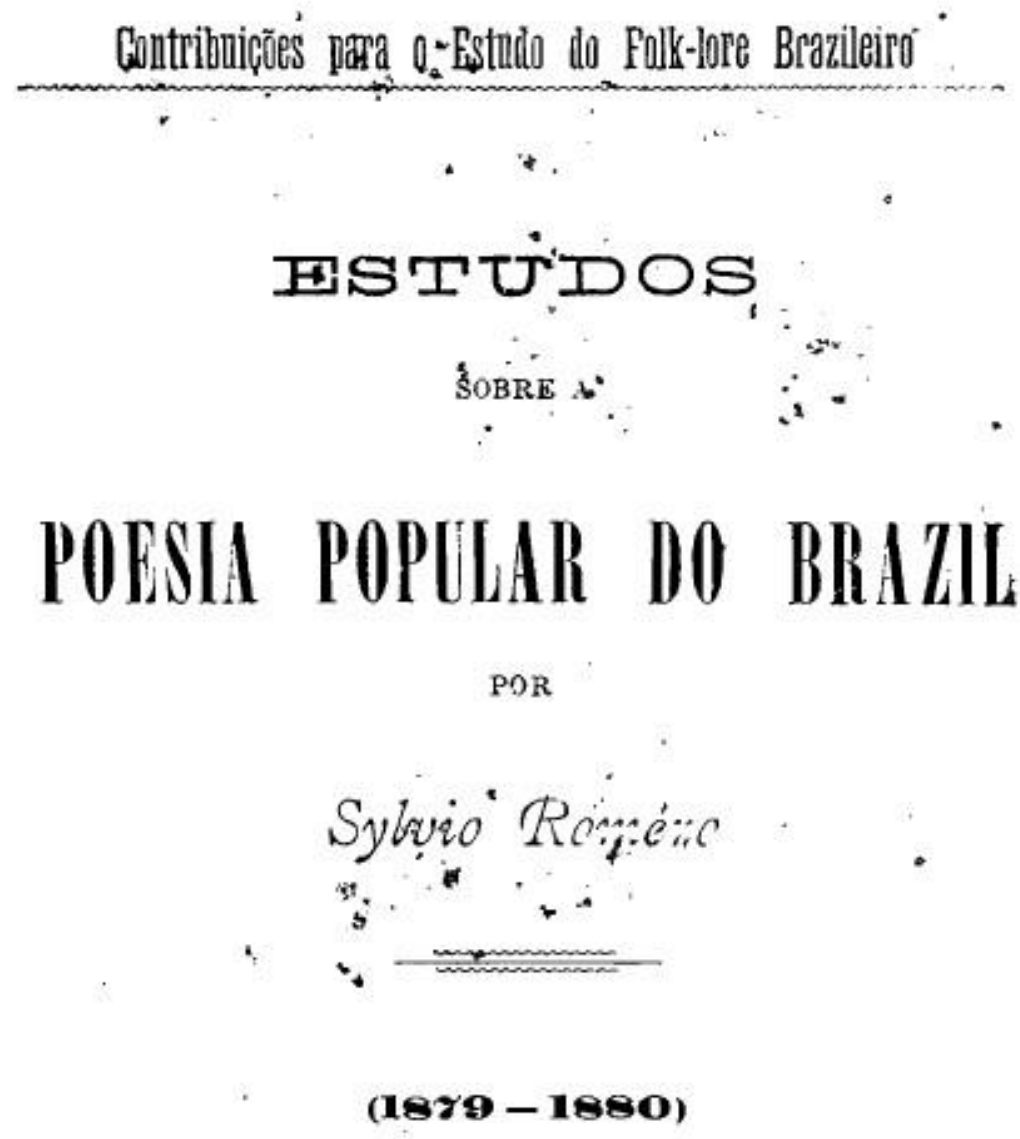

- RIO de JANEIRO

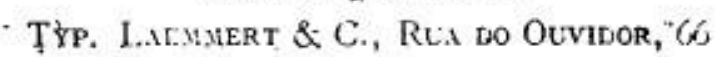

$1 \overline{888}$ 


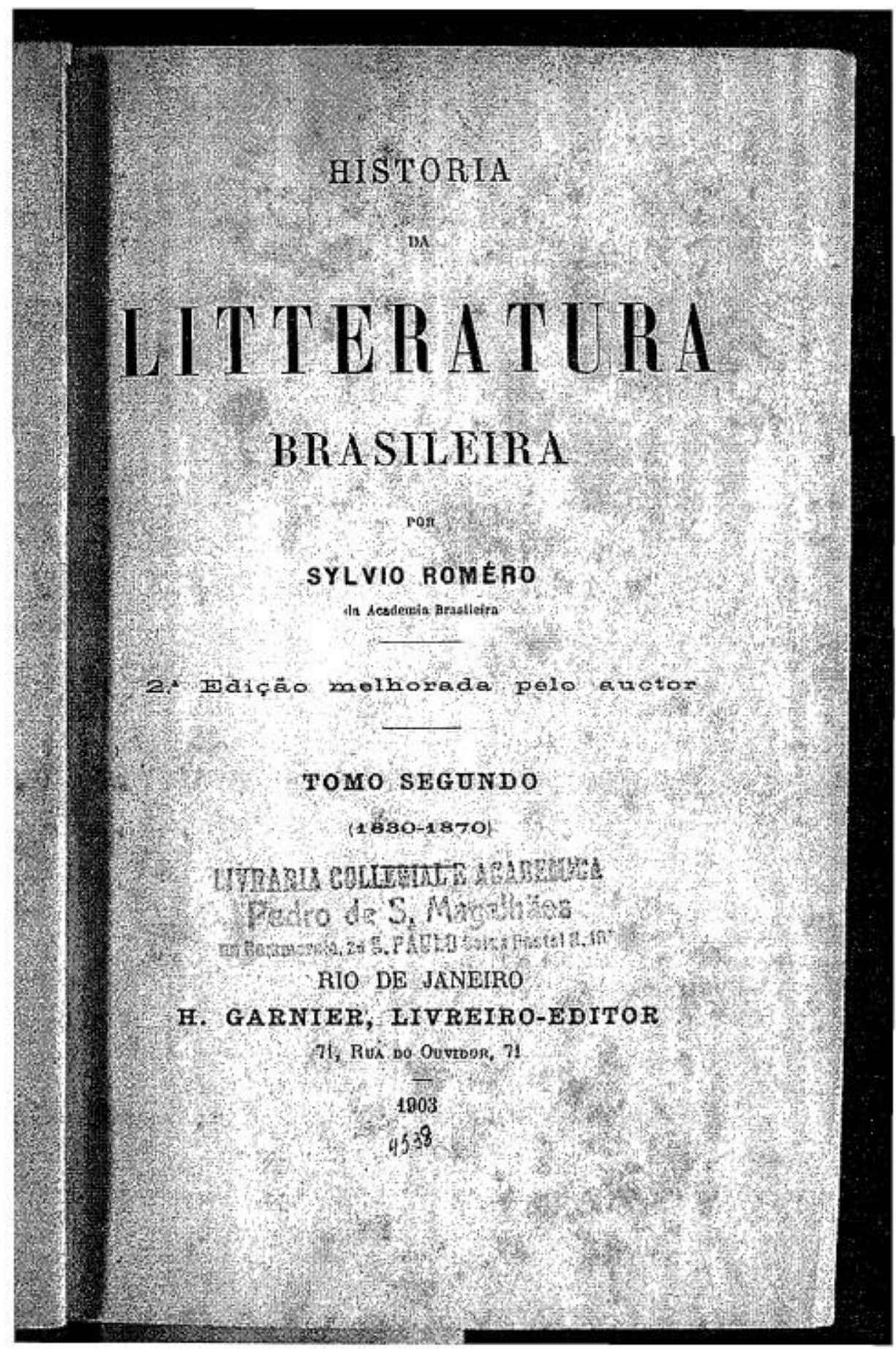




\section{DOUTRINA COVTRA DOUTRIIA}

- evolucionismo e o positivismo na

Republica do Brasil

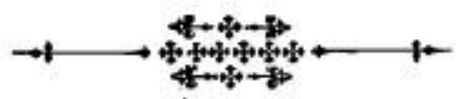

1. Serie

RIO DE JANEIRO

EDYTOR - J. B. NENES 
o

\section{SQLDIO ROMÉRO}

\section{A America Latina}

(Analpse do lloro de igual titulo do Dr. M. BOMFIM)

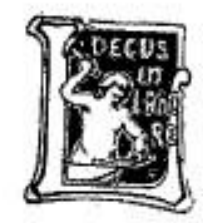

PORTO

IIVRARIA OFARDRON

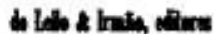

F. das Carmelitae, 144

1000 